\title{
Bihać kao sjedište Bihaćke kapetanije i slobodni kraljevski grad
}

\section{Stanić, Damir}

Doctoral thesis / Disertacija

2020

Degree Grantor / Ustanova koja je dodijelila akademski / stručni stupanj: University of Zagreb, University of Zagreb, Faculty of Humanities and Social Sciences / Sveučilište u Zagrebu, Filozofski fakultet

https://doi.org/10.17234/diss.2020.7151

Permanent link / Trajna poveznica: https://urn.nsk.hr/urn:nbn:hr:131:199193

Rights / Prava: In copyright/Zaštićeno autorskim pravom.

Download date / Datum preuzimanja: 2023-04-26

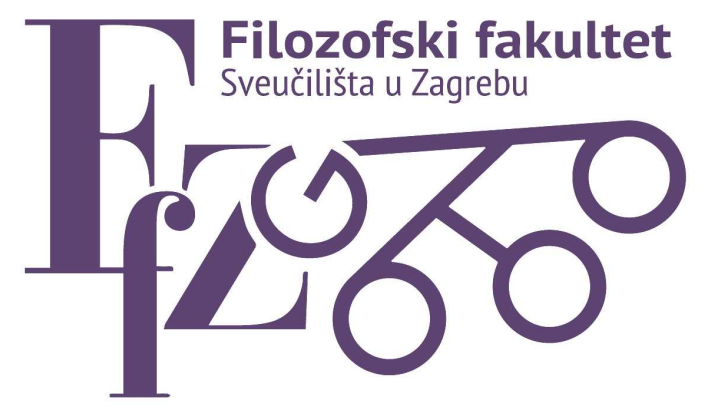

Repository / Repozitorij:

ODRAZ - open repository of the University of Zagreb

Faculty of Humanities and Social Sciences
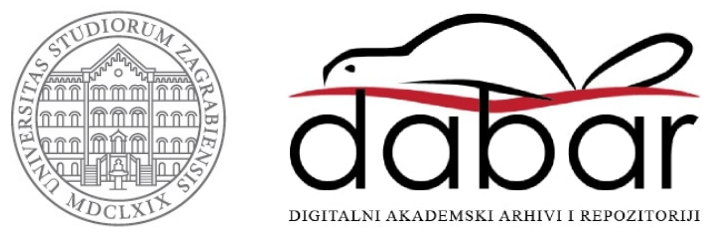
Filozofski fakultet

Damir Stanić

\section{BIHAĆ KAO SJEDIŠTE BIHAĆKE KAPETANIJE I SLOBODNI KRALJEVSKI GRAD}

DOKTORSKI RAD

Zagreb, 2020. 


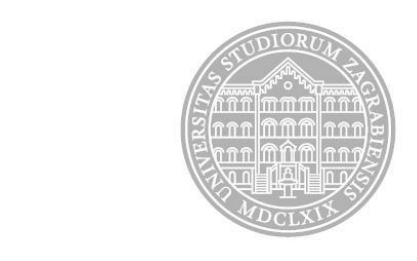

Sveučilište u Zagrebu

Filozofski fakultet

Damir Stanić

\title{
BIHAĆ KAO SJEDIŠTE BIHAĆKE KAPETANIJE I SLOBODNI KRALJEVSKI GRAD
}

\author{
DOKTORSKI RAD
}

Mentorica: prof. dr. sc. Nataša Štefanec, red. prof.

Zagreb, 2020. 


\title{
0 \\ University of Zagreb
}

Faculty of Humanities and Social Sciences

Damir Stanić

\section{BIHAĆ AS A SEAT OF THE BIHAĆ CAPTAINCY AND A FREE ROYAL CITY}

\author{
DOCTORAL DISSERTATION
}

Supervisor: dr. sc. Nataša Štefanec, Full Professor

Zagreb, 2020. 


\section{ŽIVOTOPIS MENTORICE}

Nataša Štefanec rođena je 1973. u Čakovcu. Početkom 1997. završila je studij filozofije i povijesti na Filozofskom fakultetu u Zagrebu. Krajem 1996. upisala je M.A. History Program na Central European University u Budimpešti gdje je magistrirala u lipnju 1997. Godine 1998. upisala je poslijediplomski studij povijesti na Filozofskom fakultetu u Zagrebu te po drugi put magistrirala u veljači 2000. na temu iz povijesti obitelji Zrinski. Godine 1998. upisala je doktorski studij povijesti na CEU u Budimpešti, gdje je doktorirala u lipnju 2004. Od svibnja 2001. zaposlena je kao znanstveni novak na Zavodu za hrvatsku povijest Odsjeka za povijest Filozofskog fakulteta u Zagrebu. Godine 2017. izabrana je u znanstveno-nastavno zvanje redovnog profesora na Odsjeku za povijest istog fakulteta. Od 2006. do 2013. vodila je Poslijediplomski studij hrvatske povijesti Odsjeka za povijest Filozofskog fakulteta u Zagrebu (predbolonjski sustav). Jedan je od pokretača, a trenutno i zamjenik voditelja Poslijediplomskog doktorskog studija ranoga novog vijeka (djeluje od 2008). Intenzivno je radila i na izradi Doktorskog studija predmoderne povijesti. Bavila se organizacijom niza domaćih i međunarodnih konferencija. Od 2001. redovito izvodi nastavu iz obveznih i izbornih predmeta na Odsjeku za povijest Filozofskog fakulteta u Zagrebu. Akad. god. 2006/7. izvodila je obaveznu nastavu na Filozofskom fakultetu u Splitu, a od 2014/15. do 2017/18. izvodila je obaveznu nastavu na Odsjeku za povijest Filozofskog fakulteta u Rijeci.

Osim brojnih stipendijskih i istraživačkih boravaka u Austriji i Mađarskoj, razdoblje od rujna 2002. do veljače 2003. provela je na School of Southeast European Studies, University College London, kao Croatian Teacher/Fellow. Bila je gostujući znanstvenik na GWZO (Geisteswissenschaftliches Zentrum Geschichte und Kultur Ostmitteleuropas) na Sveučilištu u Leipzigu (svibanj-lipanj 2009), a usavršavala se i u Kini (srpanj 2013.). Istražuje hrvatsku povijest ranog novog vijeka, povijest plemstva, povijest Vojne krajine u srednjoj i jugoistočnoj Europi te institucionalno i pravno funkcioniranje habsburško-osmanskog pograničja.

Posljednjih godina bavi se i demografskom poviješću, poviješću nasilja te sociokulturnim praksama na krajini. Na poziv je sudjelovala na nizu međunarodnih znanstvenih konferencija.

Sudjelovala je u radu nekoliko znanstveno-istraživačkih projekata, a od 2007. do 2014. godine bila je voditeljica istraživačkog projekta registriranog pri MZOŠ. Objavila je dvije monografije, uredila nekoliko knjiga na hrvatskom i engleskom jeziku te objavila niz 
znanstvenih i stručnih članaka na nekoliko jezika. Recenzirala je niz znanstvenih knjiga, a redovito recenzira članke za brojne znanstvene i stručne časopise. 


\section{SAŽETAK}

Slobodni kraljevski grad Bihać bio je do osmanskog osvajanja 1592. jedan od najvažnijih urbanih, a time i sociopolitičkih centara onodobnoga hrvatskog prostora. Izvanredno pozicioniran uz komunikaciju koja je spajala jadranski i panonski prostor, smješten na toku rijeke Une, zaštićen planinama te dobro naseljen i utvrđen, Bihać će vrlo brzo postati važno vojno središte u kontekstu sukoba s Osmanlijama. Desetljećima prije stupanja dinastije Habsburg na ugarsko-hrvatsko prijestolje započet će proces transformacije Bihaća u jedan od centara protuosmanskoga obrambenog sustava, a taj će proces kulminirati nakon 1527. kada grad postaje sjedište Bihaćke kapetanije, zborno mjesto Hrvatske krajine te ključna točka za sigurnost hrvatskog prostora i unutrašnjeaustrijskih zemalja, primarno Kranjske.

Iako je slobodni kraljevski grad Bihać nastavio funkcionirati pod naslijeđenom gradskom upravnom strukturom, odvijalo se to u bitno drugačijem kontekstu. Sve izraženija osmanska ekspanzija i formiranje krajiškog sustava kao habsburškog odgovora, u konačnici je dovelo do podređenosti civilne gradske strukture onoj kapetanijskoj - o kojoj je uostalom ovisila i obrana grada.

U prvom dijelu disertacije istražio sam i prezentirao kontekst nastanka Bihaćke kapetanije, njezin teritorijalni razvoj, promjene u strateškom značenju kroz promatrani period, broj i karakteristike vojnika gradske posade te vojnih postrojbi slanih u pomoć gradu, stanje i promjene u fortifikacijskoj infrastrukturi grada, a posebno poglavlje posvećeno je bihaćkim kapetanima i višim časnicima koji su bili dio gradske posade. Istražio sam i problematiku dopreme i skladištenja oružja i opreme u gradu te obavještajnu, stražarsku i poštansku važnost Bihaća u krajiškom kontekstu.

U drugom dijelu disertacije fokusirao sam se na pojedine društvene procese kao posljedice pograničavanja, odnosno militarizacije hrvatskog prostora koja se očitovala $u$ porastu stanovništva uključenog u ratne aktivnosti i uzdizanjem krajiške upravne strukture nad tradicionalnom civilnom strukturom - $\mathrm{u}$ ovom slučaju bihaćkom gradskom općinom. Nakon prikaza razvoja, statusa $\mathrm{i}$ dostupnih podataka o pripadnicima gradske općine $\mathrm{u}$ promatranom periodu, prezentirao sam dinamiku suodnosa civilnih i vojnih vlasti, demografsku problematiku Bihaća, odnosno pitanje broja stanovnika, poziciju Bihaća u kontekstu velikih migracija stanovništva na pograničju i prema unutrašnjosti uključujući i uskočka kretanja. Na kraju sam istražio kako i odakle se prehranjivalo bihaćko stanovništvo, kako je uređen opskrbni sustav te odakle su i kojim komunikacijama pristizale namirnice za gradsku vojnu posadu. 
Budući da je hrvatsko pograničje bilo dio protuosmanskoga defenzivnog sustava na širem europskom prostoru te da je Bihać bio najvažniji grad na hrvatskom pograničju, vjerujem da će istraživanje navedene problematike biti relevantno i na široj regionalnoj/europskoj razini. Protuosmanski napor prije svega je zajednički regionalni pothvat stoga istraživanje tema poput ove implicira aplikaciju širega međunarodnog rakursa, što otvara prostor za precizniju kontekstualizaciju položaja hrvatskih zemalja u onodobnome međunarodnom kontekstu. Također, istraživanje razvoja Bihaćke kapetanije kao pogranične vojne institucije, a zatim i transformacija koje su zahvatile društvo jednog grada na pograničju može biti relevantno i u kontekstu znanstvene discipline „studija granica“ koja postaje sve aktualnija u današnjem svijetu, opterećenom geoplitikom, klimatskim promjenama i ekstenzivnim migracijama.

Ključne riječi: Bihać, Bihaćka kapetanija, slobodni kraljevski grad, Hrvatska, Habsburška Monarhija, Osmansko Carstvo, 16. stoljeće, Unutrašnja Austrija, Kranjska, krajina 


\section{SUMMARY}

Prior to the Ottoman conquest in 1592, the free royal city of Bihać was one of the most important urban, and therefore, socio-political centres in the Croatian territory. Extremely well positioned on the communication that connected the Adriatic and Pannonian area, located along the Una River, protected by the mountains, well populated and fortified, Bihać very soon became one of the most important military centres within the context of the conflict with the Ottoman Empire. The process of transformation of Bihać into one of the antiOttoman defence centres began decades before the Habsburg dynasty claimed the HungarianCroatian throne in $1526 / 1527$. This process would eventually culminate after 1527 , when the city became the headquarters of the Bihać captaincy, a rallying place on the Croatian border and a key defensive location for the security of the Croatian and the lands of Inner Austria primary Carniola.

The free royal city of Bihać continued to function with its traditional administrative structure, but now in a very different context. The ever increasing Ottoman expansion and the formation of the border captaincy as a response to that expansion finally led to the subordination of the city's civil administrative structure to the administration of the border captaincy - upon which the city's defence eventually depended.

In the first part of the dissertation I will present the context of the creation of the Bihać captaincy, its territorial development, changes in strategic importance through the observed period, the number and characteristics of the paid soldiers that made the city's garrison and military units sent as reinforcement, the characteristics and changes in the fortification infrastructure of the city. Special chapter is dedicated to the Bihać's captains and senior officers who were part of the city's garrison. I will also address the problem of transport and storage of weapons and equipment in the city, as well as the relevance of Bihać for intelligence, guarding and postal networks within the anti-Ottoman border context.

In the second part of the dissertation I will focus on certain social processes which occurred as the consequence of the militarization of the Croatian territory, which are reflected in the increase of the population involved in war activities and the elevation of the military border administrative structure over the traditional civil structure one - in this case, Bihać's city municipality. After presenting the position, status and available information about the members of the city's social and administrative structure during the observed period, I will present the dynamics of the relations between civil and military authorities, the demographic issues of Bihać, i.e. the issue of the number of inhabitants, the position of Bihać within the 
context of the large population movements on the border and towards the interior. In the end I will research how and form where did the population of Bihać ensure its sustenance, how did the supply system function and by which transport routes were the supplies for the military garrison brought into the city.

Since the Croatian border was one of the sections of the anti-Ottoman defensive system in the wider European area, and Bihać was most important city on the Croatian border, I believe that this research will be relevant on a wider regional/European level. The antiOttoman effort is primarily a joint regional venture and the addressing of topics such as the aforementioned, implies the appliance of the wider international perspective, which opens the scope/space for a more precise contextualization of the position of Croatian countries in the contemporary international context. Also, exploring the development of the Bihać captaincy as a border military institution, and then the transformations that affected the society of a specific border city can be relevant within the context of the scientific discipline of the "border study", which, in today's world burdened with geopolitical, climate and migratory issues, could become all the more relevant.

Keywords: Bihać, Bihać captaincy, free royal city, Croatia, Habsburg Monarchy, Ottoman Empire, 16th century, Inner Austria, Carniola, Border 


\section{SADRŽAJ}

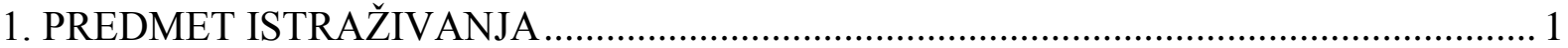

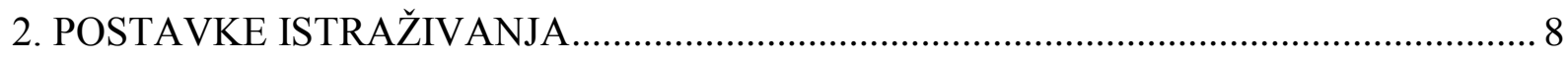

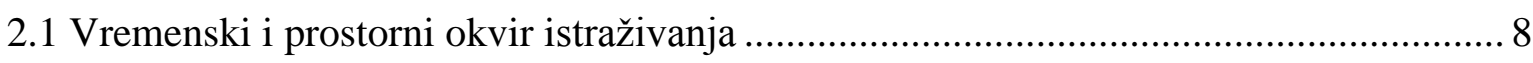

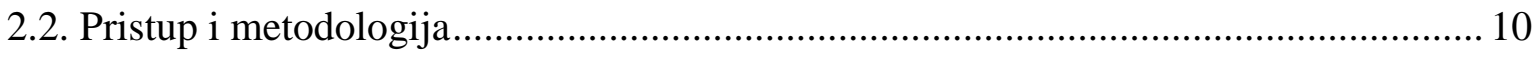

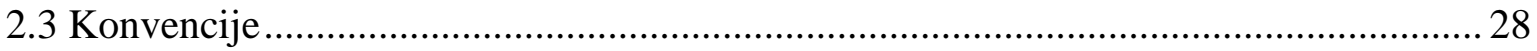

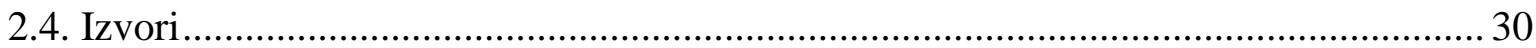

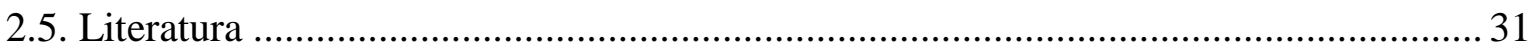

3. RAZVOJ KRAJIŠKOG SUSTAVA - NASTANAK I RAZVOJ BIHAĆKE KAPETANIJE 35

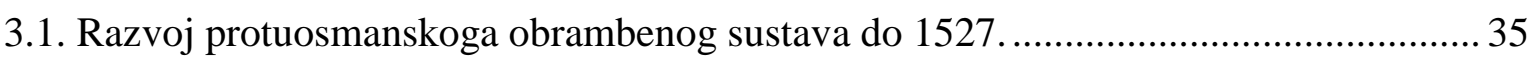

3.2. Razvoj protuosmanskoga obrambenog sustava nakon 1527 .................................... 41

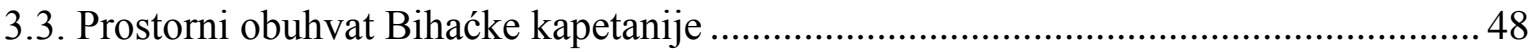

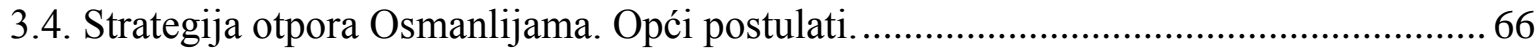

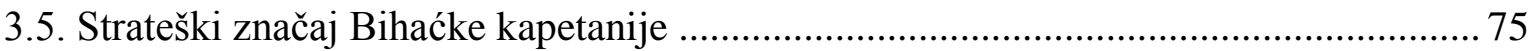

3.5.1. Strateški položaj Bihaća i Bihaćke kapetanije s obzirom na osmansko

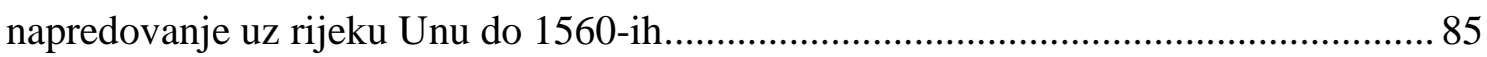

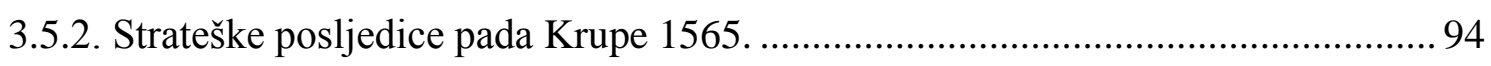

3.5.3. Nastavak osmanskog napredovanja uz rijeku Unu ........................................... 99

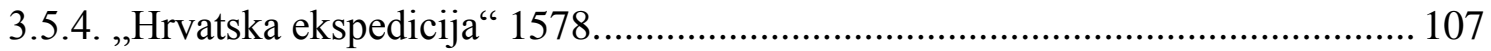

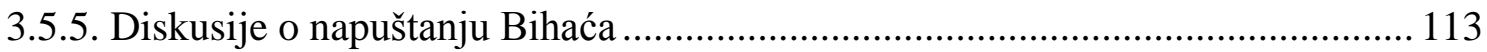

3.5.6. Osmanska kolonizacija Krbave i Like te posljedice za Bihaćku kapetaniju....... 119

3.5.7. Početak kraja i kontroverzno osmansko osvajanje Bihaća ................................. 124

4. BROJNOST I KARAKTERISTIKE VOJSKE NA PODRUČJU BIHAĆKE KAPETANIJE

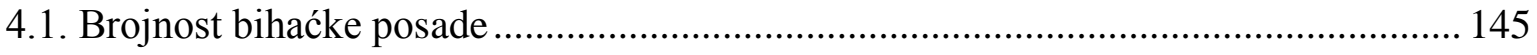

4.2. Karakteristike vojnih rodova u sastavu bihaćke posade .......................................... 161

4.3. Vojne postrojbe slane u pomoć obrani Bihaća i Bihaćke kapetanije ........................ 170

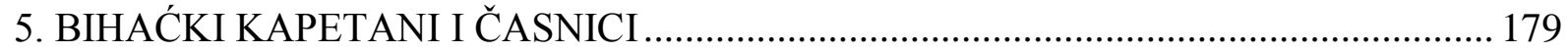

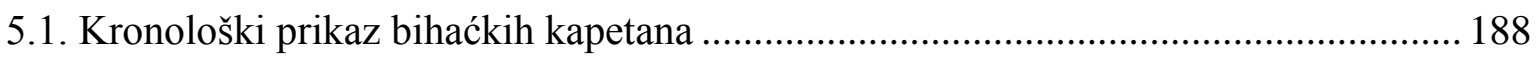

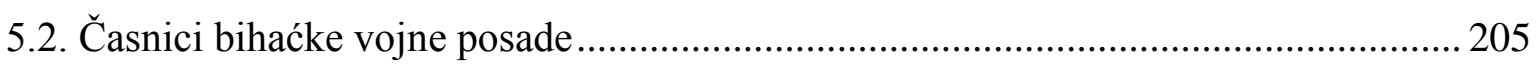

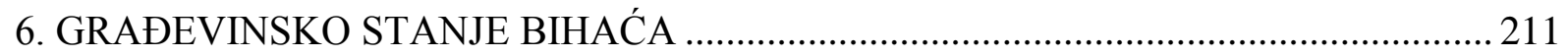

7. SKLADIŠTENJE ORUŽJA I VOJNE OPREME U BIHAĆU ........................................ 237 
8.1. Razvoj obavještajnog sustava Bihaćke kapetanije ................................................... 259

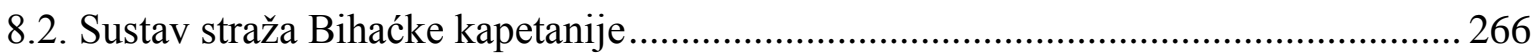

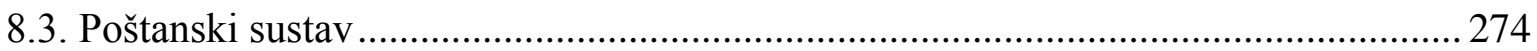

9. SLOBODNI KRALJEVSKI GRAD BIHAĆ NA POGRANIČJU .................................... 280

9.1. Srednjovjekovno nasljeđe - ustroj i promijene ........................................................ 280

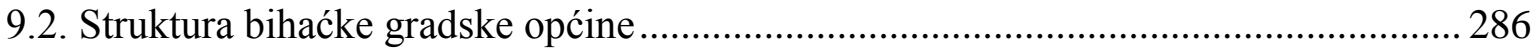

9.3. Unutrašnje napetosti u pograničnom gradu. Civilna i vojna vlast $u$ „klinču“ ............ 294

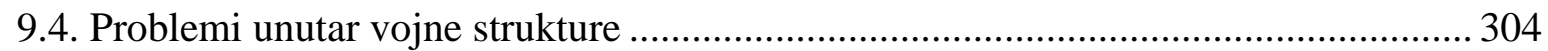

10. DEMOGRAFSKI KONTEKST POGRANIČNOGA GRADA....................................... 316

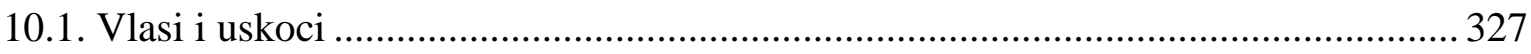

11. ŽIVOT NA ISTURENOM POGRANIČJU - „BOG NAM JE SVJEDOK, DA MI DALJE

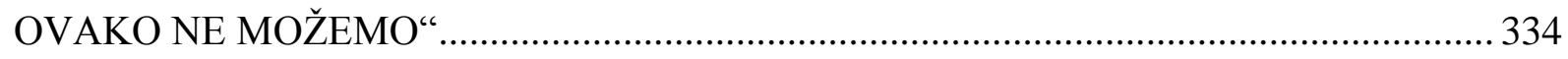

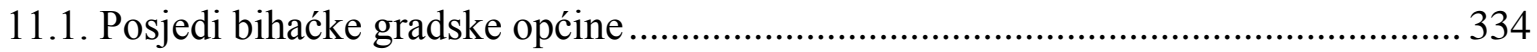

11.2. Trgovinska aktivnost bihaćke gradske općine ....................................................... 341

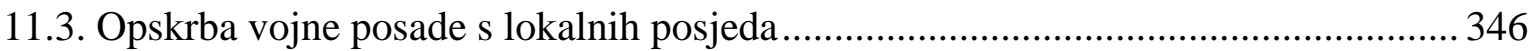

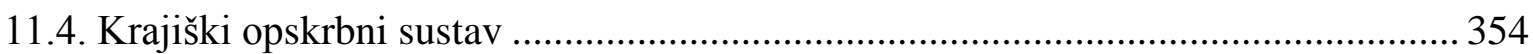

11.5. Ključna opskrbna ruta - „Wyhitscherin Reiss“ ili „,Beglaitung“ “.............................. 362

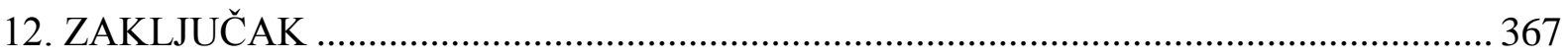

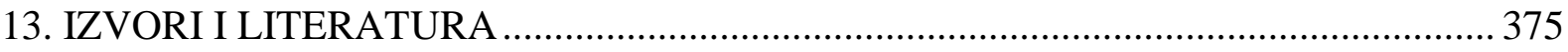

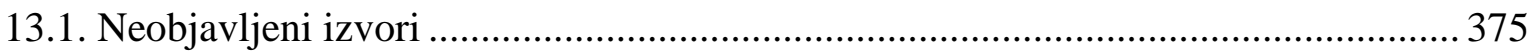

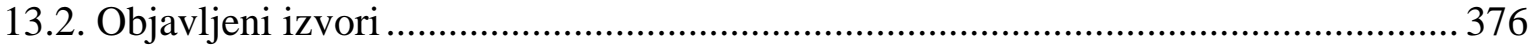

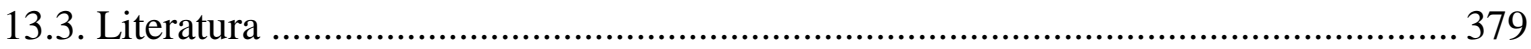

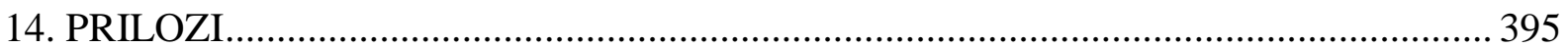

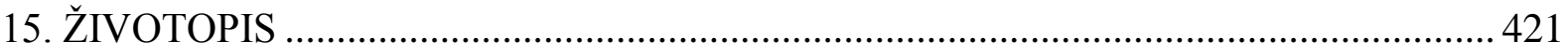




\section{PREDMET ISTRAŽIVANJA}

Ova disertacija proizvod je želje i znanstvene potrebe da se analizira uloga slobodnoga kraljevskoga grada Bihaća i Bihaćke kapetanije u burnom periodu od dolaska dinastije Habsburg na ugarsko-hrvatsko prijestolje 1527. pa do pada grada pod osmansku vlast u lipnju 1592. ${ }^{1}$

Polazišna hipoteza koju sam nastojao dokazati jest da je Bihać u promatranom razdoblju neuralgična točka obrane cijele Hrvatske krajine, a samim time i ostataka Hrvatskoslavonskog Kraljevstva ${ }^{2}$ te zemalja Unutrašnje Austrije, prije svega Kranjske. Iako se u historiografiji često navodi da je zborno mjesto hrvatskog pograničja Senj, smatram da je, barem do podizanja Karlovca 1579., Bihać u najmanju ruku jednako važan, ako ne i važniji. Povoljni geografski položaj, srednjovjekovno urbano i političko nasljeđe te demografski potencijal predstavljali su ključne faktore promocije Bihaća u centralnu točku hrvatskoga krajišta. Prominentni krajiški status, koji je Bihać baštinio barem od druge polovice 15 . stoljeća, grad će zadržati sve do kraja 1570-ih kada će njegovu stratešku važnost izmijeniti osmanska osvajanja u Pounju te podizanje Karlovca. No, bez obzira na proces degradacije u strateškom, materijalnom pa i društvenom pogledu, Bihać će sve do pada pod osmansku vlast u lipnju 1592. i dalje ostati jedno od najvažnijih uporišta protuosmanskoga obrambenog sustava i shodno tome adekvatno branjen iako je obrana Bihaća i bihaćkom kapetanu podređenih utvrda iziskivala golem financijski, organizacijski, logistički i u konačnici, a to je uvijek nužno apostrofirati, ljudski napor.

Dakle, ovim radom nastojao sam predstaviti razvojni put Bihaća od jednog od najvažnijih središta hrvatskog srednjovjekovlja do perifernog i opkoljenoga grada na čijoj se obrani i dalje ustraje zbog geostrateškog položaja i baštinjenog prestiža. Figurativno rečeno, trudio sam se prezentirati desetljećima dug proces transformacije Bihaća od metropole (metropolis) i glave (caput) Hrvatske, odnosno od ,izuzetnog ključa kršćanstva“33 pa do

\footnotetext{
${ }^{1}$ Habsburgovce navodim kao ugarsko-hrvatske kraljeve iako do kraja 1530-ih njihovo pravo na ugarskohrvatsku krunu osporava protukralj, erdeljski vojvoda Ivan Zapolja kojeg, između ostalog, podržavaju i Osmanlije. Zapolja je imao mnogo pristalica na području Kraljevine Slavonije dok su njegovi glavni privrženici na prostoru Kraljevine Hrvatske najmoćniji hrvatski velikaši tog doba - Krsto i njegov otac Bernardin Frankopan.

${ }^{2}$ Sredinom 16. stoljeća Hrvatsko Kraljevstvo i Slavonsko Kraljevstvo napokon će srasti u jedan sociopolitički organizam iako su u ranijem periodu, bez obzira na mnoštvo međusobnih poveznica, predstavljala dva zasebna politička, a u nekim segmentima i društvena entiteta.

${ }^{3}$ „treffenlichen Schlussl der Cristennhait" navodi se u jednom spisu iz listopada 1543. HR-HDA-913, Zbirka preslika na papiru, Zbirka preslika vojnih spisa iz Štajerskog zemaljskog arhiva u Grazu, Militaria, kutija 2, str. 185. (Dalje HDA, Militaria).
} 
„siromašne, jadne, trošne i raspadnute utvrde“ koja je smještena daleko na isturenom pograničju. $^{4}$

Sama disertacija podijeljena je u dva glavna dijela. U prvom dijelu predstavio sam proces formiranja Bihaćke kapetanije dok sam u drugom dijelu disertacije nastojao prikazati društvene posljedice formiranja krajiškog/kapetanijskog sustava, odnosno sve intenzivnije militarizacije grada. U prvom dijelu disertacije pokušao sam odgovoriti na osnovno istraživačko pitanje - kakva je bila uloga Bihaća, odnosno Bihaćke kapetanije u procesu ustrojavanja habsburškoga kapetanijskog sustava na Hrvatskoj krajini od 1527. do 1592. Zato se u teorijsko-metodološkom smislu prvi dio disertacije može percipirati kao tradicionalniji dio koji je više usmjeren prema institucionalnoj krajiškoj povijesti. No, iako je okvir možda tradicionalniji, ipak sam nastojao proširiti istraživački rakurs obrađujući teme poput sastava zapovjednoga kadra, kompozicije vojske, strategije ratovanja, stanja fortifikacija i opskrbnog sustava itd., čime neizbježna vojna/ratna tematika postaje dio širega društvenog konteksta.

U drugom dijelu disertacije nastojao sam prikazati društvene posljedice formiranja krajiškog/kapetanijskog sustava, odnosno militarizacije referentnog prostora - odnose između vojnih i civilnih vlasti, napetosti unutar krajiške strukture, migracije te problematiku osiguravnja hrane i opskrbe na krajištu. Iako su korišteni izvori uglavnom vojne provenijencije, formalizirani i tipski, njihovi autori često izravno i neizravno referiraju na razne društvene fenomene pograničja. Drugačije nije ni moglo biti jer je rat dominantna transformacijska sila ugarsko-hrvatskog prostora $\mathrm{u}$ promatranom periodu, pa je iz mnogobrojnih vojnih izvora metodom sita moguće izvući velik broj podataka o različitim društvenim aspektima pograničja.

Slobodni kraljevski grad Bihać (u izvorima apostrofiran i kao „kuća cesarove svitlosti“(55) predstavljao je jedno od najvažnijih urbanih središta hrvatskog srednjovjekovlja. Smješten u plodnoj Bihaćkoj dolini na razmeđu panonskog, mediteranskog i dinarskoga geografskokulturnog areala, pozicioniran uz tzv. Kraljevsku ili Vojnu cestu (via exercitualis, via exercitus, via Colomani regis, magna via), prastaru prometnu vertikalu koja je spajala

\footnotetext{
${ }^{4}$ Arhiv Republike Slovenije, Deželni stanovi za Kranjsko, kutija 287, fascikl 164, Bihać, 16.2.1576, 1r, rbr. 487. Kapetan Sebastian Lamberg na Herbarta Auersperga i Jobsta Josepha Thurna. (Dalje SI AS 2, DSK).

${ }^{5}$ Radoslav LOPAŠIĆ, Bihać i Bihaćka krajina, Matica Hrvatska, Zagreb, 1890, 80.
} 
jadranski i panonski prostor, a koja je dobrim dijelom pratila tok rijeke Une ${ }^{6}$, Bihać je za onodobno hrvatsko zaleđe predstavljao prvorazrednu sociopolitičku lokaciju. ${ }^{7}$ Naime, na potezu od Knina do Gradeca u razvijenome srednjem vijeku nije postojalo urbano naselje ekvivalentnog statusa. ${ }^{8}$ Doduše, na vlastelinskim posjedima formirana su prosperitetna urbana središta, poput Modruša ili Steničnjaka, no ona nisu zadobila pravni, pa onda ni sociopolitički status kakav je imao Bihać. No, budući da kasnosrednjovjekovni period razvoja Bihaća još uvijek nije adekvatno istražen te da je u fokusu disertacije kasniji temporalni odsječak, ovaj segment bihaćke povijesti nužno će ostati preglednog karaktera jer bi u protivnom postojala opasnost od preopterećivanja cijelog rada.

Iako se u izvorima prvi puta spominje tek 1260, bihaćko naselje nedvojbeno je (mnogo) starije. ${ }^{9}$ Jasan indikator toga je privilegij o proglašenju slobodnim kraljevskim gradom iz 1262. u kojem se spominju neke već postojeće povlastice, a i tada dobivene ekstenzivne privilegije pokazuju da je tamo već postojalo (proto)urbano naselje razvijenijeg stupnja. Na temelju razreza poreza ,zemljarine“ (terragium) Mladen Ančić izračunao je da je već 1262 . u Bihaću moralo biti najmanje 150 kuća! ${ }^{10}$ Takva koncentracija kuća sugerira da se ne radi o naselju (sasvim) recentnog postanka. ${ }^{11}$ No, bez obzira na mutne početke, na važnost Bihaća upućuje i činjenica da su spomenutim privilegijem Bišćanima dodijeljena i neka

\footnotetext{
${ }^{6}$ O Kraljevskoj ili Vojničkoj cesti biti će riječi dalje u tekstu, pa je ovdje dovoljno navesti da je polazila od Zadra (ili u nekim varijantama Splita), a zatim preko Ravnih kotara, Knina, uzduž rijeke Une, pa preko Bihaća, Topuskog, Zagreba, Koprivnice ulazila u ugarski prostor.

${ }^{7}$ Opisujući misiju zagrebačkog biskupa Pavla Karlu Dračkom u Italiju, poznati ranonovovjekovni historiograf Juraj Rattkay navodi da se na jadranskoj obali „diže primorski grad Senj, utvrda na visokoj stijeni, po nekim metropola Dalmacije, po drugima pak Hrvatske; oni koji tvrde da je Senj u Dalmaciji, hoće da bi metropola Hrvatske bio Bihać.“ Juraj RATTKAY, Spomen na kraljeve i banove Kraljevstva Dalmacije, Hrvatske $i$ Slavonije, Hrvatski institut za povijest, Zagreb, 2001., 174. Stjepan Brodarić pak navodi: „Glavni grad Slavonije je Zagreb, a Hrvatske Bihać (Bichygium), dok je ranije bio Knin (Tininium). Stjepan BRODARIĆ, Mohačka bitka 1526, Dukat, Vinkovci, 1990., 25.

${ }^{8}$ Pitanje davanja određenih kraljevskih privilegija kninskoj varoši ostaje otvoreno. Vidi Mladen ANČIĆ, Knin u razvijenom i kasnom srednjem vijeku, Radovi Zavoda za povijesne znanosti HAZU u Zadru, sv. 38, 1996., 5395 .

${ }^{9}$ Prema narodnoj predaji, Bihać i Senj gradile su Bika i Seka, kćeri stanovitog „velmože“. Narodna pjesma spominje da ga je s Karlovcem sagradio Ivan Karlović dok hrvatski kroničar Ivan Tomašić navodi da je grad osnovan 1205. LOPAŠIĆ, Bihać, 42. Nadalje, Lopašić donosi narodnu predaju prema kojoj je sva zemlja do rijeke Vrbasa bila u posjedu Crne kraljice koja je stolovala u Bihaću i borila se protiv Osmanlija. Kada su Osmanlije prevladali i zauzeli grad, otišla je preko mora. IBID., 2. Predaja o Biki i Seki, odnosno o Bihaću i Senju, pokazuje važnost i međusobnu vezu tih dvaju gradova, ujedno i glavnih kapetanijskih središta na hrvatskom prostoru.

${ }^{10}$ Bišćani su plaćali paušalni iznos od 15 maraka, a uobičajeni iznos po „vratima“ za slavonske varoši (!) iznosio je između 12 i 20 denara. Jedna marka vrijedila je 200 denara. Mladen ANČIĆ, Bihaćki kraj od 1262. do početka XV stoljeća, Glasnik arhiva i Društva arhivskih radnika Bosne i Hercegovine, god. 25, 1985., 205.

${ }^{11}$ Doduše, moglo se raditi o naselju formiranom nakon tatarskih pustošenja na poticaj centralne vlasti ciljanim okupljanjem raspršenoga lokalnog pučanstva i novih kolonista, no to su tek pretpostavke koje bi trebalo potvrditi. Madžarski povjesničar István Petrovics navodi da je kralj Bela IV. poticao razvoj gradova na ugarskom prostoru nakon provale Tatara primarno da bi zaštitio stanovništvo u slučaju nove provale, a ne da bi ojačao gradove u ekonomskom smislu. István PETROVICS, King Matthias and the Towns of the Realm, Analele Banatului, serie nouă. Arheologien. Istorie, XXI, 2013., 284.
} 
specifična prava - prije svega potpuno izuzeće od vlasti bana i izuzeće od dužnosti ukonačivanja bilo koga osim samog kralja. S iznimkom Virovitice, i to kroz kraći period, takav privilegij nije imao niti jedan drugi grad na hrvatsko-slavonskom prostoru. ${ }^{12}$ Tako široko impostirane povlastice pokazuju da je središnja kraljevska vlast nastojala pretvoriti Bihać u snažno uporište neovisno o bilo čijoj vlasti (uključujući i bansku) osim kraljevske. Taj inicijalni impuls omogućio je društveno uzdizanje Bihaća koji u razvijenome srednjem vijeku postaje važna strateška točka za intervencije središnje vlasti na prostoru Hrvatskoga Kraljevstva. To se osobito manifestiralo prilikom konfrontacija središnje vlasti s hrvatskim velikašima i plemstvom 1320-ih i 1330-ih kada je Bihać u nekoliko navrata zborno mjesto okupljanja kraljevske vojske. U tom se kontekstu središnjoj vlasti posjedovanje utvrda uzduž rijeke Une nametalo kao preduvjet efikasnog prodora prema jugu. I stoljeće kasnije, 1430-ih, prvi korak bana Matka Talovca u borbi za preuzimanje Nelipićevih dobara upravo je ovladavanje Humljanima i Ripčem, plemenom i utvrdom u neposrednoj blizini Bihaća. ${ }^{13}$

Kronološki promatrano, izuzevši vrlo kratku epizodu bosanske vlasti na prijelazu iz 14. u 15. stoljeće, Bihać je sasvim neovisnim ostao punih 148 godina, sve do 1410. kada ga je kralj Žigmund Luksemburški zbog akutnih financijskih problema zajedno sa Sokolom i Ripčem založio zagrebačkom županu Pavlu Čuporu i njegovu bratu Stjepanu za svotu od 6 000 florena. $^{14}$

Unatoč tome, Bihać je jedan od rijetkih gradova na hrvatskom prostoru koji je status slobodnoga kraljevskoga grada sačuvao do u 15. stoljeće. Štoviše, Bišćani nisu bili prisiljeni, kao mnogi drugi, osigurati svoj naslijeđeni pravni položaj povećanim davanjima. ${ }^{15}$ Od dolaska obitelji Čupor započinje novo poglavlje u povijesti grada u kojem je Bihać pod upravom moćnih velikaških obitelji. Tako već 1426. kralj Žigmund za iznos od 28000 forinti zalaže Nikoli Frankopanu Bihać sa Sokolom, Ripčem, Čokom, Rmnjem, Kninom, Labom,

\footnotetext{
${ }^{12}$ Mladen ANČIĆ, Bihać - slobodna kraljevska varoš, Istorijski zbornik, Univerzitet »Đuro Pucar Stari« Banjaluka, Institut za istoriju u Banjaluci, IV/4, 1983., 129. Bihać je u upravnom pogledu ranije pripadao Hrvatskoj, odnosno Psetskoj županiji, ali se od početka 14. stoljeća navodi kao dio Zagrebačke županije. Krajem 15. stoljeća Kraljevski sud u Bihaću određen je da rješava jednu parnicu između obitelji Milutinić od plemena Kulišića i franjevačkog samostana sv. Ivana kod Skradina, ali su Milutinići tražili da se prema starom običaju Kraljevine Hrvatske postupak održi u Lučkoj županiji, a ne u Bihaću koji se nalazi u Zagrebačkoj županiji. LOPAŠIĆ, Bihać, 50.

${ }^{13}$ Ivan BOTICA, Krbavski knezovi u srednjem vijeku, doktorska disertacija, Filozofski fakultet Sveučilišta u Zagrebu, Zagreb, 2011., 206. Za okupljanje vojske i ovladavanje unskim prostorom vidi IBID. 66-67; 96-97; 148.

${ }_{14}^{14}$ ANČIĆ, Bihaćki kraj, 193; Lajos THALLÓCZY, Sandor HORVÁTH, Also-Szlavoniai Okmanytar (Dubica, Orbasz es Szana Varmegyek) 1244.-1719., Codex diplomaticus partium regno Hungariae adnexarum, Monumenta Hungariae Historica, Diplomataria, vol. XXXVI, Budimpešta, 1912., dok. II, 321-322.; Zrinka NIKOLIĆ, Obitelj Čupor Moslavački, Radovi Zavoda za znanstvenoistraživački i umjetnički rad u Bjelovaru, br. 4, 2011., 285.

${ }^{15}$ ANČIĆ, Bihaćki kraj, 204.
} 
Vrlikom, Ostrovicom, Skradinom, Lučkom županijom, Bužanama, Poljicama te svim kraljevskim Vlasima u Hrvatskoj. ${ }^{16}$ Osam godina kasnije kralj Žigmund poklanja grad Stjepanu Frankopanu. ${ }^{17}$ Međutim, pitanje je da li su Čupori, pa onda i Frankopani, imali upravu nad cijelim gradom, uključujući i kaštel, ili samo nad njegovim gradskim dijelom varoši. Lopašić navodi da je prilikom diobe Frankopanskih imanja 1449. varoš (oppidum) Bihać, uza Sokol, pripala knezu Bartolu. ${ }^{18}$ Ovo pitanje ipak tematski i kronološki izlazi iz okvira ovoga rada te zahtijeva zasebno istraživanje.

Budući da se do sada nitko, osim često citiranog Radoslava Lopašića, nije pobliže bavio ovim periodom povijesti grada, potrebno je suzdržano procjenjivati kakve je implikacije po status gradske općine mogla imati podređenost moćnim hrvatskim velikašima i kasnije banovima. Ne treba automatski pretpostavljati da su se Čupori, Frankopani, zatim Ivaniš Korvin, pa i banovi poput Lászla Egervárija, Andrása Bothe itd. nužno neprijateljski odnosili prema bihaćkoj gradskoj općini jer je i njima vjerojatno bilo u interesu posjedovati gospodarski i trgovački prosperitetne urbane centre.

Bihać je u posjedu obitelji Frankopan ostao do pristajanja uz cara Svetog Rimskog Carstva Njemačke Narodnosti Maksimilijana I. prilikom sukoba s ugarsko-hrvatskim kraljem Vladislavom II. Jagelovićem početkom 1490-ih zbog čega ga je napao i zauzeo ban László Egervári. Otprilike između proljeća 1490. i 21. kolovoza 1491. kralj Vladislav II. zalaže Bihać banu Egerváriju kao naknadu za 12000 florena duga. U Egervárijevim rukama grad ostaje do siječnja ili veljače 1493. kada ga na zahtjev kralja mijenja za neke posjede u županiji Fejér. ${ }^{19}$ Nakon smirivanja sukoba i potpisivanja ugovora o nasljeđivanju između dviju vladajućih dinastija Bihać je opet u posjedu Frankopana iako Neven Budak ne isključuje ni mogućnost određenoga kondominija. ${ }^{20}$

Ubrzo je grad, kao dio miraza Beatrice Frankopan, došao u ruke njezina supruga, hercega Ivaniša Korvina. ${ }^{21}$ Nakon Korvine smrti 1505. Bihać je u vlasništvu Beatrice Frankopan do udaje za drugog supruga Georga markgrofa od Brandenburga, a već 1509.

\footnotetext{
${ }^{16}$ BOTICA, Krbavski knezovi, 198.

${ }_{17}^{17}$ Neven BUDAK, Uloga Bihaćke komune u obrani granice, Historijski zbornik, XLII, 1989., 165.

${ }^{18}$ LOPAŠIĆ, Bihać, 272-273.

19 Arpad NOGRADY, A List of Ransom for Ottoman Captives Imprisoned in Croatian Castles (1492), u: Ransom Slavery along the Ottoman Borders, (Early Fifteenth - Early Eighteenth Centuries), ur. Geza David i Pal Fodor, Brill, Leiden-Boston, 2007., 31; THALLÓCZY, HORVÁTH, Also-Szlavoniai, dok. CLI, $246-248$.

${ }^{20}$ BUDAK, Uloga Bihaćke, 165.

${ }^{21}$ Ivaniš Korvin i njegova supruga Beatrice često su boravili u Bihaću gdje im se 1499. rodio i sin Kristofor (Krsto). Vjekoslav KLAIĆ, Povijest Hrvata, knjiga 4, Zagreb, 1975., 254-255. Između ostalih, i bosanski sandžakbeg Skender paša Mihaloğlu poslao je poslanstvo i darove na Kristoforovo krštenje. Ivan KUKULJEVIĆ SAKCINSKI, Beatrice Frankapan i njezin rod, pretisak iz Vijenca, Zagreb, 1885., 25.
} 
stekao ga je tadašnji ban András Botha. Tri godine kasnije Bothina udovica predaje grad novom banu Emeriku Perenyju. ${ }^{22}$

Dakle, neposredno prije formiranja habsburške kapetanije Bihać je usko povezan sa službom bana. Uz navedene banove, odavde je svojim aktivnostima rukovodio i proslavljeni hrvatski ban Petar Berislavić za kojeg i Ivan Tonko Mrnavić navodi da je boravio „pak najčešće u Bihaću, hrvatskom sjedištu na rijeci Uni, odakle je kao na dlanu mogao nagledati sve opasne situacije i u nuždi priteći u pomoć““. ${ }^{23}$ Nakon dolaska dinastije Habsburg na ugarsko-hrvatsko prijestolje 1527. grad je prešao iz neposredne banske uprave u ruke bihaćkog kapetana. Iako su Frankopani još desetljećima imali pretenzije na grad, ta je težnja ostala tek nerealizirana ambicija. ${ }^{24}$

Što se sociopolitičkog konteksta tiče, sve do druge polovice 15. stoljeća Bihać je još uvijek relativno siguran i zaštićen grad, odnosno važno vojno-političko središte u kojem stoluju banovi, ali i u kojem se povremeno održavaju hrvatski sabori pa se u izvorima navodi kao „glava“ i „metropola Hrvatske“ (caput Croatiae, metropolis Croatiae). Stoga nije iznenađujuće da se Bihać već od druge polovice 15. stoljeća pretvara u središte jednog odsječka protuosmanskoga obrambenog sustava, a o čemu će biti riječi dalje u tekstu. U opisu geografske karte hrvatsko-slavonske krajine iz 1581., koju je papinski nuncij u Grazu poslao državnom tajniku u Vatikanu, navodi se tako da je Bihać „,najstarija naseobina i prva granica prema Carigradu“. 25

Eskalacijom sukoba s Osmanlijama u prvim desetljećima 16. stoljeća te dolaskom Ferdinanda Habsburškog na ugarsko-hrvatsko prijestolje 1527. započinje proces formiranja habsburškoga krajiškog sustava. Njegove uporišne točke na hrvatskom prostoru bile su Senj, Klis te, naravno, Bihać. ${ }^{26}$ Čak i u dramatičnom 16. stoljeću Bihać i njemu gravitirajući unski prostor još su dugo relativna zona sigurnosti. Štoviše, prostor oko Bihaća svojevrsna je demografska oaza na Hrvatskoj krajini u kojoj se još dugo zadržala određena staleška infrastruktura, pa se na hrvatsko-slavonskom saboru još 1570. navodi da hrvatski staleži obitavaju u pojedinim krajevima na prostoru nekadašnje Zagrebačke županije južno od Kupe

\footnotetext{
${ }^{22}$ BUDAK, Uloga Bihaćke, 165; LOPAŠIĆ, Bihać, 48-49.

${ }^{23}$ Ivan Tonko MRNAVIĆ, Životopis Petra Berislavića, Hrvatski institut za povijest, Muzej grada Trogira, Zagreb-Trogir, 2008., 11.

${ }^{24}$ Franjo Frankopan Slunjski navodno još 1555. u jednom pismu upućenom kralju Ferdinandu navodi da je Bihać njegov grad. LOPAŠIĆ, Bihać, 51.

${ }^{25}$ Karlo HORVAT, Prilozi za hrvatsku povijest iz arhiva rimskih, Starine, JAZU, knjiga 34, 1913., dok. 5, 73.

${ }^{26}$ Iako je Jajce bilo izrazito važna protuosmanska utvrda, tada je već u potpunom okruženju i vrlo će brzo potpasti pod osmansku vlast. Jajce se uostalom nalazilo na bosanskom, a ne hrvatskom prostoru.
} 
te oko Bihaća i Ripča. ${ }^{27}$ U burnim desetljećima 16. stoljeća Bihać će zadržati istaknutu ulogu sjedišta kapetanije (u izvorima apostrofiran kao „glavna krajiška utvrda“ Haubtortfleckhen $^{28}$ ) i obrambenog središta Hrvatske krajine. Ipak, važnost Bihaća simultano je imala i opterećujući efekt na cjelokupni krajiški sustav jer je za njegovo održavanje trebalo osigurati velika financijska i materijalna sredstva, a o ljudskim gubicima da i ne govorimo.

Osmanlije su uspjeli zauzeti Bihać tek 1592., dakle pri samom kraju dugotrajnog perioda kontinuirane osmanske ekspanzije na hrvatskom prostoru. U promijenjenim okolnostima, s padom gotovo cijelog Pounja i izgradnjom Karlovca u pozadini, izmijenila se i strateška važnost Bihaća. Slikovito rečeno, od stupa obrane on se pretvara u ruševnu nosivu gredu koja više prijeti nego što garantira sigurnost. No, osmanskim zauzimanjem Bihaća nije uslijedio njegov potpuni kraj već samo završetak jednog poglavlja njegove povijesti nakon kojeg je započelo novo povijesno razdoblje, u kojem je ovaj sada osmanski grad i dalje zadržao prominentni status u regionalnome sociopolitičkom kontekstu.

\footnotetext{
${ }^{27}$ Ferdo ŠIŠIĆ, Hrvatski saborski spisi, knjiga III, Monumenta spectantia historiam Slavorum meridionalium, Zagreb, 1916., dok. 266, 290-291.

${ }^{28}$ SI AS 2, DSK, kutija 286, fascikl 164, Ljubljana, 4.12.1577., 1v, rbr. 300. Predstavnici kranjskih staleža na bihaćkog kapetana Sebastiana Lamberga.
} 


\section{POSTAVKE ISTRAŽIVANJA}

\subsection{Vremenski i prostorni okvir istraživanja}

Kao što je navedeno, u fokusu ovog rada je period od dolaska nadvojvode Ferdinanda na ugarsko-hrvatsko prijestolje u siječnju 1527. pa do pada Bihaća pod osmansku vlast u lipnju 1592. Međutim, budući da su periodizacije naknadni kognitivni konstrukt, historiografski mehanizam koji nam omogućava da se nosimo s kompleksnim i teško uhvatljivima povijesnim procesima, vremenski okviri nužno poprimaju manje rigidan karakter. Tako je i u ovom slučaju. Kada je argumentacija zahtijevala izlazak iz zadanih temporalnih okvira, to sam i činio, ali krajnje oprezno, nastojeći da me taj postupak ne odvede predaleko od sukusa istraživanja. Zbog toga sam u raniji period posezao samo kada je to bilo nužno za analizu/interpretaciju određene problematike u referentnom periodu. Takvih temporalnih skokova najviše je drugom dijelu rada jer je nemoguće analizirati društvene posljedice osmanskih osvajanja bez prezentiranja procesa transformacija kasnosrednjovjekovnih obrazaca $u$ nešto dužem vremenskom razdoblju. U razdoblje nakon osmanskog osvajanja Bihaća 1592. zakoračio sam tek nakratko, kako bi referirao na vlašku kolonizaciju unskog prostora.

Prostorni okvir istraživanja definiran je dvojako. U prvom dijelu disertacije on je širi jer je Bihaćka kapetanija bila ustrojena na prostoru koji se danas uvelike poklapa s prostorom Bosanske krajine na teritoriju Republike Bosne i Hercegovine te nekih dijelova Korduna, Banije, Like i Krbave na prostoru Republike Hrvatske. No, geografski prostor, kojeg se ova disertacija u određenoj mjeri dotiče, mnogo je širi te obuhvaća dijelove današnje sjeverne Bosne i Hercegovine, Hrvatskog Primorja, Gorskog kotara, Žumberka, Kranjske pa čak i Koruške, Štajerske, Istre i grofovije Gorice. Razlog tome leži u kompleksnosti formiranja krajiškog sustava te važnosti Bihaća i Bihaćke kapetanije za obranu ostataka Hrvatskoga i Slavonskoga Kraljevstva te zemalja Unutrašnje Austrije (Kranjske, Koruške, Štajerske i grofovije Gorice).

Sam prostor Bihaćke kapetanije omeđivale su Trgovska gora na sjeveru/sjeveroistoku, planina Plješevica prema zapadu pa i jugu, širi slunjski prostor i rijeka Korana prema sjeverozapadu te planina Grmeč prema istoku/jugoistoku. Plješevica i Grmeč funkcionirale su kao izrazito važne prirodne barijere bez kojih bi razvitak Bihaća, odnosno strateško konfiguriranje Bihaćke kapetanije, bilo bitno drugačije. Između njih protječe rijeka Una, koja 
je sve do ulaska u Bihaćku dolinu, a zatim i od izlaska iz Bihaćke doline do današnje Bosanske Krupe, hitra planinska rijeka koja teče kroz dubok klanac da bi se dalje transformirala u sporiju nizinsku rijeku. U središtu toga prirodnog defenzivnog sklopa, $\mathrm{u}$ jednoj plodnoj dolini, smješten je Bihać. ${ }^{29}$

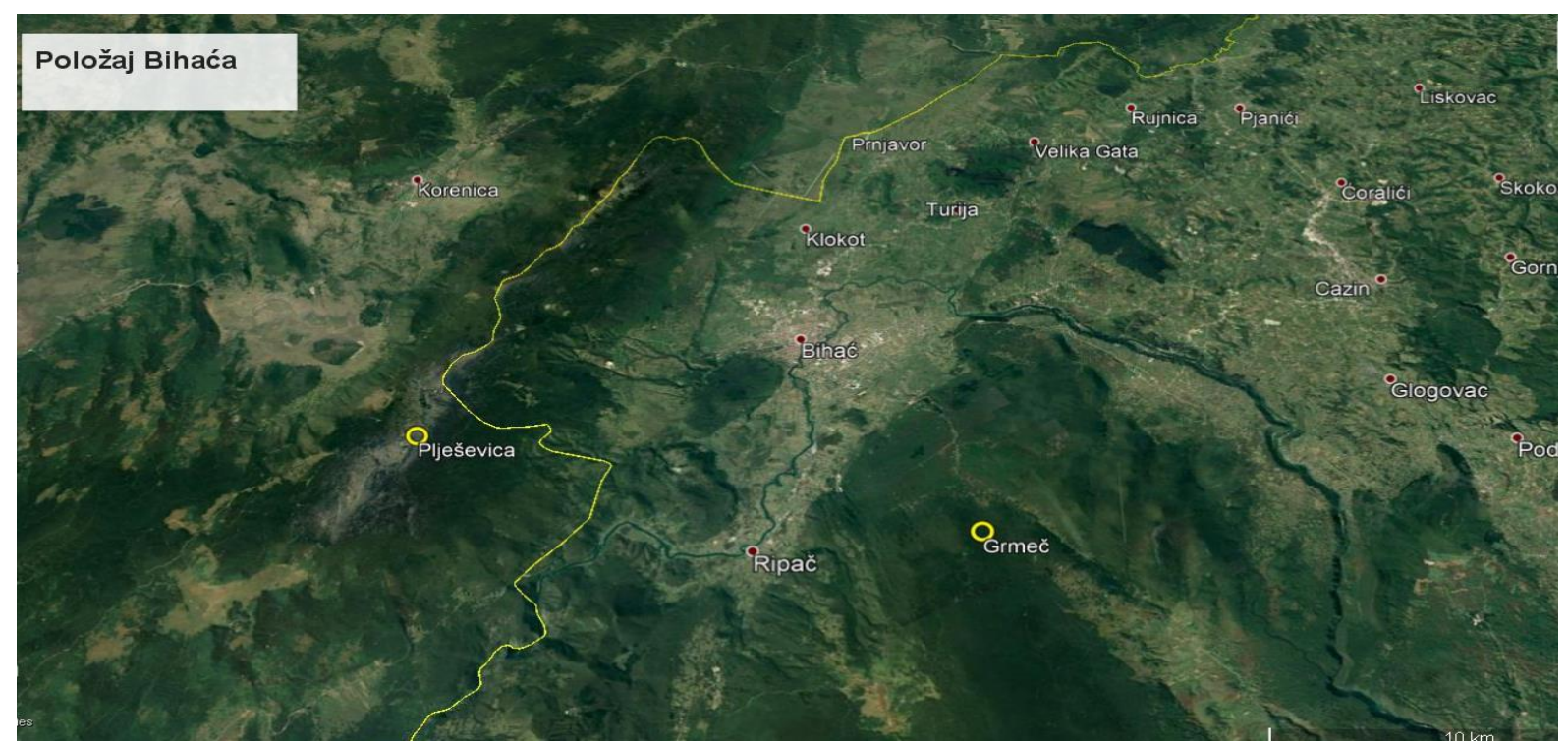

Slika 1. Bihać, pozicioniran uz rijeku Unu između Plješevice i Grmeča. ${ }^{30}$

Navedeni prostor u krajiškom kontekstu sredinom 16. stoljeća predstavljao je centralni dio Hrvatske krajine za koju se u izvorima navodi da od Senja do Siska iznosi 24 njemačke milje dok je distanca između Senja i Bihaća iznosila točno polovicu, odnosno 12 njemačkih milja. ${ }^{31}$ Dakle, u središtu cijelog prostora Hrvatske krajine nalazio se Bihać.

$\mathrm{Na}$ tom prostoru formirana je u višedesetljetnom rasponu Bihaćka kapetanija koja je 1527. brojala tek dvije utvrde, Bihać i Ripač, da bi se do sredine 16. stoljeća taj se broj u jednom trenutku popeo na 24 utvrde koje se u izvorima navode kao kapetaniji/kapetanu

\footnotetext{
${ }^{29} \mathrm{U}$ predosmanskom periodu na promatranom prostoru nalazile su se slavonske županije i hrvatske plemenske župe. Oko obje Kladuše i Peći prostirala se Gorička županija, a oko Vranograča i Bužima Gorska županija. Prostor Tržca na Korani spadao je u Drežničku županiju. Od Krupe prema Bihaću nalazila se Psetska županija, a oko Ripča Humska koja je još 1493. imala svoju administrativnu strukturu sa županom i četiri suca stola Humskog. Južno od Bihaća nalazila se Nebljuška županija, a oko Lapca i Rmnja Lapačka županija. LOPAŠIĆ, Bihać, 13-14.

${ }^{30}$ Većina kartografskih prikaza napravljena je u u programu https://earth.google.com/.

${ }^{31}$ HDA, Militaria, kutija 4, sine dato, čini se iz 1551., str. 242-245.; IBID., sine dato, 1553., str. 13-20. Lenković o stanju na Hrvatskoj krajini. Iako dužina njemačke milje može varirati, kao ogledna dužina uzima se oko 7,5 km. Zlatko HERKOV, Prinosi za poznavanje naših starih mjera za dužinu i površinu, Zbornik Odsjeka za povijesne znanosti Zavoda za povijesne i društvene znanosti Jugoslavenske akademije znanosti i umjetnosti, vol. 8, 1977., 207-208. Prema tome izračunu ukupna bi distanca od Senja do Siska bila oko $180 \mathrm{~km}$ dok bi ona između Senja i Bihaća iznosila oko 90 km. Današnja je cestovna udaljenost između Senja i Bihaća veća, oko 120 $\mathrm{km}$. No, budući da ne znamo kojim principom, odnosno kojim prometnicama se tada određivala, sama distanca manje je bitna, već je važan središnji položaj Bihaća na potezu od Jadranskog mora do Siska.
} 
„uokolo podređene utvrde“ (vmbligenden incorporierten Ortfleckhen). ${ }^{32}$ Prije samog pada Bihaća 1589. ta nekoć prostrana kapetanija svedena je tek na pet utvrda u neposrednom gradskom arealu Bihać, Ripač, Sokol, Izačić i Drežnik. Do opsade Bihaća u lipnju 1592. izgubljeni su i Ripač i Izačić.

Ovdje treba naglasiti da su pojedine utvrde, poput Ripča, Sokola i Izačića, desetljećima usko povezane s obranom Bihaća, odnosno Bihaćke kapetanije, pa je shodno tome i njihova prisutnost u disertaciji veća. Za neke utvrde Bihaćke kapetanije, nije sačuvano dovoljno arhivskoga gradiva što ograničava mogućnost podrobnije obrade njihove pozicije unutar krajiškog sustava, odnosno Bihaćke kapetanije. Druge su utvrde pak tek kratko bile u sastavu Bihaćke kapetanije.

U drugom je dijelu disertacije prostorni obuhvat je uži u poglavljima u kojima je istraživački fokus usmjeren na prostor koji je pripadao ili gravitirao bihaćkoj gradskoj općini. Riječ je o posjedima koji su se uglavnom nalazili unutar gabarita Bihaćke doline, na prostoru od Ripačkog klanca na jugu, između planina Plješevice prema zapadu i Grmeča prema istoku, pa prema Izačiću i Brekovici na sjeverozapadu i sjeveroistoku.

Detaljan prikaz prostornog obujma Bihaćke kapetanije i bihaćke gradske općine nalazi se $u$ odgovarajućim poglavljima dalje u radu. Konačno, bez obzira na teritorijalne diskrepancije, te dvije administrativne strukture bile su neraskidivo povezane pa je zato njihov suodnos jedna od važnijih tema ove doktorske disertacije.

\subsection{Pristup i metodologija}

Budući da je hrvatska ranonovovjekovna povijest prije svega povijest imperijalnih višegraničja, u epistemološkom i metodološkom smislu koncepti „granica“ i „pograničja“ predstavljaju nezaobilazne heurističke alate za njezino istraživanje. Iako se u starijoj historiografiji navedena problematika nije pozicionirala kao zasebni istraživački objekt, pograničja danas predstavljaju sve zanimljiviju istraživačku temu različitih znanstvenih disciplina koje se mogu objediniti pod zajedničkim nazivnikom „studija granica“.

$\mathrm{Na}$ međunarodnoj razini povijest istraživanja granica i pograničja duga je i kompleksna. Granice i pograničja desetljećima su interpretirane kao faktori razdvajanja, barijere koje u realnom i simboličkom pogledu rastavljaju suprotstavljene države, narode,

\footnotetext{
${ }^{32}$ SI AS 2, DSK, kutija 286, fascikl 164, Bihać, 14.11.1574., rbr. 234. Burckhard Saloman na nadvojvodu Karla.
} 
kulture itd. To je osobito isticano pri analizi kontaktnih zona između europskih kolonista i raznih urođeničkih naroda na globalnoj razini. $U$ tako postavljenom ideološkointerpretacijskom okviru granice i pograničja prezentirane su u svojoj najradikalnijoj formi i kao razdjelnica između civilizacije i barbarstva. Takav pristup osobito je došao do izražaja formiranjem prve istraživačke paradigme koja je svoj fokus usmjerila izravno na pograničje, tzv. Frontier Thesis, nastale krajem 19. stoljeća u Sjedinjenim Američkim Državama. ${ }^{33}$

Kada je riječ o europskim granicama i pograničjima, one su analizirane primarno iz geopolitičkog rakursa, s istraživačkim fokusom usmjerenim prema pravnoj i geografskoj tematici. ${ }^{34}$ Europske granice i pograničja nisu bili divlji i prazni prostori koje je trebalo kolonizirati ili „civilizirati“, već se prije svega radilo o imperijalnim kontaktnim zonama koje je trebalo dobro analizirati pa čak i okupirati da bi mogle biti formirane precizne i kompaktne granice. $^{35}$

Međutim, društvene promjene i promjene znanstvenih paradigmi tijekom 20. stoljeća neminovno su utjecale na promjenu percepcije o karakteru i značenju granica i pograničja. $S$ vremenom su istraživanja polako izlazila iz geopolitičkog okvira pa se širio i krug disciplina koje su se u određenoj mjeri bavile proučavanjem granica i pograničja - osobito kada se radilo o problematici države, nacije, suvereniteta, državljanstva, migracija te o kompleksnom pitanju identiteta koji je na pograničnim područjima usko povezan s procesima akulturacije, hibridizacije te multikulturalizmom, postkolonijalizmom itd. ${ }^{36}$

Inspirirana društvenim promjenama druge polovice 20. stoljeća, potaknuta raznim obratima u povijesnoj znanosti, ali i u znanosti općenito, uokvirena globalizirajućim svijetom, znanost o granicama i pograničjima postupno se razvila od početnih uskih binarnih kategorija i redukcionizma prema percepciji granica i pograničja kao prostora u kojima se određena društva sukobljavaju, ali jednako tako susreću i preklapaju. U izmijenjenome

\footnotetext{
${ }^{33}$ Naime, „otac“ te paradigme, američki povjesničar Frederic J. Turner, objavio je 1894. vrlo utjecajan esej „The Significance of Frontier in American History“ u kojem je iznio tezu da je upravo prodor europskih doseljenika na američki Zapad pokrenuo proces formiranja specifičnoga američkog identiteta. Štoviše, prodor europskih doseljenika interpretiran je kao prodor civilizacije u prostor lišen civilizacijskih normi - vlasti, poljoprivrede, gradova, pismenosti, vladavine prava itd. Linda DARLING, The Mediterranean as a Borderland, ROMES, 46, 2012., 54-55.; Pal FODOR, Introduction, u: Ottomans, Hungarians, and Habsburgs in Central Europe. The Military Confines in the Era of Ottoman Conquest, ur. Geza David i Pál Fodor, Brill, Leiden; Boston; Köln, 2000., XI. Tako je stvoren još i danas u Sjedinjenim Američkim Državama popularan mit o posebnosti pa i superiornosti ,,američkog čovjeka“.

${ }^{34}$ Michiel BAUD, Willem van SCHENDEL, Toward a Comparative History of Borderlands, Journal of World History, vol. 8, br. 2, 1997., 212.

${ }^{35}$ Bradley J. PARKER, Lars RODSETH, Introduction. Theoretical Considerations in the Study of Frontiers, u: Untaming the Frontier in Anthropology, Archeology and History, ur. Bradley J. Parker, Lars Rodseth, The University of Arizona Press, Tuscon, 2005., 7.

${ }^{36}$ Thomas M. WILSON, Hastings DONNAN, Borders and Border Studies, u: A Companion to Border Studies, ur. Thomas M. Wilson, Hastings Donnan, Wiley-Blackwell, 2012., 2.
} 
interpretacijskom okviru granice i pograničja prestaju se promatrati isključivo kao prostori separacija, isključivosti i sukoba te ih se počinje percipirati kao kontaktne zone koje mogu, ali i ne moraju biti konfliktne prirode. Iako je u pograničnim ambijentima nasilje česta pojava, u takvim arealima može se odvijati miran i perspektivan suživot. Upravo su pogranične zone često prostori izražene društvene dinamike s intenzivnom kulturološkom, demografskom, političkom, vojnom, komercijalnom razmjenom. ${ }^{37}$ Iako analiziranje separativne funkcije pograničnih prostora nije napušteno, danas se simultano analizira i njihova integrativna funkcija, odnosno problematika kulturnih transfera, heterogenosti, tolerancije te općenito sličnosti i razlike pograničnih društava koje se pojavljuju kao posljedica međusobne interakcije. $^{38}$

U zadnjih dvadesetak godina u SAD-u se pojavila nova interdisciplinarna paradigma Border studies koja se primarno bavi analiziranjem američko-meksičke pogranične zone, ali je uz razne prilagodbe i globalno aplicirana. Ova disciplina promatra pograničje kao prostor u kojem se određena društva susreću i preklapaju, a naglasak se stavlja na integrativnu funkciju prostora. $^{39}$

Razlike u karakteru granica i pograničja odražavaju se i na terminološkoj razini, pa se u konceptualnom pogledu termin frontier najčešće primjenjuje pri analiziranju predmodernih pograničja, nedefiniranih i fluidnijih granica dok je koncept border(lands) uglavnom vezan uz pogranične zone modernih država s jasno zacrtanim granicama. ${ }^{40}$ No, bez obzira na karakter razgraničenja, riječ je o rubnim, kontaktnim prostorima dviju ili više različitih kultura,

\footnotetext{
${ }^{37}$ FODOR, Introduction, XI.

${ }^{38}$ Sve izraženija kritika Turnerova pristupa iznjedrila je krajem 1980-ih u Sjedinjenim Američkim Državama novu historiografsku školu tzv. New Western History koja se udaljila od binarnog redukcionizma okrenuvši se analiziranju sociokulturnoga konteksta granica i pograničja. Ova škola pograničje više ne percipira kao proces nastanka nadmoćnoga „,američkog čovjeka“, već kao specifično mjesto i vrijeme, „but it becomes a series of distinct attitudes and practices“. Pojavila su se i nastojanja da se vrijednosno obojeni termin frontier zamjeni „with vocabulary they see as a clearer statement of a frontier's defining characteristics and as less culturally charged", poput Middle ground, cultural contact zone ili čak inter-group contact situation. Kathryn A. EDWARDS, Families and Frontiers: Re-Creating Communities and Boundaries in the Early Modern Burgundy, Studies in Central European Histories, Brill, Boston, 2002., 4. O konceptu Middle ground vidi Richard WHITE, The Middle Ground. Indians, Empires, and Republics in the Great Lakes Region, 1650-1815, Cambridge University Press, 1991. Jedna od začetnica spomenute historiografske škole je i Patricia Nelson LIMERICK, autorica utjecajnog djela The Legacy of Conquest: The unbroken Past of the American West, W.W. Norton \& Company, 1987.

${ }^{39}$ DARLING, The Mediterranean, 54-56. Najistaknutija figura ove paradigme jest njezin začetnik, američki povjesničar Oscar J. Martinez. Izbor iz djela: Border People. Life and Society in the U.S.-Mexico Borderlands, University of Arizona Press, 1994.; Troublesome Border, University of Arizona Press, 2006.

40 Victor PRESCOTT, Gillian D. TRIGGS, International Frontiers and Boundaries. Law, Politics and Geography, Martinus Nijhoff Publishers, Leiden - Boston, 2008., 12. „Frontier and border are not synonyms, even though one often tends to employ them without perceiving their correct meaning. The frontier is a belt of territory that holds in itself the idea of 'front': the enemy who may advance or fall back is beyond it. The same applies to the French frontière, the Italian frontiera and the Spanish frontera." Maria Pia PEDANI, The OttomanVenetian Border (15th-18th Centuries), Edizioni Ca'Foscari, Venezia, 2017., 12.
} 
etničkih zajednica ili političkih entiteta, čija međusobna interakcija može, ali i ne mora biti konfliktne naravi. ${ }^{41}$ To su prostori simultanog suživota i konfrontacije, interkulturalne komunikacije i isključivosti, odnosno prostori izrazite društvene dinamike u kojima se odvija intenzivna kulturološka, ideološka, vjerska, komercijalna razmjena. ${ }^{42} \mathrm{U}$ takvim stvarnim i simboličkim liminalnim prostorima moć i otpor paradoksalno konvergiraju, a one simultano bivaju stvorene političkim strategijama, ekonomskim strukturama, kulturnim značenjima i identitetima, ljudskim iskustvom i svakodnevnom praksom koje istodobno i stvaraju. ${ }^{43}$

Formiranje pograničja usko je povezano s dinamikom odnosa između suprotstavljenih/susjednih država, njihovim internim razvojem te strateškim percepcijama pograničja. Za hrvatsko ranonovovjekovno višegraničje Drago Roksandić kaže: „Nedoumice na tromeđi pojačava i učinak nedoumica u središtima državne moći. Nijedna od imperijalnih sila novu tromeđu ne smatra trajnijim rješenjem, a nijedna nema snage za izlazak iz njezinih ambiguiteta. Nijedna od njih svoju politiku na tromeđi ne doživljava kao prilog njezinoj stabilizaciji, već prije svega kao ishodište daljnjih imperijalnih prodora, a da za to nalazi, u vremenskoj perspektivi, sve manje moći“ “. ${ }^{4}$

Iako formiranje pograničja može biti rezultat konfrontacija distinktivnih socijalnih, ekonomskih ili ideoloških organizacija, ono je često posljedica kontakta i kolizije između društava na različitim razvojnim razinama, što je pak uglavnom primarno vojno i tehnološko pitanje. ${ }^{45}$ Političke granice mogu, ali i ne moraju korespondirati s društvenim razgraničenjima koja u mnogočemu čine razliku između (ne)pripadanja određenoj zajednici, definiraju njezine

\footnotetext{
${ }^{41}$ O granicama i pograničjima vidi Maria BARAMOVA, Border Theories in Early Modern Europe, u: European History Online (EGO), izdanje Institute of European History (IEG), Mainz, 12.3.2010. URL: http://iegego.eu/en/threads/crossroads/border-regions/maria-baramova-border-theories-in-early-modern-europe; Pristup 3. siječnja 2017.

${ }^{42}$ FODOR, Introduction, XI.

${ }^{43}$ Zrinka BLAŽEVIĆ, Triplex Confinium - Liminal Spaces of Transculturation and Hybridisation in the Early Modern Period“, u: Die Erschließung des Raumes, ur. Karin Friedrich, Wiesbaden: Harrassowitz Verlag, 2014., 743. Liminilna zona ,is a transcultural space in which strategies for personal or communal selfhood may be elaborated; a region in which there is a continual process of movement and interchange between different cultural entities“. Zrinka BLAŽEVIĆ, At the Crossroads: Methodologies for Liminal Spaces, u: Liminal Spaces of Art between Europe and Middle East, Cambridge Scholars Publishig, Cambridge, 2018., 3. Iako se često apostrofira važnost komparativnih istraživanja, ona su još uvijek relativno rijetka. Za komparaciju hrvatskog i kavkaškog višegraničja vidi Alfred J. RIEBER, Triplex Confinium in Comparative Context, u: Constructing Border Societies on the Triplex Confinium, ur. Drago Roksandić, Nataša Štefanec, Central European University, Budimpešta, 2000., 13-28.

${ }^{44}$ Drago ROKSANDIĆ, Triplex Confinium. Ili o granicama i regijama hrvatske povijesti, Barbat, Zagreb, 2003., 133.

45 PARKER, RODSETH, Introduction, 11. Podrobnije vidi Michael MANN, The Sources of Social Power, Volume I: A History of Power from the Beginning to A.D. 1760., Cambridge, 1986.; Eric R. WOLF, Europe and the People Without History, Berkley, 1982.
} 
vrijednosti, pravila ponašanja itd. U našem slučaju definitivno treba voditi računa o nepodudarnosti političkih granica i pograničja s onim sociokulturnim. ${ }^{46}$

Osobit utjecaj na istraživanje pograničnih zona imala je antropologija koja je spuštanjem istraživačkog fokusa na ljude koji žive uz granice uputila na to da se pogranično društvo ne bi trebalo reducirati na prikaze koje su o njima konstruirali predstavnici država, medija i akademske zajednice. Antropolozi su se počeli baviti pograničjima i kontaktnim zonama još u prvim desetljećima prošlog stoljeća fokusirajući se isprva na problematiku difuzije, odnosno razmjene kulturnog materijala između različitih populacija te pitanje etniciteta. S vremenom je istraživačka optika sve više usmjeravana prema odnosima moći koji su utjecali na proces difuzije što je pak vodilo uvođenju novog heurističkog koncepta akulturacije. Akulturacija, koja je još 1930-ih definirana kao „fenomen koji je rezultat kontinuiranog neposrednog kontakta dvoje pojedinaca koji dolaze iz različitih kultura“, isprva je percipirana kao bezazlen proces, no ubrzo se, kao reakcija na suvremene društvene procese, počela povezivati s kolonijalnim i kapitalističkim odnosima moći. ${ }^{47}$

I sam koncept „razgraničenja“ (boundary) više nužno ne predstavlja ekvivalent političkom i/ili državnom, odnosno fizičkom razgraničenju, već podrazumijeva i niz simboličkih razgraničenja kojima pojedinci i zajednice definiraju svoju društvenu realnost. Razgraničenja između društvenih skupina u pograničju više se ne percipiraju kao statični, već dinamični i varijabilni fenomeni čije istraživanje predstavlja osnovu analize sličnosti i razlika između pograničnog stanovništva. Iz takvih istraživanja razvila se i recentna borderland anthropology koja se bavi pitanjima nacionalnosti, identiteta, jezične i kulturološke hibridnosti itd. ${ }^{48}$ Iz te perspektive stvarna i metaforička pograničja identificirana su „ne kao

\footnotetext{
${ }^{46}$ PARKER, RODSETH, Introduction, 11 . "The boundary among ethnic groups is no longer regarded as a static phenomenon, as a frozen dividing line which crucially informs all social action within its own perimeter. Instead, it is regarded as a dynamic phenomenon of changeable forms: the analysis of its processual character is henceforth the point of departure for studying the relationships between ethnic groups. In this vein, the term »boundary « does not stand as an equivalent for a political borderline but rather implies a series of symbolic delineations that the actors use in defining their social reality.” Duška KNEŽEVIĆ-HOČEVAR, Studying International Borders in Geography and Anthropology: Paradigmatic and Conceptual Relations, Geografski zbornik, XXXX, 2000., 87 .

${ }^{47}$ PARKER, RODSETH, Introduction, 7.; WILSON, DONNAN, Borders, 6.

48 „Hybridity emphasizes the reciprocal interactions between different, even antagonistic, cultures and subcultures while giving enhanced status to practices of creolization and syncretism and to the previously neglected sites of cultural production. Linked to the postcolonial shift of the center-periphery axis, it represents a new understanding of cultural dynamics. Instead of placing this idea of cultural dynamics at the center of systems of cultural meaning - as was the case with the interpretive turn with its assumptions of cultural consensus - the concept of hybridity views marginal, border and overlapping zones, as well as interstitial spaces, as culturally productive. It sees the 'displacements' that result from global networks and interdependencies as especially useful. In other words, 'routes' are more productive than 'roots', as James Clifford expressed it in his book Routes (1997)." Doris BACHMANN-MEDICK, Cultural Turns. New Orientations in the Study of Culture, De Gruyter, Berlin/Boston, 2015., 142.
} 
analitički prazne prijelazne zone, već kao područja kreativne kulturološke produkcije“. ${ }^{49}$

Dakle, u pograničnim prostorima paralelno egzistiraju, sukobljavaju se i uzajamno oblikuju razne politike, ideologije, tradicije, institucije, običaji i svakodnevna iskustva što posljedično može voditi formiranju novih identiteta, lojalnosti i načina života općenito. ${ }^{50} \mathrm{U}$ tako kompleksnom okruženju mogu se manifestirati procesi hibridizacije, dakle prožimanja, ali i procesi fragmentacije koji pak vode ograničavanju kontakta između pograničnog stanovništva i posljedičnom razbijanju njihove kohezije. ${ }^{51}$ Kao što je terenski rad etnologa Fredricka Bartha pokazao, interakcija između različitih populacija može usmjeriti društvene procese $u$ drugom smjeru, prema intenzivnoj homogenizaciji i zatvaranju zajednica koje teže zadržati identitete u kontekstu kulturne razmjene i ekonomske međuovisnosti. ${ }^{52}$ Dakle, specifična pogranična dinamika može, uvjetno rečeno, „otvoriti“ ili ,zatvoriti“ prostor iako taj razvoj najčešće lebdi između tih dviju krajnosti.

$\mathrm{Na}$ istraživanja pograničja zadnjih desetljeća snažno je utjecala reinterpretacija značenja i uloge koncepta „prostora“ u znanstvenoj paradigmi. Sve do prijelomne knjige Henrija Lefebvrea La production de l'espace iz 1974., a zatim i knjige Anthonyja Giddensa The Constitution of Society iz 1984., ,prostor“ je percipiran kao više-manje puka pozadina, tek prirodna pozornica na kojoj se odigrava društveni život. No, danas se prostor promatra ne samo kao primarno geografska pozadina, slikovito rečeno kao ne pretjerano zanimljiva ili utjecajna kulisa ljudske egzistencije, već kao prostor „kompleksnih konfiguracija socijalnih praksi“, odnosno „simbola i kognitivnih atribucija“ u kojima je „gdje“ se nešto događa od presudne važnosti za razumijevanje ,zašto“ i „kako“ se to događa. ${ }^{53}$ Prostor je produkt

\footnotetext{
${ }^{49}$ Pamela BALLINGER, „Authentic Hybrids“ in the Balkan Borderlands, Current Anthropology, vol. 45, br. 1, $2004,31$.

${ }^{50}$ Claire NORTON, Nationalism and the Re-Invention of Early-Modern Identities in the Ottoman-Habsburg Borderlands. Region, Regional Identity and Regionalism in Southeastern Europe, Ethnologia Balkanica. Journal for Southeast European Anthropology, vol. 11, 2007., 85.

${ }^{51}$ PARKER, RODSETH, Introduction, 13. Kontaktne situacije mogu rezultirati i fragmentacijom, kao što pokazuje slučaj Maja u regiji Peten u Gvatemali. Bježeći pred španjolskim osvajačima, oni su u valovima pristizali u gvatemalsku prašumu što je, uz borbu za ograničene resurse, vodilo diferencijaciji unutar iste populacije, formiranju separatnih identiteta, a na kraju i etničkih grupa. Isto, 13.

52 Fredrick BARTH, Ethnic Groups and Boundaries: The Social Organization of Culture Difference, Little, Brown and Company, 1969. Vidi prije svega Barthov uvodni esej o etničkom identitetu, 9-37.

${ }^{53}$ O posljedicama ,prostornog obrata“ (Spatial Turn) vidi Barney WARF, Santa ARIAS, Introduction: the reinsertion of space into the social sciences and humanities, u: The Spatial Turn. Interdisciplinary perspectives, ur. Barney Warf i Santa Arias, Routledge Studies in Human Geography, London-New York, 2008., 1; Doris BACHMANN-MEDICK, Spatial Turn, u: Cultural Turns: Neuorientierungen in den Kulturwissenschaften, Rowohlt-Taschenbuch-Verlag, Reinbek bei Hamburg, 2009., 284-328. U novije vrijeme velik je utjecaj njemačke sociologinje Martine Löw. Osobito se ističe njezino djelo Raumsociologie, Suhrkamp, Frankfurt am Main, 2001.
} 
ljudske prakse i spoznaje te ga kao takvog oni koji u tom ambijentu žive ili su s njime povezani neprestano stvaraju, interpretiraju i transformiraju. ${ }^{54}$

Nagli porast interesa za problematiku ,,prostora“ vodio je do pojave tzv. topološkospacijalnog zaokreta koji je reinterpretirao ulogu prostora u društvenoj teoriji i društvenom procesu, ponovno reintegrirao humanu geografiju u znanost o društvu i filozofiju te potaknuo propitkivanje odnosa između geografskog znanja i društvenog djelovanja. ${ }^{55}$ Iz tog se rakursa prostor otkriva kao multidimenzionalna, višeslojna pa čak i kontradiktorna konstrukcija koja simultano sadrži fizičku i društvenu razinu, s tim da je potonja proizvod namjerne i nenamjerne ljudske aktivnosti. Ključna posljedica distinkcije fizičkog i društvenog prostora jest mogućnost koegzistencije raznih društvenih prostora u istom fizičkom prostoru, a to znači da različita populacija može na različite načine upotrebljavati, interpretirati i strukturirati isti fizički prostor. Prostor je markiran društvenim praksama (social practice), a značenja koja mu se pripisuju neraskidivo su povezana s ljudskim iskustvom i percepcijom samog prostora. Tako konfiguriran prostor više nije homogen, već višeslojan i kontradiktoran do te mjere da se o njemu više ne može govoriti u singularu, već se mora razlikovati nekoliko dimenzija „istog“ prostora. To pak vodi analiziranju ne samo fizičke komponentne prostora nego i njegova „društvenog“ aspekta koji pak stvaraju i reproduciraju ljudi. U takvom kontekstu prostor istodobno postaje ,preduvjet i rezultat društvene prakse (social practice)“, satkan od fizičkog prostora i atribuiranih mu simbola. Sama fizička pozadina i dalje ostaje važna, ali u onoj mjeri u kojoj je ljudi modificiraju, odnosno percipiraju. „Društveni prostor“ može biti odvojen od fizičkog prostora koji je sam po sebi lišen simboličkih interakcija koje se formiraju isključivo u „društvenim prostorima“. Tek u „društvenim prostorima“ nastaju „simbolički markeri“ koji se potom manifestiraju u fizičkom prostoru. Ključna konzekvenca gradiranja prostora jest činjenica da u istom fizičkom prostoru mogu simultano egzistirati višestruki „društveni prostori“' 56

Ovakva interpretacija prostora osobito je primjenjiva na kompozitnim pograničnim prostorima poput hrvatskog krajišta koji su sukcesivno i simultano zaposjedale ili nastanjivale razne društvene kategorije i etnokonfesionalne zajednice koje ne samo da su imale distinktivne interese već su taj prostor zasigurno i različito doživljavale. Ovakav pristup podupire ideju pograničja kao kompleksne zone unutar koje koegzistiraju, miješaju se i

\footnotetext{
${ }^{54}$ Nils MÜLLER, Social Frontiers Modernizing an old paradigm for modern border research, izlaganje s konferencije „The Multifaced Economic and Political Geographies of Internal and External EU Borders, održane od 23. do 26. rujna 2011. u gradu Veria u Grčkoj, 2.

${ }_{55}^{55}$ Stipe GRGAS, O zaokretu ka prostoru, Filozofska istraživanja, 125, god. 32, sv. 1, 2012., 169-170.

${ }^{56}$ MÜLLER, Social Frontiers, 3-4.
} 
konfrontiraju razni individualni i kolektivni, socijalni, ekonomski, vojni i politički interesi koje nije moguće analizirati i razriješiti nekritičkim korištenjem ipak suviše limitirajućeg koncepta „predziđa kršćanstva““.

Budući da su dosadašnja istraživanja pograničja u većoj mjeri usmjerena na kontaktne zone koje razdvajaju fiksirane granice, dakle granice u modernijem smislu riječi, navedeni pristupi samo su u određenim segmentima primjenjivi pri analizi pograničja predmodernih država koje dugo nisu imale jasno definirane linije razgraničenja, a suverenitet pojedine vlasti ovisio je prije svega o sposobnosti određene političke instance da na određenom prostoru ubere poreze i mobilizira vojsku. ${ }^{57}$ Stoga se, bez obzira na važnost i popularnost spomenutih znanstvenih paradigmi, rezultati njihovih istraživanja mogu samo parcijalno primijeniti u drugim dijelovima svijeta. To osobito vrijedi za europski kontinent u promatranom periodu kada su granice i pograničja specifičnoga vojno-političkoga karaktera i nastale u dugotrajnim imperijalnim sukobima. Iako su akteri tih velikih konfrontacija za svoje suparnike koristili pejorativne i ideološki obojene izraze poput barbari, divljaci, primitivci i slično, ipak se, za razliku od primjerice sjevernoameričkog slučaja, radilo o protivnicima čiji vojno-tehnološki i društveno-civilizacijski razvoj nije $\mathrm{u}$ neusporedivu raskoraku. Uz određene ograde $\mathrm{u}$ promatranom periodu na referentnom prostoru nema preciznijeg razgraničenja, a svakako nema državnih granica u modernom smislu, o čemu će biti riječ dalje u tekstu.

S obzirom na specifičan položaj i najčešće distinktivan razvoj, pogranična se društva često razlikuju od onih u unutrašnjosti. ${ }^{58}$ Štoviše, unatoč često prisutnom antagonizmu, suprotstavljena pogranična društva neodgodivo uspostavljaju specifične socijalne mreže i dijele interese čime postaju svojevrsni corpus separatum u odnosu na unutrašnjost. Poznati istraživač azijskih pograničja Owen Lattimore konstatirao je još 1955. da lokalne aktivnosti i interesi pograničnog stanovništva vode formiranju autonomnih društvenih veza koje pak to stanovništvo mogu separirati i razlikovati od stanovništva u unutrašnjosti te udaljavati od politike središnjih vlasti. Zato su ambivalentne lojalnosti pograničnog stanovništva od velike povijesne važnosti. ${ }^{59}$

\footnotetext{
${ }^{57}$ Kornelija JURIN-STARČEVIĆ, Osmanski krajiški prostor: rat i društvo u jadransko-dinarskom zaleđu u 16. $i$ 17. stoljeću, doktorska disertacija, Filozofski fakultet Sveučilišta u Zagrebu, Zagreb, 2012., 4.

${ }^{58}$ DARLING, The Mediterranean, 58.

${ }^{59}$ Owen LATTIMORE, The Frontier in History, u: Anthropological Theory, ur. Robert A. Manners, David Kaplan, New Jersey, 2009., reprint izdanja iz 1968., 374. Za problematiku lojalnosti na Hrvatskoj krajini vidjeti i Damir STANIĆ, Ambivalentna lojalnost na Hrvatskoj krajini u 16. stoljeću, u: Franz Vaniček $i$ vojnokrajiška historiografija. Zbornik radova sa znanstvenog skupa s međunarodnim sudjelovanjem, ur. Robert Skenderović, Stanko Andrić, Hrvatski institut za povijest - Podružnica za povijest Slavonije, Srijema i Baranje, Slavonski Brod, 2017., 121-142.
} 
Iako političke i konfesionalne distinkcije nikako ne treba zanemariti, dapače, one su jedan od ključnih generatora društvenog razvoja, pogranično stanovništvo na habsburškoosmansko-mletačkom pograničju dijelilo je mnogobrojne tradicije, interese i običaje te prihvaćalo iste standarde vezane uz koncepte časti, ratništva i junaštva. ${ }^{60}$ Spomenute okolnosti i prakse vodile su formiranju novoga običajnog prava koje je dijelilo stanovništvo i s habsburškog i s osmanskog pograničja - tzv. „vire krajiške“ ili „,zakona krajiškog“, a koje je pak u mnogočemu kontradiktorno paradigmi Antemurale Christianitatis. ${ }^{61} \mathrm{~S}$ obiju strana krajišta dominiralo je autohtono ili iz relativne blizine doseljeno kršćansko stanovništvo koje se teško može diskreditrati odrednicom „drugi“ - osim u političkom pogledu. U našem su slučaju oni vezivno tkivo pograničja, koje na mikrorazini i mezorazini u mnogočemu kontrira dihotomijama političke pa i civilizacijske makroperspektive. Običajno pravo dominiralo je na habsburškom pograničju sve do prvih desetljeća 18. stoljeća kada je država pokrenula ozbiljne reformske procese radi implementacije čvršće kontrole nad krajiškim stanovništvom iako ta nakana nikada nije do kraja realizirana pa su mnogi atavizmi preživjeli do recentnih vremena.

Pograničje, dakle, treba sagledavati kao varijabilni koloplet odnosa, interesa, ambicija, kako onih odozgo, tako i onih odozdo. Pogranično stanovništvo nikako nije samo objekt politike centralnih vlasti već ga se mora promatrati kao subjekt koji aktivno pridonosi formiranju i transformiranju prostora u kojem živi integrirajući u pogranični ambijent razne osobne aspekte poput obitelji, poslovnih aktivnosti, običaja itd. ${ }^{62}$ Stoga je karakter pograničja te odnos između rubnih prostora $\mathrm{i}$ središta moći u konačnici nemoguće pojmiti bez razumijevanja kako je bilo živjeti u tom prostoru. ${ }^{63}$ Pogled s periferije često pruža bitno drugačiju sliku od one centralizirane. Ugledna australska povjesničarka Wendy Bracewell zaključila je da:

„A more complete understanding of conflict and community demands an approach to history that could bridge the gap between the various political, religious and social structures that shaped frontier life, and the ways the people of the triple frontier made their own choices, selecting the rhetoric most useful to the occasion, manipulating the rules or exploiting expectations about how

\footnotetext{
${ }^{60}$ Catherine Wendy BRACEWELL, Frontier Blood-brotherhood and the Triplex Confinium, u: Constructing Border Societies on the Triplex Confinium, ur. Drago Roksandić, Nataša Štefanec, Central European University, Budimpešta, 2000., 37.

${ }^{61}$ Nataša ŠTEFANEC, Negotiating with the „Archenemy“: The Ethics of the Croatian and Slavonian Nobility at the Christian-Ottoman Border, u: Türkenkriege und Adelskultur in Ostmitteleuropa vom 16. -18. Jahrhundert, ur. Robert Born, Sabine Jagodzinski, Jan Thorbecke Verlag, Ostfildern, 2014., 89-90.

${ }^{62}$ EDWARDS, Families, 5-6.

${ }^{63}$ I. William ZARTMAN, Introduction. Identity, Movement and Response, u: Understanding Life in the Borderlands: Boundaries in Depth and in Motion, ur. I. William Zartman, University of Georgia Press, $2010 ., 1$.
} 
they should behave - in their own interests and to their own advantage. It is only

then that we will be able to understand which divisions mattered, and when." 64

Kada govorimo o hrvatskom slučaju, Wendy Bracwell navodi da su do sada dominirala četiri pristupa istraživanju povijesti hrvatskoga krajiškog prostora: imperijalni, lokalni, nacionalni i sociohistorijski (social-historical). Prema toj bi shemi imperijalni pristup podrazumijevao pogled iz centralne perspektive fokusiran na ratove, diplomaciju, strategiju, institucionalne projekte, reforme potaknute iz središta i slično. Lokalni pristup analizirao bi pak ulogu regije, utvrde, događaja (incident) ili pojedinca u povijesti krajiškog područja dok nacionalni pristup promovira naciju kao „the key political actor, and the beneficiaries or victims of changing historical circumstance“. Naposljetku, social-historical pristup fokusiran je na „variety of social structures and patterns in interpreting frontier history ${ }^{\text {“65 }}$. Bracewell je odlično sumirala dosadašnje historiografske pristupe navedenoj temi. Rekonceptualizacija istraživanja pograničja/višegraničja unutar hrvatske historiografije afirmirana je pak s pojavom Međunarodnog istraživačkog projekta „Triplex Confinuim“ 1996. koji je u raznim aspektima osuvremenio istraživanja (vojno)krajiške povijesti uvođenjem raznih teorijsko-metodoloških inovacija poput interdisciplinarnog i internacionalnog umrežavanja stručnjaka te historijskoantropološkog, mikrohistorijskog i ekohistorijskog pristupa. U sklopu navedenoga istraživačkog projekta nastalo je nekoliko izuzetno važnih knjiga i zbornika u kojima su radove objavljivali autori relevantni u međunarodnim okvirima. ${ }^{66}$

Nastanak krajiške zone na hrvatskom prostoru rezultat je dugotrajnoga ratnog sukoba između Ugarsko-hrvatskoga Kraljevstva, a potom Habsburške Monarhije i Osmanskog Carstva koji su profilirali ugarsko-hrvatsko, odnosno hrvatsko-slavonsko krajište u jedno od najdugotrajnijih područja sukoba između kršćanstva i islama. No, uvijek treba imati na umu da je hrvatsko-slavonsko ratište tek jedno u nizu međusobno povezanih defenzivnih odsječaka

\footnotetext{
${ }^{64}$ Catherine Wendy BRACEWELL, The Historiography of the Triplex Confinium. Conflict and Community on a Triple Frontier 16th-18th centuries, u: Frontiers and the Writing of History, 1500-1850, ur. Steven G. Ellis i Raingard Eßer, Hannover-Laatzen: Wehrhahn Verlag, 2006., 224-225.

${ }^{65}$ IBID., 214-215.

66 Historijat projekta, bibliografija i publikacije dostupne su na mrežnoj stranici projekta: http://www.ffzg.unizg.hr/pov/zavod/triplex2/; zadnji pristup 26. rujna 2018.
} 
koji su se protezali od Jadranskog mora do današnje Rumunjske, pa onda i uzduž cijeloga kontaktnog prostora između kršćanskih zemalja i Osmanskog carstva. ${ }^{67}$

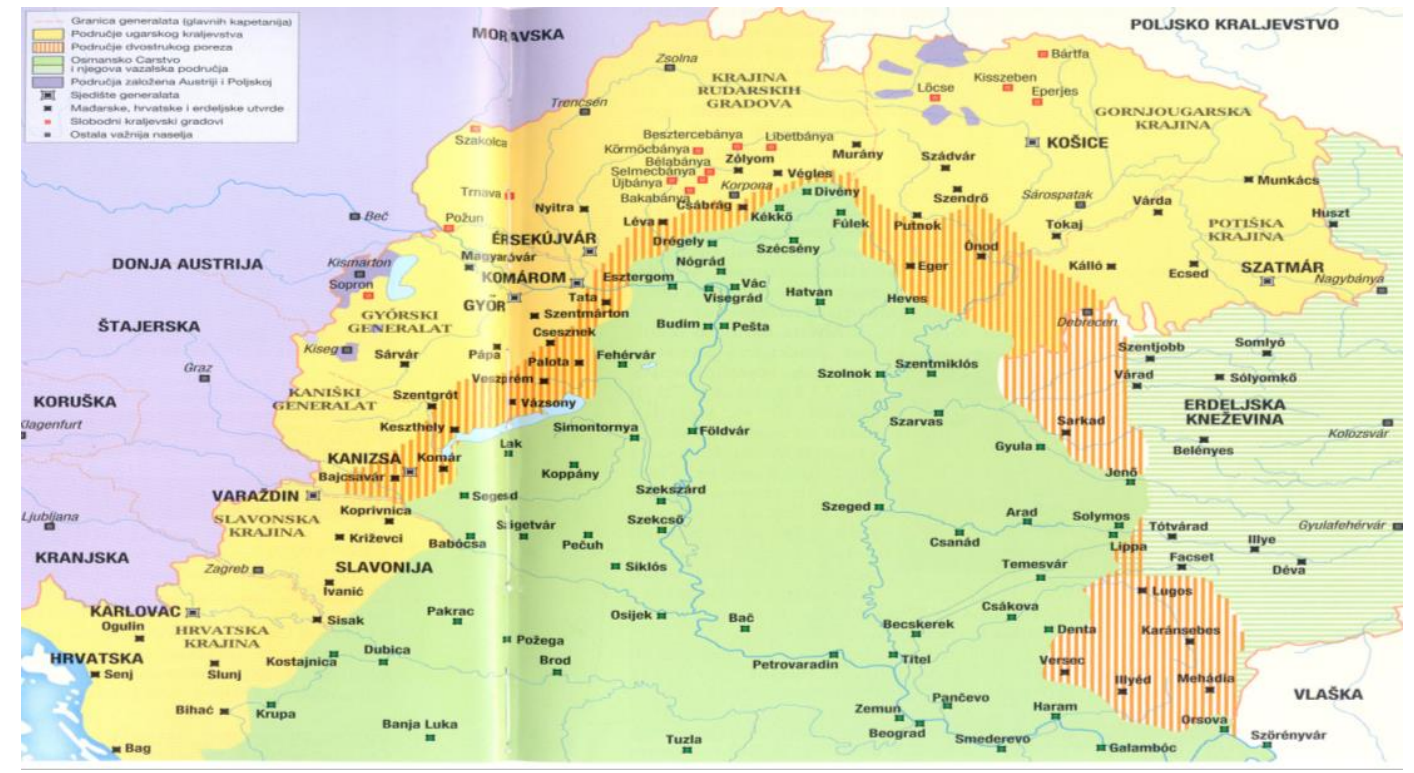

Slika 2. Prostor Ugarsko-hrvatskoga Kraljevstva s krajiškim odsječcima u drugoj polovici 16. stoljeća. ${ }^{6}$

Štoviše, do 1580-ih najintenzivniji sukobi između Osmanskog Carstva i kršćanskih zemalja (Mletačke Republike i Španjolskog Kraljevstva) odvijaju se zapravo na području Mediterana. ${ }^{69}$ Zbog toga se ratna događanja na hrvatskom prostoru ne mogu sagledavati izvan općeg okvira konfrontacija između Habsburške Monarhije i Osmanskog Carstva. Politika Porte ili bečkog dvora ovisila je ne samo o međusobnim odnosima već i o političkim relacijama s drugim državama, prije svega Perzijskim Carstvom, odnosno Francuskom, kada

\footnotetext{
${ }^{67}$ Treba naglasiti da je Antemurale Christianitatis retorika starija od ratovanja s Osmanlijama te se nalazi i na drugim razdjelnicama između kršćanstva i drugih religija. Tako na prostoru Ugarskog te Poljskoga Kraljevstva njezina primjena, kroza sintagmu fines christianitatis, seže do mongolske invazije sredinom 13. stoljeća da bi razne terminološke varijante istog ili vrlo sličnoga koncepta eksponencijalno rasle s porastom osmanske prijetnje. Pojavom tiskarskog stroja i konzekventnim bujanjem humanističkih radova koncept je raširen diljem europskog kontinenta i intenzivno je korišten u političkoj areni, ne samo kada je bilo nužno osigurati pomoć za borbu protiv „nevjernika“ već i pri (diplomatskim) unutarkršćanskim razračunavanjima. Primjerice, to je činilo Poljsko Kraljevstvo u borbi protiv Njemačkog Viteškog Reda. Paul SRODECKI, Antemurale Christianitatis, u: Religiöse Erinnerungsorte in Ostmitteleuropa. Konstitution und Konkurrenz im nationen-und epochen übergreifenden Zugriff, ur. Joachim Bahlcke, Stefan Rohdewald, Thomas Wünsch, Berlin, 2013., 804. Ugarsko Kraljevstvo je već 1410. slavljeno kao ,štit i zid nepremostivi“" kršćanske vjere, a čini se da se i Eneja Silvije Piccolomini, kasnije papa Pio II., 1458. referirao na Ugarsko Kraljevstvo kao na „zid i predziđe ili štit“ kršćanstva. János M. BAK, Hungary and Crusading in the Fifteenth Century, u: Crusading in the Fifteenth Century. Message and Impact, ur: Norman Housley, Palgrave Macmillan, New York, 2004., 119.

${ }^{68}$ Iz Géza PÁLFFY, Povijest Madžarske - Ugarska na granici dvaju imperija (1526.-1711.), Meridijani, Zagreb, 2010., 56-57.

${ }^{69}$ ŠTEFANEC, Država ili ne, 27. Tracy konstatira da je car Karlo V. svoju ulogu zaštitnika kršćanstva manifestirao u ratovima na Mediteranu. S druge pak strane, šest stotina milja duga kopnena granica Respublica Christiana pala je na leđa nadvojvode Ferdinanda. TRACY, Balkan Wars, 111.
} 
je riječ o Habsburgovcima. ${ }^{70}$ Eskalacija sukoba između Osmanskog i Perzijskog Carstva često je vodila potpisivanju mirovnog sporazuma ili primirja s Habsburškom Monarhijom. ${ }^{71}$ Ako i nije zaključeno primirje, pokret vojske na druga ratišta otvarao je prostor za upade na neprijateljski teritorij ${ }^{72}$ i nikada nije prolazio nezapaženo. ${ }^{73}$ I druga ratna žarišta utjecala su na međusobne odnose između Habsburške Monarhije i Osmanskog Carstva. ${ }^{74} \mathrm{Na}$ potpisivanje petogodišnjeg mira u Drinopolju 1547. utjecao je sukob u Jemenu, odnosno predstojeći rat s Perzijom od 1548. do 1550. koji će se pokazati neuspješnim. ${ }^{75}$ Već godinu dana nakon okončanja sukoba s Perzijom, 1551., Mehmed-paša Sokolović započinje s novim osvajanjima u Ugarskoj. ${ }^{76}$ Ciparski rat 1570. - 1573. privremeno je reducirao broj osmanskih upada na kontinentalni hrvatski prostor ${ }^{77}$ da bi nakon okončanja tog sukoba pa sve do izbijanja novog rata s Perzijom 1578. - 1580. Osmanlije ostvarili neke od najvećih vojnih uspjeha na hrvatskom području. ${ }^{78}$

Osmanska osvajanja su, kao rijetko kada u svojoj povijesti, stavila hrvatski prostor u

\footnotetext{
${ }^{70} \mathrm{U}$ drugoj polovici 16. stoljeća Habsburgovci su uspostavili diplomatske veze i s Moskovskim Carstvom nastojeći osigurati potporu za uspon Maksimilijana na poljsko-litvansko prijestolje te otvoriti pitanje uključivanja Moskve u protuosmanska djelovanja. Moskovski dvor tada je funkcionirao i kao most za uspostavu diplomatskih odnosa s Perzijskim Carstvom. Isaiah GRUBER, The Muscovite Embassy of 1599 to Emperor Rudolf II of Habsburg, masters thesis, McGill University Montreal, 1999., 7-26.

${ }^{71}$ Već je kralj Matijaš Korvin planirao uspostaviti diplomatske odnose s Perzijskim Carstvom. Jean BERENGER, Die Geschichte des Habsburgerreiches 1273-1918, Böhlau Verlag, Wien- Köln-Weimar, 1996., 118. Poštovanje Porte prema šijitskoj Perziji pokazuje špijunski izvještaj koji je poručnik postrojbe njemačkih vojnika u Bihaću Martin Hartensteiner poslao Jobstu Josephu Thurnu, a u kojem stoji: "Ferhat Beg's representative at the Porte was reportedly told, even if Christian armies penetrated as far as Istanbul, the sultan would still worry most about his eastern frontier where his real interest lay". TRACY, Balkan wars, 247, fusnota 2. Izvještaj je objavljen u: Radoslav LOPAŠIĆ, Spomenici Hrvatske krajine, knjiga I, JAZU, Zagreb, 1884, dok. XCI, 132-133.

${ }^{72}$ Krajem prosinca 1579. habsburški poslanik (orator) u Carigradu javlja da će bosanski beg na perzijsko ratište. SI AS 2, DSK, fascikl 124a, kutija 202, Carigrad, 28.12.1579., 3r.

${ }^{73}$ U lipnju 1580. trojica doušnika obavijestila su da Osmanlije smatraju da na Hrvatskoj krajini gotovo i nema vojske jer su skoro svi krenuli prema Budimu. Osmanlije su držali da je krajina u tom trenutku nebranjena što je otvaralo put namjerama Ferhat-paše da učini nešto znatno/slavno (nambhaffts). SI AS 2, DSK, fascikl 124a, kutija 202., Črnomelj, 19.6.1580. 1r. Određeni pojedinci i skupine na pograničju bili su itekako svjesni recentnih međunarodnih odnosa. Primjerice, tako je Vujin (Vuuin) Marković iz Bjelajskog polja na ispitivanju 1592. izjavio da je Hasan-beg Sauerovich (Assan Beeg Sauerouitsch) iz Glamoča donio iz Carigrada vijesti da su Perzijanci, u dogovoru s Habsburgovcima, započeli rat s Osmanskim Carstvom. SI AS 2, DSK, kutija 805, fascikl 540, 10.3.1592, 1r, bez datuma i mjesta.

${ }^{74}$ Koliko je politički okvir važan, vidi se i iz činjenice da je 1572. (dakle, u tijeku rata između Osmanskog Carstva i Mletačke Republike) pripreman veći napad na mletački dio Istre pri kojem je trebalo prijeći preko habsburškog teritorija. Porta je naredila kliškom sandžakbegu da prilikom prelaska preko teritorija „bečkoga kralja“ ne nanosi štete i nasilje lokalnom stanovništvu te ga upozorila da će se u slučaju pojavljivanja robova iz tih krajeva provesti istraga. JURIN-STARČEVIĆ, Osmanski krajiški, 146.

${ }^{75} \mathrm{O}$ potpisivanju mirovnog sporazuma u Drinopolju vidi Muhammet Zahit ATÇIL, State and Government in the Mid-Sixteenth Century Ottoman Empire: The Grand Vizierates of Rüstem Pasha (1544-1561), doktorska disertacija, University of Chicago, 2015., 70-76.

${ }^{76}$ PALFFY, Povijest Madžarske, 38-39.

${ }^{77}$ Vasko SIMONITI, Prispevek k poznavanju turških vpadov v letih od 1570 do 1575 , Zgodovinski Časopis, XXXI, br. 4, 492.

${ }^{78}$ PALFFY, Povijest Madžarske, 40.
} 
fokus šire europske zajednice. Osmansko napredovanje predstavljalo je (barem načelno) prijetnju cijeloj kršćanskoj Europi, pa je i ugarsko-hrvatsko pograničje postalo relevantno na europskoj razini. U stoljeću kontinuiranog reteriranja kršćanska Europa žudjela je za uspjesima, pa su i određeni događaji, koji iz današnje perspektive ne djeluju toliko važni u paneuropskoj perspektivi, polučili veliki odjek na kršćanskom zapadu. Tako je pobjeda habsburških četa pod Drežnikom 1578., prilikom unošenja živeža ${ }^{79}$ u Bihać, opisana u izvještaju (na čak sedam strana) kojeg primjerke danas nalazimo u institucijama u Londonu, Budimpešti, Münchenu i Jeni. ${ }^{80}$

Može se s pravom konstatirati da je rat glavni katalizator društvenih promjena na onodobnom hrvatskom prostoru. Osmanska ekspanzija urušila je institucionalnu infrastrukturu srednjovjekovnoga Hrvatskoga Kraljevstva, a ozbiljno degradirala onu Slavonskoga Kraljevstva, pokrenula ekstenzivne migracije te u konačnici izazvala društveni kolaps na širokom hrvatsko-slavonskom prostoru. ${ }^{81}$ Treba ipak naglasiti da se radilo o dugotrajnom periodu ratnih operacija koje su diktirale tempo života generacijama pograničnog stanovništva. Prvi osmanski upadi započeli su već krajem 14. i početkom 15. stoljeća da bi se intenzivirali u drugoj polovici 15. stoljeća. Dakle, stanovništvo koje je obitavalo na pograničju rađalo se i umiralo u sjeni osmanske ekspanzije što je vrlo važna činjenica za razumijevanje odnosa naspram Osmanlija, kao i internih relacija na habsburškom pograničju.

Unatoč tektonskim društvenim poremećajima koje je osmanska ekspanzija izazvala, taj se proces mora percipirati i kao proces transformacije i modifikacije, a ne isključivo destrukcije. ${ }^{82}$ Novi politički okvir, ustrojavanje novoga krajiško-administrativnog aparata, nestajanje, odnosno modificiranje starih i pojava novih elita, te formiranje novih sociokulturnih i socioekonomskih sustava, obrazaca ponašanja i mentalnih predodžbi važni su aspekti spomenute transformacije. Već i izostanak čvrsto definirane granice u predmodernom periodu, dakle i u hrvatskom slučaju, značajno je utjecao na identitete pograničnog

\footnotetext{
${ }^{79}$ Živež se u hrvatskim izvorima naziva profunt ili jiliš. Primjerice, u glagoljskom pismu senjskog vicekapetana Hansa Scharfa iz travnja 1557. stoji da je u sklopu osmanskih priprema za napad izdana naredba da svaki ,dvoje opanke da ima tr jiliša za 10 dan“. Ivan BOJNIČIĆ, Izvješća o kretnjama turske vojske uz hrvatsku granicu u drugoj polovici XVI. vijeka, Vjesnik Kr. Hrvatsko-slavonsko-dalmatinskoga zemaljskoga arkiva, 16, 1914., dok. IX, 65. Isti termin koristi i zapovjednik grobnički Mihalj Kobasić u pismu upućenom Jurju Barbu u travnju 1560. IBID., dok. XV, 71 .

${ }^{80}$ Vasko SIMONITI, Vojaška organizacija na Slovenskem v 16. stoletju, Slovenska Matica Ljubljana, 1991, 260; Branko REISP, Tiskarna Janzea Mandelca in leta 1578 tiskana pesem o zmagi Ivana Ferenbergerja nad Turki, Kronika, 23, br. 2, 1975., 81-87.

${ }^{81}$ Tomislav Raukar označio je 16. stoljeće kao stoljeće društvene razgradnje i razdvajanja hrvatskog društva. Tomislav RAUKAR, Društveni odnosi u Hrvatskoj u XV. stoljeću, Historijski zbornik, 38, 1985., 76.

${ }^{82} \mathrm{O}$ konceptu kontinuiteta i promjene vidi Peter BURKE, Concept of Continuity and Change in History, u: The New Cambridge Modern History, ur. Peter Burke, Cambridge University Press, svez. XIII, 1979., 1-15.
} 
stanovništva jer u neposrednom, fizičkom smislu nije bilo osobitih barijera kojima se branilo od ,drugosti“ ${ }^{83}$

Takav prostor mogao je simultano biti pozornica identitetskih mobilizacija i demobilizacija. Erozija ,institucionalne Hrvatske“, odnosno tradicionalnih civilnih i vojnih autoriteta morala je imati dezavuirajući efekt na „politiku vjernosti““ lokalnog stanovništva. Iako neke primarne odlike identiteta (mnogo) duže odolijevaju promjenama, danas je već ustaljeno stajalište da su identiteti kompleksne, dinamične i varijabilne kategorije formulirane, konstituirane i osporavane u najbližoj korelaciji s političkim, ekonomskim, kulturnim, konfesionalnim, nacionalnim procesima. Kada institucionalni okvir nestane, a demografski manje-više kompaktne zajednice dožive rasap, otvoren je put promjenama identiteta i lojalnosti. $^{84}$ Stoga, bez obzira na dihotomiju „mi ili oni“ koja je inherentna paradigmi Antemurale Christitanitatis, habsburško-osmansko pograničje jest, kao uostalom i razna druga pograničja, također i prijelazna zona „, between two or more states or peoples. As such, the frontier is less a dividing line and more a zone of interaction between and among those peoles, states and cultures.“ ${ }^{\text {“85 }}$ No, bez obzira na utemeljenost ovakvih navoda, nikako ne treba zanemariti činjenicu da je u promatranom periodu krajište ipak prije svega permanentna ratna zona, prostor sukoba, nasilja i stradanja.

Nadalje, izrazito je važno naglasiti da je uvijek riječ o zoni - o prostoru jer u promatranom periodu granice u današnjem značenju te riječi ne postoje, već su prvi puta na habsburško-osmanskom pograničju precizno definirane Karlovačkim mirom $1699 .{ }^{86}$ Tijekom

\footnotetext{
${ }^{83}$ Lud'á KLUSÁKOVÁ, “A European on the Road”: in pursuit of "Connecting Themes” for Frontiers, Borders and Cultural Identities, u: Imagining Frontiers, Contesting Identities, ur. Steven G. Ellis, Lud'a Klusáková, Pisa University Press, 2007., 3.

${ }^{84}$ Tako je hrvatskim plemenitim zajednicama i rodovima izrazito bitan kohezivni element posjed, bašćina, čijim gubitkom dolazi do slabljenja povezanosti između članova zajednice ili roda, migracija, a u najradikalnijoj varijanti i mentalne rekonfiguracije. Vlaškom stanovništvu u promatranom je periodu primarni kohezivni element predodžba o stvarnom ili fiktivnom srodstvu, a ne politički aspekt.

${ }^{85}$ Mark L. STEIN, Guarding the Frontier. Ottoman Border Forts and Garrisons in Europe, Taurus Academic Studies, London-New York, 2007., 5. Pendani navodi: „The frontier is a belt of territory facing the enemy, that may expand or fall back, and where different laws and religions can find a way to live together more easily than elsewhere. It is a land of clash and heroism, but of pragmatism and coexistence too. In the history of ChristianMuslim relations, this frontier way of living was, perhaps, more important than what people usually believe: between Turks and Europeans there were not only the battle of Lepanto and the two sieges of Vienna, but also many years of peaceful or armed coexistence, over land and sea, from the Balkans to the Mediterranean Sea and from the Black Sea to the Indian Ocean. It may be argued that it is easier to remember the won or lost battles and the hate for the enemy than the silence of a truce. Public papers gathered in the archives support this partial view: they are produced when people clash and not when they live in peace." PEDANI, The Ottoman-Venetian Border, 27.

${ }^{86}$ I u osmanskoj tradiciji koncept fiksirane granice počeo se formirati tek krajem 17. stoljeća jer je osmanska ideologija imala naglašen ekspanzivni karakter baziran na ratu za pravu vjeru ( $g a z a)$ i zapravo je težila uništenju postojećih granica i razgraničenja te širenju islama. No, kada je riječ o osmansko-mletačkim razgraničenjima, ona su vrlo rano poprimila formu granične linije, već od konca 15. stoljeća. PEDANI, The Ottoman-Venetian Border, 50-54. Precizno razgraničenje na dalmatinskom prostoru izvršeno je i 1540. ATÇIL, State and
} 
16. stoljeća imperijalno je višegraničje ,sjecište militariziranih periferija triju kompozitnih imperija“, a tek nakon Karlovačkog mira ono se legitimira kao „pogranična zona triju predmodernih država“" ${ }^{87}$

Štoviše, u promatranom periodu gotovo cijeli preostali teritorij Hrvatsko-slavonskoga Kraljevstva pogranična je zona. Iako su određena područja, poput primjerice današnjeg Hrvatskog Zagorja, bila mnogo sigurnija u odnosu na samo krajište, ni ona nisu bili izuzeta od osmanskih upada i psihoze uzrokovane ,turskim strahom“. Gabarite tog krajišta ipak nije lako utvrditi. Ivan Jurković podijelio je hrvatski prostor u tri zone ugroze koje su od sredine 15. do početka 17. stoljeća mijenjale prostorni opseg. Prva zona prostor je neposredne ugroze, druga zona bila bi nešto sigurnija, a u treću bi zonu ulazio prostor koji je relativno ili čak potpuno siguran od osmanskih napada. Jurković smješta unski prostor s Bihaćem u drugu zonu ugroze već od 1463. da bi se već od 1513. nadalje našao u prvoj zoni ugroze. ${ }^{88}$ Dok se do sredine 16. stoljeća široka pogranična zona na području Slavonske krajine stabilizirala, te se nije ozbiljnije mijenjala sve do Dugog rata $1590-$ ih $^{89}$, na području Hrvatske krajine teritorijalni uzmak trajao je sve do kraja 16. stoljeća. Najveći osmanski uspjesi postignuti su upravo u drugoj polovici stoljeća kada je slavonska fronta uglavnom stabilna.

Dakle, krajište je primarno pojas zemlje, a ne granična linija. Ipak, u praksi su morali postojati određeni geografski elementi (planine, rijeke, šume itd.) razgraničenja između Osmanskog Carstva i kršćanskih država. ${ }^{90}$ Utvrde su temeljni i najupečatljiviji markeri dosega nečije vlasti. Prema Milanu Vasiću, Osmansko Carstvo i Ugarsko-hrvatsko Kraljevstvo mirovnim su ugovorima iz 1503. i 1519. razgraničili svoje posjede na potezu KamengradKljuč-Glamoč. ${ }^{91}$ Iako razgraničenje utemeljeno na liniji utvrda ne isključuje zonalni aspekt jer između utvrda na krajištu nisu postojale precizno definirane crte razgraničenja i jer su utvrde

Government, 179. Treba napomenuti da je 1625. na hrvatskom prostoru zbog permanentnih sukoba dogovoreno razgraničenje između dviju strana. S habsburške strane povjerenik je bio bivši ban Nikola Frankopan Tržački, a međa je išla od Bihaća na Izačić, Bužim, Gvozdansko, Stari Novi, Zrin i Kostajnicu. LOPAŠIĆ, Bihać, 31.

87 Zrinka BLAŽEVIĆ, Istraživanje vojnokrajiške povijesti iz perspektive »studija granica«: mogućnosti i ograničenja, u: Franz Vaniček $i$ vojnokrajiška historiografija. Zbornik radova sa znanstvenog skupa s međunarodnim sudjelovanjem, ur. Robert Skenderović i Stanko Andrić, Hrvatski institut za povijest Podružnica za povijest Slavonije, Srijema i Baranje, Slavonski Brod, 2017., 59-60.

${ }^{88}$ Ivan JURKOVIĆ, The Fate of the Croatian Noble Families in the Face of the Ottoman Advance, doktorska disertacija, Central European University, Budimpešta, 2004., 27-37.

${ }^{89}$ Riječ je o velikoj i uglavnom nenaseljenoj pograničnoj zoni širokoj i do četrdesetak kilometara.

${ }^{90}$ Iako je razgraničenje na ugarsko-hrvatskom prostoru zaista fluidne prirode, ono je nužno moralo imati određene konture/gabarite kao što je to Peacock konstatirao: „every political entity has a geographical point at which it comes into contact with the world beyond." Andrew Charles Spencer PEACOCK, Introduction: The Ottoman Empire and its Frontiers, u: The Frontiers of the Ottoman World, ur. A.C.S. Peacock, Proceedings of the British Academy, Oxford University Press, Oxford, 2009., 2.

${ }^{91}$ Milan VASIĆ, Etnička kretanja u Bosanskoj krajini u XVI vijeku, Godišnjak društva istoričara Bosne $i$ Hercegovine, godina XIII, 1962., 235. 
mogle biti gotovo ili potpuno izolirane, opkoljene i zaostale u neprijateljskom području, što ih više ne čini markerom dosega nečije vlasti već neizbježnim plijenom suparnika, ovakvi sporazumi i raspored utvrda na terenu nagnali su neke istraživače, kao što je Andrew Charles Spencer Peacock, da, naravno s puno opreza i ograda, konstatiraju: „In Europe, on the front line with the Hapsburgs, something akin to a modern frontier had developed by the sixteenth century, if not before, with the two powers confronting each other across a delineated border from behind a network of fortifications, even if this frontier line was not always taken particularly seriously in practice“. 92

I zaista je postojala tendencija da se razgraničenje između zaraćenih imperija preciznije definira, pa je tako i jedan od zaključaka mirovnog ugovora u Adrianopolju 1568. pretpostavljao da će otvorena pogranična pitanja urediti posebno povjerenstvo. ${ }^{93}$ No, u suštini je pograničje ostalo zonalnoga karaktera bez precizno definiranih granica u državnom pogledu. Prvenstveno se radilo o pokušajima ustrojavanja obrambenih, a ne graničnih linija u modernom smislu. Habsburška je strana zaista u drugoj polovici 16. stoljeća nastojala učvrstiti obranu ,zatvaranjem“ pograničja, odnosno formiranjem dobro branjene i međusobno povezane linije utvrda, potpomognute nizom stražarnica, usjeka, prepreka i drugih opstrukcija koje su trebale onemogućavati prolaz osmanskim snagama. ${ }^{94}$ Međutim, niti su svi elementi tog koncepta ustrojeni na kompletnom kontaktnom prostoru, već uglavnom na glavnim prometnim koridorima i ključnim lokacijama, niti se uspjelo hermetički zatvoriti pograničje. To, uostalom, nije bilo izvedivo ni kasnije, a slobodno se može konstatirati ni danas, unatoč nevjerojatnom tehnološkom napretku.

Između isturenih utvrda s obiju strana pograničja, a u habsburškom slučaju čak i oko mnogih krajiških utvrda, nalazio se prazan, nenaseljen prostor, pa je vojnim vlastima permanentno problem implementirati ozbiljniju kontrolu nad okolnim teritorijem. Ipak, raspored pograničnih utvrda, formiranih zbog potrebe za kontinuiranim nadziranjem neprijateljske strane, „na papiru“ zaista može podsjećati na moderniju graničnu liniju. Primjerice, prema jednom prijedlogu s kraja 1570-ih, ustrojavanje defenzivne linije na Hrvatskoj krajini izgledao bi ovako: (Karlo)Bag - Senj - Brinje prema Brlogu - Otočac -

\footnotetext{
${ }^{92}$ PEACOCK, Introduction, 2.

${ }^{93}$ Ivan STEKLASA, Khevenhülerjeva vojska na Turke leta 1578, Ljubljanski zvon, god. XIV, br. XI, $1894 ., 663$. Tracy navodi da i mir u Adrianopolju 1547. ,had language about joint commissions to fix the border“ TRACY, Balkan wars, 152. Štoviše, autor navodi i da je s osmanske strane 1562. ponuđeno nešto za čime je habsburška strana petnaest godina žudjela - „that is, a credible promise of fixed boundaries in Hungary“ - no da je car Ferdinand dao ukloniti tu odredbu iz konačnoga mirovnog sporazuma. IBID, 216.

${ }^{94} \mathrm{U}$ ožujku 1582. podizale su se zasjeke (verhackung) u senjskim šumama i na prijelazima preko rijeke Korane. Ove potonje trebalo je izvesti nakon opskrbe Bihaća. HR-HDA-913, Zbirka preslika na papiru, Croatica et Windica, Croatica, (dalje HDA, Croatica) mikrofilm D-1914, br. 3, ožujak 1582.
} 
Dabar - Jesenica - Plaški - Modruš - Svetice (kod Josipdola, op.a.) - Ogulin - Tounjska Peć - Ključ - izvor rijeke Korane (između Mrežnice i Korane jedna stražarnica s deset vojnika) Drežnik - Korana prema Tržcu - Kremen - Slunj - Blagajski Turanj - Skrad - Barilović budući Karlovac. Od tamo linija bi išla na sljedeći način: Steničnjak - Bović - Brkiševina Gora - Sveti Križ - Hrastovica - Srednji Gradac - Petrova Gora - Topusko - Cetin - Bihać s pripadajućim utvrdama poput Ripča, Sokola i Izačića. ${ }^{95}$

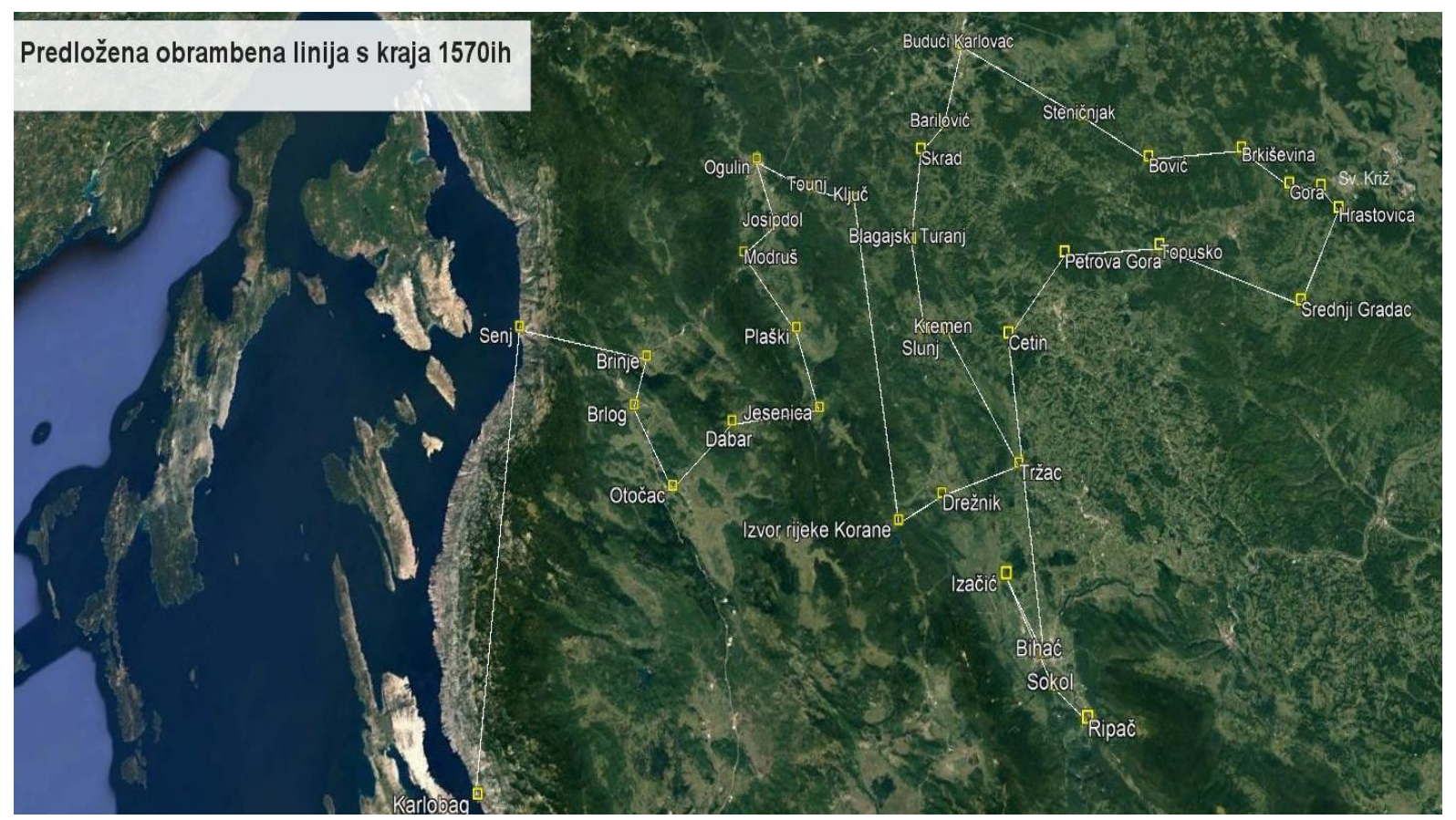

Slika 3. Prikaz predložene obrambene linije s kraja 1570-ih.

Iako članovi Dvorskog ratnog vijeća u Grazu, komentirajući taj prijedlog, navode da pogranična fronta ne bi trebala biti tako naokolo razvučena, već što kraće i pravilnije povučena, i ovdje je prije svega riječ o obrambenom konceptu zonalnoga karaktera jer se iz tih utvrda nadzirao prostor, a ne (primarno) linija. ${ }^{96}$ I hrvatsko-slavonski staleži nastojali su utvrditi i osigurati prijelaze na rijekama (Kupa, Korana itd.) te time na određeni način zatvoriti prostor. ${ }^{97}$ Međutim, i u ovom slučaju riječ je o defenzivnim mjerama, a ne formiranju graničnih linija jer je često s druge strane tih riječnih barijera i dalje prostor koji brane i/ili u kojem obitava domaće stanovništvo.

\footnotetext{
${ }^{95}$ Linija utvrđena na temelju izvora objavljenog u Lopašićevim Spomenicima Hrvatske krajine (nema završetka spisa) te izvora iz serije Croatica Dvorskog ratnog vijeća u Grazu. LOPAŠIĆ, SHK, knjiga I, dok. XLI, 75. odnosno, HDA, Croatica, kutija 1, svežanj 2, str. 36-37. Dvorsko ratno vijeće (dalje DRV) u Grazu na nadvojvodu Karla.

${ }^{96}$ HDA, Croatica, kutija 1, svežanj 2, str. 36-37. DRV u Grazu na nadvojvodu Karla.

${ }^{97}$ KLAIĆ Povijest Hrvata, knjiga 5, 288.
} 
Iako je pogranični karakter Bihaćke krajine, odnosno cijeloga unskog prostora vrlo lako elaborirati kada je riječ o periodu osmanske ekspanzije, pograničnost u povijesti ovog prostora prisutna je i ranije. ${ }^{98}$ Prije svega, u neposrednoj blizini Bihaća protezala se sociopolitička razdjelnica između srednjovjekovnoga Hrvatskoga Kraljevstva i srednjovjekovne Slavonije, odnosno Slavonskoga Kraljevstva. Prostor sjeverno od rijeke Une, Gornja i Donja Kladuša, Cazin, Ostrožac, Bužim, Bušević i Krupa, a u 14. stoljeću i sam Bihać dio su Zagrebačke županije. ${ }^{99}$ Nadalje, etimološku genezu toponima poput „otok Sv. Ladislava“ za unsku adu iz koje je izrastao grad Bihać očito treba tražiti u srednjovjekovnim razgraničenjima između Hrvatskoga Kraljevstva i Ugarskoga Kraljevstva. Čak i nakon formiranja Ugarsko-hrvatskoga Kraljevstva hrvatski prostor, udaljen od centara moći na ugarskom prostoru, zadržao je prepoznatljivu razinu socioadministrativne, a u nekim trenucima i političke partikularnosti. Stoga su, kao što je već navedeno, kraljevi anžuvinske dinastije sredinom 14. stoljeća morali organizirati prave vojne pohode da bi suzbili autonomiju hrvatskih velikaša, pri čemu je upravo Bihać polazišna točka iz koje konsolidirana središnja vlast intervenira prema gotovo nezavisnim hrvatskim velikašima na prostoru Hrvatskoga Kraljevstva. ${ }^{100}$

Također, u neposrednoj blizini Bihaća nalazila se granica Kninske i Zagrebačke biskupije, odnosno Splitske i Ostrogonske metropolije, čime je unski prostor u eklezijalnom pogledu separiran na dva dijela. Kninski biskup imao je velik posjed oko Cazina, koji je nakon osmanskog osvajanja Knina 1522. postao i biskupsko središte. Može se pretpostaviti da su crkvene granice ipak bile preciznije definirane od onih političkih, a to se pri budućem istraživanju razgraničenja definitivno treba uzeti u obzir. Iako su to prije svega interna razgraničenja, s obzirom na sve rečeno, vjerujem da unutarnje distinkcije, koje nikako ne treba poistovjećivati s pograničjem osmanskog perioda, pružaju stanoviti kognitivni okvir za razumijevanje pograničnog karaktera bihaćkog prostora u predosmanskom periodu.

I „,vanjskopolitičke“ okolnosti kasnoga srednjeg vijeka upućuju na pogranični karakter promatranog prostora. Prije svega treba spomenuti srednjovjekovnu Bosnu kao prostor odakle su dolazila alternativna, „heretička“ kršćanska učenja ili kao prostor odakle je prijetila vojna

\footnotetext{
${ }^{98}$ Zanimljivo je da Lopašić navodi da je prostor ,u bližnjoj okolici Bišća i priedjelom u zavoju Une na lievoj obali rieke“, sjeveroistično od grada i ranije nosio ime „Krajina“. LOPAŠIĆ, Bihać, 2.

99 IBID., 14.

${ }^{100}$ Otud je kralj Ludovik I. Anžuvinac intervenirao protiv nepokornih hrvatskih velikaša 1345. i 1346. ANČIĆ, Bihaćki kraj, 198.
} 
opasnost. Radi suzbijanja „hereze“ i učvršćivanja katoličkog pravovjerstva u Bihaću je sredinom 13. stoljeća podignut dominikanski samostan, očito kao polazište misionarskog djelovanja prema pograničnom prostoru. Nešto kasnije bit će podignut i franjevački samostan. S političkim uzdizanjem srednjovjekovnoga Bosanskoga Kraljevstva Bihać je na prijelazu iz 14. u 15. stoljeće na kraće vrijeme čak i potpao pod bosansku vlast. ${ }^{101}$ Shodno porastu bosanske vojne moći pod kraljevima anžuvinske dinastije započeo je već sredinom 14. stoljeća proces preuzimanja i utvrđivanja važnih strateških utvrda uz rijeku Unu, čime je formiran začetak unskoga obrambenog fronta prema istoku/jugoistoku. S porastom osmanske opasnosti, osobito od druge polovice 15. stoljeća, bihaćki će prostor već poprimiti izraženi pogranični karakter, pa će ga i izvori sve češće smještati u in confinibus Turcarum. ${ }^{102}$

S druge pak strane, i to samo naoko paradoksalno, na višestrukom pograničju smješten Bihać istodobno funkcionira kao mjesto centraliteta, kako u političkom, tako i gospodarskoupravnom pogledu. Kao što je navedeno, grad je čvrst oslonac središnje vlasti, a i nakon što ga je kralj Žigmund založio, ostaje u rukama najmoćnijih hrvatskih velikaša Frankopana.

Nadalje, grad je potom sjedište niza nositelja banske časti te se ovdje održavaju i hrvatski sabori. Dok je u kasnosrednjovjekovnom periodu trebalo pacificirati moćnu hrvatsku vlastelu i zaustaviti ekspanziju Bosanskoga Kraljevstva, kasnije se fokus usmjerio prvenstveno na zaustavljanje osmanskih prodora, pri čemu Bihać postaje jedno od glavnih krajiških uporišta zbog geostrateške i sociopolitičke uloge. Dakle, povijest Bihaća neraskidivo je povezana s kraljevskom vlašću i njezinim predstavnicima na hrvatskom prostoru. I u društvenom pogledu promatrani je prostor u srednjovjekovnom periodu demografski vrlo kompleksan pa ovdje nalazimo mnogobrojna srednjovjekovna hrvatska plemena, niz važnih gradova i utvrda, razvijenu crkvenu infrastrukturu, ključne prometnice, uz prisutnost nositelja najviših političkih vlasti, što ovom prostoru daje prvorazrednu važnost.

\subsection{Konvencije}

Iako se u historiografiji udomaćilo korištenje sintagme „Vojna krajina“ za opisivanje kompletne krajiške povijesti, u ovom radu koristio sam termin „krajina“ jer je pridjev „vojna“

\footnotetext{
${ }^{101}$ IBID., 202. Zanimljivo je da su tijekom sukoba između kralja Ladislava Napuljskog i njegova pristaše Hrvoja Vukčića Hrvatinića, sa snagama kralja Žigmunda Luksemburškog Bihać držale postrojbe odane Ladislavu, a obližnji Sokol one odane Žigmundu. LOPAŠIĆ, Bihać, 272. Bihać je tada neko vrijeme bio u rukama Hrvoja Vukčića Hrvatinića koji ga je držao kao ban Ladislava Napuljskog. IBID., 2.

${ }^{102}$ Vjekoslav KLAIĆ, Acta Keglevichiana. Najstarije isprave porodice Keglevića do boja na Muhačkom polju, Monumenta spectantia historiam Slavorum meridionalium, Zagreb, 1917., XLIX.
} 
kasniji dodatak koji implicira specifične sociopolitičke konotacije koje pak nisu karakteristične za promatrani period. Sintagmu „Vojna krajina“ ne nalazimo ni u hrvatskom ni u njemačkom onodobnom diskursu u kojima se koriste termini poput „krajina“, „konfin“, „kunfin“, odnosno grenze ili frontier. ${ }^{103}$ Pojam „krajina“ koristi se uglavnom uz teritorijalnu odrednicu poput Hrvatska, Primorska ili Slavonska krajina, što sam i ja činio. U izvorima na njemačkom jeziku najčešće se koristi sintagma Crabatische Grenze i slične inačice, ponekad i Crabatischen Confin. ${ }^{104}$ Kada sam se pak referirao na pograničnu zonu prema Osmanlijama bez partikularne teritorijalne odrednice, koristio sam termine poput „krajina“, „krajište“ ili „pograničje“.

Glavnina prevedenih njemačkih termina preuzeta je iz knjige „Država ili ne. Ustroj Vojne krajine 1578. godine i hrvatsko-slavonski staleži u regionalnoj obrani i politici“ Nataše Šefanec koja je objavljena 2011. u Zagrebu. No, budući da je prijevod stranih, uglavnom njemačkih termina ponekad izrazito kompliciran, pa čak i nemoguć zadatak, neke pojmove, poput kranjskoga staleškog izvršnog tijela Verodneten, ostavljao sam u izvornom obliku, ali u kurzivu. ${ }^{105}$

U izvorima na njemačkom jeziku Bihać najčešće dolazi u obliku Wihitsch ili Wichitsch, ali se ponekad javlja i kao Wyhitsch, Wichich, Bihitsch itd. Sve strane varijante imena Bihać prevodio sam na standardni hrvatski. Jednako sam postupao i s drugim njemačkim oblicima hrvatskih ili bosanskohercegovačkih toponima, oronima, hidronima itd. Sva mjesta koja sam mogao ubicirati i identificirati navodim u hrvatskoj ili bosanskohercegovačkoj varijanti dok u izvornom obliku i kurzivu ostavljam ona koja nisam uspio ubicirati. Često se radi o mikrotoponimima koji danas više ne postoje pod tim imenom ili nisu upisani u kartama, a za čiju bi ubikaciju trebalo izvršiti minuciozni pregled terena za što nisam imao ni vremena ni financijskih mogućnosti.

Što se osobnih imena tiče, odlučio sam ih ostaviti u izvornim oblicima: njemačkim ili rijetko ugarskim kada je riječ o osobama s njemačkog (uključujući i slovenskog) ili ugarskoga govornog prostora te hrvatskim, odnosno slavenskim kada je riječ o osobama s hrvatskog i općenito južnoslavenskoga govornog područja. Iznimke su Nikola Jurišić i Ivan Lenković,

\footnotetext{
103 ROKSANDIĆ, Triplex Confinium, 18-19; 26-27. Ivan Lenković pisao je u travnju 1560. o djelovanju Malkoč-bega na „seines Khaisers Granizen, an der Vna“. HDA, Militaria, kutija 7, Mehovo, 19.4.1560., 1r. Bez numeracije.

${ }^{104}$ SI AS 2, DSK, kutija 209, fascikl 126, Gorica, lipanj 1565., 1r, rbr. 69. Uostalom, to su činili i onodobni zapovjednici poput, primjerice, tada senjskoga kapetana Ivana Lenkovića koji je 1541. za krajište upotrijebio dvostruku terminologiju ,derselben Confin vnnd Granizen“. SI AS 2, DSK, kutija 198, fascikl 123a, Ljubljana, 15.3.1541., 2v, rbr. 1262 .

${ }^{105}$ O Verordneten vidi ŠTEFANEC, Država ili ne, 103-104.
} 
jedni od najvažnijih pojedinaca u razvoju krajiškog sustava u promatranom periodu, koji su bili kranjski plemići hrvatskog porijekla. Radi prepoznatljivosti sam odlučio zadržati hrvatske inačice njihovih imena. Bez obzira na to pojavljuju li se u njemačkoj ili latinskoj inačici, sva slavenska imena navodim u slavenskom obliku ako ih se moglo „dešifrirati“. Osmanska imena koja se pojavljuju u izvorima donosio sam u hrvatskoj inačici ako je bilo moguće utvrditi odgovarajući oblik. Ako to nije bilo moguće, ostavljao sam ih u izvornom obliku i kurzivu.

Također, naglasio bih da uporaba sintagmi poput „pad Bihaća“, „pad Krupe“ i slično nema nekakvih ideoloških, odnosno vrijednosno obojenih konotacija, već ih svjesno nastojim upotrebljavati u neutralnom kontekstu kao termine i sintagme uobičajene u svim južnoslavenskim jezicima.

\subsection{Izvori}

Okosnicu istraživanja čini arhivsko gradivo iz Arhiva Republike Slovenije u Ljubljani. Riječ je o nekoliko desetaka kutija fonda Deželni stanovi za Kranjsko, čiji se sadržaj direktno referira na razvoj krajiškog sustava na hrvatskom prostoru ili se odnosi na internu unutrašnjoaustrijsku vojnu problematiku relevantnu za krajišku povijest na hrvatskom teritoriju. Iako se uglavnom radi o gradivu vojne provenijencije (ratovanje, financiranje vojnih postrojbi, opskrba, utvrde, vojni izvještaji itd.), funkcionalna obrana implicirala je rješavanje niza organizacijskih pitanja koja su ovisila o suradnji vojnih i civilnih instanci. Stoga izvori često sadrže reference na političku, gospodarsku, demografsku i raznu drugu problematiku. Treba napomenuti da u određenim fasciklima, odnosno kutijama, postoji stanovita nesustavnost u paginaciji spisa. Iako je većina spisa paginirana, to nije učinjeno kod manjeg broj fascikala, odnosno kutija. No, ni paginacija ne određuje uvijek redoslijed spisa, već su uglavnom organizirani kronološki. To znači da su ti spisi isprva paginirani, a kasnije kronološki složeni, pa je redni broj spisa izgubio organizacijsku važnost. Bez obzira na tu pojavu, u referencama sam navodio sve paginirane stranice, ako ih je bilo.

Pri istraživanju povijesti krajiškog sustava bečki arhivi predstavljaju nezaobilaznu stanicu. U bečkom Kriegsarchivu pohranjen arhivski fond Croatica et Windica sadrži gradivo najviše vojno-upravne instance Hrvatske i Slavonske krajine od 1578. Dvorskoga ratnog vijeća u Grazu. Unatoč drastičnom škartiranju, taj je fond od neprocjenjive važnosti za istraživanje povijesti hrvatsko-slavonske krajine. Osobno sam koristio kserokskopije i 
mikrofilmove navedenog fonda koje se nalaze u Hrvatskom državnom arhivu u Zagrebu. Prilikom navođenja izvora ove zbirke navodio sam stranice jer su kserokopije paginirane od broja jedan nadalje u svakoj kutiji. Za izvora s mikrofilmova navodio sam godinu, mjesec i tekući broj spisa.

U bečkom Finanz-und Hofkammerarchivu, konkretno u fondu Hoffinanz Ungarn, sačuvan je registar desetine i davanja vlastelinstva Sokol te posjeda podređenih Bihaćkoj kapetaniji iz 1548. Budući da je sačuvano ili barem poznato malo takvih dokumenata, ovaj registar važan je izvor za ispitivanje gospodarskih odnosa te demografskih kretanja u referentom periodu.

U hrvatskim arhivima variraju kvaliteta i opseg gradiva. U Hrvatskom državnom arhivu je vrlo malo izvornoga gradiva vojne provenijencije iz tog perioda. Glavnina izvora zapravo su preslike gradiva iz bečkih arhiva i Štajerskoga zemaljskog arhiva u Grazu koji su također sadržavali važne podatke o temi disertacije. Preslike iz Štajerskoga zemaljskog arhiva, tzv. Militaria, dijelom su paginirane nakon preuzimanja, pa sam u tom slučaju prilikom citiranja navodio kutiju, godinu i novu paginaciju. Kada paginacije nije bilo, navodio sam kutiju, mjesto i datum ako je bilo navedeno te recto i verso stranica preslika unutar samog spisa.

U Arhivu Hrvatske Akademije znanosti i umjetnosti čuva se i ostavština Radoslava Lopašića, najvažnijeg istraživača bihaćke povijesti, koji je u originalu i prijepisu prikupio znatnu količinu izvora o Bihaću i Hrvatskoj krajini. Većina gradiva relevantnog za ovaj rad objavljena je u Lopašićevim zbirkama „Spomenici Hrvatske krajine“ (vidi popis literature), ali sam u Lopašićevoj ostavštini pronašao i nekoliko prijepisa važnih izvora iz bečkih arhiva koji nisu uvršteni u navedene zbirke izvora.

Od objavljenih zbirki izvora osobito sam koristio one koje su objavili Radoslav Lopašić, Emilij Laszowski, Ferdo Šišić, Aleksa Ivić, Lajos Thallóczy, Antal Hodinka i Sandor Horváth, a čiji se popis može pronaći u popisu izvora na kraju disertacije.

\subsection{Literatura}

Unatoč nedvojbenoj važnosti Bihaća, povijest grada te okolnog prostora i dalje je nedostatno istražena. Nakon Lopašićeve monografije o Bihaću i Bihaćkoj krajini s kraja 19. stoljeća stručnih radova o unskom prostoru gotovo da i nema. Izuzetak čine dva rada Mladena Ančića, jedan Nevena Budaka, jedan prijepis i prijevod jednog izvora o napadu bihaćkog kapetana na 
Ostrožac 1585. Nedima Zahirovića te opsežan rad Mithada Kozličića o povijesnim kartografskim prikazima unskog prostora. Kao što sam naveo, upravo poražavajuće kratka bibliografija o jednom od najvažnijih urbanih središta hrvatskog srednjovjekovlja, a onda i habsburško-osmanskoga krajišta, predstavlja osnovni poticaj za pisanje ove disertacije. ${ }^{106}$

Iako je od publikacije Lopašićeve knjige „Bihać i Bihaćka krajina“ prošlo zaista mnogo vremena, ona je i dalje polazište za bilo kakvo istraživanje o referentnom prostoru. Unatoč sasvim prirodnoj činjenici da su se s vremenom neke Lopašićeve konstatacije pokazale zastarjelim i neodrživima, Lopašić je, da citiramo Ančića, ,pokazao istančan osjećaj za prošle događaje, kojim je često nadomještao nedostatak dokumenata““ ${ }^{107}$ Lopašić je obradio i „,civilnu“ i krajišku povijest Bihaća i promatranog prostora, pa su rezultati njegova istraživanja podjednako inkorporirani u oba segmenta disertacije.

Što se tiče povijesti Bihaćke kapetanije kao dijela protuosmanskoga obrambenog sustava, knjiga „Država ili ne. Ustroj Vojne krajine 1578. godine i hrvatsko-slavonski staleži u regionalnoj obrani i politici“ Nataše Štefanec pruža najkvalitetniju analizu institucionalnog razvoja Hrvatske i Slavonske krajine u 16. stoljeću i to u regionalnom kontekstu. Autorica je vrlo detaljno rekonstruirala pozadinu i važnost odluka donesenih na saboru u Brucku 1578., dominantnu ulogu unutrašnjeaustrijskih staleža te razvoj ključnih elemenata krajiškog sustava u praksi. Nedim Zahirović je prepisao i preveo zanimljiv izvještaj bihaćkog kapetana Franza Hörnera o napadu na Ostrožac $1585 .^{108}$

Nadalje, iscrpno sam se koristio radovima Milana Kruheka, osobito njegovom knjigom „Krajiške utvrde Hrvatskog Kraljevstva u 16. stoljeću“ u kojoj je autor na temelju objavljenih i neobjavljenih izvora detaljno prezentirao razvoj krajiškog sustava na Hrvatskoj i Slavonskoj krajini, s osobitim fokusom na karakteristike, važnost i stanje fortifikacija na promatranom prostoru.

Na temelju arhivskoga gradiva pohranjenog u Arhivu Republike Slovenije, slovenski povjesničar Vasko Simoniti istraživao je posljedice osmanskih osvajanja po slovenske

\footnotetext{
${ }^{106}$ Ovdje se referiram prvenstveno na literaturu o Bihaću do osmanskog zauzimanja grada 1592. O Bihaću u osmanskom periodu vidi Nenad MOAČANIN, Bihać i osmanski obrambeni sustav na sjeverozapadu Bosanskoga ejaleta 1592.-1711., u: Spomenica Ljube Bobana, ur. Mira Kolar-Dimitrijević, Zagreb, 1996., 105111.

${ }^{107}$ ANČIĆ, Bihaćki kraj, 193. Ančić je i diskutirao s Brankom J. Bokanom o tome je li Bihać izgrađen na unskom otoku ili ipak nije. O diskusiji vidi: Branko J. BOKAN, Srednjovjekovni grad Bihać izgrađen je na brežuljku pored Une a ne na Uni, Istorijski zbornik, godina VII, broj 7, Univerzitet »Đuro Pucar Stari« Banjaluka, Institut za istoriju u Banjaluci, 1986., 233-236. te Mladen ANČIĆ, Da li je srednjovjekovni Bihać nastao na otoku, Istorijski zbornik, Univerzitet »Đuro Pucar Stari« Banjaluka, Institut za istoriju u Banjaluci, god. VII, br. 7, 1986., 237-238.

${ }^{108}$ Nedim ZAHIROVIĆ, Crtica iz ratovanja na Krajini: napad zapovjednika Bihaća Franza Hornera na Ostrožac 31. svibnja 1585. godine, Historijski zbornik, god. LXVII, 2014., 83-92.
} 
(unutrašnjeaustrijske) zemlje pri čemu se u svojim istraživanjima neizbježno doticao i hrvatskog prostora. Budući da je nemoguće razumjeti krajiški razvoj bez uključivanja unustrašnjoaustrijskog prostora, Simonitijevi radovi predstavljali su važnu literaturu u mojem istraživanju. Géza Pálffy intenzivno je pisao o razvoju protuosmanskoga defenzivnog sustava na prostoru Ugarskoga Kraljevstva. Pálffy je u svojim radovima na engleskom i njemačkom jeziku prikazao ustroj krajiškog sustava, ulogu plemstva, razvoj strateških koncepata, učinke vojne revolucije na ugarskom ratištu itd.

Hrvatski povjesničar Ivan Jurković objavio je važne priloge o migracijama i statusu hrvatskog plemstva za vrijeme osmanske ugroze. Jurković je u svojim radovima obradio ili spomenuo razne obitelji koje su ili potjecale iz okolice ili određeno vrijeme boravile u Bihaću i promatranom prostoru.

Rijedak uvid u „drugu stranu“ krajišta omogućila je disertacija hrvatske osmanistice Kornelije Jurin-Starčević koja je obradila razvoj osmanskog pograničja na hrvatskom i zapadnobosanskom prostoru u 16. i 17. stoljeću. Autorica se ne dotiče samo Bihaća već i niza drugih „krajiških tema“ koje su važne za ovo istraživanje.

Radovi poznate australske povjesničarke Wendy Bracewell i talijanske povjesničarke Marie Pije Pedani omogućavaju dragocjeni međunarodni rakurs na regionalnu problematiku, odnosno kontekstualizaciju događaja, procesa i fenomena na hrvatskom prostoru u širem, europskom okviru. Wendy Bracewell bavila se raznim pitanjima habsburško-osmanskog pograničja na našem prostoru, od historiografskih tema, preko senjskih uskoka do pograničnih društava, običaja i tradicija, a Maria Pia Pendani se doduše bavila osmansko-mletačkim relacijama, ali tematski relevantnim za ovo istraživanje.

Što se pak urbane povijesti tiče, oslonio sam se na radove domaćih autora Nevena Budaka, Mladena Ančića, Danijela Jelaša te na radove mađarskih povjesničara Katalin Szende i Istvana Petrovicsa koji se bave problemom razvoja gradova na komplementarnome ugarskom prostoru. Radovi Mladena Ančića o srednjovjekovnoj povijesti Bihaća pokazali su se iznimno vrijednima, osobito zato što moje istraživanje tek periferno zahvaća taj period. U kombinaciji s Lopašićevom knjigom, Ančićevi radovi predstavljaju temeljnu literaturu o srednjovjekovnom periodu bez kojih bih teško mogao kontekstualizirati urbani razvoj šesnaestostoljetnog Bihaća. Na temelju dostupnih vrela Ančić je analizirao povijest Bihaća i bihaćkoga kraja od prvog spomena do zalaganja grada Pavlu Čuporu 1410., pa jedino zbog čega možemo žaliti jest što autor u svojim radovima nije obradio kompletni period 15 . stoljeća.

Neven Budak je u svojem radu o ulozi Bihaća u obrani od Osmanlija, na temelju 
objavljenih i neobjavljenih izvora, dao kvalitetan i informativan prikaz važnosti Bihaća za obranu hrvatskog pograničja u 16. stoljeću. Autor se referirao i na srednjovjekovni ustroj bihaćke gradske općine, komentirao demografsko stanje, problem opskrbe, osiguravanja hrane i trgovine u 16. stoljeću te općenito problem obrambenog potencijala. Zato je njegov rad vrlo važan za ovu disertaciju. U svojem je magistarskom radu o gradovima Požeške, Vukovske i Srijemske županije u srednjem vijeku Danijel Jelaš dao pregled procesa urbanizacije navedenog prostora, pri čemu su upravne paralele bile bitne za moju disertaciju. Mađarski povjesničari Katalin Szende i Istvan Petrovics bave se istraživanjem raznih aspekata razvoja gradova na ugarskom prostoru pa su njihovi radovi bili korisni za kontekstualizaciju slobodnoga kraljevskoga grada Bihaća u širem, ugarsko-hrvatskom kontekstu. Detaljne reference o navedenim i korištenim naslovima mogu se pronaći u popisu literature na kraju ovog rada. 


\section{RAZVOJ KRAJIŠKOG SUSTAVA - NASTANAK I RAZVOJ BIHAĆKE KAPETANIJE}

\subsection{Razvoj protuosmanskoga obrambenog sustava do 1527.}

Kao što je već spomenuto, prvi poznati defenzivni sustav na unskom prostoru formirali su još sredinom 14. stoljeća ugarsko-hrvatski kraljevi iz dinastije Anžuvinaca kao oslonac u borbi protiv nepokornih hrvatskih velikaša, odnosno kao obrambeni bedem protiv ekspanzivne politike Bosanskoga Kraljevstva. Taj strateški blok činile su utvrde Sokol kod Bihaća, Ostrožac $^{109}$ i Ripač, s time da se kao najvažnija utvrda navodi Sokol koju kralj Žigmund Luksemburški apostrofira kao glavnu utvrdu ,između Hrvatske i Slavonije““. ${ }^{110}$ Navedene utvrde bile su izrazito bitne i za sigurnost Bihaća jer su nadzirale pristup Bihaćkoj dolini. Njihovom obranom, paralelno je štićen i sam grad.

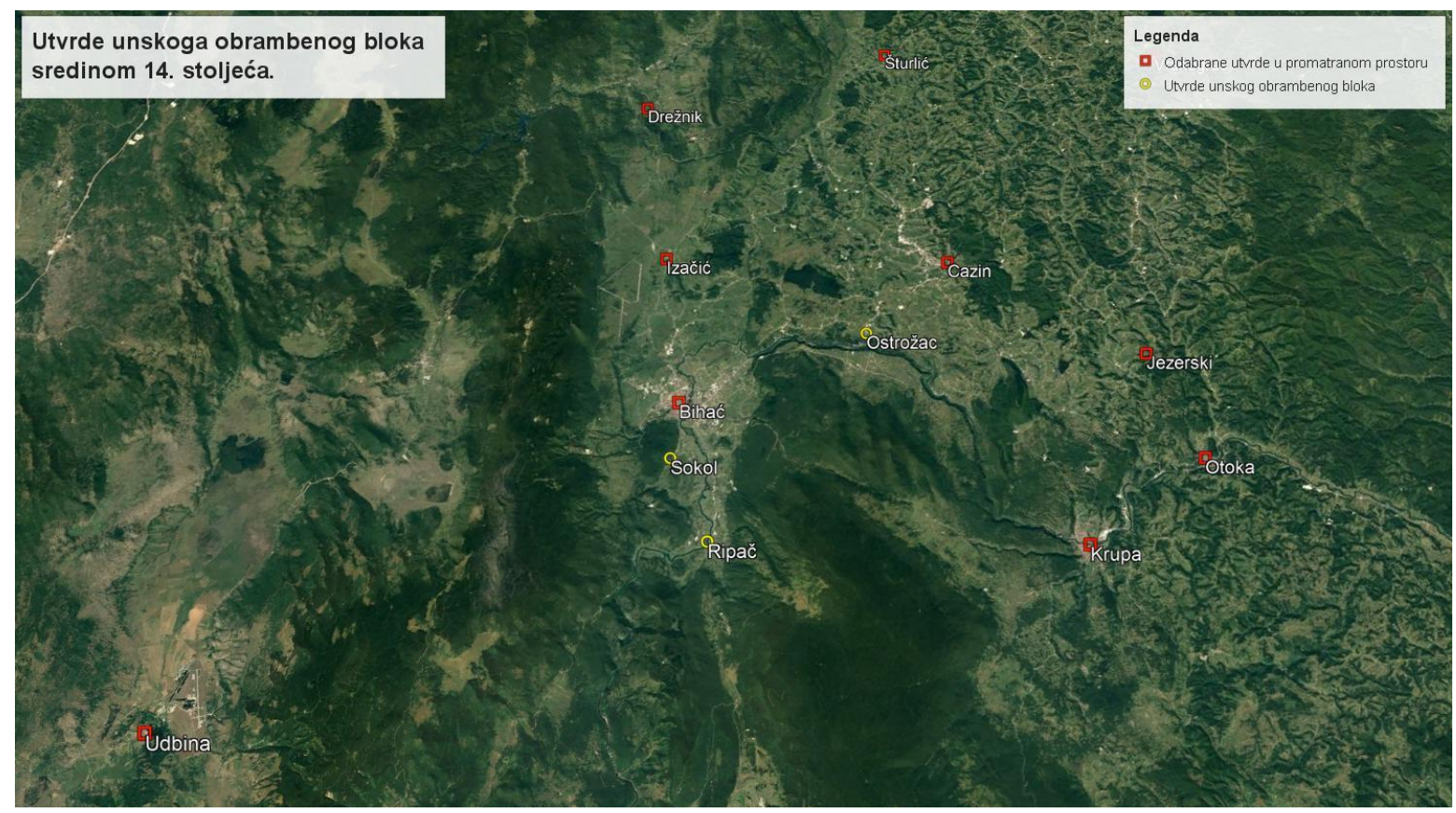

Slika 4. Utvrde unskoga obrambenog bloka i Bihać sredinom 14. stoljeća.

\footnotetext{
109 Castrum Ostrožac, koji su prvoj polovici 14. stoljeća podigli velikaši Babonići na posjedu kupljenom od plemena Sučana, a zbog izbijanja rata s Bosanskim Kraljevstvom, od Babonića preuzima kralj Žigmund i to kako navodi „poradi čuvanja ojačanja i obrane našega kraljevstva Slavonije“. ANČIĆ, Bihaćki kraj, $200-201$. Kralj Žigmund oduzima 1395. Blagajskima Krupu i Ostrožac te ih dodijeljuje Hrvoju Vukčiću Hrvatiniću ne bi li umanjio njegovu prijetnju. Hrvoje KEKEZ, Plemići rod Babonića do kraja 14. stoljeća, doktorska disertacija, Filozofski fakultet Sveučilišta u Zagrebu, Zagreb, 2012., 165.

${ }^{110}$ Sokol se prvi puta spominje 1369. Vojnom posadom zapovjedao je kaštelan koji se nalazio pod banskom jurisdikcijom. Kaštelan je imao sudske ovlasti nad podložnicima koji su živjeli na posjedima utvrde. ANČIĆ, Bihaćki kraj, 199.
} 
Budući da karakteristike ovoga (proto)defenzivnog sustava na unskom prostoru nisu detaljnije istražene, u ovom ga je trenutku teško preciznije valorizirati. No, već svega nekoliko desetljeća kasnije defenzivni fokus bit će primarno usmjeren na Osmanlije koji već od početka 15. stoljeća pljačkaju širi unski prostor. ${ }^{111}$ Mladen Ančić, na temelju darovnice kojom kralj Žigmund Luksemburški 1408. daruje braći Tumpa za zasluge obrane Ripča i Sokola od „Bosanaca i Turaka“ tada napušteni posjed Peći, smatra da prvi spomen Osmanlija u ovim krajevima treba tražiti oko $1405 .{ }^{112}$ Dakle, osmanski napadi na promatranom su prostoru započeli vrlo rano te su generacije lokalnog stanovništva stasale u ambijentu permanentnih vojnih sukoba. Upravo je to višegeneracijsko iskustvo ratovanja s Osmanlijama jedna od glavnih karakteristika hrvatskog stanovništva u promatranom periodu, što, između ostalog, potvrđuju i riječi predstavnika kranjskih staleža koji nadvojvodi Ferdinandu 1520. predlažu da u službu uzme Hrvate te hrabre vitezove navikle na neprijatelja - dakle, Osmanlije. ${ }^{113} \mathrm{U}$ travnju 1522. nadvojvoda Ferdinand pak u svojoj instrukciji austrijskim staležima navodi da se „viteške kršćanske ljude Hrvate“ može promatrati kao „predziđe i čvrsti štit“ (ain zwinger mauer und vester schilt) njihovih zemalja. Navodi da Hrvati već godinama uz veliko prolijevanje krvi zadržavaju neprijatelja gubeći pritom živote, žene, djecu i dobra te ako im se siromašenima i iscrpljenima ne pomogne, neće se moći dalje sami obraniti te će sav teret pasti na austrijske zemlje. ${ }^{114}$

Bez obzira na postupni porast osmanske prijetnje, unski će prostor još dugi niz godina biti relativno siguran jer su osmanske provale bile primarno pljačkaškog, ali ne i osvajačkoga karaktera. Ipak, zbog sve intenzivnijih osmanskih upada na ugarskom prostoru, a osobito nakon katastrofalnoga kršćanskog poraza kod Nikopolja 1396., središnja vlast započinje s ozbiljnijim protuosmanskim obrambenim mjerama. Tada poduzete mjere nisu se u osnovi razlikovale od kasnijih strateških principa - središnja vlast nastojala je centralizirati obranu preuzimanjem uprave nad pograničnim utvrdama na donjem Dunavu, ojačati postojeće i podići nove utvrde te preuzeti zapovjedništvo nad mobilnim jedinicama i vojnicima

\footnotetext{
${ }^{111}$ Tako je, primjerice, već u prvim desetljećima 15. stoljeća stradalo nešto sjevernije smješteno Petrinjskogradačko vlastelinstvo. Vlastelin Ivan Sudar žali se 1433. da su petrinjski posjedi opustošeni od Osmanlija. Dakle, već su tada napadani posjedi na širem prostoru. Josip ADAMČEK, Glina i njezina okolica u srednjem vijeku“, u: Glina. Glinski kraj kroz stoljeća, ur. Drago Roksandić i Mira Kolar-Dimitrijević, Zagreb, 1988., 14. ${ }_{112}^{112}$ ANČ́IĆ, Bihaćki kraj, 203.

${ }^{113}$ Simoniti navodi da kranjski staleži predlažu nadvojvodi Ferdinandu da Hrvate te ,junaške ljudi, ki z veliko težavo varujejo mali ostanek svoje kraljevine med Uno in Koplo, vzameju v službo za varstvo meje. Zelo so namreč uporabni zaradi svojega viteškega poguma in navajenosti na sovražnika, prav tako pa je njihovo deželo polno hrbibov in voda, vredno obdržati kot plemenito dragocenost.“ Vasko SIMONITI, Turki su v deželi že, Mohorjeva družba, Celje, 1990., 110.

${ }^{114}$ Lajos THALLÓCZY, Antal HODINKA, A horvát véghelyek oklevéltára 1490-1527, Codex diplomaticus partium regno Hungariae adnexarum, Monumenta Hungariae Historica, vol. XXXI, Budimpešta, 1903., dok. LII, 64.
} 
stacioniranima u utvrdama. ${ }^{115}$ Nadalje, madžarski povjesničar János M. Bak navodi: „The dominant strategy, in so far as one existed at all, was to assist the buffer states' of the northern Balkans, and to attempt to secure their loyalty to Hungary, in other words, to encourage them to resist Ottoman subjection. This worked well enough when the Hungarian forces seemed to be strong enough, but less well when the Porte appeared to gain the upper hand."116 Uspostavljanje tampon-zone u okolnim državama i kraljevstvima (Vlaška, Srbija, Bosna) isti je princip koji će kasnije primjenjivati i Habsburgovci, odnosno staleži Unutrašnje Austrije formirajući svoj obrambeni bedem na hrvatskom prostoru.

Prvi sustavniji protuosmanski defenzivni sustav organiziran je 1430-ih uspostavljanjem tzv. sustava tabora. Na hrvatsko-slavonskom prostoru tada su ustrojena tri tabora: Hrvatski, Slavonski i Usorski tabor. ${ }^{117}$ Hrvatski tabor obuhvaćao je južni i primorski dio Hrvatske, Slavonski tabor teritorij uz rijeku Unu, a najveći, Usorski tabor prostor južno od rijeke Save. ${ }^{118}$ Prema odredbama o vojnom ustrojstvu iz 1432./33. unski prostor s Bihaćem branili su slavonski ban, knezovi Blagajski, vranski prior i zagrebački župan, svi s po jednim banderijem od 500 ljudi, te Ladislav Tot Susedgradski sa 100 konjanika. ${ }^{119}$ U trenutku smrti kralja Žigmunda Luksemburškog 1439. cjelokupni defenzivni sustav prostirao se na potezu od Transilvanije do Jadranskog mora, a iste godine podijeljen je na dva krila - istočno, od Szörenyja do Beograda pod zapovjedništvom transilvanijskog vojvode i zapadno, hrvatskoslavonsko krilo pod zapovjedništvom bana. Iako su oba krila rijetko nastupala sinkronizirano i koordinirano $^{120}$, sustav je bio ,adequate for permanent defence“, kako to navodi Géza Pálffy. ${ }^{121}$ Također, treba naglasiti da su se Bihać i prostor oko rijeke Une nalazili u Slavonskom, a ne Hrvatskom taboru, te da je obrana uglavnom pod ingerencijom hrvatsko-

\footnotetext{
${ }^{115} \mathrm{U}$ tom pogledu osobito je važan sporazum sa srpskim despotom Stefanom Lazarevićem iz Tate 1426. jer je tada dogovoreno da će nakon despotove smrti niz utvrda, uključujući i Beograd, ući u sastav Ugarskoga Kraljevstva. Richard HORVATH, The Castle of Jajce in the Organization of the Hungarian Border Defence System under Matthias Corvinus, u: Stjepan Tomašević (1461-1463) - slom srednjovjekovnog Bosanskog Kraljevstva, Zbornik radova sa znanstvenog skupa održanog 11. i 12. studenog 2011. u Jajcu, Hrvatski institut za povijest, Katoličko bogoslovni fakultet u Sarajevu, Zagreb, 2013., 91.

116 János M. BAK, Hungary and Crusading in the Fifteenth Century, u: Crusading in the Fifteenth Century. Message and Impact, ur. Norman Housley, Palgrave Macmillan, New York, 2004., 119.

${ }^{117}$ Nataša ŠTEFANEC, Diet in Bruck an der Mur (1578) and the Estates on the Croatian, Slavonian and Kanisian Military Border, doktorska disertacija, Central European University, Budimpešta, 2004., 23.

${ }_{118}$ Ive MAŽURAN, Hrvati i Osmansko Carstvo, Golden Marketing, Zagreb, 1998., 28; Milan KRUHEK, Kostajnica u protuturskoj obrani Hrvatskoga Kraljevstva, Povijesni prilozi, 21, 2001.,72.

${ }^{119}$ BOTICA, Krbavski knezovi, 149.

${ }^{120}$ Ferenc SZAKALY, The Hungarian-Croatian Border Defense System and its Collapse, u: From Hunyadi to Rakoczi: War and Society in late medieval and early modern Hungary, War and Society in Eastern Central Europe, ur. János M.Bak i Bela K. Kiraly, Brooklyn College Press, 1982., 146.

${ }^{121}$ Geza PALFFY, The Origines and Development of the Border Defence System Against the Ottoman Empire in Hungary (up to the Early Eighteenth Century), u: Ottomans, Hungarians, and Habsburgs in Central Europe. The Military Confines in the Era of Ottoman Conquest, ur. Geza David i Pal Fodor, Brill, Leiden-Boston-Köln, 2000., 10.
} 
slavonskih instanci i velikaša vezanih uz slavonski prostor, a to je još jedan pokazatelj „prijelaznoga“" karaktera unskog prostora.

Nakon propasti Bosanskoga Kraljevstva i uspješnog protuudara kralja Matijaša Korvina u Bosnu 1463. ustrojen je novi obrambeni blok formiranjem Jajačke, Srebrničke, Mačvanske i Severinske banovine, kojima se šest godina kasnije pridružila i Senjska kapetanija. Kruhek navodi da je stvaranje Senjske kapetanije primarno usmjereno protiv mletačkih pretenzija na istočnoj Jadranskoj obali te da Senj, tek s rastom osmanske opasnosti i proširenjem defenzivnog prostora na utvrde u Lici, postaje jedna od glavnih utvrda za zaustavljanje osmanskog napredovanja. ${ }^{122}$ Obrana se 1460 -ih temeljila na dvjema linijama utvrda - isturenoj liniji koja se protezala od Severina u današnjoj Rumunjskoj, preko Beograda, Šapca, Srebrenika, Banja Luke, Jajca pa sve do Knina, Skradina, Klisa i ušća Neretve na krajnjem jugu te na stotinjak kilometara uvučenoj pričuvnoj liniji koja je započinjala oko Temišvara te preko Srijema, Dubice, Krupe, Bihaća i Otočca završavala sa Senjom u Hrvatskom Primorju. ${ }^{123}$

Prema Gaboru Agostonu, organiziranje funkcionalnijega obrambenog sustava posljedica je suočavanja s mnogo snažnijim Osmanskim Carstvom nego li je to bio slučaj do tada. ${ }^{124}$ Obranom su, svaki na svojem odjeljku, upravljali ban Hrvatske i Dalmacije, zatim temišvarski šerif na donjem Dunavu te transilvanijski vojvoda. Pod njihovom ingerencijom nalazile su se vojne postrojbe i mreža utvrda te županijski i plemićki banderiji. Géza Pálffy tvrdi da je upravo u tom kontekstu 1476. izvršeno spajanje funkcije bana Hrvatske i Dalmacije i bana Slavonije, i to s namjerom da mu se podrede zapovjednici pograničnih utvrda te mobilne jedinice koje su podizale i držale županije, odnosno baruni i plemstvo na određenom prostoru. ${ }^{125}$

Defenzivni kostur sačinjavale su kraljevske i magnatske utvrde, a prostor između utvrda pokrivale su uglavnom banderijalne čete. U važnijim utvrdama smještene su kraljeve postrojbe, bez obzira na to kome su utvrde pripadale. Za opskrbu i vojnu pomoć odgovorne su

\footnotetext{
${ }^{122}$ Milan KRUHEK, Krajiške utvrde Hrvatskog kraljevstva tijekom 16. stoljeća, Institut za suvremenu povijest, Zagreb, 1995., 46, fusnota 57. Za razvoj Senjske kapetanije vidi Vedran KLAUŽER, Ustrojstvo i djelovanje Senjske kapetanije od njezina osnutka da organizacije Vojne krajine po vrhovnom zapovjedniku Ivanu Lenkoviću (1469.-1563.), doktorska disertacija, Hrvatski studiji Sveučilišta u Zagrebu, 2015.

${ }^{123}$ Ivan JURKOVIĆ, Turska opasnost i hrvatski velikaši - knez Bernardin Frankopan i njegovo doba, Zbornik Odsjeka za povijesne znanosti Zavoda za povijesne i društvene znanosti Hrvatske akademije znanosti $i$ umjetnosti, vol.17, Zagreb, 2000., 65; TRACY, Balkan Wars, 34.

${ }^{124}$ Gabor AGOSTON, Ottoman Conquest and the Ottoman Military Frontier in Hungary, u: A Millennium of Hungarian Military History, ur. Béla Király i László Veszprémy, No. 114., Boulder Co., 2002., 85.

${ }^{125}$ PALFFY, The Origines, 10-11. Jurković navodi da razlog leži u činjenici što je podređeni teritorij bio prevelik da bi obranom administrirala samo jedna osoba. Kada je funkciju bana obnašala jedna osoba, tada se radilo o izrazito moćnim pojedincima poput Ivaniša Korvina, Petra Berislavića ili Ivana Karlovića. JURKOVIĆ, The Fate, 58.
} 
bile Zagrebačka, Križevačka, Požeška, Vukovska i Srijemska županija ${ }^{126}$, a s obzirom na teren i financijske okolnosti, pješaštvo je dominiralo nad konjaništvom. ${ }^{127}$ Pálffy konstatira da je centar zapadnoga hrvatsko-slavonskog krila bio upravo Bihać. ${ }^{128}$ Budući da Bihać nije bio u sastavu navedenih banovina, a ni Senjske kapetanije, Pálffyjev navod možemo protumačiti kao još jedan pokazatelj njegova socipolitičkog, pa onda i vojnog značenja na hrvatskoslavonskom prostoru.

Unatoč permanentnim financijskim problemima i činjenici da je politički i vojni fokus uglavnom bio usmjeren prema srednjoeuropskom prostoru, za vladavine kralja Matijaša Korvina obrana južnih granica Ugarsko-hrvatskoga Kraljevstva zadovoljavajuće je funkcionirala. Doduše, puni potencijal nije postignut jer se središnja vlast zadovoljila stabiliziranjem fronte i aktivnom obranom ugroženih područja, dok su se ofenzivna djelovanja uglavnom svodila na provale na osmansko područje bez ozbiljnije namjere za osvajanjem izgubljenih kršćanskih teritorija.

U promatranom periodu utvrde oko rijeke Une ulaze u obrambene sustave, odnosno preuzimaju sve istaknutiju pograničnu ulogu. Uz već spomenute utvrde u okolici Bihaća (Sokol, Ripač, Ostrožac), treba izdvojiti Krupu nad kojom je 1487. zapovjedništvo preuzeo senjski kapetan Petar Tarnok od Mačkaša. ${ }^{129}$ Mnoge od utvrda koje će kasnije ući u sastav Bihaćke kapetanije, poput Cazina, Izačića, Ostrošca, ali će još dugo ostati u privatnom posjedu, također su prolazile kroz slične procese iako su ostale izvan specifično organiziranoga obrambenog ustroja. $\mathrm{O}$ tome procesu bit će riječ dalje u tekstu.

Novi moment ratovanja s Osmanlijama nastupio je dolaskom dinastije Jagelovića na ugarski tron 1491. Iako se dosadašnja historiografija uglavnom (pre)kritički odnosila prema naporima i rezultatima obrambenih mjera kraljeva iz dinastije Jagelović, najnovija istraživanja ipak (poprilično) mijenjaju tu stereotipnu, pa čak i anegdotalnu predodžbu. Bez obzira na to što je moć centralne vlasti zaista degradirala u odnosu na razdoblje vladavine kralja Matijaša Korvina te bez obzira na to što su interni sukobi velikaša ozbiljno narušili obrambenu moć Ugarsko-hrvatskoga Kraljevstva pa su pojedini dijelovi Kraljevstva zaista zapali u kaotično stanje, treba napomenti da je tijekom vladavine kraljeva Vladislava II. i Ludovika II. utrošen ogroman novac na protuosmansku obranu. ${ }^{130}$

\footnotetext{
${ }^{126}$ MAŽURAN, Hrvati, 39.

127 JURKOVIĆ, Turska opasnost, 70.; KLAIĆ, Povijest Hrvata, knjiga 4, 280.

${ }^{128}$ PALFFY, The Origines, 12.

${ }^{129}$ Vedran KLAUŽER, Petar Tarnok od Mačkaša (de Machkas), kapetan Senjske kapetanije (1486.-1492.), u: Ascendere historiam. Zbornik u čast Milanu Kruheku, ur. Marija Karbić, Hrvoje Kekez, Ana Novak i Zorislav Horvat, Hrvatski institut za povijest, Zagreb, 2014., 86.

${ }^{130}$ Tako je, primjerice, kralj Vladislav 1504. utrošio visokih 20000 zlatnih forinti za uzdržavanje Jajačke
} 
Sukobi su ponovno eskalirali nakon relativno mirne vladavine sultana Bajazida II. (1481. - 1512.) kada na hrvatskom prostoru nije bilo većih osvajanja. Ustoličenjem Selima I. (1512. - 1520.) započelo je razdoblje intenzivnih osmanskih ofenzivnih djelovanja. Iako je glavnina vojnih akcija bila usmjerena prema istočnim i jugoistočnim granicama Osmanskog Carstva, na zapadnom je krajištu ostvaren velik uspjeh probijanjem obrane Srebreničke banovine i osvajanjem sjeveroistočne Bosne. Niz ofenzivnih uspjeha nastavljen je na hrvatskom krajištu 1513. zauzimanjem Čačvine, Nutjaka na Cetini, Vira kod Imotskog, Sinja, Ostrovice, Zečeva, Zadvarja i Sonkovića, a godinu dana kasnije i Korlata i Karina. ${ }^{131}$ Time je nepovratno narušen dugogodišnji ekvilibrij između Ugarskog-Hrvatskog Kraljevstva i Osmanskog Carstva ${ }^{132}$, a osmansko pograničje pomaknulo se u neposrednu blizinu Bihaća.

Zanimljivo je da su velika osmanska osvajanja na hrvatsko-bosanskom prostoru ostvarena u razdoblju kada je Osmansko Carstvo na svojim istočnim granicama bilo uključeno u teške borbe s Perzijskim Carstvom. Prema izvještajima mletačkih diplomata, taj je sukob toliko iscrpio osmanske snage da su do 1519. osmanski vojnici sami tražili „Zatvaranje“ istočnog i otvaranje zapadnog fronta s Ugarsko-hrvatskim Kraljevstvom koji su smatrali slabijim protivnikom. Ta zapadna fronta napokon je otvorena s dolaskom Sulejmana I. na prijestolje u rujnu $1520 .{ }^{133}$

Sulejmanovo ustoličenje, katastrofalni poraz na Mohačkom polju 1526., promjena vladajuće dinastije i početak građanskog rata na području Ugarsko-hrvatskoga Kraljevstva, uvod su u novo, dramatično doba osmanske ekspanzije. U trenutku kada je sultan Sulejman stupio na prijestolje, Osmansko Carstvo prostiralo se na 1,5 milijuna km², brojalo oko 12-13 milijuna stanovnika, ubiralo godišnji prihod od 4-5 milijuna dukata te permanentno držalo 100 000-120 000 vojnika. Osmanlije su raspolagali i s rastućom riječnom i morskom flotom. S druge pak strane, Ugarsko-hrvatsko Kraljevstvo prostiralo se na $300000 \mathrm{~km}^{2}$ teritorija, brojalo oko 3,3 milijuna stanovnika i raspolagalo s državnim proračunom do 250000

banovine da bi od 1506. do 1512. za njezinu obranu bilo isplaćeno još 25100 zlatnih forinti. U istom je periodu opći protuosmanski napor financiran s visokih 145000 zlatnih forinti. Središnja vlast na hrvatskom prostoru financirala je ne samo bana već i konjanike i pješake koji su osiguravali gradove pojedinih hrvatskih knezova. Ban je držao 200 plaćenih konjanika. Senjsku kapetaniju kralj je posebno financirao s 2000 forinti. Središnja vlast podmirivala je trošak uzdržavanja 1152 vojnika, 752 konjanika i 200 pješaka raspoređenih po utvrdama i pod zapovjedništvom pojedinih hrvatskih knezova, što je godišnje iznosilo 16800 forinti. Kralj se starao i o popravku i održavanju Klisa, Sinja, Knina i Rmnja. KRUHEK, Krajiške utvrde, 52; KLAIĆ, Povijest Hrvata, knjiga 5, 25; 45. To definitivno nisu zanemarivi izdaci, osobito kada se uzme u obzir da su navedene cifre utrošene samo za obranu hrvatskog i bosanskog prostora.

131 JURIN-STARČEVIĆ, Osmanski krajiški, 21-22; 25.

${ }^{132}$ FODOR, Introduction, XV.

${ }^{133}$ AGOSTON, Ottoman Conquest, 87. 
forinti. ${ }^{134}$ Ugarsko-hrvatsko Kraljevstvo suočilo se sa superiornim protivnikom u naponu snage, oponentom koji je u punom smislu riječi tadašnja velesila. Bez obzira na mogućnosti otpora koje su stajale na raspolaganju, da bi se zaustavio takav protivnik trebalo je osigurati širu regionalnu pa i paneuropsku potporu. Čak i da je dinastija Jagelovića ostala na prijestolju, bez potpore zemalja u zaleđu, a prije svega resursa imperijalne dinastije Habsburgovaca, teško da bi Ugarsko-hrvatsko Kraljevstvo samostalno izdržalo taj furiozni osmanski nalet.

\subsection{Razvoj protuosmanskoga obrambenog sustava nakon 1527.}

Kao što je već navedeno, iz hrvatske perspektive (pre)često se zanemaruje činjenica da dolaskom Habsburgovaca na ugarsko-hrvatsko prijestolje sukob s Osmanlijama prerasta u konflikt dviju velesila koji je involvirao cijelu srednju Europu, Mediteran pa i šire. ${ }^{135}$ Hrvatsko-slavonsko krajište sastavni je dio krajiškog sustava koji se protezao od Jadranskog mora do Transilvanije/Erdelja, a koji je sačinjavalo šest krajiških odjeljaka - Hrvatska s Primorskom te Slavonska krajina na hrvatskom prostoru, Kaniška i Đurska krajina, krajina Rudarskih gradova te Gornjougarska krajina. ${ }^{136}$ Nadalje, Habsburgovcima Osmanlije nikada nisu bili jedini oponenti. U prvim desetljećima Ferdinandove vladavine Ugarsko-hrvatskim Kraljevstvom narušene su interne stabilnosti kompozitnih habsburških zemalja koje su, uz osmansko napredovanje, ozbiljno uzdrmali pojava vjerske reformacije, veliki seljački ustanak 1525. te u konačnici izbijanje katastrofalnoga građanskog rata koji je na području Ugarsko-

\footnotetext{
${ }^{134}$ PÁlLFY, Povijest Madžarske, 29; AGOSTON, Ottoman Conquest, 85-110. Tracy navodi da je 1512. prihod sultana Bajazida II. iznosio 12 milijuna dukata što je bilo pedeseterostruko više od cara Maksimilijana I. te šezdeseterostruko više od prihoda kralja Vladislava II. TRACY, Balkan Wars, 76.

${ }^{135}$ PÁLFFY, Die Türkenabwehr, 100.

${ }^{136}$ Cijeli taj prostor osiguravalo je između 16 i 17000 konjanika i pješaka, a pridodaju li se tom broju i plemićke čete, ukupan broj vojnika na habsburškoj strani pograničja iznosio je oko 30000 ljudi. Financiranje obrane na takvome velikom prostoru proždiralo je golemih 1500000 rajnskih guldena godišnje, a s time su Habsburgovci jedva izlazili na kraj. FODOR, Introduction, XVII. Od ukupnog je iznosa za plaće vojnika stacioniranih u 72 utvrde na hrvatsko-slavonskom području otpadalo 22 posto financijskih sredstava. PALFFY, The Origins, 49. No, za razliku od hrvatskog i slavonskog plemstva koje je financijski minimalno participiralo u obrani, doprinos ugarskih staleža bio je neusporedivo veći iako su i oni ovisili o pomoći austrijskih staleža. Geza PÁLFFY, The Border System in Hungary in the Sixteenth and Seventeenth Centuries, u: A Millennium of Hungarian History, ur. László Veszprémy, Bélá K. Király, New York, Columbia University Press, 2002., 113. Ugarski staleži raspolagali su 1560-ih s maksimalno 750-800 000 rajnskih guldena, Ipak, taj iznos, koji bi bio dovoljan za pokrivanje troškova polovice plaća vojnika u pograničnim utvrdama, nikad nije u potpunosti utrošen u vojne svrhe. Novac stvarno utrošen u vojne svrhe pokrivao je tek 25-35 posto plaća vojnika u pograničnim utvrdama. Geza PÁLFFY, Scorched-Earth Tactics in Ottoman Hungary: On Controversy in Military Theory and Practice on the Habsburg-Ottoman Frontier, Acta Orientalia Academiae Scientiarum Hungaricae, vol. 61, No. 1-2, 2008. , 187-188. Treba napomenuti da je i Osmanlijama uzdržavanje ugarskog serhata (krajišta) predstavljalo veliki financijski teret na koji su trošili iznos u vrijednosti od pola godišnjeg prihoda Egipta koji je u 16. stoljeću bio najunosnija osmanska provincija. PEACOCK, Introduction, 25.
} 
hrvatskog Kraljevstva bjesnio više od desetljeća. Pomoć koja je stizala iz Svetog Rimskog Carstva Njemačke Narodnosti bila je izrazito bitna, ali ipak limitirana opsega jer je i Carstvo bilo opterećeno raznim internim i eksternim konfliktima u kontinentalnoj Europi i na Mediteranu. $^{137}$

U historiografiji postoje različiti stavovi o porijeklu habsburškoga obrambenog sustava. Prema uglednome madžarskom povjesničaru Ferencu Szakalyju, srednjovjekovni obrambeni sustav urušio se 1520-ih, pa je habsburški krajiški sustav tek parcijalno naslijeđen iz prethodnog razdoblja. Stoga on ne bi bio rezultat kontinuiranog razvoja, već ponovnog organiziranja cijelog sustava. ${ }^{138}$ Slično je i s krajiškim sustavom na hrvatskom prostoru. Dok jedni naseljavanje uskoka na Žumberak promatraju kao početak procesa formiranja krajiškog sustava $^{139}$, drugi taj proces vezuju uz djelovanje važnih vojnih zapovjednika. Tako, primjerice, Pálffy smatra da postavljanjem Erasma Thurna za glavnog zapovjednika Senja, Bihaća, Ripča i Otočca te podređenih utvrda (zapravo cijele „stare Hrvatske krajine“), nakon što se Petar Keglević 1538. odrekao zapovjedništva nad podređenim mu utvrdama, započinje stvaranje zapadnog dijela Hrvatske krajine od Une do Jadranskog mora te da se implementacija krajiškog sustava najbrže odvijala baš na hrvatskom prostoru i to na potezu od Senja do Bihaća od 1526. do 1540. ${ }^{140}$ Gunther Rothenberg smatra da je imenovanje Hansa Ungnada Obristen veldthauptmannom na Hrvatskoj i Slavonskoj krajini 1540. presudan moment $\mathrm{u}$ formiranju krajiškog sustava. ${ }^{141}$ Različiti stavovi povjesničara svjedoče da formiranje krajiškog sustava nije bio u potpunosti planski vođen proces, već je on tekao postupno i prema potrebama trenutka. Stoga je vrlo teško odrediti njegovu ,nultu točku“.

No, habsburški krajiški sustav svakako nije niknuo ni iz čega jer se čini malo vjerojatnim da višedesetljetno pogranično iskustvo, $\mathrm{u}$ institucionalnom, vojnom $\mathrm{i}$ općedruštvenom pogledu, ne bi utjecalo na razvoj habsburškoga defenzivnog pojasa. Iako je srednjovjekovni obrambeni sustav dobrim dijelom kolabirao, on je i dalje mogao odnosno morao poslužiti kao model organiziranja novog sustava. Uostalom, Senjska kapetanija

\footnotetext{
137 Primjerice, na saboru njemačkih staleža u Innsbrucku 1518. predloženo je da se na južnim granicama Hrvatske od Jurjeva do Martinja (od 24. travnja do 11. studenoga) drži 4000 konjanika i 2000 pješaka dok se ne organizira opći vojni pohod na Osmanlije. KRUHEK, Krajiške utvrde, 64.

${ }_{138}$ ŠTEFANEC, Država ili ne, 397-398; SZAKÁLY, The Hungarian-Croatian, 141-158.

139 Andrej HOZJAN, Die ersten steirischen Kundschafter vnd Postbeförderer. Spionage, Kontraspionage und Feldpost der Grazer Behörden zwischen 1538 und 1606, Mitteilungen des Steiermärkischen Landesarchivs, 48, 1998, 240.

${ }^{140}$ PALFFY, The Origins, 20-22.

${ }^{141}$ Gunther E. ROTHENBERG, The Military Border in Croatia, 1522-1747, Urbana, 1960., 34.
} 
postojala je tada već više od pola stoljeća dok je razvoj Bihaćke kapetanije započeo odmah nakon izbora nadvojvode Ferdinanda za hrvatskoga kralja. ${ }^{142}$

Nadalje, smatram da je Géza Pálffy ispravno zaključio da je upravo Bihać ključan u procesu formiranja krajiškog sustava i to kao centar nastajuće Hrvatske i Primorske krajine 1530-ih i 1540-ih. ${ }^{143}$ Proces institucionalnog krajiškog razvoja trajao je desetljećima i kulminirao je tek nakon sabora u Brucku na Muri 1578. kada je sva terenska vojska na krajini smještena u pogranične utvrde. Nataša Štefanec navodi da je tek period od 1578. do 1606. vrijeme „konsolidacije krajine i razdoblje u kojem je krajina počela funkcionirati kao kompaktan sustav “. ${ }^{144}$ Zapravo su tek tada zaživjele standardne kapetanije kakve opstaju sve do velikih krajiških reformi 18. stoljeća. Kapetanije su obuhvaćale pojedine utvrde i vojne formacije na određenom području, ali tada još ne i zaokruženi teritorij, kao što će biti slučaj dvjestotinjak godina kasnije. Njih su ustrojili i financirali unutrašnjeaustrijski staleži te se nisu nalazile pod banskom ingerencijom, već isključivo pod zapovjedništvom stranih zapovjednika, odnosno zapovjednika koje su namjestile središnje vlasti i austrijski staleži.

Ključne figure reorganizacije defenzivnog sustava na hrvatsko-slavonskom prostoru bili su vladari kuće Habsburg te staleži Unutarnje Austrije koji su caru Maksimilijanu I. već 1518. predložili formiranje obrambenog pojasa u Hrvatskoj. ${ }^{145}$ Nadvojvoda Ferdinand pomagao je obranu na hrvatskom prostoru barem od 1521. ${ }^{146}$, a već 1522 . staleži Svetog Rimskog Carstva Njemačke Narodnosti okupljeni u Nürnbergu traže da se Ferdinandu predaju utvrde u Senju, Krupi, Kninu, Skradinu, Klisu i Ostrovici. ${ }^{147}$ Simoniti navodi da su već sljedeće godine Senj, Krupa i Klis u rukama austrijskih staleža dok su Osmanlije osvojili Knin, Skradin i Ostrovicu. ${ }^{148}$ Grof Niklas Salm stariji poslao je hrvatskom banu već krajem lipnja 1522. pojačanje od nekoliko stotina pješaka za Bihać jer se bojao napada na grad i Krupu koji su za njega „ključevi i putovi“ za Hrvatsku, Slavoniju i zemlje Unutrašnje Austrije. ${ }^{149}$ Godinu dana kasnije kontingent od nekoliko stotina konjanika pod Salmovim zapovjedništvom dolazi na hrvatski prostor. ${ }^{150} \mathrm{Njihova} \mathrm{asistencija} \mathrm{posljedica} \mathrm{je} \mathrm{međuovisnosti}$ hrvatskog i unutrašnjeaustrijskog prostora pri obrani od zajedničkog neprijatelja. Kao što je to

\footnotetext{
${ }^{142}$ Fedor MOAČANIN, Vojna krajina do kantonskog uređenja 1787., u: Vojna krajina. Povijesni pregledhistoriografija-rasprave, ur. Dragutin Pavličević, Zagreb, 1984., 25. O periodizaciji vojnokrajiške povijesti vidi i Fedor MOAČANIN, Radovi iz povijesti Vojne krajine, SDK Prosvjeta, Zagreb, 2016., 67-76.

${ }^{143}$ PÁLFFY, Die Türkenabwehr, 112.

144 ŠTEFANEC, Država ili ne, 22; 398.

145 TRACY, Balkan Wars, 77.

146 PÁlLFY, Povijest Madžarske, 31.

${ }^{147}$ ŠTEFANEC, Država ili ne, 80.

${ }^{148}$ SIMONITI, Vojaška organizacija, 232.

${ }^{149}$ THALLÓCZY, HODINKA, A horvát véghelyek, dok. XCIX, 156-157.

${ }^{150}$ ROTHENBERG, The Military Border, 16.
} 
desetljećima ranije činilo Ugarsko-hrvatsko Kraljevstvo na prostoru susjednih zemalja, staleži Unutrašnje Austrije nastojali su zadržati neprijatelja na distanci i onemogućiti provale na svoj teritorij dok je onemoćalo hrvatsko-slavonsko plemstvo tražilo čvrst oslonac u pozadini. ${ }^{151}$

Ipak, do 1527. obrana grada prvenstveno je ovisila o kraljevskoj vlasti, odnosno o banu i lokalnom plemstvu. Kada je jedan veliki kontingent od 1500 konjanika s hrvatskog prostora trebao u kolovozu 1521. krenuti prema kraljevskim trupama (trajala je opsada Beograda), grof Bernardin Frankopan morao je sa 100 konjanika ostati braniti Bihać od očekivanog napada 2000 bosanskih Osmanlija. ${ }^{152}$ Habsburgovci i austrijski staleži bili su potpuno svjesni kakva se opasnost približava njihovim zemljama, pa je krajem kolovoza u instrukciji nadvojvode Ferdinanda navedeno da će u slučaju pada Beograda biti ugrožena cijela Slavonija, a ako Osmanlije zauzmu Zagreb, Jajce i Bihać (Wyhetsch), opustošit će i Štajersku i Kranjsku. ${ }^{153}$ U ožujku 1522. ban Ivan Karlović obavještava nadvojvodu Ferdinanda da bosanski paša namjerava napasti Krupu i Bihać. ${ }^{154}$ Sa svakim osmanskim podvigom međuovisnost hrvatsko-slavonskog i austrijskog prostora postajala je sve izraženija, a zajednički obrambeni napor imperativ.

Važno je apostrofirati da su razgranate veze između hrvatsko-slavonskog i unutrašnjeaustrijskog (prvenstveno kranjskog i štajerskog) prostora u određenom obujmu uspostavljene još u predosmanskom periodu, a s osmanskom ekspanzijom dodatno su se intenzivirale. Suradnju hrvatskog plemstva i habsburške vladarske kuće očigledno pokazuje činjenica da se tijekom sukoba između cara Svetog Rimskog Carstva Njemačke Narodnosti Maksimilijana I. i Vladislava II. Jagelovića oko ugarskog prijestolja početkom 1490-ih (naj)ugledniji hrvatski velikaši, poput Ivana Frankopana Cetinskog, Nikole Frankopana Tržačkog, Mihajla Blagajskog, sinova banova Talovaca itd., bore na strani cara Maksimilijana. Štoviše, mirom u Požunu 1491. oni su ne samo abolirani već im je dopušteno da i dalje služe pod carem Maksimilijanom, uz uvjet da polože prisegu vjernosti i pokornosti kralju Vladislavu. ${ }^{155}$ Hrvatsko plemstvo ulazilo je, dakle, već tada u službu careva Svetog Rimskog Carstva Njemačke Narodnosti, a intenzitet kooperacije pokazuje i činjenica da je

\footnotetext{
${ }^{151}$ To potvrđuje i hrvatsko plemstvo okupljeno na izbornom cetinskom saboru početkom siječnja 1527. kada navode da „njegovo posvećeno kraljevsko veličanstvo nas i Kraljevinu Hrvatsku eto već više godina milostivo darivaše i od bijesnih Turaka branijaše da nas njihovo bjesnilo ne prisili odmetnuti se od vjere pravovjerne i države kršćanstva, te da je isto kraljevsko veličanstvo druga nebrojena dobročinstva nama podijelilo“. KLAIĆ, Povijest Hrvata, knjiga 5, 83.

${ }^{152}$ THALLÓCZY, HODINKA, A horvát véghelyek, dok. XXXIV, 32.

${ }^{153}$ IBID., dok. XXXV, 36.

${ }^{154}$ IBID., dok. XLI, 47.

${ }^{155}$ KLAIĆ, Povijest Hrvata, knjiga 4, 214.;219.
} 
pojedinim hrvatskim velikašima koji su bili u najamničkoj službi, poput Bernardina Frankopana 1511., iznimno dopušteno regrutirati osobe s unutrašnjeaustrijskog prostora. ${ }^{156}$

Uostalom, Krsto Frankopan, jedan od najuglednijih hrvatskih velikaša u prvim desetljećima 16. stoljeća, godinama je jedan od najistaknutijih habsburških vojskovođa, da bi s izbijanjem građanskog rata pristao uz Ivana Zapolju. Vasko Simoniti navodi da je do sredine 1520-ih dobar dio hrvatskih knezova i nižeg plemstva u habsburškoj službi. ${ }^{157}$

Važnost habsburških zemalja za obranu hrvatskog prostora bila je tolika da su hrvatski staleži već na saboru u Cetinu u travnju 1528. od kralja Ferdinanda zatražili pripojenje Hrvatskog Kraljevstva austrijskim Nasljednim zemljama. ${ }^{158}$ U sljedećim desetljećima hrvatsko-slavonski staleži postojali su sve više ovisni o središnjoj vlasti i staležima Unutrašnje Austrije koji su sve autoritativnije organizirali obranu i njome upravljali na hrvatskom prostoru. Proaktivni i poduzetni unutrašnjeaustrijski staleži uspjeli su već od prvih desetljeća na krajištu formirati vojni sustav paralelan banskom, „a uz to potpuno funkcionalan, s kvalificiranim i utjecajnim zapovjednicima i uglavnom stalnom, mada iznosima neustaljenom financijskom potporom iz austrijskih zemalja“. ${ }^{159}$ Svote kojima su hrvatsko-slavonski staleži doprinosili obrani i institucionalnom razvoju krajina sasvim su neusporedive s golemim iznosima koje su utrošili unutrašnjeaustrijski staleži i centralna vlast. Pauperizirano i iscrpljeno domaće plemstvo, involvirano u svakodnevne sukobe s premoćnim protivnikom, teško je moglo financijski parirati unutrašnjeaustrijskom plemstvu. ${ }^{160}$

Kao što je već spomenuto, prve jedinice u službi tada još nadvojvode Ferdinanda pojavile su se na hrvatskom prostoru početkom 1520-ih. Plaćena kraljevska vojska na krajištu je isprva ciljano i privremeno stacionirana, a kao glavna vojna središta od samog početka profilirali su se Senj, Klis i Bihać. ${ }^{161}$ Kraljevske vojne posade namještene su u Senj i Klis odmah nakon izbora Ferdinanda 1527. dok je Bihać zaposjednut u ljeto te godine. ${ }^{162}$ No, ubrzo nakon

\footnotetext{
${ }^{156}$ SIMONITI, Vojaška organizacija, 120.

${ }^{157}$ SIMONITI, Turki su, 103.

158 ŠTEFANEC, Država ili ne, 82, fusnota 183; ŠIŠIĆ, HSS, knjiga I, dok. I, 50-55.

159 ŠTEFANEC, Država ili ne, 203.

${ }^{160}$ IBID., 333. O financiranju obrane vidi 331-392.

${ }^{161}$ Fedor MOAČANIN, Organizacijske strukture Vojne krajine do sredine 18. stoljeća, Arhivski vjesnik, 34-35 1991.-1992., 157-158.

162 PÁLFFY, The Origins, 21. Pálffy navodi da je Bihać zaposjednut nakon ostavke bana Ferenca Batthyányja 1528., ali to je očit lapsus jer je ispravno citirao izvore koji pokazuju da se to zbilo 1527 . Ti spisi su objavljeni u već spominjanoj zbirci THALLÓCZY, HODINKA, A horvát véghelyek i bit će prezentirani dalje u tekstu.
} 
stupanja na prijestolje kralja Ferdinanda i hrvatsko-slavonski staleži tražili su da središnja vlast preuzme obranu pograničnih utvrda. $\mathrm{Na}$ Hrvatskom saboru održanom u Cetinu u travnju 1528. staleži su od kralja Ferdinanda, koji se i obvezao čuvati staleške slobode i običaje te kršćansko jedinstvo te koji je pristao držati 1000 konjanika i 200 pješaka, od čega 200 konjanika i 200 pješaka pod zapovjedništvom kraljeva vrhovnog zapovjednika, a ostatak pod zapovjedništvom lokalnog plemstva, zatražili da namjesti stalne puškare u pogranične utvrde te preuzme nadzor i opskrbu utvrda. ${ }^{163}$

Krajiška vojska razvila se iz plaćenih mobilnih trupa koje su financirane komorskim prihodima vladara, a od 1520-ih do 1540-ih i kontribucijom austrijskih staleža. Budući da se dugoročno pokazala preglomaznom i nepokretnom, vrlo se brzo zaključilo da treba ustrojiti obrambenu liniju na neprohodnom, šumovitom i brdovitom terenu Hrvatske krajine. Stoga je započeo proces koji su vladari preuzimali utvrde. Štefanec kaže:

„Predajom sve većeg broja utvrda u kraljevske ruke od 1540ih godina, vladar i austrijski staleži glomaznu su pokretnu vojsku počeli preobražavati u stalnu stajaću vojsku raspodijeljenu po krajini, koja je naoružana i opskrbljena trebala na mjestu događaja sprečavati osmanske upade i pljačke, a veće napade odbijati uz pomoć tradicionalnih insurekcijskih vojnika i banske vojske iz Hrvatsko-slavonskog Kraljevstva te, eventualno, raznih dodatnih četa iz drugih zemalja“. 164

Hrvatsko plemstvo često je samoinicijativno tražilo da kralj namjesti svoje postrojbe i preuzme odgovornost za obranu njihovih utvrda dok je hrvatski sabor 1537. tražio da se kraljevske postrojbe namjeste u Krupu, Novi, Otok, Bušević, Cetin, Slunj, Izačić, Kostajnicu, Drežnik, Tržac i Dubicu, Hrastovicu te kaštel Gradec. ${ }^{165}$ Kada su procijenili da ih više ne mogu braniti ili da im je taj teret postao nepodnošljiv, hrvatsko plemstvo nastojalo je prodati ili zamijeniti svoje utvrde odnosno posjede za one u sigurnijem ambijentu. ${ }^{166}$

Hrvatska krajina zapravo do 1560-ih godina nema jasno definiranoga kapetanijskog ustroja izvan Senjske i Bihaćke kapetanije te je još krajem 1550-ih podijeljena na dva dijela -na „staru Hrvatsku krajinu od Bihaća do mora“ i na „novu Hrvatsku krajinu od Save do Bihaća“. ${ }^{167}$ Dakle, upravo je Bihać demarkacijska točka cijele Hrvatske krajine što je još

\footnotetext{
163 ŠIŠIĆ, HSS, knjiga I, dok. 66, 98-102.

164 ŠTEFANEC, Država ili ne, 394-395.

165 Josip ADAMČEK, Ratovi s Turcima i položaj zavisnih seljaka u Pokuplju u drugoj polovici XV i XVI stoljeća, u: Karlovac 1579-1979, ur. Đuro Zatezalo, Historijski arhiv u Karlovcu, Karlovac, 1979., 44.

${ }_{166}$ Tako je, primjerice, Franjo Blagajski 1560. za simboličan iznos prodao banu Brubno i Bojnu, utvrde bez kmetova. IBID., 45

167 ŠTEFANEC, Država ili ne, 398; PÁLFFY, The Origins, 28.
} 
jedan dokaz njegova centralnoga defenzivnog položaja. Hrastovica i Ogulin postaju kapetanijska središta tek od 1564. Kapetanije dobivaju imena prema tim centrima, naoružavaju se i opskrbljuju iz njihova arsenala i skladišta te po potrebi pojačavaju ljudima. Također, dio utvrda na isturenom pograničju osiguran je plaćenim kraljevskim vojnicima, ali one nisu bile u kapetanijskom sastavu poput šest zrinskih pounjskih utvrda, koje su sve do kasnih 1570-ih prema željama obitelji izdvojene iz kapetanijskog sustava. Takva pozicija komplicirala je obranu pa je zapovjednik Zrina Thomas Dornberg 1577. tražio da ih se inkorporira u sastav Bihaćke kapetanije. ${ }^{168}$

Krajiškom vojskom zapovijedao je vrhovni ratni zapovjednik Hrvatske i Slavonske krajine kojemu su bila podređena dva zamjenika (verwalter) odgovorna za svoj dio krajišta. Podzapovjednik na Hrvatskoj krajini uveden je 1532., a na Slavonskoj krajini $1542 .{ }^{169}$ Krajem 1550-ih Hrvatska krajina podijeljena je na „Staru“ i „Novu“ Hrvatsku krajinu, pa su imenovana i tri dozapovjednika (obrist-lieutant), za obje hrvatske krajine i Slavonsku krajinu. ${ }^{170}$ Važan moment razvoja krajiškog sustava jest osnivanje Dvorskoga ratnog vijeća u Beču 1556., kojemu je, iako se bavilo općom vojnom problematikom, jedan od najvažnijih zadataka bilo organiziranje i upravljanje protuosmanskom obranom na cijelome pograničnom prostoru - od Transilvanije do Jadranskog mora. Ovo tijelo bilo je podređeno Dvorskoj komori koja je osiguravala sredstva za njegovo djelovanje te se uglavnom fokusiralo na obranu ugarskih krajina jer su Hrvatska i Slavonska krajina sve više prepuštene na brigu staležima Unutrašnje Austrije. ${ }^{171}$ Međutim, budući da su organiziranje i koordiniranje obrane na tako golemom prostoru iziskivali velik napor, sve se više nametala potreba ustrojavanja novog tijela koje bi upravljalo obranom na hrvatsko-slavonskom krajištu, a kojim bi rukovodili unutrašnjeaustrijski staleži. Tako je 1578. formirano Dvorsko ratno vijeće u Grazu koje je podređeno i odgovorno nadvojvodi, ali i staležima.

Treba napomenuti da ni strateške pozicije bečkih organa i unutrašnjeaustrijskih staleža nisu uvijek bile kompatibilne jer dok su centralna tijela morala razmatrati i koordinirati obranom cjelokupnoga obrambenog sustava, unutrašnjeasustrijski staleži više su se fokusirali na krajine koje su oni financirali i koje su branile njihov teritorij. No, bez obzira na određena

\footnotetext{
168 ŠTEFANEC, Država ili ne, 398-399.

${ }^{169}$ IBID., 199.

${ }^{170}$ PÁLFFY, The Origins, 37.

${ }^{171}$ O Dvorskom ratnom vijeću u Beču i Grazu vidi. ŠTEFANEC, Država li ne, 213-248.; Thomas FELLNER, Heinrich KRETSCHMAYR, Die österreichische Zentralverwaltung. Geschichtliche Übersicht. Abt. I, Bd. 1, Veröff. d. Komission f. neuere Geschichte Österreichs 5, Beč, 1907., 234-243.; Winfried SCHULZE, Landesdefension und Staatsbildung. Studien zum Kriegswesen des innerösterreichischen Teritorialstaates (15641619), Wien-Graz-Köln, 1973., 73-77.
} 
razmimoilaženja i različite interese, centralna tijela u Beču i unutrašnjeaustrijski reprezentanti uspijevali su postići kompromis i zajednički formirati protuosmanski defenzivni sustav.

S druge pak strane, vojni status bana u promatranom je periodu sve više degradirao. Tradicionalno, ban je u kraljevoj odsutnosti obnašao funkciju vrhovnog zapovjednika kraljevinske vojske u čiji je sastav ulazila banderijalna i insurekcijska vojska. Kraljevinski prihodi bili su nedostatni za financiranje banske vojske, pa je većina sredstava isplaćivana iz Ugarske komore. Naravno, time je slabio utjecaj Hrvatsko-slavonskoga Kraljevstva, a konzekventno i bana kao njegove najprominentnije figure. $U$ takvim okolnostima mnogi su oklijevali pristupiti banskim snagama te su nastojali dobiti mjesto u plaćenoj austrijskoj vojnoj službi. ${ }^{172}$

Tijekom čitavog 16. stoljeća prisutan je pad broja vojnika u banskoj postrojbi. Pri izboru za hrvatskoga kralja nadvojvoda Ferdinand pristaje na uzdržavanje 1000 konjanika i 200 pješaka, s tim da je 200 konjanika i 200 pješaka pod zapovjedništvom vrhovnog zapovjednika kraljevske vojske. Sredinom stoljeća ban ima na raspolaganju 600 konjanika i 400 pješaka, a u drugoj polovici 1560-ih broj pada na 400 konjanika i 200 haramija. Od 1570ih taj broj zadržao se na oko 300 konjanika i 300 pješaka. Iako se nije radilo o zanemarivom broju ljudi te iako je ban i dalje zadržao sudsku ingerenciju na cijelom teritoriju Hrvatskoslavonskoga Kraljevstva, njegova je moć degradirala jer je podređen nadvojvodama, a u vojnom pogledu izjednačen sa zapovjednicima krajiških odsjeka. Iako se protiv te odluke žustro protestiralo pa su tako i ugarski staleži na saboru u Požunu 1578. protestirali protiv suženja banskih vojnih ovlasti i podređivanja nadvojvodama, prilike su se toliko izmijenile da povratak na staro više jednostavno nije bio moguć. ${ }^{173}$

\subsection{Prostorni obuhvat Bihaćke kapetanije}

Kao što je već navedeno, prvu obrambenu formaciju na unskom prostoru (Sokol, Ostrožac, Ripač) ustrojili su još sredinom 14. stoljeća ugarsko-hrvatski kraljevi iz dinastije Anžuvinaca. ${ }^{174}$ Iako su unske utvrde tada oslonac u borbi protiv nepokornih hrvatskih velikaša, a zatim protiv pretenzija/ekspanzije Bosanskoga Kraljevstva, vrlo brzo Osmanlije

\footnotetext{
${ }^{172}$ U kontekstu razgovora o izboru novog bana 1541. ugarski namjesnik Aleksije Thurzo pisao je kralju da „su ionako svi ratoborni ljudi iz Hrvatske i Slavonije pošli za plaću služiti pokrajinama (nasljednim) vašega veličanstva“. KLAIĆ, Povijest Hrvata, knjiga 5, 194.

173 ŠTEFANEC, Država ili ne, 251-254.

174 ANČIĆ, Bihaćki kraj, 201.
} 
postaju glavni antagonist. Bihać postaje dio sastava ili je barem (neposredno) vezan uz Slavonski tabor, formiran sredinom 1430-ih. S porastom osmanske prijetnje, osobito od druge polovice 15. stoljeća, Bihać, kao jedno od najvažnijih urbanih središta hrvatskog prostora, postaje i jedno od ključnih obrambenih uporišta iako je još u periodu vladavine kralja Matijaša Korvina dio druge, uvučene linije utvrda koja se protezala od Transilvanije do Jadranskog mora.

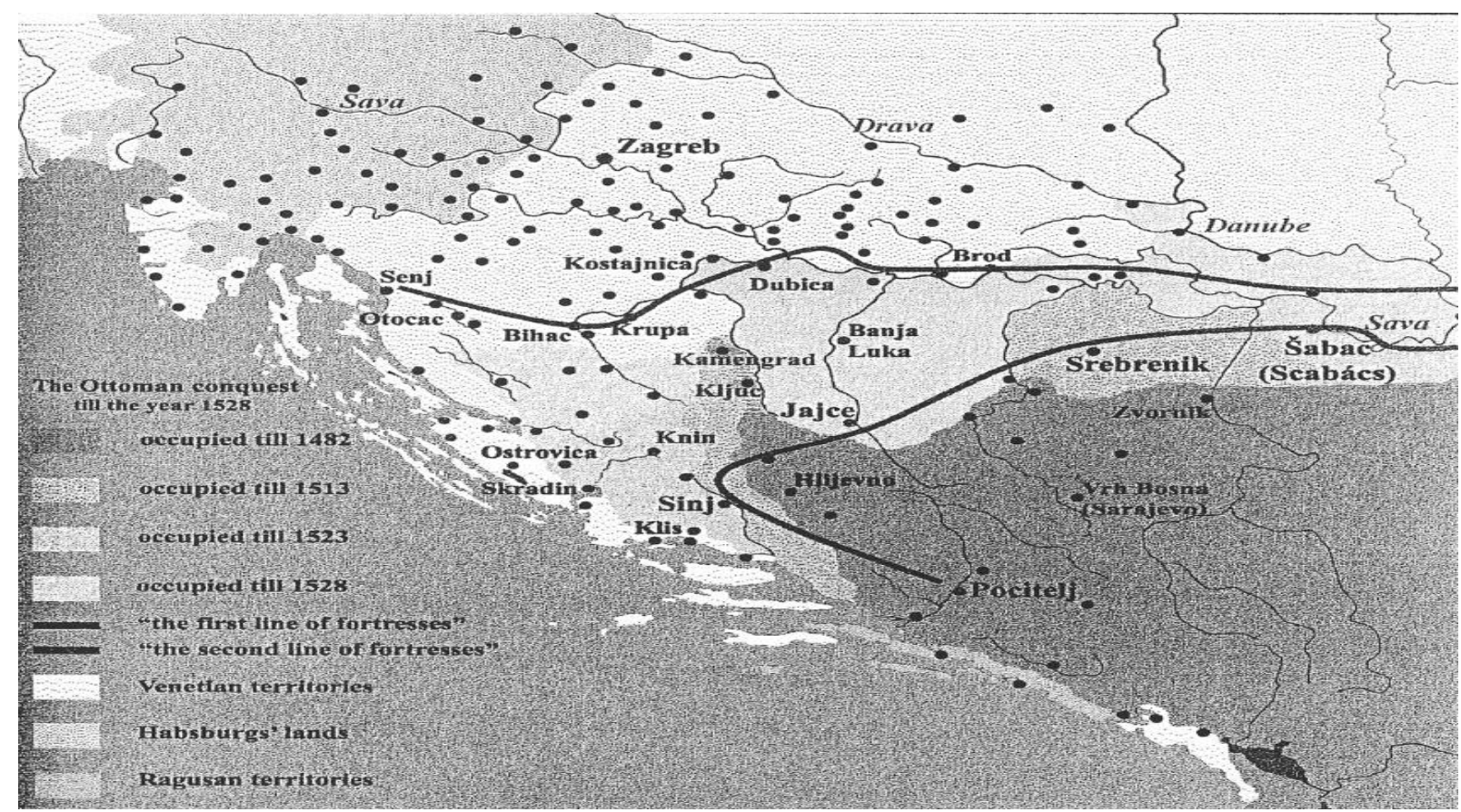

Slika 5. Dvije protuosmanske obrambene linije iz predhabsburškog perioda. ${ }^{175}$

Dakle, do osmanskog osvajanja u lipnju 1592. Bihać je akumulirao i više nego stoljetno pogranično iskustvo. Takvu percepciju imali su i suvremenici što se može iščitati u raznim izvorima. Već 1494. hrvatski staleži i prelati na saboru u Bihaću adresiraju papi pismo u kojem navode da osmansku silu ,već sedamdeset godina zaustavljamo gubeći naša tijela, živote i sva moguća naša dobra te poput kule i predziđa kršćanstva branimo svakodnevnim ratovanjem kršćanske zemlje, koliko nam je to uopće ljudski moguće.“176 Od kraja 15. stoljeća Bihać se već navodi kao dio krajiškog pojasa prema Osmanlijama, a to potvrđuju i kasniji izvori. U jednom popisu osmanskih napada na Hrvatskoj krajini od 1582. do 1593., uz opasku o padu Bihaća, stoji da je izgubljen grad koji je već 160 godina „najisturenija krajiška

\footnotetext{
${ }^{175}$ Karta preuzeta iz: JURKOVIĆ, The Fate, 329.

${ }^{176}$ KRUHEK, Krajiške utvrde, 49. Hrvatski staleži isti su dan uputili pismo i caru Maksimilijanu te njemačkim carskim staležima, a to je pismo odmah i prevedeno na njemački. Oba pisma publicirana su u: Ferdo ŠIŠIĆ, Rukovet spomenika o hercegu Ivanišu Korvinu i borbama Hrvata s Turcima (1473-1496), Starine, JAZU, knjiga 38, Zagreb, 1937., dok. 178 i 179, 232-237.
} 
utvrda““. ${ }^{177}$ I Friedrich Kreckwitz, habsburški poslanik u Carigradu, protestira na Porti u listopadu 1592. zbog zauzimanja Bihaća, grada koji je već 100 godina krajiška utvrda. ${ }^{178}$ Dakle, krajiško iskustvo Bihaća, odnosno promatranog prostora, mnogo je duže od samog formiranja habsburške kapetanije.

Prvi kapetan koji se spominje u Bihaću bio je Juraj Stražemanski koji nakon smrti bana Andrije Botha 1511. upravlja kaštelom uime novoizabranog bana Emerika Perenyja. To je navelo Vjekoslava Klaića na zaključak da je tada i formirana Bihaćka kapetanija. ${ }^{179}$ No, Lopašić navodi da je zapravo nakon Bothine smrti Pereny pozvao staleže da upute kapetana Stražemanskog da zauzme bihaćki kaštel, no da ne čini štete građanima te da održava mir s ljudima udovice Botha koja je pak grad ubrzo predala u ruke novom banu. ${ }^{180} \mathrm{U}$ pozadini ovog sukoba zapravo je stajao velik dug koji je kralj imao prema pokojnom banu koji je obnašao i dužnost senjskoga kapetana. Botha je čak i u oporuci tražio od izvršitelja oporuke, kneza Ivana Krbavskog, da kralju ne preda Senj dok ne podmiri dugovanje. To je pitanje s njegovom udovicom Anom de Chak riješeno 1512. ${ }^{181}$ Dakle, radilo se o internom problemu između udovice bivšeg bana i novoizabranog bana kao predstavnika središnje vlasti, a cijeli slučaj pokazuje da je kaštel pod banskom ingerencijom. Teško se može konstatirati da je tada formiran kapetanijski, odnosno bilo kakav specifični krajiški sustav koji bi imao sjedište u Bihaću i posebnog zapovjednika s određenom prostornom ingerencijom. Iako već važno pogranično sjedište, Bihać je još uvijek primarno bansko uporište unutar tradicionalnoga vojno-administrativnog okvira. Tako su ban Emerik Pereny i ban Petar Berislavić u Bihaću držali po 100 konjanika i pješaka. ${ }^{182}$

Kada je riječ o habsburškom periodu, treba apostrofirati da je zbog važnosti u regionalnom okviru unski prostor inicijalni „koridor ulaska“ Habsburgovaca i staleža Unutrašnje Austrije na hrvatski teritorij. Naime, 1522. nadvojvoda Ferdinand preuzima od Nikole Zrinskog obranu Novog i Dobre Kuće na Uni, a ubrzo na hrvatsko ratište dolaze plaćene habsburške jedinice pod zapovjedništvom grofa Niclasa Thurna starijeg, i to s instrukcijama da vode posebnu brigu o bihaćkom odnosno unskom prostoru koji su, uostalom, Osmanlije te godine i napali. ${ }^{183}$ Krajem travnja ili početkom svibnja 1522. Sigmund

\footnotetext{
${ }^{177}$ Aleksa IVIĆ, Prilozi za povijest Hrvatske i Slavonije u XVI. i XVII. vijeku, Starine, JAZU, Zagreb, knjiga 35, 1916., dok. XXVII, 343.

178 „ain Granizhauss geweesen “. HDA, Croatica, kutija 3, svežanj 6, str. 211.

179 BUDAK, Uloga Bihaćke, 165.

${ }^{180}$ LOPAŠIĆ, Bihać, 3. Juraj Stražemanski bio je istaknuti zapovjednik, između ostalog srebrenički ban 1494 . 1495. te jajački ban 1505. - 1510 .

${ }^{181}$ KLAUŽER, Ustrojstvo i djelovanje, 42-43.

182 LOPAŠIĆ, Bihać, 60.

${ }^{183}$ KRUHEK, Krajiške utvrde, 72; THALLÓCZY, HODINKA, A horvát véghelyek, dok. CX, $182-187$.
} 
Weichlsberg s austrijskim postrojbama, novcem, oružjem i opremom stigao je u Bihać gdje je nekoliko dana čekao dolazak bana Ivana Karlovića. Na koncu se s banom susreo u Mutnici gdje mu je predao vojnike, novce, puške i barut. ${ }^{184}$ Počekom lipnja te godine Hans Helfenberg predlaže da raspoložive štajerske postrojbe krenu preko Steničnjaka do Bihaća gdje je ban okupljao svoje postrojbe zbog osmanske opsade Knina. ${ }^{185}$ Dakle, unutrašnjeaustrijske postrojbe sudjelovale su u obrani hrvatskog odnosno unskog prostora godinama prije proglašenja nadvojvode Ferdinanda ugarsko-hrvatskim kraljem. Kao simbolični pokazatelj povezanosti Bihaća i Habsburgovaca može se navesti i činjenica da su upravo u Bihaću hrvatski staleži 18. srpnja 1526. izdali punomoć Bernardu Tumpiću, njihovom poslaniku nadvojvodi Ferdinandu. ${ }^{186}$

Kaštel (castrum) u Bihaću preuzeo je u ljeto 1526. novi ban Ferenc Batthyány iz ruku bivšeg bana Jánosa Tahyja koji ga više nije želio držati. ${ }^{187}$ Proces formiranja Bihaćke kapetanije unutar habsburškog (krajiškog) sustava započeo je gotovo od trenutka proglašenja nadvojvode Ferdinanda kraljem 1. siječnja 1527. Dva dana nakon izbora (3. siječnja) Ferdinandovi poslanici u svojem izvještaju s popisom gradova koje treba preuzeti navode da $\mathrm{u}$ Bihać treba smjestiti 50 strijelaca (puchsenschützen), a u Ripač njih $15 .^{188}$ Ripčem, kao kraljevskim gradom, tada je zapovijedao Ivan Golec (Hanns Goletcz). ${ }^{189}$

Kralj je zaista odmah nastojao preuzeti obranu Bihaća, ali se primopredaja poprilično zakomplicirala. Kralj Ferdinand već u pismu, koje 1. siječnja 1527. šalje ljubljanskom biskupu Christophu Rauberu, Erasmu Dornbergu i Stefanu Pemflingeru, spominje nekakav izvještaj o Bihaću koji je sastavio Nikola Jurišić. Također, u tom pismu navodi da viceban Ivan Svetački (Hansen Schwegkhaky) do sada u grad nije htio pustiti vojnike koji su poslani na zahtjev samoga bana. Kralj je od navedenih zahtijevao da s banom odmah razriješe ovaj problem. ${ }^{190}$ Dakle, i prije formalnog proglašenja kraljem Ferdinandove su postrojbe trebale ući u Bihać, a Jurišić sastavlja izvještaj o obrani/stanju grada. Svetački pak nije htio pustiti

\footnotetext{
${ }^{184}$ IBID., dok. LXIII, 103.

${ }^{185}$ IBID., dok. LXXXV, 139; IBID., dok. XC, 144.

${ }^{186}$ Emilij LASZOWSKI, Habsburški spomenici Kraljevine Hrvatske, Dalmacije i Slavonije (dalje HSKHDS) knjiga I, Zagreb, 1914., dok. 8, 8.

${ }^{187}$ LOPAŠIĆ, Bihać, 57; Matija MESIĆ, Gradja mojih razprava u „Radu“, Starine, JAZU, knjiga 5, 1873. Zagreb, dok. CCLXXVI, 259-20.

188 ŠIŠ́IĆ, HSS, knjiga I, dok. 48, 65.

${ }^{189}$ IBID., dok. 47, 61.

190 THALLÓCZY, HODINKA, A horvát véghelyek, dok. CDLIII, 592.
} 
kraljevske vojnike (trabanten) u grad jer od bana (von seinem Hn.) nije primio nikakvu naredbu da to učini. ${ }^{191}$

Još krajem siječnja Nikola Jurišić izvještava da je riječ o namještanju 64 vojnika (knecht) koje je uputio ugledni kranjski plemić i vojni časnik Hans Püchler, ali da se ni sami vojnici nisu osobito potrudili ući u grad, već su željeli od tamo odmah otići. Ivan Karlović jedva ih je uspio zadržati. Budući da problem nije riješen, Karlović je strahovao da je to trenutak u kojem bi Krsto Frankopan mogao pokušati poduzeti nešto protiv njega. ${ }^{192}$ Jurišić je i ranije pisao kralju da bi trebalo narediti vicebanu Svetačkom da bolje uredi obranu grada ili da ga preda kralju te naglasio da on sam do tada nije imao zapovjedništvo nad utvrdama koje pripadaju kralju, već samo ban. ${ }^{193}$

Sredinom veljače naređeno je da se tim vojnicima (trabanten) isplati 97 rajnskih guldena. ${ }^{194}$ No, ulaz u grad im i dalje nije bio dozvoljen iako se postavlja pitanje da li im je bio zabranjen pristup u kompletan grad ili samo u kaštel. Naime, moguće je da su u gradu, ali izvan kaštela čekali razrješenje ovog spora. Budući da se radilo o gradu na prostoru Ugarskohrvatskoga Kraljevstva podređenog banu, donjoaustrijska vlada tražila je 25. veljače od ljubljanskog biskupa Raubera i Stefana Pemflingera da pokušaju problem riješiti i s bivšom kraljicom Marijom, udovicom Ludovika II., i njezinim savjetnicima. ${ }^{195}$ Glavni uzrok problema zapravo je bilo nastojanje bana Batthyányja da se prije primopredaje grada realiziraju uvjeti dogovora koji je postigao s kraljem prilikom preuzimanja banske službe. ${ }^{196}$ Bihać je bio dovoljno veliki ulog za to.

Početkom ožujka kralj javlja Donjoaustrijskoj komori (An die camer in Österreich) da je ban Batthyány tražio da se Bihać opskrbi oružjem, barutom i svime potrebnim te naređuje da se grad pregleda i opskrbi. Prema potrebi, kralj je dozvolio da se u grad namjesti ne više od 100 vojnika. ${ }^{197}$ Tih dana ljubljanski biskup Rauber i Stefan Pemflinger javljaju da je ban pristao da se u Bihać namjesti kraljevska posada, ali da je ban napomenuo da je vojnicima koji su trenutno u gradu dužan plaću za nekoliko mjeseci te da je banov vicekaštelan

\footnotetext{
${ }^{191}$ BUDAK, Uloga Bihaćke, 165; THALLÓCZY, HODINKA, A horvát véghelyek, dok. CDLXXIII, 621-622.; „Even simple questions sometimes had to go down an Austrian chain of command, then up a Hungarian chain of command, and back down again. In 1527, men sent to Bihać by the commander of Austrian troops in Croatia were denied entrance: Bihać's commandant would admit them only on orders from his superior, who in turn awaited instructions from the council of Hungary via the ban of Croatia“. TRACY, Balkan Wars, 111.

192 THALLÓCZY, HODINKA, A horvát véghelyek, dok. CDLXI, 600.

193 „Dann E. kgl. Mt. wais, das ich pisher den flecken halben, so E. kgl. Mt. zusteen, kain bevelh gehabt, als allain der waan". IBID., dok. CDLXI, 601.

${ }^{194}$ IBID., dok. CDLXVII, 611; IBID., dok. CDLXXIII, 622.

${ }^{195}$ IBID., dok. CDLXXV, 623-624.

${ }^{196}$ IBID., dok. CDLXXIX, 626.

197 IBID.
} 
(underburggraven) izvijestio da će napustiti grad ako im se u roku od 14 dana ne isplati navedeno dugovanje. Budući da je postojao strah od djelovanja pristaša Ivana Zapolje, tražili su da se banu pošalje 300-400 dukata da posada ostane na svojim mjestima dok se kralj ne vrati iz Češke. ${ }^{198}$

Radilo se zapravo o vrlo ozbiljnom i delikatnom problemu ne samo zbog sveprisutne osmanske opasnosti već i radi bojazni da bi u građanskom ratu između pristaša Ferdinanda i Ivana Zapolje jedan tako važan grad mogao dospjeti u ruke Ferdinandova konkurenta za prijestolje, odnosno u ruke njegova glavnog privrženika na hrvatskom prostoru - Krste Frankopana kojemu je Zapolja uostalom i obećao Senj i Bihać. ${ }^{199}$ Ipak, taj se scenarij na kraju nije ostvario. $^{200}$

Kralj je pak krajem travnja od hrvatskih stelaža zatražio da mu se prepusti grad. ${ }^{201}$ Preciznije, tražio je preuzimanje grada odnosno trgovišta i kaštela u Bihaću (oppidum et castrum Wyhysch). ${ }^{202}$ No, još koncem svibnja donjoaustrijski savjetnici u petoj točki prijedloga odgovora poslanicima hrvatskih staleža Bernardu Tumpiću i Mihovilu Skobljiću navode da je Nikoli Jurišiću naređeno da uloži maksimalan napor ne bi li utvrda (flegkhn) Bihać došla u kraljevski posjed. ${ }^{203}$

Do kraja srpnja Bihać je napokon u posjedu kralja jer u pismu od 24. srpnja 1527.

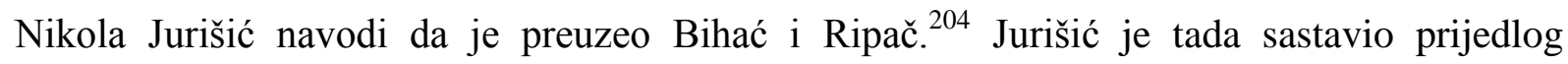
obrambenih mjera za zaštitu grada, što predstavlja važan trenutak u razvoju Bihaćke

\footnotetext{
${ }^{198}$ IBID., dok. CDLXXXX, 627.

199 Janez WEISS, In conterminiss. Razvoj mejne pokrajine Metliške in odnosi s hrvaško-slavonskim prostorom s poudarkom na prisotnosti in posesti rodbin Erdődy in Frankopan, u: Med cesarstvom in kraljevstvom. Študija čezmejnih kulturnozgodovinskih povezav, ur. Petra Svojšak, Miha Seručnik, Vanja Kočevar, Znanstvenoraziskovalni centar Slovenske akademije znanosti in umetnosti, Ljubljana, 2013., 50. Sredinom lipnja 1530. Ivan Lenković javlja da se kod Plavna okuplja osmanska vojska koja će napasti Bihać ili provaliti u Kranjsku iako se među Osmanlijama priča da će asistirati zagrebačkom biskupu. LASZOWSKI, HSKHDS, knjiga I, dok. 367, 352. I na ovom izdvojenom primjeru vidljivo je koliko je građanski rat zakomplicirao situaciju na cijelome hrvatskom prostoru. Iako je devastacija na slavonskom prostoru bila neusporedivo veća, tadašnji bihaćki vicekapetan morao je strahovati hoće li Osmanlije pomoći zagrebačkom biskupu protiv središnje vlasti kojoj je Lenković bio odan, a to pak pokazuje svu dramatiku internih sukoba - barem kada se promatraju iz kršćanske perspektive.

${ }^{200}$ Iako je hrvatsko plemstvo gotovo unisono stalo iza kralja Ferdinanda, ipak je Petar Rebrović, hrvatski plemić i vicekapetan Bihaćke kapetanije, još krajem kolovoza 1531. javio da nakon smrti bana Karlovića zbog banske časti vlada veliko nezadovoljstvo u zemlji, da se „Sve“ okreće protiv Ferdinanda te da se danonoćno kuju planovi i okupljaju plemići i grofovi smjerajući se podvrgnuti Zapolji. SI AS 2, DSK, kutija 191, fascikl 119, 22.8.1531., Bihać, 1r-1v. Ivan Rebrović na kapetana Erasma Thurna.

${ }^{201}$ BUDAK, Uloga Bihaćke, 166; Tracy navodi: „Once the Sabor agreed to make Bihać and Ripać royal castles, various expedients were found to keep garrisons there, and this well-defended region would remain reasonably well populated into the 1570s.“. TRACY, Balkan Wars, 116; LOPAŠIĆ, Bihać, 57.

${ }^{202}$ Joseph CHMEL, Actenstücke zur Geschichte Croatiens und Slawoniens in den Jahren 1526 und 1527., Beč, 1846., dok. br. XXXIV, 49.

${ }^{203}$ ŠISŚIĆ, HSS, knjiga I, dok. 68, 105.

204 „so ich Wichitsch und Repetsch eingenumen“. THALLÓCZY, HODINKA, A horvát véghelyek, dok. DXLIV,
} 695. 
kapetanije. Jurišić je savjetovao da zapovjedništvo nad kaštelom i gradom Bihaćem trebao preuzeti kompetentni plemić porijeklom iz zemalja Njegovog Veličanstva - primarno očito s prostora Unutrašnja Austrije. ${ }^{205}$

Budući da su Jurišićevi prijedlozi inkorporirani u elaboraciju raznih poglavlja ove disertacije, ovdje će se predstaviti samo sumirano. Jurišić je tražio da se izvrše popravci kaštela i podignu nove utvrde, Ripač potpuno zaštiti zidom, namjesti oružara (Zeugmeister) i opskrbnika (Profantmeister), stacionira veća vojna posada naoružana vatrenim oružjem (topovima falkonetima i puškama kukačama) te da se organizira dojavna služba. Također, predložio je da se za obranu Izačića i Blagaja, koji da bi mogli ostati nezaposjednuti, godišnje izdvoji 200 rajnskih guldena da bi se još neko vrijeme mogli održati jer ako ih preuzme kraljevska vlast, neće ih se moći braniti bez velikog troška. ${ }^{206} \mathrm{U}$ kratkom komentaru na iznesene prijedloge $\mathrm{u}$ istom izvoru upisano je da vladaru u ovom trenutku nije moguće zaposjesti sve utvrde, ali će se o tome već referirati. ${ }^{207}$

Prema Milanu Kruheku, ovim Jurišićevim izvještajem te promjenom kaštelana 1528., kada kapetan Erasmo Thurn zamjenjuje dotadašnjega kaštelana Jacoba Raunacha, zapravo započinje proces okupljanja ,susjednih utvrda i tamošnjih posjeda“ u kapetaniju. ${ }^{208}$ No, u Bihaću je i prije dolaska Erasma Thurna bio kraljev kapetan (der Innhaber vnnd Haubtman desselben Flekhen), s tim da je obrana hrvatskih krajiških utvrda bila pod ingerencijom ugarske vlade (Hungerischen Regierung) i Ugarske komore. Međutim, budući da se ugarske instance nisu mogle adekvatno brinuti o obrani hrvatskog prostora, kralj Ferdinand je najkasnije od srpnja 1528. tražio od kranjskih staleža da pomognu opskrbom i vojnicima dok ne pronađe načina kako organizirati daljnju obranu. Kralj je tražio da se u Bihać na neko vrijeme namjesti 100 vojnika, ili već onoliko koliko ih je ranije bilo, te da se dopremi dovoljno živeži da grad može izdržati eventualnu osmansku opsadu do dolaska pojačanja. ${ }^{209}$ Zbog neuredne opskrbe i manjkavog osiguranja grada te neisplate plaća kraljev kapetan (vnnßer Haubtman von Wihitsch) već je sredinom srpnja određeno vrijeme boravio na

\footnotetext{
${ }^{205}$ IBID., dok. DXLIV, 693.

${ }^{206}$ KRUHEK, Krajiške utvrde, 83.; „,dan wo ir Mt. schon die 2 gschlosser zu ir Mr. henden namb, mocht ir. Mt. mit ainem vill grossern costen nit underhalten“. THALLÓCZY, HODINKA, A horvát véghelyek, dok. CXLIV, 692-694.

${ }^{207}$ „,aber gl Mt. seiner anzaigen berichten“. IBID., dok. DXLIV, 695.

${ }^{208}$ KRUHEK, Krajiške utvrde, 109. Jacob Raunach je s 12 konjanika dio kranjske plaćene konjice okupljene u Vinici u travnju 1530, ali je i jedan od zapovjednika nad tada podignutim pješacima - martolozima. Među konjicom je prisutan i Ivan Lenković s tri konjanika. SI AS 2, DSK, kutija 230, fascikl 136, Vinica, 8.4.1531., knjižice bez paginacije.

${ }^{209}$ SI AS 2, DSK, kutija 409, fascikl 281, Beč, 15.7.1528., 1r-1v, rbr. 517-518. Kralj Ferdinand na Niclasa Thurna, zemaljskog upravitelja Kranjske.
} 
kraljevskom dvoru ne bi li riješio te probleme. ${ }^{210}$ Nažalost, taj kapetan tada nije imenovan, pa je teško zaključiti radi li se o navedenom Jacobu Raunachu ili nekom drugome.

Tek u studenom 1528. središnja je vlast od kranjskih staleža tražila da se dogovore s Ersamom Thurnom o preuzimanju mjesta kapetana u Bihaću ili da pronađu drugoga kandidata ukoliko on to odbije. ${ }^{211}$ Čini se da ovdje treba tražiti stvarni početak kranjske dominacije nad Bihaćkom kapetanijom. No, kao što je rečeno, formiranje krajiškog sustava je prije svega proces, pa tako i Kruhek navodi da je do intenzivnije ,prostorne povezanosti bihaćkog Pounja kao vojnički organizirane obrambene jedinice kapetanijskog tipa došlo [...] nešto kasnije“. ${ }^{212}$

Već od početka 1530-ih uz Bihać je neposredno povezan i Ivan Lenković, jedan od najvažnijih aktera narastajućega krajiškog sustava na hrvatsko-slavonskom prostoru te kasniji senjski kapetan i zapovjednik Hrvatske i Slavonske krajine. Naime, nakon jedne molbe, koju su u veljači 1530. predstavnici gradske općine adresirali na kralja Ferdinanda, u grad je poslan tada mladi Ivan Lenković koji ubrzo javlja da je u gradu toliko malo vojske da jedva mogu pokriti čuvanje gradskih vrata. Osim deficita vojnika, vodostaj rijeke Une na nekim je mjestima tada bio toliko nizak da je Lenković razmišljao o nabijanju našiljenih kolaca u korito ne bi li na taj način barem konjanicima zapriječio upad u grad. Lenković se savjetovao s građanima o tome treba li podignuti vodostaj rijeke branom i bastionom (dass wasser mit einer wuer vnd pollwerch zuschbelen), ali su mu građani malodušno odgovorili da nema smisla graditi jer se iz toga ne mogu izvući ni utjeha ni korist kad vojnici (lanzknecht) odlaze i bježe iz grada. ${ }^{213}$ Sredinom svibnja 1530. austrijski staleži na saboru u Slovenj Gradcu doznačili su sredstva za utvrđivanje i opskrbu Klisa, Senja, Otočca, Bihaća i Ripča. ${ }^{214}$

Dakle, jezgru kapetanije činili su Bihać i Ripač, a to konstatiraju i predstavnici hrvatsko-slavonskih staleža na savjetovanju u Grazu gdje navode da je za obranu zemlje nužno opskrbiti Bihać i Ripač koji su i ranije „kao kraljevski gradovi bili pod posebnim kapetanima“. ${ }^{215}$ Ipak, Lopašić kaže da je prvi kapetan, koji je zamijenio kaštelana pod svojim

\footnotetext{
${ }^{210}$ SI AS 2, DSK, kutija 194, fascikl 122, Beč, 13.7.1528., 2v, rbr. 108. Kralj Ferdinand na Niclasa Thurna, zemaljskog upravitelja Kranjske.

${ }^{211}$ SI AS 2, kutija 409, fascikl 281, Beč, 29.11.1528., 1v-4v, rbr. 582-587. Kralj Ferdinand na kranjske staleže.

${ }^{212}$ KRUHEK, Krajiške utvrde, 109-110.

${ }^{213}$ IBID., 88; LASZOWSKI, HSKHDS, knjiga I, dok. 367, 351-352.

${ }^{214}$ LOPAS̆IĆ, Bihać, 62.

${ }^{215}$ KLAIĆ, Povijest Hrvata, knjiga 5, 159; Ivan Lenković se krajem kolovoza 1531. potpisuje - „Ich Hanns Lencowitsch, des edlen gestrenngen Herrn Erasm von Thurn Ritter Haubtman zu Wihitsch vnd Repitsch Leytenandt“. SI AS 2, DSK, kutija 193, fascikl 120, Bihać, 26.8.1531., 2r, rbr. 80. Ivan Lenković na Hansa Katzianera.
} 
zapovjedništvom, dakle Erasmo Thurn uz Bihać i Ripač držao i Kamengrad, ${ }^{216}$ Nisam pronašao potvrdu te tvrdnje u pričenim izvorima.

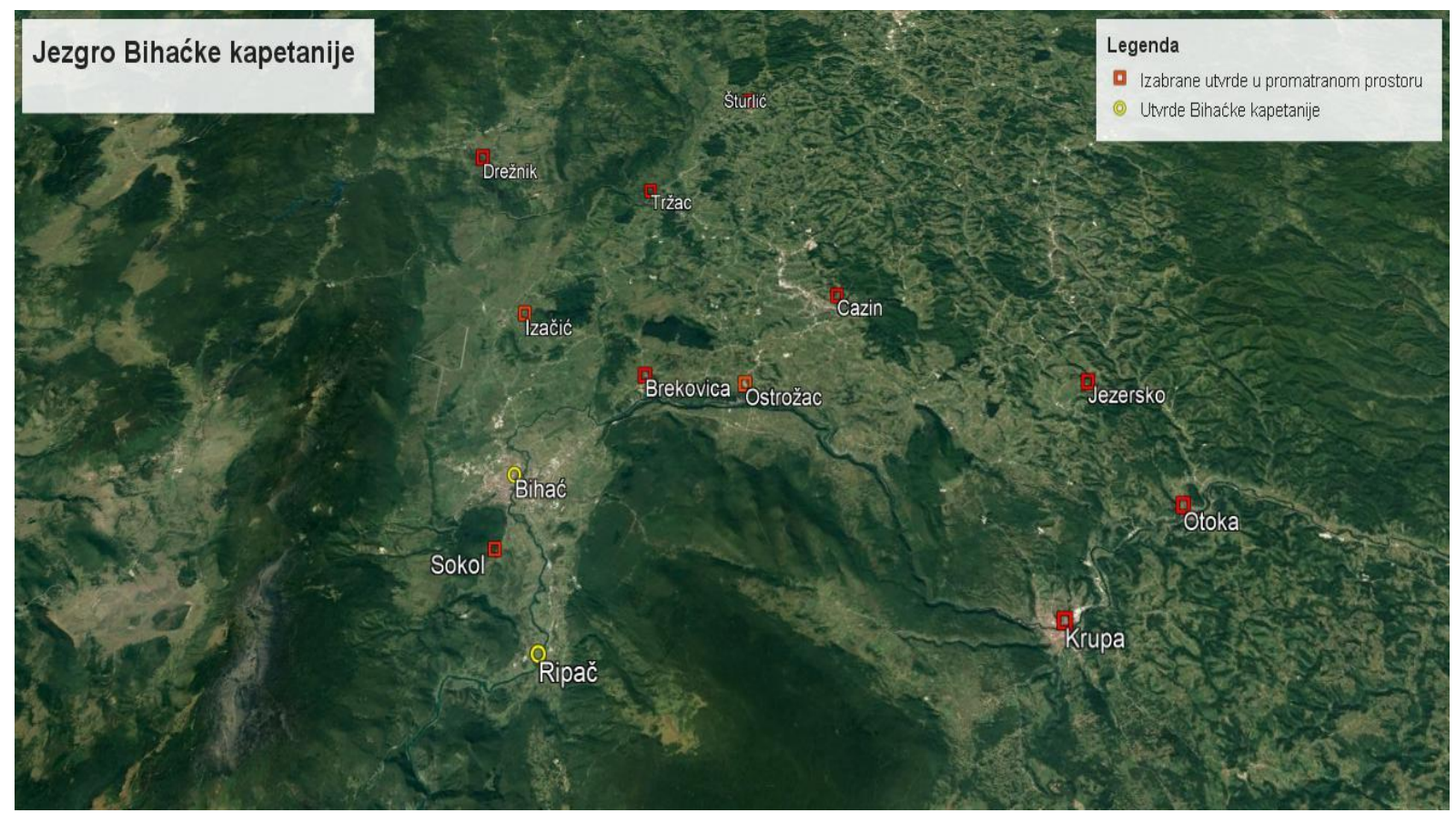

Slika 6. Bihać i Ripač - jezgra Bihaćke kapetanije krajem 1520-ih.

Uz Bihać i Ripač, pod neposrednom kraljevskom zaštitom tridesetih su godina (čini se) još i Krupa, Sokol, Izačić i Brekovica. Problem pri analiziranju teritorijalnog obuhvata Bihaćke kapetanije izaziva činjenica da su određene utvrde ostale u privatnim rukama i nakon što je u njima namještena kraljevska posada te da su neke od njih očito samo privremeno bile podređene bihaćkom kapetanu. Kada je nakon smrti Ivana Karlovića u kolovozu 1531. između kralja i Nikole Zrinskog došlo do trzavica oko posjedovanja grada Krupe, kralj Ferdinand opominjao je Zrinskog da „ne svojata grad Krupu i ne pravi neprilike podanicima grada, jer su oni u njegovo ime podređeni njegovom bihaćkom kapetanu, a sam je grad zbog njegove posebne obrambene važnosti, on uzeo pod svoju zaštitu“. 217

Nada Klaić navodi da su u desetljeću vladavine kralja Ferdinanda jedino Bihać i Ripač pod njegovom direktnom ingerencijom dok su ostale lokalne utvrde, poput Krupe, Novog, Otoke, Buševića, Cetina, Slunja, Izačića, Drežnika, itd., u rukama velikaša, plemstva ili

\footnotetext{
${ }^{216}$ LOPAŠIĆ, Bihać, 63

${ }^{217}$ KRUHEK, Krajiške utvrde, 111; LASZOWSKI, HSKHDS, knjiga II, dok. 106, 89; Tracy navodi da je Nikola Zrinski tvrdio da je Krupa sigurnija pod njegovom upravom nego pod zapovjedništvom udaljenog Bihaća. TRACY, Balkan Wars, 116.
} 
crkve. ${ }^{218} \mathrm{U}$ raznim utvrdama zaista je namještana kraljevska posada iako su formalno ostale u privatnom vlasništvu.

Čini se da je Izačić (privremeno) dospio pod ingerenciju bihaćkoga kapetana Petra Keglevića tijekom 1537., i to nakon što je krajem 1536. navodno bio bez ikakve posade barem petnaestak dana. Ta je utvrda bila od izvanredne važnosti za sigurnost Bihaća jer je bila pozicionirana na krucijalnoj komunikaciji sa zaleđem, o čemu će biti više riječi dalje u tekstu. $^{219}$ Pod zapovjedništvom bihaćkoga kapetana 1537. nalazili su se Ripač, Golubić, Sokol, Brekovica, Toplički Turanj i Izačić. ${ }^{220}$ Međutim, Izačić vjerojatno nije odmah trajno inkorporiran u puni sastav Bihaćke kapetanije jer Keglević 1538. od kralja traži da preuzme obranu samo Bihaća i Ripča jer ih on „nema čime braniti““. ${ }^{221}$ Također, Lopašić navodi da je Stjepan Izačić predao grad bihaćkom kapetanu 1540. zato što ga više nije mogao braniti. ${ }^{222}$

Nadalje, sredinom 1538. na kraljevu intervenciju banovi Keglević i Nádasdy s posjednicima Sokola uspijevaju postići dogovor oko uključivanja te važne utvrde u sustav Bihaćke kapetanije. Već više puta spominjani Sokol u neposrednoj blizini Bihaća zaposjela je kraljevska posada pod zapovjedništvom bihaćkoga kapetana, a vlasnicima je kao odšteta isplaćivana godišnja apanaža od 100, a kasnije i 150 forinti. Kralj se također obvezao vratiti Sokol njegovim vlasnicima kad nastupe sigurnija vremena. ${ }^{223}$

Oko posjedovanja i obrane Sokola bilo je trzavica s obitelji Vragović koja ga je htjela vratiti u svoj posjed. Tako je oko 1540. Bartlmeu Raunachu naređeno da preda utvrdu Vragovićima ako je zatraže. Budući da to nije učinjeno, iste godine preuzeo ju je novi bihaćki kapetan Mert Gall. Novopostavljeni kapetan tvrdio je da je Sokol u Vragovićevim rukama bio loše opskrbljen i bez dovoljne količine streljiva, a često da ga nisu čuvala ni dva vojnika. Također, Gall je apostrofirao važnost Sokola konstatirajući da se padom te utvrde ne bi dugo održali ni Bihać ni Ripač. ${ }^{224}$

Mert Gall imao je tada problema i s preuzimanjem Ripča od Juraja Grabusa zbog duga od 400-500 rajnskih guldena, ali nije jasno da li se radilo o dugu za Grabusovu službu ili dugu na neki način povezanom uz samu utvrdu. Grabus se očito intenzivno žalio kralju i na hrvatsko-slavonskim saborima, pa je savjetovano da mu se preda utvrda ako dođe kraljeva

\footnotetext{
${ }^{218}$ Nada KLAIĆ, »Ostaci ostataka« Hrvatske i Slavonije u XVI. stoljeću (od Mohačke bitke do Seljačke bune 1573. g.), Arhivski vjesnik, 16, 1973., 273.

${ }^{219}$ KRUHEK, Krajiške utvrde, 112-113; LASZOWSKI, HSKHDS, knjiga II, dok. 330, 327; IBID., dok. 346, 340-341

${ }^{220}$ LOPAŠIĆ, Spomenici Hrvatske krajine, knjiga III, dodaci, br. III, 390.

${ }^{221}$ N. KLAIĆ, »Ostaci ostataka«, 263.

${ }^{222}$ LOPAŠIĆ, Bihać, 140.

${ }^{223}$ KRUHEK, Krajiške utvrde, 113. O Sokolu i njegovim vlasnicima bit će više riječi dalje u tekstu.

${ }^{224}$ LASZOWSKI, HSKHDS, knjiga II, dok. 493, 488.
} 
naredba. Međutim, na Grabusov zahtjev kapetan Gall je i dalje tamo trebao držati 3-4 vojnika (knecht) koji bi služili uz Grabusove ljude te trebali biti „u slozi s njim i drugim susjedima“. ${ }^{225}$ Kao što je navedeno, Gall je tada preuzeo i Izačić, ali je predložio da se utvrda poruši jer od nje neće biti koristi već samo troškovi. ${ }^{226}$ Gall nije bio usamljen u tom stavu - to su naime savjetovali i neki, neimenovani, ,drugi“ (vnd annder). ${ }^{227} \mathrm{U}$ popisu vojske 1540. u sastavu Bihaćke kapetanije nalazili su se Bihać, Ripač, Sokol, Izačić i Toplički Turanj. ${ }^{228}$

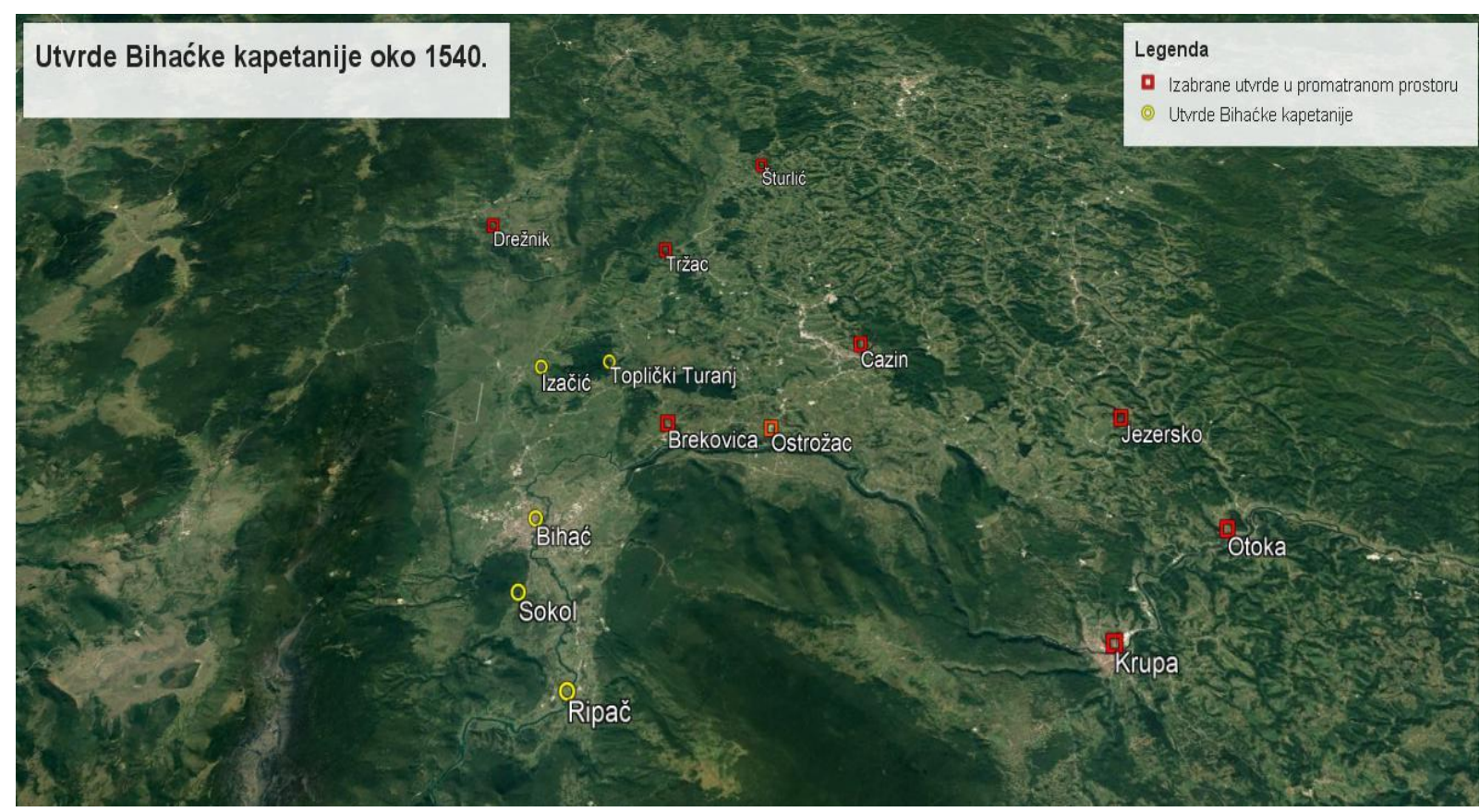

Slika 7. Bihaćka kapetanija oko 1540.

Kruhek navodi da je u periodu vrhovnog zapovjedništva Ivana Ungnada, a zatim i Ivana Lenkovića, dakle od 1540-ih do 1560-ih, organizirana i poboljšana obrana Senjske i Bihaćke kapetanije, ali da je postrance ostao prostor između Bihaća, Korane i Gline te osobito Une, Save i Kupe, u kojem je bilo mnogo privatnih vlasnika. ${ }^{229}$ Prema vojnom popisu iz 1559. kraljevske posade nalazile su na širemu promatranom prostoru u sljedećim mjestima: Bihaću, Ripču, Izačiću, Omršlu (Aindersle), Topličkom Turnju-Brekovici, Tržcu, Drežniku,

\footnotetext{
${ }^{225}$ SI AS 2, DSK, kutija 193, fascikl 119/120, Bihać, 24.5.1540., 1r, rbr. 270. Predstavnici kranjskih staleža na Merta Galla.

${ }^{226}$ LASZOWSKI, HSKHDS, knjiga II, dok. 493, 488.

${ }^{227}$ SI AS 2, DSK, kutija 193, fascikl 119/120, Bihać, 24.5.1540.,1v, rbr. 271. Predstavnici kranjskih staleža na Merta Galla.

${ }^{228}$ SI AS 2, DSK, kutija 244, fascikl 143, 1540., 1r-4r, rbr. 252-258. Kozličić navodi da je Toplički Turanj stajao na mjestu današnjeg lokaliteta Panjigrad koji se nalazi deset kilometara sjeverno-sjeverozapadno od Bihaća, uz rijeku Toplicu. Midhat KOZLIČIĆ, Unsko-sansko područje na starim geografski kartama (Izbor karata, planova $i$ veduta u kontekstu historije Unsko-sanskog područja od kraja 15. do početka 18. stoljeća), Nacionalna i univerzitetska biblioteka BIH, Arhiv Unsko-sanskog kantona, Sarajevo-Bihać, 2003., 48.

${ }^{229}$ KRUHEK, Krajiške utvrde, 174.
} 
Slunju, Šturliću, Krupi, Buševiću, Gvozdanskom, Furjanu, Jezerskom itd. ${ }^{230}$ Međutim, ne navodi se koje su od utvrda pod zapovjedništvom bihaćkoga kapetana, pa se može pretpostaviti da se do tada situacija nije bitno promijenila, već da je pod njegovom ingerencijom bila standardna ,,jezgra“ kapetanije, s dodatkom sela Omršal koje se nalazilo između Brekovice i Ostrošca i gdje su držane straže.

Kao što to Nataša Štefanec pokazala, ključno razdoblje ustrojavanja jasnijega kapetanijskog ustroja na Hrvatskoj krajini uslijedilo je zapravo tek početkom 1560-ih, kada se između 1559. i 1564. pojavljuju četiri kapetanije - uz senjsku i bihaćku, još i hrastovička te ogulinska. ${ }^{231}$ Ako se promotri izvještaj o stanju utvrda i obrane Hrvatske krajine koji je 1563. sastavio Ivan Lenković, primjećuje se da su tek Bihać, Ripač, Sokol, Izačić i drveni kaštel Blažuj pod zapovjedništvom bihaćkoga kapetana, odnosno u kraljevskim rukama, dok je većina utvrda na širemu unskom prostoru s kraljevskom posadom još uvijek u privatnom vlasništvu. Tako su Kobasići držali Brekovicu, knezovi Blagajski Ostrožac i Stijenu, Frankopani Tržački Tržac i Drežnik, a Frankopani Slunjski Krstinju, Donju i Gornju Kladušu te Cetin. Nadalje, biskup kninski držao je Cazin, Keglevići Bužim, Mikulići Podzvizd, Mihajlo Turk Peći, Šturlić utvrdu Šturlić, a knezovi Peranski Hresno. ${ }^{232}$

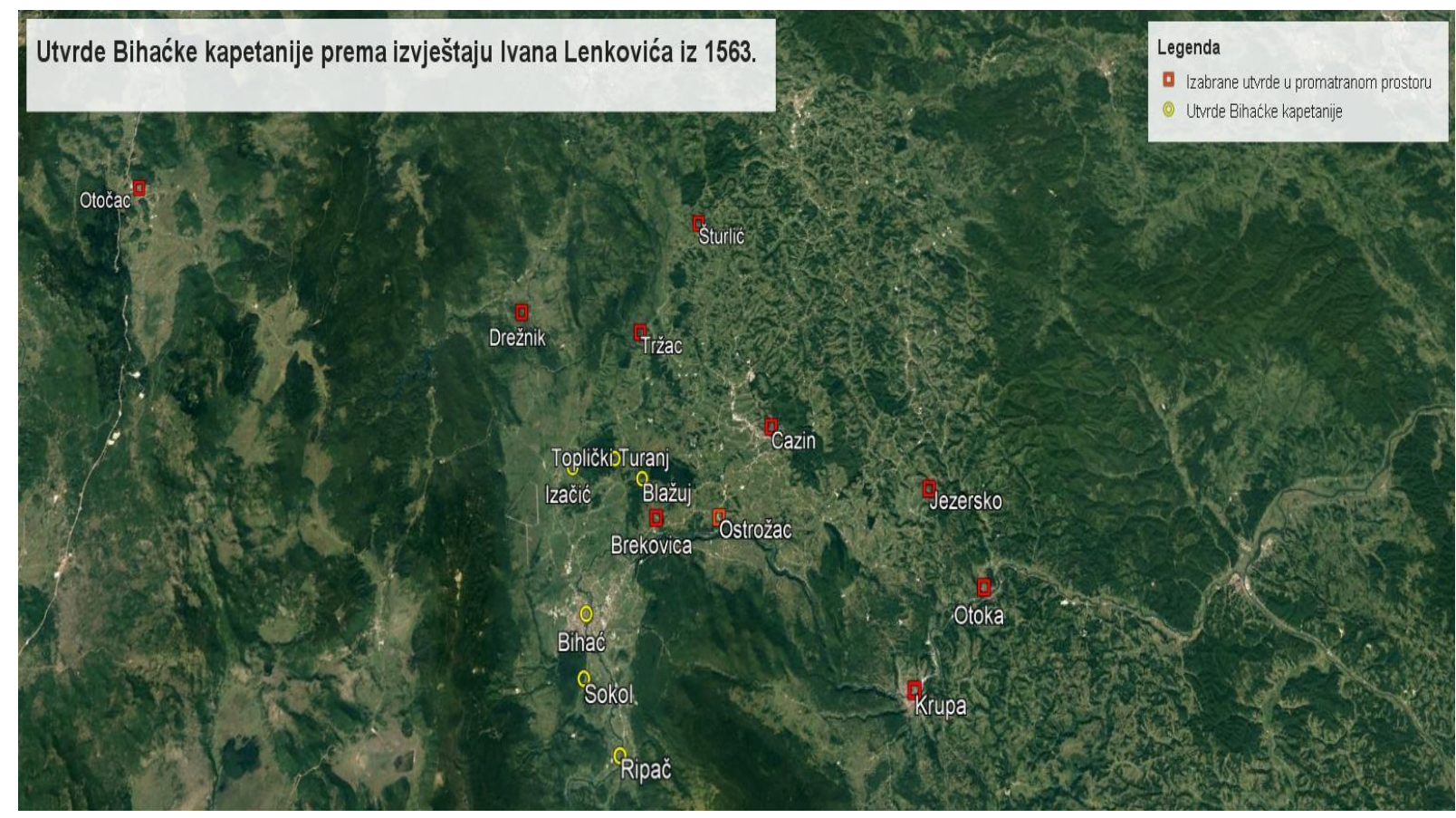

Slika 8. Bihaćka kapetanija 1563. prema Lenkovićevu izvještaju.

\footnotetext{
${ }^{230}$ Österreichische Staatsarchiv, Kriegsarchiv, Feldakten, Altefeldakten (dalje ÖeStA, KA-AFA), fascikl 13, 1559-7-ad7, 22-29.

${ }_{231}$ ŠTEFANEC, Država ili ne, 399.

${ }^{232}$ KRUHEK, Krajiške utvrde, 190-192.
} 
Već iste te godine u inspekciju krajišta poslano je posebno kraljevsko povjerenstvo koje je sastavilo opširan izvještaj na temelju kojeg je potom uređen krajiški sustav. ${ }^{233}$ Povjerenstvo je zaključilo da je u Bihaću potrebno namjestiti iskusnog vojnika koji bi kao kapetan zapovijedao Ripčem, Jesenicom, Drežnikom, Izačićem, Tržcem, Brekovicom, Ostrošcom, Cazinom i Stijenom. Za zapovjednika su predložili Georga Kronschalla čija je mjesečna plaća trebala iznositi 100 rajnskih guldena. ${ }^{234}$ Povjerenstvo je predložilo da se, ako nitko ne želi preuzeti odgovornost za Toplički Turanj, utvrda poruši te da se novi turanj za 300 rajnskih guldena podigne na brdu Lisovac nedaleko od prijelaza Mač kod Brekovice. Od tamo se moglo nadgledati „u veliku daljinu“ prema Đavoljem vrtu, Plješevici, Bihaću, Brekovici, Ostrošcu, Krupskim brdima, Stijeni, Cazinu, Mutnici, Šturliću, Tržcu, Furjanu, Drežniku i Izačiću. ${ }^{235}$ Taj prijedlog nije u potpunosti realiziran te Toplički Turanj nije porušen iako Kronschall jest preuzeo kapetaniju.

No, realiziran je prijedlog povećanja broja utvrda Bihaćke kapetanije koja sljedeće godine broji već 20 utvrda. Za komparaciju, Hrastovička je kapetanija tada brojala osam utvrda, Ogulinska dvanaest, Senjska devet dok ih je sedam ostalo neraspoređeno. Radilo se o sljedećim mjestima: Bihać, Ripač, Sokol, Izačić, Brekovica-Toplički Turanj, Ostrožac, Tržac, Drežnik, Stijena, Cazin, Krstinja, Donja Kladuša, Gornja Kladuša, Bužim, Podzvizd, Peći, Hresno, Cetin i Šturlić. ${ }^{236}$

\footnotetext{
${ }^{233}$ Izvještaj su potpisali: Jacob Lamberg, zemaljski poglavar Kranjske, Erasmo Mager, Franz Poppendorf, Pongratz Windischgrätz, Franz Teuffenpach, Servacij Teuffenpach, Paul Thanhaussen, Seifrid Dietrichstein, Cristoph Madarax, Dietrich Auersperg i Maximillian Lamberg. IBID., 245, fusnota 409. O dužnostima, procedurama i radu povjerenstva na krajini vidjeti Danijela COFEK, Nataša ŠTEFANEC, Vojnokrajiške institucije u praksi: Slavonska krajina 1578. godine, Podravina, vol. X, br. 19, 2011., 5-44.

${ }^{234}$ AHAZU, Lopašić, E. Prijepisi iz austrijskih arhiva, br. 15, str. 28.

${ }^{235}$ IBID., str. 65-66.

${ }^{236}$ ŠTEFANEC, Država ili ne, 475-476.
} 


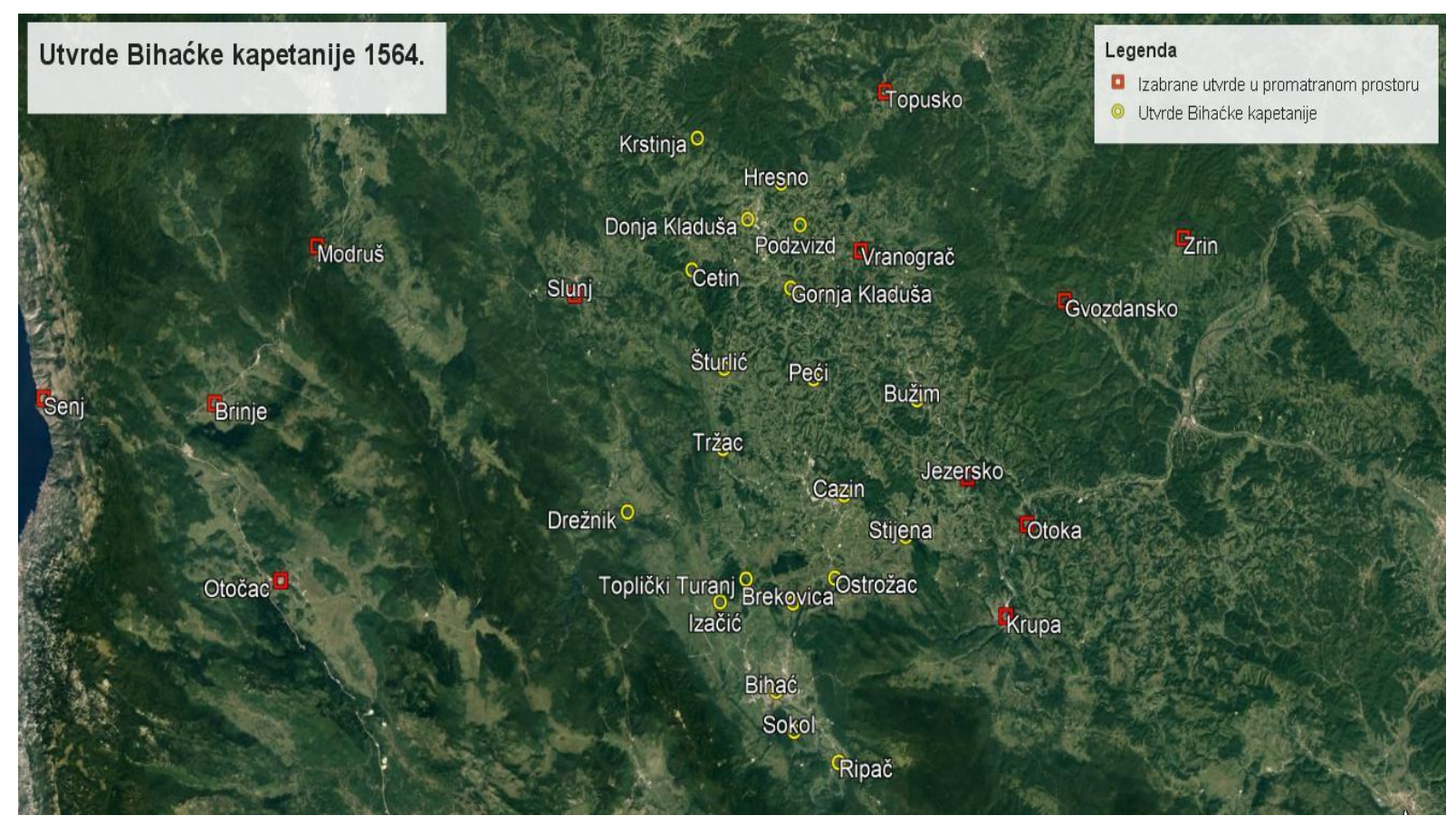

Slik 9. Utvrde Bihaćke kapetanije 1564.

U sastavu Bihaćke kapetanije 1573. nalazi se već 21 utvrda, jer tada pod kapetanijom i Blagajski Turanj (danas Hrvatski Blagaj kod Slunja). ${ }^{237}$ Takav raspored održao se do $1576 .{ }^{238}$

Prema prijedlogu Bečkog savjetovanja iz kolovoza 1577., Bihaćka kapetanija trebala je narasti na čak 29 utvrda u sljedećem sastavu: Bihać, Sokol, Ripač, Brekovica, Ostrožac, Toplički Turanj, Izačić, Blagajski Turanj, Krstinja, Hresno, Vrangorač, Donja Kladuša, Gornja Kladuša, Cetin, Perna, Peći, Sveti Juraj, Podzvizd, Šturlić, Gvozdansko, Pedalj, Zrin, Srednji Gradac, Mutnica, Gora, Ajtić, Mašin ili Dugišinov kaštel, Greda i Bojna. ${ }^{239}$

Međutim, isti mjesec nadvojvoda Karlo izvještava nadvojvodu Ernesta i carske savjetnike o stanju na krajištu te navodi da su u sastavu Bihaćke kapetanije 24 utvrde: Bihać, Ripač, Sokol, Drežnik, Tržac, Slunj, utvrda i trgovište Cetin, Izačić, Toplički Turanj, Brekovica, Ostrožac, Kremen, Hojsić (Heüsitsch pruggen Castell), Blagajski Turanj, Hresno, Gornja Kladuša, Donja Kladuša, Sveti Juraj u Ostroškoj šumi, Podzvizd, Peći, Šturlić Vranograč, Perna i Kneja. ${ }^{240}$

Dakle, sada je iskazana ponešto drugačije situacija. Naime, u sastavu Bihaćke kapetanije navedeni su Drežnik, Tržac, Kremen i Slunj koji su ranije bili dio Ogulinske

\footnotetext{
${ }^{237}$ IBID., 478.

${ }^{238}$ IBID., 480.

${ }^{239}$ IBID., 484.

${ }^{240}$ LOPAŠIĆ, SHK, knjiga I, dok. XXVI, 41.
} 
kapetanije te Podzvizd koji ranije nije uopće naveden. Nema pak Zrina, Gvozdanskog, Blinje, Gore, Bojne, Hajtića, Mazina, Grede i Mutnice koji su dio Hrastovičke kapetanije. ${ }^{241}$

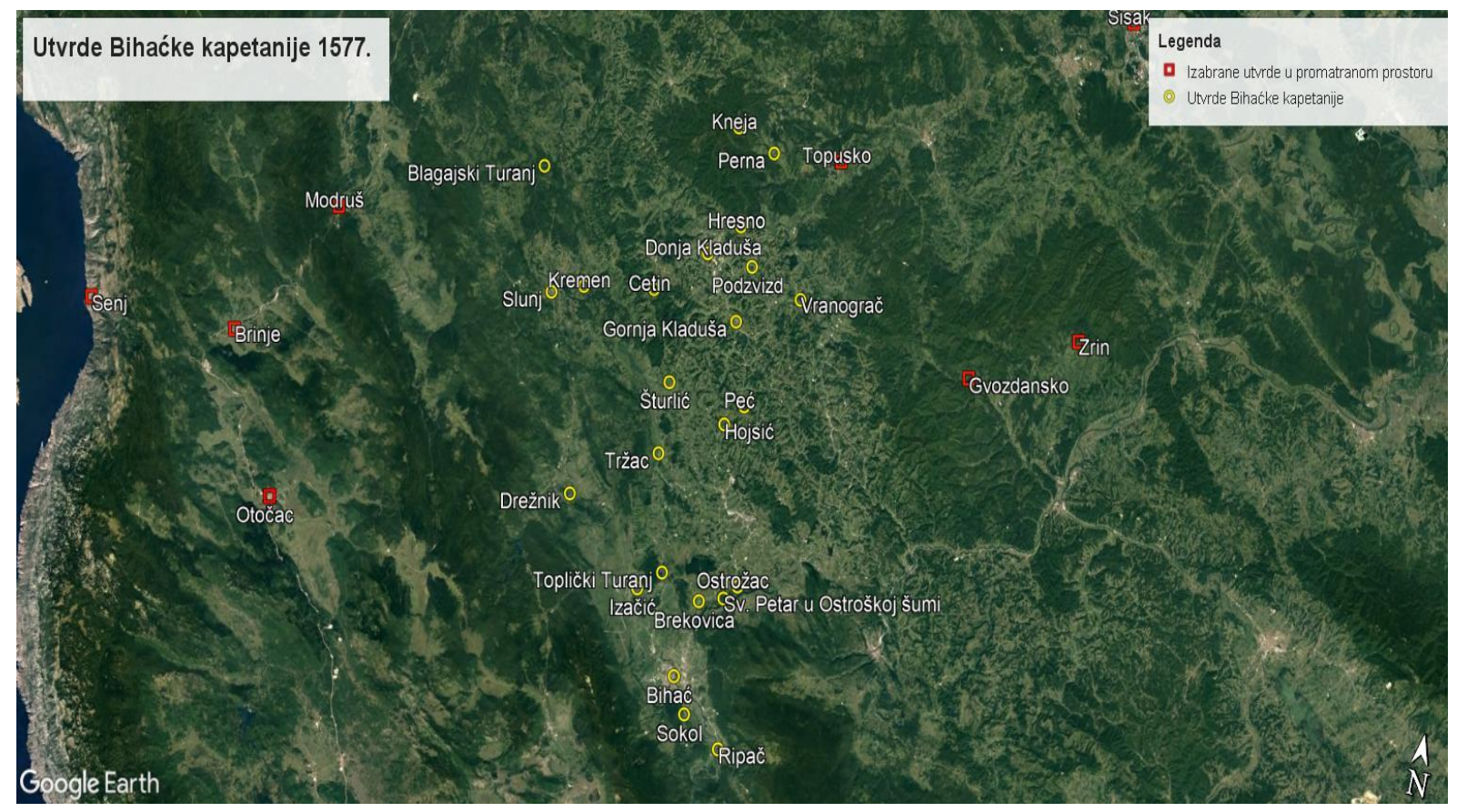

Slika 10. Bihaćka kapetanija 1577.

Diskrepancije između planiranog i realnog stanja te brojne promjene svjedoče o permanentnom restrukturiranju krajišta, ali i gubitku utvrda na hrvatskom prostoru konkretno Stijene, Bužima i Cazina koje su zauzeli Osmanlije. Ovako veliki broj utvrda pod zapovjedništvom jednog čovjeka te činjenica da su se Osmanlije osvajanjem Bužima i Cazina zaboli kao klin u središte jedne tako prostorno velike upravne jedinice predstavljali su golemo opterećenje za bihaćkoga kapetana. Daljnja osmanska osvajanja na unskom prostoru (o kojime će biti riječ dalje u tekstu) te interna reorganizacija krajišta učinili su sve obrambene sheme bespredmetnima. Bihaćka je kapetanija pala na samo devet utvrda, a Hrastovička na dvije. No, porastao je broj utvrda pod direktnim zapovjedništvom glavnog zapovjednika. Konkretno, radi se o povećanju s tri na devet utvrda (Hresno, Donja Kladuša, Priseka, Greda, Stanković, Klimna Gora, Mašin, Perna i Gradac). Tih devet utvrda pripadalo je uglavnom Bihaćkoj kapetaniji što znači da je ona vidno reducirana i zbog osmanskih osvajanja i zbog interne reorganizacije. ${ }^{242}$ To je učinjeno, kaže Štefanec, jer se pripremao veliki napad na Osmanlije (tzv. Hrvatska ekspedicija - Crabatische Expedition - o kojoj će biti riječi dalje u

\footnotetext{
${ }^{241}$ IBID.

242 ŠTEFANEC, Država ili ne, 400.
} 
radu) pa se smatralo da je potrebno što više ovlasti na području u kojem se trebao odviti napad, staviti u ruke jednog čovjeka. ${ }^{243}$

Nadalje, 1578. ustrojena je nova Slunjska kapetanija (uskočka kapetanija) u čiji su sastav ušli Cetin i Slunj iz Bihaćke kapetanije te Plaški iz Ogulinske kapetanije. Štefanec navodi da je logika iza njezina formiranja bila „u redistribuciji utvrdnih i terenskih vojnika te upošljavanju neplaćenih vojnika“. Budući da je ukinuta terenska vojska, a moralo ih se ostaviti na plaći, namješteni su u utvrde na prostoru u kojem su tradicionalno boravili. ${ }^{244} \mathrm{U}$ sastavu Bihaćke kapetanije 1578. nalaze se Bihać, Ripač, Sokol, Jesenica, Drežnik, Izačić, Brekovica, Tržac i Toplički Turanj. ${ }^{245}$

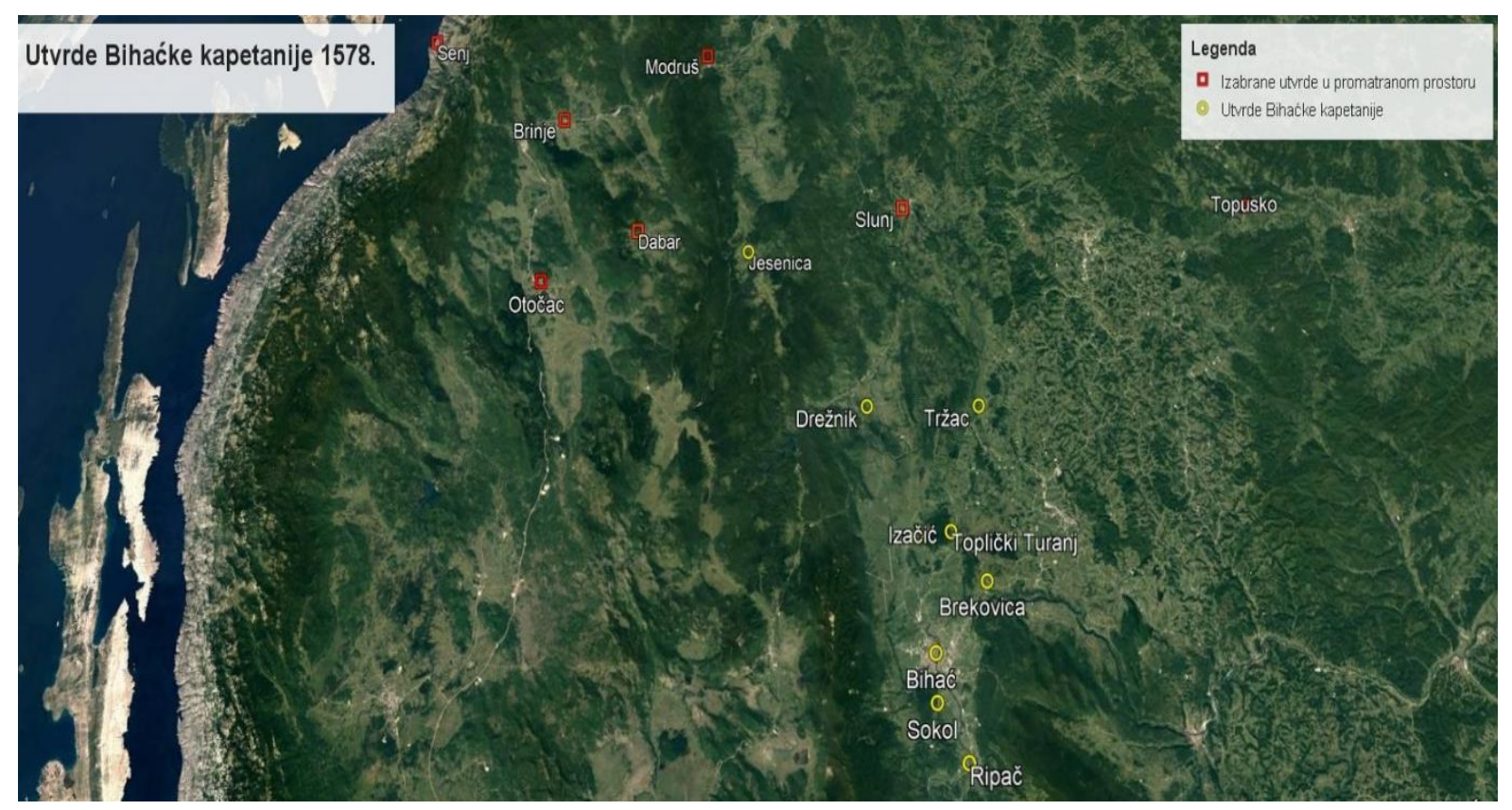

Slika 11. Bihaćka kapetanija 1578.

Popis utvrda početkom ožujka 1579. najbolje pokazuje koliko su osmanska osvajanja te interna reorganizacija nakon sabora u Brucku ostavili traga na Bihaćkoj kapetaniji. Naime, od nekoć prostrane kapetanije ostale su tek pet utvrda - Bihać, Ripač, Sokol, Izačić te Drežnik, koji su 1578. zauzeli Osmanlije, ali je iste godine osvojen i kasnije će biti dio Bihaćke kapetanije. Toplički Turanj i Brekovica ostali su pak nezaposjednuti. Sva ostala mjesta bila su ili u sastavu nove Slunjske kapetanije (Cetin i Tržac) ili pod neposrednim

\footnotetext{
${ }^{243}$ IBID., 401.

${ }^{244}$ IBID., 401-403.

245 ÖeStA, KA-AFA, fascikl 25, 1578-3-2.
} 
zapovjedništvom zapovjednika Hrvatske krajine (Donja Kladuša, Blagajski Turanj, Hresno). ${ }^{246}$

Međutim, prilike su se nakon saboru u Brucku 1578. ipak stabilizirale. Povećanja ulaganja i krajiške reforme imale su svakako pozitivan efekt, a nema sumnje da je ipak bilo lakše braniti manji broj utvrda, bez obzira na to što su se nalazile na isturenoj krajini i gotovo opkoljene. Bihaćka kapetanija brojala je 1582. šest utvrda - Bihać, Ripač, Izačić, Sokol, Drežnik i Tržac. ${ }^{247}$ No, promjena je bilo i u tom periodu, a neke utvrde stajale su nezaposjednute na području pod ingerencijom bihaćkoga kapetana. U proljeće 1584 . zapovjednik Hrvatske i Primorske krajine Jobst Joseph Thurn tražio je da Drežnik ponovo pripadne Bihaćkoj kapetaniji zato što je njegov zapovjednik Juraj Križanić (koji je uveden u zapovjedništvo kada je Drežnik ponovno osvojen od Osmanlija) postao zapovjednik novog turnja na Korani (Križanić Turanj) te nije mogao adekvatno obnašati obje funkcije. ${ }^{248}$ Budući da je Drežnik u ranijim popisima naveden kao dio Bihaćke kapetanije, očito je u tih nešto više od godinu dana došlo do promjene statusa utvrde. Brekovica je pak ostala prazan i napušten thuern koji je u travnju 1584. Jobst Joseph Thurn dao porušiti kako bi spriječio Osmanlije da je obnove i zaposjednu. Brekovicu su do temelja uništili tako da je Thurn javljao nadvojvodi Karlu da se više ne treba brinuti o tome da bi je Osmanlije mogli zaposjesti. Nadalje, Thurn je naveo da će isto učiniti i s Topličkim Turnjem. ${ }^{249}$ Doduše, Thurn je u jednom trenutku imao namjeru i namjestiti posade u sve napuštene utvrde od Ostrošca do Tržca na Korani, ali to se očito nije ostvarilo. ${ }^{250}$

\footnotetext{
${ }^{246}$ LOPAŠIĆ, SHK, knjiga I, dok. XLIII, 79.

${ }^{247}$ Géza PÁLFFY, A Magyarországi és délvidéki végvárrendszer 1576. és 1582. évi jegyzékei, Hadtörténelmy Közlemények, No. 1, Budimpešta, 1995., 175-176. ${ }^{248}$ LOPAŠIĆ, SHK, knjiga I, dok. LXXXIX, 129.

${ }^{249}$ IBID., dok. XC, 131. Doduše, još istog mjeseca iz Bihaća je javljeno Thurnu da špijuni navode da Osmanlije namjeravaju zaposjesti Brekovicu vojnicima iz Ostrošca, ali da nisu sigurni zna li beg da je Brekovica uništena. IBID., dok. XCI, 132. Brekovicu i Toplički Turanj namjeravao je još sredinom 1582. srušiti bihaćki kapetan Obritschan. HDA, Croatica, mikrofilm D-1914, br. 11, lipanj 1582.

${ }^{250}$ LOPAŠIĆ, SHK, knjiga I, dok. XC, 131-133.
} 


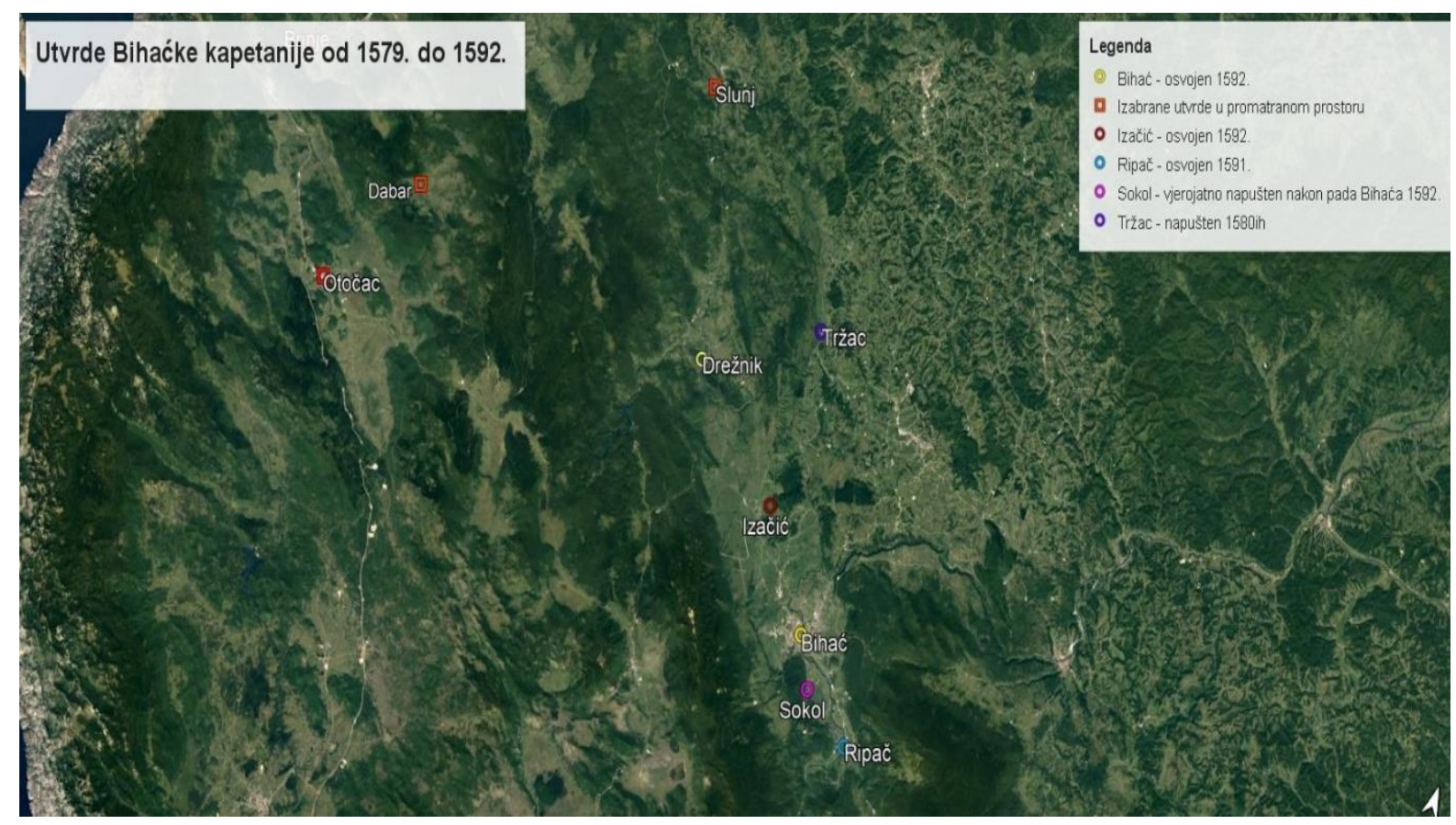

Slika 12. Bihaćka kapetanija od 1579. do pada pod osmansku vlast

Prema vojnom popisu iz 1589., u sastavu Bihaćke kapetanije nalazili su se Bihać, Ripač, Izačić i Drežnik. ${ }^{251}$ Sokol se ne spominje, ali razlog je vjerojatno u tome što se zaposjedao vojnicima iz bihaćke posade. Ovakva se situacija manje-više održala do početka 1590-ih. Osmanlije su Ripač zauzeli 1591., a zatim 1592. osvajaju prvo Izačić pa Bihać. Što se Sokola tiče, nije poznato jesu li ga Osmanlije zauzeli prije osvajanja Bihaća, pa je velika vjerojatnost da je ili napušten ili predan nakon pada Bihaća jer se u takvoj konstelaciji nikako nije mogao održati. Sudbina Drežnika i Tržca, kojim je još 1590. zapovijedao Gašpar Križanić, također je nejasna. ${ }^{252}$

Dakle, jezgru Bihaćke kapetanije činile su dvije utvrde u kraljevskom posjedu - Bihać i Ripač. Ustrojavanjem kapetanijskog sustava kontinuirano je rastao broj utvrda koje su se nalazile direktno pod zapovjedništvom bihaćkoga kapetana, odnosno broj privatnih utvrda u kojima se nalazila kraljevska vojska nad kojom je bihaćki kapetan imao ingerencije. Nakon što je sredinom 1560-ih kapetanijski sustav na hrvatskom prostoru poprimio sustavniji i definiraniji oblik, broj utvrda u sastavu Bihaćke kapetanije još je porastao na 24. Odgovornost za izrazito velik broj utvrda smještenih na centralnom prostoru Hrvatske krajine predstavljao je golemo opterećenje za bihaćke kapetane koji su zbog toga ulagali i žustre prigovore, o čemu će biti riječi dalje u tekstu. Nedostatna financijska sredstva, logistički problemi, premali

\footnotetext{
${ }^{251}$ SI AS 2, DSK, kutija 230, fascikl 136, 1589., 11r-12r.

${ }^{252}$ LOPAS̆IĆ, Bihać, 290-291.
} 
broj plaćenih vojnika, loše građevinsko stanje činili su situaciju vrlo teškom. Nakon velikih osmanskih osvajanja 1570-ih, o kojima će biti riječi u sljedećem poglavlju, broj je utvrda pao na svega nekoliko, a glavni su razlozi osmansko zauzimanje ili interna reorganizacija. Kapetanija koja je do jučer imala velik broj utvrda u svom sastavu sada se ponovno našla reducirana na nekoliko utvrda s početka habsburškog perioda.

U završnom činu te krajiške drame, pred osmansko zauzimanje grada, kapetanija se ponovno sažela u početnu jezgru - Bihać, Ripač, Sokol uz Izačić. Kada je izgubljen Ripač, ta integralno povezana predstraža Bihaća, vrlo brzo dogodilo se ono gotovo neizbježno Osmanlije su zauzeli Izačić, a potom i sam Bihać.

\subsection{Strategija otpora Osmanlijama. Opći postulati.}

Iako je strategija otpora osmanskom napredovanju u pojedinim fazama adaptirana trenutnim okolnostima, ona je tijekom većeg dijela 16. stoljeća naglašenoga defenzivnoga karaktera. Géza Pálffy čak navodi da na ugarskom prostoru sve do 1540-ih zapravo i nije postojala jasna strategija otpora osmanskom ekspanzionizmu. ${ }^{253}$ Pálffy smatra da je to posljedica, građanskog rata između pristaša Ferdinanda Habsburškog i Ivana Zapolje te činjenice da austrijsko plemstvo u tom periodu nije bilo dovoljno upoznato s karakterom ratovanja na ugarskom krajištu. Tek 1550-ih stasat će nova generacija austrijskog plemstva koja će se dobro upoznati sa situacijom na ugarskom prostoru koje je njihovim prethodnicima predstavljalo terra incognita, zaključuje Pálffy. ${ }^{254}$

Habsburška strategija, barem od sredine 16. stoljeća, svodila se na postizanje i održavanje primirja kao preduvjeta konsolidacije i poboljšanja obrambenog sustava te pronalaska načina da se adekvatno reagira na osmanski pritisak. ${ }^{255}$ Dok su ranije i

\footnotetext{
${ }^{253}$ PÁLFFY, Die Türkenabwehr, 109.

${ }^{254}$ PÁLFFY, The Border System, 114.

${ }^{255}$ Dvorsko ratno vijeće krajem 1576. referira se na tri tipa osmanskih napada. Prvi je napad paše koji s redovnom krajiškom vojskom namjerava napasti jednu utvrdu ili kaštel. Odgovor na takvu prijetnju podrazumijevao je održavanje krajiških utvrda, redovitu isplata plaća, dobru uvježbanost vojnika i propisno naoružanje. U takvim slučajevima redovitoj vojsci u pomoć bi dolazile dodatne snage. Dakle, uredno financiranje ključno je za realizaciju ove strategije. Također, napomenuta je potreba rotiranja vojske, uglavnom u tromjesečnim intervalima iz unutrašnjeaustrijskih zemalja na krajinu. Drugi tip napada odnosi se na napad beglerbega. U takvom slučaju trebalo je osigurati veće zalihe i podići insurekcijsku vojsku, a carski su staleži pak odobrili da se pomoć predviđena za dvije godine isplati u jednoj. Preporuka je bila da se u službu uzme više zapovjednika nad konjicom i pješacima i to onih koji su bliže granici da bi mogli adekvatno i promptno reagirati. Treći tip napada je opći napad kojem je na čelu stajao sam sultan. U tom slučaju trebalo bi održati opširno savjetovanje i na temelju osmanskih akcija vidjeti kakvu strategiju i taktiku najbolje upotrijebiti. Jedino što su
} 
poduzimane velike vojne kampanje, od polovice stoljeća one polagano nestaju sa strateškog horizonta, a središnja vlast sve intenzivnije nastoji formirati defenzivnu liniju utvrda. Stoga je kralj Ferdinand već 1546. od Ugarskog sabora tražio organiziranje linije utvrda, odnosno da u ruke njegovim kapetanima, povjerenicima ili banu svaki posjednik preda utvrdu koju nije u stanju braniti. $^{256}$

Okretanje defenzivi bila je posljedica velikih osmanskih osvajanja centralnoga ugarskog prostora 1540-ih i 1550-ih, odnosno gubitka prostora uz rijeku Dravu 1560-ih koja su kulminirala padom Sigeta $1566 .{ }^{257}$ Najvišima ešalonima habsburške politike postalo je sasvim jasno da će vrlo teško ofenzivno nastupati protiv Osmanlija, a takav striktno defenzivni stav dodatno je učvršćen nakon dramatičnih gubitaka na unskom frontu 1570-ih. Čak su i povremene veće napadne operacije, poput tzv. Hrvatske ekspedicije, izvođene oko rijeke Une 1578., bile lokalnog i ograničenog karaktera, poduzimane radi utvrđivanja i poboljšavanja defenzivnih pozicija, a ne radi ozbiljnog vraćanja izgubljenog teritorija. Više se gotovo nije raspravljalo o velikim vojnim operacijama. ${ }^{258}$

Sklapanje i održavanje primirja postali su strateški imperativ. Naime, nastojalo se održavati primirje kako bi se u kakvim takvim stabilnijim/mirnijim periodima mogao formirati i ojačati obrambeni sustav. ${ }^{259}$ No, potpisivanje primirja nije značilo prestanak sukoba, a često ni daljnjih osmanskih osvajanja. ${ }^{260}$ Iako u razdobljima mira ili primirja

napomenuli jest da bi se trebalo isprazniti cijelo pograničje te na taj način stvoriti opskrbne probleme za neprijatelja. ŠTEFANEC, Država ili ne, 289-290.

${ }^{256}$ IBID., 393.

${ }^{257}$ PÁLFFY, Die Türkenabwehr, 110. Namjera je bila da se „by utilizing the most important geopolitical characteristics of the country, separate defense zones - castle regions - would be established around the frontier fortresses located in different parts of Hungary". Te zone (border fortress generalcies Grenzoberhauptmannschaften) bile su pod upravom glavnih utvrda ,in accordance with uniform principles“. PÁLFFY, The Border System, 114; ŠTEFANEC, Država ili ne, 139-142.

${ }^{258}$ Nataša ŠTEFANEC, Osmanski zapovjednici i struktura osmanske i habsburške vojske na hrvatskom djelu krajišta (prema špijunskim izvještajima iz 1570-ih), Ascendere historiam. Zbornik u čast Milana Kruheka, Hrvatski institut za povijest, Zagreb, 2014., 212.

259 Defenzivna politika habsburškog dvora manifestirala se i onda kada su protiv Osmanskog Carstva dogovorene ili planirane šire vojne alijanse. Car Maksimilijan je, manjim dijelom radi neugodnih ratnih iskustva, a većim dijelom radi lošega financijskog stanja i nevoljkosti vojske da se upusti u rat, odbio nakon pobjede kod Lepanta 1571. sudjelovanje u velikoj protuosmanskoj koaliciji u kojoj su participirale Mletačka Republika, Španjolska i Papinska Republika. Maksimilijan je u siječnju 1576. odbio i prijedlog nadvojvode Karla da se za obranu od Osmanlija postigne sporazum s Papom jer se bojao da bi Osmanlije to mogli protumačiti kao neprijateljski čin. ROTHENBERG, The Military Border, 41-43. Primirje s Osmanlijama ostalo je gotovo dogma. Tako je nešto ranije, sredinom prosinca 1559., budimski beglerbeg proslijedio na Portu pismo „od kraljeva sina“, vjerojatno Maksimilijana, kojim ovaj izražava duboku privrženost „amanu“ ili "viri“, dakle miru, te u kojem navodi da je nekoliko puta naređeno njegovim podređenima da „ne idu na begove i vojsku koja je na granicama $i$ da nikome na turskoj strani ne pripremaju i ne nanose štetu“. S Porte je stigla naredba Malkoč-begu da se također pridržavaju ,vire“. Ešref KOVAČEVIĆ, Muhimme Defteri; Dokumenti o našim krajevima, Monumenta Turcica Historiam Slavorum Meridionalium Illustrantia, Muhimme defteri, knjiga 1, svezak 1, Sarajevo, 1985., dok. 28, 16.

${ }^{260}$ Prilikom pregovaranja o mirovnom sporazumu 1533. neprijateljstva na pograničju trebala su načelno prestati, a veliki je vezir navodno izjavio da se „niti kokoš ne smije oteti“. Od svega toga uglavnom nije bilo ništa. 
uglavnom nije bilo ekstenzivnog zauzimanja teritorija, velika osmanska osvajanja na unskom prostoru sredinom1570-ih započela su baš u periodu kada je na snazi bio aktivan mirovni sporazum. $^{261}$

Najintenzivnije vojnostrateške rasprave vodile su se upravo 1570-ih, a dominantna figura tih savjetovanja i glavni kreator habsburške vojne strategije bio je Lazarus Schwendi, jedan od najpoznatijih vojnih teoretičara i vojskovođa tog doba. ${ }^{262}$ Realno sagledavajući odnos snaga između zaraćenih imperija, Schwendi se zalagao za defenzivni pristup $\mathrm{s}$ naglaskom na izbjegavanje izravnih konfrontacija s Osmanlijama, očuvanje mira pod svaku cijenu te vođenje obrambenog rata, sve dok se okolnosti ne promjene u habsburšku korist. Predlagao je izbjegavanje angažiranja plaćenika te oslanjanje na prethodno educirano i uvježbano domaće stanovništvo od kojeg bi se formirale lokalne vojne jedinice. U sastav tih jedinica ulazilo bi i plemstvo, a navedene mjere trebale su smanjiti vojne izdatke i stvoriti motiviranije vojnike. ${ }^{263}$ Schwendi je sredinom 1570-ih predložio da se u ojačane utvrde na krajini stalno nasele kmetovi i zanatlije, da im se dodijeli zemljišni posjed te da ih se primjereno plati za vojnu službu koju bi obnašali. ${ }^{264}$

Defenzivnu stratešku poziciju poduprlo je 1576. i Dvorsko ratno vijeće u Beču. ${ }^{265}$ No, na Bečkom savjetovanju 1577. iskristalizirala su se dva pristupa obrani - prijedlog Lazarusa Schwendija o stvaranju jakih i dobro organiziranih obrambenih odsjeka te prijedlog Hansa

\footnotetext{
Habsburški ambasador Giovanni Maria Barzizza i novi veliki vezir Ajas Mehmed-paša mnogo realnije su referirali na pogranične čarke. U engleskom prijevodu to je lakonski opisano na sljedeći način - „violations of the truce were regrettable if not altogether preventable". TRACY, Balkan Wars, 119.

${ }^{261}$ Osmogodišnje primirje potpisano je 22. prosinca 1575., ali je prekinuto nakon smrti kralja Maksimilijana krajem 1576. Vasko SIMONITI, Prispevek k poznavanju turških vpadov od leta 1576 do začetka gradnje Karlovca leta 1579, Zgodovinski časopis, XXXIV, 1980., 87. Već u siječnju sljedeće godine habsburška strana nastoji produžiti osmogodišnje primirje. ŠTEFANEC, Država ili ne, 275.

${ }^{262}$ Lazarus Schwendi (1522.-1583.) bio je član carskih staleža, carev osobni savjetnik, vodeći teoretičar i vojni strateg svog doba te jedan od osnivača Dvorskog ratnog vijeća u Beču. Iako je njegovo neposredno djelovanje primarno vezano uz Gornjougarsku krajinu, Schwendi je imao golem utjecaj na razvoj krajiškog sustava na cijelom pograničju. ŠTEFANEC, Država ili ne, 143. Paneuropsko značenje sukoba s Osmanlijama, a onda i pozicije hrvatskog prostora u takvoj geostrateškoj shemi. pokazuje i činjenica da su njemački carski staleži okupljeni na saboru u Regensburgu 1576., raspravljajući o protuosmanskoj obrani, obećali doznačiti 705000 forinti, ali i predložili da se za osiguranje Ugarske, Hrvatske i Slavonske krajine formira novi viteški red koji bi svoje vojne snage stacionirao u Kanjiži, Koprivnici, Sisku i Gvozdanskom. SIMONITI, Prispevek, 1980., 90. Kralj Ferdinand i papa Klement VII. (pontifikat 1523. - 1534.) razgovarali su o namještanju reda Ivanovca u Hrvatsku (Dubica, Bjelovar, Pakrac, Klis i osobito Vrana), no sukobi s Francuskom opstruirali su tu nakanu. Vladimir von SCHNURBEIN, Die Bemühungen des Hauses Habsburg zur Ansiedlung von Ritterorden beim Aufbau der Militägrenze, Arbeitskreis Militär und Gesellschaft in der Frühen Neuzeit e. V. Militär und Gesellschaft in der Frühen Neuzeit, 12, Heft 1, Universität Potsdam, 2008., 38-41.

${ }^{263}$ ŠTEFANEC, Država ili ne, 273-274.

${ }^{264}$ SIMONITI, Prispevek, 1977., 500.

265 ŠTEFANEC, Država ili ne, 274.
} 
Ruebera koji se zalagao za aktivniju obranu. ${ }^{266}$ Prihvaćen je Schwendijev defenzivni prijedlog, a time je na terenu započeo proces „zatvaranja“ granice koji je pretpostavljao mjere poput poplavljivanja riječnih dolina pomoću brana, blokiranje prijelaza preko rijeka, podizanje stražarnica na prijelazima, rušenje strateški nepotrebnih utvrda i slično. ${ }^{267}$ Primarni ciljevi tih mjera i odredbi donesenih na saboru u Brucku bili su stabilizacija fronte i obrana od neprijateljskih napada. ${ }^{268}$

Obrana hrvatskog prostora strateški se nije mnogo razlikovala od generalnih strateških postulata, iako treba naglasiti da su pri ustrojavanju krajiškog sustava na hrvatskom prostoru habsburška kuća i unutrašnjeaustrijski staleži igrali još važniju ulogu. Za razliku od ugarskog slučaja, između hrvatskog i unutrašnjeaustrijskog prostora nisu postojale nepremostive političke, jezične ili neke druge barijere. Već je spomenuto da su mnogi hrvatski velikaši ratovali na strani cara Maksimilijana I. protiv Vladislava II. Jagelovića te da su imali priliku ostati u njegovoj službi i nakon okončanja sukoba. Ne treba opet ponavljati da Habsburgovci i staleži Unutrašnje Austrije na razne načine potpomažu obranu hrvatskog prostora mnogo prije nego što je Ferdinand zasjeo na ugarsko-hrvatsko prijestolje.

No, ako se i odmaknemo od političko-vojnog konteksta, postoje mnogobrojne veze između hrvatskog i primarno kranjskog prostora. Prije svega, slavenski svijet s obiju strana granica mogao se relativno lako sporazumjeti. ${ }^{269}$ Dio germanofonoga unutrašnejaustrijskog plemstva poznavao je slovenski, pa i hrvatski (osobito oni koji su služili na krajini), a nedvojbeno je i hrvatsko plemstvo u određenoj mjeri poznavalo njemački. Uostalom, uvijek se moglo komunicirati na univerzalnome latinskom jeziku. Rodbinske veze između hrvatskog i primarno kranjskog plemstva postojale su u predosmanskom periodu, a kasnije su se još intenzivirale. Kompleksna migracijska kretanja dodatno su „familijalizirala“ hrvatski i unutrašnjeaustrijski prostor. U konačnici je hrvatski prostor geografski mnogo uži i mnogo manje zahtjevan za upoznavanje od golemoga ugarskog područja, pa ni taj aspekt nije morao

266 IBID., 157.; Géza PÁLFFY, The Habsburg Defense System in Hungary Against the Ottomans in the Sixteenth Century: A Catalyst of Military Development in Central Europe, u: Warfare in Eastern Europe, 15001800., ur. Brian J. Davies, Brill, 2012., 47-61.

${ }^{267}$ PALFFY, The Border System, 119-120.

${ }^{268}$ KRUHEK, Krajiške utvrde, 281.

${ }^{269}$ Niclas Salm stariji je u lipnju 1522. iskazao veliku potrebu za prevoditeljem, pa se dogovarao s mariborskim (Marchburg) sucem Andreenom Frommacherom, koji je dobro poznavao prilike u Hrvatskoj i Slavoniji, njihov jezik i običaje. Frommacher je trebao držati i dva konjanika. THALLÓCZY, HODINKA, A horvát véghelyek, dok. CVI, 177. 
imati limitirajući efekt. Ne treba naglašavati da su habsburški nadvovjode, kao vladari Unutrašnje Austrije, također bili itekako dobro upoznati sa situacijom na području Hrvatskoslavonskog Kraljevstva. Unutrašnjeaustrijsko plemstvo imalo je dobru vojnu naobrazbu, a služenjem na krajištu lako su mogli steći i veliko ratno iskustvo. Uostalom, sam Pálffy navodi da je Hrvatska krajina poslužila kao model za organiziranje krajine na općoj razini. ${ }^{270}$

Unutrašnjeaustrijsko plemstvo (i predstavnici kraljevske vlasti) teško da bi mogli voditi proces formiranja krajiškog sustava da nisu dobro poznavali geostratešku i sociopolitičku situaciju na hrvatskom prostoru. To pokazuje i činjenica da su unutar unutrašnjeaustrijskoga staleškog miljea rasprave o strategiji obrane od Osmanlija prisutne već od početka 16. stoljeća. Također, već od 1560-ih krajinu obilaze posebna povjerenstva koja na temelju neposrednog uvida u stanje na terenu predlažu kako urediti pograničnu zonu. ${ }^{271}$

Strateške postavke središnjih vlasti i staleža Unutrašnje Austrije na hrvatskoslavonskom prostoru nakon poraza kod Gorjana 1537. također su primarno defenzivne. ${ }^{272}$ Središnja vlast nastojala je formirati obrambeni pojas preuzimajući odgovornost za sve više pograničnih utvrda ili namještajući kraljevske čete u privatne utvrde. Iznimno se podižu nove, uglavnom manje utvrde, a manje fortifikacije oko kraljevskih utvrda utvrđuju se ili češce ruše. ${ }^{273}$ Provala na neprijateljski teritorij je dakako mnogo, ali vojne akcije kojima bi cilj bio osvajanje izgubljenog teritorija bile su vrlo rijetke i uglavnom neuspješne. To grčevito nastojanje da se održi relativni mir lijepo pokazuje nalog cara Maksimilijana zapovjedniku Hrvatske krajine Herbartu Auerspergu iz srpnja 1569. u kojem stoji da Auersperg mora revno braniti habsburški teritorij od svakog napada, ali istodobno poštivati sve odredbe postojećega mirovnog ugovora, odnosno ne dati neprijatelju nikakav izgovor za napad. Ako Osmanlije žele izvesti ili pak izvedu kakav manji upad na naš teritorij, Car je instruirao da „ti se nećeš naglo osvećivati i upadati u njegov teritorij, već (ćeš) naš teritorij s doličnim marom braniti i štititi te čekati našu odluku“. ${ }^{274} \mathrm{U}$ instrukciji za glavnog zapovjednika Hrvatske krajine 1578. navedeno je pak da on ima pravo uzvratiti na neprijateljski napad, ,ali oprezno i s puno

\footnotetext{
${ }^{270}$ PALFFY, The Origins, 23.

271 ŠTEFANEC, Država ili ne, 288. Razni izvještaji krajiških zapovjednika sastavljani su naravno i ranije. Primjerice, Ivan Lenković je u siječnju 1552. kralju poslao izvještaj o stanju na Hrvatskoj krajini koji je sastavio prethodne godine. Emilij LASZOWSKI, HSKHDS, knjiga I, dok. 360, 412-416.

${ }^{272}$ KRUHEK, Krajiške utvrde, 96.

${ }^{273}$ PALFFY, The Origins, 25-25.

${ }^{274}$ SI AS 2, DSK, kutija 209, fascikl 126, Beč, 11.7.1569., 1r-1v. Car Maksimilijan na Herbarta Auersperga. Međutim, kada je bilo potrebno, car Maksimilijan ipak je znao zauzeti i ofenzivniji i riskantniji pristup kao u slučaju osvajanja Szatmara koji su Erdeljci zauzeli 1564. usprkos primirju TRACY, Balkan wars, 217-218.
} 
planiranja i predostrožnosti.“ Krajiški zapovjednici su u svakom slučaju morali voditi brigu da svojim potezima ne ugrozi mir. ${ }^{275}$

Za razliku od staleža Unutrašnje Austrije, hrvatsko-slavonsko plemstvo nije oblikovalo ozbiljniju, promišljeniju i dugoročnu obrambenu strategiju. Domaće plemstvo odbijalo je provesti reforme nužne za preoblikovanje vojnog sustava poput izmjene poreznog sustava ili povećanja izdataka za obranu, a zato nisu bili u mogućnosti ustrojiti stalno tijelo koje bi upravljalo strateškim i praktičnim aspektima obrane. Na lokalnoj razini obrana je prepuštena inicijativi pojedinih plemića. ${ }^{276}$ Doduše, treba napomenuti da su hrvatskoslavonski staleži u nekoliko navrata smislenije i angažiranije (i ravnopravnije!) raspravljali o protuosmanskim defenzivnim mjerama. ${ }^{277}$ To se prvi put dogodilo 1538 . kada su poslanici slavonskih staleža prisustvovali savjetovanju u Grazu i odgovarali na upitnike o tome kako unaprijediti obranu, a zatim na hrvatskom saboru u Steničnjaku 1558. gdje se raspravljalo o organizaciji obrane na području između rijeka Une, Save, Kupe i Korane, dakle na području „,između Slavonske i Hrvatske krajine“ koje je bilo „najslabije posjednuto krajiškim plaćenim posadama pod austrijskim zapovjedništvom i zasad najslabije organizirano““. ${ }^{278}$ No, i ovdje se radilo o ne pretjerano inovativnim mjerama koje su uglavnom bile svedene na osiguranje radnika za utvrđivanje gradova te postavljanje stražara na najosjetljivijim mjestima. ${ }^{279}$ Međutim, sustavna, pomno promišljena i dugoročna strategija otpora nije formulirana.

Prema izvještaju članova kraljevskog povjerenstva koje je krajem 1563. obišlo Hrvatsku i Slavonsku krajinu, osnovni problem obrane Hrvatske krajine bila je ,prostorna razbijenost i izduženost, brojnost, rastepenosti i nedovoljna povezanost utvrda, od kojih su

\footnotetext{
275 ŠTEFANEC, Država ili ne, 275.

${ }^{276}$ IBID., 110.

${ }^{277}$ Treba napomenuti da su se 1520-ih Habsburgovci i predstavnici austrijskih staleža informirali i savjetovali s banovima, pa su tako 1522. Sigmund Weichselberg i Hans Helfenberg poslani banu da bi se s njime savjetovali kako zaustaviti Osmanlije i kakvo je obrambeno stanje u Hrvatskoj. Budući da je obrambeno stanje bilo loše, zaključeno je da Hrvatima hitro treba pomoći. THALLÓCZY, HODINKA, A horvát véghelyek oklevéltára, dok. LII, 67.

278 ŠTEFANEC, Država ili ne, 175; KLAIĆ, Povijest Hrvata, knjiga 5, 155-161. U lipnju 1524. u Ljubljani se raspravljalo o prijedlogu Nikole Zrinskog za napad na Kamengrad, a prisutni su bili i hrvatski predstavnici (Krabatten). U ovom ranijem periodu, kada su čak i domaći staleži razmatrali ofenzivne akcije, hrvatsko plemstvo ima svoju ulogu u promišljanju defenzivnih mjera, ako već ne strategija, iako je ovo, čini se, dominantno bio prijedlog Nikole Zrinskog. THALLÓCZY, HODINKA, A horvát véghelyek, dok. CCXXV, 343. ${ }^{279}$ Tada je zaključeno da će Krupu 15 dana utvrđivati 200 podložnika vlastelinstva Steničnjak, grad Tržac će 15 dana utvrđivati plemići Barišćine, Goričana, Peći i Završja, a kroz isti period grad Slunj plemići Klokočki, Smrčkovići i Vojnovići s 200 ljudi. Dogovorena je obnova utvrda uz rijeku Unu te podizanje prepreka na Glini, Tounjčici, Mrežnici i Orljaku, a definirano je da će 50 ljudi, koje su dobrim dijelom izdržavali Blagajski, Frankopani Slunjski, Frankopani Tržački te Keglevići, stražariti na potezu od Save do Vinodola. Također, staleži su oštro istupili protiv namjera Ivana Lenkovića da se poruše one utvrde od kojih nema koristi, odnosno čije zadržavanje može predstavljati sigurnosnu opasnost ako ih Osmanlije osvoje i iskoriste za daljnje napredovanje. ŠTEFANEC, Država ili ne, 174-175; ŠIŠIĆ, HSS, knjiga III, dok. 14, 21-26; 27-36; KRUHEK, Krajiške utvrde, 176-184.
} 
neke u opustjelom ambijentu, a druge duboko u pozadini““. ${ }^{280}$ I tada je strateški naglasak stavljen na formiranju guste linije utvrda zaposjednutih s plaćenom vojskom, a središnja vlast nastojala je preuzeti ili barem smjestiti plaćenu vojsku u što više privatnih utvrda na pograničnom prostoru. ${ }^{281}$

Paralelno s namještanjem plaćenih vojnika u dotad još privatne utvrde, osobito za zapovjedanja Ivana Lenkovića, krenuo je postupak destrukcije strateški nebitnih ili opterećujućih fortifikacija što je izrazito iritiralo i uznemiravalo hrvatsko-slavonske staleže ${ }^{282}$ No, logika iza tih poteza bila je sasvim jednostavna. Naime, nastojalo se grupirati vojnike u manjem broju utvrda jer se održavanjem mnogobrojnih utvrda rasipala vojna sila i ugrožavao cijeli defenzivni blok te se na taj način nastojalo spriječiti njihov pad u osmanske ruke. ${ }^{283}$ Mali broj vojnika po utvrdama nije predstavljao garanciju uspješne obrane pa bi se tako izgubili i utvrda i dragocjeno ljudstvo. Treba apostrofirati i problematiku opskrbe, naoružavanja i obnove mnogobrojnih utvrda što je često predstavljalo logističku i financijsku noćnu moru.

Iako se nastojalo smanjiti broj branjenih utvrda, osnovni strateški cilj bio je formiranje guste linije utvrda koje bi „zatvorile“ ugroženi prostor. Već je spomenuto povjerenstvo iz 1563. konstatiralo da na području Hrvatske krajine postoje dvije obrambene linije. U prvu obrambenu liniju spadali su tako Bihać i sve utvrde na Uni, Ostrožac, Brekovica, Krupa, Cazin, Stijena, Bužim, Izačić, Tržac, Drežnik, Jesenica, Otočac, Brinje, Dabar i Senj. Utvrde druge obrambene linije bile su Mutnica, Šturlić, Cetin, Slunj, Peći, Kladuša Gornja i Kladuša Donja, Krstinja, Klokoč, Furjan, Bojna, Bruvno, Podzvizd i još neke poput Zrina i Gvozdanskog te Modruša i Ogulina. ${ }^{284}$ Dakle, opet se radi o obrambenim linijama, ali ih treba promatrati primarno iz vojnostrateške perspektive, a ne kao modernu graničnu liniju. U ranonovojekovnom periodu na krajini se uvijek radi o prostoru, o zoni unutar koje su na određeni način pozicionirane i organizirane utvrde.

\footnotetext{
${ }^{280}$ KRUHEK, Krajiške utvrde, 200.

${ }^{281}$ PALFFY, The Origins, 25-25.

282 ŠTEFANEC, Država ili ne, 291.

${ }^{283}$ IBID., 302.

${ }^{284}$ KRUHEK, Krajiške utvrde, 225.
} 


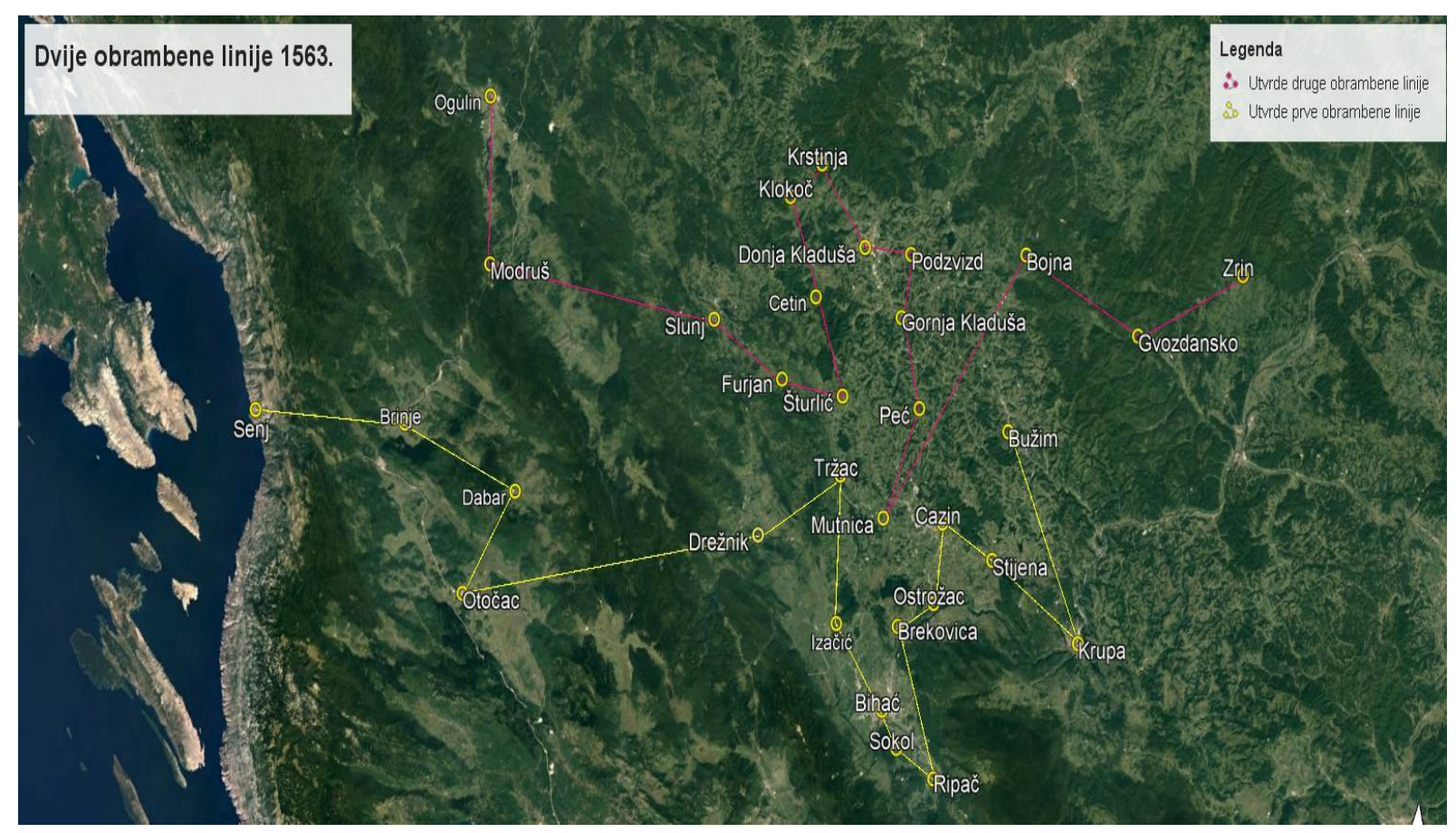

Slika 13. Dvije obrambene linije prema iskazu kraljevskog povjerenstva iz 1563.

Neprijateljski upadi mogli su se suzbijati jedino nadzorom i kontrolom „prostora“ pa se od samog početaka formiranja habsburškoga krajiškog sustava nastojalo angažirati stalne jedinice koje su patrolirale i nadzirale brdovito i šumsko područje na Hrvatskoj krajini i uz hrvatsko-kranjsku granicu. Kranjski su staleži 1553. elaborirali da je važno držati terensku vojsku u „brdima i šumama“ jer se osmanske pješačke i konjaničke čete od 50, 60, 80, 100, 300, 400, 500 pa sve do 1000-2000 i još više ljudi mogu okupiti u dva, tri ili četiri dana, pa je zapovjedniku teško raspolagati pravovremenim obavijestima. Osmanlije pak potajice provaljuju u Hrvatsku, Kranjsku, na Kras, prema Metlici i drugim mjestima, napadaju neopskrbljene utvrde te noću na počinku i danju pri poljodjelskim poslovima odvode ljude u zarobljeništvo. Zato je trebalo zaposjesti i nadzirati šumske predjele jer ako se to propusti učiniti jedne godine ili u ljetnom periodu, nitko neće moći obrađivati polja. ${ }^{285}$

Da bi se doskočilo tom problemu, godinu dana ranije podignuto je 250 konjanika, od kojih je 150 bilo pod zapovjedništvom bana i 100 pod zapovjedništvom Ivana Lenkovića, te 750 pješaka i strijelaca. ${ }^{286}$ Sada se tražilo osiguravanje šumskih areala s najmanje 400

\footnotetext{
${ }^{285}$ SI AS 2, DSK, kutija 229, fascikl 136, 1553., 3r. Takvi napadi započeli su već 1520-ih i 1530-ih, a kranjski poslanik na unutrašnjeaustrijskome međuzemaljskom saboru iz ožujka 1541., Erasmo Scheyer tvrdio je da su Osmanlije promijenili taktiku te prodiru kroz pusto i brdovito područje gdje ih nije moguće detektirati i upozoriti ljude. Napadali su stalno, a čak i kada bi došla pomoć, primirili bi se i opet napadli kada se te postrojbe povuku. Stanko JUG, Turški napadi na Kranjsko in Primorsko od prve tretjine 16. stoletja do bitke pri Sisku (1593), Zgodovinski časopis, IX, br. 1-4, 1955., 32-33.

${ }^{286}$ SI AS 2, DSK, kutija 229, fascikl 136, 1553., 3r.
} 
konjanika i 800 pješaka. Pješake se moglo u zimskim mjesecima na nekoliko mjeseci otpustiti, ali konjanike se moralo držati i zimi jer čim se snijeg počne otapati i nastupi prikladno vrijeme, neprijatelj provaljuje i čini štete kao što to radi i ljeti. ${ }^{287} \mathrm{Na}$ okupljanju staleža Unutrašnje Austrije u Grazu 1553., na kojem je sudjelovao i kralj Ferdinand, dogovoreno je da će se držati mnogo više vojske na krajini, a do 1556. financijsko se izdvajanje Štajerske, Kranjske i Koruške za protuosmansku obranu više nego udvostručilo, odnosno povećalo se sa 134000 na 280000 rajnskih guldena godišnje. ${ }^{288}$

Ivan Lenković je sredinom studenog 1557., kada se zbog dolaska zime razgovaralo o otpuštanju 200 husara (geringen pfärt) te jednog dijela pješaka i martologa u šumama (200 pješaka), savjetovao da se to ne čini jer ujesen i zimi nije ništa manja opasnost od neprijateljskog upada nego u ljetnom periodu, kao što je pokazalo iskustvo zadnjih nekoliko godina na području Hrvatske i Slavonije. Lenković je konstatirao da je vojsku na krajini potrebno držati zimi, po snijegu i po kiši bez razlike. ${ }^{289}$ Međutim, zbog velikih troškova Lenković se ipak priklonio stavu predstavnika kranjskih staleža te je zapovjedniku Hrvatske krajine Georgu Saueru naredio da navedene postrojbe otpusti, ali da one koji ostanu u službi stacionira na najvažnije stražarske lokacije od Bihaća do Jadranskog mora. ${ }^{290}$

U sljedećim desetljećima broj vojnika na hrvatsko-slavonskom prostoru, na terenu i u utvrdama, narastao je na oko 5000 plaćenih i do 10000 neplaćenih vojnika. Trend povećanja broja vojnika, primarno pješaka, vidljiv je i u slučaju Bihaćke kapetanije, o čemu će biti riječi u zasebnom poglavlju. Generalna strategija zatvaranja prostora manifestirala se i podizanjem

\footnotetext{
${ }^{287}$ IBID.

${ }^{288}$ Ivan Lenković predložio je 1553. za Hrvatsku krajinu proračun od 67000 rajnskih guldena što je pet puta više od svote koju je Kranjska utrošila na Hrvatsku krajinu 1548. I zaista, prema sumarnom iznosu troškova iz 1555. Kranjska je u godinu dana na Hrvatsku krajinu utrošila 65000 rajnskih guldena. Sveukupno su Kranjska i Štajerska tada uložile 169000 rajnskih guldena, u odnosu na 37000 rajnskih guldena uloženih 1546. TRACY, Balkan Wars, 173-174.

${ }^{289}$ SI AS 2, DSK, kutija 201, fascikl 124, Varaždin, 16.11.1557., 1r, rbr. 448. Ivan Lenković na predstavnike kranjskih staleža. Nije ni Osmanlijama uvijek uspijevalo savladati zimske uvjete. U veljači 1561. jedna se „osobito velika“ osmanska vojska, sačinjena od konjanika i pješaka, pokušala probiti prema Krasu kroz skoro dva metra visok snijeg. Unatoč velikom trudu odustali su negdje između Otočca i Brinja i vratili se nazad. Iza sebe su ostavili čak oko 2200 lopata. HDA, Militaria, kutija 7, Zagreb, 20.2.1561., 1r. Ivan Lenković na predstavnike štajerskih staleža.

${ }^{290}$ SI AS 2, kutija 201, fascikl 124, Varaždin, 16.11.1557., 1r, rbr. 449. Ivan Lenković na Georga Sauera. Sauer je isprva rasporedio konjanike koji su ostali u službi u Slunj, Tržac, Otočac i Tounj, a petoricu vojvoda s podređenim vojnicima oko Slunja, Jesenica, Brinja, Modruša i Ogulina. Međutim, budući da je od senjskog kapetana primio pismo o osmanskom okupljanju, a s raznih mjesta u Hrvatskoj čula se pucnjava mužara za uzbunjivanje i vidjele se upaljene gromače, ubrzo ih je pozvao je k sebi. SI AS 2, kutija 201, fascikl 124 Črnomelj, 14.12.1557., 1r, rbr. 529. Georg Sauer na Ivana Lenkovića.
} 
zasjeka u šumama i formiranjem raznih prepreka na putovima. ${ }^{291}$ Krajinu, dakle prostor, a ne liniju, nastojalo se zatvoriti te formirati jedan veliki i povezani obrambeni blok.

\subsection{Strateški značaj Bihaćke kapetanije}

Bihać i Bihaćka kapetanija bili su od izvanredne strateške važnosti u obrani od Osmanlija. Takav istaknuti položaj Bihaća proizlazio je prije svega iz geografske lokacije - smještaju na unskom otoku zaštićenom vodama te okolnim gorjem, odnosno planinama Plješevicom i Grmeč koje omeđuju Bihaćku dolinu. Kada se tome pridoda gradski tvrđavinski sustav, dobiva se prirodno-fortifikacijski sklop koji je predstavljao čvrstu defenzivnu cjelinu.

Obrambenom potencijalu Bihaća svakako je pridonijela i činjenica da se, za razliku od ostalih srednjovjekovnih gradova i utvrda, mnogo lakše uklopio u moderne vojne tokove. Naime, Kruhek je kao tri najvažnija nedostatka srednjovjekovnih utvrda u kontekstu sukoba s Osmanlijama u promatranom periodu naveo njihov položaj, koji je primarno odgovarao zaštiti i administraciji vlastelinstva, a ne zaštiti (sve pustijeg) teritorija od permanentnih osmanskih napada, zatim deficit prostora u samim utvrdama potrebnim za smještaj većih vojnih snaga, živeži i opreme te zastarjelu srednjovjekovnu arhitekturu (kule, visoki zidovi) koja je bila neadekvatna za obranu od vatrenog naoružanja, primarno topova. ${ }^{292}$

Bihać očito nije baštinio te nedostatke. Grad je bio smješten u nizini, okružen vodama rijeke Une i na tranzitno, dakle i strateški izrazito povoljnom mjestu. Iz Bihaća se moglo promptno djelovati nizvodno ili uzvodno rijekom Unom te pokrivati prostor u zaleđu, a kanjon rijeke Une te planine Grmeč i Plješivica činile su sa samim gradom snažan defenzivni sklop. Nadalje, Bihać je za onodobne prilike bio velik grad s dovoljnim kapacitetima za smještaj veće vojne posade. Štoviše, oko samoga grada bilo je dovoljno prostora za veća vojna okupljanja, kao, primjerice, na utoku potoka Klokota u Unu u neposrednoj blizini grada na kojem je podignut logor za kraljevske čete koje su 1345. krenule u akciju suzbijanja samovolje hrvatskih velikaša. Vojske kralja Ludovika, hrvatsko-slavonskog bana Nikole Seča i bosanskog bana Stjepana II. Kotromanića susrele su se upravo pred Bihaćem. ${ }^{293}$ Opetovana iseljavanja iz grada zasigurno su otvarala dodatan prostor za smještaj posadnih vojnika ili

\footnotetext{
${ }^{291}$ Kranjski staleži predložili su u srpnju 1579. da se s raznih kranjskih posjeda (Mehovo, Metlika, Črnomelj, Kostel, Kočevje, Rijeka itd.) podigne od svake sesije (hueben) jedan snažan muškarac opskrbljen dobrom sjekirom i živeži za nekoliko dana, da bi podizali zasjeke na krajištu. HDA, Croatica, kutija 1, svežanj 2, Karlovac, 29.7.1579.

${ }^{292}$ KRUHEK, Krajiške utvrde, 14-15.

${ }^{293}$ ANČIĆ, Bihaćki kraj, 198.
} 
novih doseljenika i u izvorima se nikada ne navodi problem smještaja. Usto, Bihać je u cijelome promatranom periodu konstantno obnavljan, utvrđivan i nadograđivan, vjerojatno mnogo više od drugih krajiških utvrda i gradova, a dograđivana su i najsuvremenija arhitektonska rješenja za obranu od topova, poput bastiona. O svemu navedenom bit će riječ u sljedećim poglavljima.

Stoga ne iznenađuje da su unutrašnjeaustrijski, primarno kranjski, staleži već u prvim desetljećima 16. stoljeća naglašavali da su Bihać i druge utvrde na rijeci Uni poput Krupe ili Ripča „ključevi Hrvatske i Kranjske“. Tako su kranjski staleži već 1520-ih tražili da se „preostali majhni del hrvaške kraljevine med Uno in Kolpo ne pusti gol in pust.“294 Slične formulacije ponavljaju se sve do pada Bihaća pod osmansku vlast. I spomenuto krajiško povjerenstvo iz 1563. apostrofiralo da se Bihać nikako ne smije izgubiti jer o njemu ovisi obrana Hrvatske i unutrašnjeaustrijskih zemalja. ${ }^{295}$ Kranjski staleži pišu pak nadvojvodi Karlu u kolovozu 1574. da „cijela Hrvatska krajina ovisi o Bihaću i Ripču“296, a godinu dana ranije, prilikom rasprava o izboru novoga bihaćkog kapetana, nadvojvoda konstatira da je stvar toliko važna da je ne želi sam na sebe preuzeti jer „sudbina cijele domovine toliko ovisi o dobro provedenoj zamjeni zapovjednika““ 297

I u bitno izmijenjenim okolnostima, nakon velikih gubitaka na unskom prostoru 1570ih i podizanja Karlovca 1579., kada u strateško-operativnom pogledu Bihać postaje prije opterećenje nego prednost, vojne strukture ulažu maksimalan napor da sačuvaju grad u kršćanskim rukama. Krajem travnja 1578., kada je Bihaću zaprijetila opasnost „kao nikada do sada“, nadvojvoda Karlo traži od kranjskoga zemaljskoga kapetana Waikharda Auersperga da učini sve što je u njegovoj moći da se pomogne Bihaću jer je to presudno za „dobrobit i opstanak domovine“ - dakle Kranjske. ${ }^{298}$ Kada su se krajem ožujka 1592. pojavile vijesti da je Hasan-paša Predojević čvrsto odlučio osvojiti Bihać, vojne vlasti u Grazu tražile su od kranjskih staleža da doznače određenu količinu novaca za obranu i pokrenu opći ustanak jer je Bihać „ključ“ Kranjske i Koruške. ${ }^{299}$ Iako su u krajiškom diskursu takve dramatične konstatacije sasvim uobičajene pa je potencijalni pad svake iole važnije utvrde prezentiran

\footnotetext{
${ }^{294}$ SIMONITI, Vojaška organizacija, 229.

${ }^{295}$ KRUHEK, Krajiške utvrde, 209.

${ }^{296}$ SI AS 2, DSK, kutija 286, fascikl 164, Ljubljana, 1.8.1574., 1v, rbr. 252-253. Kranjski staleži na nadvojvodu Karla.

${ }^{297}$ SI AS 2, DSK, kutija 244, fascikl 143, Beč, 27.2.1573., 1r, rbr. 290.

${ }^{298}$ SI AS 2, DSK, kutija 286, fascikl 164, Graz, 28.4.1578., 1v, rbr. 407. Nadvojvoda Karlo na predstavnike kranjskih staleža.

299 „vnrurig Bascha in Bossen...ja auch berait in anzug seye“. SI AS 2, DSK, kutija 203, fascikl 124b, Graz, 25.3.1592., 1r-3r. Nadvojvoda Ernest i Dvorsko ratno vijeće u Grazu na kranjske Verordneten.
} 
kao eventualni početak kraja kršćanskog zaleđa pa i šire, kada je riječ o utvrdama na unskoj obrambenoj liniji, a osobito Bihaću, zaista se nije radilo o pretjerivanju. ${ }^{300}$

Takva strateška važnost Bihaća simultano je bila prednost i opterećenje. Kršćanska strana silno je strahovala od gubitka Bihaća jer su sasvim logično rezonirali da će u tom slučaju Osmanlije u gradu formirati administrativno sjedište te stacionirati velike vojne snage. Kranjski staleži u jednoj tužbi, koju su nakon velikih osmanskih napada 1561. adresirali kralju Ferdinandu, navode da Osmanlije potencijalno mogu u Bihaću namjestiti 300 konjanika i još toliko pješaka, pa ih od tamo neće moći otjerati ni svih ,ppet austrijskih zemalja“ zajedno. Još su se žalili da se u Kranjskoj može naći nemali broj ljudi koji samo čekaju pad grada pa da pobjegnu iz zemlje, a da isto priželjkuju i Mlečani koji bi tada osvojili Senj i Rijeku te im zatvorili izlaz na more! $!^{301}$

U listopadu te godine i koruški staleži navode da je Bihać „srce i predziđe“ Kranjske te da između Bihaća i Ljubljane nema veće utvrde koja bi se mogla oduprijeti Osmanlijama. ${ }^{302}$ Stavovi kranjskih i koruških staleža pokazuju dvije bitne karakteristike Bihaća, odnosno unskog prostora, a to su prvorazrednu stratešku ulogu i vojnu važnost ne samo na lokalnoj razini već i u regionalnom kontekstu te potencijalno negativni efekt koji bi gubitak takvog uporišta mogao izazvati na širem prostoru. To su jasni pokazatelji internacionalizacije hrvatskog prostora u promatranom periodu.

Srednjovjekovna Hrvatska nije poput Slavonije, Srijema i Ugarske bila zaštićena obrambenim potencijalom velikih rijeka poput Save i Dunava. I zaista „gorovitost, šumovitost i obdarenost rječicama hrvatskog prostora zapravo pogodovala napadački orijentiranima neprijateljima“ koji su u takvom ambijentu lako pronalazili zaklon. ${ }^{303}$ No rijeka Una definitivno je predstavljala ozbiljnu defenzivnu prepreku kojoj su, kao što je rečeno, „sekundirale“ dvije dominantne prirodne barijere - planine Plješevica i Grmeč.

\footnotetext{
${ }^{300}$ Gotovo dvadeset godina nakon osmanskog osvajanja Bihaća kranjski su staleži nadvojvodi Ferdinandu izložili mjere zaštite Hrvatske i Primorske krajine, a u njima su naveli da su prije nego je vor jahren osvojen Bihać, najisturenija i najstarija granična utvrda (gränizhauss) u Hrvatskoj zajedno s tokom rijeke Une i utvrdama Ripač, Sokol, Izačić, Ostrožac, Cazin, Stijena, Bužim i Zrin, okolnosti u Hrvatskoj i susjednoj Kranjskoj još bile sigurnije i mirnije te se nije toliko trebalo plašiti neprijateljskog upada. Doduše, naglasili su da je bilo teško i pogibeljno do tamo dopremiti živež i osigurati financijska sredstva za obranu. LOPAŠIĆ, SHK, knjiga II, dok. XXXVIII, 48-49.

${ }^{301}$ JUG, Turški napadi, 4.

302 IBID., 43.

303 JURKOVIĆ, Turska opasnost, 66.
} 
Plješevica je dominirala zapadnim/jugozapadnim horizontom i svojom veličinom štitila grad od napada iz smjera Krbave i Like. Budući da ju nije bilo lako savladati, planina je opstruirala i kretanje habsburških snaga - osobito u nepovoljnim vremenskim uvjetima. Uz Plješevicu, tu su bila i teško prohodna Plitvička jezera koja su se nazivala Vražji vrtal, odnosno na njemačkom Teufelsgarten. Kada je Herbart Auersperg u travnju 1566. naumio iz Zavalja preko Plješevice provaliti pod Udbinu, domaći ga je svijet od toga odgovorio jer će ako krene tim smjerom, zbog velikog snijega i blata nastradati konji. Stoga se Auersperg vratio do Ripča i od tamo provalio u kotar Lušci, spalio do 300 kuća i s velikim se plijenom stigao nazad. ${ }^{304} \mathrm{~S}$ istočne strane grad je štitila planina Grmeč, također impresivna prirodna barijera.

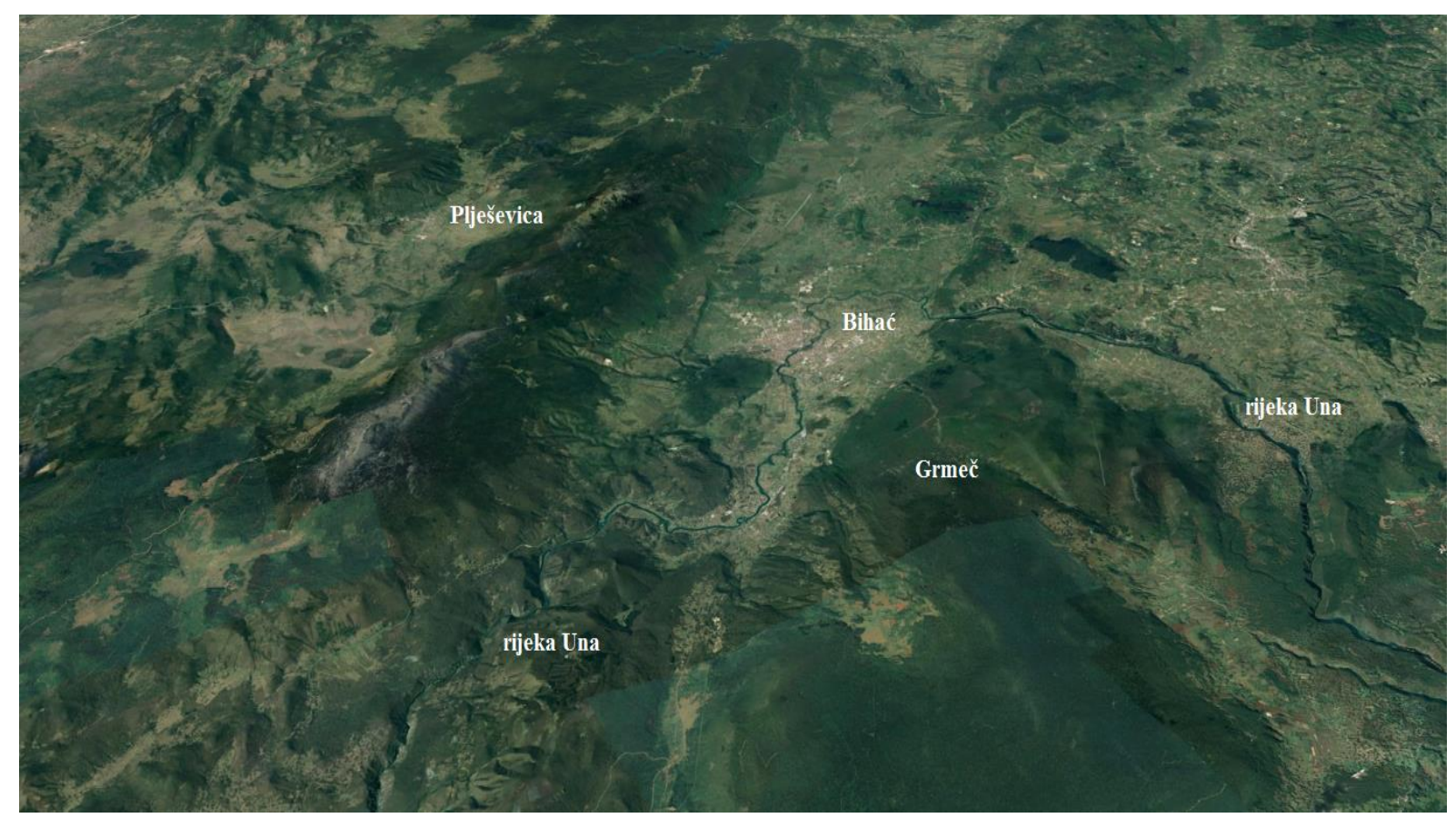

Slika 14. Položaj Bihaća u odnosu na planine Plješevicu i Grmeč te rijeku Unu.

Od vrlo važnih riječnih prijelaza kod Martin Broda i Ostrovice pa do Račića i Lohova pred ulaz u Bihaćku dolinu proteže se dubok kanjon koji čini teško prohodnu prirodnu prepreku od presudne važnosti za obranu cijeloga referentnog prostora. S južne strane, nizvodno Unom moglo se ploviti tek od Ripča do Bihaća. ${ }^{305}$ Nakon što „oteče“ iz Bihaćke doline, rijeka Una ponovo prolazi kroz dubok kanjon čiji su prijelazi osigurani čvrstim

\footnotetext{
${ }^{304}$ V. KLAIĆ, Povijest Hrvata, knjiga 5, 327.

${ }^{305}$ SI AS 2, DSK, kutija 805, fascikl 540, Bihać, 11.11.1591., 1r. Kapetan Christoph Obritschan na zapovjednika Hrvatske krajine.
} 
uporištima - Brekovicom, Ostrošcem i Krupom. Od današnje Bosanske Krupe dalje Una se već pretvara u rijeku nizinskoga karaktera. Rijekom se teško plovilo i zbog mnogobrojnih slapova od sedre koji rijeku „lome“ na otprilike svaka tri kilometara. ${ }^{306}$

Obje strane nastojale su ovladati tokom rijeke Une kako bi utvrdili defenzivnu liniju ili njezinim osvajanjem stekli povoljnije pozicije za daljnju ekspanziju. ${ }^{307}$ Osmansko napredovanje unskim prostorom trajalo je desetljećima, a strateška važnost Bihaća i cijele „unske fronte“ ozbiljno je narušena tek s velikim osmanskim vojnim uspijesima 1570-ih. Osmanlije su zapravo već krajem 15. stoljeća, odnosno u prvim desetljećima 16. stoljeća u potpunosti zavladali „gornjim“ tokom rijeke Une južno od Ripča - prije svega već spomenutim prijelazom u Martin Brodu. Ipak, zbog konfiguracije terena, obrambenog potencijala bihaćkog prostora te vjerojatno i zbog osmanskih vojnostrateških interesa, osmanske provale više su bile usmjerene prema Modrušu, Otočcu, Gorskom Kotaru i Krasu te zaobilazno prema Kranjskoj, nego prema samom Bihaću, odnosno centralnome unskom prostoru. Kao što ću prikazati u ovom poglavlju, osmansko napredovanje prema Bihaću odvijalo se uzvodno rijekom Unom iz smjera istok-sjeveroistok dok je „ličko-krbavski front“ ipak desetljećima zadržao stabilne gabarite. Najjednostavnije rečeno, bitka za rijeku Unu svodila se na osvajanje i kontrolu nad riječnim prijelazima, odnosno fortifikacijama koje su te komunikacije nadzirale. ${ }^{308}$

Štoviše, smatram da je, bez obzira na sekundarnost hrvatsko-bosanskoga krajišta u generalnom obračunavanju između Habsburške Monarhije i Osmanskog Carstva, unski front ipak bio važan za obje strane. Pritom je bio posebice važan za habsburšku stranu jer je branio i osmanski prodor u habsburške nasljedne zemlje te potencijalni alternativni prilaz samom Beču iako taj plan zapravo i nije imao nekakvu realnu perspektivu izvan konteksta skretanja pažnje s glavnoga osmanskog napadnog pravca kroz Ugarsku. ${ }^{309}$ Unatoč tome, vojnostrateška važnost riječnih prijelaza bila je velika. ${ }^{310} \mathrm{U}$ memorandumu koji je u lipnju 1570.

\footnotetext{
${ }^{306}$ Branka RAUNIG, Neki podaci o sojeničkim naseljima u Bihaćkom polju, Opuscula archeologica, 27, 2003., 269.

${ }^{307}$ Uostalom, to pokazuju i osmanska nastojanja da pomaknu pogranični pojas na tu rijeku, a kasnije i rijeku Kupu da bi na tim prirodnim preprekama mogli uspostaviti svoj obrambeni pojas. JURIN-STARČEVIĆ, Osmanski krajiški, 47.

${ }^{308}$ Ivan Kobasić tražio je od Ivana Katzianera 1531. pomoć za očuvanje Brekovice i važnog prijelaza preko rijeke Une. LASZOWSKI, HSKHDS, knjiga II, dok. 50, 38.

${ }^{309}$ Tracy navodi da su „Even as shields for the Austrian duchies, Slavonia and Croatia were not as valuable as Hungary or Transylvania." TRACY, Balkan Wars, 118.

${ }^{310}$ To potvrđuje i činjenica da su Osmanlije upravo radi osiguravanja nesmetanog prijelaza preko rijeke Une kod Ostrovice, na ruti prastare komunikacije, podigli jedno od rijetkih ex nihilo stvorenih naselja koje je kasnije dobilo ime Kulen Vakuf. Važnost novog naselja pokazuje i podizanje sultanske „državne džamije“ u tom mjestu. KOZLIČIĆ, Unsko-sansko područje, 179-180. Jedan od ključnih preduvjeta velikoga osmanskog napredovanja unskim prostorom 1570-ih bio je pontonski most kojeg je Ferhad-beg podigao kod Novog na Uni, a preko kojeg
} 
sastavio Franz Poppendorf jasno se navodi važnost Bihaća u blokiranju osmanskih prijelaza preko rijeke Une. Naime, autor slikovito konstatira da, sve dok je Bihać u habsburškim rukama, samo nekoliko martologa odjednom može prelaziti rijeku Unu i to na „kožnim jastucima“"(leather pillows). ${ }^{311}$

Izvori sadrže mnogobrojne navode o opetovanima osmanskim nastojanjima da zauzmu prijelaze - gazove ili brodove te ade u okolici Bihaća. Tako je, primjerice, u glagoljskom pismu datiranim 25. travnja 1566. habsburški špijun pod pseudonimom Sveti Zaharija javio senjskom vicekapetanu de Sachiju da su dva kalauza obećala Mehmed-begu „učiniti brod k Bihću, kadi ni prvo nigdar bilo, i dovesti pred grad, čine jedne konope, čudnu stvar, debele ka lantina, ke će priko vode načinjati, a verh njih lese, po kih kane Bihać uzeti“. Ti konopi pleli su se u Livnu. Međutim, špijun je bio sumnjičav prema mogućnostima osmanske vojske te je smatrao da se bega ne treba bojati zato što „ljudi, ke je opravil u vučine, nisu vridni jednoga krajcara, a veli, da će vsu hrvacku zemlju š nji(mi) projti““ ${ }^{312}$ Osmanlije su dakle na poprilično kretivan način nastojali savladati rijeku Unu tako što su namjeravali preko rijeke razapeti konope debele poput lantina ${ }^{313}$, na njih staviti daske te na taj način prići gradu $\mathrm{i}$ pokušati ga zauzeti. U izvještaju koji je stigao dva dana kasnije iz istog izvora već se navodi da Osmanlije na mjestu „Kadi će se broditi, sohe u zemlju zabijaju, k čemu se vežu oni konopi, na ke kane lise stavljati tamo pri Bihću“. Uz to, u Kninu se tada i pripremao (načinja/zuegericht) veliki top nazvan Deli Margeta. ${ }^{314}$ Dakle, već i činjenica da su Osmanlije planirali primijeniti takve neuobičajene metode za osvajanje Bihaća govori o izazovu koji je stajao pred njima.

Osobitu pažnju Osmanlije su uložili u pokušaje da ovladaju bihačkom Otokom, riječnom adom koja se nalazi ispred samoga grada (Wichitscher Wöhrdt oder Insl), a na kojoj su, barem u kasnijem periodu, naizmjenično stražarili građani (Burgerschafft) te hrvatski i njemački vojnici iz gradske posade. ${ }^{315} \mathrm{U}$ jednom izvještaju o stanju krajišta i osmanskog

su transferirane vojne snage i teško naoružanje u bihaćku pozadinu. Elma KORIĆ, Kapetani rijeke Save u 16. stoljeću, u: Rijeka Sava u povijesti, Zbornik radova znanstvenog skupa održanog u Slavonskom Brodu 18-19. listopada 2013, ur. Branko Ostajmer, Slavonski Brod, 2013., 248.

311 TRACY, Balkan wars, 225, fusota 285.

312 Priložen je i njemački prijevod u kojem stoji da su se kalauzi, vodiči ponudili „,durchs Wasser bey Wihitsch ein Furtt zu finden vnd zu machen, dadurch man gar zu der Stadt khumen mag. Man macht gar grosse Sall oder Strik, dikh vnd gross wie die antenna, das war wie die Stangen darauf Segel an Schiffungen hangen, dieselben Saller welen sy vber das Wasser spannen vnd darauf Holz richten, dardurch sy zu der Stadt khumen, vnd die Stadt also gewinnen mechten.“ BOJNIČIĆ, Izvješća, dok. XXIX, 81-82.

313 „Lantina - duga drvena motka, uvijek duža od broda, na koju se vezuje latinsko jedro; horizontalno drvo za koje je privezano jedro križa jarbol, maca, bum; motka za razapinjanje jedra." Silvio BRAICA, Kratki pojmovnik o moru, ribarstvu i pomorstvu, Ethnologica Dalmatica, vol. 22, br. 1, 2015., 371.

${ }^{314}$ BOJNIČIĆ, Izvješća, dok. XXX, 83.

${ }^{315}$ SI AS 2, DSK, kutija 230, fascikl 136, 1586., 12r. 
serhata iz 1551. jasno je izrečeno da se grad neće moći održati ako Osmanlije zauzmu Otoku. ${ }^{316}$ Početkom kolovoza 1561. čak 5000 osmanskih pješaka i nekoliko stotina konjanika napalo je ade između Bihaća i Ripča, čini se ne osobito uspješno, a šest dana kasnije 600 konjanika napalo je i bihaćku Otoku. Da bi prešli rijeku, polovina osmanskih konjanika sjahala je s konja i pješke napala Otoku, ali bez većeg uspjeha - zarobljeno je tek petero osoba. ${ }^{317}$ I koruški staleži u lipnju 1574. navode da Osmanlije na sve načine nastoje pronaći nekakav prijelaz kod Bihaća kako bi provalili na „,bihaćki otok“ (Wichitscher Wordt) ${ }^{318}$ preko kojeg su u grad dopremana pojačanja i opskrba pa je i njegova obrana predstavljala imperativ. ${ }^{319}$ Za vrijeme suših razdoblja i/ili u ljetnim mjesecima vodostaj rijeke znao je jako pasti, a prilaz Otoci gotovo presušiti pa je tada postojala opasnost da ju Osmanlije napadnu i spale (na Otoci su u predosmanskom i u osmanskom periodu bile i kuće). ${ }^{320}$ Kapetan Georg Zoblsperg tvrdio je, primjerice, početkom rujna 1558. da se nitko ne sjeća da je vodostaj rijeke Une bio toliko nizak. ${ }^{321}$

Kranjski ratni savjetnik Balthasar Katzianer iscrpno je opisao napad s kraja rujna 1565. na bihaćku Otoku i malu adu na kojoj se nalazilo selo Golubić, a koji se na kraju pokazao katastrofalan za Osmanlije (poginula je većina osmanskih martologa). ${ }^{322} \mathrm{U}$ napadu koji se odigrao 19. rujna navedene godine, a koji je izgleda bio dio osmanskog pustošenja na širem prostoru između rijeka Une i Korane, sudjelovalo je oko 300-500 martologa i 700 konjanika. Prema navodima grofa Frankopana Tržačkog, koji je u Črnomelju osobno osobno opisao tijek akcije, najmanje 4000 osmanskih konjanika i 1000 pješaka pod vodstvom Mehmed-bega Sokolovića i Husain-bega od Gradiške (Hussain weg von Gradisskhen) pljačkalo je i to čini se ne osobito uspješno oko Klokoča, Kladuša, Smrčkovića, Stojmerića te Tržca. Zatim je navedenog datuma, oko 1000 Osmanlija napalo bihaćku Otoku, ali ih je većina poginula. Ubrzo je u Črnomelj stigao i bihaćki vojnik Luka Motschkhruch koji je pak

\footnotetext{
316 „Khombt der Feindt in den Word, So mag sich das Stattl nit erhallteni“. HDA, Militaria, kutija 4, 1551., bez oznaka, izvještaj pod naslovom „Die Gränizen von Zeng, da ist von Mor, bis gen Sissegkh and den wasserflu $\beta$ Saw. 24 gueter meil wegs lanng".

${ }^{317}$ HDA, Militaria, kutija 7, Novigrad na Dobri, 23.8.1561., 1r. Ivan Lenković na predstavnike štajerskih staleža. 318 „, die Turckhen allenthalben weeg suechen, wie sie durchs wasser bei Wihitsch einen furt finnden, vnd durch die Auen in Wihitscher whert prechen möchten“. SI AS 2, DSK, kutija 286, fascikl 164, Klagenfurt, 3.6.1574., $1 \mathrm{r}$, rbr. 260. Koruški staleži na predstavnike kranjskih staleža.

${ }^{319}$ SI AS 2, DSK, kutija 286, fascikl 164, 2.7.1573., 1v-2r, rbr. 108-109.

${ }^{320}$ Zoblsperg ga je s konjanicima i pješacima morao nadzirati krajem kolovoza 1558. „Nachdem der Wërdt Ser druckhen vnd das Wasser so gar khlein sy wurde mir den werdt uberfallen vnd abprenen“. SI AS 2, DSK, kutija 201, fascikl 124, Bihać, 31.8.1558., 1r, rbr. 708. Georg Zoblsperg na kranjskog zemaljskog kapetana i kranjske Verordneten.

321 SI AS 2, DSK, kutija 201, fascikl 124, Bihać, 5.9.1558., 1r, rbr. 756. Georg Zoblsperg na Balthasara Katzianera, kranjskog ratnog savjetnika na Slavonskoj i Hrvatskoj krajini.

${ }^{322}$ SI AS 2, DSK, kutija 286, fascikl 164, pored Kremena, 21.9.1565., 1v-2r, rbr. 16-17. Herbart Auersperg na predstavnike kranjskih staleža.
} 
svjedočio da je navedenog dana kasno predvečer, kada su se spremali zatvoriti gradska vrata (wie man schon die Tor zuesperren wollten), u grad pristigao jedan Vlah i kapetanu dojavio da 300 osmanskih martologa i 700 konjanika iz Ostrovice i Belaja sutradan namjerava na dvama mjestima napasti bihaćku Otoku. Osmanlije iz Belaja raspolagali su i s nekoliko kožnih čamaca (Lidrene Schiff), koji su trebali pješacima poslužiti da kod Golubića prebrode rijeku i napadnu spomenuto selo, dok su konjanici trebali prijeći rijeku (tada niskog vodostaja) na nekom drugom neimenovanom mjestu i napasti samu Otoku. Bihaćki kapetan i kapetan koruških strijelaca koji su se tada nalazili u gradu, sa svojim podređenim strijelcima tu su noć postavili zasjedu kod Golubića. I sami su raspolagali čamcima i drugom opremom. Osmanlije su zaista na spomenuto mjesto stigli u ranu zoru te započeli čamcima prelaziti na „malu adu“ na kojoj se nalazilo selo Golubić. Habsburške snage ostale su u tišini čekati dok svi nisu prešli rijeku i tada su napali. Većina osmanskih martologa bila je upucana, izbodena, utopljena i sasječena (erschossen, erstochen, ertrenkht vnd nidergehauen), a dosta ih je i zarobljeno. Bišćani su zarobili 60-70, a posade Ripča i Sokola nekolicinu Osmanlija. ${ }^{323}$ Spomenuti bihaćki vojnik čak je tvrdio da je martologa bilo i više od dojavljenog, oko 500, a da je konjanika bilo oko 700. No, osmanski konjanici na kraju nisu ni prešli rijeku, već su se, čuvši i vidjevši što se događa, povukli na neku uzvisinu i od tamo promatrali kreševo. Njih su krenuli goniti bihaćki konjanici kojih se navodno skupilo jedva desetak, zatim njemački vojnici i pripadnici bihaćke posade te nekolicina onih koji su sudjelovali u sukobu, ali su im tek uspjeli oduzeti ,jednu lijepu crvenu zastavu na koplju koja je pripadala konjanicima iz Belaja““. ${ }^{324}$ U post scriptumu Katzianerovog izvještaja napisano je da je habsburška strana prerano podigla galamu, zbog čega se mnogo Osmanlija zapravo i spasilo. Navedeno je da su s osmanske strane poginuli vojvoda iz Srba te Serkho vojvoda. ${ }^{325}$ Ovaj izvještaj o teškome osmanskom porazu lijepo demonstrira važnost pravovremenih informacija u krajiškom kontekstu ratovanja te važnost koju su obje strane pridavale ovladavanju riječnim otocima kod Bihaća.

\footnotetext{
${ }^{323}$ SI AS 2, DSK, kutija 414, fascikl 284, Črnomelj, 28.9.1565., 1r-1v, rbr. 1369-1370. Balthasar Katzianer na Ivana Lenkovića.

${ }^{324}$ „,ain schon Rotten Faan auf ainer Copj, So Sy zu Roß gefuert, der Welej gehert genomen“. SI AS 2, DSK, kutija 414, fascikl 284, Črnomelj, 28.9.1565., 2r, rbr. 1375. Balthasar Katzianer na Ivana Lenkovića.

325 SI AS 2, DSK, kutija 414, fascikl 284, Črnomelj, 28.9.1565., 2v, rbr. 1372. Balthasar Katzianer na Ivana Lenkovića.
} 


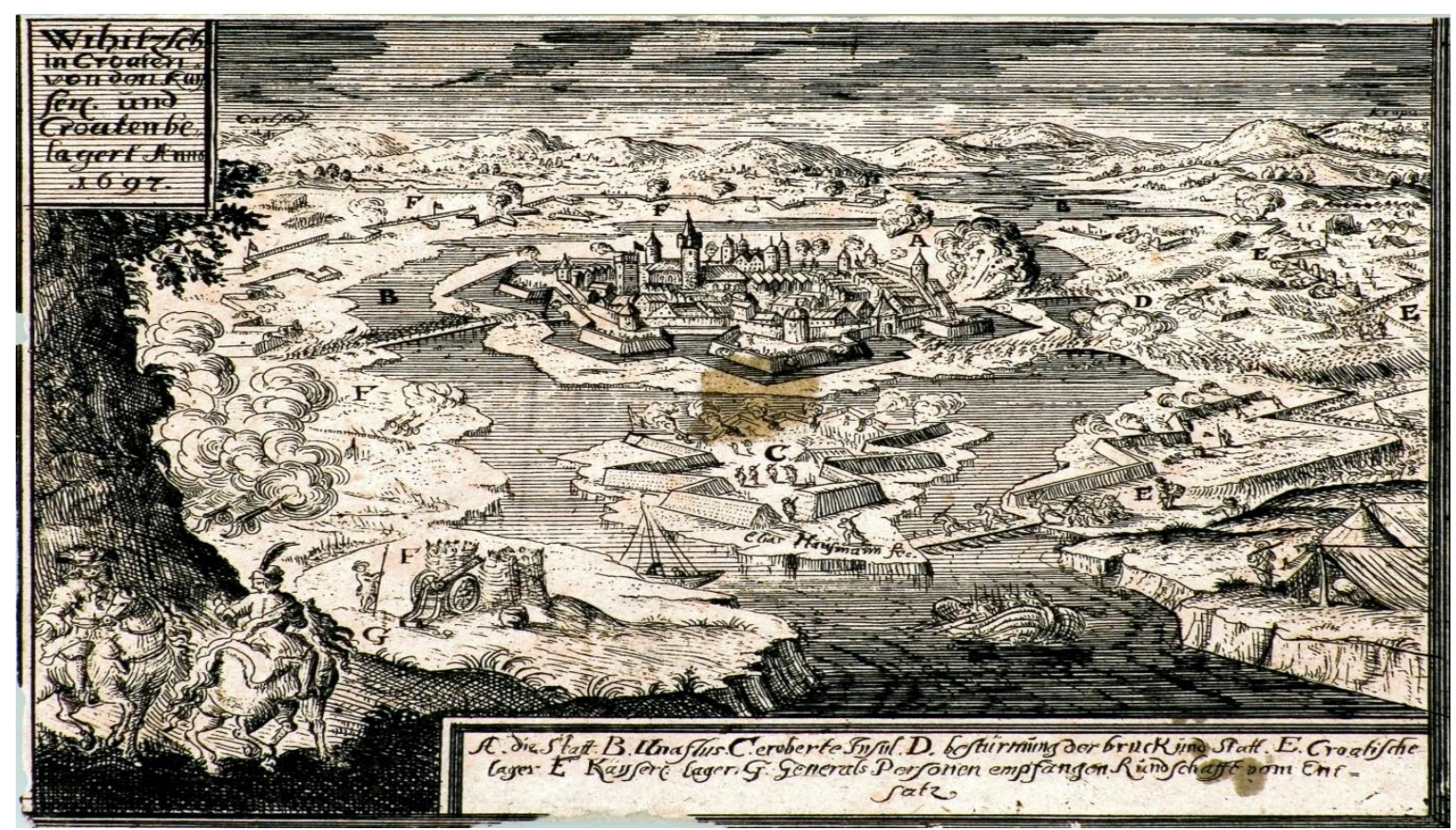

Slika 15. Prikaz Otoke prilikom napada habsburške vojske na Bihać $1697 .{ }^{326}$

Jednako tako, izrazita pažnja morala se poklanjati mostovima koji su preko Otoke vodili u grad. Trebalo ih je osiguravati te držati u dobrom stanju, osobito radi opasnosti od urušavanja kada se preko njih dopremao teži teret poput, primjerice, topova. ${ }^{327} \mathrm{Za}$ prijevoz preko rijeke koristile su se i splavi, ponekad poprilično velike, jer je krajiško povjerenstvo iz 1563. preporučilo zapovjedniku da načini splav na kojoj bi se moglo prevoziti dvadeset do trideset konja. ${ }^{328}$ Također, upotrebljavani su i mostovi sastavljeni od čamaca iako su mostovi tog profila (često) bili privremeni kao što je to slučaj s ,die Pruckhen an den Scheffen koji su stajali negdje ispod crkve kod Velihova (Welethaw) sjeverno od grada, gdje su 1573. Osmanlije na konjima preplivali rijeku na mjestu gdje to ranije nikada nisu učinili pa zato lokacija nije bila branjena. Čini se da je to mjesto lokalnom stanovništvu služilo za zbjeg. ${ }^{329}$

Koliko je potencijalni (nenadani) prijelaz neprijatelja preko rijeke izazivao strah pokazuje i događaj iz ožujka 1576. kada su, nakon što su dan ranije četovali na nekoliko mjesta oko Bihaća, Osmanlije u noći s 13/14. kopljima mjerili širinu rijeke. ${ }^{330}$ Takav potez izazvao je pravu paniku na kršćanskoj strani. Veliku zabrinutost, a ponekad i paniku među lokalnim stanovništvom i vojnom strukturom, izazivao je i niski vodostaj rijeke Une odnosno presušivanje kanala ili jarka oko grada koji je punio tok rijeke. Već je navedeno da je

\footnotetext{
${ }^{326}$ HR-HDA-913, Grafička zbirka, Mjesta, inv. br. 1358.

327 ŠTEFANEC, Država ili ne, 299.

${ }^{328}$ KRUHEK, Krajiške utvrde, 211.

${ }^{329}$ SI AS 2, DSK, kutija 286, fascikl 164, Bihać, proljeće 1573., 1r-1v, rbr. 215-216.

${ }^{330}$ SI AS 2, DSK, kutija 287, fascikl 164, Bihać, 30.3.1576., 1r, rbr. 515. Bihaćki časnici na Hansa Auersperga.
} 
početkom 1530-ih Ivan Lenković zbog toliko niskog vodostaja razmišljao da na pojedinim mjestima nabije u korito našiljene kolce ne bi li time onemogućio konjanike da prodru u grad. ${ }^{331}$ Krajem kolovoza 1557. bilo je pak nužno s čak 500 strijelaca osigurati okolne krajiške gradove do zime ili barem dok „,vodostaj oko Bihaća ponovo ne naraste“. ${ }^{332}$ Krajem srpnja 1556. bihaćki kapetan javio je da će velika osmanska vojska koja se okuplja oko Ključa vjerojatno udariti na Ripač i Bihać jer se kod sela Suče (Sutche) na raznim mjestima moglo prijeći rijeku i izbiti na Otoku. Nije bilo bilo niti potrebe načiniti puno mostova jer je vodostaj kod grada bio toliko nizak da se moglo pristupiti samim zidinama. ${ }^{333}$ Krajem travnja 1565. bihaćki kapetan Georg Kronschall ostao je šokiran kada je, dolazeći u grad, vidio da je vodostaj rijeke Une toliko nizak da je 40-50 ljudi pod mostovima prema Zavalju (Saulle) lovilo rakove. Odmah je k sebi pozvao vojne časnike i gradskog suca na dogovor o tome kako podići vodostaj rijeke jer su tada bili sasvim otvoreni osmanskom napadu. Problem je bio u tome što je rijeka krenula novim tokom (ain Newen gang Auff dy lannge Pruckhen gegen dem Wörd genumen) te je na dvije strane sasvim „otekla“ od grada. Kapetan je s podređenim vojnicima, građanima i seljacima (Pawern) pod svojim zapovjedništvom danonoćno radio kako bi se rijeka ponovno usmjerila oko grada, prema Zavalju. Zato je od Herbarta Auersperga i unajmljenih strijelaca tražio hitnu asistenciju. ${ }^{334}$ Kada je u takvom kontekstu, obilježenom vječitom ratnom psihozom, na neprijateljsku stranu uskočio netko upućen $\mathrm{u}$ lokalne prilike, krajiška vlast inzistirala je na maksimalnom oprezu. Tako je bilo i 1581. kada je na osmanski teritorij uskočio stanoviti Ivan Uskok (Juuan Vßgogkh) koji je dobro poznavao staze i putove oko Bihaća te gdje se najlakše mogla prijeći rijeka. ${ }^{335}$

Dakle, prijelazi preko rijeke Une bili su izrazito važni i permanentno $u$ fokusu zaraćenih strana. Na adama i šumama podizale su se zasjeke, a interveniralo se i u sam tok rijeke Une, kao što to pokazuje izvještaj Herbarta Auersperga iz travnja 1562. Auersperg je iz Bihaća javljao Ivanu Lenkoviću o radovima na zasjekama na adama i šumama od Mača sve do Sokola koji da se mogu izvršiti u roku od tri dana, dok su intervencije u samu rijeku Unu

\footnotetext{
${ }^{331}$ KRUHEK, Krajiške utvrde, 88; LASZOWSKI, HSKHDS, knjiga I, dok. 367, 351-352.

332 „biß der Wasser vmb Wihtisch widerumb etwas anlauffen“. SI AS 2, DSK, kutija 201, fascikl 124, Vranograč 28.8.1557., 1v, rbr. 556. Bihaćki kapetan Georg Sauer na kranjske Verordneten.

${ }^{333}$ SI AS 2, DSK, kutija 201, fascikl 124, Bihać, 28.7.1556., 1r rbr. 186. Bihaćki kapetan Georg Sauer na zapovjednika Hrvatske krajine Merta Galla.

${ }^{334}$ SI AS 2, DSK, kutija 282, fascikl 162, Bihać, 1r-1v, rbr. 146-147. Georg Kronschall na Herbarta Auersperga.

335 SI AS 2, DSK, kutija 287, fascikl 164, 1r, rbr. 879., nema potpisa, datacije ni mjesta. Bihaćki kapetan Sebastian Lamberg spomenuo je 1577. stanovitog Juuana Uskhogkha kao osobu koju su Osmanlije zarobili te prisilili da bude kalauz pri jednom napadu na Bihać. Navedeni je bio dio prethodnice od dvadeset konjanika poslanih loviti zarobljenike, ali je na kraju uspio prebjeći na habsburški teritorij. Možda je riječ o istoj osobi. AHAZU, Lopašić, E. Prijepisi iz austrijskih arhiva, br. 16, str. 1. Sebastian Lamberg na Hansa Auersperga.
} 
bile teže i zahtjevnije pa mu je bilo teško prognozirati koliko bi mogle trajati. ${ }^{336}$ Radilo se o intervencijama koje su trebale osigurati i zatvoriti ulaz u prostor cijele Bihaćke doline. Uskočke vojvode Šobat, Vujin Pauković i Vraneš Radogošić morali su poslati svoje ljude za zaštitu radnika u Bihaću što je izazvalo potencijalni problem jer su stigle obavijesti da Osmanlije planiraju napasti Jezersko, Meniće ili eventualno Peći. ${ }^{337}$

\subsubsection{Strateški položaj Bihaća i Bihaćke kapetanije s obzirom na osmansko napredovanje uz rijeku Unu do 1560-ih}

Kao što je navedeno, sam početak promatranog perioda, uz stalnu osmansku opasnost, obilježen je izbijanjem građanskog rata između pristaša Ferdinanda Habsburga i Ivana Zapolje, pri čemu je ugrožena i obrana Bihaća jer je prijetila opasnost od napada Zapoljina najeminentnijeg sljedbenika na hrvatskom prostoru - Krste Frankopana. Dok je na području Slavonskog Kraljevstva građanski rat poprimio dramatičnu notu, na prostoru Hrvatskoga Kraljevstva sukobi nisu toliko eskalirali. Kad je krajem rujna 1527. umro Krsto Frankopan, Zapolja je izgubio glavni oslonac na prostoru Hrvatskoga Kraljevstva, pa je i razina opasnosti za Ferdinandove pristaše zamjetno pala.

No, u predvečerje građanskog rata ban Ferenc Batthyány savjetovao je kralju da Bihać i Senj, dva najvažnija grada za obranu Hrvatske, nikako ne smije nikome prepustiti. Bihać, nastavlja Batthyány, najvažniju utvrda južnih hrvatskih krajeva, treba opskrbiti vatrenim naoružanjem, barutom, streljivom, hranom i većim brojem vojnika. ${ }^{338}$ Batthyány je kasnije ponovno potencirao stratešku važnost Bihaća tražeći od kralja da za njegovu obranu odredi 100 strijelaca i svu potrebnu ratnu opremu. ${ }^{339}$ Hrvatsko plemstvo također je tražilo od kralja da se osigura Bihać „koji je ključ obrane južne Hrvatske“ protestirajući da je nekada u tom gradu bilo stacionirano 100 pješaka i 100 konjanika, a sada je tamo tek pet stražara. ${ }^{340}$

Staleži su već na cetinskom saboru 1527. konstatirali da su unske utvrde tako međusobno povezane da bi gubitak jedne utvrde značio propast cijele obrambene fronte, a

\footnotetext{
${ }^{336}$ HDA, Militaria, kutija 7, Bihać, 20.4.1562., 1v.

${ }^{337}$ HDA, Militaria, kutija 7, Cetin, 21.4.1562., 1r. Herbart Auersperg na Ivana Lenkovića.

${ }^{338}$ Krsto Frankopan izazivao je osobitu bojazan. Batthyány tako navodi: „Si castro prescripto Byheg ab hostibus aliquid contigerit, aut illud hostes vel Christoferus groff occupauerit, serenitatis vestre dampnum erit“. ŠIŠIĆ, HSS, knjiga I, dok. 38, 41; KRUHEK, Krajiške utvrde, 80.

${ }^{339}$ „Promittimus eciam per fidem et honorem nostrum ac iuramus, quod castrum Byhegh maiestati sue tanquam regi Hungarie et eius nomine fideliter tenebimus et defendemus, in cuius presidio maiestat regia suis sumptibus alet peditos centum pixidarios, suppeditait exiam tormenta e pulueres necessarios prout maiestat regia antea se facturam fuerat pollicita“. ŠIŠIĆ, HSS, knjiga I, dok. 55, 86.

${ }_{340}$ IBID., knjiga I, dok. 66, 101; KRUHEK, Krajiške utvrde, 82.
} 
jedva bi se mogle održati i tri dana jer u njima nema ljudi niti bilo čega potrebnog za obranu. ${ }^{341} \mathrm{U}$ kolovozu 1528. ban Batthyány osobno je pregledao Bihać i Ripač te u pismu kralju Ferdinandu naveo da će propasti Hrvatska, Slavonija i Kranjska ako se izgube te utvrde (si castra), kao što je nakon pada Beograda propalo Ugarsko Kraljevstvo. ${ }^{342}$

Takve su procjene bile sveprisutne i u konačnice točne. Iako proces osvajanja nije bio tako munjevit kao što su to mnogi (ponekad ciljano dramatično) pretpostavljali, probijanje unske fronte krajem 1530-ih početak je dugotrajnog procesa pada cijelog Pounja i njegova zaleđa. Naime, dok je na krbavsko-ličkom prostoru pograničje ostalo manje-više stabilno od kraja 1520-ih nadalje, unski je prostor sukcesivno osvajan sve do pada Bihaća 1592. U ovom će se poglavlju prvo analizirati propast unske obrambene linije, a zatim prikazati karakteristike krbavsko-ličkog ,fronta“ te završiti s osmanskom opsadom grada u lipnju 1592.

Već 1530. hrvatski staleži strahovali su da je unska obrambena fronta, koja da je od starine bila glavni branik Hrvatske, dovedena u pitanje jer su se pojavile glasine da će vlasnik Kostajnice, Stjepan Berislavić, ,izdati grad Turcima“ ${ }^{343}$ Postupno napredovanje rijekama nije nikakav novitet u povijesti vojnih ekspanzija, a tu strategiju primjenjivali su i Osmanlije. Tako je tok Dunava sustavno osvajan tijekom stoljeća i pol, a i na drugoj strani carstva postupno su osvajane i utvrde uz rijeke Tigris i Eufrat. ${ }^{344}$ Iako se trenutno ne može znati jesu li lokalni/regionalni osmanski vojni stratezi imali kakav dugoročni cilj ekspanzije rijekom ili se radilo o „logičnom“ iskorištavanju komunikacija i mogućnosti koje je taj prostor pružao, rijeka Una predstavljala je primarnu trasu osmanske ekspanzije. Važnost rijeke Une potvrđuje i to što je 1574., dakle u razdoblju kada su bile u tijeku pripreme za velika osmanska osvajanja na unskom prostoru, spomenut i Mehmed, osmanski kapetan rijeke Une. ${ }^{345}$

Prva pukotina na unskoj obrambenoj liniji otvorena je 1538. padom Dubice, za koju Ivan Lenković tvrdi da su je njeni branitelji predali Osmanlijama. ${ }^{346}$ Iako su Osmanlije isprva Dubicu zaposjeli manjom posadom, nastojanja bana Petra Keglevića da izvrši kontraudar nisu uspjela jer su čak i lokalni velikaši poput Zrinskih oklijevali participirati u takvom

\footnotetext{
341 „si vnum castrum in fluuio Wn dicto Turci reciperint, vltra remanere non possimus, in tali enim gubernacione et ordine sunt". ŠIŠIĆ, HSS, knjiga I, dok. 66, 99; KRUHEK, Krajiške utvrde, 82.

${ }^{342}$ LASZOWSKI, HSKHSD, knjiga I, dok. 124, 110-111.

${ }^{343}$ KLAIĆ, Povijest Hrvata, knjiga 5, 117.

${ }^{344}$ Gabor AGOSTON, Where Enviromental and Frontier Studies Meet: Rivers, Forests, Marshes and Forts along the Ottoman-Hapsburg Frontier in Hungary, u: The Frontiers of the Ottoman World, ur: A. C. S. Peacock, Proceedings of the British Academy, 156. Oxford: Oxford University Press, 2009., 58.

${ }^{345}$ KORIĆ, Kapetani rijeke Save, 248.

346 James D. Tracy navodi da su Osmanlije zauzeli Dubicu početkom 1537., ali su je Zrinsku ubrzo povratili, da bi je Osmanlije ponovo zauzeli u svibnju 1538. No, navodi da je 1540. ponovno u Zrinskim rukama. TRACY, Balkan Wars, 102.
} 
pothvatu. ${ }^{347}$ Nakon pada Dubice habsburške posade Jasenovca i grada Subockog same su napustile svoje utvrde. Već sljedeće godine, kao osveta za ubojstvo Ivana Katzianera u Kostajnici, započeli su ciljani osmanski napadi na pounjske posjede obitelji Zrinski. Prema Kruheku, tada je devastiran cijeli kraj između Kostajnice, Goričke, Pedlja, Zrina i Gvozdanskog te je već tada postalo jasno da će se defenzivna fronta morati prebaciti na sjeverne obronke Zrinske gore, odnosno na tok rijeke Kupe. ${ }^{348}$ Nema sumnje da su pustošenja morala biti dramatična, no otvoreno je pitanje koliko je stanovništva stradalo i kakve je to posljedice moglo ostaviti. Napadnuti rudnici srebra u Gvozdanskom i dalje su ostali operabilni, a Osmanlije tada nisu osvojili nijednu utvrdu. No, time je započeo dugotrajni proces osmanskog osvajanja bihaćkog zaleđa.

Za sigurnost Bihaća osobit su problem zapravo predstavljali strateški izrazito bitni Zrinski posjedi oko rijeke Une, odnosno njihova obrana. Tako je, primjerice, Hans Ungnad početkom 1554. iskazao nezadovoljstvo načinom na koji je ban Nikola Zrinski držao plaćene vojnike na krajištu. ${ }^{349}$ Utvrde prema Kostajnici predstavljale su takvo strateško opterećenje da je kralj tražio da se one poruše. Međutim, unatoč opsežnim pripremama, hrvatsko plemstvo na saboru u Steničnjaku 1558. odbilo je to učiniti. Stoga je Ivan Lenković pisao banu Petru Erdödyju da će mu te utvrde predati, da ih neće više zaposjedati plaćenim vojnicima, a ban da će morati preuzeti odgovornost ako se ne izvrše kraljevski nalozi o rušenju određenih utvrda. ${ }^{350}$ Hrvatsko-slavonski sabor, koji je održan početkom ožujka 1560. u Zagrebu, ipak je zatražio da se Zrinski s kraljem sporazumi oko obrane utvrda na Zrinskoj gori. ${ }^{351}$ No, Zrinske unske utvrde ipak su i dalje predstavljale defenzivni problem.

Jedan od mehanizama stabiliziranja pogranične fronte bilo je, dakle, rušenje strateški nevažnih ili opterećujućih utvrda na pograničju. Iako se u hrvatskoj historiografiji ponekad osuđivalo takve postupke kao poteze neosjetljive na hrvatske interese, treba naglasiti da su i domaći staleži zahtijevali rušenje pojedinih utvrda. Naime, na ugarskom saboru u veljači 1546. od kralja je zatraženo da delegira bana ili nekog od kapetana ili povjerenika da pregledaju „gradove, kaštele i tvrđice“ u Kraljevinama Slavonije i Hrvatske te da one

\footnotetext{
${ }^{347}$ KRUHEK, Stvaranje i utvrđivanje granice na Kupi u XVI i XVII stoljeću, u: Vojna krajina. Povijesni pregled-historiografija-rasprave, ur. Dragutin Pavličević, Zagreb, 1984., 220. O padu Dubice vidi. KRUHEK, Krajiške utvrde, 122-125.

${ }^{348}$ IBID., 126.

${ }^{349}$ Hans Ungnad pisao je kralju Ferdinandu početkom 1554: „Dann ich kan eur kgl. Mt. sovil mit grund gehorsambist anzaigen, das mit dem gelt und uncosten so eur kgl. Mt. järlieh auf den herrn ban verwenden tuet, eur kgl. Mt. und dern vaterland wenig gedient wird. dann sein kriegsvolk ist an den gränizen nit zu sehen noch zu erfragen“. ŠIŠIĆ, HSS, knjiga II, dok. 263, 391-392.

${ }_{350}$ IBID., knjiga III, dok. 16, 27-28; IBID., dok. 18, 31-32; IBID., dok. 19, 33-34.

${ }^{351}$ KRUHEK, Krajiške utvrde, 184; ŠIŠIĆ, HSS, knjiga III, dok. 37, 64-70.
} 
potrebne za obranu preuzme, a ostale „dade porušiti i spaliti“ da ne padnu Osmanlijama u ruke. ${ }^{352}$ I hrvatsko-slavonski staleži raspravljali su o rušenju nepotrebnih objekata. Zato Lenkovićev prijedlog za rušenje raznih utvrda oko Une iz 1563. i nije nešto radikalno novo iako je izazvao prijepore među hrvatskim plemstvom - osobito Zrinskim. Lenković je tada čak predložio da se poruše i važne utvrde kao što su Zrin i Gvozdansko koje je branilo 200, odnosno 100 plaćenih kraljevskih vojnika. ${ }^{353}$

Budući da se najveći broj utvrda predloženih za rušenje 1563. nalazio na potezu između Bihaća, Zrinske gore i Pounja, za razliku od, primjerice, utvrda oko rijeke Kupe od kojih nijedna nije uvrštena na taj popis, Kruhek je to interpretirao kao rezultat strategije povlačenja s već probijene unske fronte, iako je Lenković i dalje inzistirao na obrani Bihaća i podređenih mu utvrda koje, kako Kruhek opet navodi ,čuvaju prostor krajnjeg zapadnog krila obrane koje drže utvrde Senjske kapetanije“. ${ }^{354}$ No, kao što će se kasnije u radu dokazati, već su se tada na unutrašnejaustrijskoj razini vodile rasprave o tome treba li Bihać sasvim napustiti i prebaciti obranu zapadnije ili ne. Iako se od tog plana tada, kao što će biti slučaj i kasnije odustalo, sama činjenica da se o tome naveliko raspravljalo demonstrira koliko je teško bilo braniti unski prostor nakon što su Osmanlije „probili“ rijeku.

Umjesto da se situacija popravi, ubrzo se zbio novi „moment loma“ na unskoj fronti gubitak Kostajnice. Taj strateški važan grad je krajem srpnja 1556., navodno za poveći iznos, Osmanlijama predao njegov zapovjednik Pankratz Lusthaller. ${ }^{355}$ Taj čin izazvao je pravi šok na habsburškoj strani, a dramu je dodatno potencirala činjenica da se lokalno hrvatsko stanovništvo željelo (u određenoj mjeri) podčiniti Osmanlijama. Naime, kralj Ferdinand tražio je tada od predstavnika kranjskih staleža da se spali, opljačka i uništi kao primjer drugima, podanike grofova Blagajskih koji se žele podčiniti neprijatelju, za što da se do sada u Hrvatskoj rijetko ili gotovo nikada nije čulo. ${ }^{356}$

Ovi događaji moraju se promatrati u kontekstu širih osmanskih operacija na području Ugarsko-hrvatskog Kraljevstva, primarno, dakako, opsade Sigeta koja je trajala od sredine

\footnotetext{
${ }^{352}$ KLAIĆ, Povijest Hrvata, knjiga 5, 214. Zrinski je, primjerice, 1561. odbijao sastanak s Ivanom Lenkovićem i banom oko rušenja nekih svojih utvrda (bez obzira na to što je tu namjeru sankcionirao car) iako je Lenković držao da takav stav ugrožava cijelu krajinu, a osobito Bihać. ŠTEFANEC, Država ili ne, 291-291, fusnota 856.

${ }^{353}$ SI AS 2, DSK, kutija 411, fascikl 282, 1563., 3v-4r, rbr. 52-53.

${ }^{354}$ KRUHEK, Krajiške utvrde, 195-197.

${ }^{355}$ Zapovjednik Hrvatske krajine Mert Gall javlja da je Lusthaller predao Kostajnicu bez ikakve potrebe (on alle nott) te da je „,damit er mit dem Turkhen Sider Verschmen Michaeln..., derhalben in Practica gestanden“. SI AS 2, DSK, kutija 201, fascikl 124, Budomerić, 21.7.1556., 1r, rbr. 292. Mert Gall na predstavnike kranjskih staleža. Stanoviti Panngracz Lustaller bio je 1551. pješak u Bihaću s mjesečnom plaćom od 8 forinti. LOPAŠIĆ, SHK, knjiga III, dok. X, 411.

${ }^{356}$ SI AS 2, DSK, kutija 201, fascikl 124, Beč, 31.7.1556., 1v, rbr. 211. Car Ferdinand na predstavnike kranjskih staleža.
} 
lipnja do kraja srpnja te godine. Već krajem svibnja Ivan Lenković javlja da je sultan naredio osvajanje Sigeta u Ugarskoj, ali i istodobne napade na području Ugarske, Slavonije i Hrvatske, i to na kopnu i na moru. Lenkovićev dienner iz Beograda je pak javljao da se bosanski paša i Malkoč-beg ne mogu usuglasiti oko toga gdje udariti jer bosanski paša želi na Hrastovicu i/ili Sisak, a Malkoč-beg na Bihać, Ripač i utvrde na Uni. Stoga su obojica poslali čauše na Portu po daljnje instrukcije. ${ }^{357} \mathrm{Na}$ kraju je uslijedio napad na Slavoniju, prema Zagrebu, ali je i dalje postojala realna prijetnja napada na Bihać u koji su kao pojačanje poslani pješaci iz Kranjske te njima pridruženi uskoci. Već 4. kolovoza u Bihaću se nalaze Mert Gall i Sigmund Semenitsch s određenim brojem strijelaca te stotinu uskoka. Međutim, budući da su primili plaću tek za period od mjeseca dana, izgleda da više nisu željeli ostati u gradu, već su ga započeli napuštati grad zajedno s lokalnim stanovništvom. Bilo je potrebno čak postaviti straže ne bi li ih se zaustavilo. ${ }^{358}$ Do kraja mjeseca, Lenković već javlja Caru da su svi kranjski pješaci napustili grad, osim stotinu uskoka. ${ }^{359}$ Radilo se o visokoj brojci od 400 strijelaca umjesto kojih je Lenković morao poslati dvojicu kranjskih zapovjednika s drugih 400 strijelaca. ${ }^{360}$ Ovakvi slučajevi nisu bili rijetkost, a bit će analizirani dalje u tekstu.

Nakon tih uspjeha, uslijedio je novi potres na unskoj fronti - Osmanlije su zauzeli Novi na Uni, a zatim Lišnicu, Otoku i Bušević. Prvo je 1557. zauzet Novi na Uni. U osmanskim muhimmi defterima navodi se da je nakon osvajanja Kostajnice spaljena tvrđava Novi, „nakon čega je s neprijateljskog teritorija došao jedan nefer 'prebeg' koji je saopštio neke važne podatke o neprijatelju. Prebjeg je bio i u Istanbulu. Primio je i islam. Zbog svega toga, Mehmed paša (bosanski beg, op.a.) ga je nagradio timarom od 4000 akči“, što je odobreno na Porti. ${ }^{361}$ Taj je prebjeg nedvojbeno imao određenu ulogu u osmanskim osvajanjima na prostoru oko Novog, Otoke i Buševića. Možda će buduća istraživanja osmanskih izvora pokazati o kome se radilo.

U ljeto 1557. Malkoč-beg namjeravao je zauzeti i Bihać. Barem je tako krajem kolovoza izjavio Šimun Vukelić (Schimon Wugelitsch), iznad Starigrada zarobljen harambaša osmanskih martologa, kojeg je senjski kapetan nekoliko godina ranije (vor Jarn) koristio i za

\footnotetext{
357 SI AS 2, DSK, kutija 201, fascikl 124, Pobrežje, 30.5.1556., 1r-1v, rbr. 343-344. Ivan Lenković na predstavnike kranjskih staleža.

${ }^{358}$ SI AS 2, DSK, kutija 201, fascikl 124, Bihać, 4.8.1556., 1r, rbr. 391.

${ }^{359}$ SI AS 2, DSK, kutija 201, fascikl 124, Zagreb, 25.8.1556., 1v, rbr. 313. Kranjski staleži su na najugroženija mjesta postavili 700 vojnika. No, zbog manjka financijskih sredstava bilo ih je teško držati u službi, pa je Lenković i od koruških staleža tražio da pošalju 300 haramija i 100 konjanika ili da pomognu pri financiranju kranjskih postrojbi što je predstavljao uobičajen zahtjev. SI AS 2, DSK, kutija 201, fascikl 124, Zagreb, 26.8.1556., 1r-1v, rbr. 199-200. Ivan Lenković na koruške staleže.

${ }^{360}$ SI AS 2, DSK, kutija 201, fascikl 124, Zagreb, 28.8.1556., 1r-1v, rbr. 301-302.

${ }^{361}$ KOVAČEVIĆ, Muhimme Defteri, dok. 20, 20.
} 
dobivanje obavijesti. Vukelić je tvrdio da je Malkoč-beg poslao sultanu osobnog ćehaju s molbom da mu se dozvoli zauzimanje Bihaća ili Otočca vatrenim naoružanjem. Čini se da je Malkoč-beg podigao svoje postrojbe i prije povratka čauša iz Carigrada. ${ }^{362}$ Osmanske snage stajale su krajem rujna na Livanjskom polju, ali je među njima zavladala velika glad pa su se dijelom razišli. No, zapovjednik Hrvatske krajine Georg Sauer bojao se da se neće tako lako razići jer ništa planiranog nisu realizirali te da će ipak možda nešto pokušati „sljedeću mjesečinu“" kada stigne živež. ${ }^{363}$

I zaista, do 4. listopada Osmanlije su se opet okupljali na Livanjskom polju, ali je sada pak nedostajalo živeža i novaca s habsburške strane pa su se Sauerovi okupljeni vojnici počeli razilaziti. Unatoč tome, Sauer je planirao provaliti na osmanski prostor na koji je poslao uhode i špijune, a odlučio je okupiti pješake i konjanike te uskoke koji nisu u službi. Ako provala neće biti izvediva ili Osmanlije krenu u napad, Sauer je planirao okupljenu vojsku iskoristiti za obranu. ${ }^{364}$ Četiri dana kasnije (8. listopada) Saueru je stiglo poslanstvo od Ivana Dolovića i drugih plemića iz okolice Zrina koji su od zarobljenika saznali da će okupljena osmanska vojska graditi Novi na Uni. Iako je Sauer imao respektabilnih 1200 vojnika, nije smatrao da može nešto učiniti, jer je vladala „nečuvena glad“ zbog koje je smatrao da ne može držati okupljene uskoke i hrvatske vojnike (koji nisu bili u službi) ni tri dana. ${ }^{365}$ Novi na Uni tada, čini se, nije obnavljan jer je bihaćki kapetan Georg Zoblsperg javio da je bosanski ćehaja došao pod grad s nekoliko stotina pješaka i konjanika, no kada je saznao za okupljanje habsburških i hrvatskih snaga, odlučio ništa ne poduzimati jer nisu bili prisutni paša ili visoki zapovjednici (haubt). Ipak, pregledao je i izmjerio karakteristike mjesta, a topove je ostavio u turnju podignutom u mjestu Khosorskhy Lug kod Novog. Špijunski izvještaji sugerirali su da u Lišnici neki (ettlich) žele predati mjesto Osmanlijama, pa je Zoblsperg tražio da se pazi na utvrdu. $^{366}$ Osmanlija je, prema izvještajima straža, ukupno bilo 2000 konjanika i 3000 pješaka. ${ }^{367}$

Početkom prosinca Zoblsperg ponovno javlja da Malkoč-beg skuplja veliku vojsku

\footnotetext{
${ }^{362}$ SI AS 2, DSK, kutija 201, fascikl 124, Senj, 24.8.1557., 1r, rbr. 557. Herbart Auersperg na Georga Sauera.

${ }^{363}$ SI AS 2, DSK, kutija 201, fascikl 124, kod Peći, 24.9.1557., 1r, rbr. 570. Georg Sauer na predstavnike kranjskih staleža.

${ }^{364}$ SI AS 2, DSK, kutija 201, fascikl 124, kod Cetina, 4.10.1557., 1r, rbr. 438. Georg Sauer na predstavnike kranjskih staleža.

${ }^{365}$ SI AS 2, DSK, kutija 201, fascikl 124, zu Zerz, 8.10.1557., 1r, rbr. 482. Georg Sauer na predstavnike kranjskih staleža.

${ }^{366}$ SI AS 2, DSK, kutija 201, fascikl 124, Bihać, 21.10.1557., 1r-1v, rbr. 443-444. Georg Zoblsperg na Georga Sauera.

${ }^{367}$ SI AS 2, DSK, kutija 201, fascikl 124, Budomerić, 21.10.1557., 1r-1v, rbr. 440-441. Georg Sauer na predstavnike kranjskih staleža.
} 
pješaka i konjanika za udar na Petrov Gvozd i Hrvatsku (Petrawgoßdt vnnd in Crabaten). ${ }^{368}$ Osmanlije su Novi započeli obnavljati sljedeće godine jer 14. listopada 1558. bihaćki kapetan Georg Zoblsberg javlja da Malkoč-beg namjerava provaliti u Hrvatsku te da je naredio da se od svake kuće podigne jedan čovjek i jedan vol za obnovu Novog. Osmansko konjaništvo trebalo je simultano provaliti na hrvatsko područje i vezati (dio) habsburških snaga kako bi se građevinski radovi mogli sigurno izvršiti. ${ }^{369}$

Bihaćki kapetan 11. studenoga zaista navodi da su građevinski radovi na Novom okončani te da je utvrda zaposjednuta s jakom posadom. Zoblsberg javlja i da je Malkoč-beg tražio predaju blagajske Otoke na Uni, a da je tamošnji upravitelj (pfleger), čim je uočio osmanske postrojbe koje navodno nisu bile brojne niti nisu planirale opsadu, zapalio utvrdu na četiri mjesta te s narodom pobjegao prema Buševiću (mit dem Folckh gen Wuschefitsch). ${ }^{370}$

U studenom su zauzeti i Lišnica i Bušević, nakon čega je, navodi Lenković, u ostatku Hrvatske ,preoteo maha opći bijeg i razdor te brojni hrvatski seljaci pristaju uz turskoga pašu“. ${ }^{371}$ U studenom je Malkoč-beg poslao stanovitog Stärgaritsche, koji je ranije iz Krupe prebjegao Osmanlijama, u povjerljivu misiju prema „seljacima u Hrvatskoj“ (Pauern in Khrabaten) koje je trebao navesti da im se podlože jer da su u protivnom Osmanlije prijetili tu zimu cijelu Hrvatsku spaliti. Malkoč-beg je hrvatskom stanovništvu obećavao sedmogodišnje oslobođenje od službi njemu i sultanu. Sve to navodno je ponukalo 31 kuću Hrvata da prebjegnu pod Novi, a prelazak stanovništva na osmansku stranu čak se i nastavio jer je jedan osmanski zarobljenik tvrdio da se preko pedeset kuća „naših seljaka“ naselilo pod Novi i da tamo podižu kuće. ${ }^{372}$

Zanimljiv je i za osmansko napredovanje bihaćkim zaleđem važan višegodišnji proces demografske stabilizacije ovog prostora. Karl Kaser navodi da je 1553. u Lišnici bilo samo 20 podanika, oko Novog 100, oko Otoke njih 20, dok je oko Krupe bilo još oko 300 podanika.

\footnotetext{
${ }^{368}$ SI AS 2, DSK, kutija 201, fascikl 124, Bihać, 5.12,1557., 1r-1v, rbr. 528. Georg Zoblsperg na Georga Sauera. ${ }^{369}$ SI AS 2, DSK, kutija 201, fascikl 124, Bihać, 14.10.1558., 1r, rbr. 780. Georg Zoblsperg na predstavnike kranjskih staleža.

370 „,vnder des von Wlagay odock geschikht“. SI AS 2, DSK, kutija 201, fascikl 124, Bihać, 11.11.1558., 1r, rbr. 639. Georg Zoblsperg na predstavnike kranjskih staleža. Zoblsperg je zapravo već krajem kolovoza javljao da špijuni donose obavijesti da Malkoč-beg vrši radnje (mit Practikhen vmbher) ne bi li zauzeo Bušević i Otoku. SI AS 2, DSK, kutija 201, fascikl 124, Bihać, 8.8.1558., 1r. Georg Zoblsperg na predstavnike kranjskih staleža.

${ }^{371}$ KLAIĆ, Povijest Hrvata, knjiga 5, 283. Lopašić kaže da je Lenković javljao da je Bušević 1559. razoren od krajiških snaga. LOPAŠIĆ, Bihać, 114-115. To je točno jer je i krajiško povjerenstvo 1563. konstatiralo da su ranije razoreni i napušteni Jamnica, Bračaj i Bušević. AHAZU, Lopašić, E. Prijepisi iz austrijskih arhiva, br. 15, str. 36 .

372 „das nun edlich vnd 50 Heysser vnsserer Pauer sich vnnder Nofy grädt Nider gethan vnd dasselbs heysser pauen“ SI AS 2, DSK, kutija 201, fascikl 124, Bihać, 11.11.1558., 1r, rbr. 639. Georg Zoblsperg na predstavnike kranjskih staleža.
} 
Oko Ostrošca bilo je čak i nekoliko sela, a u Brekovici „kuća i podanika“. ${ }^{373}$ I Hans Ungnad je početkom slijedeće godine naveo da je pod Novim još oko 100 podanika (undersassen), a oko Krupe njih 400-500. ${ }^{374} \mathrm{~S}$ obzirom na spomenute navode, nema sumnje da je na tom prostoru nešto od ovoga domaćeg hrvatskog svijeta ostalo ili prešlo pod osmansku vlast. Primjerice, dok na području osmanske nahije Dubica barem do 1563. nije upisano nijedno selo te dok su tek te godine na području nahije Kostajnica upisana dva sela s 25 kuća, na prostoru nahije Novi nalazilo se tada već 13 naselja s 235 kuća. ${ }^{375}$ To sugerira da je na prostoru nahije Novi zaista ostalo nešto starosjedilačkog stanovništva te da je nahija Novi izrazito važna u daljnjoj osmanskoj ekspanziji unskim prostorom. Iako je teško procijeniti kakva je bila uloga „domaćeg elementa“ $u$ tom procesu, pojedini izvori sugeriraju da nije beznačajna. ${ }^{376}$ Takva kombinacija zasigurno je zaslužna za relativno velik broj naselja na području nahije Novi 1563. Marko Šarić postavio je pitanje porijekla novljanskih i kostajničkih „,madžarskih“ Vlaha iz popisa 1563. Naime, postavio je pitanje jesu li to potomci preseljenih jajačkih martologa, dakle s Vrbasa, ili starosjedioca. ${ }^{377} \mathrm{~S}$ obzirom na sve navedeno, očito se, barem dijelom, radi o potomcima starosjedioca na ovom prostoru, što cijelu priču čini još kompleksnijom jer su uključeni u ,vlaški društveni red, plaćali su vlaški porez (filurija) i obnašali martološku službu na granici“، 378

Prema svemu navedenom, rekao bih da je sasvim jasno da je dio lokalnog stanovništva prihvatio, a vjerojatno i sudjelovao u osmanskom zauzimanju tog prostora. Osobne ambicije i/ili interesi zajednica u liminalnim ambijentima imperijalnih pograničja u kombinaciji s kontinuiranim osmanskim vojnim pritiskom i egzistencijalnim strahom nedvojbeno su

\footnotetext{
${ }^{373}$ Karl KASER, Slobodan seljak i vojnik. Rana krajiška društva (1545-1754.), knjiga I, Naprijed, Zagreb, 1997., 35.

374 ŠIŠIĆ, HSS, knjiga II, dok. 263, 392.

${ }^{375}$ VASIĆ, Etnička kretanja,240.

${ }^{376} \mathrm{Da}$ je na cijelom unsko-savskom potezu zaista ostalo starosjedilačkog stanovništva pokazuje i izvještaj Wolffa Englebrechta Auersperga na nadvojvodu Karla s početka svibnja 1585. u kojem stoji da je obavijesti o osmanskim planovima dojavio neki zarobljeni Hrvat Lubenkho koji ih je saznao od neimenovanoga kneza stanovništva iz okolice Gradiške koji pak nisu Vlasi već rimokatolici (Bey Gradischkho. ...dieselben alle al $\beta$ wisundt nicht Wallachen sonndern des Römischen glaubens Cristen sint). SI AS 2, DSK, kutija 203, fascik1 124a, Karlovac, 2.5.1585., 1v, Wolff Engelbrecht Auersperg na nadvojvodu Karla. I u defteru iz 1604. na ovom prostoru nalazimo razmjerno mnogo imena koja upućuju na katoličku vjeroispovijest. Primjerice, u varoši pod tvrđavom Novi zabilježeni su Jakov Staničić, Grgur Perić, Juraj Brzić, Tomaš Marić, Stipan Slavić itd. U varoši Lešnica (očito Lišnica) navedeni su Marko Salčić, Blaž Janjić, Stipan Vanić, Martin Živkov, Jure Radelić itd. Adem HANDŽIĆ, Opširni popis Bosanskog sandžaka iz 1604. godine, sv. I/2, Bošnjački institut Zürich-Odjel Sarajevo, Orijentalni institut Sarajevo, Sarajevo, 2000., 520-531. Marko Šarić navodi da je taj defter nastao nešto ranije, 1592. - 1595., a da je 1604. izvršena samo posljednja redakcija. Marko ŠARIĆ, Vlasi na tromeđi: suživot u sukobima u graničnim društvima i kulturama Morlakije (16.-17. stoljeće), doktorska disertacija, Filozofski fakultet, Zagreb, 2010., 87.

${ }^{377}$ Marko ŠARIĆ, Etnokulturna kretanja u srednjem Pounju u ranom novom vijeku s posebnim osvrtom na bivšu općinu Zavalje, u: Podplješevički graničari. Zbornik radova: Povijesni prikaz podplješevičkih sela, Udruga bivše općine Zavalje, ur. Želimir Prša, Ivan Brlić, Željko Holjevac, br. I, Zagreb, 2017., 36.

${ }^{378}$ IBID.
} 
određene skupine „usmjerile“ prema prihvaćanju ili podčinjavanju osmanskoj vlasti. Kolonizacijom primarno vlaškog svijeta osvojeni je prostor (dodatno) demografski ojačan, fortifikacije su obnavljane, komunikacije građene i vojno-administrativni aparat ustrojavan da bi se iz stabiliziranog pograničja napredovalo dalje. Budući da su se obnova utvrda i kolonizacija odvijale relativno brzo nakon zauzimanja prostora, može se pretpostavljati da su i prije samih vojnih operacija postojali definirani planovi uređenja nove stečevine. Tako su Lišnica i velik dio doline Une prema Buševiću i Krupi vrlo brzo kolonizirane vlaškim stanovništvom s bosanskog prostora. ${ }^{379}$

Budući da su osvajanjem ovog dijela Pounja Osmanlije otvorili put u bihaćko zaleđe te dublje u unutrašnjost Hrvatske i Slavonije, porasla je važnost zrinskih utvrda na Zrinskoj gori, osobito Gvozdanskog preko kojeg je vodio važan put od Novog prema Pokuplju. Stoga je krajiško povjerenstvo iz 1563. tražilo da se tamo drži jaka posada od 100 hrvatskih pješaka (jer za konjanike nije bilo mjesta) od koji bi njih 25 svakodnevno izlazilo nadzirati putove prema Zrinu, Krupi i Stijeni. ${ }^{380}$ Utvrdu je trebalo preuzeti od Zrinskih, a rudnike koji su prije godinu i pol sasvim napušteni ponovno staviti u pogon. ${ }^{381}$ Dakle, Gvozdansko je postalo važno komunikacijsko čvorište i važna lokacija za bočnu obranu Bihaćke kapetanije. Spomenuto povjerenstvo predložilo je da se u Zrin namjeste jaka posada (50 arkebuzira, 50 husara, 50 njemačkih vojnika i 100 haramija) i iskusni zapovjednik pod čijom bi kontrolom bile utvrde u Gvozdanskom i Krupi. ${ }^{382}$ To je Kruhek protumačio kao prijedlog stvaranja svojevrsne „treće kapetanije“ koja bi imala „istu zadaću na prostoru zrinskog Pounja kao i Bihać i Senj na svojem obrambenom području“. ${ }^{383}$ To je period reorganizacije krajiškog sustava na hrvatskom prostoru, pa će tako sljedeće godine (1564.) i Bihaćka kapetanija imati 20 utvrda u svom sastavu. Članovi krajiškog povjerenstva tada su još pokazali određeni optimizam, pa su tako ustvrdili da bi se uređenjem obrane od Bihaća do Zrina moglo još držati Unu te možda i zauzeti Kostajnicu i Novi. ${ }^{384}$ No, umjesto da se lokaliziranim protuudarom stabilizira i osigura unsko krajište, ubrzo se zbio jedan od najvećih osmanskih uspjeha na promatranom prostoru - zauzimanje Krupe u ljeto 1565.

\footnotetext{
${ }^{379}$ LOPAŠIĆ, Bihać, 11.

${ }^{380}$ AHAZU, Lopašić, E. Prijepisi iz austrijskih arhiva, br. 15, str. 35-36.

${ }^{381}$ AHAZU, Lopašić, E. Prijepisi iz austrijskih arhiva, br. 15, str. 68

382 AHAZU, Lopašić, E. Prijepisi iz austrijskih arhiva, br. 15, str. 36-37.

${ }^{383}$ KRUHEK, Krajiške utvrde, 217-218.

${ }^{384}$ AHAZU, Lopašić, E. Prijepisi iz austrijskih arhiva, br. 15, str. 69.
} 


\subsubsection{Strateške posljedice pada Krupe 1565.}

Početkom 1560-ih pokrenut je novi val napada na hrvatskom prostoru. Čini se da ga je inicirao sam sultan koji je 1560. naredio Malkoč-begu zauzimanje utvrda Bihaćke kapetanije. $^{385}$ Osmanlije su ubrzo započeli i s logističkim pripremama za napadne operacije, pa tako Ivan Lenković javlja caru u travnju 1560. da je Malkoč-beg kod trgovišta u Novom na Uni podigao dva drvena bastiona, nekoliko graba oko Une te da je naredio da se probije jedan široki put prema Kostajnici. ${ }^{386}$ U svibnju Osmanlije četiri puta upadaju na hrvatski prostor, a početkom lipnja napadaju Novigrad (Todorovo) gdje je igrom slučaju eksplodirao barut i uništio utvrdu te usmrtio tristotinjak ljudi. ${ }^{387}$ Sredinom lipnja dolaze vijesti da je Malkoč-beg dao u Gradiški (Grädischkhy Wrod) natovariti topove i mnogo streljiva na brodove (Schiffung) koji su se nalazili na rijeci Savi te da je u Bosni dao popisati nekoliko stotina konja i volova. Sandžacima Hercegovine, Hlivna, Bosne i Čazme potajno je naredio da na sljedeći dan Sv. Ivana Krstitelja brzo podignu svoje konjanike i pješake te pohitaju u Novi na Uni. Lenković je smatrao da će udariti ili na Hrastovicu i Sisak, ili na Bihać, Ripač i Ostrožac. $^{388}$

No, već 1562. potpisano je primirje koje je pak prekinuto smrću kralja/cara Ferdinanda krajem srpnja 1564. čime je ponovno otvorena mogućnost izvođenja većih vojnih operacija. ${ }^{389}$ I zaista već sljedeće godine uslijedio je pravi šok za kršćansku stranu - izgubljena je Krupa. ${ }^{390}$ Iako Krupa nije ulazila u sastav Bihaćke kapetanije, bila je od velike strateške važnosti za Bihaćku kapetaniju jer je zatvarala njezin istočni bok i barem načelno suzbijala osmanske prelaze preko rijeke u bihaćko zaleđe. Uostalom, kao što je već navedeno, od 1520-ih Krupa je uz Bihać, apostrofirana kao „ključ“ Hrvatske i zemalja u zaleđu. Ta „najisturenija utvrda“ bila je i ,ključ i vrata susjednog, najisturenijeg i najugroženijeg, mjesta Bihaća“, kao što su to navodili kranjski staleži. ${ }^{391}$

\footnotetext{
385 JUG, Turški napadi, 42.

${ }^{386}$ HDA, Militaria, kutija 7, Mehovo, 19.4.1560., bez paginacije. U izvorniku bi trebalo biti 3r, ali su među preslike umetnuta još dva priloga pisana istoga dana.

${ }^{387}$ LOPAŠIĆ, Bihać, 224.

${ }^{388}$ HDA, Militaria, kutija 7, Koprivnica, 17.6.1560., 1r-1v. Ivan Lenković na predstavnike štajerskih staleža.

389 SIMONITI Turki su, 172. Međutim, intenzivno ratovanje odvijalo se i za vrijeme primirja, pa je tako u travnju 1565. velika osmanska vojska od 3000-4000 ljudi napala vlastelinstvo Steničnjak. Iako nisu pričinili štete kao godinu dana ranije, zarobljeno je čak oko 400 osoba. SI AS 2, DSK, kutija 202, fascikl 124a, 16.4.1565., 1r1v. Herbart Auersperg na predstavnike kranjskih staleža.

${ }^{390}$ Niz dokumenata o padu Krupe citirala je Nataša Štefanec u ŠTEFANEC, Država ili ne, 140, fusnota 347.

391 „,des negst angelegnen gefährlichesten eüsseristen Ortfleckhens Wyhitsch“. SI AS 2, DSK, kutija 209, fascikl 126, 10.6.1565, Ljubljana, 3r, rbr 11. Predstavnici kranjskih staleža na cara Maksimilijana i nadvojvodu Karla.
} 
Sama utvrda nalazila se na uskoj kamenitoj stijeni s desne obale rijeke Une, dakle uvjetno rečeno s „osmanske strane“ što je pak kompliciralo njezinu obranu. Utvrdu je dodatno osiguravala i pritoka Krušnica koja se pored utvrde ulijeva u rijeku Unu, a koja cijelim svojim tokom od izvora, koji je bio pola milje od grada, nije imala ,pogodna mjesta gdje bi se lako moglo prijeći konjem“. ${ }^{392}$ Do trenutka kada je već više puta spomenuto krajiško povjerenstvo 1563. vršilo inspekciju utvrde, ona je bila na sasvim isturenom pograničju i odatle više nije bilo puta prema drugim utvrdama. ${ }^{393}$

Osvajanjem Krupe Osmanlije su zauzeli jednu od najvažnijih utvrda na unskom prostoru i vrlo važan prijelaz preko rijeke te osigurali vjerojatno najvažniju točku okupljanja osmanske vojske za napade prema Bihaću. Koliko je Krupa bila bitna pokazuje i konstatacija Herbarta Auersperga iz listopada 1565., da više ne vrijedi nikakav obavještajni rad (kundtschafft haltung) jer su Osmanlije osvajanjem Krupe osigurali nesmetan prijelaz preko rijeke Une. Naime, ranije su Osmanlije morali preko Kostajnice i Novog na Uni provaljivati u Hrvatsku, za što je pak trebalo vremena pa se moglo osigurati obavijesti. Osvajanjem mostova u Krupi mogli su mnogo lakše i brže provaliti u Hrvatsku - navečer krenuti i u toku noći stići do Korane pa i dalje, drugi dan pustošiti i još se isti se dan vratiti nazad, kao što su učinili krajem prethodnog mjeseca. Od tada je trebalo prema Krupi i oko rijeke Une cijelu zimu držati vojsku na terenu. ${ }^{394}$ Indikativno je da je Ivan Lenković anticipirao potencijalnu opasnost od „osmanske“ Krupe jer je još početkom 1560-ih predložio da se ona poruši, pritom naglasivši da je „ključ“ Bihaćke kapetanije zapravo Brekovica gdje se također nalazio važan prijelaz preko rijeke. ${ }^{395}$

Osmansko osvajanje Krupe često je prezentirano kao jedan od najkontroverznijih događaja na Hrvatskoj krajini u 16. stoljeću. Pojedini autori upirali su prstom u „njemačke“ zapovjednike optužujući ih da nisu htjeli ili se nisu usudili pomoći opsjednutoj posadi te da su sprječavali hrvatsko plemstvo da to učini „,na svoju ruku“. Izvori pokazuju da se ipak radilo o mnogo kompleksnijem problemu. Prije svega, postoje indicije da su Zrinski bili u najmanju ruku indiferentni prema sudbini utvrde na prostoru s kojeg se ta obitelj već povukla prema sjeveru. Naime, u sadržaju muhimme deftera od 29. rujna 1565. stoji da je Krupa napadnuta

\footnotetext{
${ }^{392}$ KRUHEK, Krajiške utvrde, 214. Osmanlije su opsjedali Krupu već 1522., 1523. i 1524. Vojska bosanskog paše opsjedala je 1523. četiri mjeseca grad u kojemu je kaštelan bio Ivan Novaković. Kršćanska vojska tada se okupila na Ostroškom polju i podigla novi most preko Une nakon čega su se Osmanlije povukli. STEKLASA, Padec Krupe, 173.

${ }^{393}$ KRUHEK, Krajiške utvrde, 214-215.

${ }^{394}$ SI AS 2, DSK, kutija 414, fascikl 287, Črnomelj, 11.10.1565., 1v-2r, rbr. 1408-1409. Herbart Auersperg na predstavnike kranjskih staleža.

${ }^{395}$ KRUHEK, Krajiške utvrde, 190.
} 
jer je od Zrinskog stiglo pismo u kojem je stajalo: »Ta tvrđava nije naša. Činite šta hoćete«. Budući da je habsburška strana protestirala zbog osmanskog osvajanja grada, Porta je od bosanskog bega tražila navedeno pismo da bi im ga mogli predočiti. ${ }^{396}$ Istinitost ovih tvrdnji trenutno nije moguće utvrditi, ali s obzirom na kompleksan odnos Zrinskih i Osmanlija te povlačenje Zrinskih na sjever, nikako ih ne treba a priori odbaciti.

Odmah nakon osmanskog opsjedanja utvrde bihaćki kapetan poslao je prethodnicu odnosno manji broj vojnika promatrati razvoj događaja i ohrabriti opsjednute u utvrdi s druge strane rijeke Une. ${ }^{397}$ Posada je brojala tek 28 ljudi s Matijašem Bakićem na čelu. ${ }^{398}$ Kada se habsburška vojska okupila, omjer snaga bio je otprilike izjednačen, oko 3000 ljudi s obiju strana. Osmanlije su ipak imali komparativnu prednost jer je habsburška vojska morala preći rijeku Unu koja je zbog kiša bila povišenog vodostaja. Osmanlije su već u početku opsade spalili most te sve čardake i mlinove na Uni, pa iako je habsburška vojska raspolagala s 14 čamaca, prebacivanje vojnika na drugu stranu rijeke bio je krajnje riskantan potez. ${ }^{399} \mathrm{U}$ izvorima se spominjala i mogućnost korištenja prijelaza kod Ripča, što je bila zaobilazna ruta, na kojoj je čak u slučaju uspješnog unošenja živeži i opreme u opsjednutu Krupu, prijetila opasnost od nesigurnog povratku kroz neprijateljski teritorij. Stoga je na kraju bihaćkom kapetanu naređeno da se pobrine za izgradnju mosta od čamaca (pontonski most) preko kojeg bi nadolazeća kršćanska vojska mogla u naletu prijeći rijeku i napasti Osmanlije na „,njihovoj“ strani. $^{400}$

Stvari se nisu razvijale kako su vojni planeri zamišljali. Vremenski uvjeti bili su nepovoljni, a cijeli plan opterećivao je takav nedostatak živeži (pissenbratt) da je Herbart Auersperg strahovao da će zbog gladi morati raspustiti vojsku. Uz vapaj upućen Ivanu Lenkoviću „Moj gospodaru, ne štedite novaca“, molio je da se odmah nabavi živež na području Metlike i transferira barem do Cetina. ${ }^{401}$ Osmanlije su iskopali četiri šanca odakle su topovima djelovali po gradu. Iako se dvadesetak vojnika uspjelo probiti u Krupu, nakon opetovanih osmanskih napada, vojvoda Bakić se 23. lipnja pokušao probiti iz grada s tek sedmoricom vojnika. Iako se s dvojicom uspio dokopati Une, utopio se u rijeci. ${ }^{402}$ Zanimljivo

\footnotetext{
${ }^{396}$ KOVAČEVIĆ, Muhimme Defteri, dok. 128, 78. No, krajem studenog bosanskom je begu javljeno da „u vezi sa tvrđavom Krupa i pismom koje je stiglo od Zrinskog, stalno na oprezu, jer je saznao da je Zrinski u pokretu.“. IBID., dok. 140, 83-84.

${ }^{397}$ STEKLASA, Padec Krupe, 288.

${ }^{398}$ LOPAŠIĆ, Bihać, 173.

${ }^{399}$ STEKLASA, Padec Krupe, 287-288.

${ }^{400}$ SI AS 2, DSK, kutija 209, fascikl 126, 20.6.1565, 1r-1v, rbr. 37-38.

${ }^{401}$ IBID., kutija 209, fascikl 126, Ostrožac, 20.6.1565, 1r-1v, rbr. 47-48. Herbart Auersperg na Ivana Lenkovića.

${ }^{402}$ LOPAŠIĆ, Bihać, 174-175.
} 
je da su vojne vlasti sumnjale u konspirativnu djelatnost uglednoga uskočkog zapovjednika Šobata Popovića koji se također nalazio u sastavu habsburške vojske kod Krupe. ${ }^{403}$

Nakon pada Krupe vojne vlasti bile su izrazito zabrinute zbog potencijalnoga daljnjeg osmanskog napredovanja prema Bihaću, unutrašnjosti Hrvatske i/ili okolnim zemljama. ${ }^{404}$ Još tijekom opsade Krupe oko 3500 Osmanlija napalo je Hotinac kod Bihaća. ${ }^{405}$ Početkom srpnja koruški staleži navode da je Ivan Lenković ranije javio da je 5000 Osmanlija popalilo sav potez do zidina Bihaća. ${ }^{406}$ Mogućnost osmanskoga daljnjeg napredovanja nametala se kao sasvim realna jer su Osmanlije ostali pod gradom u bojnom poretku, a svakim im je danom pristizalo sve više konjanika i pješaka, uključujući i postrojbe kliškog sandžak-bega. ${ }^{407}$ Ipak, iz za sada nepoznatih razloga, u jednom su se trenutku povukli.

Psihološki aspekt pada Krupe bio je razoran. Izvori pokazuju da je među bihaćkim stanovništvom zavladao veliki strah, a bihaćki kapetan Georg Kronschall žalio se naređenima kako sumnja da će moći obraniti grad u slučaju osmanskog napada vatrenim naoružanjem. Nedostajalo je, piše Kronschall, ljudi, streljiva, puščanog praha, olova, lopata, krampova, konopa i fitilja te raznoga ručnog oružja. Živeži je već poslovično nedostajalo i bili ju je teško nabaviti. 408

Nakon osmanskog zauzimanja Krupa će u izvorima figurirati kao najveći rival Bihaća, mjesto s jakom osmanskom posadom pod kojom će se okupljati i veće osmanske snage za napade prema habsburškom prostoru - primarno prema Bihaću. Sukobi između Bišćana i Krupljana bili su dramatični. Tako je krajem srpnja 1577. tristotinjak „Turaka, uglavnom delija“, kako je javljao bihaćki kapetan Sebastian Lamberg, neopaženo preko ada (awen) provalilo sve do bihaćkih mostova, dakle do samoga grada. Lamberg se nije usudio krenuti u potjeru jer je smatrao da za to ima premalo vojnika na raspolaganju. Tog jutra kada je kapetan pisao izvještaj, začuli su se i topovski pucnjevi iz Krupe, pa se Lamberg bojao da najavljuju dolazak Ferhad-bega, odnosno prekid primirja. Hitno je tražio pojačanje i opskrbu jer je

\footnotetext{
${ }^{403}$ Zanimljivo je da se među sumnjivim potezima Šobata Popovića navodi da je nakon pada Krupe kući vratio svog sina „,on Neustatten aus der schuel“. Nadalje, navodno su neki njegovi ljudi pod Krupom prebjegli Osmanlijama nakon čega su ovi još jače udarali na grad dok ga u sedmom jurišu napokon nisu i osvojili. Popovića su sumnjičili da se dopisuje s Osmanlijama i rodbinom na osmanskom teritoriju (anderen verwandschafft). Bilo je i drugih optužbi o uskakanju osoba iz njegove kuće u Osmansko Carstvo, kao i izjave zarobljenika da je Popović već „u Tursku“ poslao iznos od 800 talira. SI AS 2, DSK, kutija 202, fascikl 124a, Novo Mesto, 17.7.1565., 1r, rbr. 1046. Herbart Auersperg na predstavnike kranjskih staleža.

${ }^{404}$ SI AS 2, DSK, kutija 209, fascikl 126, Ljubljana, 19.6.1565, 1r, rbr. 22. Ivan Lenković, bez adresanta

${ }^{405}$ LOPAŠIĆ, Bihać, 67.

${ }^{406}$ SI AS 2, DSK, kutija 414, fascikl 284, Klagenfurt, 3.7.1565., 3r, rbr. 1017.

${ }^{407}$ SI AS 2, DSK, kutija 209, fascikl 126, Črnomelj, 27.6.1565, 2r, rbr. 76. Ivan Lenković na cara i nadvojvodu. SI AS 2, DSK, kutija 202, fascikl 124a, Ljubljana, 20.6.1565., kopija koncepta predstavnika kranjskih staleža za podizanje vojske na njihovom prostoru.

${ }^{408}$ SI AS 2, DSK, kutija 209, fascikl 126, logor kod Cetina 24.6.1565, 1v-2r, rbr. 79-80. Herbart Auersperg na Ivana Lenkovića
} 
strahovao da će nekoliko tisuća Osmanlija pokušati iznenada zauzeti grad prije nego li prekid primirja javno obznani. ${ }^{409} \mathrm{U}$ jednome anonimnom izvještaju iz 1581. navodi se pak da Osmanlije namjeravaju napasti Bihać te da su se za taj pothvat „više od svih drugih Turaka ponudili oni iz krupskih strana“. Krupljani su tog puta vjerojatno bili dodatno motivirani za napad jer čini se da je nešto ranije i sama Krupa bila spaljena. ${ }^{410}$

Osmanlije su napade izvodili ne samo kopnom već su u nekoliko navrata pokušali napasti Bihać spuštajući se čamcima uzvodno rijekom Unom. Tako se krajem svibnja 1584. pod Krupom okupilo nekoliko tisuća osmanskih vojnika koji su raspolagali i brodovima ili čamcima (schiffen). ${ }^{411}$ Vjerojatno je cilj bio Bihać, ali trenutno ostaje nepoznato kakav je bio rezultat ovoga velikog okupljanja. Međutim, i habsburška strana je imala uspjeha $u$ međusobnim razračunavanjima s Krupljanima. Thomas Naglić javio je u lipnju 1574. da je iz Stijene došao Luka Škarasić (Luckha Schkharasytsch) te izvijestio da je pod Krupom rasprostrto „bezbroj“ osmanskih vojnih šatora (vnzelich vil hörhutten). Radilo se zapravo o okupljanju oko 700 konjanika i pješaka koji su namjeravali napasti bihaćku Otoku (werd) do koje su čak i dojahali te promotrili situaciju. No, u Bihaću se nalazio stanoviti Radolla (vjerojatno uskok) koji je navodno sa svojim ljudima krenuo za Osmanlijama, neopaženo se približio njihovu logoru pod Krupom namjeravajući ukrasti konje Osmanlijama na spavanju. Budući da je sve bilo sasvim mirno, promijenili su plan i odlučili napasti pri čemu su uništili nekoliko vojnih šatora (horhutten) i likvidirali do 50 „Turaka“. Oteli su sedam konja, od kojih su dva bila dobri gospodski ili vojni konji (gute heren Roß). Bihaćki kapetan je za jednog nudio 200 talira. Ipak, treba napomenuti da je naređeno da se ovaj iskaz dodatno provjeri. ${ }^{412}$ U prosincu 1580. godine habsburška je vojska četovala pod Krupu, zarobila 19 ljudi, 15 konja i 20 volova. $^{413}$

\footnotetext{
${ }^{409}$ SI AS 2, DSK, kutija 286, fascikl 164, Bihać, 26.7.1577., 1r, rbr. 372. Sebastian Lamberg na kranjske Verordneten.

${ }^{410}$ „seidthero Khrupp außprendt“. SI AS 2, DSK., kutija 287, fascikl 164, 1r, rbr. 879. Nema potpisa, datacije ni mjesta.

${ }^{411}$ SI AS 2, DSK, kutija 202, fascikl 124a, 22.5.1584., kapetan Hörner, valjda u Bihaću.

${ }^{412}$ SI AS 2, DSK, kutija 286, facikl 164, Črnomelj, lipanj 1574., 1r, rbr. 258. Thomas Naglić na zemaljskog kapetana Kranjske.

${ }^{413}$ HDA, Croatica, mikrofilm, D-1913, prosinac 1580., 240.
} 


\subsubsection{Nastavak osmanskog napredovanja uz rijeku Unu}

Nakon pada Krupe velike ratne operacije preselile su se na ugarski teritorij, ali to nije zaustavilo osmanske napade na hrvatskom prostoru. Krajem travnja 1566. habsburški je špijun javljao senjskom vicekapetanu da ,se na Bihać spravlja tri sanžaki. Mustaf beg i ovi novi hlivanjski lunbarde s mista su ganuli, načijnaju se brašna svakomu kvarte dvi.“ Mustafabegu bilo je „narejeno“ napasti krajinu. ${ }^{414}$ Radilo se o već navedenom slučaju kada su Osmanlije pravili konope s daskama kako bi preko rijeke Une upali u grad. Senjski kapetan Herbart Auersperg smatrao je da ako se Bihać, Ripač, Hrastovica ili Sisak ne ojačaju ljudima, vatrenim naoružanjem, streljivom i opremom, nitko ,pod ovozemaljskim suncem“ ne može ni pomisliti da će se u slučaju napada održati, već će zajedno s cijelom Hrvatskom pasti u neprijateljske ruke. ${ }^{415}$

Već sredinom ožujka 1566. ripački porkulab Ivan Izačić traži pomoć od Ivana Lenkovića ovim riječima: „A sada (Vaša) M(ilost) neka znate, da malo manj k nam vsaki dan Turchi dohode, s jedne strane Krupljani a z druge Udvinjani i ne dadu nam ni van izlisti. I sada u četartak dohodi k nam veće dvisto Krupljanov i bihu nam kod samoga grada dvi busije učinili i malo vsi ne zgibosmo i uzeše nam dva soldata i vsu živinu, ča smo je imali. I njih pukšari bihu nam pred samimi vrati u pajatah zaseli i striljaše se ondi s nami veće od jednu uru i pojate nam vse požgaše. Zato $\mathrm{V}($ ašu) $\mathrm{M}$ (ilost) molimo da našega premilostivog g(ospo)dina priglejte nida sada veće ljudi k nam, zašto nam ne dadu ni van izlisti““. ${ }^{416}$ Ovaj apel zorno svjedoči o opetovanim udarima s boka na bihaćki prostor, iz smjera Krupe i Udbine, kao dva najvažnija osmanska uporišta na ovom prostoru. Pripreme za napad na Bihać ili Ripač potrajale su i u travnju i svibnju, a Osmanlije su naredili dopremu velikih topova u Krupu. $^{417}$

Budući da je primio obavijesti da će Osmanlije udariti na Ripač, bihaćki kapetan Matiasch Mori sredinom lipnja sljedećim je zanimljivim diskursom apelirao na bana i hrvatsko plemstvo da odmah asistiraju: „Oberh Ripča su jur veće od osamdeset ladji udilali, u čem se budu vozili i po vodi Ripču, kad ga budu terli, jagmu davali. A ovo je jur danas dvadeset dan, da je ov naš neprijatelj spravan na glavi Ripču i Bihću, a od tolika vrimena da ne bi od vas jednoga konjika ni pišca ni nijedne pomoći malo ni vele. Zato ako ča kadi kanite učiniti, ne odvlačite tomu, da se pod Krupom, zač ako budete tomu toliko dugo odvlačili,

\footnotetext{
${ }^{414}$ BOJNIČIĆ, Izvješća, dok. XXVIII, 81.

${ }^{415}$ IBID., dok. XXXI, 85.

${ }^{416}$ IBID., dok. XXVI, 79.

${ }^{417}$ IBID., dok. XXXII, 87.
} 
oćete i ovo poslati da ste i Krupu. Ripač i Bihać to je vse jedno. Ako se tomu gradu komu ča primiri, vi znate, da će tamo ostala zemlja pojti, a vi od toga činite, da najbolje znate, ili sada ili veće nigdar“. 418

Dakle, Osmanlije su namjeravali tijekom opsade rijekom Unom napasti i Ripač čiji značaj za Bihać još jednom potvrđuje i Mori apostrofirajući da su Bihać i Ripač „vse jedno“. Mori je apel poslao 15. lipnja te taj isti dan glagoljskim pismom obavijestio i senjskoga kapetana o događajima oko Ripča. Mori javlja da je dan ranije okupio „vse ove ljudi c(esarske) s(vitlosti) soldate oko sebe“ te krenuo „na Ripač gdje je s one strane Ripča za onom crikvom“ naletio na nekoliko osmanskih konjanika na straži koji, primijetivši ih, ,gori klancem pobigoše“. Mori je tamo sa svojim ljudima ostao do noći „načinjajući on most s one strane, ča su Turci bili došadči u noći raskinuli i vas on kraj do zvoja s nova dobro načinismo i još dosta lisa pripravismo vsemu o(s)talomu mostu. Onu crikvu s one strane, tu smo vsu na tla obaili i sravnjali ripački klanac s one iste strane. Ta su Turci lipo široko rasčistili i zakopali i sravnjali vsega od kraja do kraja, kuda budu mogli lipo doli s one strane pod Ripač pukše dovesti““ ${ }^{419}$ Ovaj navod pokazuje karakter krajiškog ratovanja, zaposjedanje komunikacije, opstrukcije prilaza, destrukciju postojećih građevina, mali rat u svojemu klasičnom izdanju te svu kompleksnost nužnih intervencija u prostor kako bi se topovi dopremili na željeno mjesto.

Nakon potpisivanja mira u Adrianopolju 1568. između Habsburške Monarhije i Osmanskog Carstva te izbijanja osmansko-mletačkog rata 1570. na Hrvatskoj krajini nastupilo je mirnije razdoblje. Smirivanjem rata s Mlečanima ponovno je aktivirana fronta prema Hrvatskoj krajini. Od 1572. do 1575. Osmanlije su na hrvatski prostor upali trideset puta, a 1576. navodno čak šezdeset puta. Prema izvještaju namjesnika zapovjednika Hrvatske krajine Jobsta Josepha Thurna, u tom periodu s hrvatskog prostora odvedeno je oko 12000 ljudi. ${ }^{420}$ Iako je broj možda preuveličan, zaista se radilo o teškim demografskim gubicima.

U fokusu napada bili su krajevi oko Hrastovice, Bovića i Steničnjaka, dakle područje nešto sjevernije i sjeverozapadnije od rijeke Une i onih utvrda na unskom prostoru koje će ubrzo, kao kula od karata, pasti pod osmansku vlast. Teško je reći je li to bila svjesna taktika zaokruživanja, da li se išlo za plijenom u još uvijek dobro napučenim krajevima ili je procijenjeno da se radi o slabije branjenom području. Vjerojatno ponešto od svega navedenog.

\footnotetext{
${ }^{418}$ IBID., dok. XXXIV, 89.

${ }^{419}$ IBID., dok. XXXV, 89.

${ }^{420}$ SIMONITI, Turki su, 180.
} 
$\mathrm{Na}$ početku ove faze intenzivnih osmanskih napada buknula je na hrvatskoslovenskom prostoru velika Seljačka buna 1573. u čijem su gušenju sudjelovale i vojne postrojbe Bihaćke kapetanije. Štoviše, u sukobu s pobunjenim seljacima kod Krškog poginuo je pogođen u lice i sam bihaćki kapetan Daniel Lasser. ${ }^{421}$ Takav razvoj događaja, odnosno pogibija kapetana u periodu interne nestabilnosti predstavljala je potencijalno veliku ugrozu za Bihać. I zaista, Osmanlije su iz Krupe dvaput 1573. napali Bihać i okolicu, ali nije došlo do velikog napada od kojeg se toliko strahovalo. Štoviše, krajem studenog 1573. negdje na bihaćkom prostoru navodno je došlo do sukoba u kojima je zarobljeno šest uglednih Osmanlija i jedan aga. ${ }^{422}$

Sukobi su se nastavili i sljedeće godine. U ožujku 1574. Marko Latnišić iz Cetina pisao je da su Osmanlije pod Bihaćem oteli mnogo komada stoke te zarobili čak 52 njemačka vojnika i haramija! Gubitak tolikog broja vojnika u onodobnom je kontekstu predstavljao lokaliziranu katastrofu. U rujnu 1575. došlo je do jednoga većeg napada, ali je Ferhad-begov pokušaj zauzimanja grada odbijen. Begove postrojbe palile su zato na sve strane. ${ }^{423}$ Auersperg je sredinom rujna pisao da mu je iz Bihaća stigla obavijest da pet sanđaka, bosanski, livanjski, požeški, pakrački i Allay Weeg von Belay namjeravaju napasti Bihać sa sedam velikih topova. Tražio je slanje unajmljenih strijelaca i potrebna sredstva. ${ }^{424}$ U listopadu je senjski kapetan javio da je iz Zadra pristigla obavijest od Šimuna Kanelića (Simon Khanelitsch), koji je razgovarao s jednim povjerljivim „Turčinom“, da se sprema opsada Bihaća te da je 60 osmanskih konjanika poslano prema gradu kako bi izvidjeli može li se preći rijeka. A vodostaj Une je bio toliko nizak da se to lako moglo učiniti. ${ }^{425}$

\footnotetext{
${ }^{421}$ VALVASOR, Die Ehre, IV svezak, knjiga XII-XV, 12.

${ }^{422}$ SIMONITI, Prispevek k poznavanju, 497.

${ }^{423}$ IBID., 501.

${ }^{424}$ SI AS 2, DSK, kutija 419, fascikl 287, 17.9.1575., 1r, rbr. 383. Hans Auersperg na kranjske Verordneten.

${ }^{425}$ SI AS 2, DSK, kutija 419, fascikl 287, Senj. 15.10.1575., 1r. Senjski kapetan na Hansa Auersperga.
} 


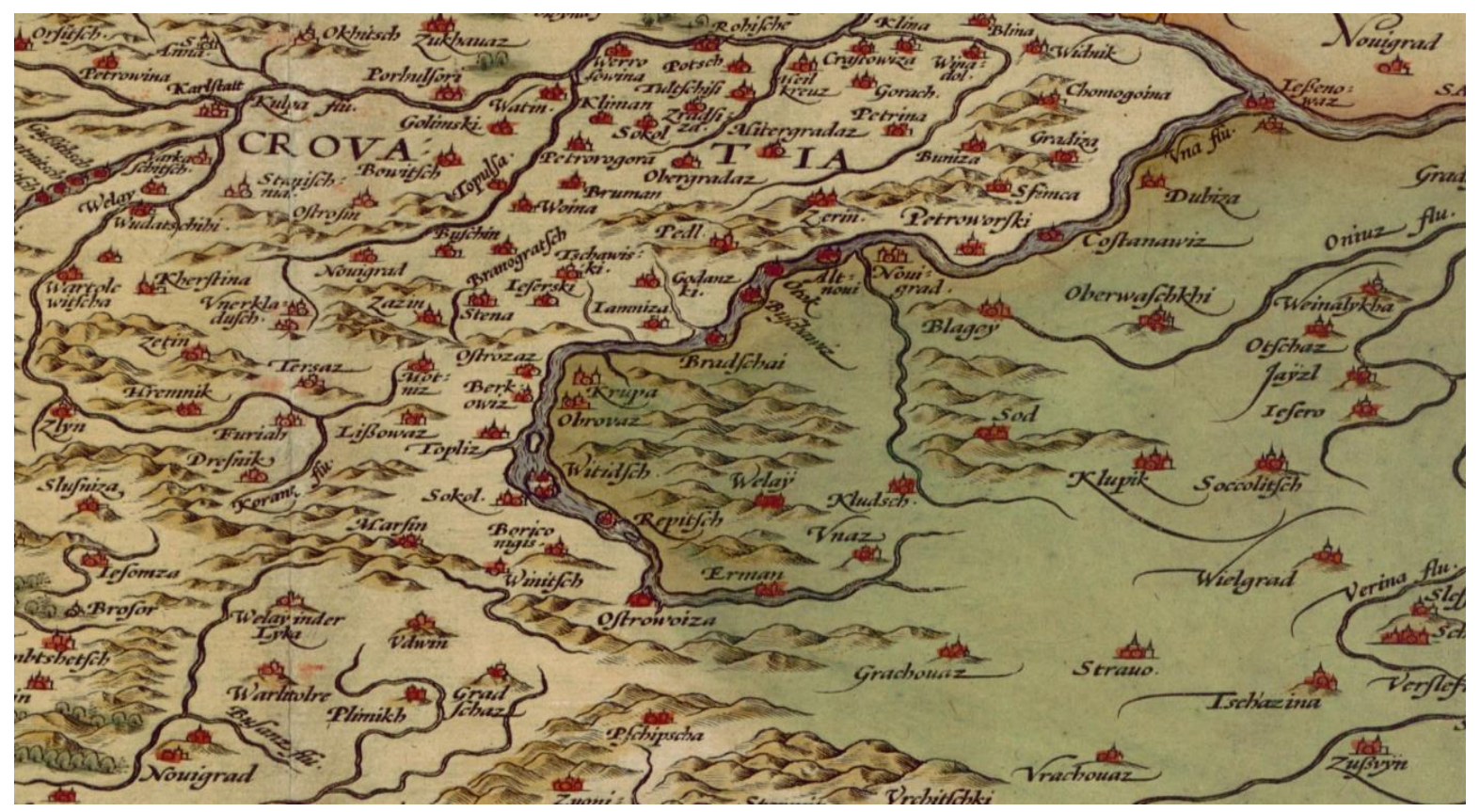

Slika 16. Prikaz Hrvatske krajine na karti iz $1572{ }^{426}$

No, vrhunac osmanske ekspanzije tek je slijedio. Osmanlije su simultano s frekventnim napadima sustavno obnavljali i zaposjedali uništene i/ili napuštene utvrde te kolonizirali vlaško stanovništvo u zaposjednute krajeve. ${ }^{427}$ Uvertira u seriju poraza na unskoj fronti je gubitak Stijene krajem 1575. Ta utvrda je u izvorima navedena kao „ain fürnemen Scarthauß“ od Bihaća udaljena tek tri njemačke milje, a od Krupe jednu i pol. ${ }^{428}$ Prema izvještaju krajiškog povjerenstva1563., Stijena je već tada bila u tako lošem stanju da je predloženo njezino rušenje i premještanje posade na stražu kod Svetog Jurja u Ostroškom polju i Toplički Turanj. Prema potrebi u Stijeni se moglo ostaviti tek stražu od šest vojnika. ${ }^{429}$ No, u trenutku pada, Stijenu je čuvala tek jedna jedina osoba dok je ostatak posade otišao po živež. ${ }^{430}$ Dakle, Osmanlije su je zauzeli bez osobitog truda. Zapovjednik Hrvatske krajine predbacivao je kasnije kranjskim Verordneten jer nije na vrijeme stigao novac za živež dok su oni pak odbacivali odgovornost, navodeći da vode brigu o vojnim potrebama, te da su ionako kasno primili njegovo pismo - kad je Stijena već izgubljena. Sugerirali su da bi živež bio

\footnotetext{
${ }^{426}$ HDA, Kartografska zbirka, A II 17.

${ }^{427}$ JUG, Turški napadi, 50.

${ }^{428}$ SI AS 2, DSK, kutija 805, fascikl 540, Ljubljana, 15.11.1575., 1r. Kranjski Verodenten na Jobsta Josepha Thurna.

${ }^{429}$ KRUHEK, Krajiške utvrde, 256-257.

${ }^{430}$ SI AS 2, DSK, kutija 805, fascikl 540, Ljubljana, 15.11.1575., 1r-1v. Kranjski Verordneten na Jobsta Josepha Thurna.
} 
dostavljen te da vojnici nisu ni trebali odlaziti izvan utvrde, pa bi utvrda još bila u habsburškim rukama. ${ }^{431}$

U prvim mjesecima 1576. ponovno je stradao kraj oko Steničnjaka, ${ }^{432}$ a u travnju 1576. velika osmanska vojska od 7000 ljudi bezuspješno je napala Hrastovicu te u povratku spalila kaštel Peći i zarobila oko 150 ljudi. Stanje na krajini je zaista bilo dramatično. Auersperg se jadao kranjskim Verodneten zbog loše situacije na krajini, jer vojnici nisu plaćeni te gladuju pa mu je teško s njima izaći na kraj. Ako se ništa ne učini, neće se izgubiti samo glavne krajiške utvrde već će Osmanlije prodrijeti i u Kranjsku, tvrdio je. Naveo je i da mu odasvud s krajine dolaze upozorenja kako se Osmanlije pripremaju za daljnje napade te da ulaže Protestando i odbija krivnju za eventualne nedaće. Tražio je hitnu asistenciju. ${ }^{433}$

U lipnju 1576. Osmanlije osvajaju prvo Bužim, pa onda i Hojsićev Gradac/Kaštel te bivši posjed kninskog biskupa, Cazin. Nakon osvajanja Bužima napali su rudnike u Gvozdanskom, ali je njihov napad suzbio Hans Auersperg. Istodobno s opsadom Cazina, opsjeli su i Ostrožac, a zatim i sam Bihać. ${ }^{434}$ Već 2. lipnja 1576. u konceptu odgovora na izvještaje Hansa Auersperga predstavnici kranjskih staleža navode da špijuni javljaju da će Osmanlije, točnije bosanski i kliški begovi, opsjesti Bihać. Auersperg je upozoravao na opasnost i tražio podizanje zemaljskog ustanka u Kranjskoj dok su predstavnici staleža dvojili o tome hoće li neuvježbani ljudi moći bilo što učiniti, a nedostajalo je i novaca i živeži. Također, navodili su da podignuta vojska nije dužna ratovati izvan granica Kranjske, a i ako bi se to učinilo, u Hrvatskoj nema utvrde u koju bi se takva vojska mogla skloniti od opasnosti. Ipak, naredili su da se podignuta konjica i prema određenom ključu mobilizirano stanovništvo drži u pripravnosti te odredili raspored u slučaju da se signalizira opasnost. Odlučeno je i da arkebuziri (schützen pferd) prate živež za Bihać, a bihaćkom je kapetanu pisano da odmah mora krenuti prema Črnomlju i pratiti opskrbni konvoj u grad. ${ }^{435}$

Nadvojvoda Karlo piše 4. lipnja da mu je Auersperg javio da se Osmanlije pripremaju u roku od četrnaest dana opsjesti Bihać te istodobno traži pomoć. Nadvojvoda je tražio od kranjskih Verordenten da se promptno isplati plaća za uskoke i tri stotine strijelaca. ${ }^{436}$ Auerspergu je pak naredio da odmah opskrbi Bihać. ${ }^{437}$ No, zatraženo/planirano očito nije bilo

\footnotetext{
${ }^{431}$ SI AS 2, DSK, kutija 805, fascikl 540, Ljubljana, 15.11.1575., 2r. Kranjski Verordneten na Jobsta Josepha Thurna.

${ }^{432}$ Krajem veljače 1576. iz okolice Steničnjaka i Ostrožina odveli su 297 osoba. SIMONITI, Prispevek, 88.

${ }^{433}$ SI AS 2, DSK, kutija 287, fascikl 164, Žužemberk, 14.4.1576., 1r, rbr. 537. Christoph Auersperg na kranjske Verordneten.

${ }^{434}$ IBID., 89.

${ }^{435}$ SI AS 2, DSK, kutija 287, fascikl 164, Ljubljana, 2.6.1576., 1r-3r, rbr. 550-554.

${ }^{436}$ SI AS 2, DSK, kutija 287, fascikl 164, Graz, 4.6.1576., 1r-1v, rbr. 555-556.

${ }^{437}$ SI AS 2, DSK, kutija 287, fascikl 164, Beč, 18.6.1576., 1r-1v, rbr. 559-560.
} 
(u potpunosti) realizirano zato što je 20. srpnja 1576. bihaćki kapetan Sebastian Lamberg pisao kranjskim Verordneten da se on, vojnici te svi građani i seljaci (Burger vnnd Paurschafft) ne mogu načuditi činjenici da su se, unatoč svim upozorenjima i izvještajima, tako loše ponijeli i ignorirali ih. ${ }^{438}$ Budući da „Turci jednu utvrdu za drugom napadaju“, Lamberg je molio novac za vojnike i straže te platno kao dio plaće za vojsku. ${ }^{439}$ Osmanlije su oko Bihaća pustošili i 30. kolovoza $1576 .{ }^{440}$ Balthasar Gall, zapovjednik zemaljskog ustanka (zuezug des gemeinen Manns) u Kranjskoj, dva je dana ranije (28. kolovoza) predviđao da će Osmanlije sigurno upasti u Kranjsku ili napasti Bihać. ${ }^{441}$ Podignuti zemaljski ustanak u Kranjskoj na kraju je ipak raspušten, no odlučeno je da se 200 strijelaca pošalje u Bihać. ${ }^{442}$ Ubrzo Auersperg javlja da mu je iz Banja Luke upravo stigao jedan špijun koji navodi da je Ferhat-begu stigao ćehaja iz Carigrada koji mu je donio jednu okovanu sablju, jedan okovani buzdovan i jedan bodež te sultanovu naredbu da mora proširiti svoju krajinu (Granizen). Da bi to izveo, podređeno mu je još pet sandžaka, a „sein Prouision Jarhlich“ povišena za 5000 dukata. Paša je planirao u roku od mjesec dana napasti Bihać ili Sisak. ${ }^{443}$ No, do napada na Bihać tada ipak nije došlo.

Kada je habsburški poslanik na Porti barun David Ungnad tražio da se vrate utvrde osvojene usprkos važećem primirju, odgovoreno mu je da su u Cazinu i Bužimu već podignute džamije pa je to neizvedivo. Iako je Ferhat-begu Sokoloviću naređeno da se mora držati odluka primirja, napadi su se nastavili čak i kada je primirje, koje je prekinuto nakon smrti cara Maksimilijana 12. rujna, obnovljeno 25. prosinca 1576. No prava katastrofa zbila se u rujnu 1577. kada su postrojbe bosanskog i hercegovačkog paše zauzele Gornju i Donju Kladušu, Šturlić, Podzvizd, Peći i Ajtić-grad te oplijenili prostor oko Hresna na Glini i Smrčkovića. ${ }^{444}$ Krajem srpnja tristotinjak Krupljana, većinom delija, napalo je Bihać. ${ }^{445}$ Već u

\footnotetext{
${ }^{438}$ SI AS 2, DSK, kutija 287, fascikl 164, Bihać, 20.7.1576., 1r-1v, rbr. 562-563.

${ }^{439}$ SI AS 2, DSK, kutija 287, fascikl 164, Bihać, 20.7.1576., 1r-1v, rbr. 563.

${ }^{440}$ LOPAŠIĆ, SHK, knjiga I, dok. XVI, 24.

${ }^{441}$ SI AS 2, DSK, kutija 287, fascikl 164, 20.7.1576., 1r, rbr. 624.

${ }^{442}$ SI AS 2, DSK, kutija 287, fascikl 164, Metlika, 6.9.1576., 1v, rbr. 675. Christoph Auersperg na predstavnike kranjskih staleža. Auersperg piše početkom rujna 1576. da mu je naređeno da sa svojim postrojbama ne prelazi „Confin zu Crabatten“ već da pričeka dolazak postrojbi iz Koruške i grofovije Gorice koje su trebale pristići kroz nekoliko dana. SI AS 2, DSK, kutija 287, fascikl 164, Metlika, 6.9.1576., 1r, rbr. 674. Smatrao je da je ipak potrebno ostaviti koruške i goričke postrojbe u Kranjskoj, gdje će ih se lakše moći uzdržavati, barem dok ne stignu nove vijesti. SI AS 2, DSK, kutija 287, fascikl 164, Metlika, 8.9.1576., 1r, rbr. 701. Christoph Auersperg na predstavnike kranjskih staleža.

${ }^{443}$,ein beschlagene Säbl ein beschlagnen Khelber oder Wußdahan gennandt sambt einen stäher". SI AS 2, DSK, kutija 287, fascikl 164, Metlika, 9.9.1576., 1r, rbr. 720. Christoph Auersperg i Casper Lamberg na predstavnike kranjskih staleža.

${ }^{444}$ SIMONITI, Prispevek k poznavanju, 91-93.

${ }^{445}$ LOPAŠIĆ, SHK, knjiga I, dok. XVI, 24; SI AS 2, DSK, kutija 286, fascikl, 164, Bihać, 26.7.1577., 1r, rbr. 372. Bihaćki kapetan Sebastian Lamberg na kranjske Verordneten.
} 
listopadu zauzeli su Bojnu i Sračicu, u studenom spalili kaštel Mazin na Glini, sredinom studenog zauzeli Ostrožac ${ }^{446}$, a bezuspješno napali Izačić. Krajem studenog 1577. Osmanlije napadaju Bihać, 20. prosinca osvajaju Zrin, a sredinom siječnja 1578. i Gvozdansko. ${ }^{447}$ Krajem ožujka 1578. Osmanlije zauzimaju i Drežnik zbog čega su, između ostalog, protestirali habsburški poslanici na Porti. ${ }^{448}$ Vojne vlasti i kranjski staleži energično su nastojali doskočiti svim problemima, a osobito su vodili brigu o obrani Bihaća. Tako je krajem studenog 1577. od 300 unajmljenih strijelaca (hagkhenschützena) polovica trebala biti poslana u Bihać, a ostatak raspoređen oko Bužima, Cazina i Ostrošca, već prema potrebi. ${ }^{449}$

U ovaj period spada i jedna ,neprovjerena“ vijest o osmanskom privremenom zauzimanju Metlike u travnju 1578. pri čemu je osmansku vojsku navodno, pri povratku kod Bihaća, napala i porazila seljačka sila od 9000 ljudi. ${ }^{450} \mathrm{U}$ izvorima nema spomena o ovom događaju koji je svakako trebao ostavio trag u arhivskom gradivu, ako se zaista i dogodio. Kranjski staleži spominju i opsadu Bihaća u kolovozu $1578 .{ }^{451}$

Još uvijek nije sasvim razjašnjeno kako je Osmanlijama uspjelo tako brzo ostvariti ovakav niz impresivnih vojnih uspjeha na unskom prostoru. Ti napadi bili su toliko intenzivni da se zapovjednik Hrvatske krajine Hans Auersperg u ožujku 1578. žalio da je na njega pao teret obrane krajine u najtežem trenutku te da bi bilo bolje da odstupi nego da praznih ruku, tjeskoban i teška srca svakodnevno promatra sve što se dešava. ${ }^{452}$ Nema sumnje da je Porta podupirala pa i tražila od Ferhad-bega osvajanja na ovom prostoru. Naime, u jednom Auerspergovom izvještaju iz rujna 1577. navodi se da su uskoci zarobili stanovitog Osmanliju iz Bužima koji da je kod Cetina zasužnjio troje ljudi, a koji je nakon ispitivanja otkrio da Ferhat-beg u Kostajnici okuplja vojsku za napad na Bihać ili Gvozdansko te da je nekoliko dana ranije begu stigao sultanov čauš s porukom da ako još ove godine ne zauzme Bihać, Sisak i Gvozdansko, sultan će znati kako ,s njime postupiti““ ${ }^{453}$ Dakle, poticaj iz središta

\footnotetext{
${ }^{446}$ Ostrožac je bio opsjednut i u srpnju 1576. kada bihaćki kapetan Sebastian Lamberg moli da se opsjednutima pošalje pojačanje jer ne mogu po drva, vodu ni ikakve potrepštine. SI AS 2, DSK, kutija 287, fascikl 164, Bihać, 20.7.1576., 1v, rbr. 563. Bihaćki kapetan Sebastian Lamberg na kranjske Verordneten.

${ }^{447}$ SIMONITI, Prispevek k poznavanju, 93-94.

${ }^{448}$ AHAZU, Lopašić, E. Prijepisi iz austrijskih arhiva, br. 17, str. 1-2.

${ }^{449}$ SI AS 2, DSK, kutija 287, fascikl 164, Ljubljana, 18.11.1577., 1v-2r, rbr. 758-759. Predstavnici kranjskih staleža na Hansa Auersperga.

${ }^{450}$ SIMONITI, Prispevek k poznavanju, 96.

451 JUG, Turški napadi, 49. Lopašić navodi da je u travnju 12000 Osmanlija opsjelo Bihać, ali da se okupilo 9000 hrvatskih seljaka koji su ih napali i porazili. LOPAŠIĆ, Bihać, 72.

${ }^{452}$ SI AS 2, DSK, kutija 202, fascikl 124, Pobrežje, 31.3.1578., 1v. Hans Auersperg na kranjske Verordneten.

453 ,mit disem ernstlichen außtrükhlichen auferlegen vnd Beuelchen ankhumen sey: Wouer der Beeg noch dis Jars Wihitsch, Syssakh vnnd Goßdannskho nit Einnembe, das der Khaiser alßdan mit Ime wool zuerfaren wisse. " SI AS 2, DSK, kutija 286, fascikl 164, zadnji dan rujna 1577, 1r, rbr. 289. Hans Auersperg na predstavnike kranjskih staleža. Otkriće i ponovno stavljanje u pogon zapuštenog rudnika Miloglav između Kamengrada i Ključa početkom 1570-ih od velike je važnosti za daljnji tijek osmanskih osvajanja u Pounju.
} 
osmanske vlasti nedvojben je, o čemu svjedoče i izvori koji su u tekstu ranije navedeni. ${ }^{454}$ Nadalje, jedan od ključnih elementa poraza definitivno leži u problemu neisplate plaća i manjkavoj opskrbi plaćene vojske što se konstantno pojavljuje u dopisima krajiških časnika iako takvi problemi, pa onda i diskurs, nisu predstavljali novost u krajiškom kontekstu. No, činjenica da su dio utvrda radi neisplate plaća i gladi vojne posade same napustile pokazuje da je situacija eskalirala do točke pucanja. ${ }^{455} \mathrm{Da}$ je lokalno stanovništvo toga bilo svjesno, pokazuje apel predstavnika bihaćke gradske općine i gradske posade s početka prosinca 1577 . u kojem su naveli: „Vidite li, gospodo, kolike grade Turci zavješe, da nijedan človik ni porkulab u njih nepoginu. Nebi špot ni sramota, da bismo je izgubili bojem ali krvi prolitjem. A ovi zločesti (biedni) junaci, ki su soldati, Nimci, Hrvati ti jure dalje nemogu nas čuvati, ni ove nevoljne kuće cesarove svitlosti, goli i lačni i neplaćeni“‘. 456

Također, ne dovodeći u pitanje osmansku vojnu spremu, taktiku i odlučnost, pri analizi ovih događaja ipak treba uzeti u obzir i potencijalne prevratničke akcije među lokalnim stanovništvom i posadama. U Auerspergovu izvještaju s kraja rujna 1577. stoji da „su utvrde jedna za drugom zbog izdaje i očaja izgubljene“, a on tome nije mogao pronaći rješenja. ${ }^{457}$ Zanimljivo je, recimo, da je deset godina ranije, kada se nakon pada Krupe ispitivalo zarobljenike u pogledu potencijalne izdaje istaknutog uskoka Šobata Popovića, „isplivala“ informacija da u Stijeni djeluje dvoje ili troje osmanskih špijuna. ${ }^{458}$

\footnotetext{
Unatoč komplikacijama, rudnik je operativan od sredine 1570-ih te je započela intenzivna proizvodnja topovskih kugli. JURIN-STARČEVIĆ, Osmanski krajiški, 100. Porta je u spomenuti rudnik poslala Yürüke, odnosno turkmenske nomadske i polunomadske konjanike koji su inače služili kao pomoćne vojne jedinice i kolonizatori raznih područja u Carstvu. Iako nisu bili pretjerano sretni s time, svojim su djelovanjem unaprijedili proizvodnju topovskih kugli. Iza 1574. u rudniku su šest mjeseci radili i Tatari. Vjeran KURSAR, Being an Ottoman Vlach: On Vlach Identity(ies), Role and Status in Western Parts od the Ottoman Balkans ( $15^{\text {th }}-18^{\text {th }}$ Centuries), OTAM, 34, 2013., 119-120.

${ }^{454}$ Za protest koji je protiv Ferhat-bega Sokolovića velikom veziru Mehmed Paši Sokoloviću u svibnju 1578. podnio habsburški orator u Carigradu vidi ŠTEFANEC, Država ili ne, 279-280.

${ }^{455}$ Primjerice, ,„mladi Kobasić“ uzeo je novac za mjesečnu plaću svoje posade, a zatim najbolje vojnike odveo sa sobom ostavivši na položaju tek četvero osoba. Bihaćki kapetan Lamberg zahtijevao je da moraju biti na svojim mjestima, ako su za to već primili plaću i preuzeli odgovornost za obranu. SI AS 2, DSK, kutija 287, fascikl 164, Bihać, 20.7.1576., 2r, rbr. 564. Sebastian Lamberg na predstavnike kranjskih staleža.

${ }^{456}$ LOPAŠ́IĆ, Bihać, 70.

457 ,ein Fleckhen nach dem andern wie zusehen durch verratterey vnd auß verzweifelung verlohren wirdet, deme Ich aber weiter durchau $\beta$ khein mitl zuerdennkhen weiß". SI AS 2, DSK, kutija 286, fascikl 164, Steničnjak, zadnji dan rujna 1577, 1v, rbr. 288. Hans Auersperg na predstavnike kranjskih staleža. Lamentirajući o padu Zrina početkom siječnja 1578., Thomas Dornberg piše da je više ljudi poginulo pri padu grada nego u „zih tih gradih zdola imenovani(h): u Buzinu, u Chazinu, u Boinoi, u Pozvizdu, u Krachichah" što također pokazuje da su neka mjesta odviše lako izgubljena. BOJNIČIĆ, Izvješća, dok. XXXIX, 94.

${ }^{458}$ SI AS 2, DSK, kutija 202, fascikl 124a, Pobrežje, 17.7.1565., 2r, rbr. 1048. Hans Auersperg na predstavnike kranjskih staleža.
} 


\subsection{4. „Hrvatska ekspedicija“ 1578 .}

Dramatični teritorijalni gubici na unskom prostoru rezultirali su povećanim ulaganjima $\mathrm{u}$ Hrvatsku krajinu te direktno utjecali na tijek rasprava na saboru u Brucku na Muri 1578. gdje se intenzivno raspravljalo o strategiji obrane Hrvatske krajine, odnosno ozbiljno načetoga unskog fronta. Najviše se diskutiralo o povlačenju obrambene linije s toka rijeke Une na rijeku Glinu, odnosno o sudbini tamošnjih utvrda. Postavljalo se pitanje treba li ih napustiti ili pokušati zadržati. Jedan od prijedloga povlačenja s rijeke Une na Glinu, o kojem se tada raspravljalo na unutrašnjeaustrijskoj razini i habsburškim dvorima, sadržavao je radikalan prijedlog o napuštanju samog Bihaća. Naime, u tom slučaju zadržao bi se Ripač ,te umjesto Bihaća, ali na najpovoljnijem mjestu na otoku, (trebalo bi, op.a.) izgraditi jedan bastion ili čvrstu kulu za pedeset vojnika.“459 Podizanje kule na bihaćkom otoku (očito Otoci) pretpostavljalo je pak zadržavanje Tržca, postupno rušenje svih drugih mjesta između Une i Gline, uz iznimku Vranograča koji je bio bitan za asistenciju obližnjem Topuskom. ${ }^{460}$ Mostove kod Kostajnice i Novog trebalo je uništiti, podići zasjeke i dva Blockhausa ${ }^{461} \mathrm{~s}$ „kršćanske“ strane rijeke Une te ojačati Hrastovicu da bi se spriječili osmanski upadi u zaleđe. ${ }^{462}$ Nadalje, Osmanlijama je trebalo uskratiti prolaz ili kod Krupe, ili kod Cazina i Ostrošca ili pak na sva tri mjesta jer bi inače postojala mogućnost da se privuku s leđa te opstruiraju dopremu živeža. ${ }^{463}$

Dakle, $u$ tom se trenutku na najvišoj razini vrlo ozbiljno razmišljalo o evakuaciji obrane s rijeke Une na rijeku Glinu, napuštanju većine glavnih utvrda na unskom prostoru, zadržavanju Ripča(!) te pretvaranju Bihaća u malo jaču isturenu obrambenu fortifikaciju. Zadržalo bi se i nekoliko utvrda ključnih za komunikaciju s „transformiranim“ Bihaćem i/ili Topuskim, ali su sva ostala mjesta između rijeka Une i Gline trebala biti razrušena. U to vrijeme spomenuti koncept „zatvaranja“ prostora aktualna je tema vojnostrateških promišljanja, a očituje se i u ovom prijedlogu. Ključni elementi toga defenzivnog koncepta bili su rušenje mostova i blokiranje prolaza na glavnim prijelazima preko rijeke Une.

Međutim, ovi prijedlozi u konačnici nisu realizirani već je odlučeno pokrenuti napadnu operaciju akciju ograničenog dosega s ciljem osvajanja toka rijeke Une i deblokade

\footnotetext{
459 ŠTEFANEC, Država ili ne, 302.

${ }^{460}$ IBID.

461 Blockhaus je čardak na kat u koji se moglo smjestiti oko 20 ljudi. Za razliku od Blockhausa, Wachthaus je prizemni čardak, stražarnica u kojoj je moglo biti smješteno od 10 do 18 vojnika. KRUHEK, Krajiške utvrde, 26, fusnota 19.

462 ŠTEFANEC, Država ili ne, 288-289.

${ }^{463}$ IBID., 298-299.
} 
Bihaća, a to je tzv. „Hrvatska ekspedicija“ (Crabatische Expedition) 1578. Iako se u izvorima najčešće navodi spomenuti naziv, službeni naziv operacije bio je Defensions Expedition in Crabaten što pak zorno pokazuje defenzivni predznak cijeloga ovog pothvata. ${ }^{464}$

Rekonkvista toka rijeke Une nije bila nikakva novost, već tendencija koja je u vojnostrateškim promišljanjima bila prisutna najmanje tridesetak godina. Još su članovi krajiškog povjerenstva iz 1563. smatrali da bi se uređenjem obrane od Bihaća do Zrina moglo i dalje braniti rijeku Unu, pa možda i zauzeti Kostajnicu i Novi. ${ }^{465}$ Krajem studenog 1577. bihaćki kapetan Sebastian Lamberg, ne mogavši prisustvovati okupljanju staleža i savjetovanju u Ljubljani, molio je da se „uz Božju pomoć“ raspravi kako zaustaviti neprijatelja dok još ima vremena i ponovo osvojiti tok rijeke Une. Istodobno se žalio da ne može biti odgovoran za toliko veliki prostor koji je kapetanija zauzimala. ${ }^{466}$ I predstavnici grada i vojske u apelu s početka prosinca 1577. napominju da su „obastriti sa vsih četirih stran“ " te da ,ako se Turci nepregnaše opet priko vode, da je zaman vas prigled i potrošak“ ${ }^{467}$

No, težnje su bile jedno, a realnost drugo. I savjetnici glavnog zapovjednika spomenute operacije, Georga Khevenhüllera ${ }^{468}$, konstatirali su da se to pokušavalo već 28 godina, ali se moralo priznati da nije ostvarivo. Stoga su zaključili da obrambenu frontu treba ustrojiti uz rijeke Glinu, Koranu, Mrežnicu, Dobru ili Kupu unatoč činjenici da na tim rijekama nema čvrstog uporišta na kojem bi se mogao temeljiti otpor, kao što je to slučaj s Unom. ${ }^{469}$ I kranjski su staleži jasno naglašavali važnost planirane operacije. Iskustvo je pokazalo, pisali su, da dok se držalo rijeku Unu, Hrvatska je još „prilično dobro stajala“, ali čim je nekoliko utvrda na Uni, poput Kostajnice i Krupe, izgubljeno, neprijatelj je stekao slobodan prijelaz preko spomenute rijeke te je gotovo cijela Hrvatska opustošena i uništena. Ipak, raskorak između aspiracija i realnosti jasno ocrtava skepsa kojom su kranjski staleži promatrali planiranu akciju sumnjajući da će se u trenutnim okolnostima uspjeti realizirati postavljeni ciljevi. Bili su potpuno svjesni da će vjerojatno morati ustrojiti obrambenu frontu u pozadini. ${ }^{470}$

\footnotetext{
${ }^{464}$ SIMONITI, Vojaška organizacija, 220.

${ }^{465}$ AHAZU, Lopašić, E. Prijepisi iz austrijskih arhiva, br. 15, str. 69.

${ }^{466}$ SI AS 2, DSK, kutija 286, fascikl 164, Bihać, 26.11.1577., 2r, rbr. 304. Bihaćki kapetan Sebastian Lamberg na kranjske Verordneten. SI AS 2, DSK, kutija 286, fascikl 164, Ljubljana, 4.12.1577., 1r, rbr. 299. Predstavnici kranjskih staleža na Sebastiana Lamberga.

${ }^{467}$ LOPAŠIĆ, Bihać, 70.

${ }^{468}$ Khevenhüller je bio dugogodišnji zemaljski kapetan Koruške, carev tajni savjetnik i ,jedan od najvažnijih ljudi u raznim Karlovim službama“. ŠTEFANEC, Država ili ne, 183, fusnota 523.

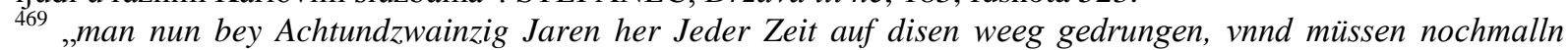
bekhennen, da es dahin (weliches der Allmecthige genediglich verhuetten wälle) nit gelangen". HDA, Croatica kutija 1, svežanj 2, veljača 1579., 66.

${ }^{470}$ HDA, Croatica, kutija 1, svežanj 2, 1578., 78.
} 
I koruški su staleži smatrali da će planirane ciljeve biti teško ostvariti, osobito bez „strane pomoći“. Čak i u slučaju potencijalnog uspjeha, nisu bili uvjereni da bi se osvojeno moglo i zadržati jer je habsburško pograničje jedna velika pustoš (,,ain grosse weite ödnuß“) dok su suparničke zemlje dobro naseljene. Stoga Osmanlije mogu reagirati unutar nekoliko sati dok trebaju tjedni da stigne pomoć iz zemalja Unutrašnje Austrije. Koruški staleži predložili su da treba preuzeti Pobrežje u Kranjskoj, tamo podići mostove preko Kupe te urediti (zuerbawen) Dubovac za rezidenciju zapovjednika i skladište za živež. ${ }^{471}$ Dakle, bilo je mnogo skepse oko mogućnosti osvajanju toka rijeke Une.

Treba naglasiti da je ovoj, za krajiške prilike velikoj ofenzivnoj akciji, primarni cilj bio deblokirati Bihać i ojačati defenzivni potencijal grada i kapetanije. Stoga je naglašeno da je cijela operacija ,pokrenuta prvenstveno radi očuvanja Bihaća““ ${ }^{472}$ Zanimljivo je da je u pripremi ove operacije devet utvrda, najvećim dijelom iz sastava Bihaćke kapetanije, izdvojeno i izravno podređeno vrhovnom zapovjedniku. To je učinjeno, kaže Štefanec, jer se držalo da je u području na kojem se trebao odviti napad potrebno staviti što više ovlasti u ruke jednog čovjeka. ${ }^{473}$

Već u ožujku 1578. u protokolu serije Croatica Dvorskoga ratnog vijeća u Grazu zabilježen je upis o osvajanju toka rijeke Une kroz vojnu operaciju u kojoj bi sudjelovalo između 10 - 12000 ljudi. ${ }^{474} \mathrm{U}$ travnju su pripreme već bile u punom jeku. Početkom travnja nadvojvoda Karlo pisao je caru da je u njegovim zemljama proglašen zemaljski ustanak, da će on osobno doputovati u Ljubljanu, a molio je cara da mu pomogne slanjem vojske ili novaca te da se u sve uključi i „ban u Slavoniji““. ${ }^{475}$ Razgovaralo se i o doznaci svote od 30000 rajnskih guldena. ${ }^{476}$ Negdje $u$ to vrijeme nadvojvoda Karlo izvijestio je i nadvojvodu Ferdinanda o opasnosti za Hrvatsku krajinu, osobito za Bihać, i zamolio za vojnu pomoć. Nadvojvoda Ferdinand odmah je ponudio podići 500 strijelaca i držati ih na plaći pet mjeseci. Međutim, loše vrijeme i nedostatak krmiva odgodili su planove. ${ }^{477}$

\footnotetext{
${ }^{471}$ HDA, Croatica, kutija 1, svežanj 2, 71-72.

${ }^{472}$ HDA, Croatica, kutija 1, svežanj 2, 20.8.1578., 505-507.

473 ŠTEFANEC, Država ili ne, 400-401

${ }^{474}$ HDA, Croatica, mikrofilm D-1911, br. 1, ožujak 1578.

475 „,dann Baan im Winidschland auch zu seinem diennst zuuerschaffen“ HDA, Croatica, mikrofilm D-1911, br. 1, travanj 1578. Nadvojvoda Karlo namjeravao je tada obići krajinu na konju da bi pokazao svoju brigu za zemlju i stekao uvid u stanje na krajištu. Iako su se savjetnici složili s njegovom namjerom, predložili su da ne posjećuje najisturenija mjesta već samo Zagreb, Hrastovicu, Sisak, Slavonsku krajinu, Međimurje prema Kaniškoj krajini i Vorrau. ŠTEFANEC, Država ili ne, 195-196.

${ }^{476}$ HDA, Croatica, mikrofilm D-1911, br. 1, travanj 1578.

${ }^{477}$ HDA, Croatica, mikrofilm D-1911, br. 2; br. 5, travanj 1578.
} 
U jeku priprema bihaćkom kapetanu Sebastianu Lambergu i podređenim mu vojnicima javljeno je da je za obranu Bihaća podignut zemaljski ustanak u nadvojvodinim zemljama te im je naređeno da u međuvremenu strpljivo ustraju u službi. Zrinskom je pak pisano da s određenim brojem svojih pješaka i konjanika treba sudjelovati u ekspediciji u Hrvatskoj. ${ }^{478}$ Slavonske haramije stacionirani oko Kaniže vraćeni su prema Hrvatskoj, a na slavonskom prostoru također je podignuta insurekcija. Zatraženo je i od Gašpara Alapića i Tomu Erdödyja da sudjeluju u insurekciji. Na kraju je i Zrinskom i koruškim staležima, koji su već bili spremi poslati zemaljski ustanak prema Ljubljani, javljeno je da se operacija odgađa. ${ }^{479}$ Niti nadvojvoda Karlo nije na kraju otputovao u Ljubljanu. ${ }^{480}$

Međutim, pripreme i konzultacije nastavljene su i u narednim mjesecima. O planovima je obaviješten i orator u Veneciji (Dornberg) kojemu je naređeno da pokuša kod dužda (herzog daselbst) osigurati određena financijska sredstva za vojnu operaciju. ${ }^{481}$ Imenovani su i kapetani konjaničkih odreda u jačini od 50 do 100 konjanika (Spalatin, Nardin, Lenković, Alapy i Tahy). ${ }^{482}$ Nadvojvoda Karlo poslao je u srpnju Vida Halecka (Veit von Hallegg) na hrvatsko-slavonski sabor radi dogovora sa staležima. ${ }^{483}$ Haleck je na saboru održanom15. srpnja pozvao staleže da sudjeluju u vojnoj operaciji, osiguraju prijevozna sredstva te da žito dijelom ustupe besplatno, a dijelom prodaju po manjoj cijeni. I zaista, staleži su za 8. kolovoz odredili opći ustanak, ali nisu pristali da ban bude podređen nijednom kapetanu. Odredili su da se na jedno kmetsko selište besplatno ustupi mjerov pšenice i mjerov zobi. Kmetovi su prikupljeno trebali besplatno dopremiti na dogovoreno mjesto. No, zamolili su i da ih se ne obvezuje na davanje više žita i prodaju po nižim cijenama. ${ }^{484}$

Što se taktičkog postupanja tiče, plan vojne akcije sadržavao je dva osnovna cilja. Prvi je bio osvajanje rijeke Une, a to je pak podrazumijevalo zauzimanje i destrukciju osmanskih utvrda sjeveroistočno i jugozapadno od Bihaća čime bi posade utvrda oko Bihaća koje su nedavno zauzeli Osmanlije bile prisiljene predati se ili napustiti svoje položaje. Da bi se to

\footnotetext{
${ }^{478}$ HDA, Croatica, mikrofilm D-1911, br. 10, travanj 1578.

${ }^{479}$ HDA, Croatica, mikrofilm D-1911, br. 13; br. 15, travanj 1578.

${ }^{480}$ HDA, Croatica, mikrofilm D-1911, br. 16, travanj 1578.

${ }^{481}$ HDA, Croatica, mikrofilm D-1911, br. 4, svibanj 1578.

${ }^{482}$ HDA, Croatica, mikrofilm D-1911, br. 6, svibanj 1578. Tako je recimo planirano da gradovi Gorica i Gradiška daju 400 strijelaca, a Trst i Rijeka po 100. HDA, Croatica, mikrofilm D-1911, br. 12, srpanj 1578. Nadalje, slijedeći gradovi su trebali dati određeni broj opkopara: Graz 32, Bruck 24, Leoben 20, Radgona 23, Fürstenfeld 15, Ptuj 24, Maribor 20, Brežice 15, Judenburg 20, Celje 20 itd. Za mjesto okupljanja bilo je određeno Celje. HDA, Croatica, mikrofilm D-1911, br. 13, srpanj 1578.

${ }^{483}$ LOPAŠIĆ, Bihać, 27. O prikupljanju i organizaciji transportu živeži vidi SIMONITI, Vojaška organizacija, 221-224.

${ }^{484}$ Ivan ERCEG, Šišićeve biljeske za povijest hrvatskih saboru u XVI. stoljeću, Zbornik Odsjeka za povijesne znanosti Zavoda za povijesne i društvene znanosti JAZU, vol. 1, 1954., 443-444.
} 
ostvarilo, trebalo je opskrbiti Bihać, osvojiti i zaposjesti Ostrožac te utvrde s druge strane (enhalb) rijeke Une, Krupu, Novi na Uni i Kostajnicu, a spaliti i uništiti osmanska uporišta u Lici i Krbavi poput Udbine, Bilaja i Bunića. Vojni planeri nadali su se da će se, realizacijom navedenih planova, osmanske posade u Cazinu, Bužimu i Gvozdanskom same predati. Paralelno s tim mjerama na najprikladnijim mjestima uz rijeku Unu, planiralo se podići nekoliko Plochäuser te ih zaposjesti s toliko vojnika da se u pozadini više ne moraju držati druge vojne posade. ${ }^{485}$ Gajila se nada da će takve ozbiljne (ernst) poteze odmah primijetiti Vlasi te s ženama, djecom i imovinom preći na habsburšku stranu, zaposjesti zemlju i štititi cijeli tok rijeke Une. To bi pak rezultiralo oslobađanjem i zaštitom cijele Hrvatske krajine. S ovim prijedlogom usuglasili su se članovi Dvorskog ratnog vijeća u Grazu naglasivši da su takav prijedlog i sami nekoliko puta izložili nadvojvodi. Ipak, bilo im je potpuno jasno da će planirani pothvat biti teško izvesti. U konačnici je zaključeno da ako se već tok rijeke Une ne osvoji, okupljene snage treba iskoristiti za podizanje i zaposjedanje Plochheuser-a. ${ }^{486}$

U navedenoj vojnoj operaciji u konačnici je sudjelovalo ukupno 10000 - 15000 pješaka i konjanika, petstotinjak konja za vuču topova, petstotinjak opkopara, prateća logistika i 18 topova. ${ }^{487}$ Uz krajiške postrojbe, angažirane su banske snage, plaćene slavonske postrojbe te oko 7000 pješaka i konjanika pristiglih iz zemalja Unutrašnje Austrije i drugih habsburških zemalja (Tirol). ${ }^{488} \mathrm{~S}$ hrvatske strane sudjelovali su ban Krsto Ungnad, zatim Juraj Zrinski, Toma Nádasdy, Toma Erdödy, Ivan Tahy, Gašpar Alapić itd. ${ }^{489}$ Vojska se okupila u Metlici i 21. kolovoza udarila logor pod Herendićevim kaštelom na Mrežnici. Od tamo su kroz „praznu i nenaseljenu“, ali „lijepu i plodnu zemlju“, kako je valjda zapisao sam Khevenhüller, stigli do Blagajskog Turnja, a zatim 27. kolovoza u Slunj odakle je dvjestotinjak haramija i husara pod zapovjedništvom Jurja Kraškovića poslano zauzeti Drežnik. Isprva su pokušali pregovarati s Osmanlijama, ali budući da to nije polučilo rezultat, Drežnik je osvojen u sukobu. Usprkos velikoj žeđi i činjenici da ih opskrba nije mogla pratiti, vojska je 30. kolovoza dospjela pod Izačić te nakon toga udarila logor pod Topličkim Turnjem. Ovdje se pokazalo petstotinjak osmanskih konjanika koji su se povukli kada je Andreas Auersperg krenuo za njima. ${ }^{490}$ Habsburška vojska stigla je 1. rujna do Cazina pored

\footnotetext{
${ }^{485}$ HDA, Croatica, kutija 1, svežanj 2, 1578., 33-34.

${ }^{486}$ HDA, Croatica, kutija 1, svežanj 2., 1578., 34-35.

${ }^{487}$ Frannz Christoph KHEVENHÜLLER, Annales Ferdinandei oder Wahrhaffte Besreibung Kaysers Ferdinandi des Andern, Erster Teil, Leipzig, 1721.,7.; LOPAŠIĆ, Bihać, 28.

${ }^{488}$ SI AS 2, DSK, kutija 287, fascikl 164, Graz, 26.7.1578., 1r-2v, rbr. 478-482. Christoph Auersperg na predstavnike kranjskih staleža.

${ }^{489}$ LOPAŠIĆ, Bihać, 28.

${ }^{490}$ KHEVENHÜLLER, Annales, 7.
} 
kojeg su se nalazila i osmanske postrojbe koje su se povukle nakon što je habsburška vojska zauzela bojni poredak. U zauzetom Cazinu Osmanlije su navodno imali veliku zalihu živeži i streljiva. Habsburška vojska stigla je 3. rujna pod Ostrožac, gdje su Osmanlije pripremili klopku namjestivši mnogo baruta u jednu kulu i tinjajuće fitilje s namjerom da sve eksplodira kada kršćanska vojska uđe u utvrdu. Međutim, Juraj Križanić je saznao za taj plan pa je izbjegnuta katastrofa, a Ostrožac osvojen bez žrtava. Osmanlije su očito ranije napustili grad. ${ }^{491}$ Ubrzo je habsurška vojska stigla pod Bužim čija se posada odbila predati. Ovdje je napokon došlo do obračuna s Osmanlijama u kojem navodno nijedna strana nije prevagnula. Habsburška vojska ostala je pod Bužimom, ali se 13. rujna počela povlačiti, pritisnuta glađu, dizenterijom, ljutom grižom (rothen Rhur) i sve brojnijim Osmanlijama. ${ }^{492}$ Krajem rujna Ferhad-beg s velikom vojskom i tri velika topa kreće na Bihać i Cazin. ${ }^{493}$ Osmanlije ubrzo ponovno zauzimaju Cazin, a početkom listopada i Ostrožac. ${ }^{494}$

Čini se da je jedan od ključnih razloga propasti ove vojne kampanje bio loš sustav opskrbe. Naravno, mora se izbjeći zamku jednostranosti i (ne)namjernog sljepila jer se prilikom razmatranja vojnih poraza njihovi uzroci prečesto svode na uočene nedostatke jedne strane, a da se istovremeno zanemaruju nedostaci druge. Na tom tragu, može se zaključiti da je ofenzivni potencijal poprilično velike habsburške vojske drastično reduciran logističkim problemima. Osmanlije su u tom sukobu u konačnici i sami angažirali velike snage, zdravorazumski iskoristili slabosti neprijatelja i upuštali se u sukobe u odgovarajućem trenutku. I bez prisutnih logističkih problema realizacija zadanih ciljeva bila bi impresivan pothvat dok je, s balastom loše uređene opskrbne linije, taj planirani pothvat bio teško izvediv.

I nadvojvoda Karlo pisao je kranjskim staležima da su za uspjeh cijelog pothvata ključni prijevoz topova i streljiva, osiguranje opskrbe vojske i dostatan broj opkopara. ${ }^{495} \mathrm{Da}$ će opskrba angažiranih snaga biti problem, vidjelo se već iz izvještaja kranjskih povjerenika Ahacha Thurna i Merta Galla koji su u pripremi ove operacije poslani na Hrvatsku krajinu da bi ustrojili opskrbne linije. Njihov izvještaj pokazuje da su s popriličnom dozom defetizma gledali na mogućnosti opskrbe tolike sile tijekom dužeg perioda. Došavši na krajinu, ustanovili su da nije pripremljeno dovoljno žita, zobi i drugih potrepština pa su namirnice

\footnotetext{
${ }^{491}$ IBID.

${ }^{492}$ STEKLASA, Khevenhülerjeva vojska, 739-742.; LOPAŠIĆ, SHK, knjiga I, dok. XVI, 26.; LOPAŠIĆ, Bihać, 29.

${ }^{493}$ SI AS 2, DSK, kutija 286, fascikl, 164, Bihać, zadnji dan rujna 1578., 1r, rbr. 395. Bihaćki kapetan Sebastian Lamberg na Hansa Auersperga.

${ }^{494}$ LOPAŠIĆ, SHK, knjiga I, dok. XVI, 26.

495 Opkopnici su naoružana pratnja topovima i vatrenom naoružanju, utvrđuju artiljerijske položaje i postavljaju Wagenburga. SIMONITI, Vojaška organizacija, 221-222.
} 
nastojali pribaviti na području Metlike i južne Kranjske. U tom pogledu lokalnom stanovništvu izdan je proglas kojim se do daljnjega zabranjivala prodaja namirnica. Budući da su zbog inozemne potražnje cijene bile u porastu, spomenuti dvojac tražio je obustavu izvoza na strana tržišta kako bi se na taj način spustila cijena traženih proizvoda. Ni u Kranjskoj nije ostalo mnogo sijena i slame, a i ono što je dopremljeno na krajinu neprijatelj je već dobrim dijelom spalio. To je onemogućavalo duži boravak zemaljskih konja na krajištu dok je za husarske konje napomenuto da će se morati zadovoljiti travom na koju su ionako navikli. ${ }^{496}$

Na kraju ovoga neuspješnog pothvata, sam se Bihać našao u opasnosti jer je bihaćki kapetan Benedict Crainer pisao da je Ferhat-paša kod Krupe s vojskom i tri topa te kreće prema Bihaću odnosno Cazinu. Osmanlije su tada već započeli s četovanjem u okolici, a nadgledali su i ključne komunikacije oko Cazina. Craineru nije preostalo ništa druge nego uvjeravati nadređene, a vjerojatno i sebe da ,će se on sam i podređeni mu časnici i vojnici uz Božju pomoć protiv zakletog neprijatelja (erbfeindt) činiti i djelovati kao časni ljudi“. 497

\subsubsection{Diskusije o napuštanju Bihaća}

Nakon navedene vojne operacije ponovno se raspravljalo o napuštanju, odnosno destrukciji Bihaća koji je s izgradnjom Karlovca 1579. i zbog velikih finacijskih izdataka koje je zahtijevala njegova obrana postajao sve veći teret. Podizanjem Karlovca, moderne utvrde koja će postati glavno zapovjedno i obrambeno sjedište Hrvatske krajine, promijenit će se i važnost samoga Bihaća. Indikativno je i važno napomenuti da Bihać uopće nije ulazio u kombinacije za sjedište glavnog zapovjednika Hrvatske krajine.

Sredinom studenog 1579. u Klagenfurtu je održano savjetovanje na najvišoj razini, na kojem je trebalo procijeniti treba li zadržati ili srušiti Bihać i Hrastovicu. Nadvojvoda Karlo zatražio je od kranjskih staleža da pošalju četiri ili pet poslanika s adekvatnim znanjem o krajini i temi savjetovanja na kojem su još prisustvovali i predstavnici koruških (die alhirige Lanndschafft), a možda i štajerskih staleža (koje kranjski staleži spominju u instrukcijama poslanicima, ali nisu spomenuti u kasnijem nadvojvodinom odgovoru), zatim Karlovi dvorski ratni savjetnici (vnnsern Hofkriegsratten) te zapovjednik Hrvatske i Primorske krajine Waikhard Auersperg. ${ }^{498}$ Predstavnike kranjskih staleža činilo je probrano društvo - spomenuti Waikhard Auersperg (zapovjednik Hrvatske i Primorske krajine te zemaljski kapetan u

\footnotetext{
496 ŠTEFANEC, Država ili ne, 439-440.

${ }^{497}$ SI AS 2, DSK, kutija 286, fascikl 164, Bihać, 30.9.1578., 1r, rbr. 395. Benedict Crainer na Hansa Ferenberga.

${ }^{498}$ SI AS 2, DSK, kutija 287, fascikl 164, Klagenfurt, 12.11.1579., 1r-2r, rbr. 813-816.
} 
Kranjskoj), Hans Auersperg, Hans Khisl (sva trojica carski savjetnici i savjetnici nadvojvode Karla), Sigmund Semenitsch te Daniel Obritschan koji će biti kasniji bihaćki kapetan. ${ }^{499}$

Kranjski staleži sastavili su prije puta, 14. studenog, instrukcije za navedene poslanike u kojima su naveli već standardne probleme obrane Bihaća - problem opskrbe okruženoga grada, problematika pristupa i osiguranja potrepština i slično. Konstatirali su da se već na ranijim okupljanjima (1563., 1575., 1577. i 1578.) zaključilo da se Bihać apsolutno mora zadržati. $^{500}$ I sada su kranjski staleži bili protiv destrukcije Bihaća jer bi se time demoraliziralo stanovništvo i vojnici na Hrvatskoj krajini, ali i stanovništvo u Kranjskoj, a nakon napuštanja Bihaća bosanski paša bi tamo odmah ustrojio rezidenciju i u plodnoj dolini naselio vlaško stanovništvo te u svako doba dana i noći prema svojoj želji napadao okolne krajeve. ${ }^{501}$ Staleži su naveli da neprijatelja treba zaustaviti, a ne otvarati mu put. Dodali su da će zaslužiti Božju kaznu ako se grad napusti te da je prema Bogu i kršćanstvu prikladnije i odgovornije da se Bihać izgubi u borbi, nego da ga se dobrovoljno preda u ruke neprijatelju, na njegovu korist i propast ove zemlje. ${ }^{502}$

Argumenti za napuštanje Bihaća, ali i Hrastovice, o čemu se također raspravljalo, bili su veliki troškovi za obranu i uzdržavanje obaju mjesta, pa je tako navedeno da je tijekom godina na održavanje i opskrbu Bihaća utrošeno čak 40000 rajnskih guldena. Pomoć iz Carstva presporo je stizala, a nije bilo osobite pomoći ni od njemačkih i talijanskih moćnika (Potenten) ${ }^{503}$ Drugo, apostrofirali su da je poznato s koliko problema i opasnosti se Bihać i cijela krajina opskrbljuju te kakvo je jako osiguranje potrebno za pratnju opskrbnih konvoja „jer je Bihać više u neprijateljskoj, nego u kršćanskoj vlasti““. ${ }^{504}$ Argumenti za održavanje Bihaća primarno su se svodili na to da su na obranu Bihaća utrošena tolika financijska sredstva i proliveno toliko „viteške krvi“, a u slučaju napuštanja grada, Osmanlije će od Bihaća napraviti glavno uporište, što se uostalom kasnije i dogodilo. Istoga dana kada je održano savjetovanje u Klagenfurtu, 17.11., datiran je nepotpisan spis u kojem na zadnjoj strani stoji regesta da je riječ o odlukama savjetovanja te u kojem se navodi da Bihać treba i

\footnotetext{
${ }^{499}$ SI AS 2, DSK, kutija 287, fascikl 164, Ljubljana, 14.11.1579., 1r, rbr. 817. Staleške instrukcije Hansu Khislu. 500 „biss aüff den eüsseristen grad zuerhalten seye“. SI AS 2, DSK, kutija 287, fascikl 164, Ljubljana, 14.11.1579., 2r, rbr. 819. Staleške instrukcije Hansu Khislu. Zaista, i u lipnju 1578. održano je savjetovanje na kojem je odlučeno da se Bihać mora zadržati, a ne napustiti. Preduvjet održanju bilo je već spominjano zauzimanje toka rijeke Une iako je to trebalo pažljivo učiniti jer je to moglo voditi u otvoreni rat s Osmanlijama. I onda se navelo da se već 1563. o tome razmatralo. SI AS 2, DSK, kutija 287, fascikl 164, Bihać, 16.6.1578, 1r$2 \mathrm{v}$, rbr. 464-466.

${ }^{501}$ SI AS 2, DSK, kutija 287, fascikl 164, Ljubljana, 14.11.1579., 2v, rbr. 820. Staleške instrukcije Hansu Khislu. ${ }^{502}$ SI AS 2, DSK, kutija 287, fascikl 164, Ljubljana, 14.11.1579., 3r, rbr. 821. Staleške instrukcije Hansu Khislu. ${ }^{503}$ SI AS 2, DSK, kutija 287, fascikl 164, Klagenfurt, 17.11.1579., 2v, rbr. 829-831. Odluke navedenog savjetovanja.

${ }_{504}$ SI AS 2, DSK, kutija 287, fascikl 164, Klagenfurt, 17.11.1579., 2v-3r, rbr. 831-832. Odluke navedenog savjetovanja.
} 
dalje braniti zbog čega je potrebno dobro promisliti kako na najsigurniji način organizirati dopremu živeži. To se na godišnjoj razini moralo dva-tri puta poduzeti. ${ }^{505}$

U konačnici je predloženo da se Bihać i dalje brani, a Hrastovica poruši, iako se i dalje o tome raspravljalo. ${ }^{506}$ Naime, početkom prosinca 1580 . nadvojvodini poslanici na zasjedanju kranjskih staleža ponovo navode da se o ovoj temi već više puta raspravljalo, prije svega na okupljanjima u Grazu u travnju 1579. te studenom 1579. u Klagenfurtu. ${ }^{507}$ Nadalje, 22. prosinca iste godine nadvojvoda Karlo traži od kranjskih staleža da mu se dostave odluke klagenfurtskog savjetovanja u pogledu Bihaća jer ih do sada nije primio! Nadvojvoda je tražio da ga se izvijesti je li odlučeno i dalje držati Bihać jer je tadašnji kapetan Sebastian Lamberg naumio napustiti poziciju pa je na kapetansko mjesto trebalo imenovati odgovarajuću osobu. $^{508}$

Obje opcije, ustrajati na obrani ili napustiti grad, i dalje su izazivale kontroverze, ali kranjski su staleži ipak zaključili da između dva zla treba izabrati manje - dugotrajnu umjesto nagle propasti. ${ }^{509}$ Bihać treba braniti dokle god je moguće jer će ga Osmanlije odmah zaposjesti ako se napusti i razruši. Štoviše, čak su predložili da se, uz asistenciju Carstva, njemačkih i talijanskih moćnika, ponovno organizira vojna akcija za osvajanje rijeke Une. ${ }^{510}$ Iako je odlučeno da se Bihać i dalje čuva, ovi izvori pokazuju desetljećima prisutnu dvojbu oko njegova statusa, odnosno treba li ga napustiti ili ne.

Vrlo zanimljiv, pa i ponešto egzotičan prijedlog Hansa Kobenzela, istaknutog diplomata, tajnog savjetnika i predsjednika Donjoaustrijske komore, pokazuje koliko je obrana Bihaća i Senja bila opterećujuća, a opet važna u međunarodnom kontekstu. Naime, on je 1582. predložio da se dva navedena grada prepuste stranom vladaru, odnosno „kralju Španjolske“ Filipu II. ${ }^{511}$ Kobenzel je kao argument naveo da se tijekom vladavine dvaju

\footnotetext{
${ }^{505}$ SI AS 2, DSK, kutija 287, fascikl 164, Klagenfurt, 17.11.1579., 1r, rbr. 853. Odluke navedenog savjetovanja. ${ }^{506}$ SI AS 2, DSK, kutija 287, fascikl 164, Graz, 7.12.1579., 1r, rbr. 826, Nadvojvoda Karlo na kranjske staleže.

${ }^{507}$ SI AS 2, DSK, kutija 287, fascikl 164., Ljubljana, 9.12.1580., 1r, rbr. 861.

${ }^{508}$ SI AS 2, DSK, kutija 287, fascikl 164, Graz, 22.12.1580., 1r, rbr. 858. Nadvojvoda Karlo na kranjske Verordneten. Protkolirani zahtjev kranjskim i koruškim staležima da rasprave treba li zadržati Bihać i neka predlože kompetentne kandidate za kapetana ako je odgovor potvrdan. HDA, Croatica, mikrofilm D-1913, br. 25, prosinac 1580. U siječnju 1581. kranjski i koruški staleži zaključili su da ga treba zadržati. HDA, Croatica, mikrofilm D-1913, br. 43, siječanj 1581.

${ }^{509}$ SI AS 2, DSK, kutija 287, fascikl 164, Ljubljana, 9.12.1580., 1v-2r, rbr. 862-863.

${ }^{510}$ SI AS 2, DSK, kutija 287, fascikl 164, Ljubljana, 14.12.1580., 1v-2r, rbr. 866-867.

${ }^{511}$ Hans Kobenzel bio je izrazito važna osoba u najvišim ešalonima habsburške politike u zadnjem kvartalu 16. stoljeća. Započeo je karijeru u dvorskoj kancelariji cara Maksimilijana II., zatim postaje vitez i komtur Njemačkoga viteškog reda, prvo u Ljubljani pa Grazu te Bečkom Novom Mjestu. Od 1571. do 1573. carski je poslanik u Rimu, a zatim od 1576. do 1581. carski poslanik u Moskvi. Od 1582. do 1594. je, kako navodi Karlo Horvat, „najmoćniji ministar nadvojvodske kuće u Gracu, pak je kao punomoćnik te kuće potpisivao i državne zaključke stvorene bilo na državnim bilo na zemaljskim saborima“. Simultano je kraljevski tajni savjetnik, dvorski kancelar i predsjednik Donjoaustrijske komore. Uza sve to, bio je i gorički i gradiški kapetan, a od 1592. zemaljski kapetan Kranjske. Dakle, radilo se o vrlo utjecajnoj osobi. Karlo HORVAT, Kobenzelovi izvještaji
} 
pokojnih vladara (Ferdinanda I. i Maksimilijana II.) mnogo puta raspravljalo o napuštanju Bihaća, a kao glavni razlog naveo je velika financijska izdavanja za posadu i opskrbu grada. Budući da je bilo jasno da će Osmanlije odmah zaposjesti Bihać ako ga se napusti na savjetovanjima je uvijek i odlučeno da se „otok i grad“ (Insel vnnd Fleckhen) moraju zadržati „do posljednjeg čavla“ (biß auf den eüsseristen Nagl). Kobenzel je dijelio taj stav, osobito od trenutka kada su Osmanlije osvojili Zrin, Gvozdansko, Bužim i Ostrožac, čime su zapriječili pristup Bihaću, te nakon što su zauzeli vodotok rijeke Une čime su otvorili mogućnost da svoje posade s druge strane rijeke pa do Banja Luke i Livna prebace u zauzete utvrde s ove strane rijeke Une. Na taj bi način mogli osvojiti ne samo „manji ostatak Hrvatske“ već bez osobite muke i „više od toga““. ${ }^{512}$ Očito je smatrao da je Bihać glavna opstrukcija takvom razvoju događaja.

Kobenzel se stoga sa štajerskim staležima podrobno savjetovao o tome kako zadržati Bihać u kršćanskim rukama i doskočiti sadašnjim i budućim problemima. Primarni problem predstavljala je činjenica da je Bihać bio toliko duboko u neprijateljskoj zemlji da ga je trebalo opskrbljivati konvojima za čije su osiguranje korišteni gotovo svi konjanici i pješaci na krajištu, zbog čega je obrambena snaga tih utvrda bila znatno oslabljena. Jedan uspješan osmanski napad na takav opskrbni konvoj mogao je rezultirati gubitkom cijele krajine. I Kobenzel i kako je pisao „njegovi staleži“, od srca bi željeli da sami obrane ne samo Bihać već i da ponovno zauzmu čitav tok rijeke Une i steknu ,prednost nad neprijateljem“, ali to nisu bili u stanju. Puka sila ih je nagonila ili da Bihać napuste ili da brzo pronađu neko drugo rješenje. ${ }^{513}$

Jedna od varijanti bila je da Car osobno preuzme obranu Bihaća ili da doznači ozbiljniju pomoć za njegovo daljnje održavanje što pak tada nije bilo izvedivo zbog „nebrojenih“ drugih izdataka. Nadalje, kranjski i koruški staleži također nisu bili u mogućnosti doznačiti više novaca ni za Bihać ni za druge utvrde. Pristigla financijska pomoć iz Carstva već je bila potrošena, a obrambenih troškova je pak bilo toliko da ih ne bi podmirili godinama, čak i da nova sredstva pristignu. Pomoć iz Carstva i staleški izdatci bili su jedva dovoljni za pokrivanje troškova posada u mirnodopskim uvjetima, a u ratnom se periodu taj trošak i više nego udvosturučavao, tvrdio je Kobenzel. Stoga je Bihać trebalo ili napustiti ili „stranom“ pomoći dalje braniti. ${ }^{514}$ Kobenzel je smatrao da će Car najbolje znati može li se iz

(1592.-1594.) kardinalu Cintiju Aldobrandiniju, državnom tajniku pape Klementa VIII, Starine, 32, JAZU, 1907., 131.-132.

${ }^{512}$ HDA, Croatica, kutija 1, svežanj 3, Graz, veljača 1582., 372-373.

${ }^{513}$ HDA, Croatica, kutija 1, svežanj 3, Graz, veljača 1582., 374-375.

${ }^{514}$ HDA, Croatica, kutija 1, svežanj 3, Graz, veljača 1582., 376-377. 
Carstva dobiti pomoć ili ne, ali je iskazao skepsu. Nadao se da će se nastaviti i isporuka pomoći koja je odobrena na prethodnom zasjedanju. Dakle, trebalo je vidjeti može li se dobiti pomoć od drugih kršćanskih vladara iako je naveo da ,gotovo svatko u svoj šanac gleda, i za drugo(g) ne pita““. ${ }^{515}$ No, u povijesti (In Historien Woll Zuwisen), nastavio je Kobenzel, dobro je poznato da su određeni vladari, ne mogavši braniti svoje zemlje, radije ih predavali svojim „dobrim prijateljima“ nego neprijatelju. To je učinio i srpski despot (Despott in Sirff.) kada je ugarskom kralju predao Beograd, samo da ga ne bi osvojili Osmanlije. S Bihaćem i Senjom je trebalo učiniti isto - pronaći vladara koji bi to bio u stanju . 516

Najbolji kandidat za takvo što bio je španjolski kralj Filip II, čije bi Napuljsko Kraljevstvo time steklo nekoliko luka „,herdißhalb auf dem Illirischen Landt“ koje bi im služile ne samo kao predziđe (vormaueren) protiv Osmanlija već i kao brana protiv njihovih susjeda Mlečana i Dubrovačke Republike. Uz defenzivnu važnost, takav bi potez u najmanju ruku potaknuo i njihov trgovački zamah (schwung), smatrao je Kobenzel. Nadalje, argumentirao je da bi Napuljsko Kraljevstvo moglo na taj prostor slati svoje Banditen, a time bi se Kraljevstvo učinilo sigurnijim te bi postojala mogućnost njegove daljnje teritorijalne ekspanzije. Banditi, kojih da nije mali broj, bili bi pak motivirani da se iskažu unutar vojne službe i prime kraljevsku milost za povratak u domovinu. Također, budući da je od povjerljivih osoba doznao da su staleži u Napuljskom Kraljevstvu često tražili od kralja da oformi jedan viteški red (Orden) kojem bi trebalo odrediti takovo sjedište s kojeg bi stalno mogli imati djelovati protiv Erbfeindt, dakle Osmanlija, smatrao je da bi cijela stvar bila vrlo brzo realizirana ako bi im se predao Bihać ili Senj. No, iako je naglasak bio na Bihaću, Kobenzel se čak pitao bi li možda bilo jednostavnije predati Senj s Otočcem, Brinjem, Brlogom, Prozorom, Ledenicama i Bagom te na Bihać alocirati 8000 rajnskih guldena koji su korišteni za te utvrde, a 6000 upotrijebiti u neke druge svrhe. Ako bi se predala oba grada, bilo bi ustupljeno oko 15 milja teritorija. Predajom Senja to bi iznosilo samo oko 6 milja, a oslobodilo bi se 50000 rajnskih guldena. Tim bi se iznosom ostale pogranične utvrde mogle dobro osigurati, a u najmanju ruku riješio bi se problem s opskrbom. Bez obzira na te digresije, Kobenzel je izrazio nadu da će španjolski kralj, u slučaju da pristane na navedeni prijedlog, preuzeti oba grada u nadi da će zaustaviti neprijatelja te vojnim putem, na kopnu i moru, možda zauzeti cijelu Bosnu, a nakon toga i Albaniju. ${ }^{517}$

\footnotetext{
515 „,vasst Jederman nur auf sein Schanz siecht, vnd nach andern nit vill fraget“. HDA, Croatica, kutija 1, svežanj 3, Graz, veljača 1582., 378.

${ }^{516}$ HDA, Croatica, kutija 1, svežanj 3, Graz, veljača 1582., 379-380.

${ }^{517}$ HDA, Croatica, kutija 1, svežanj 3, Graz, veljača 1582., 380-383.
} 
Ključan problem bilo je kako taj plan predočiti ugarskim staležima. Kobenzel je predložio da im se s dužnim poštovanjem iskaže da je to zbog toga što ne mogu pokriti troškove obrane te da im se obeća da će im vladar ili njegovi nasljednici vratiti gradove kada staleži nadoknade njihove troškove. Ono što se od neprijatelja osvoji ostalo bi pak kraljevskoj kući. Međutim, za Kobenzela je to bilo tek diskurzivno sredstvo i nerealna opcija zato što je naveo da bi troškovi, ako kralj pristane na taj prijedlog i svega nekoliko godina drži oba grada, toliko narasli da ih ni Ugarsko Kraljevstvo ni nitko drugi ne bi mogao nadoknaditi, pa bi posjedi ostali u njegovu trajnom vlasništvu. ${ }^{518}$

Sam Car bi ovakvim dogovorom više dobio nego izgubio jer će imati brigu manje, a on i staleži će smanjiti troškove i moći alocirati sredstva na druge utvrde. Car će u kralju dobiti takvog susjeda i ratnog druga (Kriegs gesselen) koji će mu prema potrebi pružiti veliku pomoć protiv Osmanlija i Mlečana, a usto kralj će imati na raspolaganju velik broj „des Teutschen vnd Ilirischen Kriegsvolckhs" koje će prema potrebi transferirati u Italiju i osigurati svoje zemlje. ${ }^{519}$ Kaže da se drugog rješenja ne može dosjetiti, osim ako ih Car ne želi predati Mlečanima, a on to ne bi preporučio jer je smatrao da bi španjolski kralj u ponuđenim uvjetima rado preuzeo Senj upravo radi Mlečana. Budući da Mlečani čine osobite probleme austrijskoj kući zatvaranjem slobodne plovidbe Jadranskim morem, stvari bi bile bitno drugačije kada bi španjolski kralj „stavio nogu“ u Dalmaciju. Uostalom, ni Mlečani nisu imali mira dok Španjolce nisu izbacili iz Herceg Novog (Castel Noua), a i šurovali su s Osmanlijama jer po pitanju plovidbe morem (navigation) manje strahuju od njih nego od Španjolaca i Napolitanaca. ${ }^{520}$

Članovi Dvorskog ratnog vijeća u Grazu smatrali su da je taj prijedlog nemoguće realizirati jer se postavilo pitanje kako bi reagirali ugarski staleži, a dvojili su i o tome bi li Filip II. bio uopće voljan preuzeti (financijske) obaveze obrane te bi li se mogao opskrbljivati i braniti Bihać koji udaljen „od mora tri dana puta preko grubog, divljeg i visokog gorja, na jednom pustom i neplodnom mjestu“. Dvorsko ratno vijeće u Grazu smatralo je da bi opskrba Bihaća preko Jadranskog mora iz smjera Napuljskoga Kraljevstva bila jednako teška kao i sada. Nadvojvodi su poslali karte Hrvatske da se i sam uvjeri, a apostrofirali su i da bi to djelovalo kao potez očajnika (Desperation). ${ }^{521} \mathrm{Na}$ kraju od svega nije bilo ništa, ali je ovaj

\footnotetext{
${ }^{518}$ HDA, Croatica, kutija 1, svežanj 3, Graz, veljača 1582., 384-385.

${ }^{519}$ HDA, Croatica, kutija 1, svežanj 3, Graz, veljača 1582., 385-386.

${ }^{520}$ HDA, Croatica, kutija 1, svežanj 3, Graz, veljača 1582., 387-389.

${ }^{521}$ HDA, Croatica, kutija 1, svežanj 3, Graz, 14.2.1582., 370-371; 391-397. Paginacija je takva jer je u spise umetnut Kobenzelov prijedlog.
} 
prijedlog ilustrativan primjer kakvu su međunarodnu dimenziju imali sukobi s Osmanlijama i na hrvatskom prostoru.

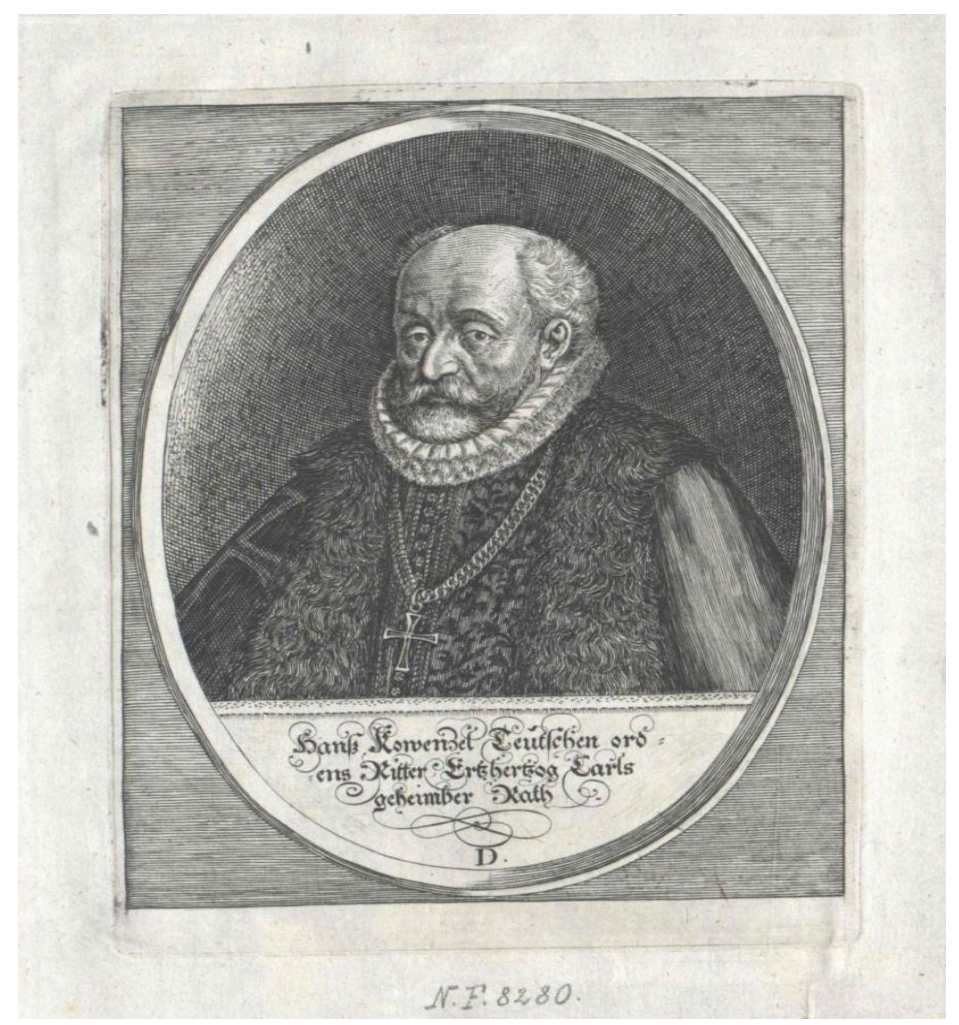

Slika 17. Hans Kobenzl. ${ }^{522}$

\subsubsection{Osmanska kolonizacija Krbave i Like te posljedice za Bihaćku kapetaniju}

Iako se osmansko napredovanje bihaćkim prostorom odvijalo primarno tokom rijeke Une, Osmanlije su već vrlo rano, do 1530-ih, prodrli u neposrednu blizinu Bihaća. Padom Knina 1522. bio im je otvoren put prema sjeveru pa su već sljedeće godine zauzeli Ostrovicu u Lici te započeli novu etapu pustošenja i pojačavana pritiska na Pounje. ${ }^{523}$ Osvajanjem Udbine 1527. Osmanlije su se „ugnijezdili““ praktično s druge strane Plješevice. Nakon osvajanja Like i Krbave do kraja 1520-ih pogranična zona i nije doživjela ozbiljne promjene sve do pada Bihaća pod osmansku vlast. Bihać i Udbina (kao uostalom i Senj i Udbina) tijekom cijelog razdoblja ostali su na istoj distanci funkcionirajući kao polazišne točke u nesmiljenom sukobu koji je devastirao, ali i na paradoksalan način i približavao sukobljena društva u jednu

\footnotetext{
${ }^{522}$ Preuzeto s Österreichische Nationalbibliothek. https://www.onb.ac.at/. http://data.onb.ac.at/rec/baa9016443 Pristup, 5.7.2019.

${ }^{523}$ KRUHEK, Krajiške utvrde, 73.
} 
sociokulturnu cjelinu. Takvi upadi bili su motivirani strateškim razlozima (preventivni napad, primjena strategije spaljene zemlje), ali su služili i kao sredstvo osiguranja egzistencije pljačkom. Konfiguracija terena oko Bihaća zapravo je omogućavala izvođenje snažnih napada s manjim brojem ljudi. ${ }^{524}$

Sjeverozapadna granica Kliškog sandžaka bila je osobito izložena napadima habsburških snaga iz smjera Bihaća, Ripča i Senja. ${ }^{525}$ Čarke i sukobi u trokutu Bihać-UdbinaSenj desetljećima su onemogućavali demografsku stabilizaciju ličko-krbavskog prostora. Osmanlije su u valovima popunjavali prostor, a zatim bi ga habsburške snage jednakom upornošću napadale te ognjem i mačem ,praznile“. Iako su neke utvrde zauzete i zaposjednute vrlo rano, mnoge su godinama ostale puste i/ili ruševne. Znamo da je na promatranom prostoru bilo barem dvadesetak utvrda koje su Osmanlije u raznim periodima nastojali obnoviti i zaposjednuti, a njihovu okolicu kolonizirati. Provedbu tih planova, odnosno administrativnu i demografsku konsolidaciju Like, pa i Krbave, onemogućavali su intenzivni napadi habsburških snaga iz smjera Otočca, Senja i Bihaća. ${ }^{526}$

Nema potrebe detaljno navoditi tijek kolonizacije te niz konfrontacija koje su iz tog procesa proizlazile, ali neki momenti moraju biti spomenuti. Intenzivno naseljavanje ličke nahije počinje oko 1550., odnosno nakon sklapanja petogodišnjeg primirja $1547 .{ }^{527}$ Prva ozbiljna kolonizacija Like poduzeta je sredinom 1550-ih. U jednome anonimnom diskursu o obrani hrvatskoga krajišta iz 1551. navedeno je da su Osmanlije tijekom prethodnog primirja obnovili Gračac (Gradschaz) u kojem je namješten „sandžak“ (der Sannsackh daselbsthin gesezt worden). Sada je Čerkez-vojvoda naumio obnoviti i dvije neimenovane prazne utvrde u

\footnotetext{
${ }^{524}$ U jednom prijedlogu o uređenju Hrvatske krajine sa sabora u Brucku 1578. stoji da Osmanlije treba protjerati iz krajeva „s ove strane toka Une“ jer će to omogućiti slabijoj habsburškoj strani da kroz „taj kraj“ izvršava snažne napade na neprijatelja te s manjim brojem ljudi činiti „svakojake prepade i prepreke“. ŠTEFANEC, Država ili ne, 295.

${ }_{525}$ To se posebno odnosilo na područje oko Kamengrada, Ključa, Udbine, Novog, Bilaja, Glamoča, Unca, Prusca, Livna itd. Dobar dio osmanskog pograničja nije bio dostatno zaštićen jer je Porta zbog financijskih razloga držala stalne posade samo u ključnim utvrdama dok su u druge utvrde ljude namještali prema potrebi. JURIN-STARČEVIĆ, Osmanski krajiški, 43. Tako je u prosincu 1557., nakon jednoga osmanskog upada na habsburški teritorij, zapovjednik Hrvatske krajine Georg Sauer planirao provaliti do Srba i Unca, uz sudjelovanje bana i Keglevića, kao i drugih za koje se nadao da će se priključiti. SI AS 2, DSK, kutija 201, fascikl 124, Črnomelj, 14.12.1557., 2v, rbr. 533. Adresirano na Ivana Lenkovića. Početkom svibnja 1566. porkulab Ostrožca Petar Forčić i neimenovani bihaćki vojvoda poslani su sa svojim ljudima na četovanje prema Udbini (gdje su zarobili jednog čovjeka i oteli nešto stoke) ne znajući da se tamo tada okupljala osmanska vojska. Saznavši za osmansko okupljanje, ostavili su stoku i postavili neprijateljskim postrojbama zasjedu na dva mjesta. Među Osmanlijama je bilo i „novih delija, s trubama i drugim“ (die Neuen delia, mit Trumbetten vnnd anndern khomen). U sedam okršaja toga dana nije stradao nitko s habsburške strane dok je nekoliko osmanskih konjanika poginulo, a mnogo ih je bilo ranjeno. Prostrijeljen je i stanoviti Baraković. SI AS 2, DSK, kutija 201, fascikl 124, kutija 286, fascikl 164, Bihać, 6.5.1566., 1v, rbr. 41-42, Matiasch Mori prijevod s hrvatskog.

${ }^{526} \mathrm{Na}$ Porti su 1557. raspolagali informacijama da je bihaćki kapetan spalio Udbinu. TRACY, Balkan Wars, 222.

${ }^{522}$ S̆ARIĆ, Vlasi na tromeđi, 84.
} 
Lici, što mu navodno nije trebalo predstavljati veliki problem jer su zidine i dalje stajale pa je trebalo tek postaviti i čuvati ulazna vrata. ${ }^{528}$

Habsburški izvori navode da je u srpnju 1555. Malkoč-beg s 3000-5000 konjanika i pješaka, potpomognut snagama hercegovačkog sandžaka koje su se tada nalazile u Lici, započeo intenzivnu obnovu Bunića, utvrde u dolini Bunićka Draga (Wunitscher Drägä) između Bihaća i Otočca. Međutim, njihove namjere omela je nekakva epidemija, vjerojatno kuga (Sterblauf) koja je zavladala u Bosni, pa se navodno i bosanski paša sklonio preko Save. $^{529}$ Sredinom svibnja 1560 . Ivan Lenković javlja predstavnicima kranjskih staleža da Malkoč-beg namjerava zauzeti i obnoviti napuštenu utvrdu Obrovac iznad Ostrožca na Uni, a istodobno će Osmanlije obnoviti i zaposjesti Perušić u Lici. ${ }^{530}$ Međutim, krajem srpnja 1560. Mihael Spalatin je s podređenim vojnicima i ljudima grofa Frankopana Slunjskog napao Udbinu te oteo konje koji su se nalazili na ispaši i do 1000 komada krupne stoke. Pokušali su na četiri mjesta zapaliti udbinsku utvrdu, ali su Osmanlije hitro ugasili vatre. No, spaljeno je čak do 200 drvenih kuća i naselje (stadl) ispred utvrde dok je, kako se navodi u izvoru, „sve ostalo" ostalo čitavo. Par dana kasnije, početkom srpnja, Spalatin je s podređenim mu njemačkim vojnicima i drugim bihaćkim strijelcima i konjanicima te nekoliko vojvoda napao brojne osmanske podanike između Ostrovice i Udbine, nekolicinu usmrtio te oteo nekoliko tisuća komada krupne i sitne stoke. Ostali osmanski podanici u krugu od nekoliko milja razbježali su se sa svojom imovinom. ${ }^{531}$

No, osmanska kolonizacija i obnova napuštenih utvrda nastavila se. Već 1566. sastavljen je sljedeći popis novoutvrđenih i naseljenih utvrda u Lici na hrvatskom jeziku:

Totu giesu popisani oni Chasteli chi giesu v Lichj sad ouih dan mimo ssastnik(?) danas kagie $\cdot 21 \cdot$ dan da giesu Turci nihoue liude vrezene Chastelle posztauili ki Chasteli bili giesu pustj let 50

Postauilisu Turci nihoue liudi vkastel Louimac

Postauili su Turci nihoue liudi vkastel Raduz.

Postauili su Turci nihoue liudi vkastell Vranik

\footnotetext{
${ }^{528}$ „allain die Thor anzuhennckhen vnd Zuuerwarn seindt“. HDA, Militaria, kutija 4, 1551., bez oznaka, izvještaj pod naslovom „Die Gränizen von Zeng, da ist von Mor, bis gen Sissegkh and den wasserfluß Saw. 24 gueter meil wegs lanng", 3 .

${ }^{529}$ HDA, Militaria, kutija 4, Slunj, 28.9.1555., 1r-1v, rbr. 17-18. Ivan Lenković na Georga Wildensteina. Ivan Lenković je u jednom drugom spisu naveo da je prostor Bunićke Drage na habsburškom teritoriju (diction). HDA, Militaria, kutija 4, 23.9.1555., 1r, rbr. 111. Ivan Lenković na Georga Wildensteina.

${ }^{530}$ SI AS 2, DSK, kutija 202, fascikl 124a, Ljubljana, 12.5.1560., 1r. Ivan Lenković na zemaljskog kapetana Kranjske Jacoba Lamberga.

${ }^{531}$ SI AS 2, DSK, kutija 413, fascikl 283, Zagreb, 8.7.1560., 2r-2v, rbr. 195-196. Ivan Lenković na cara Ferdinanda.
} 
Postauili su Turci nihoue liudi vkastell Vmedak

Postauili su Turci nihoue liudi vkastel Ribnik

Postauili giesu Turci nihoue liudi vdua Chastela Nouaka

Postauili su Turci liudi nihoue vdua kastela Barletta

Postauili su Turci nihoue liudi vdua kastela Rebzichia

Postauili su Turci nihoue liudi vdua Kastella Mogorichia

Postauili su Turci nihoue liudi v Kastel Pozitell

Postauili su Turci nihoue liudi v Ssirochi Turan

Postauili su Turci nihoue liudi vdua Kastella Smilianca

Postauili su Turci nihoue liudi v Kastel Podlapac

Postauili su Turci nihoue liudi v Kastel Schitar

Postauili su Turci nihoue liudi v Kastel Derusich

Chi Chastel giest pri Otozcu $\cdot 3 \cdot$ nimske milie

Tih Chastelou zgora pisanih giest $N .^{\circ} 20^{532}$

Početkom kolovoza 1577. senjski kapetan Casper Raab javlja da povjerljive vijesti upućuju na to da Mustafa-beg Hlivanjski namjerava u Lici obnoviti i zaposjesti neke utvrde (schlösser), prije svega „,das ander Schloß Peruschückh auf Thuerkhowina“. Raab je tražio da se u Otočac odmah pošalju uskoci te da se navedena utvrda sruši prije nego što je zauzmu Osmanlije. ${ }^{533}$ Slična nastojanja ponavljana su sve do kraja 1570-ih kada je Osmanlijama donekle uspjelo demografski stabilizirati i kolonizirati lički prostor. To potvrđuje i formiranje Krčkog, odnosno Ličkog sandžaka 1580. jer je jedan takav čin teško promatrati neovisno o naseljenosti prostora. ${ }^{534} \mathrm{U}$ izvještaju habsburškog oratora u Carigradu s kraja prosinca 1579. navodi se da je sultan na nagovor vezira Sinan-paše (Sinan Vezier Bassa) dozvolio da se oformi novi sandžak u Hrvatskoj (einnen Sansiagakh daselbst in Crabatten an vnnd aufzurichten verwillig) i za sandžak-bega postavi Idris-aga. Orator još nije saznao u kojoj će utvrdi Idris-aga imati svoje sjedište, ali u sastav novog sandžaka ulazile bi sve utvrde oko Une koje je prije nekoliko godina osvojio Ferhat-beg i njima od tada upravljao, a apostrofirao je

\footnotetext{
${ }^{532}$ SI AS 2, DSK, kutija 204, fascikl 125, sine loco, sine dato, vjerojatno veljača ili ožujak 1566.

${ }^{533}$ SI AS 2, DSK, kutija 286, fascikl 164, Senj, 5.8.1577., 1r, rbr. 357. Casper Raab na zapovjednika Hrvatske krajine.

${ }^{534}$ I Bosanski pašaluk osnovan je 1580. jednim dijelom kao odgovor na habsburške reforme nakon sabora u Brucku 1578. JURIN-STARČEVIĆ, Osmanski krajiški, 30. Sredinom stoljeća Malkoč-beg započeo je konsolidirati obranu ugroženoga sjeverozapadnog ruba Kliškog sandžaka. U tom je pogledu važna odluka o obnovi Ostrovice na Uni 1552. IBID., 45. Ispod Ostrovice na rijeci Uni Osmanlije su podigli Kulen Vakuf koji je kontrolirao prijelaz preko rijeke. Tamo je podignuta i sultanska „državna“ džamija, dakle mjesto od velike važnosti u regionalnom kontekstu. Vidi. KOZLIČĆĆ, Unsko-sansko područje, 179-180.
} 
Krupu, Cazin, Bužim, Zrin i Ostrožac te novoosvojeni teritorij preko rijeke Une, prije svega Toplički Turanj i Brekovicu koju su habsburški vojnici sami spalili i napustili još kada su Osmanlije zauzeli Cazin i Ostrožac. ${ }^{535}$

Bihać je dakle predstavljao krucijalnu prepreku administrativnoj, demografskoj i općoj stabilizaciji osmanskog serhata. Kada je sredinom 1580. eskalirao sukob na ugarskom ratištu, pojavile su se glasine da će Ferhad-beg iskoristiti odlazak krajiške vojske u Ugarsku i učiniti nešto „značajno“. Taj „značajan“ pothvat trebao je biti napad na Bihać, a povod je bilo Idrisbegovo stajalište da ne može svoj novi sandžak uspostaviti odnosno kolonizirati, bez osvajanja grada. Idris-begu je stanoviti vojvoda Osman javio da će, ako im plan, kojeg na žalost nisu detaljnije opisali, uspije, ubrzo zauzeti Bihać pa će se njihovi naseljenici moći održati ne samo s obiju strana rijeke Une već i u Lici. ${ }^{536}$

Dakle, proces kolonizacije osvojenog teritorija oko rijeke Une, ali i na području Like, nije mogao neometano teći dokle god je Bihać bio u habsburškim rukama. Ipak, na kraju je Ferhad-beg bio taj koji je krajem lipnja te godine sa svojim ljudima odmarširao na ugarsko ratište otvorivši habsburškim snagama mogućnost napada na Liku. Zapovjednik Hrvatske krajine i zemaljski kapetan u Kranjskoj Waikhard Auersperg smatrao je da je upravo tada pravi trenutak za udar na Liku jer se, unatoč miru ili bili kakvim drugim razlozima, ne smije tolerirati uspostavljanje sandžaka s „ove“ strane rijeke Une i nastavak svakodnevne kolonizacije Like. Auersperg je strahovao da se više ništa neće moći napraviti ukoliko Osmanlije nastave obnavljati i utvrđivati prazne utvrde do proljeća. ${ }^{537}$

Kolonizacija Like i Krbave izazvala je osobitu pažnju na kršćanskoj strani što je rezultiralo produkcijom mnogobrojnih izvora kojima je zajednička jedna poruka - treba zaustaviti osmansku kolonizaciju, protjerati vlaško stanovništvo i razrušiti obnovljene utvrde. Unatoč prijetnji i opsežnim pripremama, taj naum nije ostvaren iako je kršćanska strana u nekoliko navrata Osmanlijama nanijela teške gubitke. Tako se u svibnju 1590. navodi da su

\footnotetext{
${ }^{535}$ SI AS 2, DSK, kutija 202, fascikl 124a, Carigrad, 28.12.1579., 1r-1v. Safet-beg Bašagić navodi da je sjedište novog sandžaka bio Ostrožac. Safet beg BAŠAGIĆ, Kratka uputa u prošlost Bosne i Hercegovine (od G. 1463.1850.), Sarajevo, 1900., 40. Prema protokolu Dvorskog ratnog vijeća u Grazu, Idris-beg je u listopadu 1580. napustio „svoj novi sandžak“ i bio imenovan hercegovačkim sandžak-begom (vnd geen Herzogovina zum Beeg gemacht seye). HDA, Croatica, mikrofilm D-1913, br. 27, listopad 1580. Ne ulazeći u problematiku formiranja sandžaka Lika-Krka 1580., treba navesti da Nedim Zahirović smatra da je Mehmed-beg (rodonačelnik Memibegovića) bio prvi predstojnik tog sandžaka, a da je krajem 1582. radi mletačkih prigovora smijenjen te je na njegovo mjesto tada došao Idris-beg. Nedim ZAHIROVIĆ, Tragom jedne karijere: Halil-beg (Halil-paša) Memibegović od Like preko Jegra do Banja Luke, Historijski zbornik, god. LXX, br. 2, 2017., 354.

${ }_{536}$ SI AS 2, DSK, kutija 202, fascikl 124a, Črnomelj, 19.6.1580., 1v. Iskaz trojice špijuna.

${ }^{537}$,ansezung des Feindts in der Likha auch dasslben von tag zu tag daselbst, so woll alls des herdißhalb der Vnna aufrichtunden Schanschiakhtumbes, one vnndterschidt fridens oder ainchen anndern Respects, ye durchauß nit zugedulden sein ". Ferhat-paša sa svojim je snagama krenuo u Ugarsku jer su se pojavile glasine da će poljski kralj opsjesti Budu. SI AS 2, DSK, kutija 202, fascikl 124a, Karlovac, 29.6.1580., 1r-2r. Waikhard Auersperg na predstavnike kranjskih staleža.
} 
ponovno naseljene kuće osmanskih podanika, koje su u Lici prije dvije godine napuštene (außgelassne). ${ }^{538}$ Kada su Osmanlije napokon demografski i administrativno stabilizirali prostor Like i Krbave od 1580-ih, dodatno su narušili su i sigurnosnu situaciju već tada reducirane Bihaćke kapetanije koja se našla stiješnjena između Like i Krbave s jedne strane i sve brojnih osmanskih podanika na unskom prostoru s druge strane.

\subsubsection{Početak kraja i kontroverzno osmansko osvajanje Bihaća}

Nakon burnih 1570-ih, sabora u Brucku i uglavnom neuspješne „Hrvatske ekspedicije“ 1578. te podizanja Karlovca 1579. u sljedećem se desetljeću situacija na prostoru Bihaćke kapetanije donekle stabilizirala, barem kada je riječ o teritorijalnim promjenama. Doduše, Bihaćka kapetanija spala je na svega nekoliko utvrda u široj okolici grada, ali čini se da je obrana tih „ostataka ostataka“ postala kompaktnija, bez obzira na to što je grad praktički bio u okruženju te što je bilo potrebno uložiti ogroman napor i suočiti se s maksimalnom opasnošću svaki put kada je grad trebalo opskrbiti, obaviti muštru vojne posade i slično. U zasebnom poglavlju bit će više riječi o tome prometno-logističkom problemu od presudne važnosti za opstanak habsburškog Bihaća.

Na početku treba napomenuti da je 1580-ih Osmansko Carstvo bilo fokusirano prema istoku gdje su vođene uspješne, ali skupe i kompleksne vojne operacije u Gruziji i protiv Perzije. U takvom kontekstu Porta je nastojala održati mir na ugarsko-hrvatskom ratištu pa je 1584. obnovljeno primirje na period od osam godina. No, iako je car Rudolf želio 1591. produžiti mirovni sporazum, Porta je odlučila pokrenuti novi val napada. ${ }^{539}$ Time je nakon više od desetljeća u (polu)okruženju započeo niz događaja koji će u konačnici dovesti do pada Bihaća pod osmansku vlast.

Krajem 1591. Osmanlije su uspjeli zauzeti ključnu bihaćku predstražu - Ripač. Iako Lopašić slijedi Valvasora koji taj događaj smješta u 1589., izvori nedvojbeno pokazuju da se to zbilo dvije godine kasnije. Prema iskazu bihaćkoga kapetana Christopha Obritschana tijekom osmanske opsade Ripča, 7. studenog popodne (vmb Vesper Zeit) nesretnim je slučajem eksplodirao barut u ripačkoj kuli pritom ubivši prokulaba i sve prisutne s iznimkom

\footnotetext{
${ }^{538}$ HDA, Croatica, mikrofilm D-1918, br. 3, svibanj 1590. U lipnju te godine senjski je kapetan naredio ili dozvolio napad na Podlapac (Podlapech) u kojem je oteto 2000 komada krupne stoke te odvedeno nekoliko žena i djece. HDA, Croatica, mikrofilm D-1918, br. 11, lipanj 1590. Međutim, iako je istog mjeseca navedeno da su mu zabranjeni pohodi u Liku, ipak je taj mjesec napadnut i spaljen Medak, a pritom je zarobljeno 50 „Turaka“. HDA, Croatica, mikrofilm D-1918, br. 12, lipanj 1590.

${ }^{539}$ TRACY, Balkan wars, 247-248.
} 
jedne žene i jedne djevojčice (khleinen dierals) koje su pronašli žive. Do tada su se porkulab i posada, kako je Obritschan čuo, viteški držali. ${ }^{540}$ Obritschan je od nadređenih odmah tražio da mu se zbog novih okolnosti pošalje sve nužno za obranu te pojačanje od 200 ljudi na dva tjedna da ga Osmanlije ne bi iznenada napali. Obritschanov navod da su Osmanlije ipak neopaženo upali pod Ripač, bez obzira na postojanje poštapalice „Turci ne mogu padati s neba“, svjedoči o tome koliko se bojao iznenadnih osmanskih akcija. Također, izvijestio je da ga je dan ranije porkulab Sokola obavijestio da je izbrojao 243 pucnja iz velikih topova (au $\beta$ grossen stuckhen), a sljedeći dan još 60 te da je pucnjava trajala sve do noći i smjene straže. Vatreno djelovanje Osmanlija čulo se i u Bihaću. ${ }^{541}$

Iako su Osmanlije navodno namjeravali odmah obnoviti i zaposjesti grad te s jedne strane podići most, u konačnici su od svega ipak odustali. No, prije nego što su se povukli s mjesta događaja, srušili su stari most, posjekli kolje i oštetili zidine. Obritschanovi ljudi, koji su se rijekom spustili kako bi izvidjeli situaciju, pronašli su i sahranili tijelo i unakaženu glavu „dobrog junačkog porkulaba“" (geschundnen khopp guette redliche Purggraf) čije je tijelo bilo toliko spaljeno da su ga prepoznali tek po ožiljcima koje mu je nekoć nanio neki vojnik bivšega bihaćkoga kapetana Thomasa Dornberga. ${ }^{542}$

I ovi događaji moraju se sagledavati u kontekstu uvoda ili preliminarne faze tzv. Dugog rata koji će službeno trajati od 1593. do 1606., iako neki povjesničari kao početak uzimaju 1591. Pogranični sukobi nastavili su se i u nadolazećim mjesecima upadima osmanske vojske na habsburški teritorij i vice versa. O odjeku i pozadini pograničnih razračunavanja izvještaje su sastavili i habsburški poslanici u Carigradu, Bartholomeus Pezzen i Friedrich Khrekowitz, koji su početkom veljače 1592. izvještavali da treba strepiti od velike eskalacije sukoba ako bosanski paša prođe nekažnjeno za svoje postupke na hrvatskom krajištu.

Za mirno rješavanje problema perspektiva nije bila obećavajuća jer su na Porti kružile glasine da paša namjerava „ain forssere Impressa wider Ir May. Etc. Lannd furzunemben“ “543 Paša je našao ispriku u napadu habsburške vojske na Blagaj (napali su ga Karlovčani, ali

\footnotetext{
540 „Ir aigen Pulfer durch vnglükh angangen, vnd den Thurn zerworfen, den Burggrafen, auch sambt allen so darinen gewesen, ausser eines ainichen weibs vnd khleinen dierals, die lebendig dauon gefunden, erschagen, sonnst hat sich der redliche man der Purgraf sambt sein khriegsleütten, denen allen Gott genaid. Gewisslichen, wie wir gehort, ritterlich gewehrt“. SI AS 2, DSK, kutija 805, fascikl 540, Bihać, 8.11.1591., 1r. Christoph Obritschan na Andreasa Auersperga. Ripač je ,niderworfen nicht allein der feindt, sondern vilmehr das vnglükh selbst nidergeworffen“. SI AS 2, DSK, kutija 805, fascikl 540, Karlovac, 9.11.1591., 1r. Andreas Auersperg na kranjske Verordneten.

541 SI AS 2, DSK, kutija 805, fascikl 540, Bihać, 11.11.1591., 1r-1v. Christoph Obritschan na Andreasa Auersperga.

${ }_{542}$ SI AS 2, DSK, kutija 805, fascikl 540, Bihać, 11.11.1591., 1r. Christoph Obritschan na Andreasa Auersperga.

${ }^{543}$ SI AS 2, DSK, kutija 203, fascikl 124b, Carigrad, 1.2.1592., 1r. Izvještaj upućen na nadvojvodu Ernesta.
} 
Osmanlije su se žalili i na upade Senjana) i druga osmanska pogranična mjesta. Habsburška strana smatrala je pak da su prekogranični upadi s 40 ili 50 ljudi i otimanje stoke dozvoljeni te da to ne ugrožava mir. Poslanici su naglasili ono što je mnogo puta ranije naglašeno - ako se želi mir s Osmanlijama, treba zaustaviti sukobe jer im to daje izliku za napade. Također, ustvrdili su da ,iz jednog malog početka, ispasti će veliki metež. “544 Iako je, doduše, postojala neka nada da će paša zbog raznih zlouporaba biti maknut s položaja, poslanici su raspolagali informacijama da će ga sultan ipak zadržati na toj funkciji, te da mu je naredio da ne čini ništa protivno miru i ne nanosi štete habsburškoj strani. ${ }^{545}$ Unatoč tome, u kuloarima se govorilo da će paša sljedeće proljeće napasti upravo Bihać. ${ }^{546}$ Zato su poslanici preporučili da se Bihać $i$ druga mjesta opskrbe, da se zapovjednicima naredi da miruju i ne provaljuju na osmanski teritorij te da se prekršiteljima zaprijeti teškim kaznama. ${ }^{547}$

Habsburške vlasti namjeravale su obnoviti Ripač, osobito zato što su ,jedna za drugom“ pristizale obavijesti da su i Osmanlije ozbiljno naumili zaposjesti i s jakom posadom pješaka i konjanika zauzeti tu utvrdu. ${ }^{548}$ Navodno su namjeravali tamo podići jedan Plohhau $\beta{ }^{549}$ Već sredinom siječnja Dvorsko ratno vijeće u Grazu poslalo je nadvojvodi Ernestu mišljenje o obnovi Ripča u kojem je navedeno da su glavni problemi dovoz vapna iz Slunja jer to neće ostati neprimijećeno s osmanske strane te prijevoz radnika, zidara $\mathrm{i}$ obrtnika. Konstatirali su da novaca nema te da taj trošak nije predviđen u vječno prenapregnutome krajiškom proračunu, a zemaljski ustanak odavno nije bio izvan zemlje dok Osmanlije mogu podići 40000 ljudi. Cijeli pothvat trebalo je pak provesti na način da ne izazove prekid primirja. Uza sve to, trebalo je opskrbljivati i Bihać, a nedavni osmanski napad, pri kome je 14 samara, dakle tovarnih životinja (konja, mazgi ili magaraca), dijelom sasječeno te dijelom zarobljeno, pokazao je koliko je to opasno. ${ }^{550}$ Tada se opet razmišljalo se o napuštanju Bihaća, ali su Kranjska i Koruška bile protiv toga da se napusti ta preko stotinu godina stara krajiška utvrda. ${ }^{551}$ Zanimljivo je da je zapovjednik Hrvatske krajine javljao da su Osmanlije načinili skicu ili model (Abriß oder Model) za obnovu Ripča koji je Murat-aga

\footnotetext{
544 „Sonndern werde auß ainen Khlainen anfang, ain grosse Vnrhue“. SI AS 2, DSK, kutija 203, fascikl 124b, Carigrad, 1.2.1592., 1v-2r. Izvještaj upućen nadvojvodi Ernestu.

545 SI AS 2, DSK, kutija 203, fascikl 124b, Carigrad, 1.2.1592., 2v-3r. Izvještaj upućen nadvojvodi Ernestu.

${ }^{546}$ SI AS 2, DSK, kutija 203, fascikl 124b, Carigrad, 1.2.1592., 4r. Izvještaj upućen nadvojvodi Ernestu.

${ }^{547}$ SI AS 2, DSK, kutija 203, fascikl 124b, Carigrad, 1.2.1592., 4r. Izvještaj upućen nadvojvodi Ernestu.

${ }^{548}$ SI AS 2, DSK, kutija 285, fascikl 163, Graz, 3.3.1592., 1r-1v, rbr. 1024-1025. Nadvojvoda Ernest na kranjske staleže.

${ }_{550}^{5}$ SI AS 2, DSK, kutija 285, fascikl 163, Graz, 1r-1r, rbr. 1026. Nadvojvoda Ernest na Andreasa Auersperga.

${ }^{550}$ SI AS 2, DSK, kutija 285, fascikl 163, Graz, 14.1.1592., 1r-3v, rbr. 1065-1070.

${ }^{551}$ SI AS 2, DSK, kutija 285, fascikl 163, Graz, 14.1.1592., 4r, rbr. 1071.
} 
poslao sultanu u Carigrad. ${ }^{552}$

Početkom veljače bihaćki kapetan javljao je da 60 osmanskih Vlaha stražari kod Ripča kako bi bosanskom paši mogli odmah javiti započnu li habsburški radovi. Špijunski izvještaji govorili su da su Osmanlije već odredili 500 konjanika i pješaka za obnovu Ripča te da je livanjskom begu naređeno da, uz asistenciju ličkog bega, bez odgađanja izvrši planirano. ${ }^{553}$ Nekoliko dana kasnije (9. veljače) Auersperg javlja nadvojvodi Ernestu da ga je ban izvijestio da su begovi kod bosanskog paše u Banja Luci te da namjeravaju podizati Ripač. Nedostajale su preciznije vijesti jer je jedan špijun u Banja Luci bio uhvaćen, a sudbina drugog špijuna nepoznata. ${ }^{554}$

Rasprave o Ripču nastavile su se kroz veljaču, da bi početkom ožujka Auersperg u odgovoru nadvojvodi na pitanje može li se Ripač podići samo s krajiškom vojskom konstatirao da je bosanski paša prejak i da u četrnaest dana može podići preko 40000 ljudi te da se protiv takve sile teško obraniti tijekom radova. Auersperg je, nakon savjetovanja sa zapovjednicima, smatrao da bi za jednu takvu akciju bilo potrebno 20000 ljudi, za što je pak nedostajalo sredstava. Ipak, naveo je da bi se pothvat možda mogao izvesti i s 10000 sposobnih vojnika, ali bez seljaka (Pauer oder Landtvolck) na koje se, pokazalo je iskustvo, ne može osloniti. ${ }^{555}$

Početkom ožujka u cirkulaciji je i diskurs neimenovanoga bivšeg časnika i upravitelja Bihaćke kapetanije koji je, kako stoji u izvoru, imao „veliko znanje od prostoru od Bihaća do Karlovca, prema Ripču i neprijateljskoj zemlji“. U spisu se navodi da bi osmansko obnavljanje Ripča zasigurno vodilo padu Bihaća i ugrozi Karlovca i Kranjske te se žali što Ripač do sada nije obnovljen, odnosno što ga se namjerava sasvim napustiti jer to ni jedna iskusna i kompetetntna osoba ne bi savjetovala. Onima koji tvrde da je to tek jedan stražarnica (scarthaus) odgovara da je to nije točno, već da je to krajiška utvrda (Gränizhaus) o kojoj mnogo toga ovisi. Ako je Bihać najvažnija i najisturenija krajiška utvrda u Hrvatskoj, tada Ripač nije „ni najmanje sredstvo“ za njegovo zadržavanje u habsburškim rukama. ${ }^{556}$ Nije se slagao ni s namjerama da se Bihać napusti i uništi, a Slunj utvrdi, jer Bihać bi se brzo mogao

\footnotetext{
552 „, das abgerissend Model durch den Murataya“. SI AS 2, DSK, kutija 285, fascikl 163, 1r-3v, rbr. 1065-1070; SI AS 2, DSK, kutija 285, fascikl 163,1v, rbr. 1077.

${ }^{553}$ SI AS 2, DSK, kutija 285, fascikl 163, Karlovac, 4.2.1592., 1v-2r, rbr. 1051-1052.

${ }^{554}$ SI AS 2, DSK, kutija 285, fascikl 163, Karlovac, 9.2.1592., 1r, rbr. 1057.

555 SI AS 2, DSK, kutija 285, fascikl 163, Graz, 3.3.1592., 1r-1v, rbr. 1024-1025. Andreas Auersperg na nadvojvodu Erenesta.

${ }^{556}$ SI AS 2, DSK, kutija 285, fascikl 163, Beč, 5.6.1592., 1r-1v, rbr. 1037-1038. U pismu Davida Ungnada na kranjske staleže. Navodi se da je ta osoba tri godine bila zastavnik u Bihaću, a tijekom izbivanja Sebastiana Lamberga godinu dana i upravljala kapetanijom. To bi mogao biti Georg Panner ili Franz Rössel, iako će to biti potrebno dodatno istražiti.
} 
uništiti, ali se ne bi tako lako moglo naći takvo mjesto odakle bi se Osmanlijama moglo suprotstaviti. ${ }^{557} \mathrm{U}$ tom slučaju moralo bi se napustiti Sokol, Izačić i Drežnik te osloniti na Slunj koji je u lošem stanju (osobito trgovište) te bi trebalo utrošiti 50000 rajnskih guldena da ga se pretvori u tvrđavu (vesstung). Usto, između utvrde i trgovišta sa samostanom leži duboki klanac što otežava obranu. Dakle, Slunj nije smatran alternativom Bihaću. ${ }^{558}$

Do početka ožujka 1592. sa svih su strana već pristizale obavijesti o osmanskim pripremama za napad na sam Bihać. Auersperg je kranjskim staležima javljao da mu je jedan od bana delegirani plemić doveo nekog „Turčina“ koji je dan ranije uskočio iz Krupe na kršćanski teritorij, a koji se na zaklinjao životom da je bosanski paša u punome bojnom poretku stigao do Kamengrada te da namjerava ,još ovu mjesečinu, kada se pojavi, doći pod Bihać i gađati ga topništvom te neumorno nastojati silom ga zauzeti““. ${ }^{559}$ Auersperg je odmah tražio da se podigne zemaljski ustanak u Kranjskoj te da se osiguraju financijska sredstva za nabavu živeži i svega potrebnog za efikasnu obranu. Nastavlja da bi u takvoj nevolji rado priskočio u pomoć Bišćanima s vojnicima i streljivom, ali da to ne može učiniti „s praznim rukama“, odnosno prije nego pristigne potrebno za obranu. ${ }^{560}$

Krajem ožujka vrlo zanimljiv iskaz o osmanskim planovima sastavio je u Beču već spomenuti habsburški poslanik Bartholomeus Pezzen. Riječ je o informacijama koje je prikupio pri povratku iz Carigrada odakle je otputovao početkom veljače te godine. Već drugi dan putovanja sreo je ćehaju bosanskog paše sa 37 zarobljenika, preko 40 odsječenih glava i mnogo kola sa zarobljenim ženama i djecom. Svugdje kuda je prolazio govorilo se da je to tek „mala šala“ u odnosu na ono što se sprema ovo proljeće. Putem je od uglednih Osmanlija, osobito onih u Sofiji, saznao da paša namjerava zauzeti Bihać i Senj što mu je na Porti i odobreno. Od beglerbega Graecia saznao je da je njemu i njihovim spahijama naređeno da pomognu ukoliko ih pozove. Pezzen je zaključio da se svugdje kuda je prošao pričalo da je to dugo očekivana prilika za početak otvorenoga kršenja mira (offnen fridbruch sein sollte). ${ }^{561}$

Osmanske ratne pripreme bile su zaista u tijeku. Bihaćkom vojvodi prezimena Wakhata, čiju je postrojbu Lamberg sredinom ožujka poslao u izviđanje prema Udbini, uspjelo je kod Frkašića zarobiti jednog osmanskog vojnika iz Udbine za kojeg je Lamberg

\footnotetext{
${ }^{557}$ SI AS 2, DSK, kutija 285, fascikl 163, Beč, 5.6.1592., 2r-3r, rbr. 1039-1040. Navodi se u pismu Davida Ungnada na kranjske staleže.

${ }_{558}$ SI AS 2, DSK, kutija 285, fascikl 163, Beč, 5.6.1592., 3r-3v, rbr. 1040-41 Navodi se u pismu Davida Ungnada na kranjske staleže.

${ }_{559}$ SI AS 2, DSK, kutija 805, fascikl 540, Karlovac, 5.3.1592., 1r. Andreas Auersperg na kranjske staleže okupljene u Ljubljani.

${ }^{560}$ SI AS 2, DSK, kutija 805, fascikl 540, Karlovac, 5.3.1592., 1v. Andreas Auersperg na kranjske staleže okupljene u Ljubljani.

${ }^{561}$ SI AS 2, DSK, kutija 203, fascikl 124b, Beč, 20.3.1592., 1v. Nema adresanta.
} 
vjerovao da je harambaša, a koji je ovako opisao osmanske pripreme za napad na Bihać. U cijeloj zemlji bio je podignut ustanak te je svaki Vlah koji je posjedovao vola morao je dati jednog za prijevoz topova dok su oni bez volova morali dati jedan tovar zobi ili ječma umjesto jednog vola. Naime, Osmanlije su hitro postupali kako bi se prije dolaska habsburškog pojačanja dobro ušančili oko Bihaća i načinili zapreku od Klokota do ispod Plješevice, čime bi prepriječili prilaz gradu. Također, naveo je da će Osmanlije dovući sedam topova, od kojih je jedan veliki top koji mora vući 300 volova. Na kraju je otkrio da je ranije planirani napad odgođen zbog lošeg vremena, ali da je paša čvrsto naumio udariti na Bihać sa sljedećim punim mjesecom. ${ }^{562}$ Lamberg je dodao da cijela osmanska krajina, a osobito Udbinjani, spremno čekaju naredbu za napad te da neprijatelj pod grad planira prevesti vatreno naoružanje preko mostova u Krupi i brda Mač $(S a b l)$. Istodobno je pristigla i sultanova naredba da se podigne Ripač, a za to je već bilo delegirano 500 ljudi. $^{563}$

Do tada je već uvelike zavladala psihoza straha. Na raznim su stranama privođene navodne izdajice, a kolale su glasine da se paša neće zaustaviti na Bihaću, već namjerava provaliti u Kranjsku, sebi podvrgnuti uskoke i s njima poharati cijeli kraj te u povratku osvojiti Karlovac. ${ }^{564}$ Inflacija svakojakih obavijesti mogla je biti ciljana diverzija da bi se maksimalno raspršile habsburške snage.

Prije opsade Bihaća Hasan-paša je u travnju i svibnju započeo gradnju Petrinje te osvojio Gore i Hrastovicu. ${ }^{565}$ U lipnju je napokon uslijedio napad na grad. Već 10. lipnja osmanska vojska se s topovima i ratnom opremom utaborila kod brda Pokoj, a tri dana kasnije pod Bihać je stigao i paša s glavninom snaga. Dio vojske poslao je osvojiti Izačić koji je branio Gašpar Babonožić s posadom od šesnaest vojnika. Iako su prvi osmanski napad odbili, posada je prisilila porkulaba da u noći 14. lipnja potajice napuste grad. ${ }^{566}$ Bihaćki kapetan Sebastian Lamberg ,zavjerio je Nijemce, uskoke, Hrvate i građane, te su svi prisegli i tvrdu vjeru zadali da će zajedno živjeti i umrijeti“. Hasan-paša dao je pred velikim mostom ostaviti pismo u kojem je tražio od kapetana i posade da predaju grad „koji ionako pripada sultanu“, no bihaćka je posada odbila tu ponudu izjavivši da ne žele učiniti ono što su učinili ,izdajice i Božji nevjernici Hrastovičani“. Paša je pokušao poslati stanovitog Ivana Jurčića Keletu u Hotinac na razgovor, ali Lamberg na to nije pristao. ${ }^{567}$ I građani su apelirali na Auersperga da

\footnotetext{
${ }^{562}$ SI AS 2, DSK, kutija 805, fascikl 540, Bihać, 20.3.1592., 1r. Sebastian Lamberg na Andreasa Auersperga.

${ }^{563}$ SI AS 2, DSK, kutija 805, fascikl 540, Bihać, 20.3.1592., 1v. Sebastian Lamberg na Andreasa Auersperga.

564 SI AS 2, DSK, kutija 805, fascikl 540, Karlovac, 21.3.1592., 1r-1v. Georg Paradaiser na kranjske Verordneten.

${ }^{565}$ V. KLAIĆ, Povijest Hrvata, knjiga 5, 476-478.

${ }^{566}$ LOPAŠIĆ, Bihać, 173.

${ }^{567}$ IBID. 77.
} 
pomogne obećavajući da su pripravni „poginuti kao starovjerci kršćani i katolici“. 568 Zanimljivo je da Klaić navodi da je zamjenik zapovjednika Hrvatske krajine Georg Paradaiser tražio pomoć od kranjskih staleža, ali da oni nisu ,pravo vjerovali u ozbiljnost pogibelji, već su mislili da bosanski paša kani samo obnoviti i utvrditi prošle godine osvojeni Ripač“ ${ }^{569}$ Dakle, čini se da Ripač sve do opsade Bihaća nije bilo obnovljen.

Osmanlije su postavili snage na tri glavne lokacije. Kod brda Pokoj (Klaić navodi da su do tada Bišćani to brdo zvali „Nepokoj“) nalazio se Hasan-paša, drugi dio vojske nalazio se kod sela Kralja, a treći kod Ripča. (Lopašić kao lokacije navodi Pokoj, među vodama i oko Somišlja). ${ }^{570}$ Doduše, Klaić kaže da je kapetan Lamberg 13. lipnja uspio poslati po pomoć prvo dvoje uskoka, pa zatim dvoje haramija, Antuna Hrinčića i Mihajla Glačnika te zatim još trojicu haramija, Juricu Ćurilovića, Gašpara Radovića i mladog Peranskog. Kasnije se više nije moglo probiti izvan grada, osim što je 17. lipnja slunjski porkulab Nikola Barbarić pisao da je „s velikom pogibelju“ u grad uneseno neko pismo. Barbarić je javljao sljedeće: „S planine Plješevice [...] naši su vidjeli da Turci neprekidno s dvije strane topovima udaraju na Bihać. Tutnjava velikih topova dopire danas do nas. Jučer je nismo mogli čuti, jer je puhala jaka bura.“. 571

Prema svjedočanstvu dvojice, netom prije pada grada iz osmanskog zarobljeništva spašenih kršćana, Bihać je bio izložen intenzivnim topničkim udarima, ali da su se „siroti Bišćani, koliko su god mogli, držali i branili kao časni vojnici“ ${ }^{572}$ Pomoć nije pristizala jer su vojne posade okolnih utvrda, poput Slunja i Drežnika, navodno raspolagale sa zalihama puščanog praha za oko četiri pucnja. Postojala je i opravdana bojazan da će Osmanlije napasti i te utvrde. Slična situacija bila je i u Karlovcu gdje nije bilo više od jednog centa baruta koji je pak trebao tamošnjim arkebuzirima i njemačkim vojnicima. ${ }^{573}$

Lopašić ili autori od kojih on preuzima podatke najviše su se koristili izvještajem koji je 20. lipnja 1592. sastavio slunjski porkulab Nikola Barbarića. Glavni Barbarićev informant bio je bihaćki vojvoda Karabogdan, jedan od rijetkih, ako ne i jedini iz pratnje kapetana Lamberga koji je uspio uzmaći Osmanlijama nakon sukoba prilikom dogovorenog napuštanja grada. Karabogdan je svjedočio da je prethodnog petka Hasan-paša osvojio Bihać pod uvjetom da mu se Bišćani podrede. Vidjevši da se ne može održati, njemačka se posada

\footnotetext{
${ }^{568}$ V. KLAIĆ, Povijest Hrvata, knjiga 5, 478-479.

${ }^{569}$ IBID., 479.

${ }^{570}$ LOPAŠIĆ, Bihać, 77.

${ }^{571}$ V. KLAIĆ, Povijest Hrvata, knjiga 5, 479.

${ }^{572}$ SI AS 2, DSK, kutija 287, fascikl 164, Karlovac, 18.6.1592., rbr. 1368, 1r.

${ }^{573}$ SI AS 2, DSK, kutija 287, fascikl 164, Karlovac, 18.6.1592., rbr. 1368, 1r. Prema Simonitijevu izračunu, jedna centa iznosila bi oko 56 kilograma. SIMONITI, Vojaška organizacija, 185.
} 
predala uz pašino obećanje da mogu slobodno napustiti grad. Tu nekolicinu njemačkih vojnika i uskoka osmanska je vojska otpratila do Čalopek Brda, do kuda je u pratnji došao i sam paša koji se potom vratio u Bihać. Poražene je dalje pratio jedan vojvoda s 400 vojnika, a kada su došli do Metschinitsch Furt ${ }^{574}$ Osmanlije su im počeli napastovati (zu zuck) ženu i djecu te je izbio sukob (Rumor) u kojem je Thomas Gall (Thoman Gally) ${ }^{575}$ upucao Veli-agu. Karabogdan nije znao ništa reći o sudbini ostalih. ${ }^{576}$ Budući da je tvrdio da su mu Veli-aga i stanoviti Feichtouitsch izjavili da će paša udariti na Slunj, Barbarić je tražio pomoć. Pojačanje od 50 masola s Gašparom Čolnićem na čelu trebalo je stići za par dana, ali je Barbarić smatrao da će to biti prekasno. ${ }^{577}$

Međutim, kao što i Klaić navodi, nakon osam do devet dana otpora, 19. lipnja, kada su Osmanlije već prislanjali ljestve na gradske zidine, bihaćki sudac, stari sudac i podsudac tražili su od Lamberga da preda grad i tako izbjegne krvoproliće. Navodno je dogovoreno da svatko tko želi može izaći iz grada i ponijeti svoju imovinu te da je paša ulazeći u grad darivao haljinama i novcem vojnike, građane, žene i djecu. Navodi se da je stanovnicima podijelio mnogo novaca i pokazivao škrinje pune zlata obećavajući da će se i to podijeliti. Andriju Bajnaka, koji je bio rođeni Bišćanin i husar vješt hrvatskom i njemačkom pismu, postavio je za pisara. ${ }^{578}$ Kasnije se navodilo da je sve to bila varka te da je paša od 5000 kršćana dao sasjeći više od 2000, a 800 djece da je poslao u Carigrad. ${ }^{579}$ Dio zarobljenika svakako je poslan u Carigrad jer je carski poslanik na Porti javljao da je osmanskom prijestolnicom paradiralo 172 zarobljenika, da su pokazane 22 zastave otete kod Bresta i skinute iz bihaćkih crkvi, a Hasan-paša poslao je i slike Bihaća i Slunja. ${ }^{580}$ Za sada je teško u detalje opisati što se točno dogodilo, ali ne bi trebalo biti sumnje da je otpor dogovorno

\footnotetext{
${ }^{574}$ Marko Šarić ovaj brod identificira kao današnju Pašinu Luku u Vagancu. ŠARIĆ, Etnokulturna kretanja, 23.

${ }^{575}$ Steklasa tvrdi, citirajući Istvanffyja, da je riječ o Tomašu Bataliću, da se spasio samo Lamberg i šestoro od 22 vojnika te da je Lamberga paša zarobio pa pustio. STEKLASA, Kako so Turki, 488.

${ }^{576}$ SI AS 2, DSK, kutija 287, fascikl 164, Slunj, 20.6.1592., 1r, rbr. 1392. Izvještaj Nikole Barbarića.

${ }^{577}$ SI AS 2, DSK, kutija 287, fascikl 164, Slunj, 20.6.1592., 1v-2r, rbr. 1393-1394. Izvještaj Nikole Barbarića.

${ }^{578}$ LOPAŠIĆ, Bihać, 78-79.

${ }^{579}$ V. KLAIĆ, Povijest Hrvata, knjiga 5, 479-480. U tiskovini Jacoba Francuma pod naslovom „Historicae Relationis Continvatio: das ist warhafftige Beschreibunge aller fürnemen vnd gedenckwirdigen sachen, so sich hin vnd wieder in Europa....", sastavljenoj 1592. na temelju vjerodostojnih spisa, nalazi se poglavlje naslova „Der Türck nimpt Wichitsch in Crabaten eyn “ u kojem se navodi da je „Turčin“ tiranski nasrnuo na Hrvatsku, 9. lipnja opsjeo Bihać, gađao ga topovima s tri strane te napao i jurišem osvojio. Tvrdi se da je do 5000 kršćana ubijeno, a 800 djece poslano u Carigrad. Nadalje, ostali građani i stanovnici (Burger vnd Eynwohner) morali su se podložiti Osmanlijama. Kapetana, časnike i posadu, u kojoj je bilo 30 njemačkih vojnika, pustili su da izađu iz grada u pratnji jednog osmanskog vojvode s 400 konjanika. No, bivši stražmeštar i plemić Thomas Gall (stoji Bally) ubio je Veli-agu (Beli Aga) koji mu je napastvovao suprugu (seiner Madonna). Tada je izbio sukob. Ovaj izvještaj očito je temeljen na izvještaju vojvode Karabogdana koji se uostalom i spominje kao jedini poznati preživjeli. Navedeno djelo, 48. Tiskovina je dostupna na http://books.google.com, datum pristupa 13. prosinac 2018.

${ }^{580}$ LOPAS̆IĆ, Bihać, 80.
} 
prekinut te da je grad predan Osmanlijama. U izvorima nisam našao ništa o Sokolu, pa pretpostavljam da je utvrda napuštena ili predana Osmanlijama nakon pada Bihaća.

Pad Bihaća odjeknuo je i na kršćanskom zapadu. Još iste godine u Beču Leonhard Nassinger objavio je publikaciju pod naslovom „Tužne vijesti o tome kako je strašni zakleti neprijatelj kršćanskog imena Turčin, najistureniju pograničnu utvrdu Bihać u Hrvatskoj smještenu, nakon dugotrajne opsade napokon osvojio i zauzeo, te potom mnogo kršćanske krvi bijedno prolio“. U tiskovini se navodi da su 21. lipnja u jedan sat iza ponoći stigle tužne vijesti iz Drežnika i Slunja kako je dva dana ranije da je u petak 19. lipnja osvojen Bihać. Na grad je pucano s tri lokacije, dok je s četvrte pucano po kaštelu (das Schlo $\beta$ ). Kada su ljestve već stavljane na zidine, gradski sudac tražio je od kapetana da se radije predaju nego da svi izginu sa ženama i djecom. Kapetan se složio i namjeru dojavio paši koji je odmah poslao jednog uglednog bega na pregovore. Kapetan i gradski sudac tada su pristupili pred pašu koji je pristao da oni koji to žele ostanu, dok su drugi dobili garanciju za neometani izlazak iz grada. Kapetan je s 30 njemačkih vojnika, imovinom, ženama i djecom napustio grad, a paša ih je osobno pratio do Čalopeka s velikim brojem osmanskih vojnika. Od tamo ih je jedan vojvoda s 400 konjanika trebao pratiti do Slunja. No, kada je paša otišao, Osmanlije su napale i opljačkale Nijemce, a Thomas Gall, bivši bihaćki stražmeštar, upucao je uglednog Turčina Veli-agu. Izbio je sukob, a do Slunja je došao samo vojvoda Karabogdan (Karro Baday), dok se za kapetana i ostale njemačke vojnike ništa nije znalo. ${ }^{581}$

\footnotetext{
${ }^{581}$ Naslov je „Klägliche Zeitung Was massen dererschröckliche Erbfeindt Christliches Namens / der Türck/das Eusserist GränizHuaß vnd Vestung Wihitsch in Krabatten gelegen/ nach lang beschehener Belegerung / entlichen Erobert vnd eingenommen / vnd hernach im abziehen vil Christen Blut / jämmerlich vergossen / den 19. Juny / Anno 1592. “. Publikacija je digitalizirana i objavljena na mrežnoj stranici Bavarske državne knjižnice (Bayerische Staats Bibliothek) http://daten.digitale-

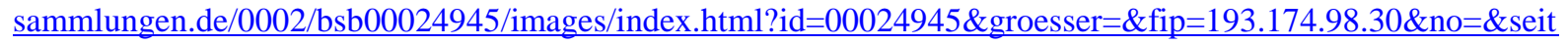
$\mathrm{e}=2$ pristup. 18. prosinca 2018.
} 


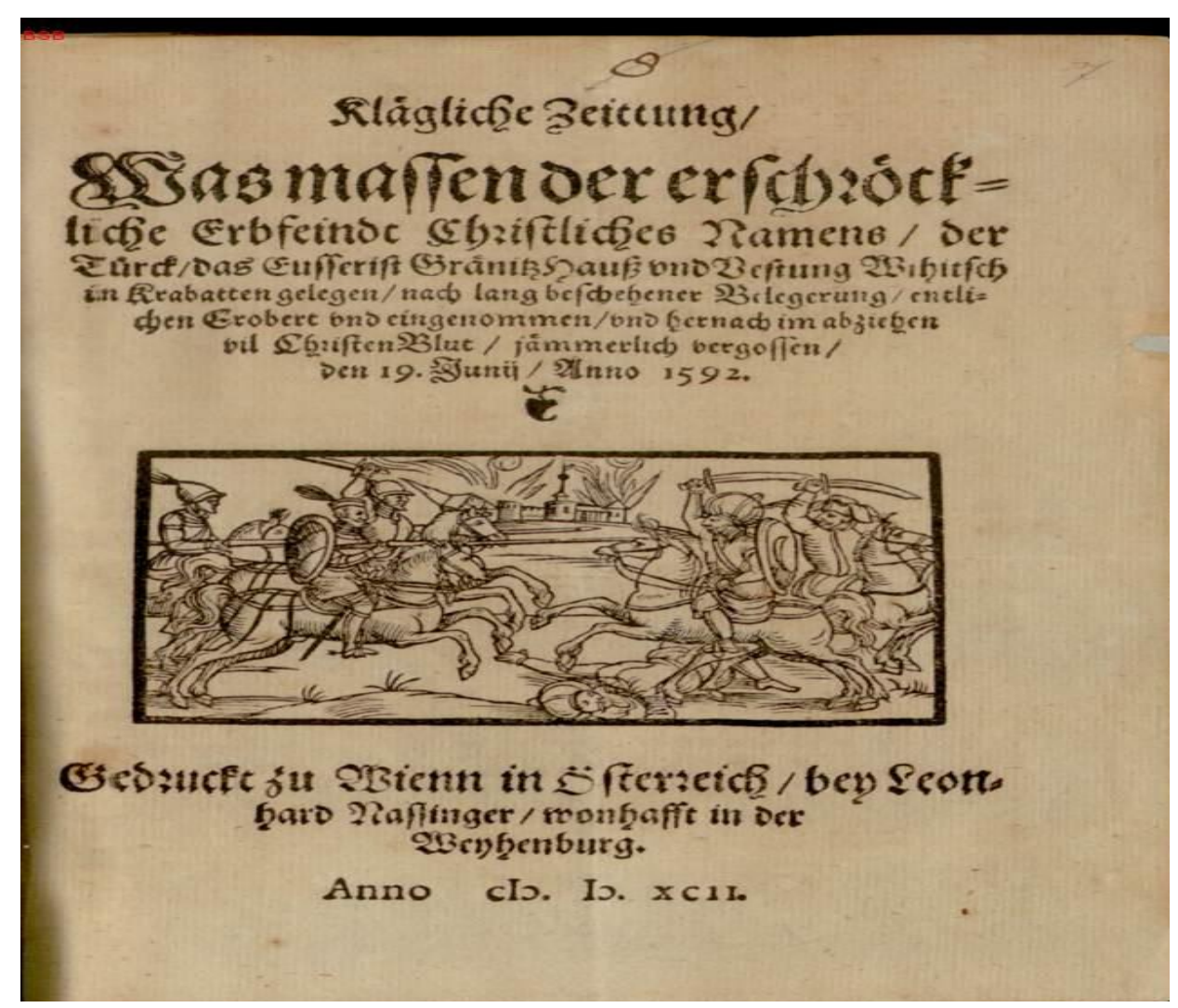

Slika 18. Naslovnica navedene Nassingerove publikacije.

Habsburški orator u Carigradu protestirao je u carevo ime protiv Hasan-paše i zauzimanja Bihaća tvrdeći da je to protivno mirovnom ugovoru te tražio da se grad vrati jer u protivnom nikad više neće predati godišnji „dar“. Na to je Čauš-paša (Cziausch Bassa) replicirao da zauzimanje nije bilo protivno mirovnom ugovoru jer nisu korišteni teški topovi i nisu izvedeni veliki napadi te su kršćani grad dobrovoljno predali. ${ }^{582}$ Nakon pada Bihaća i vijesti da će paša provaliti dalje, podčiniti uskoke i napasti Karlovac koruški staleži započeli su podizati konjicu i pješaštvo. Iako su tvrdili da su spremni promptno reagirati, jedinice koje su se okupljale, a osobito arkebuziri, nisu mogle doći u Ljubljanu prije 3. ili 4. srpnja. ${ }^{583} \mathrm{Na}$ kraju se situacija ipak smirila.

Bihać je od tada ostao u osmanskim rukama. Osmanlije su očito vrlo brzo osnovali Bihaćki sandžak jer se već krajem rujna 1592. u jednom izvještaju o kretanju osmanske vojske te okupljanju paša u Novom na Uni govori da „, Byhchju ni Udvyny ny u drugyh nyh gradoyh ny ny chlouyka oztalo, sto je za orusye, tho ye vze v'voyzku posslo. A sto ye

\footnotetext{
${ }^{582}$ Friedrich SEIDELN, Denckwürdige Gesandtschafft an die Ottomannische Pforte, Welche ehmahls auf Rö. Jayl. May. Rudolphi II hohen Befehl herr Fridrich von Krekwitz, Sr. Maj. Reichs=Hof=Rath, verrichtet, Nebst ausführlichem Berich, was hierbey so wohl mit dem Herrn Oratore selbst, al denen Seinigen vorgelauffen, aufgesezt und schrifftlich hinterlassen von Fridrich Seideln..., Görlitz, Johann Gottlob Laurentius, 1711., 9-10. Dostupno na stranici https://books.google.hr/. Pristup 28. veljače 2019.

${ }^{583}$ SI AS 2, DSK, kutija 805, fascikl 540, Klagenfurt 23.6.1592., 1r.
} 
bychkoga zansaka vojzke, tho ye na 17. ouoga mysecza pry Byhchyu nchylo, a na 18. V Krapussy, a odonle yesu naperuo prossli, da ze od zgora uzdrši “ ${ }^{584}$ Dakle, zbilo se ono što su unutrašnjeaustrijski staleži i krajiška struktura pretpostavljali. Čim se osvoji, Bihać će postati glavna osmanska utvrda na osmanskom krajištu - serhatu. Svojevrsna je povijesna ironija da se, unatoč desetljećima lamentiranja o katastrofi koja bi mogla proizaći nakon gubitka Bihaća, u generalnom smislu gotovo ništa dramatično nije dogodilo kada se to zaista zbilo. U pozadini je već stajala najvažnija regionalna utvrda, novopodignuti Karlovac, koji je predstavljao veliku prepreku daljnjem osmanskom napredovanju. Ubrzo je eskalirao otvoreni rat između Habsburške Monarhije i Osmanskog Carstva, uslijedio je i veliki osmanski poraz kod Siska 1593., borbe na ugarskom ratištu intenzivirale su se pa se postavlja pitanje koliko su nakon svega Osmanlije uopće bili spremni poduzimati veće ofenzivne akcije na hrvatskom prostoru. Sukoba je naravno bilo, ali osvajanja više ne. Štoviše, kada je riječ o Bihaću dogodilo se upravo suprotno. Juraj Lenković, sin proslavljenog Ivana Lenkovića, provalio je u studenom 1594. u Bihać, zauzeo cijeli grad osim kaštela, pri povratku ga spalio i odveo sa sobom 1200 kršćana. Dva zarobljena osmanska vojnika, tri zastave i nekoliko konja poslao je nadvojvodi u Graz. ${ }^{585}$

Tako su krajem 16. stoljeća Bihać zauzeli Osmanlije, a dvije godine kasnije spalila ga je habsburška vojska u čijem je sastavu moralo biti i onih koji su možda i godinama nastojali obraniti grad od osmanskog oružja. Sada su sudjelovali u njegovoj destrukciji, a to je još jedna povijesna ironija svojstvena krajiškoj zbilji. Može se samo postaviti pitanje kakve su im misli prolazile glavom dok su u povlačenju gledali Bihać u plamenu.

\footnotetext{
${ }^{584}$ BOJNIČIĆ, Izvješća, dok. XLIV, 98-99.

${ }^{585}$ V. KLAIĆ, Povijest Hrvata, knjiga 5, 509; Hamdija KREŠEVLJAKOVIĆ, Kapetanije u Bosni i Hercegovini, Svjetlost, Sarajevo, 1980., 102.
} 


\section{BROJNOST I KARAKTERISTIKE VOJSKE NA PODRUČJU BIHAĆKE KAPETANIJE}

Prilikom analiziranja broja i karakteristika vojnih postrojbi na području Bihaćke kapetanije treba voditi računa o nekoliko bitnih stvari. Prije svega, treba naglasiti da je promatrano razdoblje, tijekom kojeg su uvođene dalekosežne promjene u vojnoj tehnologiji, strategijama i taktikama ratovanja u Europi, u historiografiji poznato kroz paradigmu „,vojne revolucije“. Taj koncept, koji je uveo Michael Roberts 1955. i koji su zatim na svoj način argumentirali Geoffrey Parker, Jeremy Black, Clifford Rodgers i mnogi drugi, podrazumijeva uvođenje raznih vojno-tehnoloških inovacija, prvenstveno sve veću uporabu ručnoga vatrenog oružja i topova, porast broja stajaćih i profesionalnih vojski te povećani utjecaj sve većih vojski na europsko društvo. ${ }^{586}$ Uz povećanja broja vojnika, rastao je udio strijelaca i vatrenog oružja, a postupno padala važnost hladnog naoružanja, koplja i mačeva. Usto, u utvrdnom graditeljstvu pojavili su se novi elementi, tzv. „trace italienne“ (bastioni, ravelini, korištenje zemljanih nasipa, raznih formi zidina itd.), prilagođeni obrani od vatrenog naoružanja ${ }^{587} \mathrm{Na}$ europskom bojnom polju počelo je dominirati pješaštvo, a do 1520-ih vatreno naoružanje se od pomoćnog oružja pretvorilo u glavno oružje. ${ }^{588}$ Do sredine 16 . stoljeća ručno vatreno oružje postalo je prevladavajuće streljačko oružje europskih vojnika. ${ }^{589}$

$\mathrm{Na}$ specifičnome krajiškom prostoru aplicirani su glavni elementi modela razvoja europskog ratovanja. Prije svega, to su tehnološke i fortifikacijske inovacije, uporaba ručnoga vatrenog naoružanja, teških bedemskih pušaka i topova te uvođenje novih fortifikacijskih elementa. ${ }^{590}$ Najupečatljivija inovacija ipak je bila uporaba ručnoga vatrenog oružja među

\footnotetext{
${ }^{586}$ Literatura o „vojnoj revoluciji“ je golema. Temelji su naslovi sljedeći: Geoffrey PARKER, The Military Revolution. Military Innovation and the Rise of the West, 1500-1800., Cambridge, 1988.; Jeremy BLACK, War and the World. Military Power and the Fate of the Continents 1450-2000., New Haven-London, 1998.; Jeremy BLACK, A Military Revolution? Military Change and European Socitey 1550-1800., Exeter, 1986.; John Rigby HALE, War and Society in Renaissance Europe 1450-1620., McGill-Queen's University Press, 1998.; Zbornik The Military Revolution Debate: Readings on the Military Transformation of Early Modern Europe, ur. Clifford J. Rodgers, Boulder: Westview Press, 1995.

${ }^{587}$ PARKER, The Military Revolution, 6-44.

${ }^{588}$ Michael HOWARD, Rat u europskoj povijesti, Srednja Europa, Zagreb, 2002., 39.

${ }^{589}$ Clifford J. ROGERS, Tactics and the face of battle, u: European Warfare, 1350-1750, ur. Frank Tallett i D. J. B. Trim, Cambridge University Press, 2010., 213.

590 Robert I. Frost je demonstrirao da su na području sjeverne i istočne Europe bila poznata i aplicirana suvremena vojno-tehnološka dostignuća, ali da su vojne promjene pratile svoju zasebnu logiku zbog specifičnog ambijenta i potrebe izvođenja ratnih operacija. Istočna Europa nije bila ignorantna prema vojnim novitetima, već ih je prilagođavala prema svojoj potrebi. Autor zaključuje: ,historians should be cautious about adopting crude technological determinism. For the effectiveness of technology depended fundamentally on the nature of the physical and social environment in which it was applied." Robert I. FROST, The Northern War. War, State and Society in Norteastern Europe 1558-1721, Longman, 2000., 311.
} 
konjanicima i pješacima, osobito vidljiva od polovice 16. stoljeća. $^{591}$ Iako je vatrenog naoružanja stalno nedostajalo, strijelci su postali izrazito važan element na krajištu. Uz korištenje tradicionalnoga hladnog oružja - sablji, koplja, bodeža, sjekira, buzdovana i sl., sve više se upotrebljavalo i ručno vatreno oružje. Kada je sredinom rujna 1565. habsburška vojska porazila Osmanlije kod sela Golubića na Uni, velik dio osmanskih martologa bio je upucan, izboden, utopljen $\mathrm{i}$ sasječen, što demonstrira lepezu metoda i oružja korištenog $\mathrm{u}$ tom sukobu. $^{592}$

Ugarsko-hrvatsko pograničje predstavljalo je jedno od važnijih ratnih pozornica za uvođenje raznih inovacija te je služilo kao katalizator vojnih promjena. ${ }^{593}$ Prije svega, došlo je do velikog povećanja broja aktivnih vojnika. Tako je na ugarsko-hrvatskom prostoru u protuosmanskome obrambenom sustavu u drugoj polovici 16. stoljeća služilo gotovo triput više ljudi nego prije 1526., odnosno 20-22 000 naspram 7-8000. Riječ je o visokim brojevima čak i u europskom kontekstu. ${ }^{594}$ Već od 15. stoljeća na ugarsko-hrvatskom pograničju prisutno je i vatreno oružje u nezanemarivim količinama. ${ }^{595}$ Količina vatrenog oružja se tijekom 16. stoljeća još i povećavala pa je habsburška strana u odnosu na osmansku u zadnjim desetljećima stoljeća imala određenu superiornost. Na Bečkom savjetovanju 1577. ratni su

591 ŠTEFANEC, Država ili ne, 325.
592, ,erschossen, erstochen, ertrenkht vnd nidergehauen“. SI AS 2, DSK, kutija 414, fascikl 284, Črnomelj, 28.9.1565., 1r-1v, rbr. 1369-1370. Balthasar Katzianer na Ivana Lenkovića

${ }^{593}$ Pálffy navodi: „But the success of these later changes was made possible by certain innovations made by the Habsburg Monarchy during the fifty years after 1526. The foundations necessary for the establishment of a standing army were laid at this time. The Hungarian theater of war and the border defense system against the Ottomans was a very important catalyst for military development in sixteenth century Central Europe." PÁLFFY, The Habsburg defense, 51.

${ }^{594}$ IBID., 52.

595 "The military reforms started after the well-known defeat of the Christians at Nicopolis (1396), and king Sigismund of Hungary really transformed and reshaped the mobilisation and border defence system, making them both more effective, and launching a process of organisational and technical modernisation. Sigismund increased the use of wagon camps and firearms in the army, reformed the practice of mobilisation, issued standard military regulations, and contracted enormous loans to undergird military expenditures; he also maintained the support of the warrior nobility through a kind of indirect pay. These reforms stopped the Turkish advance in the southern border regions from the Adriatic littoral up to the Romanian principalities, and, with the unexpectedly successful defence of Belgrade in 1456, turned the direction of the Turks towards the East (Persia and Egypt) and the Mediterranean (the sieges of Otranto and Rhodes in 1480). The military build-up was based on a double defence line of castles with Belgrade at the centre, where some 10,000 permanently paid soldiers were stationed; the spectacular adoption of firearms from a central arsenal in Buda, distributing firearms of smaller and larger calibre to the 500 largest castles all over the country; the recruitment of professional gunmasters in the royal cities; and new mobilisation methods“. Laszlo VESZPREMY, The state and military affairs in east-central Europe, 1380-c. 1520s, u: European Warfare, 1350-1750, ur. Frank Tallett i D. J. B. Trim, Cambridge University Press, 2010., 108. Veszpremy nastavlja da: In earlier historiography, several scholars maintained that it was the lack of firearms that led to Hungary's defeat by the Turks. That is partly true, but in the fifteenth century the central European states were comparable to both the West and the East in the adoption of gunpowder weaponry, though by the battle of Mohács in 1526 Ottoman gun-founding capacity wholly exceeded that of Hungary. Proportion of the Hungarian noble troops had to be foot-soldiers equipped with firearms by 1518, and handgunners are even portrayed in miniature in 1514 grants of royal privileges, indicating that the social prestige of firearms was also considerable.”. IBID., 105. 
savjetnici izjavili da je ručno vatreno naoružanje trenutno glavna prednost nad Osmanlijama. ${ }^{596}$ Dakle, u promatranom periodu europskom je ratnom pozornicom sve više dominiralo pješaštvo oboružano ručnim vatrenim oružjem, vojske su postajale stalnije i brojnije, a utvrde su se gradile ili češće modificirale tako da se mogu nositi s vatrenom moći topova, o čemu će biti riječi u zasebnom poglavlju. Ovi elementi dolazili su do izražaja i na permanentno aktivnome habsurško-osmanskom ratištu na ugarsko-hrvatskom prostoru.

I na hrvatskom prostoru u promatranom periodu odvijao se sve intenzivniji proces društvene militarizacije, odnosno proces porasta broja stanovnika koji su na razne načine uključeni u protuosmanski otpor, bez obzira na to radi li se o plemstvu kao povlaštenoj društvenoj kategoriji tradicionalno povezanoj s vojnom službom, o ,puku“ odnosno domicilnom stanovništvu raznog statusa koje je, rađajući se i umirući na pograničju, akumuliralo nemalo vojno iskustvo ili o doseljenim vlaškim odnosno uskočkim skupinama koje su u zamjenu za specifičan društveni položaj bile dužne obavljati vojnu službu na krajištu. ${ }^{597}$ Podložničkim slojevima na prostoru Ugarsko-hrvatskoga Kraljevstva ratovanje svakako nije bila nepoznanica. Madžarski povjesničar János M. Bak pretpostavio je da je dobar dio ugarskog seljaštva, osobito onih koji su se bavili stočarstvom, bio vojno dobro potkovan. ${ }^{598}$ Do 17. stoljeća znatan dio populacije Ugarsko-hrvatskoga Kraljevstva već je aktivno participirao u vojnoj službi. ${ }^{599}$ I Fedor Moačanin konstatirao je da uloga „domaćeg

\footnotetext{
${ }^{596}$ Nakon Dugog rata 1593.-1606., Hasan Kafi al Akhisari, sudionik bitke kod Mezőkeresztesa 1596., lamentirao je kako je habsburška strana koristila moderne tipove arkebuza i topova te stekla vatrenu nadmoć dok su Osmanlije zanemarili taj aspekt. Gabor AGOSTON, Habsburgs and Ottomans: Defense, Military Change and Shifts in Power, Turkish Studies Association Bulletin, Vol. 22, br. 1, 1998., 136. No, i Osmanlije su bili dobro oboružani. Ivan Lenković je u svibnju 1561. naveo da je od 1200 dobro naoružanih i opremljenih osmanskih konjanika, čak do polovice s oklopom, a velik broj naoružan ručnim vatrenim oružjem (feuerpuchssen) provalilo na posjed grofa Slunjskog u Gorama. HDA, Militaria, kutija 7, Pobrežje, 12.5.1561., 1r. Ivan Lenković na predstavnike štajerskih staleža.

${ }_{597}$ András Borosy navodi da su na ugarskom prostoru kmetovi (serfs) redovito služili u vojsci, s tim da su u kritičnim momentima bili podizani en masse. András BOROSY, The Militia portalis in Hungary before 1526, u: From Hunyadi to Rakoczi. War and Society in late Medieval and Early Modern Hungary, ur. János M. Bak, Béla K. Király, Brooklyn College Press, Brooklyn, 1982., 74. Dakako, niži slojevi bili su u određenoj mjeri i naoružani te se već krajem 15. i početkom 16. stoljeća na prostoru Ugarsko-hrvatskoga Kraljevstva nastojalo raznim kaznama i odredbama razoružati kmetove, no bez prevelikog uspjeha. BOROSY, The Militia portalis, 70-71. Nakon Doszine bune 1514. kmetovima je ograničeno nošenje oružja. Pál ENGEL, The Realm of St. Stephen. A History of Medieval Hungary, I.B. Tauris, London-New York, 2001, 364. Simoniti kaže da je kmetska vojska na području Unutrašnje Austrije uglavnom bila oboružana lukom i strijelom te mačem, a rijetko puškama. No, nakon velike kmetske bune 1525. plijenilo se u kućama po Štajerskoj i puške i samostrele da bi kralj Ferdinand već 1533. opet dozvolio kmetovima privatno posjedovanje hladnog i vatrenog naoružanja. Iako je kasnije uslijedila djelomična zabrana, stanovnici uz pograničje mogli su i dalje nositi oružje. No, i to se promijenilo nakon gušenja Seljačke bune 1573. kada je oružje pohranjeno u oružarnicama, a seljaci naoružavani prema potrebi. SIMONITI, Vojaška organizacija, 110-111.

${ }_{598}$ BAK, Hungary and Crusading, 117.

${ }^{599}$ Béla K. KIRÁLY, Society and War from Mounted Knights to the Standing Armies of Absolute Kings: Hungary and the West, u: From Hunyadi to Rakoczi War and Society in late Medieval and Early Modern Hungary, ur. János M. Bak, Béla K. Király, Brooklyn College Press, Brooklyn, 1982., 39.
} 
elementa u krajiškoj obrani bila je uopće mnogo veća, nego što se to može ocijeniti samo na temelju vojnih mjera Sabora i bana“. 600

Iako je na temelju dostupnih/sačuvanih izvora možda teže analizirati vojni doprinos lokalnog stanovništva koje nije bilo u sastavu plaćenih i neplaćenih krajiških postrojbi, već i fragmentarni podaci pokazuju da je i domicilno stanovništvo na isturenom krajištu naoružano i vojno sposobno. Primjerice, početkom listopada 1557. zapovjedniku Hrvatske krajine i bivšem bihaćkom kapetanu Georgu Saueru pristupio je neimenovani vojnik iz Bihaća (knecht) s molbom da dopusti dvadesetorici vojnika da negdje prema Kostajnici u zasjedi dočekaju osmanske martologe. Kada im je Sauer to dozvolio, odmah su krenuli, a pridružili su im se i neki hrvatski seljaci (Khrabatischen Pauern) pa da je njihov broj narastao na osamdesetak. Ta četa napala je u jednom uskom klancu odred od stotinjak Osmanlija koji su se vraćali s četovanja oko Gvozdanskog (gdje su zarobili upravitelja, pfleger, Gvozdanskog i nekoliko osoba), pri čemu je više od dvadeset Osmanlija stradalo, petorica su živa zarobljena, a oteto je i 25 konja. Osmanski vojnici likvidirali su pak upravitelja (pfleger) Gvozdanskog čim je započeo napad. ${ }^{601}$

Nadalje, kada su u srpnju 1580. husari i arkebuziri pod zapovjedništvom Weikharda Auersperga razbili jedan osmanski odred između Steničnjaka i Ostrožina, lokalni seljaci (die Pauern) i plaćeni vojnici iz utvrda oko rijeke Gline pobili su dio osmanskih vojnika. ${ }^{602} \mathrm{U}$ protokolima Dvorskoga ratnog vijeća u Grazu navedeno je da su u kolovozu 1580. seljaci utopili (durch die Bauren) oko 300 Osmanlija u rijeci Kupi. ${ }^{603}$ Moguće je da je riječ o istom događaju. U takvom kontekstu navodi poput onog da je Ivan Izačić 1576. uzimao plaću za 15 vojničkih mjesta, a na smotru izvodio „kojekakve naoružane kmetove“604, poprimaju možda i ponešto drugačije konotacije. Ratni doprinos stanovništva na najisturenijem pograničju, kao što je bilo bihaćko, bio je svakako još izraženiji. Tako se u već spomenutom diskursu bivšega visokopozicioniranog časnika Bihaćke kapetanije iz 1592. navodi da na otocima između

\footnotetext{
${ }^{600}$ MOAČANIN, Vojna krajina, 31-32. Moačanin navodi da je na krajini u 16. stoljeću generalno bilo oko 3000 haramija, a broj plaćenih uskoka nikada nije bio veći od 1000. Svi ostali bili su starosjedioci. Fedor MOAČANIN, Radovi iz povijesti Vojne krajine, SDK Prosvjeta, Zagreb, 2016., 36. Ivan Jurković navodi: „As a rule, the only alternative, economically speaking, for all those who remained in the endangered zones was the engagement in different forms of military activity and economy". JURKOVIĆ, The Fate, 55.

${ }^{601}$ SI AS 2, DSK, kutija 201, fascikl 124, zu Zerz, 8.10.1557., 1r, rbr. 483. Georg Sauer na predstavnike kranjskih staleža.

${ }^{602}$ SI AS 2, DSK, kutija 201, fascikl 124, kutija 207, fascikl 125a, 2r-2v, Karlovac, 19.7.1580., Weikhard Auersperg na predstavnike kranjskih staleža.

${ }^{603}$ HDA, Croatica, mikrofilm D-1913, br. 39, kolovoz 1580.

${ }^{604}$ Fedor MOAČANIN, Osnovni problemi obrane Hrvatske u 16. stoljeću, u: Karlovac 1579-1979, ur. Đuro Zatezalo, Historijski arhiv u Karlovcu, Karlovac, 1979, 50. Tracy navodi, doduše za dalmatinski prostor, da osmanski prepadi ponekad nisu uspjeli jer ,peasants who took shelter were capable of defending themselves“. TRACY, Balkan wars, 61. Slično se može konstatirati i za ostatak hrvatskog prostora.
} 
Ripča i Bihaća žive seljaci i neplaćeni vojnici, ali svi „dobri, časni i iskusni vojnici“ (gutte redliche vnd geybte Khriegsleuth) koji u slučajevima različitih opasnosti zajedno s plaćenim vojnicima dobrovoljno i bez prisile sudjeluju u vojnim akcijama. ${ }^{605}$

U nesigurnim uvjetima osmanske ekspanzije na pograničnom prostoru došlo je do porasta broja vojnika što je bila posljedica prilagodbe na osmanski stil ratovanja koji su karakterizirali mnogobrojni manji i veći upadi na neprijateljski teritorij radi iscrpljivanja protivničkih snaga kako bi se demoralizirao neprijatelj, a zatim prisilio na predaju, odnosno radi lakšeg osvajanja određenog prostora vojnim akcijama. Dok su u drugoj polovici 15. stoljeća ugarsko-hrvatskim, habsburškim i mletačkim teritorijem krstarile velike osmanske osvajačke ili pljačkaše vojske koje su se na neprijateljskom teritoriju znale zadržavati i po nekoliko tjedana, Osmanlije su do početka promatranog perioda bili prisiljeni promijeniti taktiku te su započeli s izvođenjem niza nešto manjih, ali iznenadnih i opetovanih prekograničnih upada. Uglavnom se radilo o upadima nekoliko stotina, a u većim vojnim akcijama i nekoliko tisuća vojnika. Naravno, to ne znači da su upadi većih osmanskih vojnih snaga prestali, ali karakter osmanskih napada na hrvatskom i kranjskom prostoru donekle se promijenio.

U takvom kontekstu bilo je nužno zaposjesti ne samo gradove, utvrde ili razne fortifikacije na terenu (crkve, samostane itd.), već se nametala i potreba kontroliranja prostora - primarno komunikacija kojim su Osmanlije frekventno prodirali u dubinu habsburškog teritorija. Tradicionalni vojni ustroj, baziran na banderijalnom i insurekcijskom sustavu, pokazao se pak neadekvatnim u novim okolnostima te se kao imperativ nametnula potreba uvođenja novih, sve brojnijih i stalnijih vojnih formacija. ${ }^{606}$ Stoga su od 1520-ih na krajištu djelovale razne vojne formacije pod različitim jurisdikcijama. Uz tradicionalnu bansku, banderijalnu i insurekcijsku vojsku, na krajištu se nalaze isprva malobrojne kraljevinske čete koje je financirao vladar, a zatim sve brojnije „paravojne“ formacije poput uskoka te zemaljski ustanak koji je rijetko i samo u slučaju većih opasnosti podizan $\mathrm{s}$ unutrašnjeaustrijskog prostora. ${ }^{607}$

Plaćene kraljevske jedinice isprva su djelovale vatrogasno. No, budući da su se ipak pokazali neadekvatnim za zaustavljanje osmanskih napada, vrlo se brzo zaključilo da je nužno ustrojiti obrambenu liniju utvrda na šumovitom i brdovitom terenu Hrvatske krajine. Stoga je

\footnotetext{
${ }^{605}$ SI AS 2, DSK, kutija 285, fascikl 163, Beč, 5.3.1592., 1v-2r, rbr. 1037-1038. U izvještaju Davida Ungnada.

${ }^{606}$ Potreba držanja stalni(ji)h vojnih snaga pojavila se već u 15. stoljeću. Na saboru u Virovitici 1495. na kraljevu inicijativu donesena je odluka prema kojoj je trebalo osigurati 40000 forinti za držanje stalnih 10000 konjanika na granicama Hrvatske i Slavonije. KRUHEK, Krajiške utvrde, 61-62.; KLAIĆ, Povijest Hrvata, knjiga 4, 245. Ta odluka ipak nije provedena.

${ }^{607}$ ŠTEFANEC, Država ili ne, 393-394.
} 
središnja vlast započela sa sve intenzivnijim namještanjem plaćenih vojnika u utvrdama na krajiškom prostoru ili stvarnim preuzimanjem utvrda pod svoju upravu ili asistencijom privatnim vlasnicima. Nataša Štefanec taj proces opisuje ovako:

„Predajom sve većeg broja utvrda u kraljevske ruke od 1540ih godina, vladar i austrijski staleži glomaznu su pokretnu vojsku počeli preobražavati u stalnu stajaću vojsku raspodijeljenu po krajini, koja je naoružana i opskrbljena trebala na mjestu događaja sprječavati osmanske upade i pljačke, a veće napade odbijati uz pomoć tradicionalnih insurekcijskih vojnika i banske vojske iz Hrvatsko-slavonskog Kraljevstva te, eventualno, raznih dodatnih četa iz drugih zemalja“، ${ }^{608}$

Do sredine 16. stoljeća broj plaćenih vojnika narastao je na nekoliko tisuća, a kasnije oko 5000 na objema krajinama. No, na Hrvatskoj i Slavonskoj krajini ukupan broj vojnika prelazio je 10000 jer su postojale razne ,paravojne“ čete (uskoci, moralci, hajduci itd.) pod zapovjedništvom domaćih i doseljenih ljudi. Svi ti neplaćeni vojnici nastojali su ući u plaćenu vojnu službu. ${ }^{609}$ Plaćene kraljeve čete sastojale su se od plaćene utvrdne vojske (Ordinary Kriegsvolckh) i plaćene terenske vojske (Extraordinary Kriegsvolckh). Plaćena utvrdna vojska bila je stacionirana u utvrdama koje su bile pod kraljevskom upravom ili nominalno i dalje u privatnom vlasništvu, a ingerencije nad ovim jedinicama imao je zapovjednik pojedine utvrde. Terenska plaćena vojska je do reformi, implementiranih nakon sabora u Brucku 1578., bila raspoređena po taborima, šumama i gorama, a nakon navedenog savjetovanja bila je inkorporirana među utvrdnu vojsku. Mjesto služenja im je tek provizorno naznačeno i iako su im dodjeljivane zapuštene utvrde, uglavnom su obitavali u svojim domovima i bili pozivani $u$ slučaju opasnosti. Odlično su poznavali lokalni prostor, pa su često obnašali izviđačke i stražarske dužnosti, ali ih je bilo teško kontrolirati. I plaćena utvrdna i plaćena terenska vojska dijelile su se na konjicu i pješaštvo. ${ }^{610}$

Dakle, zapovjednik Bihaćke kapetanije je sve do 1578. imao neposredne ingerencije samo nad plaćenom posadom utvrda koje su podređene Bihaću kao zapovjednom središtu. Ostalim plaćenim vojnim jedinicama koje su paralelno djelovale u istom prostoru, konjanicima pod hrvatskim plemićima, martolozima i/ili uskocima, od unutrašnjeaustrijskih zemalja plaćenim strijelcima i konjanicima, upravljali su zasebni zapovjednici odgovorni

\footnotetext{
${ }^{608}$ IBID., 395.

${ }^{609}$ IBID.; Lopašić navodi da „od g. 1530. pa do g. 1555. pretvoreni su po Krajini gotovo svi vlastelinski zamci i dvorovi u tvrđe i stražarnice te su postavljene u njih jače i slabije vojne posade“. LOPAŠIĆ, Bihać, 25.

${ }^{610}$ ŠTEFANEC, Država ili ne, 396-397.
} 
isprva glavnom zapovjedniku Hrvatske i Slavonske, a kasnije glavnom zapovjedniku Hrvatske krajine, odnosno nadvojvodi. Tek nakon 1578., kada je plaćena terenska vojska ciljano izmještena po utvrdama gdje ju se moglo efikasnije upotrebljavati i nadzirati, zapovjednici pojedinih kapetanija zadobili su upravu nad cjelokupnom vojskom koja se nalazila u utvrdama, odnosno na prostoru pod njihovom ingerencijom. No, i dalje se ne može govoriti o teritorijaliziranim kapetanijama odnosno krajini što je u konačnici uslijedilo tek u drugoj polovici 18. stoljeća jer krajiški zapovjednici nisu nužno imali upravu nad teritorijem izvan gabarita pojedine utvrde, a koji je mogao biti desertan ili u privatnom vlasništvu.

Treba naglasiti da strani vojnici nisu rado služili na hrvatskom pograničju zbog opasnosti i teških egzistencijalnih uvjeta. Štoviše, među njemačkim je pješacima, landesknechtima ugarsko ratište krajnje negativno percipirano - kao najgore moguće. Kada je vojnik bio okrivljen za težak zločin, koji ipak nije zaslužio smrtnu kaznu, bio bi prisiljen obećati boriti se protiv Osmanlija i tako povratiti ugled. ${ }^{611}$ C̆ak su i vitezovi Teutonci odbijali služiti na ugarskom ratištu, pa je tako vodstvo Teutonskog reda odbilo prijedlog cara Maksimilijana da im se dodijeli Kaniža kao baza za djelovanje protiv Osmanlija. ${ }^{612}$

Slično se događalo i na Hrvatskoj krajini. Iako je teren možda bio podnošljiviji nego na Kaniškoj krajini, jer nije bilo za zdravlje pogubnoga močvarnog područja, radilo se o brdskom i šumom obraslom području koje nije bilo lagano savladati. Uostalom, boraviti na krajini je uvijek značilo riskirati život zbog čega ne iznenađuje što su se stranci često protivili stacioniranju na isturenom pograničju. Izgleda da je među stranim vojnicima osobito nepopularno bilo namještanje u krajiške utvrde jer su to doživljavali kao svojevrsnu klopku. Kranjski su staleži 1553. naveli da je iskustvo više puta pokazalo da kada se u trenucima nužde želi strane vojnike tamo poslati, ne može ih se ni obećanjima ni prijetnjom prisiliti da zauzmu posadna mjesta jer su odbijali, kako su oni sami iskazali, biti zatvoreni u utvrdama. ${ }^{613}$ U kolovozu 1576. vojnici koje je grofovija Gorica poslala na Hrvatsku krajinu nikako nisu htjeli preko međa (confinen) unutrašnjeaustrijskih zemalja i duboko u Hrvatsku, a osobito su

\footnotetext{
${ }^{611}$ ROTHENBERG, The Military Border, 38-39, fusnota 48. Kardinal Campeggio je krajem studenog 1524. primio od pape Klementa VII. ovlasti da udjeli oprost (indulgences) onima koji priključe borbi protiv „nevjernika“. Prvi takav oprost dodjeljen je vojnicima Bernardina Frankapana. Attila BARANY, War, crown and society in the eyes of papal legate: Cardinal Campeggio in Hungary (1524.-1525.), u: The Image of States, Nations and Religions in Medieval and Early Modern Central and East Central Europe, ur. Attila Barany, Reka Bozzay, Balasz Antal Bacsa, Debrecen, 2018., 141.

${ }^{612}$ ROTHENBERG, The Military Border, 44.

${ }^{613}$ SI AS 2, DSK, kutija 229, fascikl 136, 1553., 2v.
} 
se protivili mogućnosti da ih se namjesti u utvrđenja ${ }^{614}$ O slučajevima napuštanja položaja na krajini, pa i bijegu s položaja, bit će riječi dalje u tekstu.

Ponekad se događalo da ni domaći vojnici ne žele na istureno krajište, ali su razlozi takvim postupcima uglavnom egzistencijalne prirode kao što su nezadovoljstvo zbog neisplata plaća, slaba opskrba i slično. Tako su krajiški povjerenici bili spriječeni da u kolovozu 1580. otputuju iz Karlovca za Bihać zbog neposluha (vngehorsam) husara pa su se nakon nekoliko dana čekanja morali vratiti za Ljubljanu te od tamo otputovati za Senj. ${ }^{615}$ Razlog nezadovoljstva husara bila je isplata plaće (samo) u suknu zbog čega su se usprotivili nadređenima i na kraju, čini se, i napustili Karlovac. Dakle, bilo je riječ o pitanju isplata plaća, odnosno endemskom problemu plaćenih postrojbi na krajištu, a ne bojazni od djelovanju na isturenom pograničju.

Naime, plaćenim jedinicama veliki je problem predstavljala neisplata plaća i život u stalnom dugovanju. Plaće su ponekad kasnile godinama, tek su dijelom isplaćivane u novcu (ponekad nekvalitetnom), a dijelom u živeži i platnu. Ponekad je plaća isplaćivana i u žitu, ali je u tom slučaju trošak nabave žita čak i odbijan od vojničkih plaća. ${ }^{616}$ Kako bi što više novaca cirkuliralo unutar krajiškog sustava, uvedene su obaveze poput one prema kojoj su vojnici morali živež nabavljati iz vlastitih prihoda i isključivo kod vojnih opskrbnika. No, to se učestalo nastojalo zaobilaziti. ${ }^{617}$ Takvu neisplaćenu vojsku trebalo je stalno umirivati i što je moguće kvalitetnije opskrbljivati, a do koje je mjere trebalo intervenirati pokazuje podatak da je u prosincu 1583. zapovjednik Hrvatske krajine posadama u Karlovcu i Bihaću poslao, uz

${ }^{614}$ SI AS 2, DSK, kutija 287, fascikl 164, Gorica, 11.8.1576., 1r, rbr. 587. Predstavnici grofovije Gorica na predstavnike kranjskih staleža.

${ }^{615}$ HDA, Croatica, mikrofilm D-1913, br. 38, kolovoz 1580. Povjerenicima je naređeno da im ne isplate ni taller ni pfening već da ih otpuste iz službe i na njihovo mjesto uzmu druge. HDA, Croatica, D-1913, br. 39, kolovoz 1580 .

${ }^{616}$ BRACEWELL, Senjski Uskoci, 94. Zakašnjela isplata plaće nije specifičnost hrvatskog krajišta, već je riječ o jednom od osnovnih fenomena vojništva u ranonovovjekovnoj Europi. Vojnici su se snalazili trgujući, baveći se poljoprivredom, krijumčarenjem oružja i slično. PÁLFFY, Schorched-Earth, 188. Pravi problem zapravo nije bila visina plaća već njihova neredovita isplata te nerealno visoke cijene živeži. Prema Štefanec, običan bi pješak-trabant mogao dobiti maksimalno 160 denara (jedan gulden iznosi 80 denara), a haramije do 240 denara mjesečno. Elitnije postrojbe, kao što su arkebuziri, mjesečno su mogli zaraditi i do 640 denara. Riječ je o solidnim primanjima jer je, primjerice, izvanredni kraljevski porez (dika) iznosio uglavnom od 100 do 250 denara po selištu godišnje, a prosječna dnevnica se od 1550-ih do 1590-ih kretala od 8 do 12 denara dnevno. Pinta vina (tri litre) je 1578. iznosila između 5 i 6,25 denara, telić je tijekom čitavog stoljeća stajao od 18 do 87 denara, a kvarta žita (44,47 litara) nuđena je 1571. vojsci za pretjeranih 100 denara. ŠTEFANEC, Država ili ne, 373-374. Dakle, u usporedbi s navedenim cijenama, plaćeni vojnici imali su dobra primanja iako je pitanje koliko su novca zaista primili jer su prije isplate plaća vojnicima, vojni blagajnik i opskrbnik odbijali dugove, troškove avansiranja provijanta, namirnica, platna itd. Tek nakon toga ostatak se isplaćivao vojnicima IBID., 445. Ponekad bi im se, na njihovo veliko nezadovoljstvo, od plaće odbijao čak i trošak streljiva koje su koristili u sukobima s neprijateljem. Anna Maria GRÜNFELDER, Vojna Krajina i reformski procesi u ranom novom vijeku, s posebnim osvrtom na Primorsku krajinu i grad Senj, Senjski zbornik, 36, 2009., 106. Ako je isplata plaća kasnila mjesecima, (ponekad i godinama), nagomilani dug mogao je ,pojesti“ dobar dio, ako ne i cijelu plaću. Tako su vojnici mogli ostati praznih ruku i nakon muštre vojnici.

${ }^{617}$ ŠTEFANEC, Država ili ne, 432. 
nešto platna, i nekoliko stotina pari obuće (etlich hundert Par Schuech) ${ }^{618} \mathrm{U}$ zimi je obuća možda bila vrjednija i od novca.

Problem neisplaćivanja plaća nije spadao samo u egzistencijalnu sferu, već je imao negativan učinak na cijeli krajiški sustav. Toga su bili svjesni i visokopozicionirani pojedinci u vojnim strukturama. Tako je na saboru u Brucku 1578. konstatirano da je nemoguće vojsku držati na krajini bez adekvatne plaće te da je radi nastojanja da se tu nešto uštedi „uslijedilo najviše šteta““ ${ }^{619}$ Izvori su prepuni bojazni da će u kontekstu očekivanih osmanskih upada vojnici, kojima se dugovalo za plaće i/ili koji su bili nedovoljno opskrbljeni, teško moći pružiti adekvatan otpor. ${ }^{620} \mathrm{U}$ jednoj predstavci koju su na hrvatskom jeziku u rujnu 1575. iz Novigrada na Dobri nadvojvodi Karlu uputili krajiški časnici i hrvatsko plemstvo stoji da „ka zu ze yur po thyh dob, da ye gozpodin bogh uasse mylozty u oue krayne donezal, uchynyla y chyne ze u zaky dan, dozta zu Krsschanzkyh duss prez broya po thurzkoy zemly razpelyanyh, a ono cha ye ozthalo od Thurak, tho ze ye uze po zuythu razasslo ozthauyussy uze, hyse, zythue y uynograde obthesane, uzrok ye, da nygdyr plachena na ouoy krayny pysscza ny konyka ny zthrase ny“، ${ }^{621}$

Stanje možda i nije bilo baš tako krajnje dramatično kao što bi se iz ovih navoda moglo iščitati, ali je neisplata plaća i manjkava opskrba permanentno velik problem nastajućega krajiškog sustava, s negativnim posljedicama za disciplinu i lojalnost plaćenih vojnika. Sredinom studenog 1574. bihaćki kapetan Sebastian Lamberg tražio je da se njemačkim vojnicima u gradu isplati zaostatak plaća za otprilike pet mjeseci, a javio je da mu dnevno dolaze i hrvatski vojnici kojima plaće kasne i do devet mjeseci i „predaju zastave“ te više ne žele sudjelovati u vojnim akcijama i držati straže. Slična dugovanja tada postoje i prema konjanicima u Bihaću. ${ }^{622}$ Lamberg se i tri godine kasnije, krajem studenog 1577., žalio da su zbog neisplaćenih zaostataka bihaćki konjanici i pješaci, kao i ostala posada po utvrdama, pred stanjem pobune te da je morao slušati mnogo ružnih riječi. ${ }^{623}$

Problem dugovanja osobito bi eskalirao $u$ dramatičnim trenucima prijetećega

\footnotetext{
${ }^{618}$ HDA, Croatica, mikrofilm D-1914, br. 3, prosinac 1583.

${ }^{619}$ ŠTEFANEC, Država ili ne, 301.

${ }^{620}$ SI AS 2, DSK, kutija 202, fascikl 124a, Ljubljana, 27.2.1565., 1v. Predstavnici kranjskih staleža na cara Maksimilijana i nadvojvodu Karla.

${ }^{621}$ IVIĆ, Prilozi za povijest, dok. 4, 305.

${ }^{622}$ SI AS 2, DSK, kutija 286, fascikl 164, Bihać, 14.11.1574., 2r, rbr. 236. Sebastian Lamberg na kranjske Verordneten.

${ }^{623}$ „vil vbeln nachredens anhören mue $\beta^{\prime}$, SI AS 2, DSK, kutija 286, fascikl 164, Bihać, 26.11.1577., 1v, rbr. 303. Sebastian Lamberg na kranjske Verordneten. Predstavnici kranjskih staleža javili su da su dalje proslijedili njegov apel te izrazili nadu da će se na savjetovanjima o krajiškom sustavu koja su se tada odvijala biti riješeno i pitanje isplata plaća vojnicima te ostali nedostaci sustava. SI AS 2, DSK, kutija 286, fascikl 164, Ljubljana, 4.12.1577., 1r, rbr. 299. Predstavnici kranjskih staleža na Sebastiana Lamberga.
} 
osmanskog napada. Tada je često trebalo ad hoc isplatiti određenu svotu kako bi se vojnike zadržalo na položajima. Nakon pada Krupe, krajem srpnja 1565., hrvatski i njemački vojnici u Bihaću bili su nezadovoljni zbog neisplate plaća te se kapetan Kronschall bojao da zapovjednici neće imati autoritet nad njima ako dođe do eskalacije problema. Sve je zakomplicirala i činjenica da je među posadu stiglo nekoliko „drznika“ koji su ih poticali na neposluh. ${ }^{624}$ Iako do pobune nije došlo, situacija se nije promijenila još mjesecima.

$\mathrm{Na}$ savjetovanju, održanom vjerojatno u Ljubljani 24. listopada 1565., izaslanici bihaćke posade (Wichitscherischen gesannten), svjedočili su da su okolnosti u gradu problematične jer nisu isplaćene ni gradska posada, a ni kranjski i koruški strijelci koji su ranije poslani kao pojačanje. Čini se da je tada zaključeno da kranjski i koruški strijelci imaju prioritet pri isplati dok se od bihaćke posade (Ordinary) tražilo da ostanu na svojim mjestima. Plan je bio da im se najbrže moguće doznači dvomjesečna plaća i dopremi živeži za dva mjeseca. U konačnici je svaki poslanik primio 20 talira te su otpremljeni nazad u Bihać s jednim Trostbrief - utješnim pismom kojim ih se pozivalo na strpljenje i ostanak na svojim mjestima, kao što se to često događalo. Obećala se tada i isplata plaće za 50 bihaćkih konjanika koji su već ranije bili otpušteni iz službe. ${ }^{625}$ Dakle, problem osiguravanja sredstva za plaće vojnicima svakako je predstavljao veliko opterećenje za nastajući krajiški sustav. Međutim, unatoč svim problemima koji su se opetovano pojavljivali, zanimanja za vojnu službu nikada nije nedostajalo.

Više kao digresiju nego pravilo treba napomenuti da se ponekad znalo dogoditi i sasvim suprotno, iako je neredovita isplata plaća uobičajena pojava na krajištu. Tako u protokolu Dvorskoga ratnog vijeća u Grazu za rujan 1580. stoji da su Bišćani primili 900 rajnskih guldena više od onoga što im pripada. ${ }^{626}$ Dio tog novca krajiški su povjerenici trebali odbiti i predati bivšem bihaćkom upravitelju, a sada kapetanu Hrastovice, Paulu Scheyeru, jer već neko vrijeme nije primio plaću. ${ }^{627}$

\footnotetext{
${ }^{624}$ SI AS 2, DSK, kutija 414, fascikl 284, Bihać, 17.8.1565., 1v, rbr. 1156. Georg Kronschall, čini se na predstavnike kranjskih staleža.

${ }^{625}$ SI AS 2, DSK, kutija 202, fascikl 124a, 24.10.1565., 1v-3r. Koncept/bilješke sa savjetovanja.

${ }^{626}$ HDA, Croatica, mikrofilm D-1913, br. 38, kolovoz 1580.

${ }^{627}$ HDA, Croatica, mikrofilm D-1913, br. 44, rujan 1580.
} 


\subsection{Brojnost bihaćke posade}

Uz Senj i kasnije Karlovac, Bihać je imao najbrojniju i najraznolikiju vojnu posadu na Hrvatskoj krajini. Primarna zadaća bihaćke posade bila je obrana grada, ali su participirali i u obrani prostora/utvrda pod ingerencijom bihaćkog kapetana, a prema potrebi i mogućnostima i šire. Radilo se uglavnom o nekoliko stotina vojnika - pješaka i konjanika o kojima će biti riječi dalje u poglavlju. Uz za krajiške prilike brojnu vojnu posadu u obrani je participiralo i lokalno stanovništvo pa Neven Budak konstatira da je obrana bihaćkog područja u prvom redu počivala na brojnom stanovništvu koje je moglo podići i preko tisuću branitelja. ${ }^{628}$ Iako je važnost domaćeg stanovništva velika, o čemu je bilo riječi i na početku poglavlja, obrana je u prvom redu počivala na plaćenoj vojnoj posadi koja je bila nositelj čitave obrane. S druge strane, budući da se u sastavu posade dobrim dijelom nalazilo domaće stanovništvo, vojnu službu možemo promatrati kao svojevrsno čvorište u kojem su se isprepleli interni i eksterni elementi, o čemu će pak biti riječi u drugom dijelu rada. Tako je recimo sredinom 1571 . Osmanlije u zamku namamio Petar Stefan (Petter Stephan), bivši bihaćki građanin i pripadnik plaćene vojne posade koji je dvije godine ranije prebjegao na osmanski teritorij za svojom bivšom robinjom (Rabina) koja da „ga je opčinila“ (pezaubert). Da bi dobio dozvolu da se ponovno vrati na habsburški teritorij, morao je nekim pothvatom protiv Osmanlija dokazati da mu se može vjerovati. ${ }^{629}$ Ovi su navodi još jedna je potvrda visoke participacije lokalnog stanovništva unutar krajiškog sustava, odnosno procesa intenzivnog povojačenja hrvatskog prostora.

Da je u gradu zaista bilo dosta potencijalnih vojnika pokazuje i tvrdnja kraljevskog povjerenstva iz 1563. da se u Bihaću nalazi mnogo građana koji su upisani u vojne popise, dakle u plaćenoj vojnoj službi, ali se bave svojim privatnim poslovima i obrađuju polja, te aktivno ne pridonose obrani, ne drže stražu i idu u vojne akcije. ${ }^{630}$

Što se plaćene/kraljevske vojske tiče, ona je u Bihaću bila brojna i prije nego što je nadvojvoda Ferdinand zasjeo na ugarsko-hrvatsko prijestolje. Lopašić navodi da su banovi Emerik Pereny i Petar Berislavić u Bihaću držali po 100 konjanika i pješaka. ${ }^{631}$ Krajem siječnja 1513. u Bihaću i Kninu bilo je već 172 pješaka (peditibus) koji su pojedinačno

\footnotetext{
${ }^{628}$ BUDAK, Uloga Bihaćke, 166.

${ }^{629}$ HDA, Militaria, kutija 9, Črnomelj, 3.6.1571., 1r. Herbart Auersperg na nadvojvodu Karla.

${ }^{630}$ AHAZU, Lopašić, E. Prijepisi iz austrijskih arhiva, br. 15, str. 27.

${ }^{631}$ LOPAŠIĆ, Bihać, 60.
} 
primali 3 florena mjesečno. ${ }^{632} \mathrm{U}$ burnome tranzicijskom periodu 1526./1527. očito je došlo do pada broja plaćenih/kraljevskih vojnika jer se hrvatski staleži u travnju 1527. žale da je u Bihaću ranije bila smještena kraljevska posada od 100 pješaka i 100 konjanika, a sad ih je navodno tek petero. ${ }^{633}$

Kao što je u tekstu prezentirano, situaciju je zapravo zakomplicirao viceban Ivan Svetački koji u grad nije htio pustiti 64 kraljevska vojnika. ${ }^{634} \mathrm{U}$ travnju 1527. hrvatski staleži tražili su da se u Bihać namjesti 50, a u Ripač 15 strijelaca te da se 180 strijelaca i 50 konjanika razmjeste u Otočac, Klis, Starigrad i Senj. ${ }^{635}$ Već krajem svibnja Donjoaustrijska komora piše kranjskom vicedomu da je velika vojska od 12000 Osmanlija poslana na Hrvatsko Kraljevstvo (in kgl. Mt. Kgreich Krabaten) te da je slijedi još jedna osmanska vojska pa su hrvatski staleži molili da se u Bihać hitno namjesti 100 vojnika (knecht) ${ }^{636} \mathrm{Na}$ koncu je Bihać tek krajem srpnja u kraljevo ime preuzeo Nikola Jurišić koji je odmah predložio da se u grad namjesti jaka posada od 200 čeških strijelaca i 100 hrvatskih husara, a u Ripač kapetan te 25 pješaka i 32 husara, koji su mogli biti izuzeti iz bihaćke posade. Jurišić je predložio da kralj kapetanom strijelaca imenuje osobu po svojem izboru, ali da se kapetanom nad stotinu lakih konjanika treba imenovati nitko drugi do Gašpara Perušića (Caspar Peroschitz) jer tamo nema boljega kandidata. ${ }^{637}$ Čini se da tada, krajem srpnja, posada još nije zauzela svoja mjesta jer Jurišić navodi da se vojnike koji će biti namješteni (Das kriegsfolk, so zu Wichitsch ligen werden) nužno mora isplatiti i muštrati s početkom (angang) svakog mjeseca jer u protivnom tamo neće htjeti ostati. ${ }^{638}$

Krajnje je upitno je li realiziran taj ambiciozni prijedlog. Najvjerojatnije nije zato što već nekoliko godina kasnije, krajem veljače 1530., predstavnici bihaćke gradske općine mole kralja da pošalje 100 konjanika i 200 pješaka. ${ }^{639}$ I nešto kasnije, kada se u lipnju 1530. kod Plavna okupljala osmanska vojska, bihaćki vicekapetan Ivan Lenković javljao je da ima jedva toliko vojnika da može zaposjesti glavna gradska vrata (Thör), a i ti vojnici će odstupiti ako

632 Lajos THALLÓCZY, Sándor HORVÁTH, Also-Szlavoniai Okmanytar (Dubica, Orbasz es Szana Varmegyek) 1244.-1719., Codex diplomaticus partium regno Hungariae adnexarum, Monumenta Hungariae Historica, Diplomataria vol. XXXVI, Budimpešta, 1912., dok. XXII, 350-351.

${ }^{633}$ N. KLAIĆ, »Ostaci ostataka«, 262; ŠIŠIĆ, HSS, knjiga I, dok. 101, 66; KRUHEK, Krajiške utvrde, 82; V. KLAIĆ, Povijest Hrvata, knjiga 5, 94. Lopašić navodi da se ban Batthyány u veljači 1527. dogovarao s ljubljanskim biskupom Rauberom oko bihaćke posade te da je ban tražio da se ne uzimaju Nijemci, već kvalitetni češki i slavonski strijelci (gut püchsenschutzen). LOPAŠIĆ, Bihać, 57.

${ }^{634}$ THALLÓCZY, HODINKA, A horvát véghelyek, dok. CDLXI, 600.

${ }^{635}$ Nada KLAIĆ, Nastajanje Krajine u XVI stoljeću s posebnim obzirom na postanak Karlovca, u: Karlovac 1579-1979, ur. Đuro Zatezalo, Historijski arhiv u Karlovcu, Karlovac, 1979., 53, fusnota 23.

${ }^{636}$ THALLÓCZY, HODINKA, A horvát véghelyek, dok. DXXIV, 671.

${ }^{637}$ „,da er ist an diser ort nit zu verpessern“. IBID., dok. DXLIV, 693-694.

${ }^{638}$ IBID., 693.

${ }^{639}$ LASZOWSKI, HSKHDS, knjiga I, dok. 269, 261. 
im se u roku od tri do pet dana ne isplate plaće. ${ }^{640}$ Početkom sljedećeg mjeseca vicekapetan Lenković javlja da su „die Winidischen knecht“ dijelom napustili Bihać, pa su Štajerci, koji su u tom ranijem periodu aktivnije pomagali i obranu na Hrvatskoj krajini, poslali bihaćkom kapetanu Thurnu 500 rajnskih guldena iz svote namijenjene vojsci u Ugarskoj, a to je trebalo biti dostatno za održavanje posade te popunjavanje ispražnjenih mjesta. ${ }^{641}$

Iste te godine na međuzemaljskom saboru unutrašnjeaustrijskih staleža u Slovenj Gradcu (Windischgratz) predloženo je da se u Bihać namjesti 70 vojnika, a u Ripač njih 50. Za Klis je tada predviđeno 70, Senj 150, Otočac 40, Brinje 32 i Kamengrad 12 vojnika. Svaki vojnik trebao je dobiti mjesečnu plaću od 4 rajnska guldena. ${ }^{642}$ Taj je naum dijelom realiziran jer se u travnju 1532. u Bihaću nalazi 70, a u Ripču 25 vojnika s mjesečnom plaćom od 4 rajnska guldena. ${ }^{643}$

Do 1537. broj plaćenih vojnika u Bihaću narastao je na 81 pješaka i 56 konjanika. U Ripču je tada bila relativno brojna posada od 25 pješaka, 21 konjanika i 6 stražara dok je u obližnjem selu Golubiću bilo stacionirano 4 vojnika. U Sokolu se nalazilo 5 pješaka i 4 konjanika, Brekovici 4 pješaka, Topličkom Turnju 2 pješaka i 4 konjanika, a u Izačiću 6 pješaka. ${ }^{644}$ Dakle, već tada je u Bihaću za krajiške prilike zaista brojna posada, a treba ponovno naglasiti da su u popisima navedeni samo plaćeni vojnici dok je ukupan broj za obranu sposobnih/involviranih osoba bio i veći. Ukupno je na prostoru Bihaćke kapetanije bilo 218 plaćenih vojnika.

\footnotetext{
${ }^{640}$ IBID., dok. 367, 352.

${ }^{641}$ SI AS 2, DSK, kutija 191, fascikl 119, Metlika, 7.7.1530., 1r, rbr. 63. Kralj Ferdinand i ratni savjetnici na Hansa Katzianera. Štajerski su staleži naravno i kasnije pomagali obranu Hrvatske krajine, osobito Bihaća. Krajem svibnja 1566. predstavnici kranjskih staleža uputili su molbu štajerskim staležima da je zapovjednik Hrvatske krajine Herbart Auersperg tražio da za pojačanje Bihaća i Ripča podigne 400-500 vojnika, pa je poslao Gašpara Raaba i Christofa Premba (koji je trebao biti kapetan podignutoj postrojbi) da u Štajerskoj podignu vojsku. Molili su da im dobrosusjedski, kao i do sada, pruže maksimalnu asistenciju. HDA, Militaria, kutija 8, Ljubljana, 20.5.1566., 1r-1v.

${ }^{642}$ LASZOWSKI, HSKHDS, knjiga I, dok. 505, 469-470.

${ }^{643}$ KLAUŽER, Ustrojstvo i djelovanje, 94, fusnota 422.

${ }^{644}$ LOPAŠIĆ, Bihać, 60;213; LOPAŠIĆ, SHK, knjiga III, dodaci, br. III, 390.
} 
Tablica. 1. Broj plaćenih vojnika u utvrdama Bihaćke kapetanije 1537.

\begin{tabular}{|l|r|l|l|}
\hline \multicolumn{1}{|c|}{ 1537. } & konjanici & pješaci & stražari \\
\hline Bihać & 56 & 81 & 6 \\
\hline Ripač & 21 & 25 & \\
\hline Golubić & & 4 & \\
\hline Sokol & 4 & 5 & 6 \\
\hline Izačić & & 6 & 218 \\
\hline Brekovica & & 4 & \\
\hline Toplički Turanj & 4 & 2 & \\
\hline Prema rodovima & 85 & 127 & \\
\hline Sveukupno & & & \\
\hline
\end{tabular}

Sljedeći zabilježeni navod o broju vojnika na promatranom prostoru pokazuje da je u travnju 1540. u Bihaću „i okolnim utvrdama“ isplaćeno 126 konjanika i 75 pješaka. No, prema instrukcijama kraljice Ane (kralj Ferdinand je tada izbivao iz Kraljevstva), broj vojnika u Bihaću i okolnim utvrdama trebalo je modificirati tako da se broj konjanika smanji na 40, a broj pješaka povisi na 125 ljudi. To je trebalo učiniti i prije muštre koja je tada održana jer se kraljica čudila činjenici da je, unatoč dogovoru o reduciranju broja vojnika, isplaćena te $\mathrm{i}$ dalje zadržana zatečena i odviše brojna posada. Nadalje, navedeno je da se konjanike koji će ostati u reduciranoj posadi treba angažirati među otpuštenim konjanicima koji su se još uvijek zadržavali u Bihaću i okolnim utvrdama. ${ }^{645}$

Do kraja travnja nekolicina je vojnika napustila grad pa je kralj naredio da se ispražnjena mjesta popune. ${ }^{646}$ Negdje prije svibnja te godine načinjen je popis konjanika i pješaka u utvrdama Bihaćke kapetanije kojom je tada upravljao Bartlme Raunach. Prema navedenom popisu, bihaćku je posadu tada činio 51 pješak i 23 konjanika uključujući i samog Raunacha. U Ripču je bilo 9 pješaka i 7 konjanika te 3 stražara na rijeci Uni, u Sokolu 5 pješaka, Izačiću 3 i u Topličkom Turnju 2 pješaka. Sveukupno su u utvrdama Bihaćke kapetanije tada bila 103 plaćena vojnika, odnosno 73 pješaka i 30 konjanika. ${ }^{647}$ To su za više od polovicu manje brojke od onih iz 1537., a nisu navedeni ni Brekovica ni Golubić.

\footnotetext{
${ }^{645}$ SI AS 2, DSK, kutija 244, fascikl 143, Beč, 19.4.1540., 1r, rbr. 248.

${ }^{646}$ SI AS 2, DSK, kutija 286, fascikl 164, Beč, 26.4.1540., 1r-1v, rbr. 3-4. Kralj Ferdinand na predstavnike kranjskih staleža i vicedoma.

${ }^{647}$ SI AS 2, DSK, kutija 244, fascikl 143, 1540., 1r-4r, rbr. 252-258.
} 
Tablica 2. Broj plaćenih vojnika u utvrdama Bihaćke kapetanije prije svibnja 1540.

\begin{tabular}{|l|r|r|r|}
\hline prije svibnja 1540. & konjanici & pješaci & \multicolumn{1}{l|}{ stražari } \\
\hline Bihać & 23 & 51 & 3 \\
\hline Ripač & 7 & 9 & 5 \\
\hline Sokol & & 3 & 3 \\
\hline Izačić & 30 & 2 & 103 \\
\hline Toplički Turanj & & 70 & \\
\hline Prema rodovima & & & \\
\hline Sveukupno & & & \\
\hline
\end{tabular}

Kada je u svibnju 1540. Mert Gall od Rudolfsecka preuzeo kapetaniju, konstatirao je da je smanjenje broja vojnika posljedica povećanja plaća plemićima koji su ovdje služili, stražmeštru, pisaru i vojnim službenicima, kako da je bilo i navedeno u muster registru. ${ }^{648}$ Sada se pak pojavio problem jer konjanici nisu htjeli služiti zbog planiranog smanjenja broja vojnika, pa je Gall smatrao da treba prebaciti dio plaća pješaka na konjanike jer bez njih nema koristi od pješaka u utvrdama. ${ }^{649} \mathrm{~S}$ druge pak strane, predstavnici kranjskih staleža i kranjski vicedom smatrali su da je dovoljno 40 konjanika, kao što je i naređeno, jer bi se s povećanim brojem konjanika kapetan samo opteretio potencijalnim neposluhom i pobunom. ${ }^{650}$ Ovakva je konstatacija očito dijelom bazirana na činjenici da su konjanici uglavnom bili plemićkog staleža, osobe specifičnoga društvenog statusa i autopercepcije, povlašteni sloj ljudi koji su lako mogli doći u sukob s nadređenima u krajiškoj strukturi. No, u pozadini je vjerojatno primarno stajalo pitanje novaca odnosno plaća, kao što se najčešće događalo.

Iako je planirano smanjene broja plaćenih vojnika, u srpnju 1540. u utvrdama Bihaćke kapetanije bila su 182 plaćena vojnika. U Bihaću je bila posada od 70 pješaka i 98 konjanika. Tada su u Topličkom Turnju bila 3, a u Izačiću 4 pješaka, dok je u Sokolu stacionirano 7 stražara s kaštelanom kao zapovjednikom. ${ }^{651}$ Dakle, ponovo je povećan broj vojnika u gradu, osobito konjanika. Ripač se valjda ne navodi jer je tada bio u posjedu Jurja Grabusa.

\footnotetext{
${ }^{648}$ LASZOWSKI, HSKHDS, knjiga II, dok. 493, 489

${ }^{649}$ IBID., 488-489.

${ }^{650}$ SI AS 2, DSK, kutija 193, fascikl 119/120, Bihać, 24.5.1540., 2r, rbr. 271.

${ }^{651}$ LOPAŠIĆ, SHK, knjiga III, dodaci, dok. V, 395-396.
} 
Tablica 3. Broj vojnika u utvrdama Bihaćke kapetanije u srpnju 1540.

\begin{tabular}{|l|r|r|r|}
\hline srpanj 1540. & konjanici & pješaci & stražari \\
\hline Bihać & 98 & 70 & 7 \\
\hline Sokol & & & \\
\hline Izačić & & 4 & 7 \\
\hline Toplički Turanj & & 3 & 182 \\
\hline Prema rodovima & 98 & 77 & \\
\hline Sveukupno & & & \\
\hline
\end{tabular}

Pet godina kasnije, 1545., bihaćku posadu čine 53 pješaka te 51 konjanik, a od tog broja 10 je konjanika u pratnji kapetana Georga Sauera. Broj plaćenih vojnika pao je na ispod stotinu ljudi, a realizirano je i ranije planirano smanjenje broja konjanika. U Ripču je bilo stacionirano 15 pješaka i 3 stražara, u Sokolu 9 pješaka, Izačiću njih 6, a u Topličkom Turnju 5.652

Tablica 4. Broj plaćenih vojnika u utvrdama Bihaćke kapetanije 1545.

\begin{tabular}{|l|l|r|r|}
\hline \multicolumn{1}{|c|}{ 1545. } & konjanici & pješaci & \multicolumn{1}{c|}{ stražari } \\
\hline Bihać & 51 & 53 & 3 \\
\hline Ripač & & 15 & \\
\hline Sokol & & 9 & 3 \\
\hline Izačić & & 6 & \\
\hline Toplički Turanj & 51 & 5 & 142 \\
\hline Prema rodovima & & 88 & \\
\hline Sveukupno & & & \\
\hline
\end{tabular}

Četiri godine kasnije brojevi su slični. U Bihaću su 40 konjanika i 51 pješak, u Ripču 19 pješaka, Sokolu njih 7, Izačiću 3 i Topličkom Turnju $4 .{ }^{653}$ 
Tablica 5. Broj plaćenih vojnika u utvrdama Bihaćke kapetanije 1549.

\begin{tabular}{|c|c|c|}
\hline 1549. & konjanici & pješaci \\
\hline Bihać & 40 & 51 \\
\hline Ripač & & 19 \\
\hline Sokol & & 7 \\
\hline Izačić & & 3 \\
\hline Toplički Turanj & & 4 \\
\hline Prema rodovima & 40 & 84 \\
\hline Sveukupno & & 124 \\
\hline
\end{tabular}

I do sredine stoljeća broj plaćenih vojnika ostao je približno isti. Naime, prema navodima kranjskih staleža iz 1553., Bihać, Ripač Sokol, Izačić, Toplički Turanj i Brekovica bili su zaposjednuti sa 190 pješaka i konjanika. Za komparaciju, istodobno je u Senju, Brinju, Brlogu i Drežniku bilo „najmanje“ 383 vojnika. ${ }^{654}$ U iskazu troškova iz 1553. u Bihaću je stacionirano 50 od ukupno 200 konjanika te 50 od ukupno 400 plaćenih pješaka na Hrvatskoj krajini. ${ }^{655}$ Međutim, budući da su špijuni javljali da Malkoč-beg u proljeće planira napasti Ripač i zauzeti bihaćku Otoku, Ivan Lenković tražio je da se „stara“ posada pojača sa 60 strijelaca i 50 konjanika. ${ }^{656}$

Dakle, do sredine stoljeća broj plaćenih vojnika nešto je manji nego što će biti koju godinu kasnije. Uzrok tome može se tražiti u činjenici da je unski prostor do tada ipak bolje naseljen nego što će to biti od 1560-ih te da su uokolo još uvijek mnogobrojne plemićke utvrde pa je u odnosu na prostor Senjske kapetanije vjerojatno bilo potrebno manje plaćenih vojnika. Uostalom, prostor koji su tada pokrivale utvrde Bihaćke kapetanije bio je mnogo manji i pokrivao je manje-više prostor Bihaćke doline.

No, već krajem 1550-ih broj plaćenih vojnika bitno je veći. Do proljeća 1557. u gradu i kaštelu Bihaću s Otokom „staru“ posadu činilo je 50 konjanika te čak 179 pješaka. Tada se planiralo namjestiti dodatnih 40 vojnika u grad. Postojeću posadu od 36 vojnika u Ripču planiralo se ojačati s 14 njemačkih vojnika dok je posadu od 8 vojnika u Sokolu trebalo ojačati sa 6 novih vojnika. U Izačiću je posadi od 9 vojnika trebalo pridodati još 15 dok je 10

\footnotetext{
${ }^{654}$ SI AS 2, DSK, kutija 229, fascikl 136, 1553., 2r.

${ }^{655}$ HDA, Militaria, kutija 4, naslov „Hannsen Lennkhowitsch Beyleüffige auffzaichunng...“”, str. 4-5; LOPAŠIĆ, Bihać, 60.

${ }^{656}$ HDA, Militaria, kutija 4, naslov „Hannsen Lennkhowitsch Beyleüffige auffzaichunng...“, str. 3.
} 
plaćenih vojnika u Topličkom Turnu-Brekovici trebalo pridodati barem još toliko. „Riječnu stražu“" (Wasser Scart) u Omršlu držalo je 4 vojnika. ${ }^{657}$

Tablica 6. Broj plaćenih vojnika u utvrdama Bihaćke kapetanije 1557.

\begin{tabular}{|l|r|r|r|r|l|l|}
\hline 1557. & konjanici & pješaci & ukupno & $\begin{array}{l}\text { pojačanje } \\
\text { pješaka }\end{array}$ & $\begin{array}{l}\text { pojačanje } \\
\text { njemačkih } \\
\text { vojnika }\end{array}$ & $\begin{array}{l}\text { S } \\
\text { pojačanjima } \\
\text { ukupno }\end{array}$ \\
\hline Bihać & 50 & 179 & & 40 & & \\
\hline Ripač & & 36 & & & & \\
\hline Sokol & & 8 & & 6 & & \\
\hline Izačić & & 9 & & 15 & & \\
\hline $\begin{array}{l}\text { Toplički } \\
\text { Turanj }\end{array}$ & & 10 & & 10 & & \\
\hline Omršal & & 4 & & & & \\
\hline $\begin{array}{l}\text { Prema } \\
\text { rodovima }\end{array}$ & 50 & 242 & & 71 & & \\
\hline Sveukupno & & & 292 & & & 377 \\
\hline
\end{tabular}

Dvije godine kasnije broj plaćenih vojnika u Bihaću dodatno je porastao. Lopašić navodi da je kralj 1557. odlučio pojačati (pomnožio) bihaćku posadu s 200 vojnika. ${ }^{658}$ Lopašić je vjerojatno mislio na 200 njemačkih vojnika koje je od kranjskih staleža, a u ime tadašnjeg upravitelja kapetanije Georga Zoblsperga, za bihaćku posadu molio časnik Jeronim Podlipnik. I Zoblsperg i Podlipnik tvrdili su da im je Lenković usmeno obećao te ljude, ali je Lenković u pismu kranjskim staležima naveo da oboje griješe jer da se ti vojnici mogu angažirati jedino ako vladar doznači potrebna sredstva. ${ }^{659}$

Prema vojnom proračunu iz 1559., samo se u Bihaću, u gradu i kaštelu (der Stat vnnd Sclo $\beta$ ), nalazilo 360 plaćenih „njemačkih i slavonskih“ (Teutsch vnnd Windischen knecht) vojnika na koje je mjesečno odlazilo 1490 guldena. To je najveći broj plaćene vojske na cijelom prostoru „stare Kranjske i Hrvatske krajine“, odnosno od Bihaća do Jadranskog mora. Iza Bihaća najveći broj vojnika nalazi se u Rijeci - njih 294. Iako u ovom konkretnom slučaju nije navedeno koje su točno utvrde u sastavu Bihaćke kapetanije, očito je raspored ostao isti kao dvije godine ranije. U Ripču je tada 50 vojnika sa stražarima, Sokolu 12 vojnika, Omršlu 4 vojnika, Izačiću 20, Topličkom Turnju i Brekovici 10 plaćenih vojnika. Tada je u utvrdama Bihaćke kapetanije sveukupno bilo 456 plaćenih vojnika.

\footnotetext{
${ }^{657}$ SI AS 2, DSK, kutija 411, fascikl 283, 1.1.1557., 7v-8r.

${ }^{658}$ LOPAŠIĆ, Bihać, 75.

${ }^{659}$ SI AS 2, DSK, kutija 414, fascikl 283, Varaždin, 13.7.1557., 1v, rbr. 1180. Ivan Lenković na predstavnike kranjskih staleža.
} 
Tablica 7. Broj plaćenih vojnika u utvrdama Bihaćke kapetanije 1559.

\begin{tabular}{|l|r|}
\hline & 1559. \\
\hline Bihać & vojnici \\
\hline Ripač & 360 \\
\hline Sokol & 50 \\
\hline Omršal & 12 \\
\hline Izačić & 4 \\
\hline Brekovica-Toplički Turanj & 20 \\
\hline Sveukupno & 10 \\
\hline
\end{tabular}

Budući da je u svim 22 utvrdama na prostoru „stare Kranjske i Hrvatske krajine“ bilo 1012 plaćenih vojnika (na koje je mjesečno odlazilo 4116, a godišnje 49402 guldena), njih više od trećine nalazilo u Bihaću, a gotovo polovica u utvrdama Bihaćke kapetanije. Istodobno, na „novoj Kranjskoj i Hrvatskoj krajni“, od Bihaća do Siska nalazi se ukupno 800 plaćenih vojnika (pješaka) u 13 utvrda. Najviše ih je bilo stacionirano u Hrastovici i Zrinu, po 120 ljudi. U Gvozdanskom ih je bilo 50, Jamnici 20, Krupi 50, Buševiću i Bratscheyu 60, dvorcu Jezersko 6, Furjanu 4, Slunju 10 itd. ${ }^{660}$ Broj plaćenih vojnika stacioniranih u Bihaću znatno je premašivao broj plaćenih vojnika u drugim važnim utvrdama, s iznimkom Rijeke. ${ }^{661}$ Dakle, u manje od šest godina broj plaćenih vojnika u Bihaću u najmanju se ruku udvostručio, a povećao se i broj vojnika u ostalim Bihaću podređenim utvrdama.

Četiri godine kasnije, 1563., izvještaj o krajištu prvo je sastavio Ivan Lenković, a krajem godine i posebno krajiško povjerenstvo. Ivan Lenković naveo je da je u Bihaću posada od 320 pješaka i konjanika, ali da bi je trebalo ojačati s najmanje 300 pješaka i 100 konjanika jer posada podupire i obranu okolnih utvrda. Za Sokol koji je branilo 12 stražara Lenković predlaže pojačanje od još 12 , za Ripač u kojem je 60 vojnika pojačanje od još 100 vojnika dok je predložio da se poruše Izačić, kojeg je branilo 20 vojnika, i Toplički Turanj, kojeg je branilo 4 vojnika. ${ }^{662}$

Već iste te godine krajište je pregledalo posebno kraljevsko povjerenstvo koje je pak predložilo da u Bihaću bude stacionirano 50 arkebuzira (schützen pfärdt), 100 njemačkih vojnika s puškom i oklopom na čelu sa zapovjednikom koji bi zapovijedao svim pješačkim i konjaničkim stražama. Uz zapovjednika nad njemačkim vojnicima nalazili bi se još jedan zastavnik, narednik, opskrbnik, oružar i tri puškara. Nadalje, u Bihaću je trebalo stacionirati i

\footnotetext{
${ }^{660}$ ŠTEFANEC, Država ili ne, 472-473.

${ }^{661}$ U Senju je doduše bilo tek 12 plaćenih vojnika, ali ne treba naglašavati da su tamo djelovali primarno neplaćeni vojnici.

${ }^{662}$ KRUHEK, Krajiške utvrde, 190-191; LOPAŠIĆ, SHK, knjiga III, dodaci, dok. XVI, 429.
} 
150 hrvatskih pješaka, tri vojvode, tri zastavnika i 15 desetara. Straže u gradu dnevno je trebalo držati 25 hrvatskih vojnika, a na bihaćkoj Otoci 20 stražara, jer posada nije smjela napuštati grad. Vojna posada s jednim zapovjednikom na čelu trebala je stražariti u novopodignutoj kuli na adi pri brodu Mač (Mätsch) kod Brekovice, a smjenu vršiti na tjednoj ili mjesečnoj bazi. Pod bihaćkim kapetanom navodi se još drveni kaštel Blažuj s 4 stražaračardaklije, a predviđeno je podizanje još jednog čardaka za 8 stražara. ${ }^{663}$ Povjerenstvo je predložilo da se u Jesenicu, odakle se morao nadzirati prostor prema Drežniku s jedne i Dabru s druge strane, namjeste čak 100 pješaka, porkulab, dvoje vojvoda, dvoje zastavnika, deset desetnika (rottmeistera) i jedan puškar. Identičnu posadu predložili su za Drežnik odakle se trebao nadzirati potez prema Jesenici s jedne i Izačiću s druge strane. Izačić je još pripadao obitelji Izačić, ali je povjerenstvo smatralo da treba namjestiti 16 pješaka koji bi nadzirali potez prema Drežniku i Bihaću. ${ }^{664} \mathrm{U}$ Tržcu, koji je pripadao istoimenoj grani obitelji Frankopana, a koji je naveden kao čvrsta utvrda u kojoj se nalazilo 12 pješaka, trebalo je biti stacionirano 60 konjanika. Odavde se nadzirao prostor prema Drežniku i Bihaću. ${ }^{665} \mathrm{U}$ Ripču je posadu trebalo činiti 20 njemačkih strijelaca (hakhenschützen) koji bi potpadali pod bihaćku posadu i bili jednako opremljeni te 20 hrvatskih pješaka. ${ }^{666} \mathrm{U}$ Sokolu, predstraži Bihaća, trebalo bi namjestiti 6 njemačkih strijelaca i 4 hrvatska pješaka te njemačkog zapovjednika. ${ }^{667}$ Povjerenstvo je predložilo da se u Brekovicu zbog prostranosti smjesti 50 konjanika, a budući da oko utvrde nije bilo šume, smatrali su da nije potrebno više od 12 stražara. ${ }^{668} \mathrm{U}$ utvrdi i trgovištu u Ostrošcu trebalo je namjestiti 100 hrvatskih vojnika s porkulabom, dvoje vojvoda, dvoje zastavnika, deset desetnika i puškarom, a u Topličkom Turnju trebalo je držati 4 stražara, i to samo do podizanja novog turnja na brdu Lisovcu. ${ }^{669} \mathrm{U}$ Cazinu je trebalo postaviti posadu od 50 husara s kapetanom, upravitelja, zastavnika, trubača i 20 hrvatskih vojnika s dva desetnika. I napokon, u Stijeni, koja se nalazi iznad Krupe i u šumovitom predjelu, trebalo je postaviti jaku posadu koja bi se sastojala od 50 hrvatskih pješaka, vojvode, zastavnika i pet desetnika. ${ }^{670}$ Dakle, broj predloženih vojnika bio je velik.

Sljedeće godine zbila se velika teritorijalna promjena Bihaćke kapetanije koja je sada u svom sastavu imala 20 utvrda. Posadu Bihaća činilo je dvoje zapovjednika (navedeni kao

\footnotetext{
${ }^{663}$ KRUHEK, Krajiške utvrde, 212-213; AHAZU, Lopašić, E. Prijepisi iz austrijskih arhiva, br. 15, str. 28.-29.

${ }^{664}$ AHAZU, Lopašić, E. Prijepisi iz austrijskih arhiva, br. 15, str. 24-25.

${ }^{665}$ IBID., str, 26.

${ }^{666}$ IBID., str. 30-31.

${ }^{667}$ IBID., str. 31.

${ }^{668}$ IBID., str. 32.

${ }^{669}$ IBID., str. 32-33.

${ }^{670}$ IBID., str. 32-33.
} 
zapovjedno osoblje), zatim 245 pješaka (haramija, njemačkih vojnika i uskoka), 58 konjanika i 30 stražara. U Ripču je tada poprilično velika posada od 62 pješaka, u Sokolu i dalje 12 vojnika, Izačiću 20, Brekovici-Topličkom Turnju 21 pješak i 4 konjanika. Nadalje, Ostrožac je branilo 40 vojnika, Tržac 20, Drežnik 20, Stijenu 16, Cazin 40, Krstinju 10, Donju Kladušu 10, Gornju Kladušu 10, Bužim 24, Podzvizd 10, Peći 16, Hresno 10, Cetin 10 i Šturlić 8 vojnika. ${ }^{671}$ U utvrdama Bihaćke kapetanije tada je visokih 698 plaćenih vojnika.

Tablica 8. Broj plaćenih vojnika Bihaćke kapetanije 1564.

\begin{tabular}{|c|c|c|c|c|}
\hline 1564. & zapovjednici & pješaci & konjanici & stražari \\
\hline Bihać & 2 & 245 & 58 & 30 \\
\hline Ripač & & 62 & & \\
\hline Sokol & & 12 & & \\
\hline Izačić & & 20 & & \\
\hline Ostrožac & & 40 & & \\
\hline Tržac & & 20 & & \\
\hline Drežnik & & 20 & & \\
\hline Toplički Turanj-Brekovica & & 21 & 4 & \\
\hline Stijena & & 16 & & \\
\hline Cazin & & 40 & & \\
\hline Krstinja & & 10 & & \\
\hline Donja Kladuša & & 10 & & \\
\hline Gornja Kladuša & & 10 & & \\
\hline Bužim & & 24 & & \\
\hline Podzvizd & & 10 & & \\
\hline Peći & & 16 & & \\
\hline Hresno & & 10 & & \\
\hline Cetin & & 10 & & \\
\hline Šturlić & & 8 & & \\
\hline Prema rodovima & 2 & 604 & 62 & 30 \\
\hline Sveukupno & & & & 698 \\
\hline
\end{tabular}

Devet godina kasnije, 1573., popis vojske Bihaćke kapetanije detaljniji je pa je tako navedeno da su u Bihaću tada jedan zapovjednik, 126 haramija, 80 njemačkih vojnika, 58 konjanika i 44 stražara. U svim ostalim utvrdama pod zapovjedništvom bihaćkog kapetana bili su stacionirani samo pješaci haramije. U Ripču ih je i dalje bilo 62, u Sokolu 12, u Izačiću 20, Brekovici-Topličkom Turnju 21, Ostrošcu 39, Tržcu 20, Drežniku 20, Stijeni 12, Cazinu 40, Krstinji 10, Gornjoj Kladuši 10, Donjoj Kladuši 10, Bužimu 24, Podzvidzu 10, Peći 16, Hresnom 10, Cetinu 10, Šturliću 8 i Blagajskom Turnju $10 .{ }^{672}$ Broj vojnika u utvrdama Bihaćke kapetanije nešto je pao u odnosu na raniji popis, konkretno s 698 na 642 čovjeka. U

${ }^{671}$ ŠTEFANEC, Država ili ne, 475-476.

${ }^{672}$ IBID., 477-478. 
Bihaću je pao broj pješaka s 245 na 206 ljudi, ali je zato porastao broj stražara za 14 pa je taj pad nešto ublažen. Međutim, to je i dalje izrazito velika posada u krajiškom kontekstu. Uostalom, to je vidljivo i kada se usporedi s drugim utvrdama kapetanije u kojima broj vojnika varira od 8 do 40, s iznimkom Ripča koji je ionako integralno povezan s Bihaćem. Što se tiče ostalih sjedišta kapetanija na hrvatskom prostoru, u Hrastovici je tada bilo 100 haramija i 20 njemačkih vojnika, u Ogulinu samo 20 haramija, a u Senju oko 240 haramija, pa je vidljivo da je u Bihaću i raznolikost postrojbi veća. Samo su još u Hrastovici namješteni njemački vojnici.

Tablica 9. Broj plaćenih vojnika u utvrdama Bihaćke kapetanije 1573.

\begin{tabular}{|l|l|r|r|r|r|}
\hline \multicolumn{1}{|c|}{ 1573. } & zapovjednici & haramije & $\begin{array}{l}\text { njemački } \\
\text { vojnici }\end{array}$ & konjanici & stražari \\
\hline Bihać & 1 & 126 & 80 & 58 & 44 \\
\hline Ripač & & 12 & & & \\
\hline Sokol & & 39 & & & \\
\hline Ostrožac & & 20 & & & \\
\hline Izačić & & 20 & & & \\
\hline Tržac & & 20 & & & \\
\hline Drežnik & & 21 & & & \\
\hline Toplički Turanj & & 12 & & & \\
\hline Stijena & & 10 & & & \\
\hline Cazin & & 10 & & & \\
\hline Krstinja & & 10 & & & \\
\hline Donja Kladuša & & 24 & & & \\
\hline Gornja Kladuša & & 10 & & & \\
\hline Bužim & & 16 & & & \\
\hline Podzvizd & & 10 & & & \\
\hline Peći & & 10 & & & \\
\hline Hresno & & 10 & & & \\
\hline Cetin & & 490 & & & \\
\hline Sturlić & & & & & \\
\hline Blagajski & & & & & \\
\hline Turanj & & & & & \\
\hline Prema rodovima & & & & & \\
\hline Sveukupno & & & & & \\
\hline
\end{tabular}

Prema popisu iz 1576. u utvrdama Bihaćke kapetanije bilo je 700 plaćenih vojnika. U Bihaću je bilo stacionirano 126 haramija, 100 njemačkih vojnika, 48 konjanika i 44 stražara. ${ }^{673}$ Dakle, broj vojnika porastao je zahvaljujući povećanju broja vojnika njemačke

${ }^{673}$ U vojnom proračunu iz 1576., koji je objavio Géza Pálffy, stoji da je u Bihaću sveukupno 250 vojnika na koje mjesečno odlazi 1741 rajnski gulden. Broj vojnika u ostalim utvrdama uglavnom odgovora gornjem popisu. 
posade s 80 na 100. U ostalim utvrdama i dalje su stacionirani samo pješaci haramije. U Ripču ih je i dalje bilo 62, u Sokolu 12, u Izačiću 20, Brekovici-Topličkom-Turnju 21, Ostrošcu 39, Sv. Jurju u Ostrožačkom polju (ranije nije naveden) 8, Tržcu 20, Drežniku 20, Stijeni 12, Cazinu 40, Krstinji 10, Gornjoj Kladuši 10, Donjoj Kladuši 10, Bužimu 24, Podzvidzu 10, Peći 16, Hresnom 10, Cetinu 10, Šturliću 8 i Blagajskom Turnju $10 .{ }^{674}$ No, da su navedeni brojevi vojnika često samo idealne projekcije ili trenutno stanje pokazuje konstatacija nadvojvode Karla s kraja 1576. prema kojoj je u Bihaću tek 86 gladnih njemačkih vojnika bez baruta i „ostalog potrebnog““675

Tablica 10. Broj plaćenih vojnika u utvrdama Bihaćke kapetanije 1576.

\begin{tabular}{|l|r|l|l|l|}
\hline \multicolumn{1}{|c|}{ 1576. } & haramije & $\begin{array}{l}\text { njemački } \\
\text { vojnici }\end{array}$ & konjanici & stražari \\
\hline Bihać & 126 & 100 & & \\
\hline Ripač & 62 & & & \\
\hline Sokol & 12 & & & \\
\hline Ostrožac & 39 & & & \\
\hline Izačić & 20 & & & \\
\hline Sv. Juraj & 8 & & & \\
\hline Tržac & 20 & & & \\
\hline Drežnik & 20 & & & \\
\hline Toplički Turanj & 21 & & & \\
\hline Stijena & 12 & & & \\
\hline Cazin & 40 & & & \\
\hline Krstinja & 10 & & & \\
\hline Donja Kladuša & 10 & & & \\
\hline Gornja Kladuša & 10 & & & \\
\hline Bužim & 24 & & & \\
\hline Podzvizd & 10 & & & \\
\hline Peći & 16 & & & \\
\hline Hresno & 10 & & & \\
\hline Cetin & 10 & & & \\
\hline Šturlić & 8 & & & \\
\hline Blagajski Turanj & 10 & & & \\
\hline Prema rodovima & 498 & & & \\
\hline Sveukupno & & & & \\
\hline
\end{tabular}

Géza PÁLFFY, A Magyarországi és délvidéki végvárrendszer 1576. és 1582. évi jegyzékei, Hadtörténelmy Közlemények, No. 1, Budimpešta, 1995., 145-146.

${ }^{674}$ ŠTEFANEC, Država ili ne, 480.

${ }^{675}$ SI AS 2, DSK, kutija 244, fascikl 143, Graz, 28.12.1576., 1r, rbr. 347. Nadvojvoda Karlo na Hansa Auersperga. 
Dvije godine kasnije Bihaćka kapetanija pala je na samo devet utvrda - Bihać, Ripač, Sokol, Izačić, Brekovica, Toplički Turanj, Jesenica, Drežnik i Tržac. Broj njemačkih vojnika skočio je na 200, a haramija nešto pao. Pokazat će se privremeno su u posadu Bihaća uvedeni i elitni arkebuziri, a broj husara je smanjen na 50. Broj haramija u Jesenici, Drežniku i Tržcu povećan je na 50, a Ripač, Sokol i Toplički Turanj zaposjedani su vojnicima iz sastava bihaćke posade. Sveukupno je u devet utvrda Bihaćke kapetanije bilo visokih 599 plaćenih vojnika.

Tablica 11. Broj plaćenih vojnika u utvrdama Bihaćke kapetanije 1578.

\begin{tabular}{|l|r|r|r|r|}
\hline \multicolumn{1}{|c|}{ 1578. } & \multicolumn{1}{l|}{ haramije } & \multicolumn{1}{l|}{$\begin{array}{l}\text { njemački } \\
\text { vojnici }\end{array}$} & \multicolumn{1}{l|}{ husari } & \multicolumn{1}{l|}{ arkebuziri } \\
\hline Bihać & 114 & 200 & 50 & \\
\hline Ripač & iz Bihaća & 25 iz Bihaća & & \\
\hline Sokol & 20 & & & \\
\hline Izačić & 15 & & & \\
\hline Brekovica & iz Bihaća & & & \\
\hline Toplički Turanj & 50 & & & \\
\hline Jesenica & 50 & & & \\
\hline Drežnik & 50 & & & \\
\hline Tržac & 299 & & & \\
\hline Prema rodovima & & & & \\
\hline Sveukupno & & & & \\
\hline
\end{tabular}

Dakle, broj vojnika u Bihaću i utvrdama Bihaćke kapetanije relativno je stabilan od 1560-ih do velikih osmanskih osvajanja sredinom 1570-ih. S povećanjem broja utvrda u sastavu kapetanije rastao je naravno i ukupan broj plaćenih vojnika. No, broj vojnika u samim posadama bio je relativno stabilan. U Bihaću je pak, vjerojatno kao odgovor na kontroverzne gubitke pojedinih utvrda, ali i obavijesti koje su dovodile u pitanje vjernost samih Bišćana, 1576. povećan broj njemačkih vojnika koje su vojne vlasti smatrale povjerljivijim od domaćih haramija iako je i među njima bilo domaćeg svijeta. No, gledajući na razini cijele kapetanije, broj vojnika nije se bitno promijenio. Nakon tih poražavajućih poraza na unskoj fronti te nakon što su vojne strukture u Beču zabrinuli špijunski izvještaji o osmanskim snagama na cijelom prostoru od Erdelja do Jadranskog mora 1570-ih, predloženo je povećanje broja krajiških utvrda i vojnika na cijelom krajiškom prostoru. Najveći porast planiran je upravo na Hrvatskoj krajini i to kod broja utvrdnih konjanika (husara) koji su do tada bili stacionirani samo u Bihaću, s njih 58 na čak 708 husara u raznim utvrdama. Terenska vojska trebala je biti reducirana s 1000 na 600 ljudi, a plemićki konji „,na terenu“ više se ne spominju jer su očito 
inkorporirani među utvrdnu vojsku. Za izvanredne potrebe ostalo je tek 100 haramija i 100 husara koji su bili podređeni glavnom zapovjedniku. ${ }^{676}$

Međutim, kao što je ranije navedeno, zbog osmanskih osvajanja i interne reorganizacije Bihaćka kapetanija teritorijalno je bitno reducirana pa se 1579. u njezinu sastavu navode tek tri utvrde u kojima je i dalje bilo stacionirano visokih 202 njemačka vojnika, 150 haramija i 50 husara, na koje je mjesečno odlazilo 2308 rajnskih guldena. U samom Bihaću bilo je stacionirano 100 haramija, 200 njemačkih vojnika i 50 husara, Ripač se zaposjedao njemačkim vojnicima iz Bihaća, a Izačić je branilo 50 haramija ${ }^{677}$ Dakle, dok je broj haramija nešto porastao, broj njemačkih vojnika ostao je isti. Arkebuziri, najelitniji rod konjice, više nisu prisutni u Bihaću. Iako su husari povučeni s terena u utvrde, u Bihaću se njihov broj zadržao na 50 što je veličina standardne husarske postrojbe.

Tablica 12. Broj plaćenih vojnika u utvrdama Bihaćke kapetanije 1579.

\begin{tabular}{|l|r|r|r|}
\hline \multicolumn{1}{|l|}{ 1579. } & haramije & \multicolumn{1}{|l|}{ njemački vojnici } & \multicolumn{1}{l|}{ husari } \\
\hline Bihać & 100 & 200 & 50 \\
\hline Ripač & & zaposjedan iz Bihaća & \\
\hline Izačić & 50 & & 50 \\
\hline Prema rodovima & 150 & 200 & 400 \\
\hline Sveukupno & & & \\
\hline
\end{tabular}

Godine 1582. u Bihaću je 200 njemačkih vojnika, 100 haramija i 50 husara na koje je s plaćom kapetana mjesečno odlazilo 2186 rajnskih guldena. Za Ripač je navedeno da su tamo stacionirani njemački vojnici iz bihaćke posade, kao što je bio slučaj i ranije, dok je u Izačiću te Tržcu i Drežniku, sada opet u sastavu kapetanije, bilo stacionirano po 50 haramija. ${ }^{678}$

Tablica 13. Broj plaćenih vojnika u utvrdama Bihaćke kapetanije 1582.

\begin{tabular}{|c|c|c|c|}
\hline 1582. & haramije & njemački vojnici & husari \\
\hline Bihać & 100 & 200 & 50 \\
\hline Ripač & & $\begin{array}{r}\text { zaposjedan iz } \\
\text { Bihaća }\end{array}$ & \\
\hline Izačić & 50 & & \\
\hline Tržac & 50 & & \\
\hline Drežnik & 50 & & \\
\hline Prema rodovima & 250 & 200 & 50 \\
\hline Sveukupno & & & 500 \\
\hline
\end{tabular}

\footnotetext{
${ }^{676}$ ŠTEFANEC, Država ili ne, 402.

${ }^{677}$ LOPAŠIĆ, SHK, knjiga I, dok. XLIII, 78-79.

${ }^{678}$ PÁLFFY, A Magyarországi, 175-176.
} 
Unatoč teškoj poziciji u kojoj su se grad i kapetanija našli nakon ranijih osmanskih osvajanja, početkom lipnja 1586. u Bihaću je obavljena muštra te je vojni povjerenik Georg Feurer našao „Nijemce i Hrvate“ u punom broju i dobro naoružane. Službu su napustili konjanici i pješaci koji su to željeli, a njihova su mjesta odmah popunjena. ${ }^{679}$ Prema vojnom proračunu iz te godine, u Bihaću je, uz kapetana i poručnika, još zastavnik njemačke postrojbe te njegov „momak“ (jungen), zatim protestantski svećenik (predicant), ranarnik/brijač (veldschreiber), profos, dva vodiča (fürer), bunjar i svirač frule/frulaš te tamničarevi momci (Stekhenkhnecht). ${ }^{680}$ Njemačkih vojnika u Bihaću je tada 157, husara 50, a haramija $92 .{ }^{681}$

Dakle, došlo je do osjetnog pada njemačkih vojnika, a malo se smanjio i broj haramija. U Ripču su tada porkulab, koji je zapovijedao nad 23 njemačka i 22 hrvatska vojnikaharamija, jedan stražmeštar i zastavnik. Sokol se zaposjedao iz Bihaća, a u Izačiću su se nalazili jedan porkulab, jedan zastavnik, Rottmeister (zapovjednik jednog manjeg odreda unutar „zastave“, a sastojala se od 12 vojnika ili šest dvostruko plaćenih vojnika -Doppelsöldner) te 30 hrvatskih vojnika-haramija. Naposljetku, u Drežniku je zapovijedao vojvoda, a posadu su čini zastavnik, rottmeister, te 29 hrvatskih vojnika-haramija. ${ }^{682}$

Tablica 14. Broj plaćenih vojnika u utvrdama Bihaćke kapetanije 1586.

\begin{tabular}{|c|c|c|c|}
\hline 1586. & haramije & njemački vojnici & husari \\
\hline Bihać & 92 & 157 & 50 \\
\hline Ripač & 22 & 23 & \\
\hline Sokol & & $\begin{array}{c}\text { zaposjedan iz } \\
\text { Bihaća }\end{array}$ & \\
\hline Izačić & 30 & 12 & \\
\hline Drežnik & 29 & & \\
\hline Prema rodovima & 173 & 192 & 50 \\
\hline Sveukupno & & & 415 \\
\hline
\end{tabular}

Kompletnu i propisno naoružanu posadu (so woll Teutsche alls Crabatten) na muštri u Bihaću zatekao je i povjerenik Jobst Langenmantel u studenom 1587. Nekolicina njemačkih vojnika i Hrvata napustila je službu, ali je Langenmantel odmah popunio njihova mjesta. I na

\footnotetext{
${ }^{679}$ LOPAŠIĆ, SHK, knjiga I, dok. XCV, 138. Zamjena vojnika trebala se obavljati na muštri i vojne vlasti, barem je to bio slučaju sa karlovačkom posadom u rujnu 1580., nisu dozvoljavale odlazak vojnika prije obavljanja uredne muštre. HDA, Croatica, mikrofilm D-1913, br. 44, rujan 1580. Za komparaciju, s druge strane pograničja Osmanlije su 1586. u devet utvrda pounjske fronte držali 1700 ljudi, raspoređenih na slijedeći način: Kamengrad 30, Kostajnica 330, Novigrad 150, Krupa 300, Cazin 150, Bužim 200, Ostrožac 150, Zrin 200, Gvozdansko 220 vojnika. Kornelija JURIN-STARČEVIĆ, Osmanski krajiški, 48.

${ }^{680}$ ŠTEFANEC, Država ili ne, 373-374.

${ }^{6}$ SI AS 2, DSK, kutija 230, fascikl 136, 1586., 11r-11v.

${ }^{6}$ SI AS 2, DSK, kutija 230, fascikl 136, 1586., 11r-13v.
} 
muštri u Ripču, gdje je porkulab bio Georg Raumbschlüssl, njemački i hrvatski vojnici bili su u punom sastavu i dobro naoružani. ${ }^{683}$ Treba napomenuti da Lopašić navodi da je pod Ostrožcem 1587. došlo do bitke u kojoj je bihaćka posada toliko teško stradala da se skoro u potpunosti morala popuniti. ${ }^{684}$ To se zbilo ili u kasnu zimu te godine ili je pak nakon tog poraza posada vrlo brzo popunjena.

Vojni proračun iz 1589. gotovo je identičan proračunu iz $1586 .{ }^{685}$ U Bihaću je tada 155 njemačkih vojnika, 50 husara, 78 haramija te 14 stražara u šumama. U Ripču je bilo identično stanje kao i tri godine ranije dok je u Izačiću jedan haramija manje, a u Drežniku dvoje. ${ }^{686}$ Iako nisam pronašao popise vojske iz kasnijeg perioda, može se pretpostaviti da su brojke ostale manje-više stabilne sve do lipnja 1592. i da je prilikom završne osmanske opsade grad branila posada od tristotinjak vojnika, kojoj treba pridodati i lokalno stanovništvo.

Zaključno rečeno, Bihać je u promatranom periodu imao za krajiške prilike veliku i raznovrsnu plaćenu posadu, što je jedan od elementa koji odražava prominentni status grada u obrani hrvatskog prostora. Čak ni podizanje novoga obrambenog središta, Karlovca, kao ni činjenica da je grad od kraja 1570-ih bio gotovo u okruženju, nije uvelike utjecalo na broj vojnika u sastavu bihaćke posade. Središnja vlast odlučila je Bihać i dalje braniti, a to se nastojanje manifestira na brojnosti i raznolikosti gradske posade.

\subsection{Karakteristike vojnih rodova u sastavu bihaćke posade}

Dakle, bihaćku posadu činili su haramije, njemački vojnici, husari, stražari, a ponekad i uskoci. Kada je riječ o pješaštvu, iako je dolazilo do oscilacija u broju i sastavu plaćene vojske u gradu i utvrdama Bihaćke kapetanije tijekom promatranog perioda, sve do 1570-ih najbrojnija postrojba u Bihaću su haramije, domaći pješaci, na koje je generalno otpadalo tri četvrtine ukupnog broja plaćene vojske na krajištu. U njihovu sastavu služilo je domaće stanovništvo, ljudi vični krajiškom tipu ratovanja i životu na isturenom pograničju koje su vojne vlasti uvažavale i cijenile. ${ }^{687}$

\footnotetext{
${ }^{683}$ LOPAŠIĆ, SHK, knjiga I, dok. CII, 147-148.

${ }^{684}$ LOPAŠIĆ, Bihać, 192.

${ }^{685}$ SI AS 2, DSK, kutija 230, fascikl 136, 1589., 11r-11v.

${ }^{686}$ SI AS 2, DSK, kutija 230, fascikl 136, 1589., 11r-12r.

${ }^{687}$ ŠTEFANEC, Država ili ne, 387-388.
} 
Ne bi trebalo dvojiti o tome da je domaće stanovništvo dominiralo u sastavu plaćene posade u Bihaću i u predhabsburškom periodu iako je plaćenih vojnika sa strane moralo biti, osobito za vrijeme banovanja „stranih“ banova poput Egerváryja, Perenyja ili Bothe. Za sada najraniji poznati popis vojnika u utvrdama Bihaćke kapetanije, nastao prije svibnja 1540., pokazuje da je većina vojnika domaćeg, hrvatskog te manjim dijelom uskočkog podrijetla. Osobe s njemačkim prezimenima uglavnom su obnašale više funkcije (kapetan nad lakim konjanicima, poručnik, zastavnik, puškar, vjerojatno i stražmeštar), a nekoliko ih je služilo i u sastavu konjice (Hans Gall, Matheus Gallenberg). U ostalim utvrdama posade gotovo u potpunosti čine domaći ljudi (vidi prilog 1). ${ }^{688}$ I popis vojnika, nastao par mjeseci kasnije, u srpnju 1540. (vidi prilog 2), pokazuje da su te postrojbe popunjavane u najvećoj mjeri domaćim svijetom, prvenstveno starosjedilačkim hrvatskim stanovništvom, ali manjim dijelom i uskocima (primjerice, Vukosav Kosović, Radosav Heraković, Raussa Karanović itd.) ${ }^{689}$ Slično je i s popisom vojnika iz 1551. gdje opet dominira domaći element. (vidi prilog 3). ${ }^{690}$

Haramije u utvrdama bili su, dakako, podređeni kapetanu, a njima su neposredno zapovijedali vojvode, odnosno u određenim utvrdama porkulabi/kaštelani. Standardno bi na pedesetak haramija dolazili jedan vojvoda i jedan zastavnik te pet desetnika, kao što uostalom vidimo iz prijedloga krajiškog povjerenstva iz 1563. koje navodi da je u Bihaću trebalo stacionirati i 150 hrvatskih pješaka, tri vojvode, tri zastavnika i 15 desetnika. ${ }^{691}$ Iako su participirali u svim vojnim aktivnostima na krajištu, haramije su u Bihaću bili zaduženi za držanje straža u gradu, a bili su dužni stražariti i izvan grada, na adama i okolnom prostoru, jer njemačka posada nije smjela napuštati grad. Bihaćki pješaci trebali su tako stražariti i u kuli kod Brekovice gdje su se trebali mijenjati na tjednoj ili mjesečnoj bazi.

Haramije su bili plaćeni manje u odnosu na konjanike i njemačke pješake, a iznos plaća nije im se osobito mijenjao tijekom desetljeća. Prema iskazu bihaćke vojske iz 1551., pješaci su uglavnom primali 3 rajnska guldena plaće ${ }^{692}$ dok se u izvještaju krajiškog povjerenstva iz 1563. navodi da mjesečna plaća hrvatskih pješaka treba biti 3,5 rajnska guldena. Trojica zastavnika i petnaest desetnika (rottmeister) trebaju imati mjesečno povećanje od 1 rajnskog guldena, a trojica vojvoda mjesečni dodatak od 6,5 rajnskih guldena. No, 20 haramija, koji su trebali držati stražu na bihaćkoj Otoci, trebali su pak mjesečno

\footnotetext{
${ }^{688}$ SI AS 2, kutija 244, fascikl 143, 1r-4r, rbr. 252-258. Nedatiran popis koji je nastao prije svibnja 1540.

${ }^{689}$ LOPAS̆IĆ, SHK, knjiga IIII, dodaci, dok. V, 396-397.

${ }^{690}$ IBID., dok. X, 411-412.

${ }^{691}$ KRUHEK, Krajiške utvrde, 212.

${ }^{692}$ LOPAŠIĆ, SHK, knjiga IIII, dodaci, dok. X, 411-413.
} 
primati visokih 6 rajnskih guldena po osobi. ${ }^{693}$ Radilo se o važnom mjestu koje je izloženo neprijateljskom napadu pa su i plaće tamošnjih stražara trebale biti više. Prema iskazu plaća iz 1578., haramije su primali standardnih 3-3,5 dok je desetnik primao 4-4,5 rajnskih guldena mjesečno. ${ }^{694}$ Doduše, postoje određene razlike plaća unutar rodova što je pak posljedica bolje ili lošije opremljenosti vojnika i njihova naoružanja. Tako je plaća haramija 1579. trebala iznositi mjesečno 4,5 rajnskih guldena, vojvode 10 rajnskih guldena, zastavnika s doplatkom te bubnjara 2 rajnska guldena dok je desetnik imao doplatak od 1 rajnskoga guldena. ${ }^{695}$ No, čini se da su, uz određene diskrepancije i nastojanja, plaće ostale oko 3,5 rajnskih guldena. ${ }^{696}$ Bez obzira na manju plaću u odnosu na pripadnike ostalih postrojbi na krajištu, haramije su činili temeljnu utvrdnu vojsku hrvatskog pograničja i zauzimali su važno mjesto unutar krajiškog sustava.

U kapetanijskim središtima i važnijim utvrdama bili su stacionirani i bolje naoružani i plaćeni „njemački vojnici“ (Teutsche Knecht) čije se redove nastojalo popunjavati „njemačkim“, odnosno austrijskim plemstvom. Vojnici s njemačkog, odnosno austrijskog prostora bili su prisutni u Bihaću od početka habsburškog perioda, ali se u popisima iz 1540 . još ne navode kao zasebna postrojba iako su prisutne osobe $s$ njemačkim imenima i prezimenima (primjerice Hans Gall, Michal von Rab, Hanns Khoch u prvom popisu iz 1540., odnosno Jorg Vierzig, Andre Stutz, Sebastian Schlesinger, Cristof Lisst itd. u drugom popisu iste godine). Doduše, jedan od popisa iz 1540. pokazuje da su plaćeni 3 rajnska guldena kao i haramije pa možda, čini se, još nema zasebno formirane njemačke postrojbe u gradu. (vidi priloge 1-2). ${ }^{697}$ Slično je i prema popisu iz 1551. gdje su također kolektivno navedeni samo pješaci (Fuessuolgkh zu Wichitsch) uglavnom s haramijskom plaćom od 3 rajnska guldena. Od nekolicine onih koji su imali nešto višu plaću, i ako se izuzmu stražmeštar, puškari i bubnjar (službe na koje su često namještani stranci), tek nekoliko ih ima njemačka imena i prezimena (Panngracz Lustaller, Paul Feuchtner, možda Andre Maurer i Jurko Sterllegkher). Svi su ostali domaći ljudi, uz nešto uskoka. Slično je i u ostalim utvrdama Bihaćke kapetanije. (vidi prilog 3). ${ }^{698}$

No, već krajem 1550-ih u Bihaću, u gradu i kaštelu (der Stat vnnd Scloß), nalazilo se 360 plaćenih ,njemačkih i slavonskih“ (Teutsch vnnd Windischen knecht) vojnika. ${ }^{699}$ Dakle,

\footnotetext{
${ }^{693}$ AHAZU, Lopašić, E. Prijepisi iz austrijskih arhiva, br. 15, str. 29.

694 ŠTEFANEC, Država ili ne, 372-373.

${ }^{695}$ LOPAŠIĆ, SHK, knjiga I, dok. XLIII, 78.

${ }^{696}$ SI AS 2, DSK, kutija 230, fascikl 136, 1586., 11r-11v.

${ }^{697}$ LOPAŠIĆ, SHK, knjiga IIII, dodaci, dok. V, 396-397.

${ }^{698}$ IBID., dok. X, 411-413.

${ }^{699}$ ÖeStA, KA-AFA-1559-7-ad7. str. 22-23; ŠTEFANEC, Država ili ne, 472.
} 
tada se već jasno navode njemački vojnici i od tada će oni biti permanentno prisutni u brojevima navedenim ranije u poglavlju.

Krajiško povjerenstvo iz 1563. predložilo je da u Bihaću bude posada od 100 njemačkih vojnika s mjesečnom plaćom od 5 rajnskih guldena, oboružana dobrim ručnim vatrenim oružjem (guetten handtroren) i oklopom. Zapovijedao im je poručnik koji je ujedno bio i vicekapetan, a imao je ingerencije i nad konjaničkim i pješačkim stražama za što je primao mjesečnu povišicu od 10 rajnskih guldena. Istu svotu primao je i zastavnik. Također, naveden je i narednik (velt waibl) koji je trebao poručniku pomagati u svim poslovima, osobito u onima koji se odnose na vojne akcije i stražu. On je trebao primati mjesečni dodatak od 5 rajnskih guldena. ${ }^{700}$

Prema vojnom proračunu iz 1578. 200 njemačkih vojnika u Senju i Bihaću trebali su biti vojno iskusni pojedinci naoružani kao bolje plaćeni elitniji vojnici (Doppelsoldner) te opremljeni prsobranom, pancirom i dobrim oružjem prema uobičajenim vojnim navadama“. ${ }^{701}$ Sljedeće godine navedeno je da poručnik (Lieutenant) prima plaću od 32 rajnska guldena mjesečno, zastavnik 16 , stražmeštar 12 , a pojedini vojnik bio je plaćen 5 rajnskih guldena mjesečno. Ako su vojnici zaista bili plemići, imali su pravo na dodatak na opremu i oklop, a to je iznosilo još 118 rajnskih guldena mjesečno. ${ }^{702}$ Teško je reći koliko je to iznosilo po pojedincu jer se ne zna koliko je plemića zaista bilo.

Međutim, prema proračunu iz 1586., poručnik je imao nešto manju mjesečnu plaću od 28 rajnskih guldena, zastavnik 16 te 4 rajnska guldena za svog momka (jungen), a stražmeštar nešto više 20 rajnskih guldena mjesečno. Za 155 njemačkih vojnika zajedno s doplatkom plaća je mjesečno iznosila 899 rajnskih guldena. ${ }^{703}$ Dakle, plaća je i u njihovu slučaju ponešto varirala, ali je plaća vojnika ostala oko 5 rajnskih guldena. ${ }^{704}$

Zanimljivo je da se u vojnom proračunu iz 1582. navodi da su na mjesečnoj razini u gađanju najuspješniji vojnici na muštri dobivali dodatak zvan haggengelt u iznosu 50 rajnskih guldena. Taj je novac očito prema određenom ključu razdijeljen najpreciznijim strijelcima. ${ }^{705}$ Ovaj upis pokazuje koliki je naglasak stavljan na uporabu vatrenog naoružanja u ovoj postrojbi.

\footnotetext{
${ }^{700}$ AHAZU, Lopašić, E. Prijepisi iz austrijskih arhiva, br. 15, str. 29.

701 ŚTEFANEC, Država ili ne, 381. Vojnici u kategoriji Doppelsoldner-a bili su iskusni vojnici potpuno opremljeni i naoružani. SIMONITI, Vojaška organizacija, 148.

${ }^{702}$ LOPAŠIĆ, SHK, knjiga I, dok. XLIII, 78.

${ }^{703}$ SI AS 2, DSK, kutija 230, fascikl 136, 1586., $11 \mathrm{r}$.

${ }^{704}$ SI AS 2, DSK, kutija 230, fascikl 136, 1586., 12v.

705 „Item Haggengelt darumben zuschiessen welches als offt den Jenigen, so die bessten Schu $\beta$ Monnatlich gethan, vnd durch den Haubtman oder Leüttinand zuuerzaichnen, bey den bezallungen ordenlich außzuthaillen" SI AS 2, DSK, kutija 230, fascikl 136, 1582., 7r.
} 
Na prostoru Bihaćke kapetanije njemačke vojnike nalazimo samo u Bihaću te od kraja 1570-ih u Ripču i vjerojatno Sokolu koji je 1580-ih zaposjedan vojnicima iz sastava bihaćke posade. $^{706}$ Čini se da su njemački vojnici bili stacionirani u kaštelu pored južnih gradskih vrata koja su zato prozvana Njemačkim vratima. ${ }^{707}$ Iako su u sastavu njemačke postrojbe u Bihaću služili i domaći ljudi, ovi bolje naoružani vojnici bili su smatrani discipliniranijima pa su bili zaduženi za povjerljivije poslove poput stražarenja na zidinama i gradskim vratima te nisu smjeli napuštati grad. Tako je krajem kolovoza 1576., kada se očekivao veliki osmanski napad na grad, kapetan Sebastian Lamberg na noćne straže u gradu postavio cijelo ljudstvo njemačke postrojbe dok je na vanjskim zidinama postavio hrvatske pješake i ,nadao se najboljemu“. ${ }^{708}$

Njemački vojnici bili su namješteni i na drugim povjerljivim lokacijama poput rudnika odakle je bihaćki kapetan Sauer krajem srpnja 1556. podigao 12 vojnika. ${ }^{709}$ Kada su nakon pada Krupe u ljeto 1565. kranjski staleži molili koruške da pošalju pomoć, odnosno određeni broj strijelaca ili financijska sredstva za angažiranje vojnika, na savjetovanju koruških staleža prisutni kranjski poslanik zaključio je da je malo koristi od slavonskih i hrvatskih vojnika i strijelaca (Knecht vnnd Schüzen). I kranjski su vojnici dijelom odbili ići na krajište, a i oni koji su krenuli potajno su od tamo bježali, kao što se dogodilo s unajmljenim kranjskim strijelcima koji su poslani u Bihać. Zato je tražio da se angažiraju pouzdani njemački vojnici. Koruški staleži izdali su proglas u gradovima i trgovištima Koruške da se za pet dana (8. srpnja) u Klagenfurtu okupe svi koji žele služiti kao pješaci. Pretpostavljali su da će u tako kratkom roku moći okupiti 200-300 „dobrih ljudi“ koji će se 10. srpnja uputiti u Črnomelj u Kranjskoj. Molili su kranjske staleže da osiguraju opskrbu. ${ }^{710}$ Takve postrojbe često su slane na Hrvatsku krajinu, o čemu će biti riječi dalje u poglavlju.

No, zbog sve ozbiljnijeg iseljavanja iz Bihaća od 1570-ih čak je i stražarenje na zidinama i čuvanje gradskih vrata postalo problematično jer je ponekad nedostajalo plaćenih vojnika koji bi obavljali te dužnosti. Tako se u ožujku 1576. bihaćki časnici žale da pedeset Hrvata prijeti odlaskom, a ako im se to dozvoli oni neće moći s malim bojem vojnika kojima raspolažu adekvatno čuvati utvrdu jer ih nema dovoljno za čuvati dvoja gradska vrata, a

\footnotetext{
${ }^{706}$ SI AS 2, DSK, kutija 230, fascikl 136, 1589., $12 \mathrm{v}$.

${ }^{707}$ LOPAŠIĆ, Bihać, 34.

${ }^{708}$ SI AS 2, DSK, kutija 287, fascikl 164, Bihać, 23.8.1576., 1r, rbr. 592. Sebastian Lamberg na Hansa Auersperga.

${ }^{709}$ SI AS 2, DSK, kutija 201, fascikl 124, 28.7.1556., 1r, rbr. 186. Georg Sauer na kapetana Hrvatske krajine Merta Galla.

${ }^{710}$ SI AS 2, DSK, kutija 414, fascikl 287, Klagenfurt, 3.7.1565., 1r-2v, rbr. 1013-1016. Koruški staleži na Ivana Lenkovića.
} 
kamoli gradske zidine. ${ }^{711}$ Iako su pripadnici ove postrojbe generalno bili bolje opskrbljeni od, primjerice, haramija, upravo su oni vrlo često iz Bihaća upućivali dramatične apele za pomoć navodeći da su gladni, bosi, bolesni i neopskrbljeni te na rubu preživljavanja. Osnovni problem predstavljale su manjkava opskrba i neredovita isplata plaća te činjenica da pripadnici njemačkih postrojbi, za razliku od domaćih ljudi u vojnom sustavu, nisu imali posjede u okolici grada s kojih bi se mogli prehranjivati. Već je krajiško povjerenstvo iz 1563. navelo da su njemački vojnici u Bihaću siromašni i da se zbog gladi razbolijevaju. ${ }^{712}$

Utemeljenost takvih konstatacija pokazuje i vapaj bihaćkog kapetana Sebastiana Lamberga iz studenog 1574. kako je među posadom zavladala takva glad da nije ostalo mnogo zdravih vojnika pa može čuvati samo gradska vrata dok mora zanemariti druga uobičajeno čuvana mjesta. ${ }^{713}$ Sramotno je, kaže kapetan, da se nije ništa učinilo po tom pitanju i da se siromašni vojnici tako žalosno razbolijevaju i umiru od gladi. Da su zdravi, mogli bi napustiti grad, ali ovako bolesni, iscrpljeni i beživotni ostaju ovdje i propadaju. Ako se ne dopremi novac, živež i sve ostalo potrebno, uvjeravao je Lamberg, ovdašnji vojnici, a osobito oni koji su još uvijek zdravi, neće dalje htjeti ostati u sastavu gradske posade. ${ }^{714}$ No, okolnosti se nisu odveć popravile ni desetak godina kasnije pa su se prilikom muštre u veljači 1586. vojnici žalili da nema stražarnica pa moraju stražariti izloženi kiši i snijegu, neki i bosi na golom zidu zbog čega su tražili od kapetana da se podignu stražarnice (wachthauser). ${ }^{715}$

Dakle, bolje plaćeni njemački vojnici bili su kao stranci bez posjeda u gradu čak i izloženiji egzistencijalnim nedaćama od domaćeg stanovništva koje je možda manje plaćeno, ali je raspolagalo sa zemljišnim posjedima koji su im omogućavali preživljavanje, a možda i skromnu trgovinsku djelatnost.

Što se konjice tiče, najbrojnije postrojbe na krajini bili su husari - tipična krajiška konjica, lakše opremljena i uglavnom sastavljena od domaćih plemića koji su na plaći mogli imati i više konjanika (sluga, momaka, dienner). Prema vojnim pravilima (artikulima) iz 1578., husari su morali „vse ili vetschi dela plemenite viteze s dobrimi koini, oklopi, ili panziry, shischakom, szhitom, copiem, sablo, bodeschom, batom ili sekirizo spravne imati““. Ako je tko želio pušku, mogao ju je imati. Njihovi „sluge ter lovassi“ morali su biti odrasli sposobni muškarci, naoružani i opremljeni „,nai maine panziri, wdrugom paki wsi szhiti, cupy,

\footnotetext{
${ }^{711}$ SI AS 2, DSK, kutija 287, fascikl 164, Bihać, 30.3.1576., 1v, rbr. 516. Bihaćki časnici na Hansa Auersperga.

712 AHAZU, Lopašić, E. Prijepisi iz austrijskih arhiva, br. 15, str. 28.

713 SI AS 2, DSK, kutija 286, fascikl 164, Bihać, 16.11.1574., 1r-1v, rbr. 234-235. Sebastian Lamberg na kranjske Verordneten.

${ }^{714}$ SI AS 2, DSK, kutija 286, fascikl 164, Bihać, 14.11.1574., 1v-2r, rbr. 235-236. Sebastian Lamberg na kranjske Verordneten.

${ }^{715}$ LOPAŠIĆ, SHK, knjiga I, dok. XCV, 138.
} 
sablami ter shischaki spravni biti““. ${ }^{716}$ Husari su bili prilagođeni krajiškom ratovanju, mobilni, brzi i iskusni konjanici koji su jednako participirali u većim vojnim pothvatima, kao i u vječitim manjim pograničnim okršajima s Osmanlijama u kojima su se osobito istaknuli. Dominirali su na pograničnim područjima permanentnog ratovanja prema Osmanskom Carstvu pa su tijekom 16. stoljeća i prevladali nad teškom oklopljenom konjicom. ${ }^{717} \mathrm{Te}$ postrojbe činile su osnovni tip konjice na pograničju.

Dok su husari 1540. primali plaću od 3 rajnska guldena mječeno, a pojedinci i dodatak od jednog rajnskog guldena, do travnja 1579. svaki husar primao je mjesečno 8 rajnskih guldena. Kapetan husara imao je mjesečnu plaću od 50, a zastavnik i trubač 4 rajnska guldena mjesečnog doplatka. ${ }^{718}$ Lakih hrvatskih konjanika, prvenstveno plemića, vjerojatno je u Bihaću i okolici bilo više nego što pokazuju popisi plaćene vojske, ali od samih početaka promatranog perioda husari su i u gradskoj posadi poprilično brojni. Kada je u srpnju 1527. Nikola Jurišić predložio da se u Bihać namjesti stotinu konjanika, savjetovao je kralju da izda naredbu da u sastav te postrojbe uđu protjerani plemići koji bi se s obiteljima i imovinom naselili u Bihaću čime bi se obrana grada ojačala kvalitetnim vojnicima (mit gueten leuten). No, smatrao je izrazito bitnim napomenuti da se moraju s početkom svakog mjeseca plaćati i muštrati. ${ }^{719} \mathrm{U}$ kratkoj opasci na iznese prijedloge u istom dokumentu navedeno je da će se to uzeti na razmatranje. ${ }^{720}$

U proljeće 1530. Kranjska je podigla 600 konjanika, od kojih su mnogi bili hrvatskog porijekla ili s hrvatskog prostora. Nakon dva mjeseca svi su raspušteni, osim 52 konjanika koji su trebalo za ojačanje Bihaća. Međutim, ti se konjanici sa svojim momcima nisu htjeli pomaknuti s hrvatsko-kranjske međe prije nego li im se isplati barem polovica mjesečne plaće. U Bihać su krenuli tek kada su primili 2 rajnska guldena što je bilo nešto manje od traženog iznosa. ${ }^{721}$ Zbog ratnih okolnosti za konjanike su se otimali i drugi vladari i države pa je tako slavonski sabor 1537. konstatirao da Mlečani, koji su ušli u otvoreni sukob s Osmanlijama, okupljaju konjanike obećavaju im veće plaće i krmivo. Također, navedeno je i da Ivan Zapolja daje veću plaću nego kralj Ferdinand, a dozvoljava im i slobodno pljačkanje. $^{722}$

\footnotetext{
${ }^{716}$ IBID., dok. XXXVIII, 68

717 Gyula RAZSO, The mercenary army of king Matthias Corvinus, u: From Hunyadi to Rakoczi War and Society in late Medieval and Early Modern Hungary, War and Society in Eastern Central Europe, vol. III, ur. Janos M. Bak, Bela K. Kiraly, Brooklyn College Press, Brooklyn, 1982., 132.

${ }^{718}$ LOPAŠIĆ, SHK, knjiga I, dok. XLIII, 78.

${ }^{719}$ THALLÓCZY, HODINKA, A horvát véghelyek, dok. DXLIV, 695.

${ }^{720}$ IBID., dok. DXLIV, 696.

${ }^{721}$ SIMONITI, Vojaška organizacija, 125.

${ }^{722}$ ERCEG, Šišićeve biljeske, 424.
} 
Do 1540-ih broj konjanika u gradu i kapetaniji bio je očito nešto veći u odnosu na pješake, ali je nakon odredbe kraljice Ane da se njihov broj smanji sa 126 na 40 iz travnja 1540. broj husara u Bihaću ostao na manje-više standardnoj razini od 50 ili 58 vojnika. Doduše, prema popisu konjanika načinjenog prije/oko svibnja 1540., u bihaćkoj posadi bila su tek 24 konjanika. ${ }^{723}$ Uvijek treba voditi računa o diskrepanciji između idealnih projekcija i realnog stanja na terenu iako je često teško utvrditi razlike zbog nedostatka izvora.

Popisi vojske iz spomenute 1540. pokazuje da je u sastavu lake konjice u Bihaću služilo domaće stanovništvo, pripadnici hrvatskog plemstva te uskočka elita. U popisu se nalaze istaknuti hrvatski plemić Marko Karinčić ${ }^{724}$ i njegov brat s 4 konjanika, Ivan Rebrović, član plemićke obitelji koja se istaknula u vojnoj službi u Bihaću s 3 konjanika, zatim Mikula Križanić, člana još jedne istaknute plemićke obitelji s 1 konjanikom, Juraj Vragović s 9 konjanika, jedan od Kobasića s 3 konjanika te mnogi drugi hrvatski plemići. Naveden je i istaknuti uskočki starješina Vuk Popović s 2 konjanika. (vidi priloge 1-2) ) $^{725}$

U ovoj postrojbi i dalje su primarno služili lokalni plemići, kao što to pokazuje i popis konjanika u Bihaću iz 1551. u kojem se navode Ivan Rebrović s 2 konjanika, zatim Juraj Rebrović s 1 konjanikom, Marko Karinčić s 3 konjanika te Novak Popović, očito sin, brat ili neki drugi rod Vuka Popovića itd. (vidi prilog 3). ${ }^{726}$ Krajiško povjerenstvo iz 1563. predložilo je da u Bihaću 8 husara bude u pratnji kapetana Kronschalla. ${ }^{727}$ Slične brojke i sastav vjerojatno su ostali do pada Bihaća pod osmansku vlast 1592. iako, nažalost, nisu pronađeni detaljni popisi vojnika za drugu polovicu 16. stoljeća.

Dakle, navedene postrojbe su oni koji se u izvorima pojavljuju kao vojnici Teitsch vnd Crabatischer nation, kako je to zapisao Georg Feuer prilikom muštre u veljači $1586 .{ }^{728}$ Haramije i husari bili su primarno domaći ljudi, ali i u redovima njemačke posade vjerojatno je bilo domaćeg svijeta. Uz popise vojnika, narodnosni sastav i najuglednije pojedince vojne posade u Bihaću pokazuju i imena potpisnika raznih predstavki i molbi. Iako se ne zna kojem su točno rodu vojske služili početkom travnja 1531., Hansu Katzianeru upućenu molbu potpisali su Toma od Knina, Antonio i Pavle Zlačić/Slačić, Mihael Kninjanin, Luka Munja,

\footnotetext{
${ }^{723}$ SI AS 2, kutija 244, fascikl 143, 2v-3r, rbr. 255-256. Nedatiran popis koji je nastao prije ili oko svibnja 1540.

${ }^{724}$ Karinčića dvor (Karintschiz Hoff) nalazio se u Donjoj Kladuši na brijegu iznad utvrde. HDA, Militaria, kutija 7, 1560., 1r, 6.10.1560., bez numeracije. Herbart Auersperg na predstavnike kranjskih staleža.

${ }^{725}$ LOPAŠIĆ, SHK, knjiga III, dodaci, dok. V, 395-396.

${ }^{726}$ IBID., dok. X, 411. Rebrovići će nakon osmanskog osvajanja Bihaća biti istaknuti krajiški rod u Tounju. ŠARIĆ, Etnokulturna kretanja, 22.

${ }_{727}$ AHAZU, Lopašić, E. Prijepisi iz austrijskih arhiva, br. 15, str. 29.

${ }^{728}$ LOPAŠIĆ, SHK, knjiga I, dok. XCV, 138.
} 
Ivan Boban, drugi Ivan Boban, Ivan Bakšić i Marko Trupčić. ${ }^{729}$ Svi su, dakle, potjecali s hrvatskog prostora.

Na kraju je potrebno spomenuti zanimljiv te u konačnici tek privremeno realizirani prijedlog uvođenja arkebuzira u vojnu posadu Bihaća krajem 1570-ih. Arkebuziri su bili plemići, strijelci na konjima, odjeveni u zelene kapute, parcijalno oklopljeni i naoružanim arkebuzama. Sveukupno ih je na krajištu bilo oko 500 od čega na Hrvatskoj krajini oko 300, a na Slavonskoj krajini oko 200. Usto, arkebuziri su imali sluge/momke (dienner) koje su financirali iz svojih prihoda. Budući da su bili bolje plaćeni, u njihov sastav često su nastojali ući husari, bez obzira na to jesu li bili adekvatno naoružani, opremljeni ili obučeni. Uvođenje arkebuzira izazvalo je stanovite probleme jer su se mnogi husari pokušali „ubaciti“ u redove gotovo dvostruko više plaćenih arkebuzira, a to im je često i uspijevalo jer je uglavnom nedostajalo „Nijemaca“ pa su povjerenici popunjavali redove arkebuzira domaćim husarima. Krajiške vlasti zahtijevale su od husara da obuku zelene kapute te da se bolje naoružaju i opreme. ${ }^{730}$ Što se tiče narodnosnog porijekla pripadnika ovih postrojbi, postojala je tendencija popunjavati redove arkebuzira (Schutzen Pherdt) strancima - Nijemcima, Talijanima ili Francuzima. Prema prijedlogu vojnih savjetnika iz 1578., angažirati ih je trebalo zato što su Nijemci, Talijani i Francuzi najbolje obučeni u jahanju i pucanju dok Hrvati zbog stanovitih nedostataka (očito taktičke prirode uz neadekvatnu opremljenost) trebaju ostati u jedinicama husara. Ako nadvojvoda prihvati takvu argumentaciju, hrvatskim konjanicima bi se takva odluka dalje elaborirala riječima da nije riječ o sramoćenju i odbacivanju hrvatskih konjanika, već da se to čini radi postizanja i održavanja reda te je povezano s uređivanjem stanja husara koji su tada propali do mjere da se gotovo ne može pronaći uvježban i iskusan konjanik. ${ }^{731}$

Što se arkebuzira u Bihaću tiče, već je krajiško povjerenstvo iz 1563. predložilo da se u gradu stacionira 50 arkebuzira (strijelaca na konjima). ${ }^{732}$ Taj prijedlog tada nije realiziran. Prema prijedlogu Bečkog savjetovanja iz 1577., u Bihaću je trebalo stacionirati 100 arkebuzira što je parcijalno ostvareno jer se u Bihaću, prema vojnom popisu iz 1578., nalazilo 50 arkebuzira. ${ }^{733} \mathrm{U}$ kasnijim godinama ne nalaze se u Bihaću jer su vjerojatno povučeni u Karlovac.

\footnotetext{
729 „Thomas de Thynynio, Anthonius, Paulus Zlachich, Lucas Mwnya, Johannes Boban, Johannes Boban, Johannes Baksych et Marcus Trupchych seruitores vestre magnificiencie“. LASZOWSKI, HSKHDS, knjiga I, dok. 31, 23.

730 ŠTEFANEC, Država ili ne, 385-386.

${ }^{731}$ HDA, Croatica, kutija 1, svežanj 2, veljača 1578., 62-63.

${ }^{732}$ AHAZU, Lopašić, E. Prijepisi iz austrijskih arhiva, br. 15, str. 29.

${ }^{733}$ ŠTEFANEC, Država ili ne, 484-486.
} 
Izvori pokazuju da su osmanski zapovjednici izuzetno respektirali te postrojbe, osobito njihov oklop i vatrenu moć. U izvještaju, koji je na temelju špijunskih izvještaja u veljači 1585. zapovjedniku Hrvatske krajine dostavio bihaćki poručnik Gregor Allmeyer, navedeno je da je novi paša, stigavši u Banja Luku, tražio od spahija i drugih savjetnika da mu odgovore kako je moguće da su kršćani stekli vojnu nadmoć nad njima. Odgovoreno mu je da je razlog u tome što kršćani, a osobito „die Teutsche Archubusuer“ intenzivno pucaju i oklopljeni su željezom, dakle u kvalitetnom oklopu. Na pašin upit kako onda dalje vojno djelovati i pljačkati u novim okolnostima, okupljeni su kazali da se ništa neće moći izvršiti prije eliminacije arkebuzira. To bi se učinilo tako da paša s velikom vojskom provali, a dio snaga pošalje u pljačku te na tri ili četiri mjesta postavi zasjede. Kada kršćani krenu u potjeru za napadačima, treba pričekati da se nađu unutar te zasjede te ih tada napasti i poubijati (osobito arkebuzire), a onda prema vlastitim željama dalje pljačkati. ${ }^{734}$ Ovaj slikovit prijedlog pokazuje da su osmanski uglednici držali da je preduvjet daljnjim pljačkaškim upadima, a onda i osvajanjima, eliminacija arkebuzira koje je trebalo razbiti ne direktnom konfrontacijom, već vojnom varkom i zasjedom. Iako nije jasno je li u konkretnom slučaju riječ o figurativnom opisu općih relacija na krajištu ili su se paša i osmanski zapovjednici referirali na neku specifičnu bitku u kojoj su osmanske snage poražene, sasvim je jasna percepcija važnosti arkebuzira, a onda i vatrenog naoružanja. Treba napomenuti da se ovdje vjerojatno radilo o karlovačkim arkebuzirima.

\subsection{Vojne postrojbe slane u pomoć obrani Bihaća i Bihaćke kapetanije}

Uz plaćenu vojnu posadu i lokalno stanovništvo, Bihać je kao izrazito važan grad branjen i različitim vojnim postrojbama koje su u slučaju opasnosti namještane u grad i/ili su osiguravale (širu) okolicu. Uglavnom se radilo o najamničkim pješačkim i konjaničkim postrojbama, kao što su martolozi, uskoci i unajmljeni strijelci (puchsenschüzen), koje su na plaći držali unutrašnjeaustrijski, a u ovom slučaju primarno kranjski staleži. Te postrojbe služile su kao interventne jedinice koje su trebale suzbijati osmanske upade na kranjskom i hrvatskom prostoru i bile su vrlo važne za obranu Bihaća jer su bile stacionirane i na samom krajištu kako bi mogli brže reagirati u slučaju opasnosti. Koliko je „varijabla vremena“ utjecala na vojne odluke pokazuje primjer s kraja travnja 1522., kada su se austrijske

\footnotetext{
${ }^{734}$ SI AS 2, DSK, kutija 203, fascikl 124a, 1r-1v, Bihać, 23.2.1585. Gregor Allmeyer na Jobsta Josepha Thurna. Možda je to posljedica i osmanskog poraza kod Slunja 1584.
} 
postrojbe okupile na kranjskom pograničju kako bi suzbile osmanski upad, ali su oklijevale krenuti prema Bihaću jer su u tom slučaju pješaci morali preći jednu rijeku, a to se jedva dalo izvesti u dan i pol. ${ }^{735} \mathrm{Na}$ krajištu je element vremena odnosno brze reakcije vrijeme bio od izrazitog značaja.

Stoga je, kao što je već navedeno, bilo nužno držati staln(ij)u vojsku na krajištu koja bi mogla nadzirati ugroženi prostor i brzo djelovati u slučaju opasnosti - u ovom slučaju ojačavati obranu Bihaća i podređenih mu utvrda. U izvorima ih se naziva provisionirten schutzen, a radilo se o pješacima strijelcima koji su unajmljeni na određeno vrijeme i koji su, uz oružje, opremu i opskrbu, primali dnevnice i godišnju novčanu proviziju. ${ }^{736}$ Kako je izgledao raspored tih postrojbi na Hrvatskoj krajini pokazuje jedan popis pješaka i konjanika od rujna 1556. stacioniranih na Hrvatskoj krajini. Zapovjednik Hrvatske krajine trebao je, ako tada već podignutih 200 konjanika i 500 strijelaca (Puchsenschuzen) nije bilo potrebno držati, s 200 konjanika, 200 strijelaca te 50 uskoka pod Paukom Rackovićem (Paukho Rackhouitsch) biti preraspoređen iz Bihaća u Cetin i „te krajeve“ već prema potrebi i u skladu s neprijateljskim namjerama. U Bihaću se postrojbi od 100 strijelaca trebalo pridružiti još 50 uskoka pod vojvodom Oliverovićem, a ostalih 100 strijelaca biti namješteno u Hrastovicu. Nadalje, od 200 plaćenih konjanika, njih 100 je trebalo rasporediti prema Hrastovici, Gorama, Gradcu i okolici, 50 prema Slunju, 30 prema Drežniku, a 20 prema Ogulinu. Od 400 unovačenih martologa, dakle pješaka, jedan vojvoda s 40 uskoka trebao se pridružiti strijelcima i uskocima prema Bihaću. Drugi vojvoda s 40 uskoka stacioniran je prema Drežniku, treći prema Jesenici, a četvrti prema Ogulinu, Modrušu i okolici. Preostalih pet uskočkih vojvoda s 200 vojnika trebalo je biti raspoređeno na strateškim komunikacijama od Brinja i Otočca do „Morskih gora“ (Mor gepurg) iznad Ledenica i Vinodola. Oko Kostela i na uobičajenim cestama prema Jadranskom moru trebalo je ponovo postaviti 20 vojnika. Tada je bilo planirano da stigne i čak 600 strijelaca iz Goričke grofovije. Glavni zapovjednik ih je trebao rasporediti prema svome nahođenju i potrebama. ${ }^{737}$ Dakle, trebalo je staviti pod nadzor utvrde i komunikacije na cijelom prostoru Hrvatske krajine.

\footnotetext{
${ }^{735}$ THALLÓCZY, HODINKA, A horvát véghelyek, dok. LVI, 87.

736 SIMONITI, Vojaška organizacija, 133. Termin provisionirten na hrvatskom se jeziku prevodio kao provižmonci kao što je to, doduše za uskoke, učinio ogulinski kapetan Andrija Tadiolović u ožujku 1566. BOJNIČIĆ, Izvješća, dok. XXV, 78.

${ }^{737}$ SI AS 2, kutija 283, fascikl 411, 1.9.1556., 1r-1v.
} 


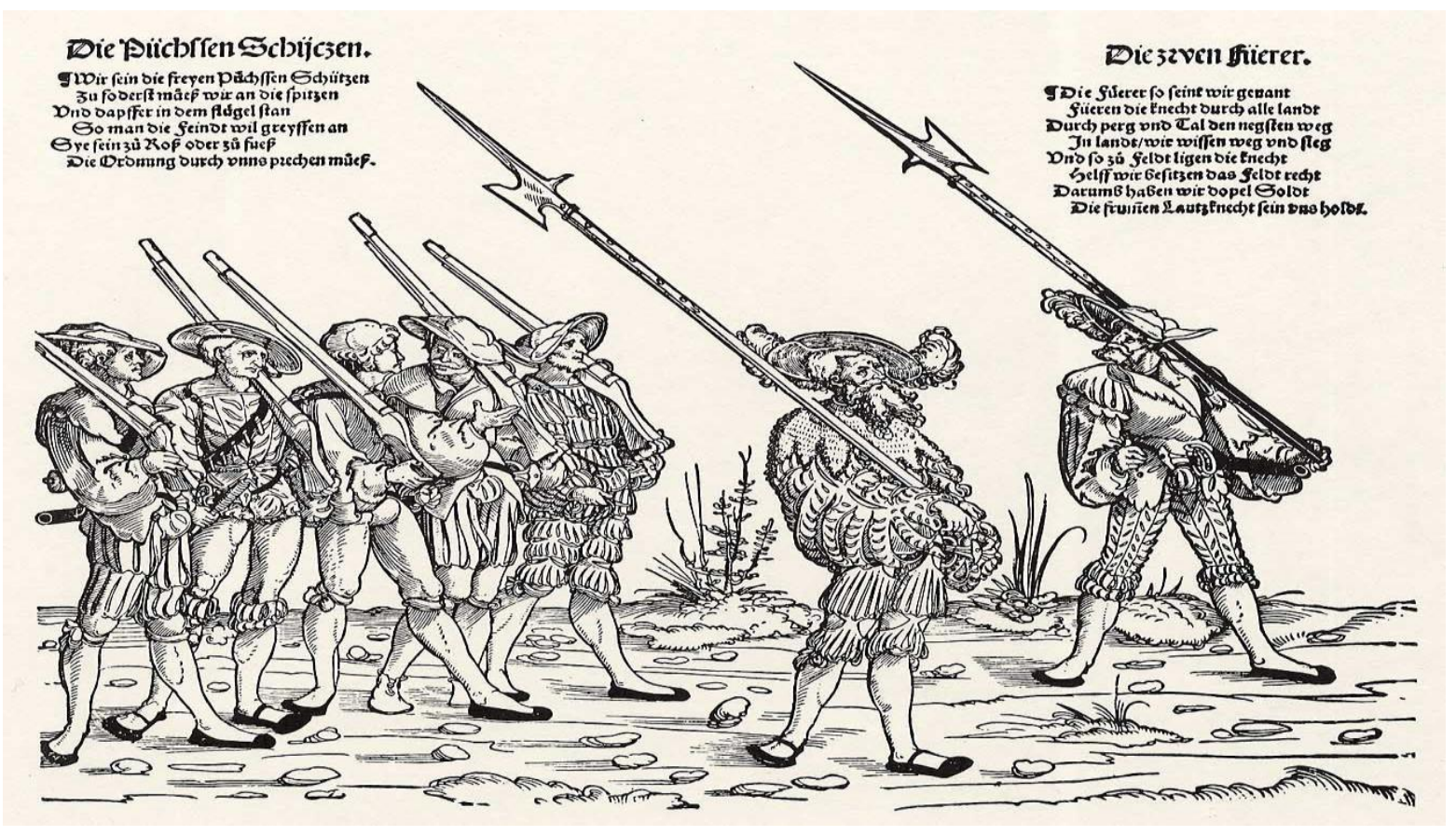

Slika 19. Prikaz strijelaca puškara s dvojicom vodiča (füerer) iz 16. stoljeća. Prema priloženoj pjesmici, vodiči su za svoju službu primali dvostruku plaću. ${ }^{738}$

Što se postrojbi u plaćenoj kranjskoj službi tiče, već od kraja 1520-ih martolozi predstavljaju temeljnu pješačku pograničnu formaciju. Riječ je o tipu pješaštva bizantske provenijencije koji je vrlo brzo apsorbiran u osmanski vojni sustav i ponegdje zadržan čak do 19. stoljeća. Te postrojbe popunjavane su uglavnom kršćanima kojima je bila dužnost služiti u pograničnim utvrdama, nadzirati putove i prijelaze te špijunirati neprijatelja. ${ }^{739} \mathrm{U}$ prvim desetljećima 16. stoljeća te postrojbe svojim su opetovanim pustošenjima nanosile ozbiljne štete hrvatskom i kranjskom stanovništvu i generirale veliki osjećaj nesigurnosti na pograničju. Budući da se takav tip vojnog djelovanja pokazao vrlo uspješnim, staleži Unutrašnje Austrije već od kraja 1520-ih i sami formiraju takve martološke postrojbe za zaštitu svojeg pograničja.

Prema odlukama Obrambenog reda zemalja Unutrašnje Austrije iz 1531., uz 400 lakih konjanika na plaći, angažirano je i 300 martologa iz hrvatske i uskočke populacije tijekom dva-tri ljetna mjeseca. ${ }^{740}$ Godinu dana ranije na dva je mjeseca angažirano 400 martologa s mjesečnom plaćom od 1 rajnskog guldena i 30 krajcara. Tada se razmišljalo da se angažira $i$

\footnotetext{
${ }^{738}$ Schoen, Erhard: Heereszug der Landsknechte, Blatt_03, Zwei Führer und fünf Büchsenschützen Dostupno na http://www.zeno.org/nid/20004286340. Pristup 12.4.2019.

739 SIMONITI, Vojaška organizacija, 126, fusnota 27. O martolozima vidi Milan VASIĆ, Martolozi u jugoslovenskim zemljama pod turskom vladavinom, ANU BIH, Odjeljenje istorijsko filoloških nauka, knjiga 17 , Sarajevo, 1967.

${ }^{740}$ SIMONITI, Vojaška organizacija, 45-46. U lipnju 1559. bihaćki kapetan Georg Zoblsperg te je postrojbe u šumama i brdima nazvao ,die Scheresanne fues knecht in gepurg“. SI AS 2, DSK, kutija 202, fascikl 124, Bihać, 1v, rbr. 890. Prijepis pisma koje je Georg Zoblsperg uputio Herbartu Auerspergu.
} 
na kraljevski trošak pošalje nešto landesknechta u Senj i Bihać, ali je zaključeno da su martolozi prikladniji jer manje koštaju, poznaju putove kojima su Osmanlije provaljivali te bolje podnose glad i nevrijeme. ${ }^{741}$ I slavonski staleži su 1539. podigli 300 martologa tijekom ljeta i zime za obranu od osmanskih upada. ${ }^{742}$

Kranjski staleži uobičajeno bi podignuli nekoliko stotina (200-400 ljudi) martologa koje bi rasporedili po šumama, nepristupačnim terenima i putovima uz pograničje kojima su osmanske pljačkaše jedinice upadale na kranjski teritorij. Od sredine 16. stoljeća martologe su zamijenile uskočke postrojbe, ali je promjena više terminološke nego semantičke naravi jer se zapravo radilo o vrlo sličnom profilu pješačkih postrojbi. Uostalom, uskočko stanovništvo cijeli je promatrani period služilo u postrojbama martologa iako se čini da je do velikih uskočkih migracija 1530-ih prevladavalo hrvatsko stanovništvo.

Martolozi, a potom uskoci bili su vrlo važni za obranu Bihaća i prostora Bihaćke kapetanije. Oko Ogulina i Bihaća, pa na potezu prema rijeci Kupi, u kolovozu 1540. trebalo je tako biti stacionirano 70 martologa plaćenih iz kranjskog proračuna. Doduše, tada su ih vojne vlasti optužile da su nemarni prema svojim dužnostima jer ih se dio vratio kućama nakon što je primio plaću. ${ }^{743}$ Takvim potezom glavne su osmanske rute za upad na zapad ostale nepokrivene što je, dakako, predstavljalo veliku opasnost za hrvatski i kranjski prostor. No, ne bi trebalo generalizirati jer, iako je lako detektirati razne nepravilnosti i kritički se odnositi prema raznim aspektima krajiškog sustava pa tako i prema martološkim/uskočkim postrojbama, oni su imali važnu ulogu u obrani hrvatskoga krajišta u promatranom periodu.

Štoviše, pojedini bihaćki kapetani ranije su i zapovijedali takvim postrojbama. U prvoj polovici 1556. na hrvatskom prostoru raspoređeno je 400 „pješaka ili martologa“ kojima su zapovijedali budući bihaćki kapetani Mihael Spalatin i Georg Zoblsperg. Jedan kapetan osobno je trebao biti stacioniran prema Jesenici te prema potrebi i prema Slunju, odnosno Bihaću, dok je drugi trebao djelovati prema Brinju i Otočcu. Dvojica vojvoda ili harambaša s 80 ljudi trebali su biti stacionirani prema Bihaću i Ripču, jedan vojvoda s 40 ljudi prema Drežniku, dvojica vojvoda s 80 ljudi prema Jesenici, a trojica vojvoda sa 120 ljudi prema Brinju i Otočcu. Jedan vojvoda s 40 ljudi trebao je nadzirati prostor prema Ključu, Tržiću, Perjasici te držati straže prema Ogulinu, a jedan vojvoda s 40 ljudi nadzirati kraj od Bribira i Ledenica prema Kranjskoj. ${ }^{744}$

\footnotetext{
${ }^{741}$ SIMONITI, Vojaška organizacija, 122.

${ }^{742}$ ERCEG, Šišićeve bilješke, 428.

${ }^{743}$ LASZOWSKI, HSKHDS, knjiga III, dok. 3, 2.

${ }^{744}$ Spalatin je prvi naveden i primao je plaću od 32 te još 20 rajnskih guldena za pet konja. Zoblsperg je naveden kao kapetan te je navedeno da mu je plaća bila identična Spalatinovoj (auch souil), ali je u spisu nedvojbeno
} 
$\mathrm{Na}$ potezu od Jadranskog mora do Bihaća 1559. bilo je devet vojvoda koji su zapovijedali odredima od 32 do 38 ljudi. Tada su oko Bihaća, odnosno na prostoru Mutnika, Cazina i Ostrožca, uskočke vojvode Šobat Popović i Demeter Dančolić vodili svaki po četu od 38 vojnika. ${ }^{745}$ Uz nadziranje prostora te su postrojbe često poslane kao pojačanja u krizna žarišta, pa tako i Bihać. Kada su u svibnju 1563. Osmanlije pojačali aktivnosti oko Obrovca, Herbart Auersperg poslao je četvoricu vojvoda u Bihać, jednog u Brekovicu, dvojicu u Ostrožac, dvojicu u Cazin i jednog u Drežnik. Trojica vojvoda sa svojim su ljudima ostali na straži (peleiben an der Scart) na Primorskoj krajini. ${ }^{746}$ Nadalje, uskoci su držali i straže u okolici Bihaća, pa je tako jedan vojvoda sa svojim ljudima u lipnju 1561. stacioniran na bihaćku Otoku. ${ }^{747}$

Međutim, kao bivši osmanski podanici koji su i dalje znali održavati kontakt s osmanskom stranom na kojoj su neki još uvijek imali rodbinu i poznanike, uskoci ponekad zaista nisu uživali povjerenje krajiških zapovjednika. Tako je u kolovozu 1544. bihaćki kapetan Georg Sauer javio da je u grad sa svojim ljudima pristigao Sigmund Semenitsch, ali najvećim dijelom, kako se izrazio „samo uskocima“. Ne može se znati je li Sauer gajio opće nepovjerenje prema uskocima, ali neposredan povod ovako oštroj reakciji bila je činjenica što je jedan uskok, koji je prije osam godina uskočio iz Osmanskog Carstva, potom se sa svojom ženom, djecom i imovinom naselio u Ripču te služio pod bihaćkim kapetanima Mertom Gallom i navedenim Sauerom, dva dana ranije ponovo prebjegao u Osmansko Carstvo. Uznemiren i ogorčen kapetan se pitao treba li on takvim ljudima vjerovati?

Međutim, i druga dvojica krajiških zapovjednika, poslanih kao pojačanje u Bihać, Bartholme Raunach i Gregor Gojmerčić, također su u svojim redovima uglavnom imali uskoke pa je Sauer tražio da mu se pošalju druge postrojbe s vojnicima kojima se moglo vjerovati. Sauer je kao pojačanje u Ripač, u kojem se nalazilo tridesetak ljudi, poslao svojeg brata i Merta Galla s petnaestak ljudi. ${ }^{748}$ Iako predstavnici kranjskih staleža nisu sumnjali da će delegirani zapovjednici bilo što prepustiti slučaju, ali s obzirom na to da je prebjegli uskok

upisano 53, a ne 32 rajnskih guldena. Vjerojatno se radi o pogrešci. Zoblspergov zastavnik (fendrich) Vukmir Lulić (Vugkhmier Lullitsch) imao je plaću od 6 rajnskih guldena. SI AS 2, DSK, kutija 201, fascikl 124, 2r-3r, 1556. Lenkovićev memorijal za zasjedanje kranjskih staleža. Spis nije numeriran iako ostali jesu.

745 ŠTEFANEC, Država ili ne, 470-471.

${ }^{746}$ SI AS 2, DSK, kutija 805, fascikl 540, logor između Smrčkovića i Blagajskog Turnja, 19.5.1563, 1r-1v, Herbart Auersperg na predstavnike kranjskih staleža.

${ }^{747}$ AHAZU, Lopašić, E. Prijepisi iz austrijskih arhiva, br. 15. Mehovo, 7.6.1561., Ivan Lenković na Herbarta Auersperga.

${ }^{748}$ SI AS 2, DSK, kutija 804, fascikl 539/540, Bihać, 1.8.1544., 1r-2r. Krajem srpnja Sigmund Semenitsch poslan je u Bihać, a ostali martolozi razmješteni po krajini tako da je Raunach s 50 martologa raspoređen oko Slunja, a 50 martologa oko Jesenice. Chrainia Klisurić u Brinje, a Gregor Gojmerčić prema Ogulinu. Gojmerčić se trebao posavjetovati s bihaćkim kapetanom i krenuti tamo gdje je bilo potrebno. SI AS 2, DSK, kutija 200, fascikl 123b, Ljubljana, 24.7.1544., 1r-1v, Wolf Engelbrecht Auersperg na predstavnike kranjskih staleža.. 
bio vojnik, bojali su se izdaje pa su savjetovali da se oni koji su s njim služili u Ripču prebace u Bihać i na njihovo mjesto namjeste drugi na čelu s dvojicom iskusnih zapovjednika. ${ }^{749}$

Sauerovu sumnju u uskočke namjere dodatno je pojačao događaj s kraja kolovoza kada su u noćnim satima bihaćki vojnici u gradu na vrijeme otkrili jedan zapaljen plast sijena. Iako nije mogao saznati tko je podmetnuo vatru, Sauer je sumnjao na uskoke pa se s Raunachom posavjetovao i zaključio da bi najbolje bilo da vladar pošalje naredbu njihovu kapetanu Hannsu Werneckhu da ih pozove k sebi te da tamo ostanu do daljnje vladareve naredbe. ${ }^{750}$ Iako je ovakvih slučajeva na krajištu svakako bilo i iako je nepovjerenje prema bivšim osmanskim podanicima ponekad bilo i opravdano pa čak i zasluženo, prebjeglo stanovništvo aktivno je participiralo u protuosmanskom naporu i bilo od velike važnosti u dugogodišnjoj obrani Bihaća.

Uskoci su napokon povučeni s terena u utvrde nove ,uskočke“ Slunjske kapetanije 1578., ali su i dalje imali važnu ulogu u obrani Bihaćke kapetanije jer su utvrde Slunjske kapetanije branile zaleđe tada već reducirane Bihaćke kapetanije i osiguravale ključnu komunikaciju kojim su u grad stizala pojačanja, oprema i živež. Uskočke čete osiguravale su te opskrbne konvoje, o čemu će biti riječi dalje u tekstu.

Na krajište su slane i dodatne postrojbe koje su platiti i unovačili unutrašnjeaustrijski staleži, a prvenstveno se radilo o unajmljenim strijelcima (provisionirten schutzen). Radilo se o nekoliko stotina vojnika, unovačenih na unutrašnjeaustrijskom teritoriju i raspoređenih na unutrašnjeaustrijskom i krajiškom prostoru, koji su kao svojevrsna „interventna“ postrojba upućivani u ugrožena područja, odnosno tamo gdje je to najpotrebnije (wo die maist not sein wierdet), kao što je navedeno u jednom izvoru. ${ }^{751} \mathrm{Na}$ čelu su im stajali iskusni vojnici s dugogodišnjim vojnim stažem na krajini, a s obzirom na to da su trebali biti zamjena za spori i neučinkoviti zemaljski ustanak na unutrašnjeaustrijskom prostoru, austrijski su staleži prema određenom ključu prikupljena financijska sredstva iskoristili za financiranje nekoliko stotina mobilnijih i efikasnijih vojnika. ${ }^{752}$

\footnotetext{
749 „alt, geubt vnd verstanndig Kriegspersonnen“. SI AS 2, DSK, kutija 804, fascikl 539/540, Bihać, 4.8.1544., $2 \mathrm{r}$.

750 „,an nachten alhie in der Statt vey ainnen Schober Hey ain feuer gelegt vnd dasselb durch meine leutt befunde worden“. SI AS 2, DSK, kutija 804, fascikl 539/540, Bihać, 23.8.1544., 1r-1v.

${ }^{751}$ SI AS 2, DSK, kutija 805, fascikl 540, Prelog, 4.7.1556., 1v. Glavni zapovjednik Hrvatske i Slavonske krajine Ivan Lenković na zapovjednika Hrvatske krajine Merta Galla.

${ }^{752}$ Vasko Simoniti detaljnije opisuje podizanje te postrojbe 1561. Zainteresirani su tjedan dana ranije javnim proglasom pozivani da se pojave na određenim mjestima u određeno vrijeme. U vojnu službu mogli su biti primljeni samo „, mladi in neporočeni, vendar na hubah sedeči in tisti, ki so edni in ki imajo veselje za rešitev sladke domovine....Ti naj bodo s puško vešči in izvežbani in sposobni, tako da se bo vsak v stiski držal kot izkušen i pogumen vojak ter se bo voljan boriti proti sovražnikom in bo do njih nepopustljiv.“ Na dan muštre izabrani su kandidati popisani, naoružani i isplaćen im je predujam. Budući da se težilo što uniformiranijem
} 
Prema potrebi kranjski su staleži mogli tražili i asistenciju koruških staleža. Obično su molili da pošalju postrojba strijelaca (ain fendlein gueten Schuzen) ili da proglase zemaljski ustanak (aufbot) u slučaju veće opasnosti ili da, ako te jedinice nisu mogle biti brzo podignute, odobre određeni iznos novaca kako bi sami mogli angažirati landtsvolckh ili uskoke. ${ }^{753}$ Kada je nakon pada Krupe 1565 . zavladala velika bojazan da će Osmanlije napasti Bihać, a vojne i civilne strukture tražile više ljudi, Herbart Auersperg lamentirao je da ne zna gdje naći dodatne vojnike, osim ako Koruščani možda ne pošalju kakvu zastavu, odnosno postrojbu. ${ }^{754}$ Koruški su staleži zaista poslali svoje strijelce u Bihać u kojem su, uz kranjske unajmljene strijelce i bihaćku posadu konjanika i pješaka, činili obrambenu grupu od čak 900 ljudi. $^{755}$

Kao i uskoci, unajmljeni su strijelci također često osiguravali opskrbne konvoje prema Bihaću, a korišteni su i kao osiguranje pri obavljanju poljoprivrednih radova (žetva, sjetva) na krajini. ${ }^{756}$ Što se njihova broja na bihaćkom prostoru tiče, radilo se o nekoliko stotina ljudi, ovisno o razini opasnosti. Kada su krajem kolovoza 1553. obavještajni podaci upućivali na realnu prijetnju od osmanskog napada, kranjski su staleži u Bihać poslali Matiascha Morija sa oko 100 strijelaca, a čini se da je ta postrojba raspuštena tek u ožujku sljedeće godine. ${ }^{757}$

Mori je i početkom 1565. u Bihaću. Predvodio je 88 strijelaca koji su u grad stigli 15. veljače i tamo ostali sljedećih pet mjeseci. U lipnju je u Bihać poslano još 96 strijelaca koji su u gradu ostali mjesec i pol. ${ }^{758} \mathrm{U}$ drugoj polovici te godine u Bihać je poslana postrojba pod zapovjedništvom Christopha Premba, koja je u gradu ostala do kraja studenog. ${ }^{759}$ Mori je još sredinom 1574. s 200 strijelaca poslan u pomoć Bihaću, a uz njega su angažirani zapovjednik

izgledu, unovačenima je prema želji dodijeljeno sukno karasje za dva para hlača i kaput, a taj se iznos odbijao od godišnje provizije. Oni stacionirani na Hrvatskoj krajini plaćani su nešto više od onih koji su ostali u pozadini. SIMONITI, Vojaška organizacija, 133-137. Međutim, sprema i oprema su često bile problem u krajiškim postrojbama. Primjerice, i konjanici ponekad nisu bili u optimalnom stanju pa su među 200 konjanika, koje je Ivan Lenković 1556. otpustio iz službe, mnogi bili loše naoružani i nemarno služili tijekom njegove odsutnosti. SI AS 2, DSK, kutija 201, fascikl 124, 4.7.1556., 1r. Ivan Lenković na Merta Galla.

${ }^{753}$ SI AS 2, DSK, kutija 286, fascikl 164, Ljubljana, kraj svibnja 1574., 2r, rbr. 270. Predstavnici kranjskih staleža na koruške staleže.

${ }^{754}$ SI AS 2, DSK, kutija 209, fascikl 126, logor kod Cetina, 24.6.1565, 2v, rbr. 81. Herbart Auersperg na Ivana Lenkovića.

${ }^{755}$ SI AS 2, DSK, kutija 414, fascikl 284, Črnomelj, 24.7.1565., 1r, rbr. 1097. Glavni opskrbnik Gallenberg na predstavnike kranjskih staleža.

${ }^{756}$ SI AS 2, DSK, kutija 286, fascikl 164, Pobrežje, 27.9.1577., 1r, rbr. 350. Herbart Auersperg na predstavnike kranjskih staleža.

757 SI AS 2, DSK, kutija 229, fascikl 136, 1553., 2v; SIMONITI, Vojaška organizacija, 431-435. Početkom kolovoza prijetio je osmanski napad na grad pa je pod Adamom Langenmantlom trebalo prema Bihaću stići čak 500 strijelaca. SI AS 2, DSK, kutija 201, fascikl 124, Varaždin, 5.8.1557., 1r, rbr. 478.

${ }^{758}$ HDA, Militaria, kutija 7, 1565./1566., 14v. Iskaz financijskih izdataka Hansa Khiesla, ratnog blagajnika na Hrvatskoj krajini za 1565. i 1566. Preslike ovog opsežnog iskaza nalaze se među preslikama spisa za 1561.

${ }^{759}$ HDA, Militaria, kutija 7, 1565./1566., 15r. Iskaz financijskih izdataka Hansa Khiesla, ratnog blagajnika na Hrvatskoj krajini za 1565. i 1566. Preslike ovog opsežnog iskaza nalaze se među preslikama spisa za 1561. 
nad uskocima Jobst Joseph Thurn te dvojica uskočkih vojvoda - kapetani Semenitsch i Gusić. $^{760}$ Sredinom srpnja 1577. na Hrvatsku krajinu poslano je 200 strijelaca pod zapovjedništvom budućega bihaćkoga kapetana Daniela Obritschana. Dobro oboružani najprije su stigli u Črnomelj gdje su dvojica neimenovanih kranjskih plemića obavila muštru i isplatila im jednu mjesečnu plaću u gotovini (im barem Gellt), a zatim su se uputili na ugroženo područje tako da ih je 100 pod Obritschanovim zapovjedništvom krenulo prema Bihaću, a 100 pod zapovjedništvom njegova zamjenika (haubtmans leutenendt) prema tada također ugroženoj Hrastovici. $^{761}$

I kod ovih postrojbi učestalo se navodi problem opskrbe i neredovite isplate plaće jer su po tom pitanju kao vojnici sa strane tijekom svojeg često višemjesečnog boravka na krajini prvenstveno ovisili o krajiškim strukturama. Tako je krajem 1577. Hans Auersperg jedva uspio osigurati strijelcima u Bihaću i Hrastovici plaću za sedam tjedana jer su prijetili da tamo više ne mogu i ne žele duže služiti. ${ }^{762}$ Iako takvih primjera ima mnogo, razmjere problema privremeno stacioniranih postrojbi na krajištu izvrsno pokazuje događaj iz kolovoza 1556. kada su u Bihaću stacionirani unajmljeni strijelci (Puchsenschuzen) te stotinu uskoka pod zapovjedništvom Hansa Galla i Sigmunda Semenitscha inzistirali da im se isplati veća plaća zato što su služili izvan zemlje (Kranjske) te su čak počeli napuštati položaje i odlaziti kući navodno zbog čežnje za obitelji i početka poljoprivrednih radova. ${ }^{763}$ Od nadređenih su navedeni zapovjednici tražili instrukcije što činiti, a bihaćki kapetan govorio je o „seljacima“ (Pauern) koji žele napustiti grad radi poljoprivrednih obaveza te o stotinu uskoka (pod vojvodom Vranešom, a očito se misli na Vraneša Badovinca) koji pak Bihać namjeravaju napustiti jer su odslužili svojih dogovorenih mjesec dana. ${ }^{764}$

Iako je vrlo brzo osigurana svota od 1000 rajnskih guldena za plaće, do 12. kolovoza strijelci su napustili grad u kojem je ostalo tek nešto uskoka. Iako je Mert Gall uspio u Bihać poslati određeni broj njemačkih strijelaca koji su mu se sami ponudili, vojnim vlastima bilo je teško pronaći zamjenu za strijelce. ${ }^{765}$ Raspravljalo se o zaustavljanju i kažnjavanju seljaka (Pauern) koji su napustili svoje položaje. Osobito su kritični bili položaji na brodu (Urfar),

\footnotetext{
${ }^{760}$ SI AS 2, DSK, kutija 286, fascikl 164, kraj svibnja 1574., 1r-1v, rbr. 264-265.

${ }^{761}$ SI AS 2, DSK, kutija 286, fascikl 164, Ljubljana, 29.7.1577., 1r-1v, rbr. 362-363. Christoph Auersperg i kranjski Verordneten na zemaljskog kapetana.

762 SI AS 2, DSK, kutija 286, fascikl 164, Steničnjak, zadnji dan rujna 1577., 1v, rbr. 288. Nepotpuni i nepotpisani spis je umetnut citirani izvor. Autor je vjerojatno Hans Auersperg.

${ }^{763}$ SI AS 2, DSK, kutija 286, fascikl 164, Bihać, 4.8.1556., 1r, rbr. 391.

${ }^{764}$ SI AS 2, DSK, kutija 286, fascikl 164, Bihać 8.8.1556., 1r-2r, rbr. 214-216. Bihaćki kapetan Georg Sauer na Merta Galla.

${ }^{765}$ SI AS 2, DSK, kutija 286, fascikl 164, Črnomelj, 12.8.1556., 1r, rbr. 402. Mert Gall na predstavnike kranjskih staleža.
} 
dakle prijelazu preko rijeke Une kod Bihaća. No, i sam Gall konstatirao je da kada bi on bio kapetan u Bihaću, ni on ne bi htio u kritičnim trenucima kraj sebe imati takve nemotivirane vojnike. Gallu je naređeno da na hrvatskom prostoru i oko Metlike pronađe dobre pješake strijelce te ih pošalje u Bihać umjesto pobjeglih, što je pak bilo teško realizirati jer je Gall već unovačio pješake za posade u Zagrebu, Hrastovici i okolici te zbog zaokupiranosti započetim poljoprivrednim radovima. Ipak, nadao se da će oko Samobora moći unovačiti nešto rudara koji su tamo u velikom broju pobjegli iz Hrvatske. ${ }^{766}$

Deset godina kasnije, u proljeće 1566., u jedan sličan slučaj bio je involviran i već spomenuti ugledni krajiški zapovjednik Matiasch Mori. Naime, te je godine Mori sa stotinu strijelaca na tri mjeseca poslan u Bihać, a budući da se u svibnju te godine dogovoreni period službe približavao kraju, Mori je javio da sa svojim ljudima namjerava napustiti grad jer nije htio ostati u Bihaću ni sata više. Herbart Auersperg oštro je reagirao navevši da će to nesumnjivo pogodovati neprijatelju koji će takav potez protumačiti kao otvoreno napuštanja obrane grada. Nadalje, od nadređenih je tražio da se Moriju naredi da u Bihaću ostanu dok ne dođe zamjena njemačkih vojnika, ali da im se odmah isplati najmanje jedna mjesečna plaća. ${ }^{767}$ Morija je oštro opomenuo da ne smije zaboraviti da su ga kranjski staleži opskrbili, platili i namjestili te da je dužan služiti tamo gdje mu je naređeno, bez obzira na opasnost. ${ }^{768}$

S obzirom na profil involviranih, može se pretpostaviti da slični potezi nisu motivirani strahom, već nepovoljnim egzistencijalnim uvjetima u kojima su se nalazili. Postrojbe poput Morijeve nerijetko su upućivane u Bihać i na krajište bez toga da im se potpuno osigurao financijski trošak odlaska i boravka na ugroženom području, pa se naknadno moralo osigurati sredstva za plaće i/ili opskrba, a često ni to nije bilo dovoljno za duži boravak na isturenom pograničju. No, bez obzira na povremene probleme, bez navedenih postrojbi Bihać bi se teško toliko dugo odupirao osmanskom pritisku. Te postrojbe nisu samo sudjelovale u neposrednoj obrani grada već su, a o tome će biti riječi dalje u tekstu, i osiguravali opskrbne konvoje koji su predstavljali ,žilu kucavicu“ opstanka Bihaća i podređenih mu utvrda. Također, sve navedeno pokazuje i izraženi regionalni karakter protuosmanskog napora na hrvatskom pograničju u kojem su zajednički interes, a prema određenom ključu i doprinos, davali akteri s prostora hrvatskih i unutrašnjeaustrijskih zemalja pod vlašću Habsburgovaca. Obrana pograničja od napada moćnog Osmanskog Carstva nužno je imala regionalni predznak.

\footnotetext{
${ }^{766}$ SI AS 2, DSK, kutija 286, fascikl 164, Črnomelj, 14.8.1556., 1r, rbr. 399. Mert Gall na predstavnike kranjskih staleža.

${ }^{767}$ SI AS 2, DSK, kutija 286, fascikl 164, Črnomelj, 9.5.1566., 2r-2v. rbr. 32-33.

${ }^{768}$ SI AS 2, DSK, kutija 286, fascikl 164, Črnomelj, 10.5.1566., 1r-1v. rbr. 37-38.
} 


\section{BIHAĆKI KAPETANI I ČASNICI}

Budući da je formiranje krajiškog sustava $\mathrm{u}$ najvećoj mjeri rezultat napora unutrašnjeaustrijskih staleža, logično je da su oni zauzimali dominantne pozicije unutar krajiške strukture. Svi vrhovni zapovjednici plaćene kraljevske vojske, a kasnije i zapovjednici Hrvatske i Slavonske krajine, uz relativnu iznimku Nikole Jurišića, koji je bio hrvatskog porijekla i istodobno kranjski plemić, bili su pripadnici unutrašnjeaustrijske elite. ${ }^{769}$ Iako su hrvatsko-slavonski staleži prigovarali zbog postavljanja „stranaca“ na glavne pozicije u krajiškom sustavu, logika iza tih postupaka bila je jednostavna. Naime, središnja vlast i unutrašnjeaustrijski staleži organizirali su i financirali krajiški obrambeni sustav nad kojim su Željeli imati što čvršću kontrolu.

Kada je riječ o zapovjednoj strukturi Bihaćke kapetanije, i ovdje su u promatranom periodu svi kapetani, s iznimkom Petra Keglevića sredinom i u drugoj polovici 1530-ih te možda Mihaela Spalatina ${ }^{770}$ u prvoj polovini 1560-ih, bili ugledni plemići s prostora Unutrašnje Austrije, i to primarno s područja Kranjske. Ranije je spomenuto da je u srpnju 1527. Nikola Jurišić, kao jednu od mjera obrane grada, predložio kralju da se za kapetana nad gradom i kaštelom imenuje sposoban plemić iz zemalja Njegovog Veličanstva koji bi zapovijedao Bišćanima i „drugima“ (das er dasselbs denen von Wichitsch und anderer das recht besitz). ${ }^{771}$

Izbor bihaćkoga kapetana predstavljao je vrlo važno pitanje te je nadvojvoda Karlo prilikom rasprava o namještanju novoga kapetana 1573. ustvrdio da je cijela stvar previše važna da bi je sam rješavao. ${ }^{772}$ Pitanje izbora bihaćkog kapetana zaista je jedno od ključnih pitanja cijeloga krajiškog sustava u promatranom periodu. Unutrašnjeaustrijski staleži polagali su svoje pravo na predlaganje kandidata za izbor krajiških zapovjednika općenito, pa tako i bihaćkoga kapetana, na temelju sporazuma o opsežnim obrambenim mjerama koje su postigli s carem Maksimilijanom, a radi se o tzv. Augsburškoj libeli iz 1510. te Insbruškoj libeli iz 1518. koje su udarile temelj obrambenoj organizaciji unutrašnjeaustrijskog prostora.

\footnotetext{
769 ŠTEFANEC, Država ili ne, 199.

770 Nisam pronašao biografske podatke o Mihaelu Spalatinu, ali Lopašić navodi da je riječ o članu splitske patricijske obitelji Alberti. LOPAŠIĆ, SHK, knjiga III, 466;469.

${ }_{771}$ THALLÓCZY, HODINKA, A horvát véghelyek, dok. DXLIV, 693.

772 SI AS 2, DSK, kutija 244, fascikl 143, Beč, 27.2.1573., 1r, rbr. 290.
} 
Osnovna je intencija bila zaštita od Osmanlija (ali i Mlečana i drugih oponenata) na samome unutrašnjeaustrijskom, a potom i hrvatsko-slavonskom prostoru. ${ }^{773}$

Prema uvriježenoj izbornoj proceduri kranjski bi staleži nakon održane interne rasprave predložili nadvojvodi i caru nekoliko prikladnih kandidata između kojih se birao novi kapetan. ${ }^{774}$ Primjerice, prilikom navedenog izbora 1573. nadvojvoda je izdao naredbu prema kojoj su se na savjetovanju morali okupiti svi plemići u krugu od četiri njemačke milje oko Ljubljane zajedno s njim, njegovim savjetnikom i zapovjednikom nad uskocima Jobstom Josephom Thurnom koji je tada mijenjao glavnog zapovjednika Hrvatske krajine. ${ }^{775}$ Okupljeni staleži naveli bi tada nekoliko prikladnih kandidata za tu poziciju, a ako nitko od predloženih kranjskih plemića nije htio preuzeti kapetaniju, zamolili bi štajerske i koruške staleže da oni predlože nekoliko sposobnih i iskusnih plemića. Ako i ta mjera ne bi urodila plodom, u obzir bi došlo angažiranje sposobnog i iskusnog ,stranca“ koji je naravno morao biti provjeren i iskusan vojnik te dobro upoznat s okolnostima na krajini. ${ }^{776}$ Nadvojvoda Karlo predložio je 1573. za kandidate „strance“ riječkoga kapetana Paula Sara i već spomenutog Mihaela Spalatina. ${ }^{777}$ Taj izborni proces do 1573. bio je već toliko formaliziran da su kranjski staleži naveli da se povode ,allten gebrauch vnd herkhomen nach““ ${ }^{778}$

No, čini se da je do 1590-ih postojala tendencija da se načini odmak od takve izborne procedure. Kada je u ožujku 1592. trebalo pronaći zamjenu za kapetana Obritschana, kranjski staleži poslali su nadvojvodi Ernestu dopis u kojem su molili da se poštuju ,prastari“ običaji i procedure. Naime, kranjske je staleže brinula činjenica da je već neko vrijeme postojao stav (ali ne preciziraju u kojim krugovima) da ova dugogodišnja procedura više nije potrebna, odnosno da nije nužno da staleži predlažu svoje kandidate te da bi trebalo biti dopušteno birati i ,strance“ na tu poziciju. Štoviše, čini se da se to i događalo jer se staleži žale da su kapetani

\footnotetext{
${ }^{773}$ SI AS 2, DSK, kutija 244, fascikl 143, Ljubljana, 10.3.1592., 2v-3r, rbr. 539-540. Kranjski staleži na nadvojvodu Ernesta. Za odluke Obrambenog reda vidi SIMONITI, Vojaška organizacija, 38-41. Na međudržavnom saboru Štajarske, Koruške i Kranjske 1530. imenovan je prvi vrhovni zapovjednik unutrašnjeaustrijskih postrojbi. Bio je to Hans Katzianer kojem su priključeni savjetnici iz svake zemlje, vojni blagajnik, a godinu dana kasnije i opskrbnik. Ta je struktura upravljala obranom na hrvatsko-slavonskom prostoru. IBID., 49. O raznim prijedlozima i varijantama obrambenih redova raspravljano je tijekom desetljeća, sve dok zajednički obrambeni red zemalja Unutrašnje Austrije, koji je predložio Lazarus Schwendy, nije usuglašen na zajedničkom saboru 1575. ŠTEFANEC, Država ili ne, 312-313.

${ }^{774}$ SI AS 2, DSK, kutija 244, fascikl 143, Beč, 10.3.1573., 1r-2r, rbr. 300-302. Car Maksimilijan na predstavnike kranjskih staleža.

${ }^{775}$ SI AS 2, DSK, kutija 244, fascikl 143, Beč, 27.2.1573., 1v-2r rbr. 291-292.

${ }^{776}$ SI AS 2, DSK, kutija 244, fascikl 143, Ljubljana, 29.11.1576., 1r-1v, rbr. 333-334.

${ }^{777}$ SI AS 2, DSK, kutija 244, fascikl 143, Beč, 27.2.1573., 1v-2r rbr. 291-292.

${ }^{778}$ SI AS 2, DSK, kutija 244, fascikl 143, Ljubljana, 10.3.1573., 2r-2v, rbr. 298-299. Predstavnici kranjskih staleža na nadvojvodu Karla.
} 
de facto imenovani i prije nego što oni pošalju svoje prijedloge. ${ }^{779}$ Uobičajenu izbornu proceduru za izbor bihaćkoga kapetana poštivali su i provodili svi vladari i nadvojvode, nastavljali su staleži, a osobito nedavno preminuli nadvojvoda Karlo koji se procedure čvrsto držao, uz iznimku imenovanja senjskoga kapetana $1585 .{ }^{780}$ Kranjski su staleži na kraju molili da se prastari običaju poštuju te da prednost pred strancima, koji bi pak svoju osobnu korist mogli staviti ispred općeg dobra, trebaju imati oni koji su prvi ugroženi, oni koji imaju neposredni interes te oni čije obitelji, imovina i posjedi ovise o izboru. Staleži su se žalili da bi stranci mogli stremiti gomilanju dobara i novca, a zatim napustiti zemlju. ${ }^{781}$ Međutim, pitanje procedure izbora bihaćkoga kapetana ubrzo je postalo bespredmetno jer je svega tri mjeseca kasnije grad pao u osmanske ruke.

Procedura izbora kapetana odnosno krajiških zapovjednika na hrvatskom pograničju pokazuje i svu kompleksnost formiranja krajiškog sustava zato što se sporazumi i dogovori između unutrašnjeaustrijskih staleža, u ovom slučaju kranjskih staleža i Cara, interpoliraju na hrvatski prostor koji, dakako, nije dio Svetog Rimskog Carstva Njemačke Narodnosti, ali je s njime povezan preko krune Sv. Stjepana i vladarske kuće te zajedničkom borbom protiv Osmanlija. Iako namješten izvan granica Unutrašnje Austrije odnosno Carstva, bihaćki kapetan svoju odanost duguje staležima, nadvojvodi i caru, a to pak transformira tradicionalne odnose moći u samom gradu i na hrvatskom prostoru generalno. Njihova pozicija jasno se očituje u načinu na koji se oni sami tituliraju ili kako ih drugi tituliraju, pa tako Sebastian Lamberg navodi da je ,,vaše presvjetlosti nadvjovode Karla od Austrije, kapetan najisturenije pogranične krajiške utvrde Bihaća““ 782

Kapetana je postavljao i potvrđivao kralj, odnosno car, a najkasnije od 1540-ih stalno su izdavana posebna pisma postavljenja (Bestallungsbrief) u kojima su navedene njihove obaveze i primanja. Kapetan Mert Gall tražio je tako 1540. da mu se uz pismo postavljenja pošalju i instrukcije, kao što je to bio slučaj sa senjskim kapetanom. ${ }^{783}$ Nažalost, u istraženome arhivskom gradivu nisam pronašao pismo postavljenja s precizno navedenim dužnostima i obavezama bihaćkoga kapetana. Međutim, sačuvana pisma postavljanja za

\footnotetext{
779 SI AS 2, DSK, kutija 244, fascikl 143, 10.3.1592., 4r-4v, rbr. 542-543. Predstavnici kranjskih staleža na nadvojvodu Ernesta.

${ }^{780}$ „ir. DHl. Erczherzogen Carlss zu Osterreich haubtman auf den eussersten graniz-hauss Wihitsch“. SI AS 2 , DSK, kutija 244, fascikl 143, Ljubljana, 10.3.1592., 3r, rbr. 540. Kranjski staleži na nadvojvodu Ernesta.

${ }^{781}$ SI AS 2, DSK, kutija 244, fascikl 143, 5r, rbr. 544.

${ }^{782}$ LOPAS̆IĆ, SHK, knjiga I, dok. LIV, 90. Sredinom 16. stoljeća Gašpar Kopastović („sluga ponizan Milosti vaše“, odnosno vojnik u službu kapetana Georga Sauera) naslovljava svoje glagoljicom pisano izvješće o kretanjima osmanske vojske „Izibranom i plemenitom vsem visoko počtovanom knezu Jurju Zavraru, kapitanu kraljevske s(vetlosti) u Bihću, bratu i prijatelju našemu“. BOJNIČIĆ, Izvješća, dok. VII, 64.

${ }^{783}$ LASZOWSKI, HSKHDS, knjiga II, dok. 493, 489.
} 
senjske kapetane, mogu poslužiti kao ogledni primjer jer su ti dokumenti bili poprilično formalizirani i ujednačeni. Senjski kapetan imao je zapovjedništvo nad utvrdama i posadama te onim vojnicima koji će u te utvrde u slučaju potrebe biti poslani. Podređen je bio caru odnosno kranjskom zemaljskom kapetanu i zemaljskom upravitelju, kao predstavnicima kranjskih staleža, te kranjskom vicedomu, kao vladarevom namjesniku u Kranjskoj. ${ }^{784} \mathrm{U}$ slučaju prigovora i sporova obraćao se navedenoj trojici, a zatim i caru. Morao je držati uredne i redovite danonoćne straže te paziti i na vrijeme reagirati na osmanske upade, namjere i spletke (practirn), a imao je pravo prema potrebi raspoređivati vojnike u potencijalno ugrožene utvrde. U slučaju neposluha posade i nasilja prema „podložnicima“ imao ih je pravo kažnjavati te otpuštati iz službe. Također, morao je uredno i redovito popisivati i okupljati (muštrati) vojnike prilikom isplate plaća te se brinuti o gradnji i održavanju obrambenih objekata (zidina, kula) i slično. ${ }^{785} \mathrm{Uz}$ pisma postavljenja car je senjskim vojnicima poslao i tzv. Gehorsambrief, odnosno pismo pokornosti kojim je tražio da se pokoravaju novopostavljenom kapetanu. ${ }^{786}$ Kraljica Ana poslala je sredinom srpnja 1540. jedno takvo pismo bihaćkoj gradskoj općini (iudici, consulibus ac communitati ciuitas Wyhitsch) u kojem traži da se pokoravaju novom kapetanu Mertu Gallu koji je imao ingerencije nad kaštelom i cijelim gradom zajedno s pripadnostima. ${ }^{787}$

Također, barem u ranijem periodu, kapetan je imao ovlasti pregovora s lokalnim osmanskim zapovjednicima pa je tako kapetan Gall 1540. imao slobodne ruke za dogovor o lokalnom primirju i smirivanju sukoba s udbinskim zapovjednikom (haubtmann). Predstavnici austrijskih staleža smatrali su da je uzrok osmanskih upada četovanje „vlasnika“ krajiških utvrda zbog čega mu je car naredio da održava red i ne dozvoljava upade na neprijateljski teritorij. ${ }^{788}$

Bihaćki kapetan je morao biti iskusan vojnik i ugledan pojedinac čije se iskustvo i mišljenje uzimalo u obzir na najvišim razinama. ${ }^{789}$ Prema potrebi i mogućnostima sudjelovao je i na savjetovanjima o uređenju krajine. No, pritisnuti ratnim opasnostima i upravnim obvezama, kapetani nisu uvijek mogli osobno participirati na savjetovanjima u pozadini. To pokazuje slučaj iz studenog 1577. kada je Sebastian Lamberg namjeravao otputovati na staleško okupljanje u Ljubljanu, ali to nije mogao jer su Osmanlije izvršili prepad na bihaćke

\footnotetext{
${ }^{784}$ ÖeStA, Hofkammerarchiv, Gedenkbücher (dalje HKA, GB), sv. 72, fol. 235v-236v.

${ }^{785}$ KLAUŽER, Ustrojstvo i organizacija, 62.

${ }^{786}$ ÖeStA, HKA, GB, sv. 72, fol. 236v.

${ }^{787}$ LASZOWSKI, HSKHDS, knjiga II, dok. 501, 498.

${ }^{788}$ SI AS 2, DSK, kutija 193, fascikl 119/120, Bihać, 24.5.1540., 3v-4r, rbr. 272. Predstavnici kranjskih staleža i vicedom na Merta Galla.

${ }^{789}$ SI AS 2, DSK, kutija 244, fascikl 143, Ljubljana, 29.11.1576., 1r, rbr. 333.
} 
„stanovnike, građane i vojnike“ koji su kod Mača prikupljali sijeno te zarobili šestero ljudi i jednom odsjekli glavu. Lamberg je tada odustao od odlaska u Ljubljanu jer se bojao da Osmanlije znaju da svaki čas planira otputovati te da budno prate svaki njegov korak. ${ }^{790}$ Predstavnici kranjskih staleža tješili su ga početkom prosinca da izdrži i pričeka odluke savjetovanja. $^{791}$

Djelovanje na isturenom krajištu podrazumijevalo je poštivanje specifičnih krajiških pravila ponašanja, etikete i običaja formiranih u procesima dugotrajnih pograničnih sukoba i utemeljenih na konceptima ratništva, časti i hrabrosti. Zanemarivanje krajiških obrazaca ponašanja moglo je negativno utjecati na percepciju kapetana u očima njemu podređenoga domaćeg, ali i neprijateljskoga pograničnog stanovništva. Jedan od aspekta krajiškog etosa bili su i dvoboji odnosno megdani koji su izazivali veliku pažnju krajiškog svijeta. Krajem srpnja 1565. neimenovani brat pod Bihaćem ustrijeljenog Hassinan vojvode pred ripačkom je utvrdom ostavio pismo kojim je izazvao bihaćkoga kapetana Kronschalla na dvoboj. Smatrao je da mu je brat „protivno vjeri i nečasno“ ubijen te je pozvao kapetana da izađe izvan zidina na dvoboj ukoliko nije ,žena“ (khain Weib sey). Kapetan mu je pismeno odgovorio da će doći. ${ }^{792}$ Ipak, nije poznato je li do dvoboja zaista i došlo.

Kapetanu su bili podređeni sva vojska i zapovjednici utvrda u sastavu Bihaćke kapetanije. Kada je u studenom 1587. prilikom muštre u Drežniku umjesto vojvode Ivana Volovića (Iuan Vollouitsch) novim vojvodom imenovan Andrijaš Jurašić (Anndriaschen Juraschitsch), vojni povjerenik Jobst Langenmantel ozbiljno (ernstlicher) mu je naredio da mora biti pokoran sadašnjem i budućim bihaćkim kapetanima i nadvojvodi te da se mora ponašati na način koji pristoji časnom vojniku. Tada je u Izačiću odstupio vojvoda Juraj Kučenić (Juray Khutschenitch) i na njegovo je mjesto imenovan vojvoda Hans Rössl. ${ }^{793}$ Čini se da je barem od kraja 1580-ih bihaćki kapetan imao pravo birati ili barem predlagati svoje

\footnotetext{
${ }^{790}$ SI AS 2, DSK, kutija 244, fascikl 143, Bihać, 26.11.1577., 1r, rbr. 302 Sebastian Lamberg na kranjske Verordneten.

${ }^{791}$ SI AS 2, DSK, kutija 244, fascikl 143, Ljubljana, 4.12.1577., 1v, rbr. 30. Predstavnici kranjskih staleža na Sebastiana Lamberga. U srpnju 1577., prije održavanja velikog savjetovanja u Beču, nadvojvoda Ernest tješio je Sebastiana Lamberga i opominjao ga da obranu uredi najbolje što može i pričeka odluke savjetovanja. SI AS 2, DSK, kutija 244, fascikl 143, Beč, 15.7.1577., 1r-1v, rbr. 378-379.

792 „vber thrauen vnnd glauben vnnd nit Erlich vnnd Redlich vmbkhomen“. HDA, Militaria, kutija 8, „na pohodu“, 28.7.1565., 1r-1v. Herbart Auersperg na Ivana Lenkovića. O problemu nasilja i dvoboja na krajištu vidi: ŠTEFANEC, Institutional Control of Violence: Imperial Peace and Local Wars on the Slavonian Border in the 16th Century, u: Frieden und Konfliktmanagemenet in interkulturellen Räumen. Das Osmanische Reich und die Habsburgermonarchie in der Frühen Neuzeit, ur. Arno Strohmeyer, Norbert Spannenberger, Robert Pech, Franz Steiner Verlag, Leipzig, 2013., 63-83.

${ }^{793}$ LOPAŠIĆC, SHK, knjiga I, dok. CII, 150.
} 
zamjenike i podređene časnike jer je u studenom 1589. kapetan Dornberg trebao sam „potražiti“ poručnika. ${ }^{794}$ Naravno, nadređeni su taj izbor morali sankcionirati.

Kapetani generalno pa tako i bihaćki imali su pravo raspolagati prihodima i dohodcima gradova i utvrda kojima su zapovijedali, a ta su sredstva korištena za uzdržavanje posada. To je podrazumijevalo i ingerencije nad stanovništvom podložnim gradovima i utvrdama, kao što pokazuje već spomenuti slučaj iz 1531. kada je nakon smrti Ivana Karlovića između kralja Ferdinanda i Nikole Zrinskog došlo do sukoba oko posjedovanja grada Krupe. Vladar je opominjao Zrinskog da „ne svojata grad Krupu i ne pravi neprilike podanicima grada Krupe, jer su oni u njegovo ime podređeni njegovom bihaćkom kapetanu, a sam je grad, zbog njegove posebne obrambene važnosti, on uzeo pod svoju zaštitu“ ${ }^{795} \mathrm{U}$ popisu prihoda vlastelinstva Sokol iz 1548. te cazinske desetine navodi se da sela Omršal i Suče te 13 osoba u selu Turija spadaju pod Bihaćku kapetaniju, a kapetan je imao u zakupu desetinu topuskog opata na području cijelog posjeda utvrde Sokol, o čemu će biti riječ dalje u tekstu. ${ }^{796}$ Kako su ti posjedi bivali sve opustošeniji, tako je opskrba pa konzekventno i obrana grada bila još kompliciranija.

Najveći problem Bihaća predstavljao je nezavidan položaj u kojem se taj grad našao isturen duboko na pograničju te izložen permanentnoj osmanskoj prijetnji i raznim egzistencijalnim nedaćama $u$ pauperziranom i sve više depopulariziranom okruženju. U takvom je kontekstu obnašati dužnost bihaćkog kapetana predstavljalo veliku odgovornost, ali i veliko opterećenje. Zato ne iznenađuje činjenica da dio kandidata nije htio preuzeti tu dužnost dok je kod drugih trebalo mnogo truda i pregovora kako bi ih se nagovorilo na to. Naravno, pregovori o uvjetima službe vjerojatno su (dijelom) motivirani i nastojanjem da se izvuče što veća osobna korist, ali s obzirom na ambijent u kojem su trebali djelovati, nije iznenađujuće da su novi zapovjednici željeli osigurati što bolje uvijete za obnašanje vojne službe. Uostalom, obnašati dužnost bihaćkoga kapetana značilo je i u određenoj mjeri zanemariti svoje privatne obaveze i obiteljska imanja. Sebastian Lamberg je tako krajem veljače 1575. pisao da neće ostati duže od početka sljedećega studenog na mjestu kapetana. Naveo je uobičajene probleme, a to su loša opskrba, loše građevinsko stanje i mali broj vojnika, ali i činjenicu da mu u odsustvu propada obiteljsko gospodarstvo koje mora voditi njegova bolesna supruga. Dodao je i da mora misliti na petero male neobrazovane djece (vnerzognen Khinderlein). Sve mu to stvara više štete nego što ima koristi iz službe, a prošle

\footnotetext{
${ }^{794}$ HDA, Croatica, mikrofilm D-1918, br. 1, studeni 1589.

${ }^{795}$ KRUHEK, Krajiške utvrde, 89; LASZOWSKI, HSKHDS, knjiga II, dok. 106, 89.

796 ÖeStA, HKR, Hoffinanz in Ungarn, kutija 5, Rote nr 2 fol. 126-135.
} 
godine preminuo mu je brat Gabriel pa sada mora brinuti i o bratovoj maloj i neobrazovanoj djeci. Lamberg je obećao, kao vjerni vojnik, do navedenog datuma ostati u službi, ali je molio da se pronađe novi kapetan. ${ }^{797}$ Sebastian Lamberg lamentirao je i u rujnu 1581., u svom drugom mandatu na mjestu kapetana, da godinama već služi u „ovoj jadnoj, krajnje ugroženoj, od neprijatelja okruženoj i gotovo napuštenoj utvrdi Bihaću“ zbog čega se ne može istodobno posvetiti privatnim poslovima koji su zbog toga jako stradali. ${ }^{798}$

Dodatnu kontroverzu u nesređenim krajiškim prilikama izazvala je je potencijalna kaznena odgovornost zapovjednika za izgubljene utvrde. Na prostoru Ugarskoga Kraljevstva već je 1513. donesena zakonska odredba prema kojoj su kapetani pograničnih utvrda i gradova strogo odgovorni za njihovu obranu. ${ }^{799}$ Pitanje kaznene odgovornosti za gubitak utvrda posebno je došlo do izražaja u zadnjem kvartalu 16. stoljeća kada je intenziviran proces kontrole nad plaćenom vojskom na krajini. U najekstremnijim slučajevima moglo je doći do egzekucija odgovornih časnika. Dakle, i bihaćki kapetan je mogao biti pozvan na odgovornost zbog gubitka pojedine utvrde, a to je posebno dolazilo do izražaja u periodu kada je kapetanija brojala preko dvadeset utvrda, odnosno prilikom velikih osmanskih osvajanja na unskom prostoru 1570-ih. Bihaćkim kapetanima zasigurno nije bilo svejedno promatrati takve gubitke koji su za njih mogli imati nepovoljan sudski epilog .

Tako je prilikom dolaska krajiških povjerenika u Bihać krajem 1577. Sebastian Lamberg protestirao da se on neće smatrati odgovornim ako Osmanlije osvoje jednu ili više ovdašnjih utvrda jer se ništa dogovoreno nije do sada realiziralo. ${ }^{800}$ Par tjedana kasnije Lamberg se pak žalio da kaštelani/porkulabi nemarno služe iako im to nije mogao ni zamjeriti s obzirom na probleme s kojima se susreću, a on im nije mogao pomoći jer je bio preopterećen brigom za Bihać. Štoviše, naveo je da je više puta ekstenzivno pisao te protestirao da mu je zapovjedništvo nad tolikim brojem utvrda preopterećenje, ali nije dobio nikakav odgovor. ${ }^{801}$

Zbog manjkavosti krajiškog sustava, kapetani ili upravitelji kapetanije ponekad su bili prepušteni sami sebi kao što se zbilo krajem lipnja 1543. kada su Osmanlije provalili na Radotinu i Gradac, posjede u vlasništvu grofa Slunjskog, te odveli oko 200 ljudi i 3000

\footnotetext{
797 SI AS 2, DSK, kutija 419, fascikl 187, Bihać, 23.2.1575., 1r-1v, rbr. 59-60. Sebastian Lamberg na kranjske Verodneten.

${ }^{798}$ SI AS 2, DSK, kutija 244, fascikl 143, Bihać, 12.9.1581., 1r-1v, rbr. 512. Sebastian Lamberg na kranjske Verordneten.

${ }^{799}$ BOTICA, Krbavski knezovi, 285.

${ }^{800}$ SI AS 2, DSK, kutija 205, fascikl 125, Bihać, 8.11.1577., 1v.

${ }^{801}$ SI AS 2, DSK, kutija 286, fascikl 164, Bihać, 26.11.1577., 2r, rbr. 304. Sebastian Lamberg na kranjske Verordneten.
} 
komada krupne stoke. Kada su tadašnjem upravitelju kapetanije Mertu Gallu stigli stražari s obavijestima o napadu, odmah je javio banu i grofu Slunjskom te ispalio pucnje upozorenja, ali nitko nije htio doći. Usprkos tome, Gall je poslao svoje konjanike za Osmanlijama, ali opet mu se nitko nije priključio pa je potjera završila tek pogibijom uglednoga hrvatskog vojnika Ivana Hrelje (Hann $\beta$ Hrella). ${ }^{802}$

Što se primanja bihaćkoga kapetana tiče, on je bio jedan od najbolje plaćenih zapovjednika na krajištu. Erasmo Thurn je kao obrister an den Khrabatischen orthflekhen, dakle kao zapovjednik Senja i Bihaća, 1537. mjesečno primao visokih 264 rajnskih guldena. ${ }^{803}$ Međutim, plaća bihaćkoga kapetana bila je dakako niža. Lopašić navodi da je odlukom kraljice Ane početkom 1540-ih bihaćki kapetan trebao imati istu plaću kao i njegov senjski pandan - 500 rajnskih guldena, odnosno 41 rajnski gulden godišnje. ${ }^{804} \mathrm{U}$ popisu vojnika bihaćke kapetanije iz 1540. nije navedena plaća kapetana već samo trošak od 18 rajnskih guldena za šest konja koje je držao uz sebe. ${ }^{805}$ Kapetan Georg Sauer zaista je 1545. primao mjesečni iznos od 40 rajnskih guldena, ali je s tim iznosom uzdržavao i svojih deset konjanika. ${ }^{806}$ Četiri godine kasnije (1549.) Sauer mjesečno zarađuje 81 rajnski gulden. ${ }^{807}$ No, popis iz 1551. otkriva da je Sauer primao 41 rajnski gulden mjesečne plaće i još 32 rajnska guldena mjesečno za svojih osam konjanika. ${ }^{808}$ Adrian Gall je kao „upravitelj“ kapetanije (verwalter der haubtmanschaft) imao plaću od 16 rajnskih guldena za sebe i jednog konjanika. ${ }^{809}$ Krajiško povjerenstvo krajem 1563. predložilo je za kapetana Georga Kronschalla mjesečnu plaću od visokih 100 rajnskih guldena. ${ }^{810}$ Do ožujka 1579 . mjesečna plaća bihaćkoga kapetana skočila je već na visokih 140 rajnskih guldena, s tim da je u tu svotu ulazio i trošak njegovih osedlanih konja. ${ }^{811}$ Prema vojnom proračunu iz 1582., kapetan je za sebe i osedlane konje mjesečno primao 148 rajnskih guldena. ${ }^{812}$ Identično je bilo 1586. i 1589. ${ }^{813}$ Dakle, radilo se o visokim svotama koje su tijekom stoljeća rasle. Doduše, ne zna se koliko su osedlanih konja kapetani imali pod sobom, pa je za sada teško procijeniti jesu li viši

\footnotetext{
${ }^{802}$ HDA, Militaria, kutija 2, 1543., str. 113.

${ }^{803}$ LOPAŠIĆ, SHK, knjiga III, dodaci, dok. III, 390.

${ }^{804}$ LOPAŠIĆ, Bihać, 63.

${ }^{805}$ LOPAS̆IĆ, SHK, knjiga III, dok. V, 395.

${ }^{806}$ IBID., dok. III, 391.

${ }^{807}$ IBID.

${ }^{808}$ LOPAŠIĆ, Bihać, dok. IX, 242.

${ }^{809}$ IBID., dok. X, 411.

${ }^{810}$ KRUHEK, Krajiške utvrde, 212.

${ }^{811}$ LOPAŠIĆ, SHK, knjiga I, dok. XLIII, 78.

${ }^{812}$ SI AS 2, DSK, kutija 230, fascikl 136, 1582., 6v.

${ }^{813}$ SI AS 2, DSK, kutija 230, fascikl 136, 1586., 11v.; IBID., 1589., 12r.
} 
iznosi posljedica povećanja plaće ili broja konjanika koje su uz sebe držali. Vjerojatno oboje. No, bihaćki kapetan bio je nesumnjivo dobro plaćen.

Nadalje, uvijek je postojala mogućnost zarade kroz ratnu ekonomiju kao što su udio u plijenu, otkup zarobljenika, trgovina otetom stokom itd. Znamo da je zarobljenika, barem u nekim periodima, u Bihaću bilo mnogo. Tako su se 1494. godine iz zarobljeništva u Bihaću i Ripču otkupljivali Osmanlije koji su potjecali čak s prostora današnje Grčke. ${ }^{814}$ Kapetan Georg Zoblsperg piše pak početkom svibnja 1558. da „ima mnogo zarobljenika u kaštelu“. 815 Kapetan je imao pravo na dio ratnog plijena, a njegovi podređeni vojnici nisu smjeli dijeliti ili prodavati opljačkano bez njegova pristanka. ${ }^{816} \mathrm{Na}$ zarobljenicima se uvijek moglo lijepo zaraditi.

Iako su visokopozicionirani pojedinci kroz krajišku službu direktno i indirektno mogli akumulirati respektabilne prihode često su zbog mnogobrojnih nedostataka nastajućega krajiškog sustava bili prisiljeni trošiti i vlastita financijska sredstva ili prihode sa svojih posjeda da bi njima podređeni segment sustava zaista i funkcionirao. Takve „vatrogasne“ mjere bile su učestale. Tako je krajem srpnja 1556. Georg Sauer s teškom mukom u Ripač uputio 15 hrvatskih vojnika te 12 njemačkih vojnika iz rudnika!, s tim da je posljednje platio iz vlastita džepa. ${ }^{817}$ Upravitelj bihaćke kapetanije Paul Scheyer morao je pak u proljeće 1573. po nepovoljnoj cijeni prodati neke svinje koje je u Bihać kao otkup dopremio zarobljenik njegova šogora (schwager), a koje je Scheyer namjeravao poslati „van“ (hinauss - dakle, u unutrašnjost) i to da bi gladnim i neisplaćenim njemačkim vojnicima mogao doznačiti 30 krajcara po osobi. ${ }^{818}$ Sebastian Lamberg je krajem studenog 1574. njemačkim vojnicima bio prisiljen dati na dug svoje vlastite žitarice, pa je i sam pretrpio štetu. Nakon što je podijelio sve žitarice, založio je građanima srebrno posuđe koje je pripadalo zamjeniku opskrbnika, ali nije mogao dobiti više od pola kvarte živeži po vojniku. ${ }^{819}$

Ponekad su se kapetanima od plaće nastojala odbiti i tuđa dugovanja. Georg Feuer je prilikom muštre u Bihaću sredinom 1586. dobio nalog da s kapetanom Hörnerom porazgovara da se dug od 207 rajnskih guldena i 26 krajcara, koji je ostao iza bvišeg feldschreibera u

\footnotetext{
814 Árpád NÓGRÁDY, A list of ransom for Ottoman Captives imprisioned in Croatian castles (1492.), u: Ransom Slavery Along the Ottoman Borders (Early Fifteenth-Early Eighteenth Centuries), ur. Geza David i Pál Fodor, Brill, 2007., 28-29.

${ }^{815}$ „,hab ich vill gefangen Inn Schlo $\beta^{\prime}$. SI AS 2, DSK, kutija 201, fascikl 124, Bihać, 5.5.1558., 2v, rbr. 740. Georg Zoblsperg na zapovjednika Hrvatske krajine Georga Sauera.

816 ŠTEFANEC, Država ili ne, 208.

${ }^{817}$ SI AS 2, DSK, kutija 201, fascikl 124, Bihać, 28.7.1556., 1r, rbr. 186. Kapetan Georg Sauer na Merta Galla.

${ }^{818}$ SI AS 2, DSK, kutija 286, fascikl 164, Bihać, 17.4.1573., 1r-1v, rbr. 155-156.

${ }^{819}$ SI AS 2, DSK, kutija 286, fascikl 164, Bihać, 16.11.1574., 1r-1v, rbr. 234-235. Sebastian Lamberg na kranjske Verordneten.
} 
Bihaću Andreasa Schnebergera, naplati od kapetanove plaće, ali je Hörner žestoko prigovarao da neće plaćati ni Schnebergerove ni bilo čije dugove. ${ }^{820}$ Čini se da ta namjera nije provedena, a nije ni navedeno zašto bi kapetan morao podmiriti taj dug - je li na neki način bio (su)odgovoran ili po logici zapovjedne odgovornosti.

Nema osobito mnogo podataka o privatnom životu kapetana i viših zapovjednika $u$ gradu. Doduše, zna se da su kapetanove odaje bile u kaštelu, u kuli „prema vodi“, koju Lenović 1550. naziva ,haubtmans thurn vnd zimer“. ${ }^{821}$ Kapetana Hansa Scharffa, o kojem je inače sačuvano/pronađeno vrlo malo izvora, kritizirao je u listopadu 1561. vladar jer se pričalo da otvoreno živio s „Turkinjom“ ${ }^{822}$ Naravno, upitno je što se podrazumijevalo pod „Turkinjom“ jer nije jasno je li riječ o osobi muslimanske vjeroispovijesti ili „,tek“ o osobi s osmanskog teritorija, no na krajištu takve bračne/intimne kombinacije nisu bile nepoznate.

Unatoč svemu, bihaćki zapovjednici uglavnom su odgovorno izvršavali svoje dužnosti i izrazi da „će se boriti do zadnjeg čovjeka i vlastita groba“ najčešće nisu bili samo pitanje diskursa ili kršćanskog patosa. ${ }^{823}$

\subsection{Kronološki prikaz bihaćkih kapetana}

U sljedećem poglavlju kronološki prikazati ću redoslijed bihaćkih kapetana. Potrebno je napomenuti da je ova cjelina bazirana na pronađenim izvorima koji nisu jednako informativni za sve bihaćke kapetane. Štoviše, za neke od njih gotovo da i nisam pronašao nikakve izvore, pa će u budućnosti biti potrebno dopuniti istraživanje. Postoje i neke diskrepancije između rezultata mojeg istraživanja i Lopašićeva popisa kapetana. U prilogu ovom poglavlju donosim kronološki popis kapetana i upravitelja kapetanije sa svojim i Lopašićevim podacima. Budući da su razni aspekti službovanja bihaćkih kapetana obrađeni na raznim mjestima u tekstu, u poglavlju koji slijedi neću ih ponavljati već ću se primarno fokusirati na pitanje službovanja i imenovanja na mjesto kapetana. Nažalost, za kapetane koji su tu službu obnašali do 1560-ih bitno je manje podataka o imenovanjima i pregovorima o postavljanju u odnosu na kasnije kapetane. Također, s obzirom na opseg i temu disertacije te stanje istraženosti, obiteljsku pozadinu bihaćkih kapetana, primarno unutrašnjeaustrijskih plemića, nisam pobliže obrađivao - osim onih elemenata koji su važni za njihovu funkciju unutar Bihaćke kapetanije. Na kraju

\footnotetext{
${ }^{820}$ LOPAŠIĆ, SHK, knjiga I, dok. XCV, 139.

${ }^{821}$ IBID., knjiga III, dodaci, dok. VIII, 403.

${ }^{822}$ ŠTEFANEC, Država ili ne, 139; ÖeStA, KA, AFA, 1561-10-1; ÖeStA, KA, AFA, 1561-10-2.

${ }^{823}$ SI AS 2, DSK, kutija 203, fascikl 124a, priloženo izvještajima s početka srpnja 1585.
} 
poglavlja naveo sam časnike koje sam pronašao u izvorima, iako se ponekad radilo o vrlo kratkim i ne osobito informativnim upisima.

Kao što već navedeno, u desetljećima prije habsburškog preuzimanja Bihaća obranom su zapovijedali banovi, odnosno njima podređeni visoki zapovjednici - prije svega kaštelani. Primjerice, oko 1495. kaštelan bio Ilija Horvat (Helias Horwath) kojem je središnja vlast isplatila 33 florena za otkup iz osmanskog zarobljeništva. ${ }^{824}$ Pred početak promatranog perioda Bihaćem su upravljali ugledni hrvatski plemići i istaknuti vojni zapovjednici Gašpar Križanić i Ivan Kobasić. ${ }^{825}$ Nakon što je vladar preuzeo grad u ljeto 1527., zapovjedništvo je, prema Lopašiću, predano senjskom kapetanu Jacobu Raunachu, ali vrlo je brzo odlučeno da bude samostalan te je za prvoga samostalnog kapetana 1528. imenovan Erasmo Thurn. ${ }^{826}$ Prije postavljanja Thurna za kapetana u Bihaću se zaista nalazio neimenovani kraljev kapetan (vnnßer Haubtman von Wihitsch) koji je sredinom srpnja određeno vrijeme boravio na kraljevskom dvoru. Nažalost, taj kapetan tada nije imenovan, pa je teško zaključiti radi li se o navedenom Jacobu Raunachu ili nekom drugome. ${ }^{827}$

Thurn je zaista prvi kapetan koji se izrijekom spominje u pronađenim izvorima. ${ }^{828} \mathrm{Na}$ mjesto kapetana izabran je krajem godine jer sredinom studenog 1528. kralj navodi da se u Bihać mora namjestiti jedna ,pouzdana i ugledna“ osoba te od kranjskih staleža traži da pokušaju dogovoriti s Erasmom Thurnom da preuzme tu dužnost. Ako bi on odbio ponuđeno, kranjski staleži trebali su naći drugoga kandidata. ${ }^{829}$ Thurn će biti naveden kao kapetan Bihaća i Ripča (Ritter Hauptman zu Wichitsch vnd Repitsch). ${ }^{830}$ Radilo se vrlo uglednom kranjskom plemiću i visoko pozicioniranom pripadniku Njemačkoga Viteškog Reda koji je, čini se, ostao na položaju kapetana do siječnja 1534. U izvorima se navodi da je 1. siječnja 1535., nakon što je prethodne godine predao Petru Kegleviću „der croatischen Orte Wihitsch und Repitsch“ te s ratnim blagajnikom Hansom Peigerzheimerom izvršio obračun, u zamjenu za dug od 4578 rajnskih guldena dobio u zakup grad i kapetanstvo Metlike te maltu u Steinu i

\footnotetext{
${ }^{824}$ Lajos THALLÖCZY, Sándor HORVÁTH, Jajcza Története (bánság,vár és város), Codex diplomaticus partium regno Hungariae adnexarum, Budimpešta, 1915., dok. LXVII, 121. Što se okolnih mjesta tiče, jedan od proslavljenih protuosmanskih zapovjednika Dujam Orlovčić bio je 1505. kaštelan Sokola, Ripča i Bilaja, posjeda Beatrice Frankopan, a kada je pet godina kasnije Beatrice preminula, kralj Vladislav dodijelio je Sokol i Ripač Orlovčićima. Stjepan i Dujam su 1512. i 1513. kapetani Ripča, a 1516. vlasnik Ripča i Sokola je Grgur Orlovčić. Ivan JURKOVIĆ, The Fate of the Croatian Noble, 101-102, fusnota 269.

${ }^{825}$ Marko VEGO, Srednjevjekovni bihaćki latinski spomenici 16. vijeka, Glasnik Zemaljskog muzeja u Sarajevu, nova serija, sveska 9, arheologija, 1954., 263.

${ }^{826}$ LOPAŠIĆ, Bihać, 63. Jacob Raunach kasnije je bio kapetan Rijeke, a preminuo je 1554. KLAUŽER, Ustrojstvo i djelovanje, 62.

${ }^{827}$ SI AS 2, DSK, kutija 194, fascikl 122, Beč, 13.7.1528., 2v, rbr. 108. Kralj Ferdinand na Niclasa Thurna, zemaljskog upravitelja Kranjske.

${ }^{828}$ KRUHEK, Krajiške utvrde, 109

${ }^{829}$ SI AS 2, DSK, kutija 409, fascikl 281, Beč, 29.11.1528., 2r-2v, rbr. 582-583.

${ }^{830}$ SI AS 2, DSK, kutija 193, fascikl 119/120, 28.8.1530.
} 
Neullu. ${ }^{831}$ Doduše, Laszowski je objavio dokument, datiran 27. travnja 1534., prema kojem je kralj Ferdinand tada predao (ad manus Erasmi a Turri cedat) Erasmu Thurnu zapovjedništvo nad Bihaćem i Ripčem koji su do tada bili pod zapovjedništvom Petra Keglevića. ${ }^{832}$ No, Keglević je preuzeo kapetaniju u siječnju, o obrani Bihaća i Ripča obavještavao u lipnju te o stanju obrane javljao iz Ripča u studenom. ${ }^{833}$ Dakle, Thurn je očito prestao obnašati službu kapetana u siječnju 1534. ili je na vrlo kratko vrijeme između travnja i lipnja ponovno bio kapetan što ne djeluje uvjerljivo. Vjerojatnije je Keglević bio od siječnja u kontinuitetu kapetan.

Zna se da su se Bišćani 1532. žalili da Thurn ne boravi u gradu. ${ }^{834}$ Nije navedeno koliko dugo i kojim poslom je izbivao, ali izvori potvrđuju da je još krajem kolovoza bio izvan grada, a sredinom rujna u Metlici. ${ }^{835} \mathrm{O}$ opsadi Krupe krajem kolovoza obavještavaju ga predstavnici grada. ${ }^{836} \mathrm{~S}$ obzirom na druge službe, nije iznenađujuće da je Thurn ponekad (duže) izbivao iz grada. Uostalom, briga za Bihać i Ripač implicirala je boravke na vladarskim dvorovima i staleškim središtima gdje se rješavala tekuća defenzivna problematika. O službovanju, djelatnosti i vojnim aktivnostima Thurna i drugih kapetana raspravlja se u odgovarajućim poglavljima disertacije.

Kao što je navedeno, krajem siječnja 1534. Petar Keglević, ugledni hrvatski plemić i bivši jajački ban, obvezao se na tri godine braniti opatiju Topusko te Bihać i Ripač, s tim da je nakon isteka navedenog perioda kralj ponovno trebao preuzeti utvrde. ${ }^{837}$ Keglević je, uz veliko vojno iskustvo, akumulirao i istaknute političke, vojne i eklezijalne službe, pa je paralelno s pozicijom bihaćkoga kapetana bio i gubernator opatije Topusko te od 1537. i hrvatski ban. ${ }^{838} \mathrm{Uz}$ vojno iskustvo, intencija iza njegova postavljanja bihaćkim kapetanom očito je bila da se prihodi s još uvijek dobrostojećeg vlastelinstva opatije Topusko barem

\footnotetext{
${ }^{831}$, ,pr 4578 fl Schlo $\beta$ und Hauptmanschafft Mettling, und die Mauth zu Stein und Neull pfandweise“. Georg GÖTH, Regesten aus Schazgewölbüchern des k. k. Statthalterei-Archives in Graz, Mittheilungen des historischen Vereins für Krain, 20, br. 2, veljača, Ljubljana, 1865., 20. Erasmo Thurn bio je i pomoćnik „komturja avstrijske balije nemškega viteškega reda“. Janez WEISS, In conterminiss. Razvoj mejne pokrajine Metliške in odnosi s hrvaško-slavonskim prostorom s poudarkom na prisotnosti in posesti rodbin Erdődy in Frankopan, u: Med cesarstvom in kraljevstvom. Študija čezmejnih kulturnozgodovinskih povezav, ur. Petra Svojšak, Miha Seručnik, Vanja Kočevar, Znanstvenoraziskovalni centar Slovenske akademije znanosti in umetnosti, Ljubljana, 2013., 46.

${ }^{832}$ LASZOWSKI, HSKHDS, knjiga II, dok. 211, 196.

${ }^{833}$ IBID., dok. 217, 205; IBID., dok. 224, 213.

${ }^{834}$ KRUHEK, Krajiške utvrde, 110; LASZOWSKI, HSKHDS, knjiga II, dok. 26, 17-18.

${ }^{835}$ SI AS 2, DSK, kutija 191, fascikl 119, Bihać, 22.8.1531., 1r-1v. Petar Rebrović na Erasma Thurna; SI AS 2, DSK, kutija 191, fascikl 119., Ljubljana, 19.9.1531., 1r. Christoph Purgstall na Hansa Katzianera.

${ }^{836}$ LASZOWSKI, HSKHDS, knjiga I, dok. 92, 76.

${ }^{837}$ IBID., knjiga II, dok. 512, 509-510.

${ }^{838}$ Kralj Ferdinand imenovao je 9. prosinca 1537. Tamasa Nádasdyja i Petra Keglevića banovima, a na slavonskom saboru u Križevcima početkom siječnja stupili su na dužnost. ERCEG, Šišićeve biljeske, 425-426.
} 
parcijalno preusmjere za obranu Bihaća i Ripča. No, Kegleviću su paralelne dužnosti bile preveliko preopterećenje pa je 1538. od kralja Ferdinanda tražio da preuzme obranu Bihaća i Ripča jer ih on „,nema čime braniti““ 839

Ovdje opet dolazi do nejasnoća jer je u popisu vojske, koji je retrogradno sastavljen sredinom 1550-ih, navedeno da je već 1537. u Bihaću opet zapovjednik Erasmo Thurn, ali sada kao vrhovni zapovjednik hrvatskih utvrda (obrister an den Khrabatischen orthflegkhen). ${ }^{840} \mathrm{U}$ obiteljskoj kronici Hansa Galla, visoko pozicioniranog časnika Bihaćke kapetanije, o čemu će biti riječi dalje poglavlju, navodi se pak da je on s Erasmom Thurnom „Land Khomentheru, auch Obrister zu Wichitsch vnd Zeng“ 1538. stigao u Bihać. ${ }^{841}$ Budući da je Petar Keglević krajem veljače 1538. tražio da ga se oslobodi od dužnosti obrane Bihaća i Ripča, očito je Thurn nakon tog datuma ponovno preuzeo zapovjedništvo Bihaćem. ${ }^{842}$ Géza Pálffy smatra da je postavljanjem Erasma Thurna za glavnog zapovjednika Senja, Bihaća, Ripča, ali i Otočca te podređenih utvrda (zapravo cijele „stare Hrvatske krajine“), nakon što se Petar Keglević 1538. odrekao zapovjedništva nad podređenim mu utvrdama, započelo stvaranje zapadnog dijela Hrvatske krajine od Une do Jadranskog mora ${ }^{843}$ Thurn će i 1539. biti „Zapovjednik utvrda na Hrvatskoj krajini“ (Obrist der Krabatischen Ortfleckhen). ${ }^{844}$ Dakle, u kratkom periodu između 1538. - 1539. službe bihaćkog i senjskoga kapetana spojene su u osobi Erasma Thurna.

No, već te godine Thurn je molio da ga netko zamjeni na poziciji bihaćkog kapetana zbog zdravstvenog stanja, a kao kandidati su se spominjali Mert Gall i Niclas Schnizenbaum. ${ }^{845}$ Međutim, Lopašić u svojem popisu bihaćkih kapetana navodi da je iza Petra Keglevića kapetan bio Barthlme Raunach (Bartol Ravnikar). Nisam pronašao izvor koji bi potvrđivao da je Raunach konkretno obnašao dužnost kapetana, osim da je Mert Gall preuzeo 8. svibnja 1540. kaštel, grad i podređene utvrde od Barthlmea Raunacha obećavši da će te utvrde sa svim marom držati i čuvati kao vjerni službenik carskom veličanstvu, zemlji i ljudima koliko god to bio u stanju. ${ }^{846} \mathrm{U}$ popisu vojnika Bihaćke kapetanije iz 1540., učinjenom prije Gallova preuzimanja zapovjedništva, zaista prvo jest naveden Bartlme

\footnotetext{
${ }^{839}$ KLAIĆ, »Ostaci ostataka«, 263. Da je obrana Senja i Bihaća bila veliko opterećenje pokazuje činjenica da je senjski biskup Franjo Jozefić, kada mu je kralj dodijelio opatiju Topusko, obećao držati 50 lakih konjanika i braniti jedan od krajiških gradova, ali ne i Senj ili Bihać. LASZOWSKI, HSKDHS, knjiga II, dok. 510, 508.

${ }^{840}$ LOPAŠIĆ, SHK, knjiga III, dodaci, dok. III, 390.

${ }^{841}$ Peter von RADICS, Familien-Chroniken krainischer Adeliger im 16. und 17. Jahrhundert, Mitteilungen des Musealvereines für Krain, 16, I i II svezak, Ljubljana, 1903, 6.

${ }^{842}$ ŠIŠIĆ, HSS, knjiga II, dok. 111, 183-184.

${ }^{843}$ PALFFY, The Origines, 20-22.

${ }^{844}$ KLAUŽER, Ustrojstvo i organizacija, 146.

${ }^{845}$ SI AS 2, DSK, kutija 196, fascikl 123, 1539., 1r, rbr. 567.

${ }^{846}$ LASZOWSKI, HSKHDS, knjiga II, dok. 493, 487-488.
} 
Raunach, s tim da je precrtana njegova titula - kapetan nad lakom konjanicom (Haubtman vber die Ringhen pherg). Dakle, Raunach tada nije naveden kao bihaćki kapetan. S druge strane, oko 1540. naređeno je Bartlmeu Raunachu u Bihaću da Sokol preda obitelji Vragović ako ga zatraže, ali je utvrdu nešto kasnije preuzeo novi bihaćki kapetan Mert Gall. ${ }^{847}$ Čini se da je Raunach imao odgovornost za obranu grada zato što sredinom travnja iz Bihaća moli pomoć, ali je u izvoru opet navedeno da je kapetan nad lakim konjanicima, a ne bihaćki kapetan. ${ }^{848}$ Trebat će dodatno utvrditi je li Raunach zaista u jednom trenutku bio imenovan bihaćkim kapetanom, ali očito je prije Gallova imenovanja, i to kao kapetan na lakim konjanicima, imao obranu grada pod svojom ingerencijom.

Od svibnja 1540. na poziciji bihaćkoga kapetana nalazi se Mert Gall od Rudoflsecka koji je u izvorima oslovljavan kao „kapetan Bihaća, Ripča i podređenih utvrda“ ${ }^{849}$ Razgovori s Gallom o preuzimanju pozicije kapetana odvili su se još tijekom veljače te godine. Naime, sredinom ožujka kraljica Ana, odgovarajući na pismo zemaljskog kapetana, upravitelja i vicedoma Kranjske, navodi da su spomenuti s Gallom dogovorili da preuzme kapetaniju uz 500 i dodatnih 125 rajnskih guldena plaće te da ima pravo na jednog pisara (schreiber), jednu dvostruku plaću (Toplsoldt) i 40 lakih konjanika. Tražilo se da mu se pošalje pismo postavljenja (Bestelbrief) i plaća za pola godine. Kraljica je pak odgovorila da je kralj prije svojeg odlaska naredio da se pronađe kapetan koji bi imao nešto manju plaću od senjskoga kapetana koji je godišnje primao 400 rajnskih guldena, a bio je u lošijoj situaciji u opskrbnom pogledu te smješten na nepovoljnijem mjestu. ${ }^{850}$ Smatrala je da su navedena trojica $u$ pregovorima „otišli predaleko“. S obzirom na to da nisu našli nikoga spremnog da preuzme kapetaniju te s obzirom na to da je Gall bio kompetentan i proslavljen kranjski plemić, tražila je da s Gallom opet pokušaju dogovoriti da pristane služiti uz plaću identičnu senjskom kapetanu. Ako ne pristane, neka pristanu ili se obvežu da će mu se do kraja godine isplatiti 50, 60, 80 ili ostalih 100 rajnskih guldena ako se neće moći održati, ali kao „dar iz poštovanja“ (Vereherung) kako senjski ili neki budući kapetan ne bi tražio istu ili još veću svotu. ${ }^{851}$

U Bihaću i podređenim utvrdama muštru i isplatu su u travnju odradili kraljevski povjerenici Franz Birm i Michel Kleperger koji su nakon povratka u Beč predali izvještaj o

\footnotetext{
${ }^{847}$ IBID., 488

${ }^{848}$ SI AS 2, DSK, kutija 286, fascikl 164, Bihać, 17.4.1540., 1r-1v, rbr. 7-8. Bartlme Raunach na Nikolu Jurišića. ${ }^{849}$ „,vnnser haubtman zu Wihitsch, Repetsch vnd derselben zuegehorigen Fleckhen“. Ivan Steklasa imenovanje Marta Galla za bihaćkoga kapetana u travnju 1540. navodi kao presudan moment jer je od „leta 1540. bihaška trdnjava pripadala upravi kranjskih stanov.“STEKLASA, Padec Krupe, 286.

${ }^{850}$ SI AS 2, DSK, kutija 244, fascikl 143, Beč, 19.3.1540., 1r-1v, rbr. 238-239. Kraljica Ana na navedene.

${ }^{851}$ SI AS 2, DSK, kutija 244, fascikl 143, Beč, 19.3.1540., 1v, rbr. 239. Kraljica Ana na navedene.
} 
obavljenom poslu. ${ }^{852}$ Iz kancelarije kraljice Ane ponovljeno je da kapetan mora imati plaću jednaku Lenkoviću, odnosno 400 rajnskih guldena, ali da je naknadno uočeno da senjski kapetan ipak prima 500 rajnskih guldena. Gallu je za „Einrichtung seiner Haußwirtschafft“ trebalo doznačiti polugodišnju plaću, dakle 250 rajnskih guldena iz svote od 1000 rajnskih guldena koju su kranjski staleži odredili za krajiške utvrde. Budući da nije mogao doći u grad „praznih ruku“, naređeno je da se ostatak od planiranih 1000 rajnskih guldena, dakle 750 rajnskih guldena podijeli posadi koja je trebala brojala 40 konjanika i 125 pješaka. Tih 40 lakih konjanika nije smjelo primati višu plaću nego što je bila do tada. ${ }^{853}$ Dogovor je očito postignut, a Gall je godišnje primio 500 rajnskih guldena plaće.

Kao i drugi kapetani, Gall je ponekad bio prinuđen izbivati iz grada pa je tako do veljače 1541. „već“ neko vrijeme proveo na Ferdinandovu dvoru (ain Zeitlanng jezo an vnnsern hoff gelegen) gdje je nastojao riješiti pitanje isplate plaća vojnicima i druge potrebne stvari. Tada je očito namjeravao napustiti svoju poziciju u Bihaću jer se navodi da je „ipak“ pristao ostati na mjestu kapetana još godinu dana. No, inzistirao je na tome da se njemu i podređenim mu vojnicima isplate dugovi, pa je odobrena svota od 2000 rajnskih guldena koju su trebali isplatiti kranjski staleži. Delegirani su Jacoben Ern, ratni blagajnik Georgen Seyerl i upravitelj Hanns Peigerzhaimer da održe muštru te izvrše obračun i isplatu plaća posadi. ${ }^{854}$

Gall je još neko vrijeme izbivao iz grada u kojem je tada zapovjedništvo preuzeo njegov brat Hans Gall koji pak početkom ožujka javlja bratu da ne zna što činiti jer posada želi otići zbog neisplate plaće, a Osmanlije stalno uokolo zarobljavaju ljude. Počele su pristizati i obavijesti da se četiristotinjak Osmanlija okuplja u Udbini za napad. Hans je stoga tražio da se riješi problem plaća i namjesti još ljudi gotovo upozoravajući brata da je on osobno odgovoran za grad i kapetaniju. Hans Gall navodi da mu je i ranije pisao, ali nije primio nikakav odgovor. ${ }^{855}$ Iako je pristao obnašati dužnost još godinu dana, Mert Gall je već krajem svibnja 1541. od Nikole Jurišića tražio da se pošalje drugi kapetan koji je imućniji od njega (der aines merern vermugens ist) jer je on dao koliko je mogao, ali dalje više ne može. ${ }^{856}$ Ipak je ostao na poziciji kapetana do 1544., a to potvrđuje i spomenuta obiteljska

\footnotetext{
${ }^{852}$ SI AS 2, DSK, kutija 244, fascikl 143, Beč, 19.4.1540., 1r-1v, rbr. 242-243. Kraljica Ana na navedene.

${ }^{853}$ SI AS 2, DSK, kutija 244, fascikl 143, Beč, 19.4.1540., 3r-3v, rbr. 246-247. Kraljica Ana na navedene.

${ }^{854}$ SI AS 2, DSK, kutija 286, fascikl 164, Novo Mesto, 18.2.1541., 1r-2r, rbr. 10-12. Kralj Ferdinand na kranjske Verordneten.

${ }^{855}$ SI AS 2, DSK, kutija 123a, fascikl 198, Bihać, 2.3.1541., 1r-1v, rbr. 1186-1187. Hans Gall na Merta Galla.

${ }^{856}$ SI AS 2, DSK, kutija 123a, fascikl 198, Bihać, 22.5.1541., 1v, rbr. 1291.
} 
kronika Gallovih u kojoj je Hans napisao da mu je od 1540. brat četiri godine bio kapetan u Bihaću. ${ }^{857}$

Doduše, Valvasor i Lopašić navode da je 1543. kapetan bio Wilhelm Schnizenbaum, a da je njega sljedeće godine zamijenio Georg Sauer, bivši zemaljski kapetan Kranjske. ${ }^{858}$ No, u izvorima nisam pronašao potvrdu da je Schnizenbaum (u izvorima se navodi i kao Schniznpamer), raniji kandidat za tu poziciju, zaista bio imenovan kapetanom Bihaća, iako je svakako bio stacioniran u Bihaću i od tamo slao razne izvještaje. Naime, u ožujku 1543. Schnizenbaum je kapetan nad 200 kranjskih lakih konjanika. ${ }^{859}$ On je u lipnju u Bihaću, ali i dalje kao kapetan nad kranjskim lakim konjanicima, dok se kao upravitelj (verwalter) kapetanije navodi Mert Gall od Gallensteina. ${ }^{860}$ Krajem listopada te godine Schnizenbaum je i dalje kapetan nad kranjskim lakim konjanicima dok Bartlme Raunach zapovijeda martolozima. ${ }^{861}$ Schnizenbaum je vjerojatno, kao ranije Raunach, zapovijedao obranom grada do imenovanja upravitelja ili možda tijekom njegova izbivanja iz grada.

Sredinom srpnja u Bihaću je i dalje verwalter Mert Gall. ${ }^{862}$ Krajem kolovoza kapetan je pak Mert Gall od Rudolfsecka. ${ }^{863}$ Ovdje se dakle pojavljuju dvije osobe identičnog imena i prezimena, a to su kapetan Mert Gall od Rudolfsecka i upravitelj Mert Gall od Gallensteina. Nažalost, budući da je još uvijek neistražena povijest ove kranjske obitelji istaknute u krajiškom, odnosno bihaćkom kontekstu, trenutno nije moguće naznačiti točne relacije između njih. Vjerojatno se radi o dvije rodbinski povezane osobe iz različitih grana obitelji Gall.

No, 1546., nakon smrti Hansa Werneckha, Mert Gall od Rudolfsecka svakako je upravljao uskočkom kapetanijom ${ }^{864}$, a kasnije je zapovjednik Hrvatske krajine. ${ }^{865}$ I na ovom se primjeru vidi da su bivši bihaćki kapetani, nakon odlaska sa svoje pozicije, zauzimali najviša mjesta u krajiškoj hijerarhiji.

\footnotetext{
857 „Im 1540 Jar wart mein Brueder Mörtt Gall 4 Jare Haubtman zu Wichitsch“. RADICS, Familien-Chroniken, 6.

858 Johann Weichhard von VALVASOR, Die Ehre des Herzogthums Krain, IV svezak, knjiga XII-XV, Novo Mesto, 1877.-1879., 12; LOPAŠIĆ, SHK, knjiga III, 466.

${ }^{859}$ HDA, Militaria, kutija 2, 1543., str. 201.

${ }^{860}$ HDA, Militaria, kutija 2, 1543., str. 113; HDA, Militaria, kutija 2, 1543., str. 269. Ovaj spis datiran je 20. lipnja 1543. Mert Gall od Gallensteina je inače krajem lipnja 1545. senjski kapetan. HDA, Militaria, kutija 2, 1545., str. 134. Ostao je na toj poziciji do 1547. KLAUŽER, Ustroj i organizacija, 63.

${ }^{861}$ HDA, Militaria, kutija 2, 1543., str. 185-186.

${ }^{862}$ HDA, Militaria, kutija 2, 1543., str. 318.

${ }^{863}$ HDA, Militaria, kutija 2, 1543., str. 113.

${ }^{864}$ HDA, Militaria, kutija 3, 1546., str. 383.

${ }^{865}$ Npr. SI AS 2, DSK, kutija 201, fascikl 124, Bihać, 4.8.1556., 1r-1v, rbr. 391-392; SI AS 2, DSK, kutija 201, fascikl 124, Črnomelj, 14.4.1557., 1r, rbr. 458.
} 
Nakon Merta Galla zapovjedništvo je na dug period, od 1544. do 1557., preuzeo Georg Sauer. Nažalost, nisam pronašao izvore o njegovu preuzimanju kapetanije, ali se razni aspekti njegova dugogodišnjeg službovanja nalaze u raznim dijelovima disertacije pa ih ovdje neću ponavljati. Nakon što je napustio poziciju kapetana, Georg Sauer imenovan je zapovjednikom Hrvatske krajine. Već i to govori o kakvom se profilu osobe radilo i ponovno demonstrira da je Bihaćka kapetanije bila „odskočna daska“ za više pozicije.

Sauera je zamjenio Georg Zoblsperg, jedan od dotadašnjih zapovjednika nad martolozima stacioniranim na potezu od Bihaća do Jadranskog mora. Doduše, on je isprva, negdje u ljeto 1557., preuzeo upraviteljstvo (verwalter) nad Bihaćkom kapetanijom. ${ }^{866}$ No, do početka rujna 1558. Zoblsperg se oslovljava kao „Rom. Khay. Mt. Haubtman zu Wihitsch“ ${ }^{867}$ Kada je krajem listopada te godine morao otputovati kući, zapovjedništvo je u njegovoj odsutnosti preuzeo njegov rođak Adrian Gall. ${ }^{868} \mathrm{I}$ u ovom se slučaju vidi da je zapovjedna struktura u Bihaću često bila rodbinski uvjetovana te da su članovi nekih obitelji, poput navedenih Galla, iz generacije u generaciju služili u Bihaću ili na prostoru Bihaćke kapetanije. Zoblsperg je u lipnju 1559. i dalje kapetan. ${ }^{869}$

Nakon smrti Georga Zoblsperga oko 1560., bihaćkim kapetanom je, prema Lopašiću, imenovan Mihael Spalatin, još jedan dotadašnji zapovjednik nad martolozima i možda tek druga „domaća“ osoba na toj funkciji. ${ }^{870}$ I Spalatin je bio vrlo iskusan krajiški časnik koji je tijekom izbivanja Ivana Lenkovića bio upravitelj Senjske kapetanije ${ }^{871}$, a krajem 1550-ih zapovjednik nad martolozima. ${ }^{872}$ Spalatin se nametnuo kao prvi izbor kralja Ferdinanda 1560. iako isprva uopće nije želio preuzeti tu dužnost. Kao razloge odbijanja zapovjednog mjesta naveo je problem neisplate plaća, manjak provijanta, slabu vojnu posadu i činjenicu da se grad nalazi okružen neprijateljima. Nadalje, nije htio prihvatiti ponuđeno mjesto jer je već nakon smrti Georga Zoblsperga trebao biti imenovan bihaćkim zapovjednikom. Međutim, tome se usprotivilo više kranjskih plemića koji su inzistirali da na tu poziciju mora biti namješten jedan kranjski plemić. Spalatin očito nije htio opet dospjeti u tako neugodnu

\footnotetext{
${ }^{866}$ SI AS 2, DSK, kutija 201, fascikl 124, Varaždin, 5.8.1557., 1r, rbr. 478. Ivan Lenković na predstavnike kranjskih staleža. Za Zoblsperga kao zapovjednika martologa; SI AS 2, DSK, kutija 201, fascikl 124, Lenkovićev memorijal za zasjedanje kranjskih staleža 1556. 1r. bez broja iako su ostali spisi numerirani.

${ }^{867}$ SI AS 2, DSK, kutija 201, fascikl 124, Črnomelj, 1.9.1558., 1r, rbr. 704.

${ }^{868}$ SI AS 2, DSK, kutija 201, fascikl 124, Bihać, 21.10.1557., 1r-1v, rbr. 443-444. Georg Zoblsperg na Georga Sauera.

${ }^{869}$ SI AS 2, DSK, kutija 202, fascikl 124a, 1v, rbr. 890. Suvremeni prijepis pisma koje je Georg Zoblsperg uputio Herbartu Auerspergu.

${ }^{870}$ SI AS 2, DSK, kutija 244, fascikl 143,14.3.1560., Beč, 1r, rbr. 264.

${ }^{871}$ GRÜNFELDER, Vojna krajina i reformski, 97.

${ }^{872}$ „,haubtman vber ain Anzall Fueßknecht In den Crabatischen Waldern“ i ,Spalatin mit sein vskhokhen“. SI AS 2, DSK, kutija 804, fascikl 539/540, Črnomelj, 21.11.1559. Herbart Auersperg na predstavnike kranjskih staleža.
} 
poziciju. Ipak, unatoč tome, Spalatin se ponudio privremeno, na tri ili četiri mjeseca, preuzeti upravljanje kapetanijom, ali pod uvjetom da se posadi isplate plaće, grad opskrbi i pojača vojna posada. ${ }^{873}$

Kralj Ferdinand još 20. travnja navodi da on nema prigovora za Spalatinovo imenovanje na mjesto kapetana, ali je ipak pisao predstavnicima kranjskih staleža da predlože nekoliko prikladnih kandidata ako smatraju da je to protiv interesa Kranjske (das es ainer landschaft zuwider). Ako nemaju ili ne predlože kandidate, Spalatin bi trebao preuzeti kapetaniju. $^{874}$ Iako je Lopašić naveo da je Spalatin ostao na mjestu kapetana do 1564., u izvorima nisam pronašao potvrdu da je zaista imenovan kapetanom. ${ }^{875}$ Lopašić također navodi da nije želio prihvatiti tu poziciju. ${ }^{876}$

Od kolovoza 1561. do ožujka 1564. kapetan je zapravo Hans Scharff. ${ }^{877}$ Naime, krajiško povjerenstvo iz 1563. navodi da s početkom sljedećeg ožujka (dakle, 1564.) Scharff namjerava napustiti poziciju te da je na sastanku predstavnika unutrašnjeaustrijskih zemalja, održanom u Beču, dogovoreno da će tada kapetaniju preuzeti Georg Kronschall. ${ }^{878}$ Ostaje otvoreno pitanje je li Spalatin zaista imenovan kapetanom te kada ga je točno zamijenio Hans Scharff.

Početkom ožujka 1564. kapetaniju je preuzeo Georg Kronschall. Doduše, Lopašić navodi da je 1565. kapetan bio Adam Schrampf, no za to nisam pronašao potvrde u izvorima. Georg Kronschall teže je ranjen u pobjedi nad Osmanlijama kod Golubića 19. rujna 1565., o čemu je već bilo riječi u tekstu. U toj velikoj pobjedi Kronschall se viteški i hrabro borio. U prvom okršaju upucao je dvoje Osmanlija te „svojom rukom“ probo još nekoliko neprijatelja. Međutim, Kronscahll je u sukobu u bok primio jedan jak udarac buzdovanom ili nekim drugim oružjem (wehr). ${ }^{879}$ Čini se da mu je udarac slomio dva rebra koja su mu se zabola u abdomen (Ime zwo Ryppen Im Leib abgeworffen worden). ${ }^{880}$ Taj udarac ostavio je tako ozbiljne zdravstvene posljedice (schwären Schwacheytt) da je Kronschall oko siječnja 1566. potražio liječničku skrb u Gorici. Budući da je zbog osmanskih vojnih priprema u travnju te

\footnotetext{
${ }^{873}$ SI AS 2, DSK, kutija 244, fascikl 143, Steničnjak, 2.4.1560., 1v, rbr. 265.

874 ŠIŠIĆ, HSS, knjiga III, dok. 41, 80-81.

${ }^{875}$ LOPAŠIĆ, SHK, knjiga III, dodaci, 467.

${ }^{876}$ LOPAŠIÍ, Bihać, 65.

${ }^{877}$ Vjerojatno se radi o Hansu Scharffu (na hrvatskom jeziku potpisanom kao Ivan Šorf) koji je u travnju 1557. bio senjski vicekapetan i šogor tadašnjega senjskog kapetana Herbarta Auersperga. BOJNIČIĆ, Izvješća, dok. IX, 66-67.

${ }^{878}$ AHAZU, Lopašić, E. Prijepisi iz austrijskih arhiva, br. 14. Bihać, 3.8.1561., Hans Scharff na Ivana Lenkovića.; IBID., br. 15, str. 28.

${ }^{879}$ SI AS 2, DSK, kutija 414, fascikl 284, Črnomelj, 28.9.1565., 1r-1v, rbr. 1369-1370. Balthasar Katzianer na Ivana Lenkovića.

${ }^{880}$ HDA, Militaria, kutija 8, Črnomelj, 24.4.1566., 1r. Herbart Auersperg na nadvojvodu Karla.
} 
godine naređeno da svi kapetani i zapovjednici zauzmu svoje položaje, Kronschall je uputio pismo u kojem se ispričao što se ne može vratiti u Bihać zbog zdravlja te je molio da mu se nađe zamjena. Naveo je da su ga liječnik i svi „otpisali“ (all an mich verzagt haben) jer već tri mjeseca leži u krevetu te bi se još teže razbolio kada bi čak i prijevremeno krenuo nazad i ponovo „pao“. Da je zdrav, naveo je, već bi bio u Bihaću te konstatirao, očito misleći na Osmanlije, da „nije đavo toliko divlji kao što ga se prikazuje“. Obećao se vratiti u vojnu službu čim bude dovoljno zdrav za jahanje. ${ }^{881}$

Tijekom Kronschallova izbivanja s Matiaschem Morijem je dogovoreno da na tri mjeseca preuzme upraviteljstvo nad kapetanijom. ${ }^{882}$ Budući da je Kronschall u međuvremenu javio da ipak neće moći ostati na mjestu kapetana, Herbart Auersperg pisao je zemaljskom upravitelju Kranjske Jobstu Gallenbergu da s Lienhartom Poschom, plemićem i vojnikom s velikim iskustvom u borbi protiv Osmanlija, dogovori da preuzme mjesto kapetana. Posch je mnogo godina bio kapetan na Hrvatskoj krajini. ${ }^{883}$ Očito se nalazio negdje u blizini ili možda u samom Bihaću jer Herbart Auersperg piše da, ako on ne pristane biti kapetan, teško će se tako brzo naći nekog da tamo otputuje i zauzme mjesto kapetana. ${ }^{884}$ Auersperg je Poschu i sam poslao pismo te ga je tješio i ohrabrivao da će on i podređena mu posada u Bihaću biti bolje opskrbljena koliko god je to moguće kako bi reducirao mogućnost da radi već endemičnih nedostataka odbije ponuđeno mjesto. ${ }^{885}$ Međutim, čini se da ni on nikako nije htio preuzeti tu poziciju iako ga je Herbart Auersperg nastojao omekšati navodeći da „tko želi služiti ima tamo dobrih stvari, često pada kiša i sniježi, ali potom zasja sunce“ ${ }^{886} \mathrm{U}$ tom periodu, početkom svibnja, iz Bihaća je dramatičan apel uputio i tadašnji porkulab u Ostrožcu Petar Forčić koji je tražio više ljudi, živeži i drugih potrepština, ali i zamjenu jer tamo više nije želio služiti. Vojska mu se razilazi, a nisu primili obećanu opskrbu iako ih se molilo da se strpe do kraja ožujka. Sada je pak, Forčić navodio da može ostati u službi do kraja svibnja, pritom ne propuštajući iskazati vjernost caru i nadvojvodi. ${ }^{887}$

Posch na kraju nije preuzeo mjesto kapetana na kojem je, čini se, ostao Matiasch Mori koji se u pismu banu i „gospodi hervackoj i plemenitim ljudem“ 15. lipnja 1566. potpisuje kao

\footnotetext{
${ }^{881}$ „Dann der Teuffel ist nit so wildt, als man Im malt“. HDA, Militaria, kutija 8, Gorica, 21.4.1566., 1r-1v. Primatelj nije naveden, ali vjerojatno je upućeno kranjskim staležima, Ivanu Lenkoviću ili Herbartu Auerspergu. ${ }^{882}$ Upravitelja (verwalter), spominje u travnju Herbart Auersperg, ali ne navodi njegovo ime. Očito se radi o Moriju. HDA, Militaria, kutija 8., Črnomelj, 24.4.1566., 1r. Herbart Auersperg na nadvojvodu Karla.

${ }^{883}$ HDA, Militaria, kutija 8, Črnomelj, 24.4.1566., 1v-2r. Herbart Auersperg na nadvojvodu Karla.

${ }^{884}$ SI AS 2, DSK, kutija 249, fascikl 146a, 20.4.1566., 1r, rbr. 305.

${ }^{885}$ BOJNIČIĆ, Izvješća, dok. XXXI, 85-86.

${ }^{886}$ „,dann wer dienen will hat daselbst guett sachen, eß ist offt ain Reges wetter, eß scheindt, aber darnach die Sonnen, demnach pin ich vnabschlegiger antwortt jezo mit dem eisten gewarttundt". SI AS 2, DSK, kutija 286, fascikl 164, Črnomelj, 10.5.1566., 1r, rbr. 40, Herbart Auersperg na Lienharta Poscha.

${ }^{887}$ SI AS 2, DSK, kutija 286, fascikl 164, Bihać, 5.5.1566., 1r, rbr. 44.
} 
„Ja Mori Matijaš c(esarske) s(vitlosti) kapitan u Bihću“. ${ }^{888}$ Za period od sljedeće tri godine nisam pronašao nijedan izvor koji bi pokazivao tko je obnašao dužnost bihaćkoga kapetana.

Međutim, 1570. poziciju kapetana zauzeo je Daniel Lasser koji će na toj poziciji ostati do pogibije u Seljačkoj buni 1573. Naime, njega je početkom veljače u sukobu kod Krškog pogodilo puščano zrno u lice, pa je privremeno zapovjedništvo preuzeo Friedrich Weixelberg (Višnjegorski). ${ }^{889} \mathrm{Za}$ Weixelberga se navodi da je nekoliko godina služio na krajini te da dobro poznaje tamošnje prilike i neprijatelja. ${ }^{890}$ Weixelberg je, primjerice, 1565 . bio zapovjednik nad 40 strijelaca na konjima (schüzen phardt). ${ }^{891}$ Ubrzo je Weixelberg s Andrijom Tadiolovićem postavljen za upravitelja Hrvatske krajine dok je privremeno zapovjedništvo nad Bihaćkom kapetanijom predano Jurju Križaniću, u kojeg je pokojni kapetan imao veliko povjerenje, te Paulu Sheyeru, šurjaku pokojnog Lassera. ${ }^{892}$

Prilikom izbora za kapetana u veljači 1573. kranjski su staleži kao prikladnoga kranjskog plemića predložili upravo Friedricha Weixelberga ${ }^{893}$ Već je spomenuto da je nakon toga nadvojvoda naložio da se o tome održi savjetovanje, a u slučaju da se razmatralo angažirati nekog stranca, za svoje je kandidate predložio Spalatina ili riječkog zapovjednika Paula Saru. ${ }^{894}$ Kranjski su staleži pak u slučaju izbora stranca predložili Georga Schotenpacha, zapovjednika konjanika na području Celjskog okruga koji je ranije bio i zapovjednik konjanika u Bihaću i kojeg su tamošnji vojnici dobro poznavali. ${ }^{895}$

Na kraju je izabran ugledni kranjski plemić Sebastian Lamberg, a sačuvani su i zahtjevi koje je iznio prilikom pregovora o preuzimanju dužnosti $1573 .{ }^{896}$ Lamberg je iskazao zadovoljstvo što je Car zapovjedio da će imati iste uvjete službe kao i pokojni zapovjednik Daniel Lasser. Tražio je da se posadi barem parcijalno isplati plaća, jer „nije pametno tamo ići s praznim rukama“, da se grad opskrbi živeži dostatnom za godinu dana te streljivom, barutom i olovom. Zatražio je namještanje puškara, uredno držanje straže u brdima te

\footnotetext{
${ }^{888}$ BOJNIČIĆ, Izvješća, dok. XXXIV, 88.

${ }^{889}$ VALVASOR, Die Ehre, IV svezak, knjiga XII-XV, 12.

${ }^{890}$ Franjo RAČKI, Gradja za poviest hrvatsko-slovenske seljačke bune god. 1573., Starine, JAZU, knjiga 7 , Zagreb, 1875., dok. XLII, 219-220.

${ }^{891}$ HDA, Militaria, kutija 7, 1565./1566., 4r. Iskaz financijskih izdataka Hansa Khiesla, ratnog blagajnika na Hrvatskoj krajini za 1565. i 1566. Preslike ovoga opsežnog iskaza nalaze se među preslikama spisa za 1561.

${ }^{892}$ SI AS 2, DSK, kutija 244, fascikl 143, 7.2.1573., rbr. 163-166. Predstavnici kranjskih staleža na nadvojvodu Karla.

${ }^{893}$ SI AS 2, DSK, kutija 244, fascikl 143, Ljubljana, 17.2.1573., 1r-1v, rbr. 287-288.

${ }^{894}$ SI AS 2, DSK, kutija 244, fascikl 143, Beč, 27.2.1573., 1v-2r, rbr. 291-292.

${ }^{895}$,So ain zeit lanng zu Wihitsch haubtman vber die Pferdt gewesst, diser zeit aber haubtman de Pferdt im Cillen Viertl, vnd den dienstleüt daselbst zu Wihisch bekhennt". SI AS 2, DSK, kutija 244, fascikl 143, Beč, 10.3.1573., 2r-2v, rbr. 298-299. Predstavnici kranjskih staleža na nadvojvodu Karla.

${ }^{896}$ Sebastiana Lamberga je delibaša Kliškog sandžaka 1577. u pismu oslovio ovom riječima: „U svem visoko počtovanomu i svake počtene časti i hvale dostoinomu Šanbaštijanu Lanbirgaru, kapitanu Bihaćskomu, naipri drago pozdravlenje i mil poklon“. LOPAŠIĆ, Bihać, 307, dodatak, dok. XIV.
} 
financiranje obavještajnog sustava. Budući da je vlastitim očima vidio da je grad na nekoliko mjesta u ruševnom stanju te da se rijeka Una odmaknula od gradskih zidina, tražio je da se ti problemi riješe tako da se ponovno obnove zidine i da se rijeka ponovno usmjeri sve do gradskih zidina. Na koncu je Lamberg molio da ga, ako Bihać opsjednu Osmanlije, car i nadvojvoda neće ostaviti zaboravljenog , u takvoj strahoti“ ${ }^{897}$ Lamberg se ipak dogovorio o uvjetima službe te je preuzeo zapovjedništvo nad kapetanijom.

Tri godine kasnije, kada je Sebastian Lamberg namjeravao napustiti mjesto kapetana, kranjski su staleži za njegovu zamjenu predložili Paula Scheyera, Christopha Obritschana, Jobsta Mordaxa i Balthasara Galla. Scheyer je već imao iskustva s Bihaćkom kapetanijom jer je ranije, nakon smrti svojeg šurjaka i bihaćkog zapovjednika Daniela Lassera, upravljao kapetanijom i dobro se slagao s vojnom posadom. ${ }^{898}$ Na kraju je Sebastian Lamberg ipak ostao na svojoj poziciji do 1578. Prilikom pregovora o produženju službe u siječnju 1577., Lamberg je tražio namještanje adekvatnog broj vojnika, osigurane financije, plaću za njega, njegovih 8 konjanika i 4 pješaka, dodatnih 200 „dobrih strijelaca“ te opskrbu živeži dostatnom za godinu dana. Nadalje, iako se obvezao da će učiniti sve, „koliko mu Božja milost i prilike dopuste“, da spriječi neprijateljske pljačke i upade, zbog preopterećenosti brigom za Bihać nije htio biti odgovoran za sudbinu ostalih utvrda. Ipak, obvezao se voditi računa o načinu na koji porkulabi obnašaju svoju dužnost te obavijestiti zapovjednika Hrvatske krajine ako to neće činiti. Tražio je i da mu se dozvoli otpuštati vojnike i časnike u Bihaću i angažirati druge pa će time posada biti i poslušnija. ${ }^{899}$ Lambergu je zaista dozvoljeno otpuštati vojnike u slučaju neposluha i drugih nepriličnih postupaka, s tim da se morao konzultirati s vrhovnim zapovjednikom kada se radilo o zamjeni zapovjednog kadra. ${ }^{900}$

Uz Merta Galla i Maksimilijana Lamberga, Sebastian Lamberg bio je predložen za kranjskoga kandidata za savjetničko mjesto u novoosnovanome Dvorskom ratnom vijeću u Grazu iako je njegova kandidatura ovisila o tome hoće li biti potreban u Bihaću. Na kraju nijedan od trojice navedenih nisu ušli u kranjsku kvotu spomenutog tijela. ${ }^{901}$ No, Lamberg je nesumnjivo bio jedan od najcjenjenijih krajiških zapovjednika što je vidljivo i iz činjenice da

\footnotetext{
${ }^{897}$ SI AS 2, DSK, kutija 244, fascikl 143, Ljubljana, 20.5.1573., 1r-2r, rbr. 320- 322. Sebastian Lamberg na zemaljskog upravitelja Kranjske.

${ }^{898}$ SI AS 2, DSK, kutija 244, fascikl 143, Ljubljana, 29.11.1576., 1r, rbr. 333. Još u rujnu 1580. nastojalo se isplatiti dug koji je Scheyeru nastao tijekom upravljanja kapetanijom, a možda i kasnije. Radilo se o iznosu od 1871 rajnskih guldena. HDA, Croatica, mikrofilm D-1913, br. 3, rujan 1580. Scheyer je kasnije bio kapetan Hrastovice. HDA, Croatica, mikrofilm D-1913, br. 44, rujan 1580.

${ }^{899}$ SI AS 2, DSK, kutija 244, fascikl 143, Bihać, 4.1.1577., 1r-1v, rbr. 380-381. Sebastian Lamberg na kranjske staleže.

${ }^{900}$ SI AS 2, DSK, kutija 244, fascikl 143., 7.2.1577., 1v, rbr. 394. Nadvojvoda Karlo na Waikharda Auersperga.

901 ŠTEFANEC, Država ili ne, 217-218.
} 
je Wolffu Engelbrechtu Auerspergu i njemu (tada zapovjedniku arkebuzira u Karlovcu) predana uprava Hrvatske krajine kada je u veljači 1584. zapovjednik otputovao u Ljubljanu. $^{902}$

Nakon Lamberga kapetanom je imenovan Benedict Crainer koji je na toj poziciji, čini se, ostao do veljače 1579. kada su kao novi kandidati predloženi Jobst Mordax, Sigmund Egg, Daniel Obritschan, Christoph Haimb te Paul Scheyer koji je tada bio i kandidat za zapovjednika Hrastovice. ${ }^{903}$ Međutim, čini se da Lopašić ispravno navodi da su kapetanijom te godine upravljali prvo poručnik (leutenandt) Georg Panner, a zatim da je na mjesto kapetana ponovno zasjeo Sebastian Lamberg. ${ }^{904}$ Panner je očito bio plemenita roda jer ga je Lamberg oslovljavao s „edle herr““.905 No, osim da je napustio službu u Bihaću i 1582. obnašao službu kvartirmeštra, o njemu se zapravo malo zna. ${ }^{906}$ Sebastian Lamberg ostao je na poziciji kapetana do $1582 .{ }^{907}$ No, u tom periodu spominju se i dvojica upravitelja. Naime, u izvorima se navodi Paul Scheyer, kasniji kapetan Hrastovice, a Lopašić tvrdi da je 1581. upravitelj bio i Franz Rössel. ${ }^{908}$ Problem s upraviteljima predstavlja činjenica da iz izvora nije uvijek jasno jesu li oni upravitelji u periodu kada nije izabran kapetan ili možda kada kapetana nema $\mathrm{u}$ gradu pa oni korespondiraju $\mathrm{s}$ nadređenim instancama kao njegovi zamjenici. Ponekad je možda oboje.

Izvori kao sljedećeg kapetana navode Daniela Obritschana koji je već ranije bio jedan od kandidata za tu poziciju koju je preuzeo 1583. Međutim, Obritschanovo zapovijedanje prekinuto je pogibijom 17. prosinca 1583. kod Drežnika kada je s 40 konjanika prije zalaza sunca kod Rakovice (am Rakhouitz) napadnut od 400 osmanskih konjanika. ${ }^{909}$ On je tek druga osoba koja je poginula obnašajući dužnost bihaćkoga kapetana, ali prva koja je stradala u sukobu s Osmanlijama jer je Lassera ubilo tane ispaljeno iz oružja pobunjenih seljaka 1573. Odmah se zatražilo da se u Bihać pošalje osoba koja će preuzeti brigu o obrani do dolaska zapovjednika Hrvatske krajine koji je trebao donijeti potrebna rješenja. ${ }^{910}$

\footnotetext{
${ }^{902}$ LOPAŠIĆ, SHK, knjiga I, dok. LXXXVII, 128.

${ }^{903}$ HDA, Croatica, kutija 1, svežanj 2, 63.

${ }^{904}$ LOPAŠIĆ, SHK, knjiga III, dodaci, 467.

905 IBID., knjiga I, dok. LIV, 90.

${ }^{906}$ IBID., dok. LXXVIII, 115-116.

${ }^{907}$ HDA, Croatica, kutija 2, svežanj 4, 1584., 436-437.

${ }^{908}$ HDA, Croatica, mikrofilm D-1913, br. 44, rujan 1580; LOPAŠIĆ, SHK, knjiga III, dodaci, 467.

${ }^{909}$ SI AS 2, DSK, kutija 286, fascikl 164, Karlovac, 19.12.1583., 1r, rbr. 417. Wolff Engelbrecht Auersperg, upravitelj Hrvatske krajine, na predstavnike kranjskih staleža. Vojni povjerenik Ahaz Thurn navodi još krajem 1586. da se pokojnom Obritschanu za službu duguje još 2948 rajnskih guldena i 40 krajcara, od čega ljubljanski trgovac Hans Numb potražuje 496, a 2452 rajnskih guldena i 40 krajcara mora biti položeno kod regimentskog suca u Karlovcu. LOPAŠIĆ, SHK, knjiga I, dok. XCII, 134.

${ }^{910}$ SI AS 2, DSK, kutija 286, fascikl 164, Ljubljana, 31.12.1583., 1r, rbr. 415. Predstavnici kranjskih staleža na Wolffa Engelbrechta Auersperga.
} 
Ta je osoba bila kasniji ripački kaštelan Cristoph Schickswoll, a odmah je pisano i koruškim i kranjskim staležima da predlože svoje kandidate. ${ }^{911}$ Izvještaj o Obritschanovoj pogibiji odmah je diseminiran dalje, uključujući naravno i nadvojvodu, iako isprva zemaljski upravitelj Kranjske Wolff Thurn nije znao je li nadvojvoda uopće primio pismo. ${ }^{912} \mathrm{U}$ konceptu odgovora predstavnika kranjskih staleža upućenog Auerspergu, a datiranom 31. prosinca, zaista stoji da su predstavnici kranjskih staleža Auerspergovo pismo od 19. prosinca primili tek taj dan. ${ }^{913}$ Neuobičajeno sporo čak i za zimske mjesece, a osobito s obzirom na sadržaj.

Sljedeće godine Lopašić navodi tri kapetana i upravitelja u nizu. Prvo je kapetanom imenovan Ladislav More, zatim je upravitelj bio raniji vicekapetan, odnosno poručnik Jacob Pranck, a napokon je kapetanom imenovan Franz Hörner. ${ }^{914}$ Očito je u prvim mjesecima 1584. kapetanom bio Ladislav More, zatim prije travnja 1584. kapetanijom upravlja Jacob Pranck. ${ }^{915}$ Prije 1584. upraviteljem je bio i Hans Gerben. ${ }^{916}$ Početkom travnja raspravljalo se imenovanju novoga kapetana, ali sve je privremeno odgođeno zbog zarobljavanja nekolicine osoba kod Karlovca koje su očito poznavali ili znali za imenovanje i planiranu opskrbu grada, pa je zapovjednik Hrvatske krajine Jobst Joseph Thurn sve odgodio na nekoliko dana dok ne prikupi informacije o osmanskim namjerama. ${ }^{917}$

$\mathrm{Na}$ temelju raspoloživih izvora teško je reći do kada je odluka zaista odgođena. Iako Lopašić u svom popisu bihaćkih kapetana navodi da je 1584. kapetanom imenovan Franz Hörner, u izvorima se barem od kraja veljače do kraja travnja 1585. kao upravitelj kapetanije (Ambtsverwalter zu Wichitsch, odnosno kao leütenandt) potpisuje Gregor Allmayer. ${ }^{918}$ No, Hörner je kapetan u svibnju 1585., kao što pokazuje njegov iscrpni izvještaj o napadu i spaljivanju Ostrošca od 31. svibnja navedene godine. ${ }^{919}$ Hörner je imao iskustva s Bihaćem

\footnotetext{
${ }^{911}$ HDA, Croatica, mikrofilm D-1914, br. 21, prosinac 1583.

${ }^{912}$ SI AS 2, DSK, kutija 286, fascikl 164, Karlovac, 2.1.1584. 1r, rbr. 421.; HDA, Croatica, mikrofilm D-1914, br. 21, prosinac 1583 .

${ }^{913}$ SI AS 2, DSK, kutija 286, fascikl 164, Ljubljana, 31.12.1583., 1r, rbr. 415. Predstavnici kranjskih staleža na Wolffa Engelbrechta Auersperga, upravitelja Hrvatske krajine.

${ }^{914}$ Ivan STEKLASA, Kako so Turki, 410.

${ }^{915}$ U travnju 1584. zapovjednik Hrvatske krajine Jobst Joseph Thurn spominje upravitelja u Bihaću (verwalter zu Wichitsch). Ne imenuje ga, ali se vjerojatno radilo o Prancku. LOPAŠIĆ, SHK, knjiga I, dok. XC, 131.

${ }^{916}$ HDA, Croatica, kutija 2, svežanj 4, 1584., 17-22.

${ }^{917}$ IBID., dok. XC, 131.

${ }^{918}$ LOPAŠIĆ, Bihać, 65; SI AS 2, DSK, kutija 203, fascikl 124a, Bihać, 30.4.1585., 1r. Gregor Allmayer na Wolffa Engelbrechta Auersperga, upravitelja Hrvatske krajine; SI AS 2, DSK, kutija 203, fascikl 124a, 1r, Bihać, 21.2.1585. Gregor Allmeyer na zapovjednika Hrvatske krajine.

${ }^{919}$ Nedim ZAHIROVIĆ, Crtica iz ratovanja na Krajini: napad zapovjednika Bihaća Franza Hornera na Ostrožac 31. svibnja 1585. godine, Historijski zbornik, god. LXVII, 2014., 83-92. Jedan primjerak ovog izvještaja pronašao sam u Arhivu Republike Slovenije u Ljubljani i planirao priložiti u dodatku. S obzirom na to da je kolega Zahirović znalački transkribirao i preveo ovaj tekst upućujem na navedeni članak.
} 
jer je u studenom 1583. sa stanovitim Hauserom bio delegiran za obavljanje muštre vojske u gradu. ${ }^{920}$

Nadalje, Lopašić navodi da je Thomas Dornberg preuzeo kapetaniju 1586., ali Franz Hörner je na toj funkciji još 1587 . kada ga krajem veljače nadvojvoda Karlo pokušava skloniti da ostane na dužnosti iako paralelno traži i druge kandidate za tu poziciju. ${ }^{921}$ Izgleda da je Hörner ostao na toj dužnosti sve do 1589. jer se spominje u Fuggerovim izvještajima na početku prosinca 1588., ali pod krivim prezimenom Herman umjesto Hörner. ${ }^{922}$

Te je godine očito došlo do smjene pa je na poziciju kapetana zasjeo Thomas Dornberg za kojeg je u studenom 1589. upisano da ga je zapovjednik Hrvatske krajine „poslao u Bihaćku kapetaniju“. ${ }^{923}$ Čini se da je tada zapravo Dornberg reizabran jer je ta pozicija nuđena i Jacobu Prancku, koji je radije optirao za jedno ispražnjeno mjesto pri Archibusier Haubtmanschaff u Karlovcu, što mu je zatim i odobreno. ${ }^{924}$ Thomas Dornberg ostao ja na kapetanskoj poziciji sve do svoje smrti u studenom 1590., a do izbora novoga kapetana upravitelj je trebao biti Gašpar Križanić. ${ }^{925}$

Za novoga kapetana kranjski su staleži predložili sljedeće kandidate: Cristopha Obritschana, tada zapovjednika nad jedinicom od 100 arkebuzira u Karlovcu koji je „služeći od mladosti stekao veliko iskustvo o Hrvatskoj krajini i neprijatelju te se kroz više vojnih službi okitio slavom“, zatim Jacoba Galla od Graffenwega, koji je ranije četrnaest godina bio zapovjednik Ogulinske kapetanije, Jurja Lenkovića, zapovjednika nad jedinicom od 50 husara u Karlovcu, Wilhelma Lamberga, sina dugogodišnjega kapetana Sebastiana Lamberga koji je „nakon smrti oca na zadovoljstvo tamošnjih vojnika jedno vrijeme upravljao kapetanijom“ te Christopha Galla od S. Georgenberg-a, koji je donedavno bio zamjenik zapovjednika u Senju. ${ }^{926}$ No, čini se da su Wilhelm Lamberg i Christoph Gall otpali iz kruga kandidata zbog lošega zdravstvenog stanja. ${ }^{927}$ Kandidati koruških staleža bili su tada Georg Paradeiser, Veit

\footnotetext{
${ }^{920}$ HDA, Croatica, mikrofilm D-1914, br. 8, studeni 1583.

${ }^{921}$ SI AS 2, DSK, kutija 244, fascikl 143, Graz, 26.10.1586. (krivo navedeno 1596), 1r-1v, rbr. 550-551.

${ }_{922}$ „Aus Wihitsch von 8 Dec. 1588. Vom Hauptmann Frantz Herman. Archiduci Carolo“. Joseph CHMEL, Die Handschriften der k.k. Hofbibliothek in Wien, Beč, 1840., XXXIII, 379. Radi se o kratkoj regesti iz Fuggerovih izvještaja za 1588., koja se nalazi u kodeksu Ms Nro. 8961 koji je pohranjen u Nacionalnoj knjižnici u Beču.

${ }^{923}$ HDA, Croatica, mikrofilm D-1918, br. 1, studeni 1589.

${ }^{924}$ HDA, Croatica, mikrofilm D-1918, br. 4, studeni 1589.

${ }^{925}$ HDA, Croatica, mikrofilm D-1918, br. 5/6, studeni 1590.

${ }^{926}$ SI AS 2, DSK, kutija 244, fascikl 143, Ljubljana, 26.11.1590., 1v, rbr. 527-528. Predstavnici kranjskih staleža na tajne i ratne savjetnike u Beču.

927, ,mit leibs schwachten beladen sein vnd niderligen“. IBID.
} 
Mager i Thobias Dietrichstein. ${ }^{928}$ Na koncu je izabran Christoph Obritschan koji je svoju dužnost obnašao sve do zarobljavanja $1592 .{ }^{929}$

Njemu je zapovjedništvo isturenom kapetanijom također predstavljalo opterećenje, pa je taj ,ain alter Gränzer“" na sam Božić 1591. molio da ga se oslobodi dužnosti zapovjednika ispričavši se, između ostalog, i obiteljskim razlozima. ${ }^{930} \mathrm{No}$, kraj njegova službovanja nije nastupio mirnim povlačenjem, već je Obritschan krajem 1591. ili početkom 1592. zarobljen u zasjedi prilikom nadgledavanja utvrđivanja grada. ${ }^{931}$ Steklasa navodi da je privremeno zapovjedništvo preuzeo Joseph Dornberg. ${ }^{932}$

Prije samog pada grada, u ožujku 1592., zadnji se put, dakle, raspravljalo o zapovjedniku Bihaćke kapetanije koja je ostala ispražnjena nakon „durch auffkhindung herrn“ Obritschan. ${ }^{933}$ Budući da navedeni njemački glagol aufkündigen znači „,raskinuti, otkazati ili prekinuti nešto“, čini se da Obritschan nije preminuo u zarobljeništvu, već da je samovoljno napustio službu kapetana. Zanimljivo je da, kada su na zemaljskom saboru okupljeni staleži raspravili o tome te nadvojvodi poslali prijedloga kandidata za kapetana, u konceptu tog prijedloga, u jednom su pasusu naveli da bi prvo trebalo pokušati nagovoriti Obritschana da ostane na svojoj poziciji, ali je potom cijeli pasus prekrižen i očito izbačen iz konačne verzije. $^{934}$

Zato su kranjski staleži predložili sljedeće osobe: vicekapetana (leitenandta) Josepha Lamberga, tadašnjeg upravitelja kapetanije, Sigmunda Egka, Wilhelma Lamberga, Wilhelma Galla, Hansa Ludwiga Sauera i Daniela Schwabena Liehtenberga koji su svi bili kvalificirani i iskusni pojedinci. Popis predloženi kandidata poslan je nadvojvodi, a spomenuta je i potreba obnove Ripča kako bi se nekoga lakše privoljelo da preuzme kapetaniju. ${ }^{935} \mathrm{Na}$ koncu je kapetanom imenovan Joseph Lamberg koji će biti zadnji kršćanski zapovjednik Bihaćke kapetanije. U dijelu o osmanskom osvajanju grada u lipnju 1592. već je bilo riječi o Lambergovu kratkotrajnom, ali sudbonosnom zapovijedanju u Bihaću.

\footnotetext{
${ }^{928}$ HDA, Croatica, mikrofilm D-1918, br. 5/6, studeni 1590.

${ }^{929}$ Za njega se zalagao i Hans Friedrich Trautmansdorff koji je pisao Hansu Thurnu da se Obritschan postavi za kapetana. IBID.

${ }^{930}$ SI AS 2, DSK, kutija 244, fascikl 143, Karlovac, 2.2.1592., 1r-2r, rbr. 530-532. Andreas Auersperg na nadvojvodu Ernesta; IBID., Graz, 25.12.1591., 1r, rbr. 529. Nadvojvoda Ernest na kapetana Christopha Obritschana.

${ }^{931}$ LOPAŠIĆ, Bihać, 76.

${ }^{932}$ STEKLASA, Kako so Turki, 486.

${ }^{933}$ SI AS 2, DSK, kutija 244, fascikl 143, Ljubljana, 10.3.1592., 1r, rbr. 536.

${ }^{934}$ SI AS 2, DSK, kutija 244, fascikl 143, Ljubljana, 10.3.1592., 1v, rbr. 537.

${ }^{935}$ SI AS 2, DSK, kutija 244, fascikl 143, Ljubljana, 10.3.1592., 1v-2r, rbr. 537-538.
} 
Popis bihaćkih kapetana i upravitelja izgledao bi ovako. Nakošenim slovima navedene su osobe koje je Radoslav Lopašić naveo kao kapetane ili upravitelje, a koje nisam pronašao u izvorima ili za koje nisam mogao utvrditi jesu li zaista imenovani kapetanima. Za pojedine godine u izvorima nisam pronašao nijedan spomen imena kapetana.

Jacob Raunach, 1527. - 1528., kapetan Senja i Bihaća

Erasmo Thurn, 1528. - 1534.

Petar Keglević, 1534. - 1538.

Erasmo Thurn, 1538. - 1539., zapovjednik hrvatskih utvrda

Bartlme Raunach, 1539. - 1540., kapetan nad lakim konjanicima-husarima

Mert Gall od Rudolfsecka, 1540. - 1544.

Mert Gall od Gallensteina, 1543. - upravitelj

Wilhelm Schnizenbaum, 1543., kapetan nad lakim konjanicima-husarima

Georg Sauer, 1544. - 1557.

Georg Zoblsperg, 1557.- 1560., upravitelj pa kapetan

Mihael Spalatin, 1560., upravitelj (?)

Hans Scharff, 1561. - 1564.

Georg Kronschall, 1564. - 1565.

Adam Schrampf, 1565.

Matiasch Mori, 1565. - 1566.(?), upravitelj pa kapetan

Daniel Lasser, 1570. - 1573.

Friedrich Weixelberg, Juraj Križanić, Paul Scheyer 1573., upravitelji.

Sebastian Lamberg, 1573. - 1578.

Benedict Crainer, 1578. - 1579.

Georg Panner, 1579., upravitelj

Sebastian Lamberg, 1580. - 1582.

Paul Scheyer, 1580., upravitelj

Franz Rössel, 1581. upravitelj

Daniel Obritschan, 1583.

Christoph Schickswoll, 1583./1584., upravitelj

Hans Gerben, upravitelj, prije 1584.

Ladislav More, 1584.

Jacob Pranck, 1584. upravitelj

Franz Hörner, 1584. - 1587. 
Gregor Almeyer, 1585., upravitelj

Thomas Dornberg, 1589. - 1590.

Gašpar Križanić, 1590., upravitelj

Christoph Obritschan, 1590. - 1592.

Joseph Lamberg, ožujak 1592. - lipanj 1592., upravitelj pa kapetan

\section{2. Časnici bihaćke vojne posade}

$\mathrm{Na}$ kraju poglavlja prezentirat ću pronađene podatke o časnicima i visokopozicioniranim pojedincima unutar zapovjedne strukture Bihaćke kapetanije. O takvim osobama mnogo je manje podataka, a njihova imena uglavnom se pojavljuju u potpisima prigovora ili molbi, u momentima kada u gradu nema kapetana ili kada se raspravljalo o premještajima i/li isplatama (zaostataka) plaća. O proceduri njihova izbora i njihovim biografijama izvori su krajnje šturi. Ipak, treba naglasiti da su časničke pozicije u Bihaću zauzimali istaknuti krajiški zapovjednici, odnosno istaknuti pripadnici hrvatskog i/ili unutrašnjeaustrijskog plemstva. U ranijem razdoblju morao je dominirati domaći element, ali su u procesu ustrojavanja habsburškoga kapetanijskog sustava na časnička mjesta počeli biti namještani primarno unutrašnjeaustrijski plemići. Ipak, sve do pada pod osmansku vlast hrvatsko plemstvo u krajiškoj službi imalo je važnu ulogu u hijerarhiji i strukturi Bihaćke kapetanije, kao što pokazuje slučaj Jurja Križanića koji je nakon smrti kapetana Daniela Lassera 1573. do izbora novoga kapetana trebao upravljati Bihaćkom kapetanijom. ${ }^{936}$ Isto je trebao činiti i Gašpar Križanić nakon smrti Thomasa Dornberga u studenom 1590. ${ }^{937}$ Gašpar Križanić bio je 1570ih zapovjednik nad 100 pješaka u Bihaću. ${ }^{938}$ Zanimljiva je činjenica da je oko 1566. na nalog zapovjednika Hrvatske krajine Jurju i Gašparu Križaniću isplaćeno 50 rajnskih guldena za oporavak od zadobivenih ozljeda. ${ }^{939}$

Od hrvatskog plemstva treba spomenuti Petra Rebrovića koji je jedan od uglednijih bihaćkih časnika, a već 1517. godine bio je bihaćki vicekaštelan. ${ }^{940}$ Rebrović će 1531 . biti

\footnotetext{
${ }^{936}$ SI AS 2, DSK, kutija 244, fascikl 143, 7.2.1573., rbr. 163-166. Predstavnici kranjskih staleža na nadvojvodu Karla.

${ }_{937}$ HDA, Croatica, mikrofilm D-1918, br. 5/6, studeni 1590.

${ }_{938}$ ŠTEFANEC, Država ili ne, 71.

939 ,zu ergezlickhait Ires Empfangen Leibschadens“. HDA, Militaria, kutija 7, 1565./1567., 18v. Iskaz financijskih izdataka Hansa Khiesla, ratnog blagajnika na Hrvatskoj krajini za 1565. i 1567. Preslike ovog opsežnog iskaza nalaze se među preslikama spisa za 1561.

${ }_{940}^{94 O P A S ̌ I C ́, ~ B i h a c ́, ~} 54$.
} 
bihaćki vicekapetan. ${ }^{941}$ Ugledni hrvatski plemić Vid Ugrinović je u godinama prije dolaska Habsburgovaca jedan od zapovjednika konjanika sa sjedištem u Bihaću. ${ }^{942}$ U prosincu 1583. dugovanja je trebalo isplatiti i Pavlu Stifkoviću (Paul Stiffkhouitsch), nekadašnjem konjaničkom kapetanu (Reitthaubtman) u Bihaću. ${ }^{943}$ Stifkovići su bili lokalna obitelj koja je dala istaknute krajiške zapovjednike. U poglavlju o rodovima vojske te prilozima na kraju rada navedeni su i drugi hrvatski plemići koji su, najčešće u konjaničkim postrojbama, služili u Bihaću.

Što se „stranaca“ tiče, već 1530. u Bihaću je vicekapetan mladi Ivan Lenković koji će na toj poziciji biti (nakon Petra Rebrovića) i do otprilike 1538., a nakon toga je imenovan senjskim kapetanom. ${ }^{944}$ U pismu kapetanu Thurnu s kraja kolovoza 1531. Lenković se još potpisuje kao njegov dienner. ${ }^{945}$

Kroz desetljeća se navode i dvije osobe s prezimenom Ninderheimb. Gregor Ninderhaimb bio je stražmeštar u Bihaću $1557 .{ }^{946}$ dok je u kolovozu 1580. Georg Nindertaimb, na nalog zapovjednika Hrvatske krajine, zajedno s braćom morao biti zbrinut (vndterbringen) u karlovačku postrojbu arkebuzira. ${ }^{947}$ Gregoru Ninderhaimbu je kao izaslaniku bihaćke posade ratni blagajnik oko 1566. isplatio 20 rajnskih guldena. ${ }^{948} \mathrm{~S}$ obzirom na imena (Gregor - Georg), vjerojatno se radi o dvije različite osobe iako ne bi trebalo isključiti mogućnosti da je riječ o jednoj osobi koja je u krajiškoj službi provela dug niz godina pa je za sebe i svoju braću stekla određene zasluge. To bi značilo da je nastavio vojno djelovati i u starijoj dobi jer je trebao biti „,zbrinut“ u jednu karlovačku vojnu postrojbu.

U ožujku 1576. Hansu Auerspergu jedno su pismo uputili vojvoda Bernardin (Wernardin Weywoda), stražmeštar Casper Pekh, poručnik Christoph Franckh te upravitelj

\footnotetext{
${ }^{941}$ SI AS 2, DSK, kutija 191, fascikl 119, Bihać, 22.8.1531., 1v. Petar Rebrović na kapetana Erasma Thurna.

${ }^{942}$ Ivan JURKOVIĆ, Ugrinovići od Roga - raseljena obitelj plemenitog roda Šubića Bribirskih za trajanja osmanske ugroze, Zbornik Odsjeka za povijesne znanosti Zavoda za povijesne $i$ društvene znanosti Hrvatske akademije znanosti i umjetnosti, vol. 26, 2008., 73.

${ }_{943}$ HDA, Croatica, mikrofilm D-1914, br. 19, prosinac 1583.

${ }^{944}$ KLAIĆ, Povijest Hrvata, knjiga 5, 271. Zamjenik kapetana, barem u senjskom slučaju, na hrvatskom se jeziku navodio kao vicekapitan, kao što se primjerice apostrofirao potencijalni kasniji bihaćki kapetan Hans Scharff, oslovljen u glagoljskom pismu kao „Od mene Ivana Šorfa, vicekapitana senjskoga“. BOJNIČIĆ, Izvješća, dok. XII, 68. Jednako tako i za zamjenika zapovjednika Hrvatske krajine na hrvatskom se jeziku ponekad navodi vicekapitan. Primjerice, Balthasar Katzianer se u glagoljskom pismu početkom travnja 1559. oslovljava na sljedeći način: „Od mene Boltezera Kocianara, ces(arske) s(vitlosti) vićnika i vicekapitana Krajin hrvatcki“. IBID., dok. XIV, 670.

${ }_{945}$ SI AS 2, DSK, kutija 191, fascikl 119, Bihać, 22.8.1531., 1v. Petar Rebrović na kapetana Erasma Thurna.

${ }^{946}$ SI AS 2, DSK, kutija 201, fascikl 124, Bihać, 7.8.1557., 1r, rbr. 500. Georg Zoblsperg na predstavnike kranjskih staleža.

${ }^{947}$ HDA, Croatica, mikrofilm D-1914, br. 1, rujan 1580.

${ }^{948}$ HDA, Militaria, kutija 7, 1565./1567., 19r. Iskaz financijskih izdataka Hansa Khiesla, ratnog blagajnika na Hrvatskoj krajini za 1565./1567. Preslike ovoga opsežnog iskaza nalaze se među preslikama spisa za 1561.
} 
njemačke postrojbe (verwalter des Fanndleins) Christoph Schickswoll. ${ }^{949}$ Schickswoll će nakon pogibije kapetana Daniela Obritschana krajem 1583. biti poslan u Bihać kako bi uredio obranu. U travnju 1576. kapetanu izvještaj šalju poručnik Christoph Franckh te stražmeštar Casper Pekh. ${ }^{950}$ Jeronim Podlipnik bio je opskrbni upravitelj (proviant verwalter) u Bihaću 1562. ${ }^{951}$ Dugogodišnji opskrbnik bio je i Burckhardt Saloman. ${ }^{952}$ Šturi podaci o časnicima i vojnicima, koje sam pronašao u izvorima, donose da je Bastl Gross, nekadašnji vojnik u Bihaću, u rujnu 1580. molio da mu se isplate zaostaci. ${ }^{953}$ Isti mjesec Georg Feurer moli da ga se namjesti za zastavnika (fendrich) u njemačkoj postrojbi u Bihaću. ${ }^{954}$ U listopadu 1580. zastavnik njemačke postrojbe je Hans Feyelwart. ${ }^{955}$ Čini se da je u prosincu iste godine zastavnik Feyelwart odstupio sa svoje pozicije te mu je trebalo pronaći adekvatnu zamjenu. ${ }^{956}$ U studenom 1580. navodi se da se Georgu Jordanu treba isplatiti 53 rajnskih guldena i 40 krajcara za sein Wihitscherich verdienen. ${ }^{957}$ U veljači 1584. spominje se bivši feldschreiber Andreen Schneberger. ${ }^{958}$

Posebno je zanimljiva kronika obitelji Gall koja zapravo prikazuje događaje iz života Hansa i Andreasa Galla. Osobito su zanimljivi podaci o Hansu Gallu, bratu kapetana Merta Galla, koji je, kao što je navedeno, zauzimao visoke pozicije u zapovjednoj strukturi Bihaćke kapetanije te je u trenutku izbivanja brata njome i zapovijedao. Gall je imao zanimljiv život. Kao mladić sudjelovao je u obrani Beča 1529., a zatim je 1535. sa Sigmundom Weichselbergom bio poslanik u Osmanskom Carstvu. Sudjelovao je kao carski vojnik u ratovima u Italiji i Francuskoj 1536. itd. Za temu ovog rada bitno je da se u kronici navodi da je Hans Gall došao 1538. u Bihać s Erasmom Thurnom, tada „zapovjednikom Bihaća i Senja“, i Ivanom Lenkovićem te je tamo na dužnosti zastavnika ostao dvije godine. Zatim je 1541. imenovan zapovjednikom Ripča (haubtmann zu Repitsch) i na tom je položaju ostao sljedeće tri godine. Od 1545. do 1549. bio je na dužnosti u Senju. Gall je i kasnije bio involviran u vojne aktivnosti Kranjske pa je tako 1556. kao kapetan u Donjoj Kranjskoj bio s bratom Mertom i 250 uskoka poslan prema Kostajnici da bi zatim na zamolbu bihaćkoga

\footnotetext{
${ }^{949}$ SI AS 2, DSK, kutija 287, fascikl 164, Bihać, 30.3.1576., 1v, rbr. 516. Bihaćki časnici na Hansa Auersperga; IBID., Bihać, 10.4.1576., rbr. 524-527.; IBID., Bihać, 10.4.1557.,1r-1v, rbr. 528-529.

${ }^{950}$ SI AS 2, DSK, kutija 287, fascikl 164, Bihać, 14.4.1576., 1r-1v, rbr. 534-535.

${ }^{951}$ HDA, Militaria, kutija 7, 1562, Iskaz financijskih izdataka Hansa Khiesla, ratnog blagajnika na Hrvatskoj krajini za 1562., 6v.

952 SI AS 2, DSK, kutija 286, fascikl 164, Bihać, 14.11. 1574., 1v, rbr. 243.

${ }^{953}$ HDA, Croatica, mikrofilm D-1913, br. 2, rujan 1580.

${ }^{954}$ HDA, Croatica, mikrofilm D-1913, br. 5, rujan 1580.

${ }_{955}$ HDA, Croatica, mikrofilm D-1913, br. 30, listopad 1580.

${ }^{956}$ HDA, Croatica, mikrofilm D-1913, prosinac 1580.

${ }^{957}$ HDA, Croatica, mikrofilm D-1913, br. 3, studeni 1580.

${ }^{958}$ LOPAŠIĆ, SHK, knjiga I, dok. XCV, 139.
} 
kapetana Sauera, sa svojim strijelcima na dva do tri mjeseca ojačao obranu Bihaća. Andreas Gall (rođen 13. listopada 1554.) stigao je pak krajem lipnja 1574. u Bihać i služio je pod Sebastianom Lambergom te zastavnikom Christophom Häimom uz plaću od 8 rajnskih guldena mjesečno. Kada je u srpnju vojno povjerenstvo pregledavalo Hrvatsku krajinu (Beraitung), otišao je uz dopuštenje iz Bihaća, a krajem te godine potpuno je napustio službu u Bihaću. Sudjelovao je „Hrvatskoj ekspdiciji“ 1578., pobjedi nad Osmanlijama kod Ostrožina i paljenju Ostrovice na Uni 1580. te pustošenjima Krupe 1581. i Udbine 1582. Participirao je i u porazu Karlovčana kod Bosiljeva 9. prosinca 1582. gdje je ranjen u ruku i usta, a izgubio je dva svoja čovjeka i dva konja, kao i u raznim drugim sukobima na krajištu. ${ }^{959}$

Sredinom veljače 1592. je pak u zarobljeništvo pao još jedan ugledan kranjski plemić iz jedne od grana obitelji Gall te pripadnik bihaćke posade Hans Daniel Gall koji je sa svojim bratom Wilhelmom bio „, an einer hötz vor Wichitsch gewset“. Obiteljska kronika navodi da su Osmanlije za njegovo oslobađanje tražili veliku otkupninu te da je Gall nakon tegobnog zarobljeništva negdje oko srpnja 1594. preminuo u Beogradu. Drugi zarobljeni kršćani pokopali su ga ispred grada. ${ }^{960}$ Gall je jedan u niza članova ove ugledne obitelji koji su zauzimali prominentne pozicije u zapovjednoj strukturi Bihaćke kapetanije te jedini za kojeg se zna da je tragično stradao. Do kraja je u Bihaću služio i Thomas Gall kojem je Hasan-paša nakon predaje grada navodno predao svilene haljine koje se ovom nisu svidjele pa ih je predao jednom od Osmanlija. Paša se interesirao zašto pa mu je rečeno da ih on kao Nijemac ne cijeni te da bi mu više odgovarao novac za piće nakon čega mu je paša dao 20 talira. Gall je pri izlazu iz grada u sukobu ubio Veli-agu jer su im počeli napadati i pljačkati supruge i obitelji. $^{961}$

$\mathrm{Na}$ kraju navodim slikovit slučaj tada već bivšega bihaćkog poručnika Martina Hartensteinera. ${ }^{962}$ Otprilike u drugoj polovici ili krajem 1580-ih Osmanlije su ga zarobili i odveli ga u Carigrad gdje se kao ,weyland Lieutenant zu Wihitsch“ spominje početkom 1590ih. Bio je jedan od šesnaest uglednih zarobljenika koji su uspjeli pobjeći iz „Crnog turnja“ $u$ Carigradu. Nakon bijega iz zatvora navedeni su se razišli, a Hartensteiner se pokušao sakriti u nekim vinskim goricama jer nije mogao skinuti okove s jedne noge. No, nanjušili su ga psi

\footnotetext{
${ }^{959}$ RADICS, Familien-Chroniken, 1-11.

${ }^{960}$ IBID., 8.

${ }^{961}$ LOPAŠIĆ, Bihać, 79.

${ }^{962}$ U travnju 1584., recimo, izvještava o osmanskim namjerama LOPAŠIĆ, SHK, knjiga I, dok. XCI, 133.
} 
progonitelja te je uhvaćen. ${ }^{963}$ Njegova daljnja sudbina ostaje nepoznata. Ovaj neuspješni bijeg bivšega bihaćkog poručnika kao da nam na ilustrativan način sumira cjelokupni napor zapovjednoga kadra koji je uložen u obranu Bihaća i koji se, unatoč velikim ulaganjima i silnom trudu, u konačnici ipak pokazao nedovoljnim.

Zaključno se može konstatirati da su bihaćki kapetani i časnici obnašali vrlo odgovornu i delikatnu službu za koju su bili relativno dobro plaćeni iako su financije uvijek predstavljale velik problem. Izazova je bilo mnogo, od neposredne osmanske opasnosti do izlaženja na kraj s raznim disfunkcionalnostima nastajućega krajiškog sustava. Vojničke plaće kasnile su, opskrba nije stizala u mjeri u kojoj je to bilo potrebno, opreme i oružja uvijek je trebalo više, fortifikacije su zahtijevale stalne intervencije. Kroz desetljeća Osmanlije su napredovali i sve više okruživali Bihać, a s okolnog se prostora stanovništvo sve više iseljavalo. Sve je to narušavalo sigurnosnu situaciju i obrambeni potencijal kapetanije te generiralo (veliko) nezadovoljstvo među vojnom posadom i lokalnim stanovništvom. U takvim nepovoljnim okolnostima broj utvrda pod zapovjedništvom bihaćkoga kapetana popeo se na visoku brojku od 24 zbog čega su negodovali i sami kapetani. Pritisnuti nuždom, bili su prisiljeni trošiti i vlastita sredstva kako bi održali kakav-takav funkcionalni sustav. Međutim, velika odgovornost podrazumijevala je i viša primanja, kako direktna u vidu plaće, tako i ona indirektna u vidu dijela plijena, otkupa zarobljenika, trgovine stokom, odnosno kroz ratnu ekonomiju. Nadalje, pozicija kapetana u Bihaću predstavljala je i odskočnu dasku za daljnje napredovanje u krajiškoj strukturi pa su pojedini kapetani postali i zapovjednici Hrvatske krajine. Gotovi svi kapetani bili su ugledni plemići i/ili iskusni vojnici unutrašnjeaustrijske provenijencije što je jasan pokazatelj dominacije (unutrašnje)austrijskog plemstva u procesu formiranja krajiškog sustava na hrvatskom prostoru. Među višepozicioniranim časnicima bilo je i uglednih hrvatskih plemića dok je posada sastavljena uglavnom od domaće i/ili uskočke populacije. Obnašati službu bihaćkog kapetana bila je velika čast i obaveza jer je izazova bilo mnogo i nisu svi mogli biti savladani, ali je većina kapetana i njima podređenih časnika svoju

\footnotetext{
${ }^{963}$ Friedrich SEIDELN, Denckwürdige Gesandtschafft an die Ottomannische Pforte, Welche ehmahls auf Rö. Jayl. May. Rudolphi II hohen Befehl herr Fridrich von Krekwitz, Sr. Maj. Reichs=Hof=Rath, verrichtet, Nebst ausführlichem Berich, was hierbey so wohl mit dem Herrn Oratore selbst, al denen Seinigen vorgelauffen, aufgesezt und schrifftlich hinterlassen von Fridrich Seideln..., Görlitz, Johann Gottlob Laurentius, 1711., 61-63. Dostupno na stranici https://books.google.hr/. Pristup 28. veljače 2019.
} 
dužnost obavljala odgovorno i pouzdano. To pokazuje i činjenica da su Osmanlije osvojili Bihać tek u lipnju 1592. Naime, pitanje je bi li se grad toliko dugo održao u tako nepovoljnom položaju da nisu postojali čvrsta namjera i pomno izabrani kandidati za kapetane. 


\section{GRAĐEVINSKO STANJE BIHAĆA}

U ovome poglavlju prezentirat ću građevinsko stanje Bihaća i prikazati koliko je i na koja mjesta krajiška vlast intervenirala u urbano tkivo grada u promatranom periodu. Ova tema važna je jer pokazuje do koje je mjere krajiška vlast na pograničju posezala za određenim elementima modernoga utvrdnoga graditeljstva pretvarajući Bihać u veliku pograničnu obrambenu fortifikaciju. To je jedan od najvidljivijih elemenata procesa općedruštvene militarizacije promatranog prostora i takve su se promjene mogle najlakše vidjeti - novi bastion(i), zidine s prsobranom, otvaranje puškarnica, rušenje starih i nepotrebnih objekata u gradu i oko njega, kopanje jaraka itd.

Jedan od najvažnijih segmenata spomenute ,vojne (r)evolucije“ bile su i inovacije u utvrdnom graditeljstvu u tzv. talijanskom stilu - trace italienne. ${ }^{964}$ Zidine su postale niže $\mathrm{i}$ osigurane zemljanim nasipima kako bi amortizirale udare topništva. Počeli su se graditi novi elementi utvrda, bastioni raznih tipova koji su izlazili iz zidina i pokrivali vatrom prednju i zadnju stranu te bočne strane bastiona. Utvrde su okruživali jarci ispred kojih je trebala biti ravna otvorena površina zbog vatrenog djelovanja. ${ }^{965}$ Nažalost, sačuvano je malo predmodernog Bihaća jer je (stari) grad gotovo sravnjen sa zemljom u savezničkom bombardiranju 1944., ali određena arhitektura održala se do današnjeg dana - veliki bastion, dio zidina, Kapetanova kula i džamija Fethija. Nadalje, zapravo je pronađeno malo izvora o urbanoj strukturi grada u promatranom periodu, a dostupno je i relativno malo preciznijih prikaza grada iz 16. stoljeća. Te sam materijale koristio, a djelomično i prikazao u ovom radu. Od kraja 17. stoljeća raspolažemo s više preciznih prikaza, pa i opisa grada koji je do tada u velikoj mjeri zadržao fizionomiju predosmanskog Bihaća. No, budući da je ovom stupnju istraženosti teško prezentirati koje su sve promjene učinjene u osmanskom periodu, kao vizualnu nadopunu ovom poglavlju navest ću one građevinske elemente koji su nedvojbeno potvrđeni u ranijem razdoblju.

$\mathrm{Na}$ početku treba naglasiti da su se na Hrvatskoj krajini, a osobito oko rijeke Une, u promatranom periodu nalazile mnogobrojne plemićke utvrde podignute $u$ (kasno)srednjovjekovnom periodu prema konceptima koji su iz strateške i vojnotehnološke perspektive sve više zastarijevali. Njihovo održavanje, obnova i modificiranje predstavljali su golemo opterećenje za vječito nategnuti vojni proračun. Zato je, paralelno s preuzimanjem utvrda od strane središnje vlasti, tekao proces rušenja strateški nebitnih ili u slučaju

\footnotetext{
${ }^{964}$ AGOSTON, Habsburgs and Ottomans, 129.

${ }^{965}$ HOWARD, Rat u europskoj, 43-44.
} 
osmanskog zauzimanja potencijalno opasnih utvrda, iako se hrvatsko plemstvo žustro suprotstavljalo takvim prijedlozima.

Bihać je pak bio velik grad $\mathrm{s}$ razvijenim fortifikacijskim sustavom $\mathrm{u}$ koji se $\mathrm{u}$ promatranom periodu konstantno interveniralo obnovom postojećih, ali i konstruiranjem novih arhitektonskih elemenata, što je pak iziskivalo velika financijska sredstva. Prema prijedlogu iz 1576. za građevinske radove na Hrvatskoj krajini trebalo je uložiti visokih 73 000 rajnskih guldena, a od toga je samo za Bihać bilo predviđeno vrtoglavih 50000 rajnskih guldena. To je bio daleko najviši iznos namijenjen utvrdama Hrvatske krajine dok je na slavonskom području samo za podizanje nove utvrde Dombra iznad Legrada te Koprivnice i Cirkvene predviđeno utrošiti više, konkretno čak 60000 rajnskih guldena na svako navedeno mjesto. Za Hrastovicu se tada planiralo utrošiti 2000, Zrin 2000, Blinju 600, Pedalj 2000, Gvozdansko 500, Slunj, Cetin i Krstinju 5000, Senj 1000 i Ogulin 1000 rajnskih guldena. ${ }^{966}$ Iako su ovo ostali nerealizirani prijedlozi, barem kada je o Bihaću riječ, pokazuju s kakvim se iznosima baratalo kada je bilo riječ o građevinskim radovima na krajištu. Financijska sredstva osiguravali su središnja vlast i staleži Unutrašnje Austrije, ali je novac je ponekad pristizao i nekim zaobilaznim kanalima. Tako je, prema iskazu nadvojvode Karla sa sabora u Brucku, za izgradnju utvrda oko Bihaća namijenjeno 14000 rajnskih guldena od kazni koje je zbog određenog prekršaja trebao podmiriti jedan kranjski plemić i poslovni čovjek. ${ }^{967}$

Međutim, čak i kada je financijska pozadina bila osigurana, realizacija građevinskih radova u pograničnim mjestima poput Bihaća predstavljala je velik izazov jer je trebalo organizirati transport i dopremiti materijal, radnike i živež na istureno krajište te angažirati vojne postrojbe koje su trebale štititi te radnike od osmanskih napada. U razmatranjima prilikom pripreme više puta spominjane „Hrvatske ekspedicije“ iz 1578. naglašeno je koliki napor predstavlja angažiranje obrtnika i radnika te unošenje građevnog materijala (kamen, vapno, cigle, drvna i željezna građa) za obnovu grada. ${ }^{968}$ Tom problemu nastojalo se doskočiti opskrbljivanjem pograničnih utvrda potrebnim građevinskim materijalom i opremom da se ne bi trebalo sve to dopremati iz unutrašnjosti. ${ }^{969}$

\footnotetext{
966 ŠTEFANEC, Država ili ne, 392, fusnota 1160.

${ }^{967}$ IBID., 361.

${ }^{968}$ HDA, Croatica, kutija 1, svežanj 1, 20.8.1578., 508.

969 IBID., svežanj 2, 51-52. Vjerojatno prijepis mišljenja Dvorskoga ratnog vijeća u Grazu o prijedlogu ekspedicije. Građevni materijal nije samo dopreman iz unutrašnjosti već je u tu svrhu korištena građa razorenih i zapuštenih objekata na krajini - utvrda, crkava, arheoloških ostataka itd. Papinski legat Campeggio je krajem 1524. imao ovlasti dopuštati uzimanje kamena s napuštenih ili oštećenih crkava za podizanje utvrda. BARANY, War, crown and society, 111.
} 
Pri radovima na utvrđivanju krajiških gradova i utvrda participirali su i domaći staleži, odnosno njihovi podanici, što je jedan od rijetkih elemenata u kojem su parirali unutrašnjaustrijskim staležima u razvoju krajiškog sustava. Tako je na hrvatsko-slavonskom saboru u svibnju 1562. za popravak i utvrđivanje Bihaća i utvrda Bihaćke kapetanije delegirano 216 radnika te 34 kola. Ljude i kola trebali su podići Nikola Zrinski s posjeda Ozalj i Dubovac, Frankopani Ozaljski s posjeda Ribnik, Novigrad, Zvečaj i Skrad, Frankapani Tržački s posjeda Bosiljeva, Blagajski s posjeda Blagaj te plemići Herendići, Gusići, Hojsići, Barilovići, Klokočki, Smrčkovići, Vojnovići, Goričani, Tvrdinići, Krekovići, Banski i Jekovići. ${ }^{970}$ Dakle, radna snaga za obnovu Bihaća i okolnih mjesta pristizala je s prostora neposrednog zaleđa u kojem je tada još bilo dovoljno stanovništva za ovakve akcije, ali i s prostora zemalja Unutrašnje Austrije, opet primarno Kranjske.

U srednjovjekovnom periodu Bihać je bio velik i dobro utvrđen grad na što jasno upućuje i gradski pečat iz 14. stoljeća s prikazom gradskoga kaštela s tri kule i zastavom postavljenom na srednjoj kuli. Iako zbog vremenskih ograničenja istraživanja nije moguće analizirati razvoj bihaćkih fortifikacija u srednjovjekovnom periodu, treba naglasiti da je Bihać u promatranom razdoblju grad u potpunosti opkoljen zidinama spojenima s kaštelom. Prema najranijem detaljnom opisu bihaćkih fortifikacija koji je 1550. sastavio Ivan Lenković, grad su opasivale 1320 m (700 klaftri) dugačke te oko 0,90-0,95 m (pola klaftra) široke zidine koje je nadvisivalo sedam obrambenih kula. Kaštel je bio spojen sa zidinama i kulama. ${ }^{971}$

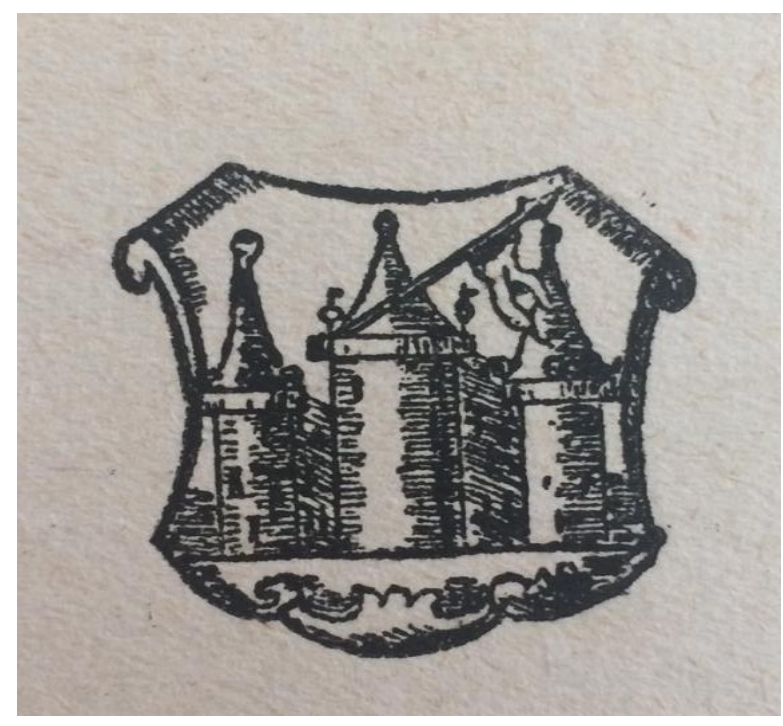

Slika 20. Grb Bihaća koji donosi Lopašić. ${ }^{972}$

\footnotetext{
${ }^{970}$ KLAIĆ, Povijest Hrvata, knjiga 5, 300.

${ }^{971}$ LOPAS̆IĆ, SHK, knjiga III, dodaci, dok. VIII, 404.

${ }^{972}$ LOPAS̆IĆ, Bihać, 5.
} 
Nažalost, o „civilnom“ arhitektonskom aspektu, izvan onog u fokusu vojnih struktura, raspolažemo s oskudnim podacima pa je trenutno gotovo nemoguće prezentirati/analizirati kompletnu fizionomiju grada. U izvorima se pojavljuju tek usputni podaci koji i ne otkrivaju mnogo više od onog što je neosporno - da je u gradu bilo kuća. Tako je 1540. u Bihaću izbio požar koji je uništio župni dvor/župnikovu kuću (Pharrers Haus) i sedam kuća iako je Bartolme Raunach izvještavao da je sve moglo završiti mnogo gore - da ni tri kuće ne bi ostale stajati. $^{973}$

Zna se da je u gradu bilo sedam crkava, a to su crkve sv. Antuna, sv. Elizabete, sv. Marije, sv. Lucije, sv. Jakova, sv. Duha i sv. Marije Magdalene. ${ }^{974}$ Gotičku dominikansku crkvu sv. Antuna iz sredine 13. stoljeća Osmanlije su kasnije pretvorili u džamiju Fethiju, ali je njezina fizionomija uvelike sačuvana pa sada predstavlja specifikum na regionalnom prostoru, odnosno srednjovjekovno kršćansko naslijeđe inkorporirano u ranonovovjekovni islamski kontekst, što je dobar primjer prožimanja različitih utjecaja na pograničju. U džamiju je pretvorena i druga manja gotička crkva koja se nalazila kod kaštela, a za koju Lopašić pretpostavlja da je riječ o kraljevskoj kapeli s dvorskim kapelanom koja se spominje u izvorima. Franjevački samostan sv. Marije nalazio se uz gradske zidine desno od Njemačkih vrata prema rijeci Uni. ${ }^{975}$

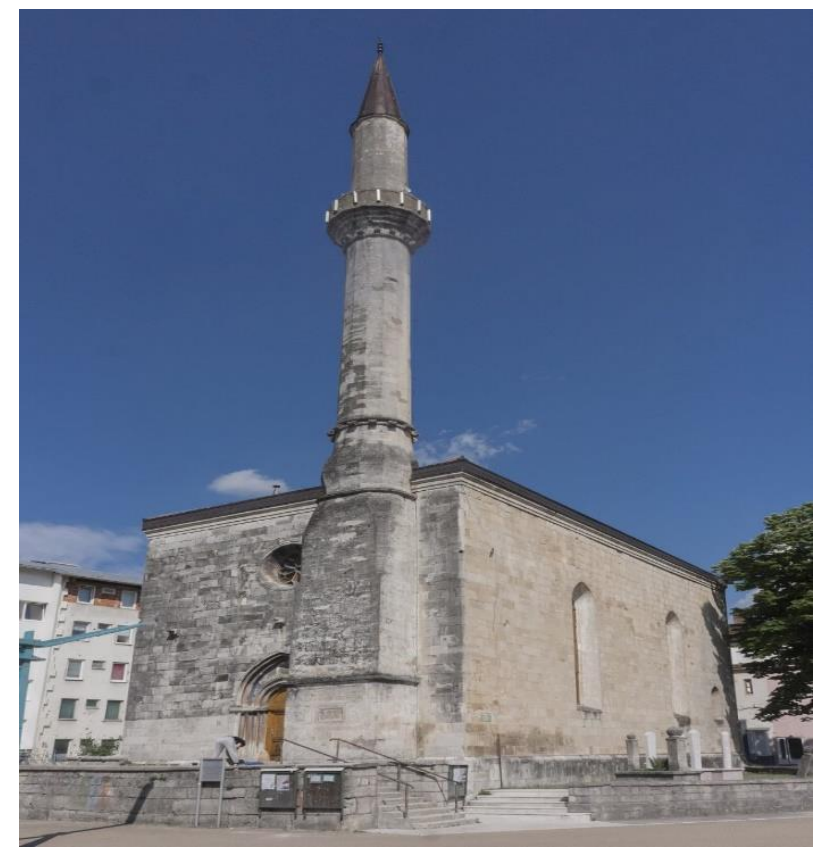

Slika 21. Džamija Fethija, bivša dominikanska crkva sv. Antuna. ${ }^{976}$

\footnotetext{
973 „,nit drey heuser bleiben hetten mugen“. SI AS 2, DSK, kutija 286, fascikl 164, Bihać, 17.4.1540., 1r, rbr. 7. Bartlme Raunach na Nikolu Jurišića.

${ }_{974}$ LOPAŠIĆ, Bihać, 52.

${ }^{975}$ IBID., 36.;38.

${ }^{976}$ Snimio Almir Kurtović, Bihać, 2018.
} 
Radoslav Lopašić u svojoj knjizi "Bihać i Bihaćka krajina" isprva navodi da se u grad ulazilo kroz troja, a zatim opisuje pak četiri gradska vrata. Tzv. Njemačkim vratima prilazilo se cestom od Zavalja dok se iz smjera Izačića u grad ulazilo kroz Zelena vrata koja su stajala uz bedem Zelengrad. Prema rijeci Uni nalazila su se (Preko)Unska vrata koja su prolazila kroz dva zida, a na bihaćku Otoku vodila su Krupska ili Bijela vrata koja su stajala „nešto dalje od Zelenih vrata, ali ipak jošte na jarku“.977 Međutim, jedan kasniji, ali detaljni prikaz osmanskog Bihaća, načinjen s habsburške strane, prikazuje pak troja vrata, a to su Njemačka ili tada Glavna vrata kraj kaštela, (Preko)Unska vrata prema Otoci, te Zelengradska koja se nazivaju i Krupska vrata. Vjerujem da je ovakav raspored identičan onome iz 16. stoljeća, odnosno da tada postoje tri glavna ulaza u Bihać: kroz Njemačka vrata na jugu, Unska vrata na istoku prema Otoci i Krupska vrata prema sjeveru. No, treba napomenuti da je vjerojatno bilo i drugih ulaza u grad pa se tako 1543. spominju mala vrata Zavala (Zabala) koja su bila dio kaštela ili su se nalazila u njegovoj neposrednoj blizini. Lenković spominje 1550. i vrata Rakov brod te manja gradska vrata Polače u kružnom dijelu zidina. ${ }^{978}$ Takva manja vrata mogla su $u$ nekom trenutku biti zazidana $\mathrm{i} /$ ili jednostavno nisu prikazana na kasnijim prikazima iako vjerujem da se radi o prvoj verziji, odnosno da kasnije nisu postojala ili da su funkcionirala tek u određenom periodu kada se spominju. Budući da je grad bio na rijeci Uni, postoji mogućnosti da je dio (manjih) vrata funkcionirao kao „vodeni ulaz“ za čamce, kao što se to i danas može lijepo vidjeti u Zrinskoj kostajničkoj utvrdi. Na to bi mogao upućivati i naziv „Rakov brod“ za jedna od vrata.

\footnotetext{
${ }^{977}$ LOPAŠIĆ, Bihać, 32.

${ }^{978}$ LOPAŠIĆ, SHK, knjiga III, dodaci, dok. VIII, 404.
} 


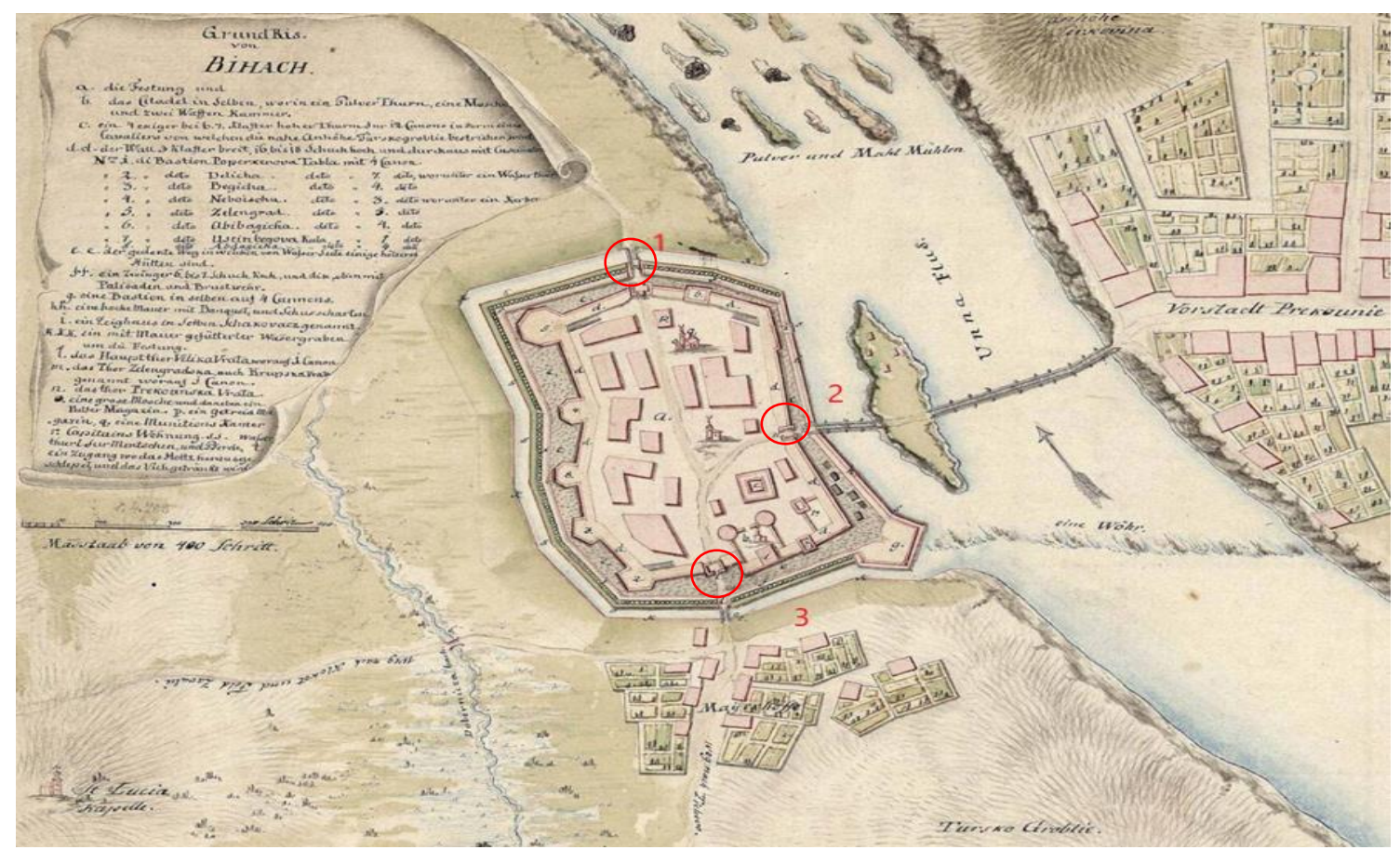

Slika. 22. 1. Krupska, 2. (Preko)Unska i 3. Njemačka vrata na prikazu Bihaća iz $1794 .{ }^{979}$

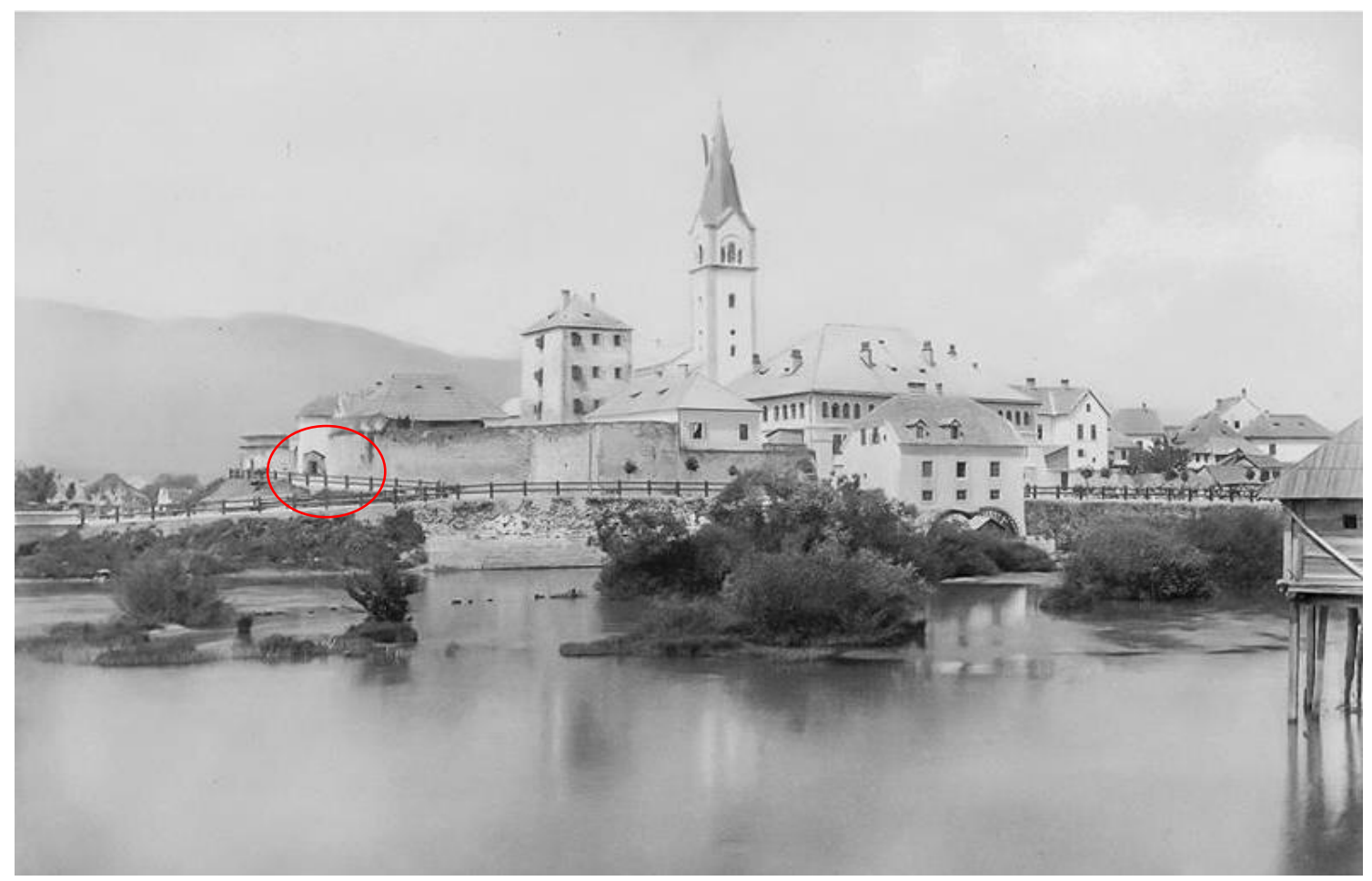

Slika 23. Fotografija Bihaća iz 1890. s (Preko)Unskim vratima. ${ }^{980}$

${ }^{979}$ Dostupno na https://maps.hungaricana.hu/hu/HTITerkeptar/2955/view/?pg=0\&bbox=-1811\%2C7072\%2C7292\%2C-2401 Pristup 13.2.2019.

${ }^{980}$ Raimund Stillfried von Rathenitz (Komotau, Böhmen 1839 - 1911 Wien), Bihac von der Brücke, Kassette mit 80 Aufnahmen: Bosnien und Herzegowina / Aufgenommen von / Baron R. Stillfried / K. u. K. Hof-Photograph / Wien / I., Reichsrathstrasse 27. 
Njemačka vrata nalazila su se uz najreprezentativniji objekt u grad, odnosno uz kaštel. Smatram da je to glavna ulazna i obrambena točka grada te se u izvorima često navode samo kao die Thor - vrata. Ta su vrata preko dana bila otvorena, a noću su se zatvarala, kao što je o tome svjedočio jedan bihaćki vojnik $1565 .{ }^{981}$

Najraniji spomen graditeljske djelatnosti u Bihaću potječe iz 1513. kada je kralj Vladislav II. doznačio određena sredstva franjevcima za obnovu njihova samostana, čvrsto građene građevine od velike strateške važnosti za obranu grada. ${ }^{982}$ Taj samostan, odnosno crkva sv. Marije, nalazio se kod kaštela i bio je spojen s gradskim zidinama. Iz Lenkovićeva izvještaja iz 1550. vidi se da se kroz neko samostansko dvorište izlazilo na rijeku, a da su redovnici čuvali ključ vrata. ${ }^{983}$ No, problem pri interpretaciji ovog podatka leži u činjenici da Lenković navodi da je riječ o dvorištu „franjevačkog“ samostana sv. Antuna (sanct Anthoni closter (Franciskani)). ${ }^{984}$ Iako je crkva sv. Antuna bila dominikanska, ipak se 1506. navodi da bihaćki franjevci kao dio Hrvatske ili Krbavske kustodije u gradu posjeduju samostan s crkvama sv. Antuna i sv. Barbare. ${ }^{985}$ Stoga ostaje pitanje da li se radi o franjevačkom samostanu koji je bio nedaleko od Njemačkih vrata ili o dominikanskom samostanu sv. Antuna kojeg su možda tijekom vremena preuzeli franjevci. S obzirom na položaj i stratešku važnost, čini se da se radilo o franjevačkom samostanu, odnosno moža o objektu koji je naveden kao kapetanov stan s prikaza iz 1794., a koji se nalazio u jugoistočnom kutu gradskih zidina uz rijeku, a iza velikog bastiona. No ovo pitanje ostaje otvoreno, barem dok se ne istraže eklezijalni odnosno odnosi redovničkih zajednica u gradu.

\footnotetext{
http://sammlungenonline.albertina.at/?query=Inventarnummer=[Foto2002/34/77]\&showtype=record, Pristup 13.3.2019.

981 „,wie man schon die Tor zuesperren wollten“. SI AS 2, DSK, kutija 414, fascikl 284, Črnomelj, 28.9.1565., 1r, rbr. 1369. Balthasar Katzianer na Ivana Lenkovića

${ }^{982}$ KRUHEK, Krajiške, 64.

983 „,denselben pruedern inyeczgemelten closter mit ernst aufzulegen, da sy ir thürll (welches durch iren gardten auf das wasser geet, vnd sy den schlüssl darzue haben) pefestigen vnd pey tag vnd nacht in guetter verwarung halten “. LOPAS̆IĆ, SHK, knjiga III, dok. VIII, 404.

${ }^{984}$ IBID.

${ }^{985}$ Franjo Emanuel HOŠKO, Franjevci u Krbavskoj biskupiji, u. Krbavska biskupija u srednjem vijeku, ur. Mile Bogović, Visoka bogoslovska škola u Rijeci, Kršćanska sadašnjost, Rijeka-Zagreb, 1988., 90.
} 


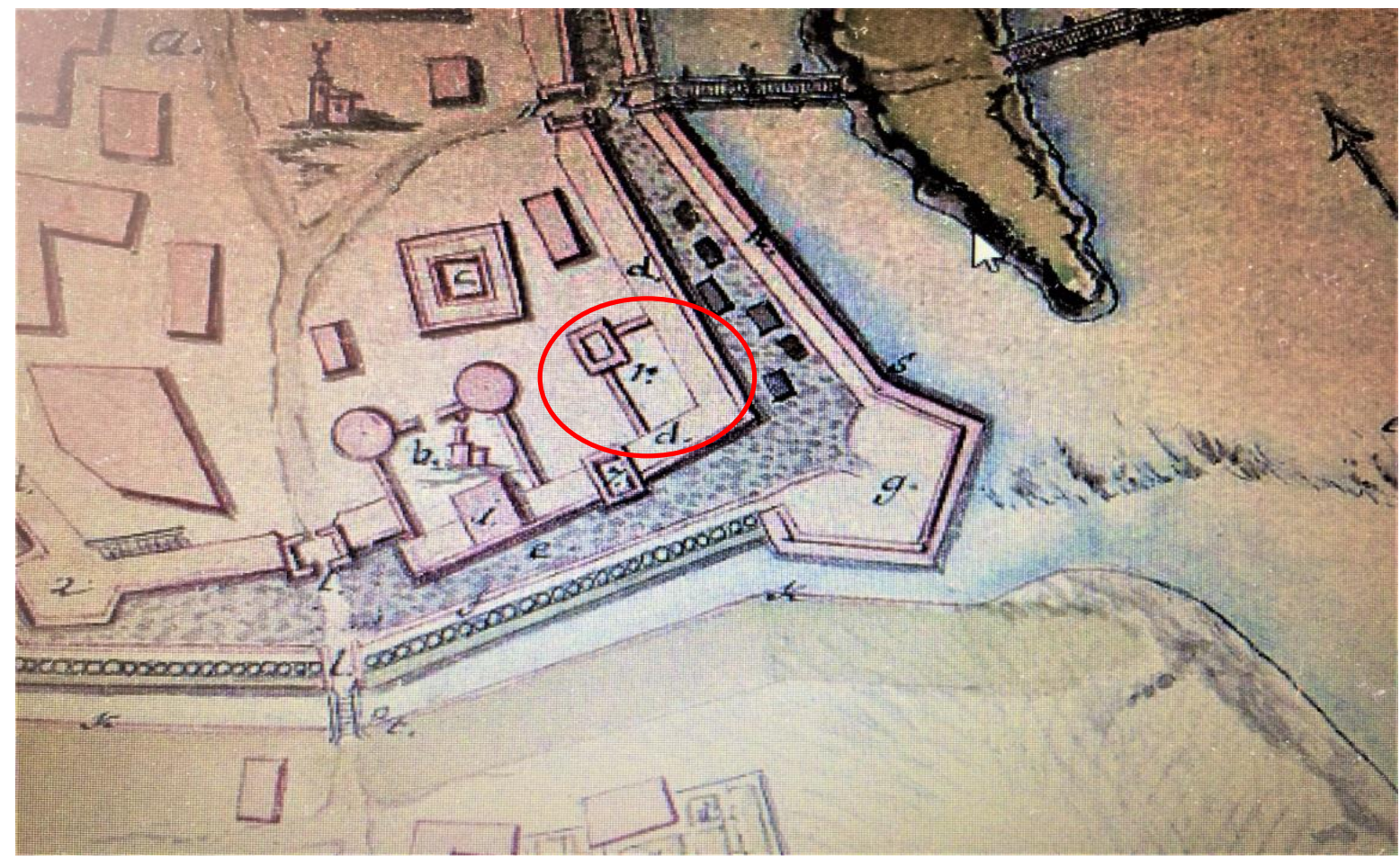

Slika 24. Položaj kapetanova stana, a ranije možda i franjevačkog samostana, na prikazu iz 1794.986

Ovaj primjer također pokazuje da je proces povojničenja, odnosno militarizacije Bihaća isprepleo razne instance u gradu - civilne, vojne i eklezijalne.

Kao što je rečeno, najreprezentativniji vojni objekt u gradu bio je gradski kaštel koji se nalazio na južnoj strani i koji je bio spojen s gradskim zidinama. Imao je tri obrambene kule i jednu četverokutnu kulu. Uz kaštel stajala su Njemačka vrata s pokretnim mostom, o čemu će biti riječi dalje u tekstu.

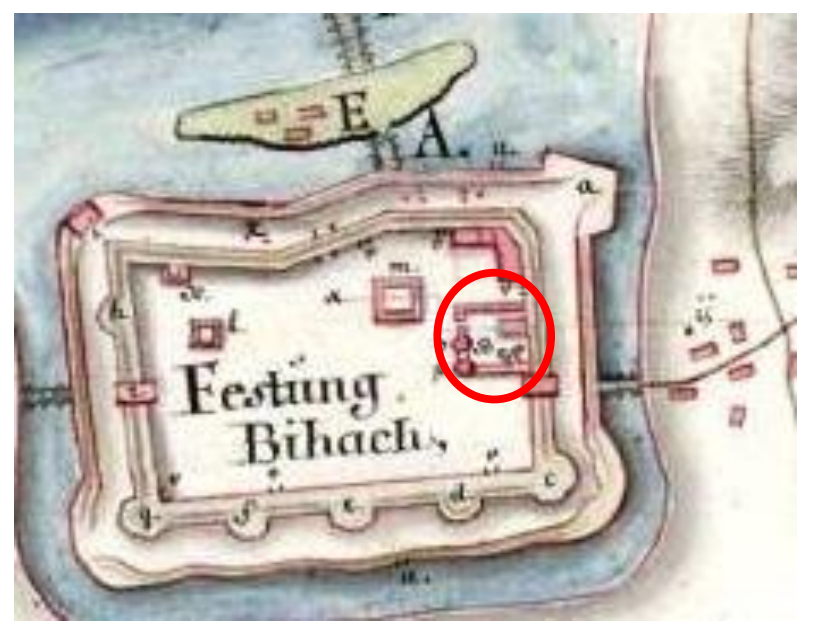

Slika 25. Položaj kaštela na planu iz 18. stoljeća. ${ }^{987}$

\footnotetext{
${ }^{986}$ Dostupno na https://maps.hungaricana.hu/hu/HTITerkeptar/2955/view/?pg=0\&bbox=-1811\%2C7072\%2C7292\%2C-2401 Pristup 13.2.2019.
} 


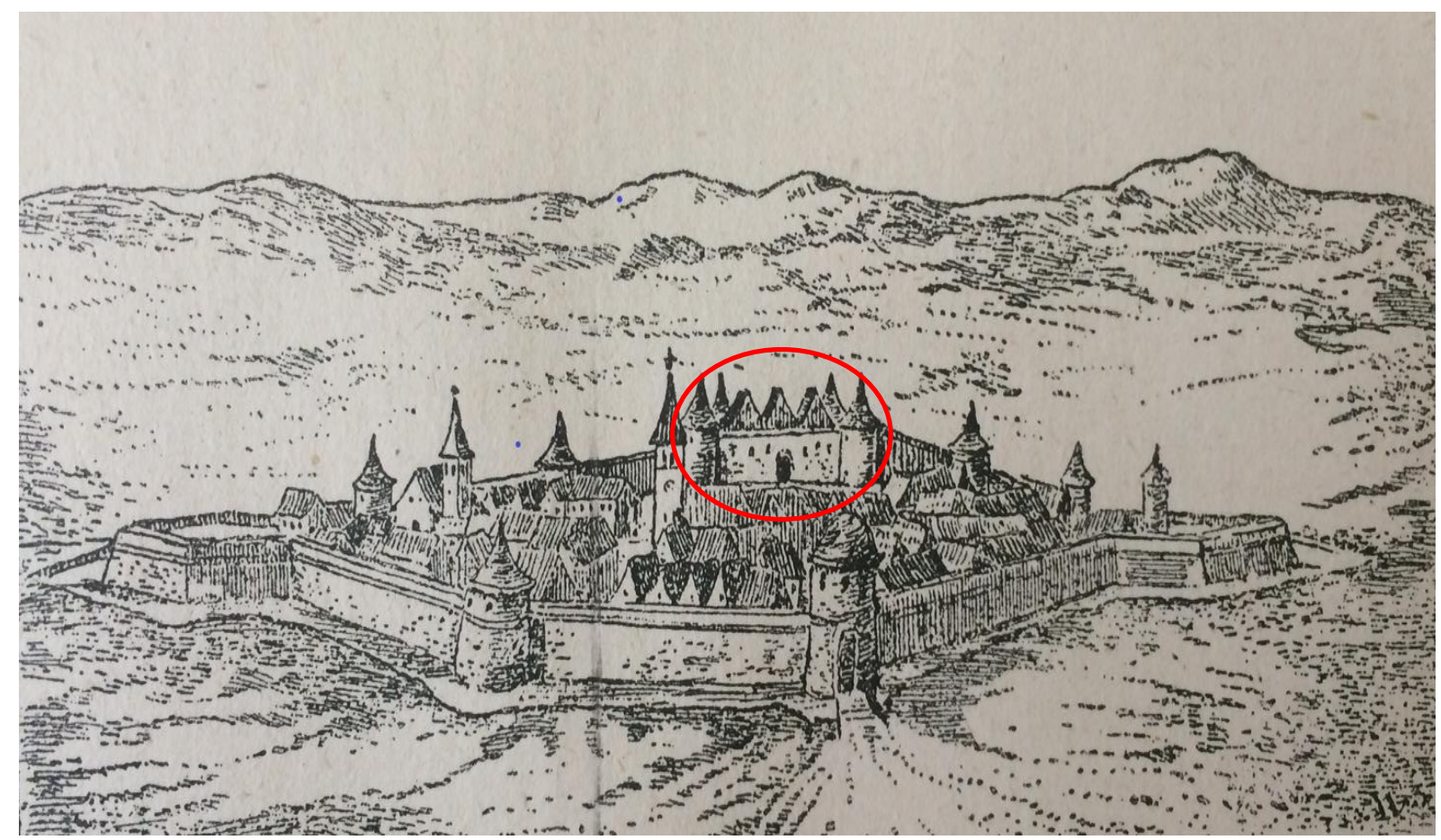

Slika 26. Prikazi kaštela na poznatom Valvasorovu bakrorezu. ${ }^{988}$

Grad je opasavao zid sa sedam kula i, čini se, barem dva bastiona, a o njegovu građevinskom stanju raspravljalo se od samog zasjedanja Habsburgovaca na ugarsko-hrvatsko prijestolje. Već se u prijedlogu obrane Bihaća, koji je u srpnju 1527. sastavio Nikola Jurišić, kao znatna potreba (merklichen notturft) navodi imenovanje jednoga graditelja (paumeistera) kojemu bi se trebala doznačiti svota od 1000 rajnskih guldena za popravak kaštela (gschloss). Takav potez, nadodao je Jurišić, izazvao bi i „,veliki nemir u Turskoj“. ${ }^{989}$ Jurišić je također zatražio da se Ripač potpuno osigura zidom jer je tek trećina mjesta bila obzidana pa je grad branila (samo) rijeka Una. Kada bi se Ripač potpuno zaštitio zidom, uplašeno lokalno stanovništvo ponovno bi se sa ženama i djecom tamo vratilo, komentirao je Jurišić. Prema njegovu mišljenju, taj se posao mogao realizirati s manjim novčanim iznosima, a ako Bihać $i$ Ripač ostanu ipak neobnovljeni, neće se dugo moći održati pred bosanskim Osmanlijama (Wossnern). U odgovoru na iznesene prijedloge, upisane u samom spisu, stoji da se zbog ratne situacije i velikih troškova, kojima je vladar opterećen te približavanja zime ne može tako hitro pristupiti izvođenju građevinskih radova, ali će se u međuvremenu poduzeti što se može,

\footnotetext{
${ }^{987}$ HR-HDA-904, Zbirka planova, Inv. br. 11

${ }^{988}$ LOPAŠIĆ, Bihać, 75.

989 THALLÓCZY, HODINKA, A horvát véghelyek, dok. CXLIV, 692.
} 
a vladar će o prijedlogu ozbiljno promisliti. ${ }^{990}$ Kasnije ćemo vidjeti da će Ripač ipak još desetljećima ostati u sličnom stanju.

Za period 1530-ih nemamo osobito detaljne izvore o građevinskim aktivnostima $\mathrm{u}$ gradu iako su se tada dogodile neke važne graditeljske intervencije. To se prije svega odnosi na podizanje bastiona koji se, smatram, nalazio na južnoj strani grada, pored Njemačkih vrata uz rijeku Unu. U lipnju 1530. vodostaj Une bio je vrlo nizak, na nekim mjestima ni ,zwaier Span“ dubok pa je vicekapetan Ivan Lenković namjeravao podići vodostaj izgradnjom brane i bastiona, ali su građani lamentirali da nema svrhe bilo što graditi kada vojnici odlaze. ${ }^{991}$ Dakle, tada još nema ni bastiona ni brane (Wuera/Wöhr) koji će kasnije biti među najvažnijim obrambenim elementima bihaćkoga utvrdnog sustava. Bastion je štitio Otoku i prilaze gradu iz tog smjera mostovima te prilaz Njemačkim vratima. $\mathrm{Na}$ bastion je prilazila brana također prikazana na planu iz 1794.

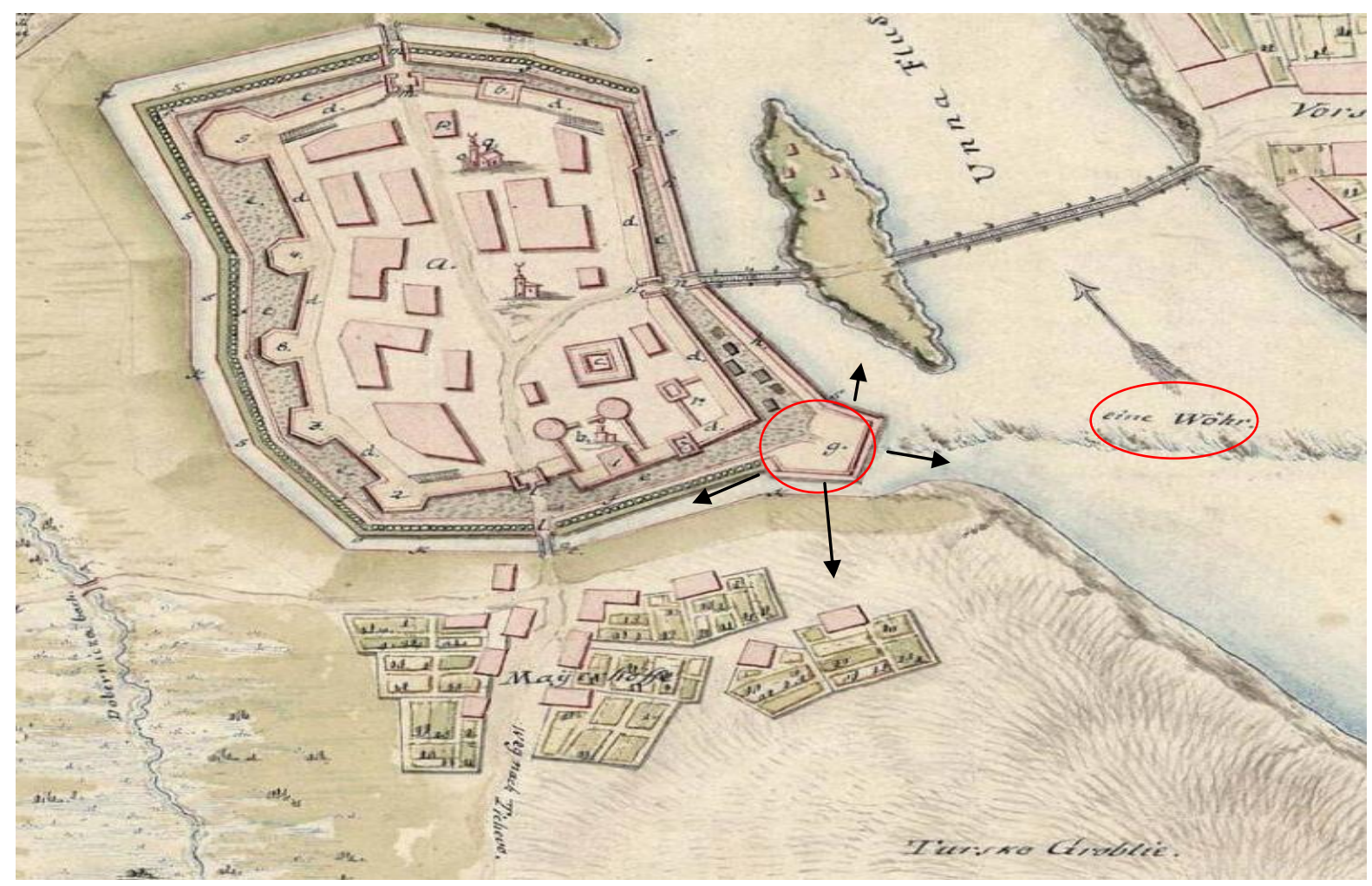

Slika 27. Prikaz velikog bastiona na južnoj strani s možebitnim smjerovima obrambenog djelovanja te brane na planu iz $1794 .^{992}$

\footnotetext{
${ }^{990}$ IBID., 692-695.

${ }^{991}$ LASZOWSKI, HSKHDS, knjiga I, dok. 367, 352.

${ }_{992}$ Dostupno na https://maps.hungaricana.hu/hu/HTITerkeptar/2955/view/?pg=0\&bbox=-1811\%2C7072\%2C7292\%2C-2401 Pristup 13.2.2019.
} 


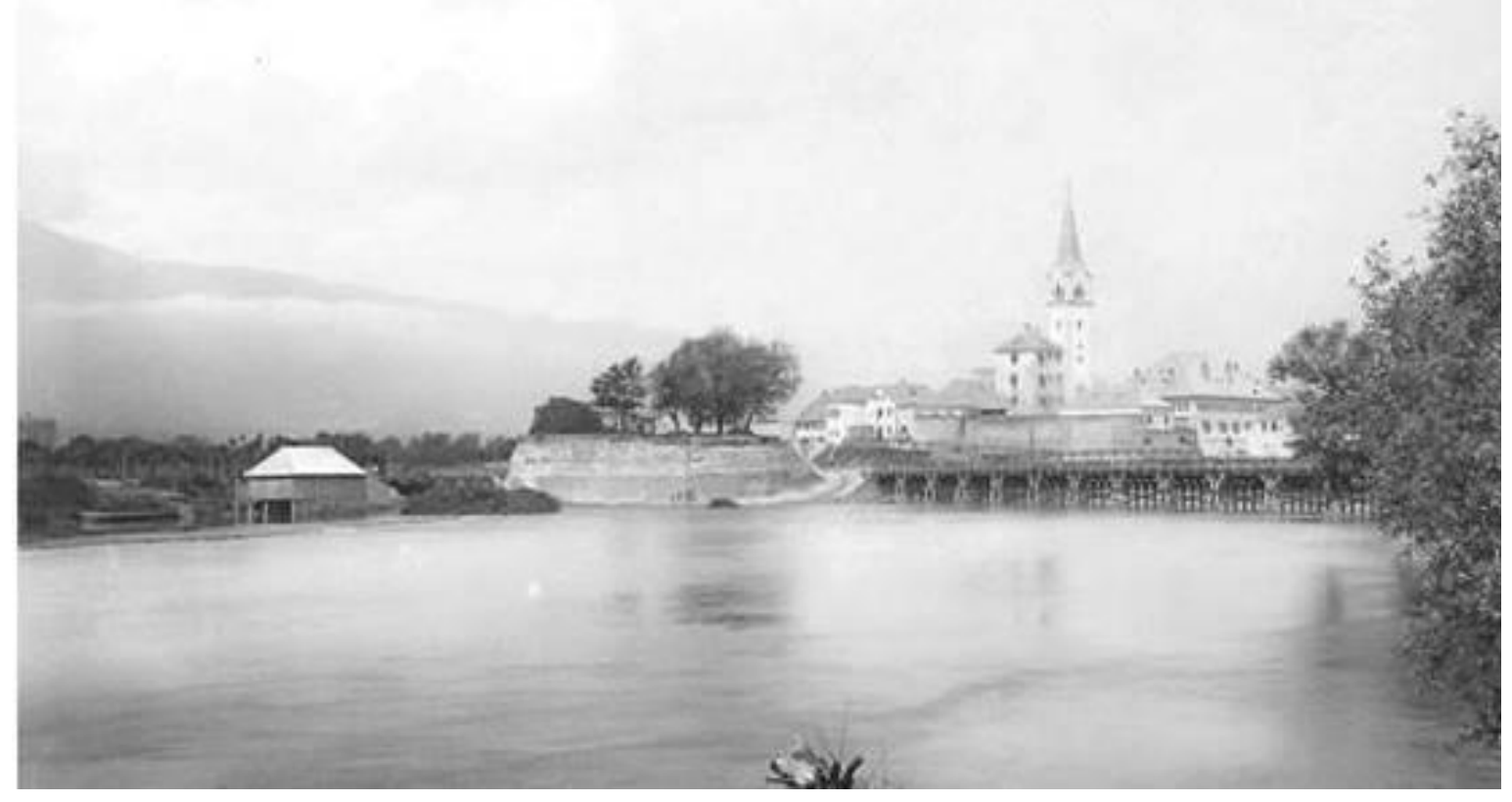

Slika 28. Veliki bastion te most na fotografiji iz $1890 .{ }^{993}$

Međutim, planirani građevinski radovi nailazili su na određene probleme. U lipnju 1531. bihaćki kapetan Erasmo Thurn od kralja je tražio građevinske intervencije, ali se pritom žalio da su bihaćki građani (purgger, purggerschaft) oslobođeni od sudjelovanja u radovima (fur dermassen robeit gefreyt) te su se očito i protivili kapetanovim pokušajima da ih prisili ili uključi u radove. Thurn je molio kralja da se od njih pismeno zatraži da participiraju u radovima jer se radi i o njihovoj sigurnosti. Izuzeće od sudjelovanja u građevinskim aktivnostima, barem kada se radilo o navedenim fortifikacijskim objektima, građani su temeljili na određenim pravima koja su posjedovali kao gradska općina. Budući da su smatrali da će im biti ugrožene njihove slobode, Thurn je sugerirao kralju da garantira da im se to neće dogoditi. ${ }^{994}$ Kralj Ferdinand zaista je pozvao 9. lipnja bihaćke građane (Ciuitati Bihigiensi) da sudjeluju u popravku zidina. ${ }^{995}$ Osiguranje radne snage za građevinske radove generalno je predstavljalo problem, pa su članovi krajiškog povjerenstva 1563. predložili da se ukine

\footnotetext{
${ }^{993}$ Raimund Stillfried von Rathenitz (Komotau, Böhmen 1839 - 1911 Wien, Bihac vom Ufer, Kassette mit 80 Aufnahmen: Bosnien und Herzegowina / Aufgenommen von / Baron R. Stillfried / K. u. K. Hof-Photograph / Wien / I., Reichsrathstrasse 27. http://sammlungenonline.albertina.at/?query=Inventarnummer=[Foto2002/34/78]\&showtype=record Pristup 13.3.2019.

994, jnen solch robeit, an jrn freyheittn vnuorgriffen were“. LASZOWSKI, HSKHDS, knjiga II, dok. 57, 44. ${ }^{995}$ IBID., dok. 58, 45.
} 
praksa puštanja zarobljenih Osmanlija, primarno martologa, na otkup, te da ih se iskoristi za veće građevinske radove, primjerice, u Bihaću (statlich gepeue). S dolaskom zime i prestankom građevinskih radova, moglo ih se prodati za veslače na galijama. Predloženo je i da se ubojice i kriminalci koji su zaslužili smrtnu kaznu na području unutrašnjeaustrijskih zemalja također iskoriste $u$ te svrhe, a njihova bi se smrtna presuda razmotrila nakon što neko vrijeme provedu na gradilištima. ${ }^{996}$

Početak izgradnje tog bastiona definitivno pada u razdoblje kada je na mjestu kapetana bio Erasmo Thurn jer 1543. predstavnici bihaćke gradske općine navode da je izgradnja bastiona započela tijekom njegova zapovijedanja. ${ }^{997}$ No, nije sasvim jasno je li izgradnja počela tijekom njegova prvog službovanja na mjestu kapetana početkom 1530-ih ili tijekom dvije godine (1538.-1539.) kada je Bihaćem zapovijedao kao „obrister an den Khrabatischen orthflekhen“. Pretpostavljam da su radovi ipak započeli početkom 1530-ih zato što su se već 1540. pojavili ozbiljni strukturalni problemi. ${ }^{998}$ Naime, taj bastion, ugrađen u gradske zidine, bio je isprva izgrađen od zemlje i pokriven travnatom površinom (travnjakom), ali kapetan Gall 1540. navodi da nije stabilan. Čini se da se već počeo urušavati, a s obzirom na to da su daljnjom degradacijom prijetili dodatni financijski troškovi, trebalo ga je čim prije osigurati jednim zidom. ${ }^{999}$ Predstavnici kranjskih staleža i vicedom pisali su Gallu da procijeni troškove kako bi kod cara mogli intervenirati da se to odmah riješi. ${ }^{1000}$ Postavlja se pitanje da li je to realizirano jer se u navedenoj molbi iz 1543. predstavnici bihaćke gradske općine žale da je djelomično propao bastion (Postein) koji je podignut još tijekom zapovijedanja Erasma Thurna i koji se nalazi na strateški važnom mjestu preko kojeg se moglo ući u grad. ${ }^{1001}$ Doduše, ako je i obnovljen par godina ranije, ali nije osiguran zidom, možda je opet propao.

Sredina stoljeća inače je razdoblje ekstenzivnih građevinskih radova na slavonskom prostoru - obnavljaju se i nadograđuju Zagreb, Ivanić, Križevci, Đurđevac, intenzivno se gradi varaždinski stari grad, a Zagrebački kaptol podiže novi kaštel u Sisku. ${ }^{1002}$ Za razliku od intenzivnih građevinskih aktivnosti na Slavonskoj krajini, na Hrvatskoj se krajini do tada,

\footnotetext{
${ }^{996}$ AHAZU, Lopašić, E. Prijepisi iz austrijskih arhiva, br. 15, str. 79-80.

${ }^{997}$ LASZOWSKI, HSKHDS, knjiga III, dok. 174, 66-167.

${ }^{998}$ Riječ je o relativno ranoj izgradnji novih fortifikacijskih elemenata, osobito ako se komparira s, naravno mnogo kompleksnijim bastionskim sustavom Beča koji se započeo graditi krajem 1540-ih. Christopher DUFFY, Siege Warfare. The Fortress in the Early Modern World 1494-1660, Routledge \& Kegan Paul, London, 1979., 202.

999 „was massen die Paschstain von Wesen in der Stat-Maur aufgepaut worden, weliche aber wahrlich nit bestandig ist". LASZOWSKI, HSKHDS, knjiga II, dok. 493, 491.

${ }^{1000}$ SI AS 2, DSK, kutija 193, fascikl 119/120, Bihać, 24.5.1540. Predstavnici kranjskih staleža i vicedom na Merta Galla.

${ }^{1001}$ LASZOWSKI, HSKHDS, knjiga III, dok. 174, 166-167.

1002 KRUHEK, Krajiške utvrde, 149
} 
prema riječima zapovjednika Hrvatske i Slavonske krajine Hansa Ungnada s kraja 1544., tek povremeno interveniralo, prije svega se nešto popravljalo ili krpalo postojeće stanje nego što se obnavljalo i gradilo novo. Prema Ungnadu, na hrvatskom prostoru od Senja do Zagreba nije bilo utvrđenja u kojem bi se mogao smjestiti veći broj vojnika te čuvati veće količine ratnog materijala, opreme i živeži. Zato se Ungnad već tada zalagao da se na tom potezu podigne nova tvrđava ili čak nove velike ratne tvrđave. ${ }^{1003}$ Zanimljivo je da tada Ungnad nije smatrao da Bihać ima kapacitet za smještaj vojske i ulogu većega logističkog centra te da se zalagao za podizanje nove ratne tvrđave. U Bihaću se $u$ tom periodu nastavila intervencija na bastionu pa je tako kapetan Georg Sauer 1. kolovoza 1544. tražio da mu se pošalje više novaca kako bi hitno mogao završiti navedeni bastion i druge građevinske poslove. ${ }^{1004} \mathrm{Za}$ radove na bastionu tražio je da mu se doznači 300 rajnskih guldena. ${ }^{1005}$

Opširan izvještaj o stanju utvrda Senjske i Bihaćke kapetanije sastavio je 1550. Ivan Lenković. Ovaj izvještaj objavljen je u trećem svesku Lopašićeve edicije „Spomenici Hrvatske krajine“, a detaljno ga je opisao Milan Kruhek u djelu „Krajiške utvrde Hrvatskog kraljevstva“. U nastavku ću koristiti Kruhekov prijevod s određenim intervencijama baziranim na izvornom gradivu. Prema Lenkovićevu izvještaju, glavna obrambena kula bila je četverokutnog oblika, a činila je dio kaštela. Nalazila se neposredno iznad toka rijeke Une. U toj je kuli trebalo obaviti popravke drvenih podnica i svodova, a da bi se zidovi kule zaštitili od destruktivnog djelovanja riječnog toka, trebalo je vanjsku stranu zida osigurati zemljanim nasipom utvrđenim hrastovima koljem. Na središnjem katu nalazila se stambena prostorija, a za gornji je kat Lenković predložio mjere karakteristične za prilagodbu starije fortifikacijske arhitekture novim varijantama vatrenog naoružanja - otvaranje novih puškarnica i uređenje zaštitnog vijenca oko novootvorene terase na koju je trebalo smjestiti teške bedemske puške. Dio tih poslova već je bio odrađen pa je za ostatak trebalo utrošiti tek 40 rajnskih guldena. Ostale tri kule tada su bile već dijelom obnovljene (stavljeni novi podovi i krovišta), uz napomenu da u kuli ,prema vodi“ treba urediti stubište i prostorije za stanovanje zapovjednika. U toj, tada zapuštenoj prostoriji bio je stan zapovjednika kada je boravio u gradu. Što se građevnog materijala tiče, on se mogao uzeti sa urušene stambene zgrade koja se nalazila pored kaštela, a na čijem je mjestu trebalo sagraditi prizemnicu s kuhinjom i stanom za poslugu. To bi koštalo 40 rajnskih guldena (no piše da je već obavljeno). Na kaštelu su već zamijenili vrata i pokretni most što je stajalo 15 rajnskih guldena. Trebalo je pojačati i vrata

\footnotetext{
1003 IBID., 157.

${ }^{1004}$ SI AS 2, DSK, kutija 804, fascikl 539/540, Bihać, 1.8.1544., 2r.

${ }^{1005}$ SI AS 2, DSK, kutija 200, fascikl 123b, Ljubljana, 3.8.1544., 1r. Predstavnici kranjskih staleža na Georga Sauera.
} 
koja su vodila preko dugog mosta izvana na gradske zidove pokraj kaštela te pomični most. Iznad vrata trebalo je izgraditi male izbočene tornjiće (erkere) od hrastova drveta s izbačenim otvorima i puškarnicama za obranu koji bi otvorenom linijom vatre štitili kaštel u gradu, most pred gradskim zidom i stražarnicu pred njima, a to bi koštalo oko 50 rajnskih guldena. U zidnima kraj dominikanskog samostana nalazila se kula kružnog tlocrta koju je trebalo ojačati eskarpom, to jest potpornom strukturom obloženom kamenom ili opekom u obliku trokuta. $\mathrm{Na}$ vrhu je trebalo urediti otvorenu platformu za topove na čvrstoj hrastovoj podnici. To bi stajalo 300 rajnskih guldena. U zadnjoj kuli trebalo je urediti puškarnice, podnicu i krovišta, a to bi koštalo 40 rajnskih guldena te bi taj posao trebali obaviti Bišćani. Nažalost, nije precizirano zašto bi za popravak upravo te kule bili zaduženi baš građani. Lenković kaže da je u gradskom zidu nasuprot unskom otočiću ,prije nekoliko godina“ podignut bastion obložen izvana zidom, no koji je sada već propao i trebalo bi ga obnoviti jer je to vrlo istaknuto i važno obrambeno mjesto na kojem se drže gradske straže. Dakle, bastion je do tada već ipak obložen zidom iako je opet trebalo građevinski intervenirati. Trošak je procijenjen na 600 rajnskih guldena, ali budući da je u trenutku pisanja već dosta toga bilo obavljeno, a bila su osigurana i sredstva, pretpostavljao je da bi obnova mogla početi na proljeće te uz dobru organizaciju biti iste te godine i završena. Lenkoviću se nije svidjela pozicija velikih vrata, smještenih nasuprot unskom otočiću, dakle Unskih vrata, pa je smatrao da ih treba zazidati i nad njima podići dobro zaštićenu kulu kružnog tlocrta, a vrata probiti na manje izloženoj lokaciji, kod crkve sv. Antuna. To bi stajalo 50 rajnskih guldena. Kutni dio gradskih zidina nasuprot franjevačkom samostanu trebalo je ojačati zemljanim nasipom s eskarpom, a to bi stajalo 200 rajnskih guldena. Franjevci su morali dobro utvrditi vrata (thürll) u gradskom zidu do kojih se dolazilo preko njihova vrta i čije su ključeve čuvali. Tamo je trebalo podići jedan mali erker ili barem manju obzidanu kulu, što je i učinjeno. Pristup do vrata Rakov Brod trebalo je utvrditi jer je grad na tom dijelu odasvud bio okružen rijekom. To bi stajalo 15 rajnskih guldena. Trebalo je utvrditi i manja gradska vrata u kružnom dijelu zidina koji se zove Polače. Radilo se o najslabije branjenom dijelu gradskih zidina uz rijeku Unu gdje nije bilo ni kule ni nasipa ni bedema. Taj zid trebalo je prelomiti i utvrditi izvana, uz trošak od 600 rajnskih guldena. $\mathrm{Na}$ cijeloj dužini kruništa nije bilo galerije, nikakva zaklona, zaštićena prolaza, odnosno ničeg za sigurniju ophodnju i obranu. Trebalo je odmah nadozidati usko krunište, načiniti puškarnice i zaštićene galerije uzduž cijele dužine. Trošak bi iznosio 350 rajnskih guldena. Kod župne crkve obrana je bila jako slaba pa je odmah predložio prigradnju zaštitnog zida, to jest neke vrste zaštićene platforme za artiljerijsku obranu. Lenković je tada pregledao i ostale utvrde pod zapovjedništvom bihaćkog zapovjednika. Prvi na redu bio je 
Ripač, velika četverokutna kula od meka kamena na tri kata, smještena milju južnije od Bihaća. Kula je bila bez krovišta već tri godine i bez zaštitnog prsobrana na vrhu iako je krunište postojalo jer je Lenković vidio njegove ostatke na jednoj strani. Bila je i raspuknuta na više mjesta, u jednom kutu poprilično propala, a veliki prozori i otvori zatvoreni tankim daskama. Dakle, kulu je trebalo detaljno obnoviti, staviti nova jaka vrata, urediti unutrašnja stubišta i hrastove podnice. Zidove je trebalo učvrstiti sa svih četiriju strana, a u kaštelanovoj odnosno porkulabovoj prostoriji probiti jedan prozor, uz trošak od 300 rajnskih guldena. Samo naselje stajalo je na unskom otočiću koji je štitio kaštel. Taj trg bio je širok oko 470475 metara (251 klafter) i bio je zatvoren zidom i ogradom od kolja, a na drugoj strani samo rijekom Unom. Dakle, ništa se važnije nije promijenilo od Jurišićeve inspekcije 1527. Kao i Jurišić, Lenković je smatrao da cijelu zapadnu stranu treba opasati zidom ojačanim zemljanim nasipom te podići most s trima dobro branjenim vratima. Trošak izgradnje zidina oko naselja iznosio bi visokih 2000 rajnskih guldena, a zaštitnog bedema oko 300 rajnskih guldena. Budući da se Lenkoviću činilo da će Ripač biti teško obraniti, predložio je da se sruše zidovi oko trgovišta i pedesetak preostalih kućeraka te da se utvrdi i brani samo kaštel. Čini se da je Sokol, pozicioniran sjeverno od Bihaća na jednoj strmoj litici i iznad rijeke Une, bio u nešto boljem stanju. No, i tu je trebalo urediti propali krov te otvoriti puškarnice i krunište na vrhu. Jednu stranu vanjskih zidina trebalo je povisiti jer su prije par godina Osmanlije na tom mjestu provalili unutra iako nisu uspjeli osvojiti kulu. Lenković je i ovdje predložio podizanje jednog erkera za stražu te stavljanje krova i popravak četverokutne kule u gradskim zidinama kroz koju se ulazilo u unutarnje dvorište. Sve to koštalo bi 150 rajnskih guldena. Lenković je svoj izvještaj o utvrdama Bihaćke kapetanije završio s Izačićem. Ta prostrana okrugla kula, okružena dvostrukim zidovima, bila je smještena na izvanrednom i lako branjivom strateškom položaju. No, drvene konstrukcije i ovdje su bile propale. Krov i podove trebalo je obnoviti, na oba vanjska zida urediti ulazna vrata te oko vanjskih zidova instalirati drvenu galeriju. Trošak tih radova iznosio bi tek 50 rajnskih guldena. Na samom kraju izvještaja Lenković je procijenio da bi nabava željezne robe za izradu vrata na nabrojenim utvrdama koštala 100 rajnskih guldena, a ukupna svota, uz iznimku okolnog zida u Ripču, 3510 rajnskih guldena. Za uređenje dviju peći za pečenje vapna u Bihaću trebalo je osigurati 100 rajnskih guldena. Ukupan trošak bio je poprilično velik, a ako se tome doda i izostavljeni trošak okolnog zida u Ripču, skočio bi na oko 5500 rajnskih guldena. ${ }^{1006}$

${ }^{1006}$ KRUHEK, Krajiške utvrde, 166-170.; LOPAŠIĆ, SHK, knjiga III, dok. VIII, 403-406. 
U periodu nakon Lenkovićeva izvještaja navode se ipak nešto skromnije intervencije. Početkom kolovoza 1557. kapetan Georg Zoblsperg javlja da su krovovi i „drugo“ u kaštelu (gchlo $\beta$ ) propali, da krovovi prokišnjavaju, a da su se u zidinama (Rinkhmauer) na nekoliko mjesta otvorile velike rupe. Sve je to trebalo odmah popraviti pa je tražio da mu se pošalje nekoliko stotina rajnskih guldena. ${ }^{1007}$

Ivan Lenković je u listopadu 1562., kada je zapovjednik na Hrvatskoj krajini Herbart Auersperg bio odsutan zbog zdravstvenih problema, okupio sve hrvatske konjanike, pješake i na saboru određene podanike za izgradnju utvrda (Crabatischen Robath) te ih poslao utvrđivati bihaćke ade (Wichitschers Wordts) i mostove pod Krupom. Budući da je došlo do osmanskog upada koji je poremetio Lenkovićeve daljnje planove, nije jasno je li taj naum izvršen. ${ }^{1008}$ Ipak, ovaj navod pokazuje da nije utvrđivana samo Otoka, glavna bihaćka ada, već i druge ade na Uni oko grada. Strateško značenje rijeke i riječnih otoka bilo je golemo.

Sljedeći detaljan izvještaj o građevinskom stanju u Bihaću sastavilo je kraljevsko povjerenstvo 1563. koje navodi da se Bihać nalazi na unskom otoku koji u dužini od skoro „velike milje“ okružuju vode rijeke Une, a pored kojeg se nalaze planine Đavolji vrtal i Plješevica. Una se oko otoka razlijeva u mnogo rukavaca koji dobro štite grad pa je Bihać, unatoč lošoj opskrbljenosti i lošem građevinskom stanju, i dalje u kršćanskim rukama. ${ }^{1009}$ Povjerenici su predložili da se u Bihaću, na kamenoj podlozi na kojoj leži grad podigne jedna, „kako se na talijanskom kaže“, citadela čije bi zidine (gemauer) bile visoke 2 tvrđavinska klaftra (werch klaffter hoch) dok bi ostatak citadele privremeno mogao biti napravljen od zemlje i pokriven travnjakom (ertrich und wasen). Za to se moglo uzeti kamenje s ruševnoga kaštela ili jednoga starog urušenog samostana. ${ }^{1010}$

Prema jugu, izvan grada i tada ruševnoga kaštela, na otprilike 200 tvrđavinskih klaftri nalazila se jedna uzvisina koja je nadvisivala kaštel. Vjerojatno su mislili na Debeljaču, brdo južno od Bihaća. Povjerenici su smatrali da je mudro, ako je to moguće i ako ne iziskuje velike troškove, utvrditi taj položaj ili se s njega povući. Očito je taj položaj branjen, ali slabije nego što su povjerenici smatrali potrebnim. Možda su tamo bile stacionirane straže. Kod bastiona prema sjeveru (mitternacht) trebalo je podići branu na kojoj bi mogli stajati i

\footnotetext{
1007 SI AS 2, DSK, kutija 201, fascikl 124, Bihać, 7.8.1557., 1v, rbr. 501. Georg Zoblsperg na predstavnike kranjskih staleža.

${ }^{1008}$ HDA, Militaria, kutija 7, Pobrežje, 16.10.1562., 1r. Ivan Lenković na predstavnike kranjskih staleža.

1009 AHAZU, Lopašić, E. Prijepisi iz austrijskih arhiva, br. 15, str. 60-61.

1010 Jedan bečki odnosno donjoaustrijski klaftar iznosi oko 1,90 cm. Ako bi se koristila ta računica, to bi iznosilo tek oko 4 metara visine. Možda zato stoji „tek“, ali nije sigurno da li se „tvrđavinski kalfter“ razlikovao od običnoga klaftra čije su dimenzije ionako ponešto varirale među regijama, odnosno državama. No, bez obzira na razliku, očito nije planirano da ta citadela bude osobito visoka, a to je u skladu s tadašnjim načelima da se grade niže i robusnije građevine zbog artiljerijskog djelovanja. IBID., str. 62.
} 
mostovi čime bi se mogla podići razina rijeke, a to bi moglo biti od koristi za obranu. ${ }^{1011}$ Dakle, povjerenstvo spominje bastion na sjevernoj strani što potvrđuje da su postojala dva bastiona, kao što to donosi i veduta grada objavljena kod Valvasora. Jedan se nalazio na jugu kod kaštela, a drugi na sjevernoj strani grada. Povjerenstvo se dalje usredotočilo na važan prijelaz preko rijeke kod Brekovice. Ovdje se na mjestu gdje su se dva toka rijeke ponovno spajala, nalazila jedna riječna ada neprestano okružena vodom imenom Mlač (Mlätsch). Povjerenici su smatrali da je neizbježna potreba nalagala da se tamo podigne zidani četverokutni turanj u kojem bi naizmjenično stražarili vojnici iz bihaćke posade oboružani s nekoliko bedemskih pušaka. Bihaćkom kapetanu naređeno je da na adi posiječe i raskrči sve raslinje te da na jednom rukavcu, koji teče iz smjera između juga i istoka, podigne jednu branu kako bi se prema potrebi mogao povećati vodostaj rijeke. To bi se moglo učiniti s malo troškova jer je na tome mjestu bilo dovoljno hrastovine za takvu gradnju. Ako se kvalitetno izgradi, taj bi turanj štitio ne samo brod/prijelaz (urfahr) već i branu koji bi inače ostali nezaštićeni. ${ }^{1012} \mathrm{U}$ izvještaju je navedeno da su i bihaćki građani već nekoliko godina primali iznos od 100 rajnskih guldena za održavanje gradskih vrata i mostova (pesserung der thor vnd pruckhen), ali da su sudac i neki građani taj novac potrošili više za svoju nego za opću korist. Povjerenici su od građana tražili iskaz troškova, ali budući da im građani nisu predočili uredne račune, smatrali su razumnim da im se do buduće carske odluke isplata tih sredstava stopira. Naredili su blagajniku Hrvatske krajine, da zaustavi predviđene isplate, kao i 200 rajnskih guldena koji su trebali biti isplaćeni za tekuću i prethodnu godinu. ${ }^{1013}$

Neki od ovih prijedloga povjerenstva možda su bili brzo realizirani jer je na Hrvatskoslavonskom Saboru 1563. određeno da se Bihać utvrdi angažmanom podanika vlastelinstva Steničnjak, Ostrožin i Topusko. Lopašić navodi da je uoči osmanskog napada 1565. po naredbi nadvojvode Karla probijen jarak pred „tvrđom“ čime je grad zaštićen vodom, ali da su 1566. posao oko uređenja jarka finalizirali sami bihaćki građani. ${ }^{1014}$ Lopašić je vjerojatno mislio na već spomenuti slučaj kada je krajem travnja 1565. bihaćki kapetan Georg Kronschall pisao da je vodostaj rijeke Une toliko nizak da je 40-50 ljudi pod mostovima prema Zavalju (Saulle) lovilo rakove. Kronschall se zbog toga s vojnim časnicima i gradskim sucem dogovarao kako podići vodostaj rijeke. Naime, Una je bila okrenula novim tokom prema dugim mostovima naspram Otoke (ain Newen ganag Auuff dy lannge Pruckhen gegen dem Wörd genumen) te je na dvije strane sasvim otekla od grada otvorivši prostora za

\footnotetext{
1011 IBID., str. 62-63.

1012 IBID., str. 63-64.

1013 AHAZU, Lopašić, E. Prijepisi iz austrijskih arhiva, br. 15, str. 27.

${ }^{1014}$ LOPAS̆IĆ, Bihać, 67.
} 
osmanski napad. Kapetan je s podređenim vojnicima, građanima i seljacima (Pawern) pod svojim zapovjedništvom danonoćno radio kako bi se rijeka ponovno usmjerila oko grada prema Zavalju, a tražio je hitnu asistenciju od Herberta Auersperga i unajmljenih strijelaca. ${ }^{1015}$ Čini se da su radovi tada i realizirani, ali pod zapovjedništvom bihaćkoga kapetana. $^{1016}$

Sredinom 1560-ih grad je konačno (ponovno) okružen jarkom i vodama rijeke Une. Planovi Bihaća koje je 1564. - 1566. načinio Nicolo Angielini, pružaju detaljni prikaz položaja grada u prostoru iako je tekstualne opise grada i Angielinijeve slikovne prikaze donekle teško usporediti. ${ }^{1017} \mathrm{Na}$ planovima je prikazan utvrđen grad sa svih strana okružen tokom rijeke Une te brojni unski otoci oko grada koji se u izvorima pak ne navode u ovakvom broju. Na otocima sjeverno od Bihaća u osmanskom su se periodu nalazili vrtovi pa pretpostavljam da je tako bilo i ranije. Vjerojatno se radilo o riječnim otocima na kojima je živjelo lokalno stanovništvo, kao što je navedeno u već spomenutom diskursu anonimnoga bivšeg visokopozicioniranog časnika Bihaćke kapetanije iz $1592 .{ }^{1018}$

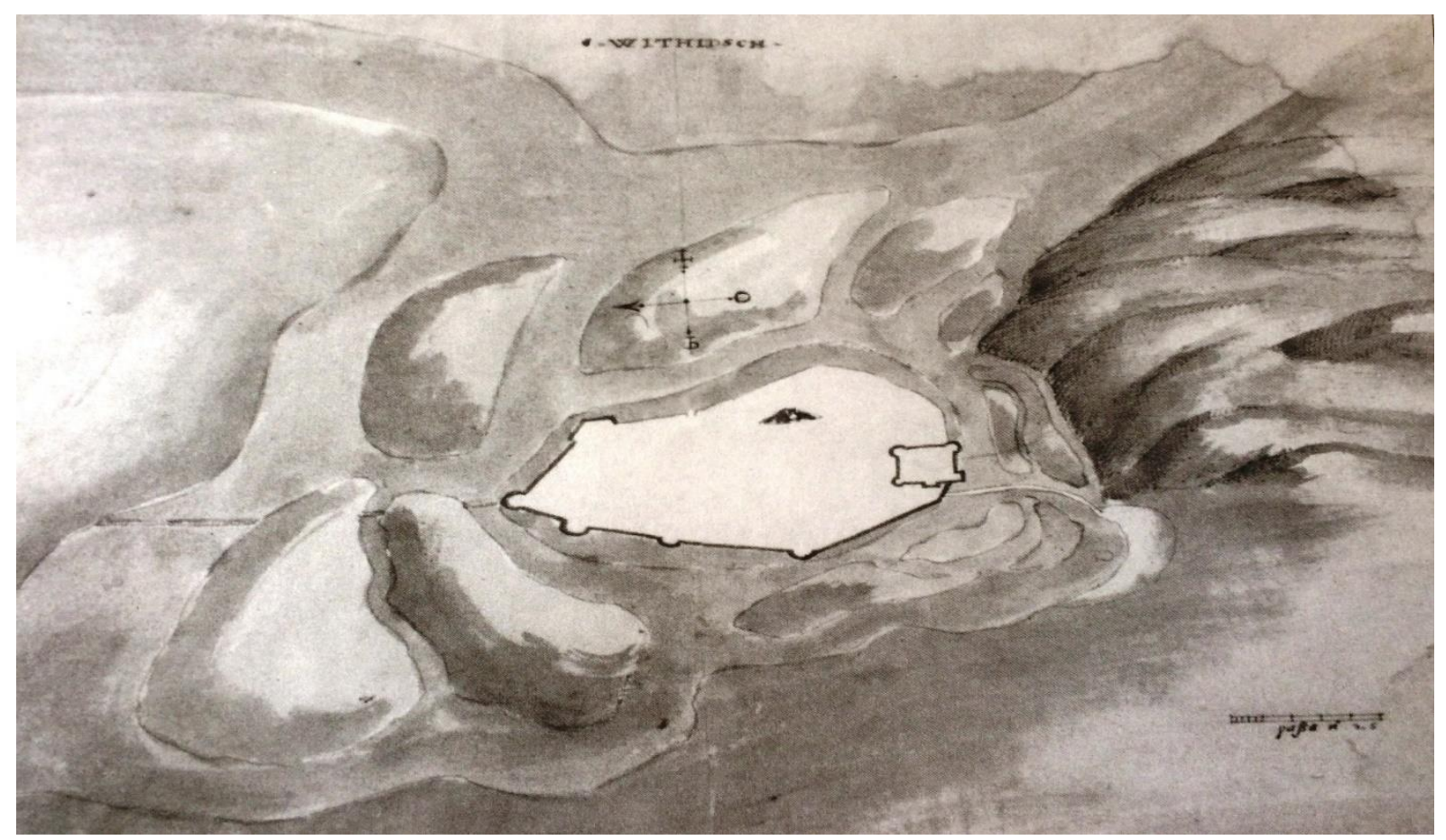

Slika 29. Angielinijev prikaz Bihaća iz 1564. $-1566 .{ }^{1019}$

\footnotetext{
${ }^{1015}$ SI AS 2, DSK, kutija 286, fascik1 282, Bihać, 1r-1v, rbr. 146-147. Georg Kronschall na Herbarta Auersperga. ${ }^{1016}$ SI AS 2, DSK, kutija 286, fascikl 282, Bihać, 1r-1v, rbr. 146-147. Georg Kronschall na Herbarta Auersperga. 1017 Pálffy navodi da karte Hrvatske i Slavonske krajine, koje je u navedenom periodu načinio Angielini, pripadaju među najstarije karte ugarsko-hrvatskog pograničja. Géza PÁLFFY, Európa Védelmében. Haditérképészet a Habsburg birodalom Magyarországi határvidékén a 16-17. Században, Papa, 2000., 138. ${ }^{1018}$ SI AS 2, DSK, kutija 285, fascikl 163, Beč, 5.3.1592., 1v-2r, rbr. 1037-1038. U pismu Davida Ungnada. ${ }^{1019}$ KOZLIČIĆ, Unsko-sansko područje, 87.
} 
Na Angielinijevim planovima vide se kaštel na južnoj strani grada, četiri kule na zapadnom obodu zidina te jedan bastion na sjeveroistočnom dijelu zidina. Dakle, nema bastiona na južnom dijelu grada gdje je kasnije prikazivan i gdje se nalazi do danas. Iako se na kasnijim prikazima jedini ili kao glavni prikazuje bastion na južnoj strani grada, na Valvasorovu prikazu grada nalaze se dva bastiona jer su očito već u promatranom periodu zaista postojala dva bastiona u gradu - jedan na sjevernoj i jedan na južnoj strani grada. Doduše, prema Valvasorovu prikazu oni bi bili pozicionirani prema istoku i zapadu, ali izvori demantiraju takvo što. Na Angielinijevom prikazu glavni prilazi su sa sjevera mostovima preko dva unska otoka te s juga također mostovima preko unskih otoka. Izlaz prema unskoj Otoci nije prikazan, a zaobljeni dio zidina uz glavni tok rijeke Une očito je predio Polača iz Lenkovićeva izvještaja iz 1550. Naznačena je i manja uzvisina u gradu i veće uzvišenje koje je izvan grada nadvisivalo kaštel, a koje je spomenulo i povjerenstvo iz 1563. Iako je plan teško usporediti s izvorima, predstavlja rani i informativni prikaz bihaćkih fortifikacija u prostoru zbog čega je dragocjen. Doduše, iznenađuje činjenica da nisu prikazani mostovi prema bihaćkoj Otoki i preko nje, a koja je bila izrazito važna u stambenom i strateškom pogledu te često spominjana u izvorima.

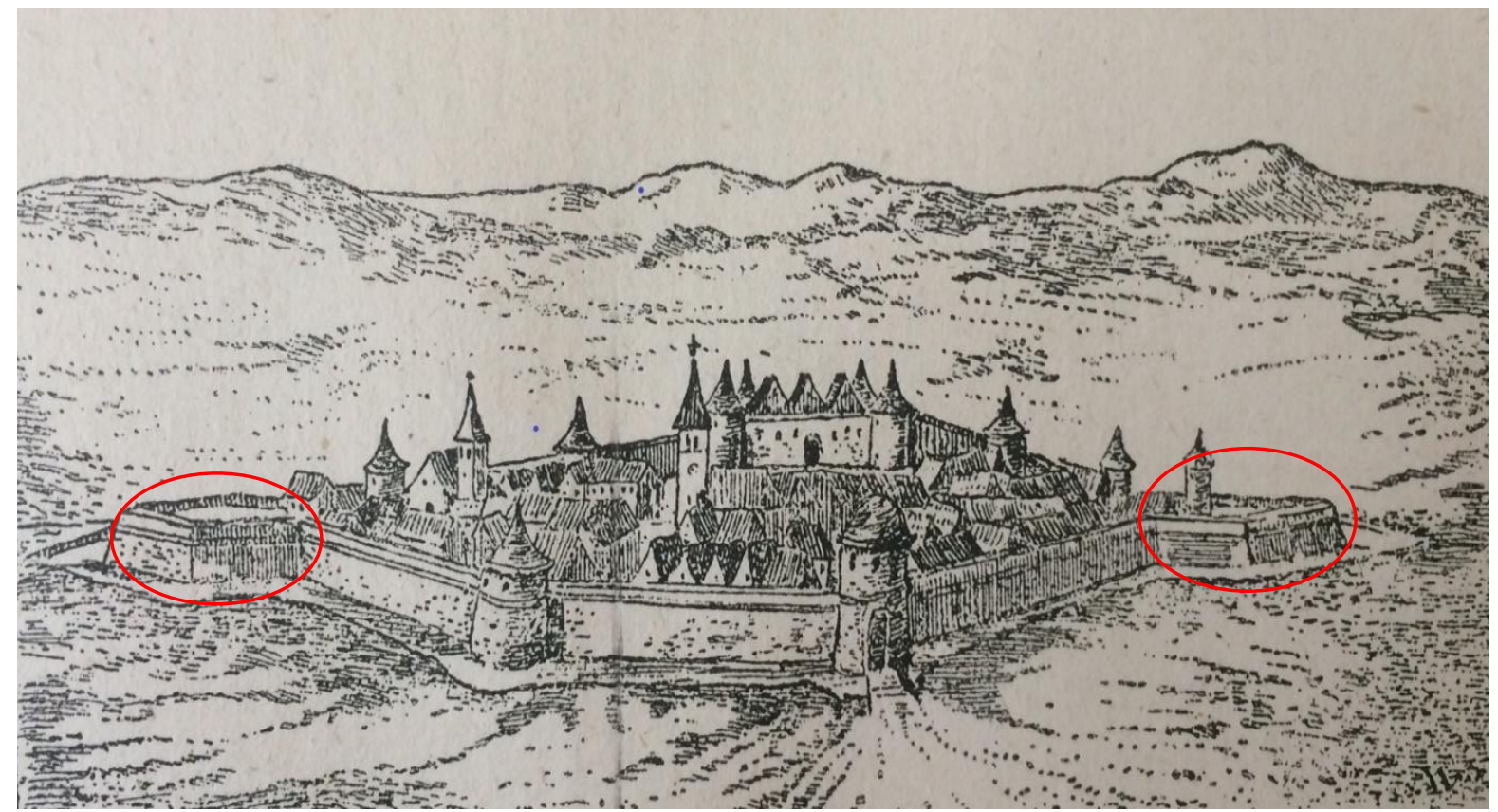

Slika 30. Dva gradska bastiona na Valvasorovu prikazu. ${ }^{1020}$

Izvori pokazuju da su se u ljeto 1566. u Bihaću odvijali radovi na „wasser gepeü“ za koje je prvo utrošeno 400 rajnskih guldena, a zatim još 1100 rajnskih guldena uključujući

${ }^{1020}$ LOPAŠIĆ, Bihać, 75. 
trošak vojnika koji su poslani u Bihać. Bihaćki kapetan Georg Kronschall za građevinske aktivnosti primio je još 221 rajnski gulden i 6 krajcara, za što je bio obvezan predati račune. ${ }^{1021}$ Iako nije navedeno o kojim se točno intervencijama radi, ukupni iznos bio je relativno visok što pokazuje da se radilo o ozbiljnim intervencijama.

U izvještaju Herbarta Auersperga, upućenom caru 12. lipnja 1569., spominju se započeti „Notwendigen Wihitscherischen Gepew“, o kojima je cara već izvještavao i građevinski povjerenik (Pau Comisari) Franz Popendorff. Auersperg je tada pisao da su doduše najbolja vremena već prošla, ali da je nužno pronaći znatna sredstva za radnike, osobito za rudare/knape (Perkhknapen). ${ }^{1022}$ Ponovno nije precizirano o kakvim se točno građevinskim radovima radilo, ali sve to pokazuje kontinuitet građevinskih radova i raznih intervencija u Bihaću.

No, u godinama koje su slijedile izvori pokazuju da je građevinsko stanje i dalje nezadovoljavajuće. U dramatičnom izvještaju iz studenog 1574. bihaćki kapetan Sebastian Lamberg pisao je da su turanj i „,velika“ vrata skroz-naskroz propali te toliko potkopani vodom koja dolazi kroz grabe da će se urušiti zajedno s pokretnim mostom ako se ne podzida najkasnije do proljeća. I prsobrani na bastionu bili su toliko raspadnuti da ih se moralo maknuti pa su sada topovi stajali nezaštićeni na otvorenom prostoru. ${ }^{1023}$ Lamberg nastavlja da nema potrebe ni pisati jer je i sam nadvojvoda upoznat s činjenicom da su kaštel, svi mostovi, kule, vrata, stražarnice, stube i sve ostalo potpuno propali, razbijeni i ruševni te se u slučaju opasnosti ne može braniti ni polovica zidina dok je druga polovica u tako lošem stanju da tome dijelu nitko ne želi ni pristupiti ili ga braniti. To se osobito odnosi na njemačke vojnike, oboružane „ručnim cijevima“ i teškim bedemskim puškama (Iren Handtrore vnnd Toppelhöggen), koji očito nisu mogli ili željeli pristupiti na zidine ili od tamo djelovati u takvim okolnostima. No, ni bihaćka gradska općina više nije željela popravljati mostove i brane (Währen) za što su ranije primali godišnju doznaku od 100 rajnskih guldena. ${ }^{1024}$ Kapetan je držao da bi se moglo, ako se u grad pošalju vojnici, drvosječe i drugi radnici, posjeći dovoljno drva za daske kojima bi se pokrio kaštel i stvorila zaliha za građevinske aktivnosti koje su planirane na proljeće. Također, budući da je bilo izgledno da će se rijeka Una na jednom mjestu kod gornjeg slapa (Schlapp) ponovno probiti, predložio je da bi se taj

\footnotetext{
${ }^{1021}$ HDA, Militaria, kutija 7, 1565./1567., 20r. Iskaz financijskih izdataka Hansa Khiesla, ratnog blagajnika na Hrvatskoj krajini za 1565.-1567. Preslike ovog opsežnog iskaza nalaze se među preslikama spisa za 1561. ${ }^{1022}$ HDA, Militaria, kutija 9, 12.6.1569., 1r-1v.

${ }^{1023}$ SI AS 2, DSK, kutija 286, fascikl 164, Bihać, 16.11.1574., 2v, rbr. 237. Sebastian Lamberg na kranjske Verordneten.

${ }^{1024}$ SI AS 2, DSK, kutija 286, fascikl 164, Bihać, 16.11.1574., 2v-3r, rbr. 237-238. Sebastian Lamberg na kranjske Verordneten.
} 
problem sada mogao riješiti s malim troškom. No, budući da je generalno nedostajalo novaca, a i građevinarima, stolarima i ostalim radnicima trebalo je isplatiti visoke plaće, do tada se ništa nije napravilo. ${ }^{1025}$

Teško je na temelju pronađenih izvora zaključiti je li tada došlo do intervencije. Nešto vjerojatno jest učinjeno, ali u veljači 1576. predstavnici kranjskih staleža oprt javljaju da su vrata i kula prema adama skroz propali. ${ }^{1026}$ Njihov izvještaj vjerojatno se djelomično temeljio na izvještaju gradskog suca Franka Kaptolovića koji je 15. veljače javio da je grad posve zapušten te da se kod gradskih vrata jedan turanj naherio skoro do urušavanja, da su mostovi u tako lošem stanju da se ni drva ne mogu prevoziti preko te da se zidine urušavaju. ${ }^{1027}$ Možda se radilo o vratima i turnju kaštela jer je nadvojvoda naredio kranjskom vicedomu da ,zu des Schlo $\beta$ notwendiger eyllender" popravke izdvoji 1000 rajnskih guldena. ${ }^{1028} \mathrm{Za}$ urušeni turanj, mostove te zasjeke na adama (verhackung der Awen) kranjski staleži planirali su odmah poslati 200 vojnika (knecht) ili uskoke za podizanje zasjeka, odnosno kao ispomoć pri poljodjelskim radovima jer su Bišćani prijetili odlaskom. ${ }^{1029} \mathrm{Na}$ koncu je početkom ožujka nadvojvoda Karlo za popravak vrata i zida potvrdio doznaku od 1000 rajnskih guldena uz četiri centa baruta - što je iznosilo oko 224 kilograma. ${ }^{1030}$ Koliko je situacija bila opasna pokazuje i činjenica da je nadvojvoda pisao caru da i on pomogne jer je riječ o ,periculum in mora" te da je prilikom popravka zidina namjeravao biti prisutan i sam zapovjednik Hrvatske krajine Hans Auersperg. ${ }^{1031}$

Slično stanje je i u studenom 1577., kada kapetan Lamberg navodi da su stražarnice i prsobrani na zidinama urušeni, a da ne bi do kraja propali, trebalo je poslati građevinare i radnike s osiguranima sredstvima. ${ }^{1032}$ Pristup zidinama očito je i dalje predstavljao velik problem jer građani i vojnici u svom apelu s početka prosinca 1577. lamentiraju „da nimamo čim dočekati našega neprijatelja, ni imamo oko ovoga nevoljnoga varoša na zidu staje, na čem bi junak stal, kada bi se nevolja prigodila, a načiniti ih nimamo čim, zač nam Turci nedadu

\footnotetext{
${ }^{1025}$ SI AS 2, DSK, kutija 286, fascikl 164, Bihać, 16.11.1574., 3r-3v, rbr. 238-239. Sebastian Lamberg na kranjske Verordneten.

1026 „,da Thor sambt dem Thurn gegen der Awen allen vngefallen“. SI AS 2, DSK, kutija 287, fascikl 164, Ljubljana, 16.2.1576, 1r, rbr. 486. Predstavnici kranjskih staleža na nadvojvodu Karla.

${ }_{1027}$ LOPAŠIĆ, Bihać, 69.

${ }^{1028}$ SI AS 2, DSK, kutija 287, fascikl 164, Graz, 16.2.1576, 1r, rbr. 491.

${ }^{1029}$ SI AS 2, DSK, kutija 287, fascikl 164, Ljubljana, 25.2.1576., 1r-2r, rbr. 496-498.

1030 SI AS 2, DSK, kutija 287, fascikl 164, Graz, 2.3.1576., 1v, rbr. 508. Nadvojvoda Karlo na cara Maksimilijana.

${ }^{1031}$ SI AS 2, DSK, kutija 287, fascikl 164, Graz, 7.3.1576., 1r-1v, rbr. 512-513. Nadvojvoda Karlo na kranjske staleže.

${ }^{1032}$ SI AS 2, DSK, kutija 286, fascikl 164, Bihać, 26.11.1577., 2r, rbr. 304. Sebastian Lamberg na kranjske Verordneten.
} 
van ni izliziti, zač su oko nas okolo turski grad, u kih Turci stoje“. ${ }^{1033}$ U takvim okolnostima vojnici su nevoljko zauzimali pozicije na zidinama jer nisu bili zaštićeni od neprijateljskog djelovanja. Dakle, može se zaključiti da je građevinsko stanje bile problematično, da je stalno trebalo intervenirati i obnavljati načete ili oštećene fortifikacije, da je rijeka stalno ispirala fortifikacije, ali da ipak nije bilo toliko dramatičnih strukturalnih problema koji bi sasvim „otvorili“ grad.

Barem ne do dramatične noći 23. svibnja 1578. kada je nakon udara groma u samostan sv. Antuna došlo do katastrofalne eksplozije. Naime, iz sadržaja pisma koje je bihaćki kapetan Benedict Crainer 23. svibnja uputio krajiškim povjerenicima stoji da je oko tri sata u noći grom udario u samostan (das wetter in das Closster eingeschlagen) pri čemu su uništeni tamo skladištena živež i streljivo te stradao određeni broj ljudi, iako Crainer još nije znao o kojem se točnom broju radilo. Uništeno je i „mnogo klaftri“ tamošnjih zidina, a to je neprijatelju otvorilo mogućnost za upad u grad. U požaru koji je uslijedio stradale su crkve sv. Antuna i sv. Marije. U post scriptumu navedenog dokumenta dramatičan je Crainerov vapaj: „Poštovana Gospodo, meni se ovdje nemoguće održati, a barut i streljivo je gotovo potrošeno. Žurite, žurite, za dragog Boga ljubljena gospodo! Ukoliko mi u jednom danu ne stigne odgovor, neću znati što mi je činiti. Turci imaju svoje špijune, no ja ću se avaj, golim rukama u Božje ime braniti, dok god će mi to tijelo moći“. ${ }^{1034}$

Dakle, udar groma u samostan u kojem su se čuvali živež i streljivo izazvao je eksploziju koja je djelomično urušila samostan i dio zidina te izazvala požar koji je u određenoj mjeri zahvatio grad, a to je pak izazvalo opću konsternaciju na regionalnoj razini. Trebalo je promptno reagirati i zaštiti izložen grad, a krajiški povjerenici smatrali su da je jedini način podići zemaljski ustanak u Kranjskoj. Tražili su od kranjskih Verodneten da u međuvremenu drže u pripravnosti plaćene postrojbe (Landtvolckh) ne bi li prema potrebi mogli odmah priskočiti u pomoć. ${ }^{1035}$ Bihaćki kapetan javio je da je urušeni zid (verbaut) popravio najbolje što je mogao te da je tamo postavio danonoćnu stražu. Čini se da je preostalo nešto živeži, no nije preostalo ništa od streljiva koje je netom dopremljeno. Zato su povjerenici planirali hitro poslati nešto tovara živeži i streljiva u grad. Zaključili su da je

\footnotetext{
${ }^{1033}$ LOPAŠIĆ, Bihać, 70.

${ }^{1034}$ SI AS, DSK, kutija 287, fascikl 164, Bihać, 23.5.1578., 1r, rbr. 429. Benedict Crainer na vojne povjerenike. 1035 SI AS, DSK, kutija 287, fascikl 164, Črnomelj, 24.5.1578., 1r-1v, rbr. 425-426. Vojni povjerenici na kranjske Verordneten.
} 
zemaljski ustanak možda ipak nepotreban te da je dovoljno poslati dio kranjskih konjanika i pješaka kao pojačanje. ${ }^{1036}$

Šteta prouzročena udarom groma godinama nije sanirana. Još početkom srpnja 1580. Sebastian Lamberg javlja da bi Osmanlije lako mogli osvojiti grad jer je bivši kapetan Crainer nekoliko klaftra uništenog zida kod samostana sv. Antuna popravio „s naslaganim komadima kamena“ (druken Stuken), ali bez korištenja vapna. Štoviše, Lamberg navodi da „ako se makne tek jedan kamen, zid bi se srušio sam od sebe“. ${ }^{1037}$ Krajem srpnja dodatne probleme prouzročio je nizak vodostaj rijeke Une te erodirani i probijeni Wasserwerckh-zidine ili neke obrambene strukture uz rijeku. ${ }^{1038} \mathrm{U}$ listopadu 1580. Dvorsko ratno vijeće u Grazu obaviješteno je o lošem građevnom stanju mostova, prsobrana i stepenica na zidinama. ${ }^{1039} \mathrm{U}$ jednom nepotpisanom izvještaju, koji je nedvojbeno sastavio bihaćki kapetan ili netko iz njegova najužega kruga, još se 1581. spominje „od baruta i groma razrušena utvrda““. ${ }^{1040} \mathrm{U}$ veljači 1581. navodi se pak „sasvim ruinirana utvrda Bihać“. ${ }^{1041}$ Crkva sv. Antuna i franjevačka crkva sv. Marije, stradale u požaru 1578., bile su još 1586 . bez krova pa su bihaćki građani i franjevački vikar poslali molbu nadvojvodi Ferdinandu da se obnove i namjeste svećenici i fratri te da se iz kranjskih prihoda ponovo isplaćuje potpora crkvi sv. Marije. Početkom studenog 1586. nadvojvoda je odredio da se župniku, kojeg je trebao odobriti zagrebački biskup!, potpora od 23 rajnska guldena i 6 1⁄2 krajcara isplaćuje iz ureda vicedoma Kranjske. ${ }^{1042}$

Međutim, iako su se u Bihaću posljedice udara groma i požara vidjele još godinama, $\mathrm{i}$ u tom periodu se gradilo i obnavljalo. U svibnju 1582. Dvorsko ratno vijeće u Grazu je na molbu kapetana Obritschana naredilo Jobstu Langenmantlu da isplati 100 rajnskih guldena za građevinske aktivnosti u Bihaću. ${ }^{1043}$ Bihać je tada opisan kao „posvuda urušen, što se zarad siromaštva građana ne može promijeniti“. ${ }^{1044}$ Međutim, zbog nepreciziranih razloga ni taj iznos nije isplaćen, barem ne do sljedećeg mjeseca. ${ }^{1045}$

\footnotetext{
${ }^{1036}$ SI AS, DSK, kutija 287, fascikl 164, Črnomelj, 24.5.1578., 2r, rbr. 430. Vojni povjerenici na kranjske Verordneten. Numeracija bi trebala biti 427, ali su preskočena dva broja.

${ }^{1037}$ SI AS 2, DSK, kutija 202, fascikl 124a, Bihać, 9.7.1580., 1r. Riječ o nepotpisanom prijepisu izvještaja kojeg je nesumnjivo sastavio netko iz bihaćke zapovjedne strukture.

${ }^{1038}$ SI AS 2, DSK, kutija 287, fascikl 164, Bihać, 9.7.1580., 1v. Sebastian Lamberg na vojne povjerenike i zapovjednike Hrvatske i Primorske krajine.

${ }^{1039}$ HDA, Croatica, mikrofilm D-1913, br. 30, listopad 1580.

${ }^{1040}$ SI AS 2, DSK, kutija 287, fascikl 164, 1r, rbr. 879. Bez potpisa, datacije ni mjesta.

${ }^{1041}$ SI AS 2, DSK, kutija 287, fascikl 164, Graz, 25.7.1581., 2r, rbr. 872. Nadvojvoda Karlo na kranjske staleže.

1042 LOPAŠIĆ, Bihać, 53-54.

${ }^{1043}$ HDA, Croatica, mikrofilm D-1914, br. 13, svibanj 1582.

${ }^{1044}$ HDA, Croatica, mikrofilm D-1914, br. 43, svibanj 1582.

${ }^{1045}$ HDA, Croatica, mikrofilm D-1914, br. 6, lipanj 1582.
} 
Jobst Langenmantel je u svojstvu vojnog povjerenika i u studenom 1587. pregledao grad te naveo da su u jednoj kuli kaštela uređeni podovi, a da je u drugoj, onoj najdonjoj (vnndteristen), potrebno postaviti nove podove jer tamo neko vrijeme borave konji dok je treća kula $\mathrm{u}$ dobrom stanju (woll verwart). Langenmantel se nije referirao na glavnu, četverokutnu kulu koju je u prethodno spominjanom izvještaju Lenković spomenuo kao dio kaštela te pozicioniranu nad tokom rijeke Une. Opće građevinsko stanje kaštela ipak je bilo gore nego u studenom 1584. kada je Langenmantel sastavio sličan izvještaj, s iznimkom stuba/ulaza u kaštel (geng im gschloss) koji je kapetan uredio. ${ }^{1046}$ Tada je izgleda nedostajalo sredstva za građevinske radove jer Langenmantel navodi da je prethodne godine bihaćkom poručniku Martinu Hartensteineru planirao poslati iznos od 200 rajnskih guldena koji je dobio od vojnog blagajnika za obnovu Bihaća, ali da je kapetan javio da to nije potrebno jer ni za prethodno doznačen novac još ništa nije izgrađeno (verbaut). Langenmantel je taj novac zato zadržao. $^{1047}$

Stotinu rajnskih guldena, koje su pak kod nadvojvode izmolili bihaćki građani, a riječ je o iznosu koji im je očito ranije redovito doznačivan, predao je Langenmantel kapetanu Hörneru da s tim novcima uredi brane, mostove i sve drugo potrebno. Čini se da je najveći problem i dalje bio pristup zidinama i stražarnicama na zidu. Langenmantel je tražio da se stražarnice poprave i pokriju da bi u nepovoljnim vremenskim uvjetima oružje njemačkih vojnika ostalo suho i sigurnije. Budući da to tada nije bilo uređeno, nije se mogla držati straža i, u slučaju nužde, pružiti otpor neprijatelju pod zidinama u tom dijelu grada (vnder der mauern vnd dasselbsten). ${ }^{1048}$ Ipak, čini se da su se građani tada ponudili iskopati na Pokoju, gdje su se obavljali poljoprivredni radovi, jedan jarak ili postaviti jednu ogradu (zaun) unutar koje bi se okolno stanovništvo, a osobito stražari, povukli kada bi nahrupio neprijatelj. ${ }^{1049}$ Dakle, građani su trebali brinuti za mostove i prilaze branama pored zidina.

Stanje bihaćkih fortifikacije bilo je u najmanju ruku manjkavo, sve do udara groma i štete koju je eksplozija baruta/streljiva prouzročila 1578. nakon čega se situacija dodatno pogoršala. Budući da su navedeni izvještaji pristizali tijekom više desetljeća, logično je bilo očekivati da Bihać opetovano treba popravljati zbog protoka vremena, vremenskih (ne)prilika, osmanskih napada, ali i nebrige. Zato treba biti oprezan sa zaključcima. Iako je grad nesumnjivo propadao, dobar dio navedenih nedostataka (osobito kada je riječ o drvenoj

\footnotetext{
${ }^{1046}$ LOPAŠIĆ, SHK, knjiga I, dok. CII, 149.

${ }^{1047}$ IBID., Riječ je o poručniku Martinu Hartensteineru koji je kasnije zarobljen i utamničen u Carigradu, kao što je prezentirano u poglavlju o časnicima. Ovdje je njegovo prezime navedeno kao Hörtensteiner, ali budući da je nekoliko puta naveden kao Hartensteiner koristiti ću tu varijantu prezimena.

${ }^{1048}$ LOPAŠIĆ, SHK, knjiga I, dok. CII, 151-152.

${ }^{1049}$ IBID., 152.
} 
konstrukciji) prisutan je i kod drugih utvrda i gradova na krajiškom/hrvatskom prostoru i nije bihaćki specifikum. No, bihaćki je slučaj specifičan zbog činjenice da su popravci i intervencije predstavljali izrazito kompleksan pothvat jer je riječ o velikom gradu na isturenom krajištu, zadnjih desetak godina gotovo okruženom od neprijatelja. Bio je velik izazov izvoditi (velike) građevinske radove u takvom kontekstu.

Jedan od načina na koji se nastojalo doskočiti ovom problemu, barem od 1580-ih, bio je opskrbiti Bihać s dovoljno materijala i opreme za radove na gradu i lokalnim utvrdama. U tom je smislu važna i u izvorima češće spominjana pilana (Sagmül) koja se nalazila na rijeci Uni u okolici grada. Naime, u lipnju 1582. ripački je kaštelan Christoph Schickswoll ponudio, ako mu se doznače sredstva, podići pilanu (Sagmül) u kojoj će proizvoditi planjke za Bihać, a za to mu je doznačeno 150 rajnskih guldena koji su trebali biti odbijeni od iznosa predviđenog za nabavu planjki ili od njegove plaće. ${ }^{1050}$ To je do 1586. realizirano, a pilana je podignuta negdje iznad utvrde na rijeci (zwischen dem wasser) prema Puschaperg na već spomenutome problematičnom mjestu zvanom „na Slapu“ (am Schläp). Do tada je Schickswoll već preminuo, no plaćeni i neplaćeni vojnici jako su se žalili na tu pilanu jer se sada na tom mjestu, kod pilane moglo ,za jedan sat zaobići rijeku pa čvrstom zemljom, a ne vodom doći do Bihaća“ što je pružalo Osmanlijama priliku za napad. Zato je prioritet bio maknuti pilanu na neku drugu adekvatnu lokaciju. ${ }^{1051}$

Nije poznato što se dalje oko toga poduzelo, ali prema mišljenju Gašpara Križanića iz listopada 1589. pilanu je trebalo preuzeti od stanovitog Wainakh-a i tamo namjestiti „njihova“ čovjeka. Dvorsko ratno vijeće u Grazu podržalo je njegov prijedlog te navelo da se za prijevoz drva na neko vrijeme delegiraju uskoci ukoliko je potrebno. ${ }^{1052}$ Do početka siječnja 1590. bihaćki kapetan je za iznos od 100 rajnskih guldena preuzeo pilanu. Sagmaister je ipak zadržan u službi, s tim da mu je plaća uvećana za 1 rajnski gulden. Tražio je da se pošalju tesari i oprema. ${ }^{1053}$ Zapovjednik Hrvatske krajine proslijedio je taj izvještaj te dodao da ne treba podići samo staru već i novu pilanu kod Bihaća, a za to se gradski opskrbnik ponudio dati opremu i/ili materijal. ${ }^{1054}$ Iz razmotrenih izvora nije bilo moguće utvrditi je li nova pilana podignuta, ali i ovaj slučaj upućuje na živahnu građevinsku aktivnost u promatranom periodu što ne iznenađujuće s obzirom na veličinu, karakteristike i na regionalno značenje grada kao što je Bihać. Također, slučaj pokazuje da su se i u finalnoj fazi habsburškog odnosno

\footnotetext{
${ }^{1050}$ HDA, Croatica, mikrofilm D-1914, br. 17, listopad 1582.

${ }^{1051}$ LOPAS̆IĆ, $S H K$, knjiga I, dok. XCV, 139-140.

1052 HDA, Croatica, mikrofilm D-1914, br. 19, listopad 1589.

${ }^{1053}$ HDA, Croatica, mikrofilm D-1918, br. 2, siječanj 1590.

${ }^{1054}$ HDA, Croatica, mikrofilm D-1918, br. 2, siječanj 1590.
} 
hrvatskog Bihaća, u (gotovo) potpunom okruženju, na lokalnoj razini podizali gospodarski objekti od velike važnosti za obranu grada.

Prezentirani izvori, iako primarno orijentirani na utvrdni sklop Bihaća, pokazuju i transformacije koje je u promatranom periodu taj grad prošao u procesu militarizacije. Novi građevinski elementi nisu bili samo puko obnavljanje zatečene utvrdne arhitekture (iako je to bio najčešći slučaj) već su spadali u kategoriju moderne vojne arhitekture kao, primjerice, navedeni bastioni koji su se počeli graditi već 1530-ih. U tu su svrhu desetljećima utrošena ili barem planirana velika financijska sredstva te je uložen veliki organizacijski, logistički i ljudski napor. Bihać je svakako predstavljao velik graditeljski izazov. Autori korištenih izvora Bihać su promatrali prvenstveno kroz vojnu optiku koja prikazuje grad pretvaran u sve veću vojarnu iako je sasvim otvoreno pitanje kako je izgledala civilna arhitektonska komponentna grada, a o kojoj za sada gotovo ništa nije moguće utvrditi. U radovima su sudjelovali i bihaćki građani, ali i u ovom pogledu uvelike ovisni o doznakama središnje/vojne vlasti. Unatoč katastrofalnom udaru groma 1578. te konzekventnoj eksploziji i požaru iza kojih su ostali spaljen grad i dobar komad urušenog zida, tijekom 1580-ih građevinsko stanje je očito dovoljno stabilno da krajiška vlast drži Osmanlije na distanci. Ni u izvještajima o osmanskoj opsadi 1592. nema naznaka da bi eventualno loše stanje bihaćkih fortifikacija igralo veliku ulogu pri padu grada. Štoviše, činjenica da je na grad danima topnički gađano s nekoliko mjesta demonstira da su se tadašnje obrambene fortifikacije pokazale dovoljno stabilnima za obranu iako vjerojatno nisu bile u optimalnom stanju. 


\section{SKLADIŠTENJE ORUŽJA I VOJNE OPREME U BIHAĆU}

Kada je riječ o građevinama, pa i generalno o prostornim kapacitetima grada, svakako treba spomenuti i problematiku skladištenja oružja i vojne opreme u gradu. Kao što je već navedeno, promatrani je period razdoblje intenzivnoga tehnološkog razvoja vatrenog oružja prvenstveno topova i ručnoga vatrenog naoružanja. Oružje iz toga modernog arsenala korišteno je naravno i u borbama s Osmanlijama na hrvatskom prostoru na kojem su dominirale teške bedemske puške što je i razumljivo jer je krajiško ratovanje karakterizirala borba za pogranične utvrde. Na ugarskom prostoru, pravcu glavnih osmanskih napada, postojala su velika i dobro opremljena skladišta oružja. ${ }^{1055}$ Iako je na hrvatskom prostoru bilo (većih) vojnih skladišta, oružja i streljiva stalno nedostajalo, a cijeli je sustav ovisio o unutrašnjeaustrijskim staležima.

U Bihaću, kao najvažnijem vojnom uporištu i najvećem gradu na Hrvatskoj krajini, čuvalo se naoružanje i oprema upotrebljavana za obranu samoga grada te zaštitu utvrda pod zapovjedništvom bihaćkoga kapetana. Ta je problematika od samog početka habsburškog preuzimanja grada 1527. jedan od gorućih pitanja. Iako su hrvatski velikaši i plemstvo i sami na razne načine nabavljali oružje i opremu, i ovaj segment obrane hrvatskog prostora već je vrlo rano počeo ovisiti o asistenciji austrijskih staleža i Habsburgovaca. Moderno oružje na hrvatski prostor dostavljano je godinama prije nego što je nadvojvoda Ferdinand proglašen hrvatsko-ugarskim kraljem pa je najkasnije od početka 1520-ih distribuirano hrvatskom plemstvu i habsburškim postrojbama, odnosno posadama krajiških utvrda. Tako su već ljeti 1522. iz gradačke oružarnice banu Ivanu Karloviću poslane 24 bedemske puške kukače (hackenpuchsen), 2000 željeznih kugli i četiri centi baruta (oko 224 kilograma). ${ }^{1056}$ Sredinom srpnja 1524. nadvojvoda Ferdinand je na zahtjev vojnika na „den Crabatschen grenizen“ naredio da se u Celje iz gradačke oružarnice pošalju 16 topova tipa Notpuchsen koje je načinio Caspar Smid i ,jedan broj“ dobrih bedemskih pušaka (hackhenpuchsen) te da se rasporede prema utvrdama, ali tako da se Notpuchsen pošalju u važnije utvrde. Zapovjednici utvrda sami su trebali preuzeti oružje u Celju i transportirati ga na krajinu i to na vlastiti trošak. $^{1057}$

1055 ŠTEFANEC, Država ili ne, 326.

1056 THALLÓCZY, HODINKA, A horvát véghelyek, dok. CXXII, 205-206. Krajem siječnja 1523. grofu Stjepanu Blagajskom poslane su dvije „željezne puške“ (Eisnin buchsen) i nešto baruta. IBID., dok. CXXXV, 234-235.

${ }^{1057}$ IBID., dok. CCXL, 378-379. 


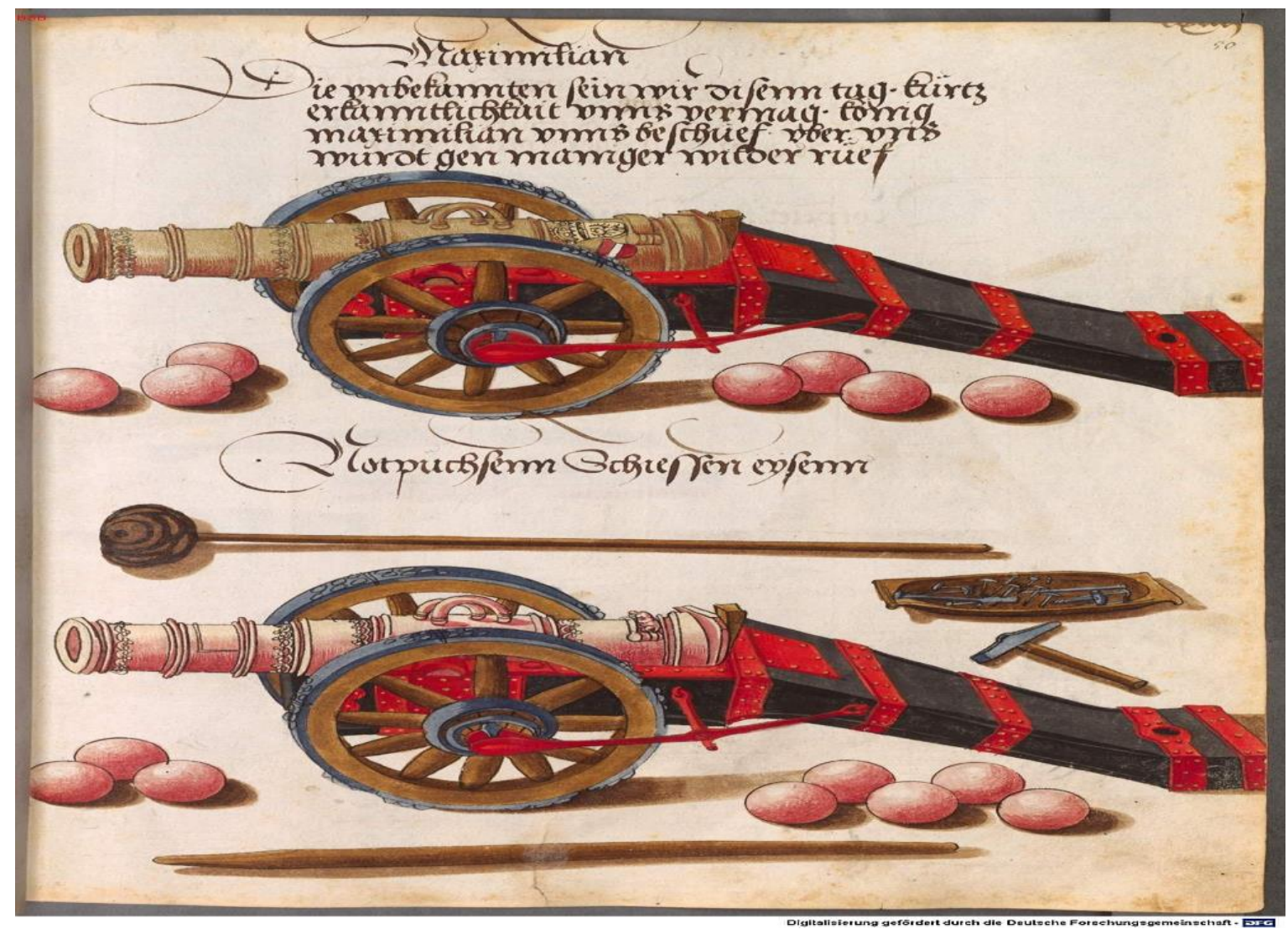

Slika 31. Top tipa Notpuchsen sa streljivom i opremom na prikazu iz knjige „Zeugbuch Kaiser Maximilians I." iz 1502. ${ }^{1058}$

Iako se oružarski sustav započeo razvijati od samog početka habsburškog perioda, bila su potrebna desetljeća da bi se ustrojio funkcionalan oružarski sustav na krajištu. Taj je aspekt krajiškog sustava standardiziran tek formiranjem Dvorskoga ratnog vijeća u Grazu 1578. kada je osnovan i Oružarski ured (oberste Zeugmeisteramt) s glavnim oružarom (Obristen Zeugwarth) na čelu. Pod ingerenciju Oružarskog ureda spadale su Hrvatska i Slavonska krajina te nadvojvodine zemlje, s tim da je glavni oružar po pitanju krajiških oružarnica bio odgovoran Dvorskome ratnom vijeću, a glede zemaljskih oružarnica Dvorskoj komori. ${ }^{1059}$ Službenici novoosnovanog ureda bili su raspoređeni i po unutrašnjeaustrijskom prostoru i na samoj krajini - u Grazu, Ljubljani, Varaždinu, a nakon 1580. i u Karlovcu. ${ }^{1060}$ No, bez obzira na postupni razvoj krajiške oružarske službe, u Bihaću, kao jednoj od najvažnijih utvrda, cijeli period prisutni su oružari i/ili puškari.

\footnotetext{
${ }^{1058}$ Dostupno na http://daten.digitale-sammlungen.de/bsb00020956/image_1 Pristup 16.3.2019. Notschlange je bio poljski top duge cijevi koji je prevozilo osam do dvanaest konja. SIMONITI, Vojaška organizacija, 196. 1059 ŠTEFANEC, Država ili ne, 243.

${ }^{1060}$ IBID., 244.
} 
Nema sumnje da se i prije 1527. oružje i oprema čuvala u gradskim prostorima, prije svega u kaštelu i kulama, ali i u drugim zidanim prostorima poput crkava, samostana itd. Nije točno jasno gdje se nalazila oružarnica u Bihaću, ali se ona (zeughaus) spominje oko 1566. kada je ratni blagajnik isplatio Jeronimu Podlipniku 23 rajnska guldena i 55 krajcara za 407 fitilja poslanih u bihaćku oružarnicu. ${ }^{1061}$ Oružarnica se spominje i u veljači $1576 .{ }^{1062}$ I na saboru u Brucku 1578. odlučeno je da u Bihaću treba urediti oružarnicu i barutanu. ${ }^{1063}$ Negdje početkom 1586. bihaćkom je kapetanu isplaćeno 50 rajnskih guldena za popravak oružarnice. ${ }^{1064}$ Vojni povjerenik Jobst Langenmantel detaljno je pregledao oružarnicu krajem 1587. te predložio da se za manji trošak, ne veći od 30 ili 40 rajnskih guldena, u turnju pored crkve postave tri podnice jedna na drugu (drey poden aufainander machet) te da se tamo pohrane barut i užad koji u „gornjoj crkvi“ sv. Elizabete leže na hrpi, a sveukupno vrijede 600 rajnskih guldena pa prijeti opasnost od propadanja. ${ }^{1065}$ Dakle, oružje, barut i oprema čuvali su se dislocirano na raznim mjestima u gradu, u vojnim objektima, ali i u drugim zidanim objektima sigurnijim od požara i/ili elementarnih nepogoda, primarno crkvama. U srpnju 1590. Dvorsko ratno vijeće u Grazu naredilo je da se pregledaju oružarnice (Zeugheuser) u Karlovcu, Bihaću i Senju, da se sastavi inventar i utvrdi što je sve odneseno između prijašnje i sadašnje muštre, a što se $\mathrm{i}$ dalje nalazi u depou, te da im se to dostavi. ${ }^{1066}$ Nažalost, taj inventar nije pronađen tijekom ovog istraživanja.

Kakav je bio kapacitet tih skladišnih prostora, odnosno s kakvim su oružjem i opremom raspolagali? Već od samog zasjedanja nadvojvode Ferdinanda na ugarsko-hrvatsko prijestolje spominju se aktivnosti u tome pogledu. Već sredinom ožujka 1527. donjoaustrijski oružar Ulrich Leisser dobio je naredbu da pregleda u kojoj je mjeri Bihać opskrbljen oružjem i streljivom te da se, ako je to potrebno, u grad odmah pošalju dodatno oružje i streljivo. ${ }^{1067}$ Krajem travnja banu Ferencu Batthyányju, u čijim je rukama tada Bihać, za obranu kraljevskih i banskih utvrda (unser und seiner slösser) dodijeljeno je šest topova halbslangen, šest falkoneta, 12 puchsen i 500 kugli, zatim petstotinjak bedemskih pušaka kukača (mer 500 hakenpuchsen) te čak 100000 kugli. Kralj je svim maltama i carinarnicama te svim

\footnotetext{
${ }^{1061}$ HDA, Militaria, kutija 7, 1565./1567., 18v. Iskaz financijskih izdataka Hansa Khiesla, ratnog blagajnika na Hrvatskoj krajini za 1565. i 1567. Preslike ovoga opsežnog iskaza nalaze se među preslikama spisa za 1561.

1062 SI AS 2, DSK, kutija 287, fascikl 164, Bihać, 18.2.1576, 1r, rbr. 488.

${ }^{1063}$ LOPAŠIĆ, SHK, knjiga I, br. XXXV, 61.

${ }^{1064}$ IBID., dok. XCII, 135.

${ }^{1065}$ IBID., dok. CII, 151.

${ }^{1066}$ HDA, Croatica, mikrofilm D-1918, br. 6, srpanj 1590.

1067 THALLÓCZY, HODINKA, A horvát véghelyek, dok. CDXCI, 639.
} 
podanicima pisao da, uz predočenje kraljevskog pisma, besplatno propuste oružje i opremu kroz svoje postaje odnosno teritorij. ${ }^{1068}$ Dio toga morao je završiti u Bihaću.

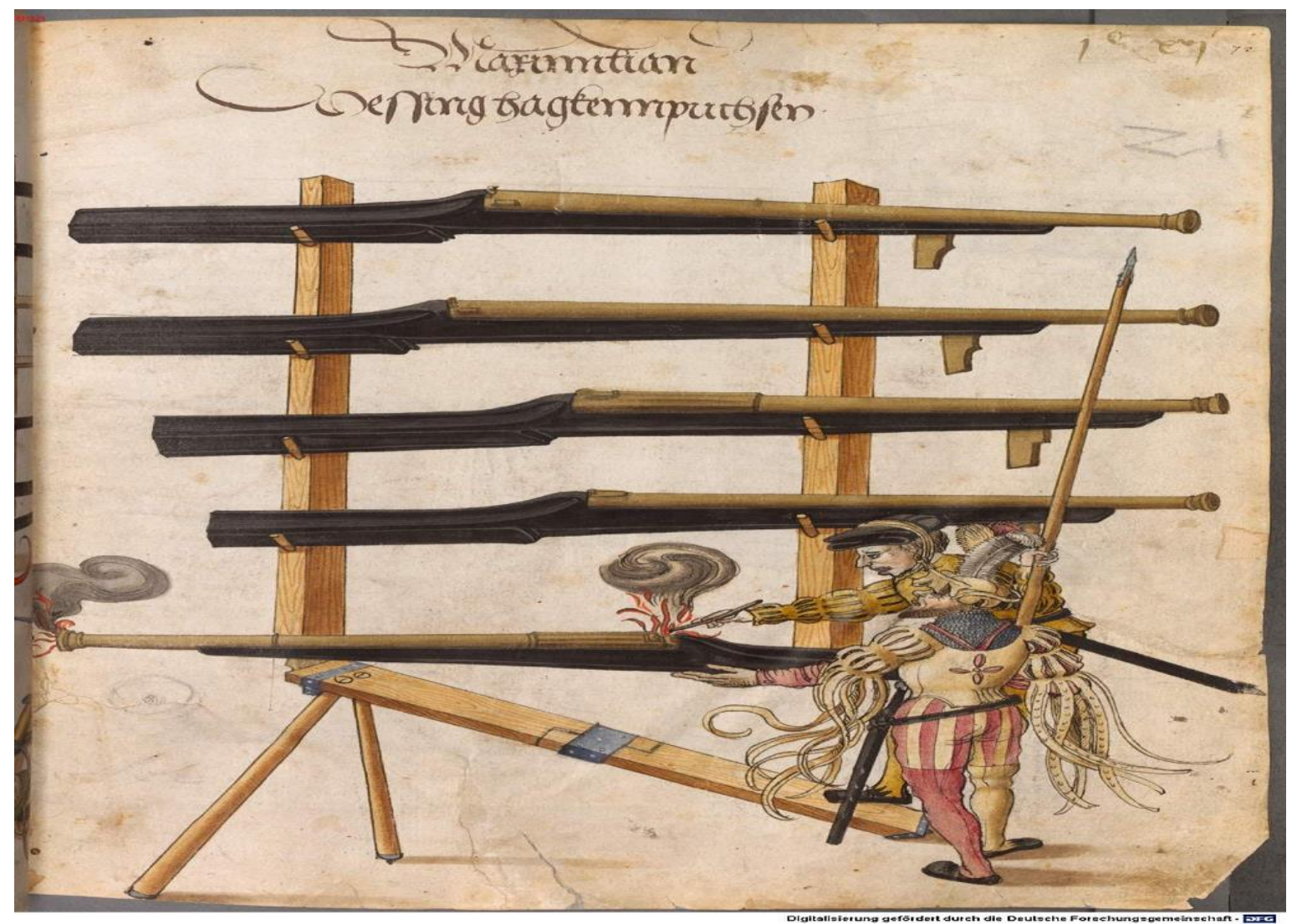

Slika 32. Teške bedemske puške na prikazu iz knjige „Zeugbuch Kaiser Maximilians I.“ iz 1502. ${ }^{1069}$

Iako središnja vlast još neko vrijeme neće preuzeti Bihać, ova instrukcija pokazuje da se odmah pristupilo dopremi oružja i opreme te da su za to bili zaduženi staleži Unutrašnje Austrije odakle su zapravo i dolazili glavnina vojne opreme i naoružanja na prostor Hrvatske krajine, prije svega iz ljubljanske oružarnice. ${ }^{1070}$ Uz oružarnicu u Ljubljani, dopremalo se i iz oružarnice u Grazu, ali i iz raznih drugih mjesta u unutrašnjosti. Primjerice, Herbart Auersperg nakon pada Krupe 1565. zatražio je da se u Bihać pošalju četiri falkoneta koje su kranjski staleži držali u Novom Mestu, a koji bi im, prema carskoj naredbi, kasnije bili nadoknađeni iz ljubljanske oružarnice. ${ }^{1071}$ Trošak prijevoza tih topova od Pobrežja do Črnomelja iznosio je 12 rajnskih guldena i 34 krajcara. Tada je Christophu Sailleru za konope

\footnotetext{
${ }^{1068}$ IBID., dok. DXIII, 660.

${ }^{1069}$ Dostupno na http://daten.digitale-sammlungen.de/bsb00020956/image_133 Pristup 16.3.2019.

${ }^{1070}$ Carska, odnosno zemaljska oružarnica u Ljubljani podignuta je 1525. SIMONITI Turki su, 112. U Ljubljani su i lijevali topove i puške, a pripravljali su i barut. SIMONITI, Vojaška organizacija, 190-193.

${ }^{1071}$ SI AS 2, DSK, kutija 209, fascikl 126, logor kod Cetina, 24.6.1565, 2v, rbr. 81. Herbart Auersperg na Ivana Lenkovića.
} 
i fitilje isplaćeno 69 rajnskih guldena i 69 krajcara te još 12 rajnskih guldena i 50 krajcara za tovare koji su to prevezli do Bihaća. ${ }^{1072}$ Tada je isplaćeno 63 rajnska guldena i 40 krajcara za prijevoz streljiva štajerskih strijelaca koji su bili namješteni u Bihać i Hrastovicu.${ }^{1073}$ Nadalje, Thomasu Nagliću je isplaćeno 307 rajnskih guldena i 49 krajcara za prijevoz tri falkoneta i streljiva do Bihaća. ${ }^{1074}$

Najkvalitetnije naoružanje čuvalo se na unutrašnjeaustrijskom prostoru dok je na samoj krajini, unatoč dopremi, uglavnom nedostajalo vatrenog naoružanja, streljiva i prateće opreme. Kranjski staleži lamentirali su u kolovozu 1574. da su Bihać, Ripač i ostale utvrde na Hrvatskoj krajini tako loše opskrbljene i namještene vojskom, oružjem i streljivom da bi se u slučaju opsade teško mogle održati četiri ili pet dana. ${ }^{1075}$ U ljeto 1577 . u Bihaću je ne samo deficit streljiva već su kotači na topovima toliko propali da je oružje bilo neupotrebljivo. ${ }^{1076}$ Kada se opisuje stanje naoružanja, u izvorima se često navodi da su topovi u skroz lošem stanju te da su neupotrebljivi, odnosno navode se fraze poput „topovi su sasvim na tlo propali“، ${ }^{1077}$

\footnotetext{
${ }^{1072}$ HDA, Militaria, kutija 7, 1565./1567., 17v. Iskaz financijskih izdataka Hansa Khiesla, ratnog blagajnika na Hrvatskoj krajini za 1565.-1567. Preslike ovoga opsežnog iskaza nalaze se među preslikama spisa za 1561.

${ }^{1073}$ HDA, Militaria, kutija 7, 1565./1567., 18r. Iskaz financijskih izdataka Hansa Khiesla, ratnog blagajnika na Hrvatskoj krajini za 1565.-1567. Preslike ovoga opsežnog iskaza nalaze se među preslikama spisa za 1561.

${ }^{1074}$ HDA, Militaria, kutija 7, 1565./1567., 19r. Iskaz financijskih izdataka Hansa Khiesla, ratnog blagajnika na Hrvatskoj krajini za 1565.-1567. Preslike ovoga opsežnog iskaza nalaze se među preslikama spisa za 1561.

${ }^{1075}$ SI AS 2, DSK., kutija 286, fascikl 164, Ljubljana, 1.8.1574., 1v, rbr. 252. Kranjski staleži na nadvojvodu Karla.

1076 ŠTEFANEC, Država ili ne, 298.

1077 „,des geschutz ganz vnd gar zu Poden fellt“. SI AS 2, DSK, kutija 287, fascikl 164, Bihać, 30.3.1576., 1r, rbr. 515. Bihaćki časnici na Herbarta Auersperga.
} 


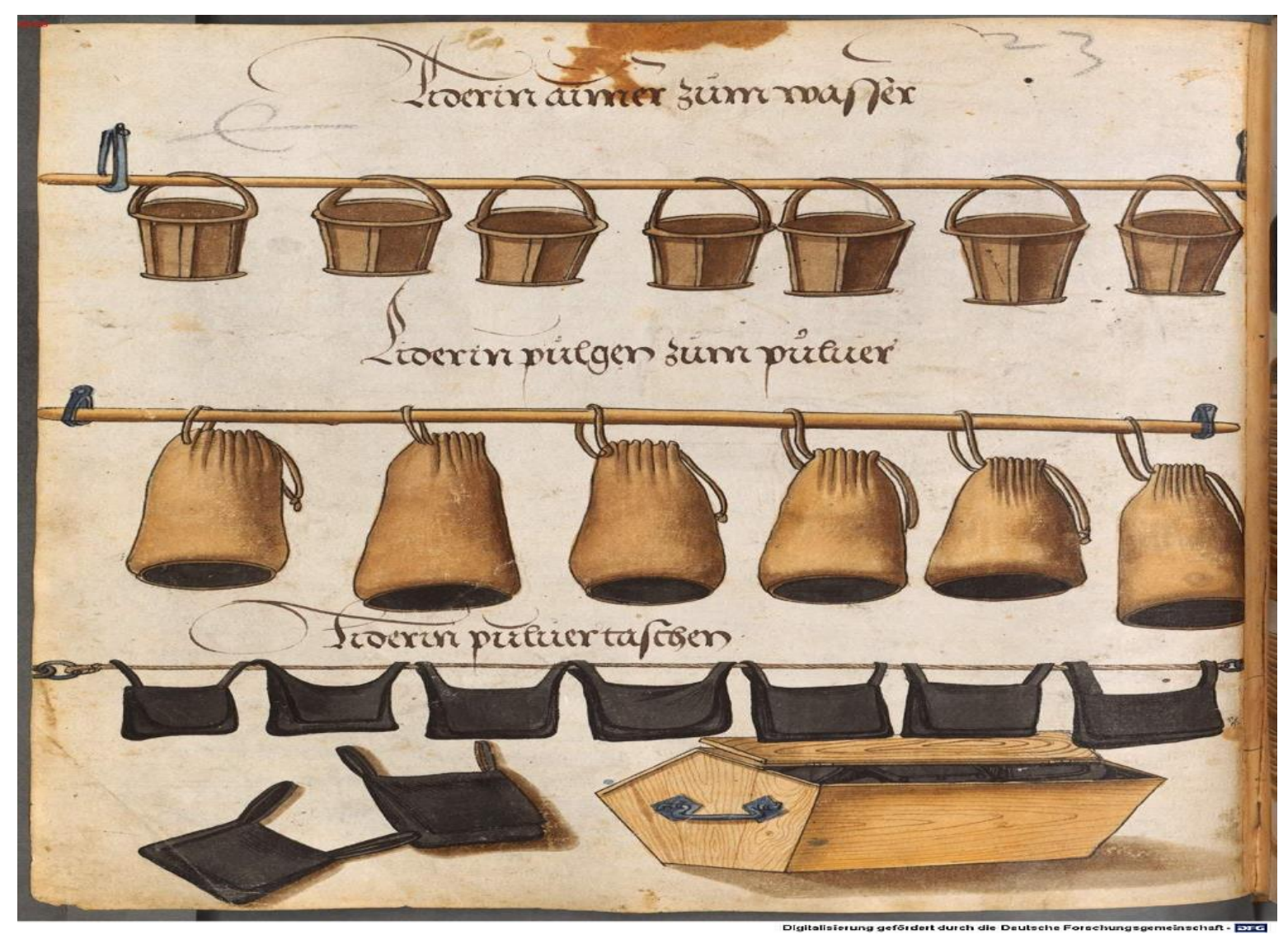

Slika 33. Oprema za prijenos vode i baruta prema knjizi „Zeugbuch Kaiser Maximilians I.“ iz $1502 .^{1078}$

Već je više puta navedeno da je transport oružja i opreme, prije svega topova i teškoga vatrenog naoružanja na krajinu predstavljao veliki izazov za krajiške vlasti. Naime, da bi se teška oprema i naoružanje prevezli na krajinu, trebalo je urediti transportne rute, osigurati prijevozna sredstva i pratnju jer je uvijek postojala mogućnost od većega ili manjega osmanskog napada. Tako je krajem srpnja 1557. bihaćki kapetan Georg Zoblsperg tražio da mu se u grad dopreme dva topa tipa Notschlenge, barut i olovo (pley) koji su se tada nalazili u Ljubljani. ${ }^{1079}$ Logistika za takvo što bila je vrlo zahtjevna. Početkom kolovoza predstavnici kranjskih staleža i kranjski vicedom odobrili su molbu te naredili Zoblspergu da pripremi i uredi putove, mostove i riječne brodove, odnosno čamce za prijevoz. Zoblsperg je zatim delegirao bihaćkog stražmeštra Gregora Ninderhaimba da uredi transportne rute, odnosno da s hrvatskim grofovima i plemstvom dogovori pripremu te uređenje putova i mostova.

\footnotetext{
${ }^{1078}$ Dostupno na http://daten.digitale-sammlungen.de/bsb00020956/image 130. Pristup 16.3.2019.

${ }^{1079}$ SI AS 2, DSK, kutija 287, fascikl 164, kutija 201, fascikl 124, 29.7.1557., 1r, br. 540-541. Georg Zoblsperg na zapovjednika Hrvatske krajine.
} 
Ninderhaimb je trebao biti prisutan cijelim putem, a bihaćkom je kapetanu naređeno da mu u susret pošalje pet ili šest konja, ali nije točno navedeno kada i kamo. ${ }^{1080}$

Distribucija oružja na samoj krajini, osobito u kasnijem periodu, bila je još kompleksnija. Kada je na saboru u Brucku 1578. predložen popravak vatrenog naoružanja u Bihaću, apostrofirano je da su to „topovi na pričvršćenim kotačima“ te da se dva-tri komada mogu uzeti za Ostrožac i Cazin. No, da bi se lakše dopremilo topove do Ostrožca, koji se nalazi manje od dvije (njemačke) milje od Bihaća, namjeravalo se prosjeći prolaze kroz šumu. ${ }^{1081}$ Ovaj prijedlog pokazuje koliki je napor trebalo uložiti kako bi se topovi prevezli s jednog mjesta na drugo, ne odviše udaljeno mjesto na isturenom krajištu - trebalo je probiti prolaze kroz šumu ili barem očistiti zarasle putove. Štoviše, u istom se prijedlogu navodi da treba popraviti i mostove kod Bihaća da se ne uruše prilikom prijevoza topova. ${ }^{1082}$

Što se samog naoružanja u Bihaću tiče, iako izvori sugeriraju da je oružja permanentno nedostajalo ili da je bilo konstantno u lošem stanju, ipak se može zaključiti da je od početka habsburškog perioda u Bihaću, a i na cijelom hrvatskom prostoru, korišteno tada suvremeno naoružanje i oprema. Takvog oružja i opreme možda nije bilo u željenom obujmu, ali ga je svakako bilo. Već je navedeno da početkom ožujka 1527. kralj javlja Donjoaustrijskoj komori (An die camer in Österreich) da ban Batthyány traži da se Bihać opskrbi oružjem, barutom i svime potrebnim. Zato kralj naređuje da se grad pregleda, prema potrebi opskrbi te, ako je nužno, ojača s ne više od stotinu vojnika. ${ }^{1083}$ Sredinom ožujka tamo je poslan donjoaustrijski oružar Ulrich Leisser koji je trebao pregledati stanje grada, utvrditi koliko je grad opskrbljen oružjem i streljivom te prema potrebi poslati dodatno oružje i streljivo. $^{1084}$

Nakon neposrednog uvida u stanje obrane u Bihaću 1527. Nikola Jurišić je kao jednu od glavnih mjera predložio da se namjesti oružar (Zeugmeister) te da se u grad dopreme tri falkoneta (srednje teška topa), 100 bedemskih pušaka kukača te odgovarajuća količina baruta i streljiva. ${ }^{1085} \mathrm{U}$ Ripač je trebalo dopremiti jedan top i 30 bedemskih pušaka kukača (Hackenpuchsen). Za održavanje navedenog naoružanja trebalo je namjestiti i jednog

\footnotetext{
1080 SI AS 2, DSK, kutija 201, fascikl 124, Bihać, 7.8.1557., 1r, rbr. 500. Georg Zoblsperg na predstavnike kranjskih staleža.

1081 ŠTEFANEC, Država ili ne, 298.

1082 IBID., 288-289.

1083 THALLÓCZY, HODINKA, A horvát véghelyek, dok. CDLXXIX, 626.

${ }^{1084}$ IBID., dok. CDXCI, 639.

1085 Oružar artiljerskih mojster, kao što ga navodi Simoniti, imao je nadzor nad svim tipovima vatrenog naoružanja koje je popravljao te je kontrolirao kvalitetu i skladištenje baruta." SIMONITI, Vojaška organizacija, 192.
} 
puškara. ${ }^{1086} \mathrm{U}$ istom spisu kao odgovor na prijedloge dopisano je da je naređeno da se tamo pošalje 20 teških bedemskih pušaka (Toplhagken), 40 „običnih“ pušaka kukača (ainfach hakgen) i četiri centi baruta. ${ }^{1087}$

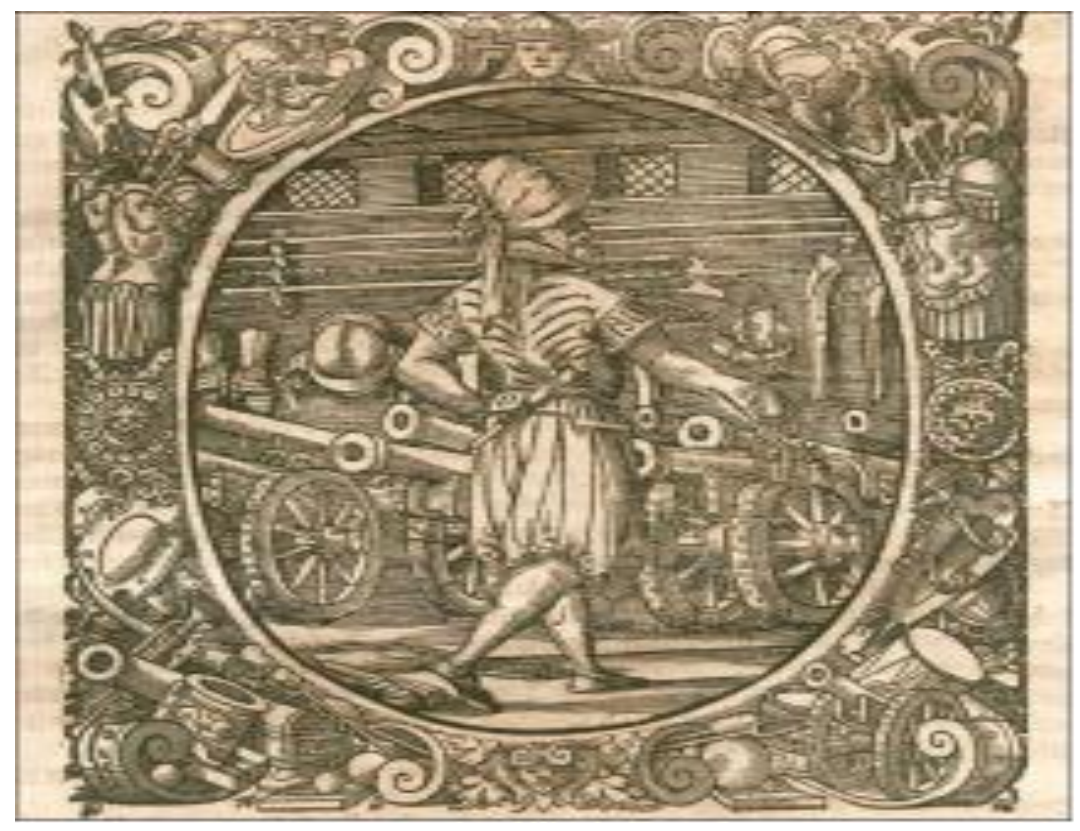

Slika 34. Prikaz oružara. ${ }^{1088}$

Iz izvora se za sada ne može utvrditi jesu li tada oružar i puškar namješteni, ali je Mert Gall tražio u svibnju 1540. da mu se pošalju puškar (Puxenmeister) i barut. ${ }^{1089}$ Krajem svibnja zaista je poslan jedan puškar da pripremi barut i dovede oružje u red, a Gallu je javljeno da tog puškara može zadržati ako ga želi ili poslati nazad ako ga ne želi. ${ }^{1090}$ Početkom svibnja 1541. Mert Gall ponovno moli da mu se pošalje jedan puškar (puchsenmeister) za kojim postoji velika potreba jer nema nikoga tko bi se brinuo o barutu i o punjenju topova. ${ }^{1091}$

Briga za oružje nije uvijek bila na željenoj razini jer je krajiško povjerenstvo iz 1563. navelo da su u Bihaću dva hauffinz i jedan falkonet djelomično raspuknuti zbog nemara puškara dok je jedan falkonet bio u urednom stanju. Budući da se topove nije pokrilo, istrunuli su kotači i postolja pa se bez nužnih popravaka nisu mogli koristiti. Povjerenici su za

\footnotetext{
1086 THALLÓCZY, HODINKA, A horvát véghelyek, dok. DXLIV, 694; KRUHEK, Krajiške utvrde, 83. Falkonet je lak poljski top koji su prevozila dva ili tri konja. SIMONITI, Vojaška organizacija, 196.

${ }^{1087}$ THALLÓCZY, HODINKA, A horvát véghelyek, dok. DXLIV, 696.

${ }^{1088}$ Leonhart FRONSPERGER, Das Kriegsbuch, II. dio, Frankfurt, 1596, 60; 204.

${ }^{1089}$ LASZOWSKI, HSKHDS, knjiga II, dok. 493, 490

${ }^{1090}$ SI AS 2, DSK, kutija 193, fascikl 119/120, Bihać, 24.5.1540., 3r, rbr. 272. Predstavnici kranjskih staleža i vicedom na kapetana Merta Galla.

1091 SI AS 2, DSK, kutija 198, fascikl 123a, Bihać, 2.5.1541., 2v-3r, rbr. 1442-1304. Kapetan Mert Gall na Nikolu Jurišića. Paginacija ne odgovara redoslijedu izvora, ali je navodim.
} 
te propuste odgovornim držali bihaćkog puškara Erharda Pfalza, podređenog uredu glavnog oružara, koji je primao plaću od 10 rajnskih guldena i preko dvadeset godina carsku proviziju. Pfalza su držali direktno odgovornim za raspuknuće jednog falkoneta te za činjenicu da topove nije prekrio daskama (pretern), što je lako mogao, već ih je ostavio propadati. Za primjer drugima otpušten je bez plaće. ${ }^{1092}$

Neimenovanom bihaćkom oružaru isplaćen je oko 1566. tromjesečni zaostatak od 30 rajnskih guldena. ${ }^{1093}$ Dakle, to odgovara visini mjesečne plaće koju je primao i Erhard Pfalz. Prema vojnom proračunu iz 1578. ili 1579., u Bihaću je trebao biti jedan oružar (Zeugwart) koji je ujedno morao biti i puškar s mjesečnom plaćom od 12 rajnskih guldena. Uz njega, trebala su biti i dva puškara s mjesečnom plaćom od 10 rajnskih guldena. ${ }^{1094}$ Dakle, radilo se o relativno visokim primanjima.

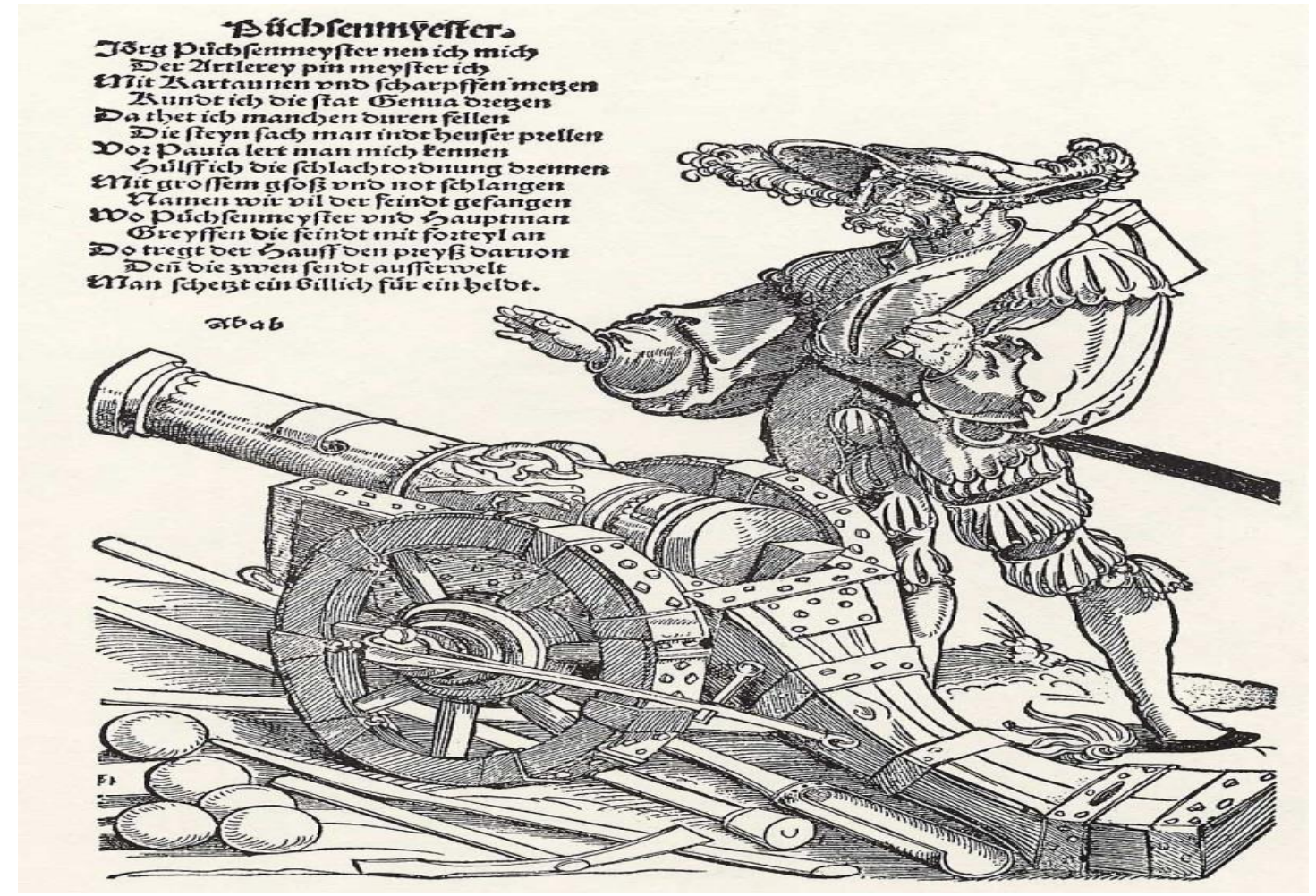

Slika 35. Puškar prema bakrorezu Erharda Schoena oko $1536 .{ }^{1095}$

\footnotetext{
1092 AHAZU, Lopašić, E. Prijepisi iz austrijskih arhiva, br. 15, str. 64.

${ }^{1093}$ HDA, Militaria, kutija 7, 1565./1567., 22r. Iskaz financijskih izdataka Hansa Khiesla, ratnog blagajnika na Hrvatskoj krajini za 1565.-1567. Preslike ovoga opsežnog iskaza nalaze se među preslikama spisa za 1561.

${ }^{1094}$ SI AS 2, DSK, kutija 230, fascikl 136, 1578. ili 1579., 11r-11v. Spisu nedostaju prednja strana i datacija, ali se nalazi u spisima za1578. i 1579. u kutiji koja je strukturirana kronološki.

1095 Bakrorez Erharda Schoena. Dostupno na http://www.zeno.org/nid/20004285891. Pristup 13.4.2019.
} 
U lipnju 1582. u Bihaću je naveden oružarski ured (Zeugwart Ambt zu Wihitsch) u koji su činili oružar, jedan oružarski službenik (Zeugdienner) te nekoliko puškara (denen Püuxenmaistern alda). Tada je dotadašnjeg oružara Mathesena Teüschmana zamijenio novi oružar prezimena Schröt dok se kao oružarski službenik navodi Georg Schueb. Navedenim puškarima tada se dugovala plaća za osam mjeseci pa je vojnom blagajniku naređeno da puškarima isplati dugovanje, ali uz odbitak živeži, dok je oružaru plaću trebalo isplatiti nakon obračuna. ${ }^{1096}$ Prema vojnom proračunu za tu godinu, u Bihaću su se nalazili jedan oružar s plaćom od 14 rajnskih guldena mjesečno te pet puškara $\mathrm{s}$ ukupnom plaćom od 48 rajnskih guldena mjesečno. ${ }^{1097}$ Prema vojnim proračunima iz 1586. i 1589., u Bihaću se pak nalaze jedan oružar s mjesečnom plaćom od 14 rajnskih guldena te pet puškara koji su mjesečno ukupno primali 50 rajnskih guldena plaće. U Ripču je tada jedan puškar s mjesečnom plaćom od 9 rajnskih guldena. ${ }^{1098}$ Plaće su, dakle, s godinama i rasle. Takvo je stanje vjerojatno ostalo do pada pod osmansku vlast.

Kada je konkretno o količini i karakteristikama oružja i opreme riječ, već u listopadu 1526. poslanik Ferenca Batthányja, prilikom predaje uvjeta za Batthányjevo preuzimanje banske časti, navodi da mu je nadvojvoda naložio da u Bihaću izmjeri topove, njihovu dužinu te kalibar streljiva. Traženi je popis dostavio, ali sumnjao je da će se (vjerojatno streljivo) moći upotrebljavati jer se u Bihaću koriste samo kamene kugle (stainpuxen). ${ }^{1099}$

U molbi bihaćkih građana upućenoj kralju Ferdinandu u veljači 1530., stoji da su u gradu tek 3 manja topa i 3 mužara iz kojih pucaju ne da bi grad branili, već da bi ljude upozorili na opasnost“. ${ }^{1100}$ Prilikom preuzimanja kapetanije u svibnju 1540. Mert Gall sastavio je popis zatečenog naoružanja i opreme. Tada su se u gradu nalazili 1 željezni Derndreyl, 3 željezna i 1 bakreni falkonet, 1 raspuknuti bakreni falkonet, 35 bedemskih pušaka kukača na drvenom postolju (hackhenpuchsen in holz eingefasst), 17 bedemskih pušaka kukača sa željeznim repom (schwanzen), 17 neispravnih bedemskih pušaka kukača, 2 željezna mužara, 24 i pol buradi baruta, 5 kalupa (Modl) za bedemske puške, 3 kalupa za falkonete, 1 kalup za Dorndreyll u jednom sanduku, oko 10000 kugli za bedemske puške kukače, 114 kugli za topove, jedna bačva sa sumporom, 5 1/2 ,Lagl mit Latt vnnd Schar Negl“", 6 ručnih cijevi (Hannd Rohr), 18 sjekira, 1 olovna sjekira, 20 helebardi, nekakva olovna ploča (ayndliff platten pley), 2 ,puchsenparer“", 8 mjera nekakvog sredstva potrebnog

\footnotetext{
${ }^{1096}$ HDA, Croatica, mikrofilm D-1914, br. 22, lipanj 1582.

${ }^{1097}$ SI AS 2, DSK, kutija 230, fascikl 136, 1582., 13r.

${ }^{1098}$ SI AS 2, DSK, kutija 230, fascikl 136, 1586., 20r; SI AS 2, DSK, kutija 230, fascikl 136., 1589., 24 r.

${ }^{1099}$ LASZOWSKI, HSKHSD, knjiga I, dok. 25, 24.

${ }^{1100}$ KRUHEK, Krajiške utvrde, 88.
} 
za lijevanje topova (acht Parndt rainigen so man zu dem Geschutz giessen braucht), 1 pila za rezanje topova, 4 krampa, 12 lopata, 2 stolarske sjekire, 1 velika i 2 male pile, 2 tesarske blanje, 1 kusa za obradu drva, 3 komada/otpada željeza (drey schrott eysen), 1 glavčina kotača, 1 pajser, 1 loša sjekira, 1 brusni kamen (schliff stein), 1 mala sjekira te 1 okovana stara kola za prijevoz topova. U Sokolu su tada bile tek 2 bedemske puške kukače ,,mit hiltzen scafftig“, 1 bedemska puška kukača sa željeznim repom (mit ainen eysnen schwantz), a u Topličkom Turnju 2 bedemske puške kukače ,mit hiltzen schafften“. ${ }^{1101}$ Iako dio popisane opreme nisam uspio identificirati, sve navedeno pokazuje da su se u Bihaću ne samo popravljali nego, očito, i proizvodili topovi jer se navode i kalupi za lijevanje topova, oruđe za rezanje i pripravci potrebni za izlijevanje topova. Što se vatrenog naoružanja tiče, bedemskih pušaka bilo je dosta, ispravnih i neispravnih 122 komada te visokih 10000 kugli za njih dok je broj topova ipak skromniji, prvenstveno se radilo falkonetima - topovima manjega kalibra. 1102 Gall je tada molio da mu se iz Krškog pošalje novi falkonet u zamjenu za rasprsnuti bakreni falkonet. ${ }^{1103}$

\footnotetext{
${ }^{1101}$ SI AS 2, DSK, kutija 193, fascikl 119/120, Bihać, 14.5.1540., 1r-1v, rbr. 256-258.

1102 Falkonet je lak poljski top koji je ispaljivao kugle mase 2 funte $(1,12 \mathrm{~kg})$. Vukla su ga dva konja. KLAUŽER, Ustrojstvo i djelovanje Senjske, 168.

${ }^{1103}$ LASZOWSKI, HSKHSD, knjiga II, dok. 493, 490.
} 


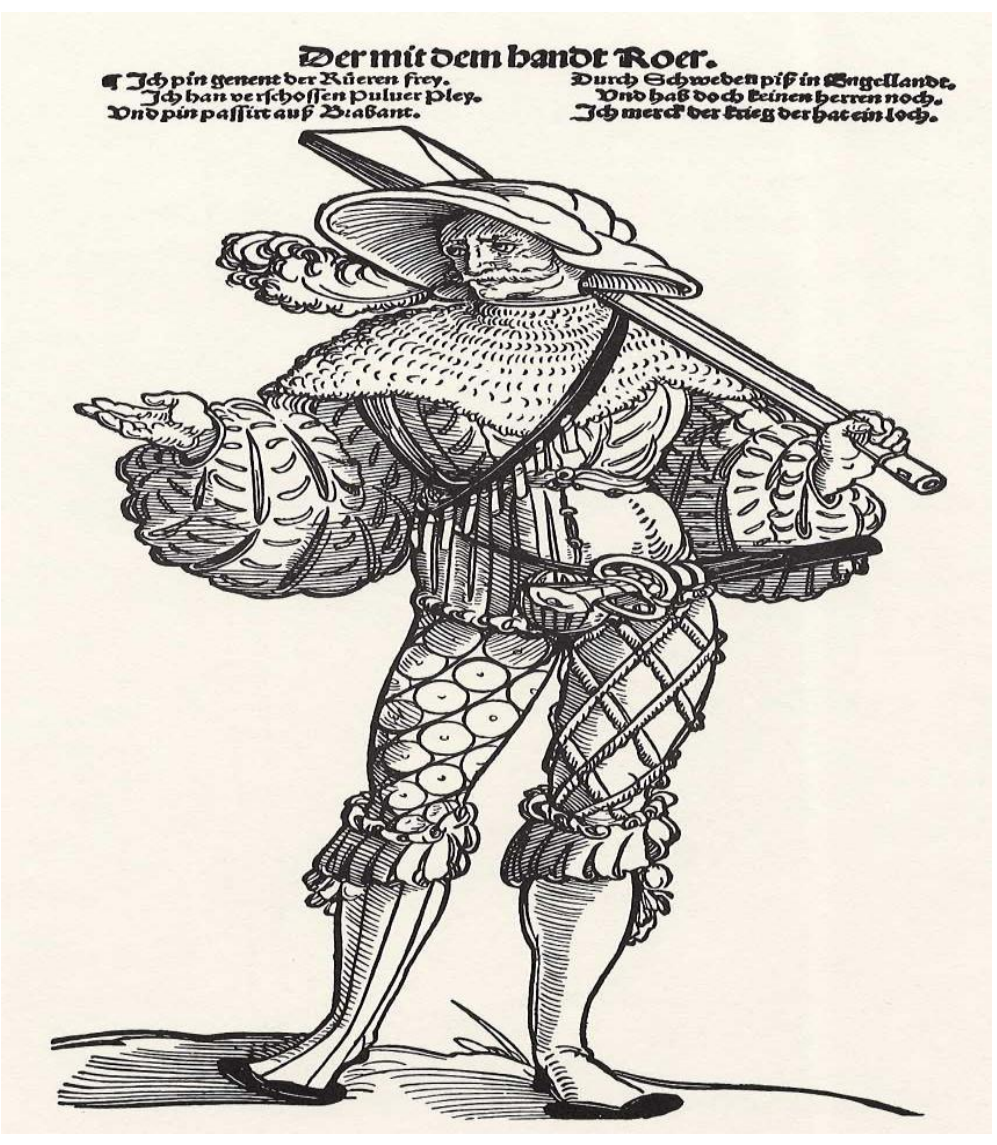

Slika 36. Vojnik s vatrenim oružjem nazivanim „ručna cijev“ (Handt Roer) prema bakrorezu Erharda Schoena oko $1535 .^{1104}$

U popisu potrebnog oružja, streljiva i streljiva, koji je pak 1556. sastavio bihaćki kapetan Georg Zoblsperg, stoji da je za 2 falkoneta potrebno poslati 1000 kugli te najmanje 150 težih bedemskih pušaka tzv. Toplhacken s pripadajućom opremom, zatim nekoliko standardnih bedemskih pušaka kukača i 8000 kugli (ain par Hackhen Püchsen souil, darzue 8000 kugln). Nadalje, tražio je i 400 ručnih cijevi (Handtrohr), 500 Muldern zum Schanz Ville, 200 komada tačaka, 200 konzola/potpornja, 4 konopa za vuču topova, zatim jedan alat

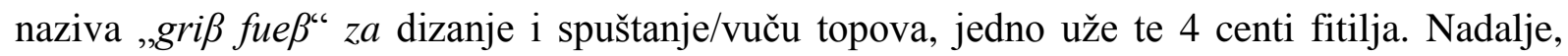
budući da je Bihać dijelom smješten na kamenom tlu, Zoblsperg je tražio oko 500 čvrstih krampova, zatim isto toliko kvalitetnih reithauen te jedan broj željeznih lopata. Također, kapetan je tražio najmanje 40 Rangstargen/Ringstagen, 25 čvrstih željeznih maljeva, 100 željeznih klinova s pločama, 20 centi dobrog željeza (guetts Ayssen) za topove i druge

\footnotetext{
${ }^{1104}$ Dostupno na http://www.zeno.org/nid/20004286596. Pristup 13.4.2019. Topplhaggen je teška, dvostruka, tvrđavinska puška teška od 9 do 14 kilograma koja je ispaljivala olovne kugle, a zahtijevala dvoje ljudi za rukovanje. Handrohr je bila neka varijanta jednostavne puške. SIMONITI, Vojaška organizacija, 196.
} 
potrebe, a to bi prema Simonitijevu izračunu iznosilo visokih 1120 kilograma željeza. ${ }^{1105}$ Dakle, količina željeznog oružja i opreme bila je znatna. Samo topovskih kugli raznog kalibra trebalo je biti barem 9000, teških bedemskih pušaka 150, a oruđa preko 1000 komada. Toliku količinu opreme i materijala trebalo je i smjestiti u adekvatnim uvjetima. Iste je godine Zoblsperg tražio da mu se dopreme i petrolej, laneno ulje, lim za kovati željezo, fitilje te jednu centu, oko 56 kilograma salitre (ein Zenden Salliter). ${ }^{1106}$

Što se lokalne proizvodnje tiče, čini se da se u Bihaću proizvodio i crni barut (Khurnpulver) zato što je kralj 1550. naredio da se Ivanu Lenkoviću isplate sredstva za salitru koja se uvozila iz Napulja, a koja je trebala biti poslana u Senj i Bihać. Salitra (kalijev ili natrijev nitrat) je, uz sumpor i ugljen, sastojak potreban za proizvodnu baruta. ${ }^{107}$ Taj je barut bio korišten za puške dok se za topove i mužare koristio Zeugpulver ili Gemeinpulver. ${ }^{1108}$ Ujednom anonimnom izvještaju sljedeće je godine navedeno da je u Bihać potrebno poslati bedemske puške kukače i crni barut (Khürntpulffer). ${ }^{1109}$

U spisima Bečkog savjetovanja u kolovozu i rujnu 1577. navedeno je da se u Bihaću te Ripču, Sokolu, Drežniku, Tržcu, utvrdi i trgovištu Slunj, Cetinu, Izačiću, Topličkom Turnju, Brekovici, Ostrožcu, Kremenu, Hojsiću, Blagajskom Turnju, Gornjoj i Donjoj Kladuši, Svetom Jurju u Ostrožačkom Polju, Podzvizdu, Peći, Šturliću, Vranograču, Perni i Kneji nalazi 1 falkon, 7 falkoneta, 3 Scharffatindl, 152 teške bedemske puške (Doplhaggen), ali uglavnom raspuknute, 6 željeznih mužara za pucnjeve upozorenja i 40 centi baruta (oko 2240 kilograma). Trebalo je još dopremiti 2 Notschalangen, 4 falkona, 23 falkoneta, 250 teških bedemskih pušaka te 20 željeznih mužara. ${ }^{1110}$ I Lopašić je objavio izvor koji pokazuje da su krajem kolovoza 1577. u utvrdama Bihaćke kapetanije bili 1 falkon (Falkhanen) $^{1111}$, 7 falkoneta, 3 Scharffentindlen, 13 željeznih cijevi/komada (eysene stücklein), 152 uglavnom raspuknutih teških bedemskih puški (Toplhaggen), 6 željeznih mužara za vituljače te 40 centi baruta. Plan je bio da se nabave još 2 Notschlangen, 4 falkona, 23 falkoneta, 500 teških bedemskih pušaka (Toplhaggen) i 20 centi baruta. ${ }^{1112}$ U drugom je spisu razlika u tome što je

\footnotetext{
${ }^{1105}$ SI AS 2, DSK, kutija 201, fascikl 124, 1r, rbr. 510. Bez datuma i mjesta. Prema Simonitijevu izračunu, jedna centa iznosila bi oko 56 kilograma. SIMONITI, Vojaška oranizacija, 185.

${ }^{1106}$ SI AS 2, DSK, kutija 201, fascikl 124, 1r, rbr. 593. Bez datum i mjesta.

1107 ÖeStA, HKA, GB, sv. 65, fol. 289r-289v.

${ }^{1108}$ Simoniti donosi omjere sastojaka potrebnih za pripremu baruta. SIMONTI, Vojaška organizacija, 194.

${ }^{1109}$ HDA, Zbirka preslika, kutija 4, 1551., bez oznaka, izvještaj pod naslovom „Die Gränizen von Zeng, da ist von Mor, bis gen Sissegkh and den wasserfluß Saw. 24 gueter meil wegs lanng“, str. 2.

1110 ÖeStA, KA, AFA, 1577-13-2; ÖeStA, HKA GB, sv. 65, fol. 289r-289v

1111 Falkon je bio poljski top srednje duge cijevi koji su prevozila četiri do šest konja. SIMONITI, Vojaška organizacija, 196.

${ }^{1112}$ LOPAŠIĆ, SHK, knjiga I, dok. XXVI, 41.
} 
predloženo da se dopremi 250 teških bedemskih pušaka više i što se navodi 13 ručnih cijevi koje se u gornjem prijedlogu ne spominju.

U studenom 1577. Sebastian Lamberg navodi da ono malo topova u Bihaću leži na mjestu jer su kotači i postolja propali, a nema osoba koje bi ih mogle podignuti. Pritom je nedostajalo olova, baruta, streljiva i topova, pa se u slučaju potrebe nisu imali čime braniti. ${ }^{1113}$ Početkom prosinca 1577. građani i posada navode da se nalaze okruženi i u očajnoj situaciji te ne znaju što više činiti nego prema Osmanlijama udarati „meda nje velikimi pukšami, ke su nam jurve v stanim izgnile i na zemlju vpale, da njimi se pomoći nemoremo“. ${ }^{1114}$ Radilo se o periodu kada je osmanska ekspanzija unskim prostorom na vrhuncu pa je u prijedlogu obrane Hrvatske krajine na saboru u Brucku 1578. navedeno: „topove u Bihaću na pričvršćenim kotačima, kao i sve ostale potrebne stvari, potrebno je odmah popraviti i dovesti u stanje pripravnosti“. ${ }^{1115}$ Krajem svibnja te godine došlo je do već spomenutog udara groma $u$ samostan sv. Antuna pri čemu je došlo do eksplozije tamo pohranjene živeži i streljiva. ${ }^{1116}$

Za kasniji period do pada pod osmansku vlast nisu pronađeni precizni popisi oružja i opreme, ali budući da su u gradu djelovali oružar i pet puškara, zasigurno je bilo dovoljno oružje, opreme i sredstava za njihovu djelatnost. Štoviše, čini se da je, bez obzira na nezavidan položaj u kojem se Bihać našao od kraja 1570-ih, i ovaj segment obrane stabiliziran pa je tako u 1580-ima i porastao broj puškara u gradu.

$\mathrm{Na}$ koncu, unatoč činjenici da izvori nisu sustavno sačuvani pa je teško detaljno analizirati količinu i sastav oružja te opreme pohranjene u Bihaću, kroz cijeli promatrani period, na temelju prezentiranih podataka može se zaključiti da je u gradu čuvano raznovrsno i moderno oružje te veća količina opreme koja je bila potrebna za rukovanje, održavanje, pa čak i proizvodnju vatrenog naoružanja, uključujući topova. Iako se u izvorima konstantno naglašava problem broja i stanja oružja i opreme, dostupni popisi pokazuju da je bihaćka posada u nekim periodima raspolagala većom količinom težih i standardnih bedemskih pušaka kukača. Topovi su uglavnom bili srednjeg i manjeg dometa, a s obzirom na popisanu opremu za lijevanje i rezanje topova, oni su se u Bihaću i proizvodili. Očito se proizvodio i crni barut. Oružje i oprema čuvani su u oružarnici koja je vjerojatno bila dio kaštela, gradskim crkvama i samostanima te u drugim zidanim i sigurnim lokacijama. Za oružje su se brinuli oružari i puškari kojih je s vremenom bilo sve više i kojima je rasla plaća. Transport oružja i

${ }^{1113}$ SI AS 2, DSK, kutija 286, fascikl 164, Bihać, 26.11.1577., 2r-2v, rbr. 304-305. Sebastian Lamberg na kranjske Verordneten.

${ }^{1114}$ LOPAŠIĆ, Bihać, 71

1115 ŠTEFANEC, Država ili ne, 299.

1116 SI AS 2, DSK, kutija 287, fascikl 164, Bihać, 23.5.1578., 1r, rbr. 429. Benedict Crainer na vojne povjerenike. 
opreme na istureno pograničje predstavljalo je logistički i sigurnosni problem koji je implicirao suradnju raznih instanci na krajištu - i vojnih i civilnih. Oružje i oprema dopremani su uglavnom s teritorija Unutrašnje Austrije, ali i s cijeloga regionalnog prostora, uključujući i prekojadranske zemlje, a to je još jedan dokaz o regionalnoj suradnji pri zaustavljanju osmanskog napredovanja. 


\section{BIHAĆ KAO OBAVJEŠTAJNO, STRAŽARSKO I POŠTANSKO SREDIŠTE}

Pogranično ratovanje $\mathrm{u}$ velikoj se mjeri svodilo na borbu za informacije jer nijedan (defenzivni) sustav nije mogao funkcionirati bez efikasnoga obavještajnog, stražarskog i poštanskog aparata. ${ }^{1117}$ Pravovremena akvizicija vjerodostojnih obavijesti na krajištu često je značila razliku između pobjede i poraza, a važnost navedenih aktivnosti pokazuje i sadržaj prijedloga kranjskih staleža o uređenju krajišta između Jadranskog mora i rijeke Save iz 1553. u kojem decidirano stoji da su dobre obavijesti, straže i pošta početak i temelj svakog ratovanja te da je o tom aspektu nužno najmarljivije voditi računa. ${ }^{1118}$ I bihaćki kapetan lamentira 1581. da je njemu ili bilo kojem drugom ovdašnjem kapetanu nemoguće obraniti utvrdu bez novaca za straže, obavijesti i poštu. ${ }^{1119}$ Te konstatacije potvrđuju i mnogobrojne u originalu ili prijepisu sačuvane obavijesti, tzv. Türkische Kundtschafften, koje svjedoče o razgranatosti obavještajne mreže na kompletnome krajiškom prostoru.

Zbog međuovisnosti hrvatskog i unutrašnjeaustrijskog prostora austrijski su staleži barem od početka 16. stoljeća angažirali hrvatske plemiće za prikupljanje obavijesti o Osmanlijama. No, Vasko Simoniti navodi da je inicijalni obavještajni aparat bio neučinkovit zbog nesuradnje među plemstvom, no da je od 1522. poprimio sustavniji karakter. ${ }^{1120}$ I zaista austrijski su staleži početkom svibnja 1522. dogovorili s banom Ivanom Karlovićem modalitete obavještajne suradnje. Karlović je trebao 14 dana prije podizanja Osmanlija u Bosni poslati upozorenja prema Mokricama, Metlici i Klani iznad Rijeke, a kada Osmanlije stignu u Hrvatsku, ponovno poslati obavijesti da bi se mogli oglasiti pucnji za uzbunjivanje i da bi se mogla pripremiti obrana. ${ }^{1121}$

Već 29. svibnja Karlović je javljao da se bosanski i mostarski paša okupljaju i za dvanaest dana namjeravaju provaliti u Hrvatsku ili „Njemačku“ te molio da mu se u Bihać

\footnotetext{
${ }^{1117}$ HOZJAN, Die ersten steirischen, 246.

1118 „Unnd nachdem an guetter Khundtschafft Scartt vnnd Posst der anfanng vnd haubtpunct alles Khriegsvesenns, vnnd furnemblich darann der Lanndt warnung vnnd gewarsamb gelegen, demnach ist von notten dieselb, wie dann der Khun. Mt. Beuelch vnnd Mainung allwegen geweset, aufs vleissigist zuerhallten ". SI AS 2, DSK, kutija 339, fascikl 136., 1r, 1553.

${ }^{1119}$ SI AS 2, DSK, kutija 287, fascikl 164, Bihać, sine dato, 1v, rbr. 880.

1120 SIMONITI Turki su, 114. Unutrašnjeaustrijske instance i/ili vladar ponekad navode da su izvještaji i obavijesti pristizale iz Hrvatske, a često od bana Ivana Karlovića. Primjerice, početkom travnja obavijesti o osmanskim namjerama stižu aus Krabaten. THALLÓCZY, HODINKA, A horvát véghelyek, dok. XLVIII, 56. Sredinom istog mjeseca ban Ivan Karlović moli kranjske staleže da pošalju pomoć jer očekuje napad bosanskog paše. IBID., dok. XLIX, 57.

${ }^{1121}$ IBID., dok. LXIII, 103.
} 
pošalju pješaci, strijelci i laka konjica. ${ }^{1122}$ Prema dogovoru, Karlović je za godinu dana trebao dobiti visokih 1200 rajnskih guldena, ali početkom veljače 1523. nadvojvoda Ferdinand piše da se u dogovoreno ne treba mnogo pouzdati te da je potrebno cijelu stvar nekako drugačije urediti. ${ }^{123}$

$\mathrm{U}$ narednim je godinama, uz bana, glavni protagonist obavještajnog aparata na hrvatskom prostoru ugledni hrvatski plemić Ivan Kobasić, o kojem će biti riječi dalje u poglavlju. Formiranje sustavne i integrirane obavještajne djelatnosti na krajištu intenziviralo se s dolaskom nadvojvode Ferdinanda na ugarsko-hrvatski tron 1526./1527. ${ }^{1124}$ Prominentnu ulogu tada su preuzeli krajiški zapovjednici, odnosno hrvatsko plemstvo koje je ionako uglavnom bilo u plaćenoj krajiškoj službi.

S druge pak strane, hrvatsko-slavonsko plemstvo, ali i cijelo Ugarsko kraljevstvo, nije imalo razvijenu samostalnu vanjskopolitičku službu, kao ni stalno tijelo koje bi bilo zaduženo za obavještajne aktivnosti, već su ovisili o informacijama koje je preko svojega diplomatskog i obavještajnog aparata prikupljala središnja vlast. Središnja obavještajna služba dostavljala je informacije pak samo relevantnim instancama, a na hrvatsko-slavonskom području to je bio tek ban. No, ban i domaće plemstvo razvili su svoje privatne obavještajne mreže koje su ipak bile limitirane na prostor neposrednog interesa (Hrvatska i Slavonska krajina, osmansko pograničje, Dalmacija, Dubrovnik) te sporadičnoga karaktera. ${ }^{1125}$ Hrvatsko-slavonski staleži će vrlo kasno, tek na saboru u Steničnjaku 1558., od kralja zatražili organiziranje i izdržavanje straža i špijuna na pograničju. ${ }^{1126}$

U obavještajnom sustavu sudjelovali su razni akteri - krajiški zapovjednici, obični vojnici, plemstvo, prebjezi, uhode, zarobljenici, trgovci, poslanstva itd. ${ }^{1127}$ Prikupljanju informacija pridonosio je zonalni karakter pograničja koje je bilo vrlo teško nadzirati što je

1122 IBID., dok. LXXXII, 137. I drugi hrvatski velikaši su se u lipnju te godine ponudili da će, ako ih se s konjanicima uzme u službu, održavati ,guet kuntschaft“ i dojaviti obavijesti 8 ili 14 dana prije osmanskog okupljanja. IBID., dok. CI, 165

${ }^{1123}$ IBID., dok. CXXXVI, 235.

${ }^{1124}$ Nedim ZAHIROVIĆ, Two Habsburg Sources of Information at the Sublime Porte in the Second Half of the Sixteenth Century, u: Power and Influence in South-Eastern Europe, 16th-19th Century, ur. By Maria Baramova idr., Zürrich-Müster, 2013., 417. Veliku ulogu u formiranju habsburške obavještajne mreže odigrao je zagrebački trgovac firentinskog podrijetla Ivan Pastor mlađi. Josip ŽONTAR, Obveščevalna služba in diplomacija austrijskih Habsburžanov v boju proti Turkom v 16. stoletju. Ljubljana, Slovenska akademija znanosti in umetnosti, 1973., 191-194.

1125 ŠTEFANEC, Država ili ne, 287-288. No, već u listopadu 1526. Ferenc Batthyány prilikom navođenja uvjeta za preuzimanje banske službe navodi da će odgovorno upravljati obavještajnim sustavom, ali budući da mu je stanovništvo sve porobljeno i izbjeglo, nema ga odakle financirati. Obavijesti je primao iz Udbine i Obrovca. LASZOWSKI, HSKHDS, knjiga I, dok. 25, 24.

${ }^{1126}$ HOZJAN, Die ersten steirischen, 249.

${ }^{1127}$ Obavijesti su pristizale i iz Dalmacije odakle su ih donosili na trgovačkim brodovima koji su, primjerice, uplovljavali u senjsku luku. SI AS 2, DSK, kutija 286, fascikl 164, Ljubljana, 30.9.1577., 1r, rbr. 335. Predstavnici kranjskih staleža na Hansa Auersperga, zapovjednika Hrvatske krajine. 
pak olakšavalo kretanje špijuna i uhoda. Zato se anonimni špijun iz Banja Luke, koji je u lipnju 1585. u Bihaću osobno informirao zapovjednika o okupljanjima Osmanlija u njegovu gradu, odmah mogao i vratiti nazad kako bi dostavio nove obavijesti. ${ }^{1128}$ Izražena dinamika pograničja, mobilnost pograničnog stanovništva i brzina s kojom su se ratni događaji odvijali omogućavali su pa i uvjetovali redovitu distribuciju informacija s obiju imperijalnih strana. Da bi se nadvladao suparnik, trebalo ga je dobro nagledati, a iako to nije uvijek bilo lako pa ni izvedivo, obje su strane imale relativno dobar uvid u neprijateljske namjere.

Prema mogućnostima vojni zapovjednik nastojao se osobno susresti s angažiranim špijunima kako bi definirali područje i ciljeve koje će špijunirati (nadgledanje vojnih jedinica, ljudi, pokreta/namjera, kadrovskih promjena itd.), dogovarali načine dostave usmenih i pismenih obavijesti što se odnosilo na to hoće li ih dostavljati osobno ili preko svojih ljudi, mjesto i vrijeme dostave, jezik obavijesti i eventualne šifre itd. ${ }^{1129}$ Dogovarali su i modalitete isplate špijuna i njegovih ljudi (mjesečno ili četvrtgodišnje, valuta), diskrecijska pitanja, dužinu službe. Ponekad su špijuni primali i posebna zaduženja poput angažiranja novih špijuna, pripremanja otkupa zarobljenika, dostava poklona osmanskim uglednicima. Špijune je trebalo angažirati najkasnije do travnja i unaprijed isplatiti. ${ }^{1130}$

U izvorima na njemačkom jeziku za habsburške uhode na osmanskom teritoriju često se koristi sintagma ,povjerljive osobe“ (vertraute Personen). ${ }^{1131} \mathrm{U}$ hrvatskom jeziku koristili su se termini sintagme poput „,naših otajnih straž tr prijatelj“. ${ }^{1132}$ Ta formulacija nije tek stilska figura, već su špijuni i uhode zbog ,prirode posla“ morale biti pouzdane osobe. U službi kralja Ferdinanda na slavonskom krajištu angažirane su samo osobe kojima se vjerovalo $^{1133}$ dok je Ivan Lenković držao pouzdanim samo informacije koje je dostavio špijun ili njegovi ljudi, čija se istinitost mogla potvrditi iskazima prebjega i zarobljenika. ${ }^{1134}$ Slično su postupali i drugi zapovjednici. Tako je Hans Auersperg početkom rujna 1576., u kontekstu velikih osmanskih napada na unskom frontu, naveo da imaju obavijesti da je livanjski beg već u pokretu, ali da ne treba sasvim vjerovati tim navodima jer potječu od zarobljenih

\footnotetext{
${ }^{1128}$ SI AS 2, DSK, kutija 203, fascikl 124a, Karlovac, 12.6.1585., 1r-1v.

1129 Špijuni su se preodijevali u neprijateljske odore/odjeću tako da bi kršćanski špijuni stavljali turbane i fesove, a osmanski bi na ugarskom prostoru stavljali ugarske visoke kape. Nataša ŠTEFANEC, Heretik njegova veličanstva. Povijest o Jurju IV. Zrinskom i njegovom rodu, Barbat, Zagreb, 2001., 53.

${ }^{1130}$ HOZJAN, Die ersten steirischen, 250-251.

1131 SI AS 2, DSK, kutija 287, fascikl 164, Bihać, 16.2.1576., 1r, rbr. 487. Sebastian Lamberg na Hansa Auersperga i Jobsta Josepha Thurna.

${ }^{1132}$ Tako je senjski kapetan Herbart Auersperg sredinom rujna 1558. javljao u glagoljskom pismu o osmanskim namjerama koje mu je obznanio prijatelj. BOJNIČIĆ, Izvješća, dok. V, 63.

${ }_{1133}$ HOZJAN, Die ersten steirischen, 247-248.

${ }^{1134}$ IBID., 252.
} 
„Turaka“. ${ }^{1135}$ U instrukciji za glavnog zapovjednika Hrvatske krajine iz 1578. jasno je navedeno da se ne smije vjerovati prebjezima ili ih uzimati u službu bez opsežnih istraga o njihovu porijeklu. ${ }^{1136}$ Prikupljene informacije morale su se komparirati te se morala utvrditi njihova vjerodostojnost, osobito kada se radilo o obavijestima prikupljenim preko vlaških starješina ili prebjega prema kojima su vojne vlasti bile permanentno nepovjerljive. ${ }^{1137}$ Informacijama se uvijek moglo manipulirati kako bi se zavaralo suparnika pa je tako, primjerice, Herbart Auersperg sa skepsom promatrao obavijesti o pojačanim osmanskim aktivnostima oko Obrovca 1563. strahujući da je riječ o namjernom odvraćanju pažnje kako bi neopaženo pokušali zauzeti Krupu ili Ripač. Radi mjere opreza u pograničnim je utvrdama ipak ostavio uskočke čete. ${ }^{1138}$

Zarobljenici su predstavljali vrlo važan izvor informacija te se prilikom priprema za prodora na neprijateljski teritorij nastojalo zarobiti neprijateljske vojnike, često prethodnice ili straže, kako bi otkrili relevantne informacije. Takav se postupak na njemačkom jeziku nazivao ,zeugen fachen“, a na hrvatskom se na takve osobe referiralo kao na ,živi jezik“. Sa zarobljenicima se često vrlo nasilno postupalo, a kranjski staleži imali su poseban pravilnik (Ordnung) prema kojem su ispitivani. ${ }^{1139}$ Ivan Izačić, porkulab ripački, sumirao je u ožujku 1566. taj nedvojbeno bolni postupak: „da mi dojde sužanj moj i ispitah ga za glase, strašeći ga“. ${ }^{1140}$ Ivan Lenković je početkom srpnja 1561. oko Sračice razbio jedan manji osmanski odred kojem je kalauz, odnosno vodič bio Juraj Verlić iz Kostajnice koji je navodno znao Malkoč-begove namjere i planove više od svih vojvoda, aga i zapovjednika. Verlić je na ispitivanju otkrio vrijedne podatke, a zatim je sa stanovitim Mikulom Čučom (Micola Tschutscha), prebjegom s habsburške strane, nabijen na kolac. ${ }^{1141}$

Identično su postupali i Osmanlije koji su kao uvertiru u svoje napade također slali manje odrede u izviđanje i „loviti jezike“. No, taj je postupak mogao biti kontraproduktivan jer su ti manji odredi mogli biti napadnuti i/ili zarobljeni i prisiljeni otkriti svoje namjere. Primjerice, to se dogodilo početkom svibnja 1544. kada je bihaćki kapetan Georg Sauer kod Bihaća razbio osmanski odred od 33 čovjeka, pritom zarobivši 25 osoba koje su ispitivanjem

\footnotetext{
${ }^{1135}$ SI AS 2, DSK, kutija 287, fascikl 164, Metlika, 6.9.1576., 1v, rbr. 675. Hans Auersperg na predstavnike kranjskih staleža.

1136 ŠTEFANEC, Država ili ne, 211.

${ }^{1137}$ HOZJAN, Die ersten steirischen, 250.

${ }^{1138}$ SI AS 2, DSK, kutija 805, fascikl 540, logor između Smrčkovića i Blagajskog Turnja, 19.5.1563, 1r-1v. Herbart Auersperg na predstavnike kranjskih staleža. Tracy navodi da su tijekom rata s Mletačkom Republikom (1499. - 1503.) sandžak-begovima izdavani nalozi za napad koji su mogli biti otpečaćeni tek kad su stigli na određenu naznačenu točku. TRACY, Balkan Wars, 53.

1139 ŠTEFANEC, Država ili ne, 287.

${ }^{1140}$ BOJNIČIĆ, Izvješća, dok. XXIV, 77.

${ }^{1141}$ HDA, Militaria, kutija 7, Sračica, 4.7.1561. 1r. Ivan Lenković na bana.
} 
dale obavijesti o pripremama osmanske vojske u Bosni i namjerama Malkoč-bega da napadne Ripač, Bihać, Krupu ili Kostajnicu, kada dobije sultanovu dozvolu. ${ }^{1142}$

Koliki je mogao biti radijus takvih špijunsko-izviđačkih akcija vidi se iz pisma koje su bihaćki pješaci i konjanici s porkulabima svih okolnih utvrda sastavili krajem lipnja 1573., a u kojem navode da su tri vojnika, Filip, Scheyerov vojnik (khnecht), zatim brat stanovitog Vukše (Vukhschin bruder) te vojnik kneza Gašpara Križanića (des khnes Gaspar Crisanitsch knecht, u hrvatskom jeziku stoji „kneza Gašpara Križanića Junak“), krenuli „,na put u martaloziju“ (drey Khnecht auff die reys Martolossen u njemačkoj inačici) duboko u „Tursku“ prema Bjelaju te zatim nazad prema Krupi i Kamengradu. Pritom su putem neprestano promatrali osmanske konjanike i pješake koji su se iz smjera Krupe, Kamengrada i Banja Luke okupljali na Bjelajskom polju. Navedeni su čak zarobili kćer nekog vlaškoga kneza koju su doveli u Bihać (koja je već ranije bila zarobljena), a koja je svjedočila da je na begov nalog neimenovani vojvoda njezinu bratu naredio da odmah podigne svoje ljude. Međutim, budući da taj nalog nije tako promptno izvršio, „Turci“ su ga pred kućnim pragom nabili na kolac. Također, izjavila je da se Osmanlije spremaju opsjesti neku utvrdu oko Bihaća, ali ne zna koju. ${ }^{1143}$ Slični kapilarni upadi u neprijateljski teritorij stalno su izvođeni.

Nadalje, obavijesti su prikupljane i od osmanskih podanika koji su se na habsburški teritorij vraćali radi podmirivanja iznosa cijene otkupa iz zarobljeništva. (tzv. cina - cijena) i obratno. ${ }^{1144}$ Ova praksa ulazi u lepezu običaja i postupaka poznatih kao „vira krajiška“, a koji su imali funkciju osigurati određenu dozu sigurnosti pograničnom stanovništvu na objema stranama krajine. Vojne vlasti nisu imale previše razumijevanja za te aktivnosti jer su takvi postupci imali potencijalno negativne sigurnosne posljedice. U instrukciji za glavnog zapovjednika izričito je zabranjeno puštati zarobljenike da se slobodno kreću krajinom odlazeći ili dolazeći s otkupninom. ${ }^{1145}$ Takve osobe često su raspolagale prvorazrednim obavijestima, bez obzira što su bili zarobljenici. Tako je krajem ožujka 1559. godine bihaćki

\footnotetext{
${ }^{1142}$ HDA, Militaria, kutija 2, svibanj 1544., 89.

1143 „, an ein Spiss gestökh“ odnosno ,,a Turci došadči tako su ga on čas pred negovom hižom pred vrati na kolac nabili“. SI AS 2, kutija 286, fascikl 164, Bihać, 29.6.1573., 1r, rbr. 129. Prijevod s hrvatskog. Lopašić je objavio hrvatski izvornik. LOPAŠÍ́, Bihać, 305, dodatak XI.

${ }^{1144}$ IVIĆ, O prvoj srpskoj, dok. VI, 264. O ovoj tematici vidi: ŠTEFANEC, Institutional Control of Violence, 63-83.; Geza PÁLFFY, Ransom Slavery along the Ottoman-Hungarian Frontier in the Sixteenth and Seventeenth Centuries, u: Ransom Slavery along the Ottoman Borders (Early Fifteenth - Early Eighteenth Centuries), ur: Geza Dávid-Pál Fodor, Brill, Leiden-Boston-Köln, 2007., 35-83.; Drago ROKSANDIĆ, Stojan Janković in the Morean War, or of Uskoks, Slaves and Subjects, u: Constructing Border Societies on the Triplex Confinium, ur. Drago Roksandić, Nataša Štefanec, CEU History Department Working Paper Series 4, Budimpešta, 2000., 239-288.

1145 ŠTEFANEC, Država ili ne, 211. U ovom pogledu zanimljiv je i izvještaj senjskoga kapetana s kraja srpnja 1557. u kojem navodi da su se iz „Turske“ vratila dva ovdašnja vojnika koja su tamo rješavala pitanje otkupa, a koji su ,souil Turkisch verstanden“ da su saznali da Osmanlije namjeravaju četovati pod Bihać i Izačić. SI AS 2, DSK, kutija 201, fascikl 124, Senj, 26.7.1557., 1r, rbr. 464. Senjski kapetan na predstavnike kranjskih staleža.
} 
kapetan Georg Zoblsperg javio da je u grad upravo pristigao Ivan Hlapčić (Juan Hlaptschitsch) koji je prije tri tjedna otputovao u Osmansko Carstvo kako bi riješio pitanje otkupa, a koji je izvijestio da Ferhat-beg trenutno nema okupljene vojske te da se među Osmanlijama priča da su sultan i car utanačili primirje na tri mjeseca. Usto, navodno je Ferhat-begu i Malkoč-begu naređeno da miruju. ${ }^{1146}$ Početkom rujna 1576., u kontekstu potencijalne opsade Bihaća, iz zarobljeništva (preciznije Banja Luke) vratio se stanoviti Marko, Jankovićev vojnik (dienner), koji je na vlastite oči vidio Ferhad-begovu vojsku kod Kamengrada te osmansku vojsku po cijelom krajištu, a procijenjeno je da je okupljanje tolike sile teško je moglo proći bez upada na habsburški teritorij. ${ }^{1147}$

Vrlo je ilustrativan i višeznačan primjer „istaknutog prebjega“ (annsehenlicher Pribegk) Šimuna Zečića (Schymon Setschitsch) koji je „mnogo štete nanio Bihaću“ (der Wihitsch vill schaden gethan), da bi krajem travnja 1561. iz Srba prebjegao na teritorij Frankopana Tržačkog te je predan bihaćkom kapetanu. Zečić je otkrio određene podatke o osmanskim namjerama, a kao osobno „osiguranje“ s dvora sandžak-bega donio je glavu jednoga uglednog Osmanlije kojega je svojom rukom likvidirao. ${ }^{1148}$ Ovaj primjer pokazuje fluidnost osobnih lojalnosti i nasilni karakter pograničnog iskustva, a činjenica da se očito radilo o katoliku, vjerojatno hrvatskom starosjediocu koji je „mnogo šteta“ nanio Bihaću, demonstrira da se krajište teško može analizirati u binarnim kategorijama - mi ili oni.

U izvorima se pojavljuju slučajevi kada su viši zapovjednici naređivali podređenim instancama da pojedine poznate zarobljenike nikako ne puštaju na otkup ili zadržavaju, već da im se te osobe predaju ili dovedu na ispitivanje ili presudu. Tako je Ivan Lenković u studenom 1557. javio zapovjedniku Hrvatske krajine i bivšemu bihaćkom kapetanu Georgu Saueru da se u Bihaću nalazi zarobljena „teška štetočina“ (häfftiger schadlicher), martolog po imenu Paporšen (Paporschen), te da ga upravitelj kapetanije nikako ne smije pustiti na otkup, bez obzira na to kome pripadao, sve do njegove daljnje zapovjedi. Takvi ljudi bili su predragocjeni da bi se s njima postupalo kao s običnim zarobljenicima, a Lenković je namjeravao spriječiti ga više „bilo kojem kršćaninu učini bilo kakvu štetu“. ${ }^{1149}$ Hans Khisl, ratni blagajnik na Hrvatskoj krajini, isplatio je 1566. devetorici bihaćkih vojnika, koji su

\footnotetext{
1146 „da mit seiner Lossung zu seinem herrn dem Khouatscheuitsch“. SI AS 2, DSK, kutija 202, fascikl 124, Bihać, 26.3.1559., 1r, rbr. 798. Georg Zoblsperg na Ivana Lenkovića.

1147 SI AS 2, DSK, kutija 287, fascikl 164, Črnomelj, 1.9.1576., 1v, rbr. 641. Christoph Auersperg na predstavnike kranjskih staleža.

${ }_{1148}^{114}$ HDA, Militaria, kutija 7, Pobrežje, 4.5.1561., 1v. Ivan Lenković na predstavnike kranjskih staleža.

${ }^{1149}$ SI AS 2, DSK, kutija 201, fascikl 124, Varaždin, 16.11.1557., 1r, rbr. 449.
} 
transportirali dvojicu „sumnjivaca“ u unutrašnjost, lijepu svotu od 25 rajnskih guldena i 40 krajcara, a u to je ulazio i trošak hrane. ${ }^{1150}$

Važnost zarobljenika, ali i izrazitu kompleksnost pograničnog iskustva pokazuje i ilustrativan slučaj bihaćkoga kovača Urbana (Vrbann). Naime, njega su Osmanlije zarobili pod Izačićem te ga poslali pred samog sultana (Khayser), da bi se potom s Malkoč-begovim sinom vratio u Kupres. Zatim je prebjegao na habsburšku stranu te u srpnju 1557. u Bihaću svjedočio o svojem iskustvu. Otkrio je da su ga pred sultana doveli lijepo ukrašena i odjevena te da mu je Malkoč-beg naredio da pred Hrustem-pašom i svim njegovim savjetnicima (Radten) svjedoči da je Malkoč-beg dva važna (namhafftig) grada, Stijenu i Omršal (Steenna vnd Amerßall) poharao i spalio te da je bihaćkoga kapetana i Herbarta Auersperga, koji su priskočili u pomoć, protjerao i gonio sve do Mutnice. Oboje da su jedva spasili živu glavu. Sultan mu je tada odlučio poštedjeti život, Malkoč-beg je za nagradu dobio u has Grahovo (Grahofa), a njegov sin Đaferbeg (Schafferbeeg) „kapetaniju u Gradiškoj“ (die Haubtmanschafft Gradisskha). Nadalje, izjavio je da je Malkoč-begu obećana asistencija nekoliko paša kako bi te godine osvojio Bihać te da su ga upravo zbog toga i poveli nazad da bi im pokazao putove, staze i odakle pucati na grad. U trenutku pisanja izvještaja pred kapetana je stigao i stanoviti Stanko Dragošić (Stanko Dragoschitsch) koji je četiri dana ranije pobjegao iz Klisa, a koji se životom zaklinjao da su pripreme već započele. I neimenovani zarobljenici potvrđivali su da se ove godine sprema udar na Bihać ili Krupu. ${ }^{1151}$ Dakle, pripreme za napad na Bihać sezale su do samoga vrha osmanske države i bile su kompleksne, a izrazito je važna bila suradnja domaćih osoba koje su poznavale lokalni teren i karakteristike grada.

Još jedan primjer svjedoči o kompleksnosti pograničnog iskustva i važnosti informacija i poznavanja terena u krajiškom ambijentu. Sredinom rujna Osmanlije su izvršili (već spomenuti) neuspješni napad na Golubić, a osmanske konjanike vodio je stanoviti Rady, kojeg je već ranije zarobio Hans Khisl, a neko je vrijeme bio i u vojnoj službu u Bihaću. Martologe je u tom napadu pak vodio Vlah Sišnavić (Wlach Sischnawitsch) koji se čak rodio u Bihaću, ali su ga nekoliko godina ranije Osmanlije zarobili zajedno s ženom i djetetom. Navedeni je od tada habsburškoj strani nanio velike štete, a u napadu je bio „martolog, kalauz i vodič‘. Sišnavić je tom prilikom poginuo. ${ }^{1152}$

\footnotetext{
${ }^{1150}$ HDA, Militaria, kutija 7, 1565./1566., 17v. Iskaz financijskih izdataka Hansa Khiesla, ratnog blagajnika na Hrvatskoj krajini za 1565. i 1566. Preslike ovoga opsežnog iskaza nalaze se među preslikama spisa za 1561. ${ }^{1151}$ SI AS 2, DSK, kutija 201, fascikl 124, Bihać, 21.7.1557., 1r-1v, rbr. 472-473.

1152 SI AS 2, DSK, kutija 414, fascikl 284, Črnomelj, 28.9.1565., 2r, rbr. 1375. Balthasar Katzianer na Ivana Lenkovića.
} 
Velikom riziku bili su izloženi oni koji su na bilo koji način participirali unutar obavještajnog sustava. Obje su strane (barem načelno) postupale nemilosrdno prema špijunima i onima koji su uhvaćeni prilikom prikupljanja obavijesti. Kažnjavanje tih nesretnika uključivalo je cijeli dijapazon brutalnih metoda poput nabijanja na kolac ${ }^{1153}$, probadanja mačem ili kopljem, utapanja itd. Uz torturu i egzekuciju, muškarce osumnjičene za špijunažu često se slalo okovane na galije, a njihove obitelji protjerivane su ili dublje u pozadinu ili u prijestolnicu. ${ }^{1154}$ Obitelji prokazanih špijuna bile su osobito ugrožene jer su muškarci mnogo lakše „uskakali“ preko pograničja sami nego sa svojom obitelji. Krajem listopada 1558. bihaćki kapetan Zoblsperg javio je da je razotkriven njegov špijun na osmanskoj strani te da je 29 ili čak više osoba povezano s njime uhvaćeno, ali da je ovaj ipak sa suprugom i djetetom uspio prijeći na habsburšku stranu. Kapetan je molio da mu se pomogne kao što mu je i obećano u takvoj situaciji, a osobito sada kada mu je pomoć potrebnija nego ikada. ${ }^{1155} \mathrm{U}$ ožujku 1592. ban Toma Erdödy obavještava o planovima bosanskog paše za napad na Bihać te o nekoliko prebjeglih uskoka koji su tijekom ljeta dostavljali korisne informacije. Među njima nalazio se jedan vrlo vrijedan uskok i špijun koji je ranije s posjeda Stjepana Gregorijanca prebjegao na osmanski teritorij, a koji je sada jedva živ pobjegao Osmanlijama, no njegova žena i djeca su zarobljeni te sva imovina zaplijenjena. ${ }^{1156}$ Ipak, razotkriveni špijuni mogli su se spasiti, pa i financijski ili čak socijalno napredovati, prelaskom u obavještajnu službu dojučerašnjih neprijatelja, odnosno preuzimanjem uloge dvostrukog agenta. ${ }^{1157}$

\subsection{Razvoj obavještajnog sustava Bihaćke kapetanije}

S obzirom na značenje na hrvatskom krajištu, Bihać je predstavljao jedan od najvažnijih centara za prikupljanje i distribuiranje povjerljivih obavijesti. U grad su pristizali špijuni

\footnotetext{
${ }^{1153}$ Žrtve su mogle biti nabijene na manje našiljeno i oguljeno drvo ili pripremljeni kolac. HOZJAN, Die ersten steirischen, 255.

${ }_{1154}$ JURIN-STARČEVIĆ, Osmanski krajiški, 148.

${ }^{1155}$ SI AS 2, DSK, kutija 201, fascikl 124, Bihać, 29.10.1558., 1v, rbr. 787. Georg Zoblsperg na predstavnike kranjskih staleža.

${ }^{1156}$ SI AS 2, DSK, kutija 805, fascikl 540, Jastrebarsko, 21.3.1592., 1r. Toma Erdödy na nadvojvodu Ernesta. Više instance poticale su uskakanje i zadržavanje na „neprijateljskom“ teritoriju jer je objema stranama bilo u interesu imati pouzdane ljude s druge strane pograničja. Tako je prema iskazima trojice habsburških špijuna iz lipnja 1580. stanoviti osmanski špijun Andrija Janković, zvani Gutischen, namjeravao uskočiti na osmanski teritorij, ali je Ferhat-beg od njega tražio da i dalje ostane na kršćanskom prostoru i dostavlja obavijesti. SI AS 2, DSK, kutija 202, fascikl 124a, Črnomelj, 19. lipanj 1580., 2r-2v.

${ }^{1157}$ HOZJAN, Die ersten steirischen, 254-255.
} 
raznih profila s okolnog prostora - iz Udbine ${ }^{1158}$, Kostajnice, Krupe, iz vlaškog i starosjedilačkog miljea, ali i pojedinci različite provenijencije pristigli iz drugih dijelova Osmanskog Carstva. Upravitelj Bihaćke kapetanije Gregor Allmayer javio je krajem travnja 1585. Wolffu Engelbrechtu Auerspergu dao mu je obavijesti o zbivanjima i stanju osmanske vojske donio ,jedan Turčin iz Carigrada, koji je unatoč tome kršćanin“, a koji je treći put izjahao iz Osmanskog Carstva. Tom prilikom razgovoru je prisustvovao i vojvoda Barkanović (Warkhanouitsch) koji je potom „u Božje ime četovao“. ${ }^{1159}$ Auersperg je o svemu izvijestio nadvojvodu Karla navodeći pritom da to (bivše) „kršćansko dijete“ njemu podređeni najugledniji uskoci poznaju od djetinjstva te da je dosad imao sreće često neopaženo ući na habsburški teritorij pa „mu treba pridati dužnu pažnju. ${ }^{1160}$ Dakle, Bihać je predstavljao čvorište na kojem su se, osim regionalne špijunsko-izviđačke mreže, ispresijecale razne osobne priče. Ivanu Lenkoviću donio je u rujnu 1555. obavijesti o kretanju Malkoč-bega jedan „Turčin“ koji je stigao iz Livna, od Welliawega Vlahovića, kojeg Lenkovića tada naziva „svojim prijateljem“. ${ }^{1161} \mathrm{U}$ drugom spisu Lenković naziva Vlahovića svojim rođakom (vettern). ${ }^{1162}$

Razvoj obavještajnog sustava sa svima trima elementima - špijunskim, stražarskim i poštanskim - započeo je u Bihaću još prije zasjedanja nadvojvode Ferdinanda na ugarskohrvatsko prijestolje. Austrijski staleži nastojali su s banom i hrvatskim plemstvom ustrojiti obavještajnu službu barem od početka 1520-ih, kako je ranije i navedeno. Tako se sredinom 1520-ih razmatralo držanja špijuna i na pašinu dvoru u Bosni iako to nije bilo lako izvedivo. U kombinaciju za to ulazila su dva hrvatska plemića - Gašpar Križanić i Ivan Kobasić (Krisinitsch und Kawaschitz). Međutim, Križanić je tada bio u Ugarskoj, pa se nastojalo dogovoriti s Kobasićem. Budući da se propustilo urediti špijunski sustav u zimsko doba, da bi sve bilo funkcionalno do ljeta, trebalo je sve postaviti prije nego što Osmanlije puste konje na pašnjake. Sve je to trebalo financirati s 300 rajnskih guldena godišnje, a ako je moguće, špijuni nisu smjeli znati jedni za druge. No, navedeno je i da će on vrhovni vrhovni

\footnotetext{
${ }^{1158}$ SI AS 2, DSK, kutija 286, fascikl 164, Ljubljana, 16.8.1574., 1r, rbr. 245.

1159 SI AS 2, DSK, kutija 203, fascikl 124a, Bihać, 30.4.1585.,1r-1v.

1160 „Sovill des Turgkhen von Constantinopl $\mathrm{Zu}$ Wihitsch ankhomendt die ein Cristen khindt, vnnd zum drittenmahl iezi auß Turgkhey entritten etc. Er von dem furnembsten mir vnntergebnen Vßgokhen von khindheit an bekhanndt ist, vnnd biß her gluckh gehabt, so offt woll versehendt haimb zukhomben, soll dennoch geburlich aufmerckh auf Ihne gehalten werde“. SI AS 2, DSK, kutija 203, fascikl 124a, Karlovac, 2.5.1585., 1r. Wolff Engelbrecht Auersperg na nadvojvodu Karla.

${ }^{1161}$ HDA, Militaria, kutija 4, 28.9.1555., Slunj, 1v, rbr. 18, Ivan Lenković na Georga Wildensteina.

1162 HDA, Militaria, kutija 4, 4.9.1555., Pobrežje, 1r, rbr. 21. Ivan Lenković na predstavnike kranjskih staleža.
} 
zapovjednik kraljevskih/austrijskih postrojbi (obristveldhaubtman) znati organizirati sustav prema svom nahođenju ako stigne u zemlju. ${ }^{1163}$

Sljedeće godine Gašpar Križanić i Ivan Kobasić ipak su pregovarali s kranjskim staležima o organizaciji obavještajnog sustava. ${ }^{1164}$ Dakle, tada su u obavještajnom sustavu istaknutu ulogu imali Gašpar Križanić i Ivan Kobasić, uz naravno bana Ivana Karlovića. Ivan Kobasić, čiji se patrimonij nalazio u samoj okolici Bihaća, zapravo je jedna od ključnih figura uspostavljanja ili barem održavanja obavještajnog sustava 1520-ih. ${ }^{1165}$ Sredinom travnja 1524. Kobasić je pristao držati špijune u „Turskoj“ i na pašinu dvoru te dostavljati obavijesti u Metliku. Naveo je da to ne čini radi novca već radi kršćanske vjere, naklonosti nadvojvode, zemlje, ljudi te osobne koristi, ali da se to ipak nije moglo realizirati bez 1200 ugarskih guldena $(U . g l)$ godišnje. Dogovor tada nije finaliziran, ali je do rješenja Kobasić pristao dostavljati obavijesti najbolje što je mogao. ${ }^{1166}$ Iako još krajem svibnja nije bilo jasno je li dogovor s Kobasićem realiziran ili ne, ${ }^{167}$ sredinom kolovoza 1524. nadvojvoda Ferdinand naredio je Josephu Lambergu da dogovori s Kobasićem, koji se već pokazao vjernim, da za 1200 ugarskih dukata ili ako je moguće manje vodi obavještajnu mrežu još godinu dana. ${ }^{1168} \mathrm{U}$ rujnu 1525. dogovoreno je s Kobasićem i Karlovićem da za 1000 ugarskih dukata drže po dvije osobe na dvije lokacije. ${ }^{1169}$ Centri toga Kobasićeva sustava bili su Lapac, Nebljuh, Bihać i Brinje. ${ }^{1170}$ Kao jedan od glavnih aktera formiranja te obavještajne mreže navodi se hrvatski plemić Vid Ugrinović od Roga. ${ }^{1171}$

U srpnju 1527. Nikola Jurišić je, kao jednu od mjera obrane grada, predložio kralju da novopostavljeni kapetan preuzme nadzor nad obavještajnim aparatom kojeg su ustrojili Ivan Karlović i Ivan Kobasić te da mu se doznače odgovarajuća financijska sredstva. Jurišić je

\footnotetext{
1163 THALLÓCZY, HODINKA, A horvát véghelyek, dok. CLXXXV, 290-292.

${ }^{1164}$ IBID., dok. CCX, 324. Međutim, sredinom svibnja 1524. nakon jednoga osmanskog upada u kraj oko Metlike, a za koji su austrijski staleži krivili Hrvate koji su Osmanlijama pomogli i nisu poslali upozorenja, navodi se da je obavještajna mreža propala jer su se braća grofovi Brinjski podredili Osmanlijama pa više ne dopuštaju paljenje vituljača ni pucanje iz mužara. Osmanlije su navodno čak boravili na njihovim posjedima. IBID., dok. CCXIV, 329.

${ }^{1165}$ Ivan Kobasić, kojeg je kralj oslovljavao s egregie, trebao je za vojnu protiv Osmanlija sredinom 1529. podići 30 konjanika. LASZOWSKI, HSKHDS, knjiga I, dok. 228, 208.

1166 THALLÓCZY, HODINKA, A horvát véghelyek, dok. CXCIII, 302-303.

${ }^{1167}$ IBID., dok. CCXVII, 331-332. Krajem svibnja Kobasić je od Josepha Lamberga primio 50 rajnskih guldena koji su bili namijenjeni banu Karloviću za postavljanje nekoliko vojnika u Udbinu koja je bila važno obavještajno središte. IBID., dok. CCXVI, 331.

${ }^{1168}$ IBID., dok. CCLVII, 413.

${ }^{1169}$ IBID., dok. CCCXXVII, 485.

1170 JURKOVIĆ, The Fate, 154-155, fusnota 450.

${ }^{1171}$ Ivan JURKOVIĆ, Ugrinovići od Roga - raseljena obitelj plemenitog roda Šubića Bribirskih za trajanja osmanske ugroze, Zbornik Odsjeka za povijesne znanosti Zavoda za povijesne $i$ društvene znanosti Hrvatske akademije znanosti i umjetnosti, vol. 26, 2008., 74.
} 
držao da se sve može izvoditi s manjim troškom i kvalitetnije nego do tada te da će to kralju i njegovim zemljama biti od veće koristi. Čini se da je to zagovaralo i hrvatsko plemstvo. ${ }^{1172}$

O kakvom se ozbiljnom poslu radilo pokazuje i činjenica da je za funkcioniranje obavještajnog sustava $\mathrm{s}$ centrom u Bihaću 1530. trebalo utrošiti visokih 1000 rajnskih guldena. Međutim, tada su bihaćki suci i gradsko vijeće Bihaća i Ripča javili o određenim, nažalost nepreciziranim, problemima sa špijunima pa je kralj naredio kranjskim Verodneten da sve ispitaju i postave na svoje mjesto. ${ }^{1173}$ Sredinom svibnja 1530. Erasmo Thurn iz Bihaća šalje tajne špijunske izvještaje, a sljedeći mjesec njegov vicekapetan (lentins) Ivan Lenković šalje mu ,turske špijunske izvještaje“. ${ }^{1174}$

Ustrojavanjem Bihaćke kapetanije, nakon što je vladar preuzeo obranu grada, njezin je zapovjednik u svoje ruke preuzeo i tu izrazito važnu vojnu aktivnost koja je bila dio šire obavještajno-poštanske mreže na hrvatskom i unutrašnjeaustrijskom području. Unatoč zastojima i povremenim komplikacijama, priljev i diseminacija obavijesti nikada nisu bili ugroženi, a već tada je dominantu ulogu imao bihaćki kapetan, a ne domaće plemstvo. Iako su obavijesti nastavile pristizati i drugim kanalima, svojim položajem $\mathrm{u}$ prostoru i vojnohijerarhijskoj shemi bihaćki je kapetan stajao na čelu razgranatog i kompleksnoga obavještajnog sustava bez kojeg bi obrana Hrvatske krajine bila nemoguća. Ova je promjena još jedan pokazatelj proaktivnosti i dominacije staleža Unutrašnje Austrije na hrvatskom krajištu. Dok je ranije ban, odnosno istaknuti hrvatski plemići, primao austrijski novac za obavijesti, sada je time rukovodio bihaćki kapetan.

Bihaćki kapetan Mert Gall poslao je u svibnju 1541. dva špijuna na osmanski teritorij te im doznačio mjesečnu plaću. ${ }^{1175}$ Ta dvojica su se ubrzo vratila iz Bosne s vijestima da se okuplja velika osmanska vojska. Gall je planirao ponovno poslati dva špijuna u Bosnu, a zanimljivo je da se žalio da ne raspolaže s toliko špijuna kao njegovi prethodnici. Također, bojao se i da ovi špijuni ne budu zarobljeni. ${ }^{1176}$ Krajem 1541. bihaćkom je kapetanu za šest mjeseci špijunske službe koja je završila u studenom isplaćeno 450 rajnskih guldena dok je senjskom kapetanu za sedam mjeseci isplaćeno 515 rajnskih guldena. Nadalje, upravitelju Ripča i njegovu službeniku, koji su dva put prenijeli novac za obavijesti u Bihać, isplaćeno je

\footnotetext{
1172 THALLÓCZY, HODINKA, A horvát véghelyek, dok. DXLIV, 693.

${ }^{1173}$ SI AS 2, DSK, kutija 286, fascikl 164, Linz, 14.10.1530., rbr. 1.

${ }^{1174}$ SI AS 2, DSK, kutija 191, fascikl 119, Bihać, 19.5.1530., 1r, rbr. 10. Erasmo Thurn na Erasma Obritschana i još jednu osobu čije je ime nečitko upisano. SI AS 2, DSK, kutija 191, fascikl 119, Metlika, 14.6.1530., 1v, rbr. 34. Predstavnici kranjskih staleža na Hansa Katzianera.

${ }^{1175}$ SI AS 2, DSK, kutija 198, fascikl 123a, Bihać, 19.5.1541., 1r, rbr. 1525.

1176 SI AS 2, DSK, kutija 198, fascikl 123a, Bihać, 22.5.1541., 1r, rbr. 1290. Kapetan Mert Gall na Nikolu Jurišića.
} 
6 rajnskih guldena za troškove, a jednom „,kundtschaffter von Wihitsch“ 2 rajnska guldena. Sveukupno je za obavijesti koje su držali i drugi zapovjednici (Schnitzenpamer, zemaljski kapetan Kranjske, Ersmo Teuffl zapovjednik husara na Slavonskoj krajini, uskočki starješina Vuk Popović te Petar Hrvat) isplaćena visokih 1434 rajnskih guldena. ${ }^{1177}$

Sredinom stoljeća spominju se ipak nešto manji iznosi. Prema prijedlogu kranjskih staleža iz 1553., na Haimblich Khundtschafft godišnje je trebalo utrošiti 100 rajnskih guldena. Identičnim iznosom financirana je i obavještajna aktivnost u Dubici dok je na onu iz Senja odlazilo 200 rajnskih guldena. Svota od 100 rajnskih guldena aplicirana je za brodove kojima su prema potrebi pristizale obavijesti iz Šibenika, Zadra vnd derselben ortten. ${ }^{1178}$

Prema iskazu izdataka za 1565./1566., za špijunske aktivnosti na Hrvatskoj krajini isplaćen je 861 rajnski gulden i 2 krajcara. Evidentirani su tu i poznati, pod pseudonimom zavedeni špijuni kao što su „Sveti Zaharija“ i „Sveti Ivan“ s isplaćenih visokih 133 rajnska guldena i 20 krajcara dok je „Sveti Franjo“ dobio nešto manje - 107 rajnskih guldena i 20 krajcara. Bihaćki kapetan Kronschall primio je svotu od 58 rajnskih guldena i 20 krajcara za isplatu špijuna, a bihaćki opskrbnik Jeronim Podlipnik svotu od 35 rajnskih guldena za svojeg špijuna. ${ }^{1179}$ Podlipnik je i 1562. primio 35 rajnskih guldena za dva špijuna koja je držao. Međutim, budući da ti špijuni nisu dalje ostali u službi, isplata je ukinuta. ${ }^{1180} \mathrm{Te}$ godine isplaćeno je i 11 rajnskih guldena i 40 krajcara jednom „Turčinu“, špijunu iz Udbine. Novac $\mathrm{mu}$ je osobno isplatio ratni blagajnik u ,samostanu u Bihaću“. ${ }^{1181}$ Dakle, špijune je uz kapetana tada držao i bihaćki opskrbnik Jeronim Podlipnik.

Navedeni iznosi zasigurno nisu bili jedina doznačena sredstva jer razni izvori pokazuju da su ponekad ad hoc isplaćivana (ili barem tražena) sredstva za održavanje straža i špijuna (skart $i$ kundtschafften). Tako je glavni opskrbnik Thomas Naglić u travnju 1573. za straže oko Bihaća doznačio dodatnih 100 rajnskih guldena. ${ }^{1182}$ Kada se u ljeto 1577 . godine činilo da će Osmanlije pokrenuti opsadu Bihaća, uz isplatu jednomjesečne plaće vojnicima, poslano je i 150 rajnskih guldena za straže i obavijesti (skart vnd kundtschafften). ${ }^{1183}$

\footnotetext{
1177 SI AS 2, DSK, kutija 198, fascikl 123a, Bihać, 1541., 1r-1v, rbr. 1238-1239.

${ }_{1178}$ SI AS 2, DSK, kutija 339, fascikl 136, 1553., 1r-1v,

${ }^{1179}$ HDA, Militaria, kutija 7, 1565./1566., 15v-16r. Iskaz financijskih izdataka Hansa Khiesla, ratnog blagajnika na Hrvatskoj krajini za 1565. i 1566. Preslike ovog opsežnog iskaza nalaze se među preslikama spisa za 1561.

${ }^{1180}$ HDA, Militaria, kutija 7, 1562., Iskaz financijskih izdataka Hansa Khiesla, ratnog blagajnika na Hrvatskoj krajini za 1562., 6v.

${ }^{1181}$ HDA, Militaria, kutija 7, 1562., Iskaz financijskih izdataka Hansa Khiesla, ratnog blagajnika na Hrvatskoj krajini za 1562., 7r.

${ }_{1182}$ SI AS 2, DSK, kutija 286, fascikl 164, 2.5.1573., 1r-1v, rbr. 143-144.

${ }^{1183}$ SI AS 2, DSK, kutija 286, fascikl 164, Ljubljana, 29.7.1577., 1r, rbr. 362. Christoph Auersperg i kranjski Verordneten na zemaljskog kapetana Kranjske.
} 
Osigurati sredstva za obavještajce (kundtshaffter) predstavljalo je izazov, osobito $\mathrm{u}$ trenucima kada je trebalo promptno reagirati i istražiti neprijateljske namjere. Kada je $\mathrm{u}$ proljeće 1558. Malkoč-beg okupljao snage za provalu na hrvatski prostor, tada bihaćki upravitelj Georg Zoblsperg namjeravao je poslati ,gehaimben Khundtschaffter“ da razotkrije njihove namjere, ali je imao problema s isplatom špijuna jer nije bilo sredstva za tu namjenu. Iako mu je s teškom mukom uspio isplatiti neki manji iznos, špijun je tražio mjesečnu plaću ili je prijetio napuštanjem službe. Zoblsperg mu je na kraju i obećao traženo, a kranjskim staležima je uputio molbu da mu odmah pošalju određeni iznos novaca kako bi obavještajci i straže u gorama mogli biti isplaćeni. Ako sredstva ne pristignu te ostanu bez obavijesti i straža, „protestirati ću i neću se smatrati odgovornim“, zaključio je na kraju Zoblsperg. ${ }^{184} \mathrm{U}$ tom trenutku straže su ipak bile razmještene u gorama, a osam dana prije pisanja Zoblspergova izvještaja četvorica vojnika poslana su u izviđanje oko Udbine. ${ }^{1185}$

Problem s analizom obavještajnog sustava leži u činjenici da ga je teže rekonstruirati zbog elementa diskrecije. Krajiško povjerenstvo iz 1563. po pitanju tajnih obavijesti navelo je da je ta aktivnost u diskreciji kapetana u Senju, Bihaću i Zrinu. ${ }^{1186}$ No, izvora o uglavnom anonimnim špijunima je zaista mnogo. Ponekad su to tek kratke reference, a ponekad se detaljnije opisuje kontekst pristigle obavijesti. Naravno, većina osoba koje su donosile obavijesti u Bihać potjecala je s osmanskog pograničja ili prostora osmanske Bosne, a ponekad su takvi iskazi prava mala riznica podataka koji upućuju i na partikularne sudbine pojedinaca, ali i na karakter cijeloga pograničnog sustava.

Jedan takav navod potječe s početka srpnja 1573. kada je iz Livna prebjegao Miko Šebrović (,seljak, koji pripada ovoj kapetaniji“) koji je nešto ranije zarobljen pod Sokolom te koji se životom zaklinjao da ga je u Livnu o osmanskim planovima osobno izvijestio ,jedan zidar, imena Jakov, koji je zarobljen još za pokojnog (kapetana, op.a.) Kronschalla kada su četovali oko Srba i Udbine, a koji je još uvijek obavljao svoj zidarski zanat u Livnu. Prema njegovu iskazu, na Bihać se spremala velika vojska s mnogo topova koja je „po prvi puta“ namjeravala osvojiti bihaćku Otoku. ${ }^{1187}$ Iz ovog se navoda vidi kako je kršćanski vojnik mogao egzistirati na osmanskom prostoru te da su mogućnosti prikupljanja informacija bile široke, pa je i jedan zarobljenik mogao pronaći načina komunicirati s jednim bivšim

\footnotetext{
${ }^{1184}$ SI AS 2, DSK, kutija 201, fascikl 124, Bihać, 5.5.1558., 1v, rbr. 738. Georg Zoblsperg na zapovjednika Hrvatske krajine Georga Sauera.

${ }^{1185}$ SI AS 2, DSK, kutija 201, fascikl 124, Bihać, 5.5.1558., 2v, rbr. 740. Georg Zoblsperg na zapovjednika Hrvatske krajine Georga Sauera.

${ }^{1186}$ AHAZU, Lopašić, E. Prijepisi iz austrijskih arhiva, br. 15, str. 44.

${ }^{1187}$ SI AS 2, DSK, kutija 286, fascikl 164, Bihać, 2.7.1573., 1r, rbr. 107. Burckhardt Saloman i Wilhelm Gall, vjerojatno na Jobsta Josepha Thurna, upravitelja Hrvatske krajine.
} 
zarobljenikom koji je svoj novi život očito stvorio na „neprijateljskom“ tlu. Ovakvi izvori stvarno svjedoče o kompleksnosti i autonomnoj logici života na pograničju.

U svibnju 1566. Herbart Auerspeg piše da već neko vrijeme u Bihaću ima jednog snalažljivog špijuna koji je dojavljivao o skoro svim osmanskim planovima. Ta neimenovana osoba bila je osmanski podanik sve dok nije bio razotkriven i uhvaćen, no uspio je pobjeći i prebjeći na habsburški teritorij gdje je ponovo nastavio sa svojom aktivnosti. Godinu dana prije ovog izvještaja spomenuti je bio jedan od ključnih aktera poraza veće osmanske postrojbe koju su „na rijeci i na kopnu“ zajednički porazili vojnici bihaćkoga kapetana te kranjske i štajerske postrojbe koje su tada bile na ispomoći u gradu. Vjerojatno je habsburškoj strani dojavio smjer kretanja i namjere osmanske vojske, a možda ih je i namamio u zasjedu. O tome se za sada može samo spekulirati. ${ }^{1188}$ Krajem travnja 1585. upravitelj bihaćke kapetanije Gregor Allmayer javio je da mu je obavijesti o osmanskim planovima donio jedan obavještajac koji „,cijelu jednu godinu nije bio u Bihaću“. Anonimni špijun došao je iz Banja Luke, izvijestio o osmanskim planovima te se zatim vratio kući uz obećanje da će pravovremeno dostaviti nove obavijesti. ${ }^{1189}$

Habsburški špijuni u osmanskim redovima često su i sami sudjelovali u napadima na habsburški teritorij iako su barem ponekad pokušavali habsburškoj strani dojaviti plan napada. U lipnju 1580. zbio se jedan događaj koji prikazuje i prirodu pograničnog ratovanja koja je u mnogočemu ovisila o informacijama, pravovremenim pripremama i brzim odlukama. Naime, nakon što su preko povjerljivih osoba primili informacije da habsburška strana priprema napad na nove osmanske naseljenike oko Jezerskog, osmanske su se snage okupile i pripremile obranu. No, kada su shvatili da od napada nema ništa, iskoristili su priliku i povoljan trenutak te s oko 200 konjanika neočekivano provalili pod Steničnjak. Trojica habsburških špijuna koji su kod Črnomelja davali iskaz o cijelom događaju, a koje se očito krivilo za nedostatak obavijesti o osmanskim namjerama iako su tada prema svojim izjavama bili u Lici, pravdala su se da nisu očekivali da će osmanske čete dalje od Jezerskog. Nije pomogla ni činjenica da su među osmanskim snagama bili habsburški špijuni jer nisu mogli učiniti ništa radi opasnosti. Također, habsburški ljudi iz Krupe nisu stigli bilo što dojaviti zbog brzine kojom se sve odvilo. ${ }^{1190}$

Špijuni nisu nužno morali dolaziti u Bihać jer su ponekad, kao što je to bio slučaju u ožujku 1576., bihaćki vojnici poslani na sastanke (Reiß) s obavještajcima na osmanskom

\footnotetext{
${ }^{1188}$ SI AS 2, DSK, kutija 286, fascikl 164, Črnomelj, 9.5.1566., 1v-2r, rbr. 28, 32.

1189 SI AS 2, DSK, kutija 203, fascikl 124a, Bihać, 30.4.1585., 1r. Gregor Allmayer na Wolffa Engelbrechta Auersperga.

${ }^{1190}$ SI AS 2, DSK, kutija 202, fascikl 124a, Črnomelj, 19.6.1580., 1r-1-v. Iskaz trojice špijuna.
} 
teritoriju. Međutim, takva opcija bila je sama po sebi opasna jer su habsburški vojnici mogli biti zarobljeni, a tada je postojala opasnost da se, uz gubitak sposobnih ljudi (što su sigurno bili oni koji su slani na takve misije), razotkriju i imena onih s kojima su se trebali sastati. Nešto slično skoro se zbilo Cvitku i Jurju Radičeviću (Zwickha vnd Juri Radischeuitsch) čiju su četu u ožujku 1576. na jednom takvom zadatku Osmanlije raspršili. Nije sasvim jasno jesu li navedeni zarobljeni, ali namjera je propala. ${ }^{1191}$

Međutim, Bihać je i unutar osmanskoga obavještajnog aparata zauzimao važno mjesto kao što to pokazuje i slučaj otkrivenoga osmanskog špijuna Šobata 1566. čiju je smrt, prema iskazu navedenog habsburškog špijuna, trgovca pod pseudonimom Sveti Franjo ( $S$. Franncisckh), Sokolović-paša osobito oplakivao. ${ }^{1192}$ Možda se radilo o istaknutome uskočkom vojvodi Šobatu Popoviću kojeg su krajiške vlasti i ranije sumnjičile za špijuniranje, očemu je bilo riječi u tekstu. Naravno, bilo je i prelazaka s kršćanskog na osmanski teritorij, i to ne samo iz kruga uskoka, odnosno bivših osmanskih podanika, nego i domicilnog stanovništva. Tako je u ljeto 1557. zarobljen stanoviti Bartol koji je iz Bihaća prebjegao na osmanski teritorij. Predstavnici kranjskih staleža nadali su se da će iz njega izvući dragocjene obavještajne podatke. ${ }^{1193}$

\subsection{Sustav straža Bihaćke kapetanije}

Drugi važan element obavještajnog sustava bio je sustav straža koji je također bio izrazito važan faktor obrane grada, kapetanije i cijele Hrvatske krajine. U jednom izvoru kranjske provenijencije stoji da se obavijesti prikupljaju na dva načina - špijunažom te stražarskim aktivnostima (Skhart oder Lanndtwacht). ${ }^{1194}$ Straže su tek rijetko predstavljale prvu instancu otpora, a njihova je primarna zadaća bila nadzirati smjerove osmanskih kretanja, akumulirati obavještajne podatke te alarmirati o neprijateljskoj aktivnosti. ${ }^{195}$ Stražari su mogli djelovati i kao izvidnice na neprijateljskom terenu, obično u skupinama od 5 do 10 ljudi, koje su tek prema vlastitoj procjeni smjele kontaktirati stanovništvo $\mathrm{s}$ druge strane pograničja, a

\footnotetext{
${ }^{1191}$ SI AS 2, DSK, kutija 287, fascikl 164, Bihać, 30.3.1576., 1r, rbr. 515. Bihaćki časnici na Hansa Auersperga. ${ }^{1192}$ SI AS 2, DSK, kutija 415, fascikl 285, 23.2.1566., 3r, rbr. 25.

${ }^{1193}$ SI AS 2, DSK, kutija 201, fascikl 124, 14.7.1557., 1r, br. 609. Predstavnici kranjskih staleža na zapovjednika Hrvatske krajine.

${ }^{1194}$ SI AS 2, DSK, kutija 194, fascikl 122, 4r-4v, rbr. 183-184. Naslov spisa „Die Türkhen Khündschafft betreffendt".

${ }^{1195}$ SI AS 2, DSK, kutija 244, fascikl 143, 1565., 1v-2r, rbr. 282-283. Waikhard Auersperg na kranjske steleže.
} 
prvenstveno su morale nadgledati pokrete osmanskih postrojbi. ${ }^{1196}$ Zapovjednik Hrvatske krajine Waikhard Auersperg u srpnju 1580. apostrofirao je njihovu važnost jer se „dobrim stražama, ne samo zemlja i ljudi štite, već se neprijatelju može pružiti višestruki otpor“،. ${ }^{1197}$ Auersperg je tada lamentirao da je neprijatelj porobio bezbrojne kršćanske duše koje se lako moglo obraniti da su postavljene potrebne straže te pomalo rezignirano zaključio da „Bog znade, bez ikakve moje krivice“. ${ }^{1198}$

I bihaćko stanovništvo i vojnici također su često lamentirali o nedostatku straža oko grada tražeći da se one uredno drže. Gradski sudac Lovro Vukoslavić i „cijela gradska općina Bihaća (Lorenz Vuckhoslawich Richter zu Wihitsch vnd die gannze gemain der Statt Wichitsch) uputila je 1573. apel Herbartu Auerspergu tražeći da se straže (uredno) drže. Povod apelu bila su dva prošlogodišnja i jedan recentni osmanski napad koji je tek pukom srećom zaustavio vojvoda Bogdanić sa svojim ljudima koji su bili na putu za Ostrožac. ${ }^{199} \mathrm{U}$ takvim okolnostima dolazilo je do raznih improvizacija pa se u listopadu 1583. bihaćka posada osobito žalila na činjenicu da su cijele godine morali iz vlastitih sredstava financirati straže u gradu i izvan njega (Scarten vnnd Wachten). ${ }^{1200}$

Da bi se držale straže u šumama, gorama i unskim otocima (awen), stražare je trebalo adekvatno platiti, a to je često predstavljalo problem. Sebastian Lamberg se tako krajem srpnja 1577. tužio da „s praznim rukama nije mi moguće nikoga na stražu u šume i ade postaviti““. ${ }^{1201}$ Kao što je već navedeno, problem održavanja i financiranja straža zauzimao je važno mjesto u pregovorima s kandidatima za preuzimanje pozicije bihaćkoga kapetana. Pregovarajući u proljeće 1573. o modalitetima preuzimanja zapovjedništva nad Bihaćkom kapetanijom, jedan od uvjeta Sebastiana Lamberga bio je uredno držanje straža u brdima (Scart zu dem Gepurg) te uredno financiranje obavještajnog sustava. ${ }^{1202}$

No, razlozi za nezadovoljstvo bili su opravdani jer je i ovom segmentu nedostajalo sustavnosti pa su sami zapovjednici ponekad morali ulagati vlastita sredstva da bi održali ili

\footnotetext{
${ }^{1196}$ HOZJAN, Die ersten steirischen, 248.

1197 „,das an guetten Schkharten, dardurch nit allein Lanndt vnd Leüt geschichert, sonnder auch den Feindt zu mehrmallen begegnt vnd widerstanndt erzaigt werden muge, das maist gelegen“. SI AS 2, DSK, kutija 202, fascikl 124a, Karlovac, 5.7.1580., 2r. Waikhard Auersperg na Christopha Auersperga i kranjske Verordneten.

1198 „vnzallich vill Cristen Seelen (welches da nut die notwenndigen Schkarten wäre leichtlich zuuerhietten geweset." te „wyß Gott on all mein schuldt“. SI AS 2, DSK, kutija 202, fascikl 124a, Karlovac, 5.7.1580., 2v. Waikhard Auersperg na Christopha Auersperga i kranjske Verordneten.

${ }^{1199}$ SI AS 2, DSK, kutija 286, fascikl 164, Bihać, 1573., 1r-1v, rbr. 215-216.

${ }^{1200}$ HDA, Croatica, mikrofilm D-1914, br. 9, listopad 1583.

1201 „,mit lähren henden waiß Ich gar niemandts auff die Skhardten in Wälder nach die Awen zubringen“. SI AS 2, DSK, kutija 286, fascikl, 164, Bihać, 26.7.1577., 1v, rbr. 373. Sebastian Lamberg na kranjske Verordneten.

${ }^{1202}$ SI AS 2, DSK, kutija 244, fascikl 143, Ljubljana, 20.5.1573., 1r-2r, rbr. 320-322. Sebastian Lamberg na zemaljskog upravitelja Kranjske.
} 
uspostavili funkcionalan sustav. ${ }^{1203}$ Uspostava stabilnoga obavještajnog sustava bila je i tema zasjedanja u Brucku 1578., a krajem navedene godine i novoformirano Dvorsko ratno vijeće u Grazu traži da se straže između utvrda u pograničnom lancu stalno i marljivo (vleisg) drže. ${ }^{1204}$ Razvoj krajiškoga stražarskog i poštanskog sustava koji je integrirao hrvatski i unutrašnjeaustrijski prostor započeo je još ranih 1520-ih. Početkom travnja 1524. zemaljski zamjenik Kranjske Joseph Lamberg delegiran je da uredi „Turgken kundschaft“, no budući da nije znao točne principe njegova dotadašnjeg načina funkcioniranja, tražio je određene pojedince da ga upute i savjetuju. Jedan od konzultiranih, Sigmund Weichslberger, odgovorio mu je da u ovako kratkom vremenu ne zna nikoga drugog s kim bi se to dogovorilo osim grofa Ferdinanda Frankopana kojem pripadaju Brinje i Tržić (Terschitsch). Naveo je tri šume, Kamenicu (Kamanitza), Lapac (Lapitz) i Ferlatrago, u kojima danonoćnu stražu moraju držati po dvije osobe s (ukupnom) plaćom od 15 ugarskih guldena (U.gl.). Stražari iz Kamenice morali su prenositi obavijesti prema Krasu i Istri, stražari iz šume Lapac prema Metlici, a stražari iz šume Ferlatrago prema Bihaću. Krećući se pješke tajnim stazama kroz šume, stražari su trebali tri dana prije provale Osmanlija donijeti obavijesti u Bihać gdje su se nalazila dva konjanika koji su, ako Osmanlije krenu na Metliku, Istru ili Kras, poštu nosila na Brinje i Tržić odakle vode putovi kojima neprijatelj najčešće prodire dalje. U Brinju i Tržiću trebala su čekati 2 ili 4 konjanika koja bi obavijesti hitno nosili dalje prema Kranjskoj. Kao što je navedeno, to je mogao organizirati samo Ferdinand Frankopan čiji je neimenovani službenik (diener) radi dopreme pušaka i baruta tada bio u Ljubljani pa je zatraženo da prijedlog prenese gospodaru. U slučaju postignutog dogovora nadzornik (aufseher) tih 6 stražara u šumama trebao je biti bihaćki župnik (pharrer zu Wieschitz) koji se već pokazao sposobnim čovjekom. Lamberg je smatrao da bi on to rado činio jer se tako štite grad Bihać i Hrvatska (die stat Wieschitz und die Krabatn). ${ }^{1205}$ Dakle, tada je vrlo važnu ulogu imao bihaćki župnik koji se i ranije pokazao sposobnim i motiviranim.

Kao i drugi segmenti obrambenog sustava, i sustav straža je formiranjem bihaćke kapetanije došao pod ingerenciju bihaćkoga kapetana. Na temelju pronađenih izvora može se zaključiti da je stražarski sustav na Hrvatskoj krajini dobrim dijelom formiran do 1540. kada je na prostoru od Jadranskog mora do rijeke Save bilo stacionirano preko 24 stražara koji su „prikriveni na raskršćima putova“ držali danonoćnu stražu. Navedeno je da su se dva stražara morala kretati jedan prema drugome te u najbližu utvrdu dojaviti sve što su opazili.

\footnotetext{
1203 Auersperg je iz vlastite „kese“ (Sekhl) plaćao neke stražare. SI AS 2, DSK, kutija 207, fascikl 125b, Karlovac, 19.7.1580., 2r. Waikhard Auersperg na Christopha Auersperga i kranjske Verordneten.

${ }^{1204}$ HDA, Croatica, kutija 1, svežanj 2, 37. Dvorsko ratno vijeće u Grazu na nadvojvodu Karla.

1205 THALLÓCZY, HODINKA, A horvát véghelyek, dok. CLXXXV, 292-293.
} 
Prikupljene vijesti konjanicima su se, ili na neki drugi način, prenosile dalje. Senjski je kapetan pod svojim zapovjedništvom držao 12 stražara na potezu od Jadranskog mora do polovice Vrhovine, a od druge polovice Vrhovine 12 stražara držao je bihaćki kapetan koji je prikupljene obavijesti slao na Ogulin. ${ }^{1206}$

Tada je Kranjska financirala sustav straža s 1200 rajnskih guldena tako da su senjski i bihaćki kapetani svaki za svojih 12 stražara primali 36 rajnskih guldena mjesečno. Od sveukupno 20 konjanika koji su tu poštu diseminirali na hrvatskom i kranjskom prostoru, bihaćki i senjski kapetani imali su pod sobom po četiri konjanika čija je mjesečna plaća po konjaniku iznosila 4 rajnska guldena. Svi poštanski konji na Hrvatskoj krajini bili su pod zapovjedništvom navedene dvojice. ${ }^{1207}$

Dakle, straže na potezu od Bihaća do Jadranskog mora bile su pod ingerencijom senjskog i bihaćkoga kapetana. Senjski kapetan nadzirao je straže u gorama i šumama do polovice (der halben Verchouina) Vrhovine, a bihaćki kapetan drugu polovicu Vrhovine te komunikacije prema Mrežnici, Petrovom Gvodzu, Bihaću, Ripču i „tom kraju“. ${ }^{1208}$ Vrhovine su bile izrazito važna točka jer su tuda Osmanlije često provaljivali prema Krasu, Kočevju i Metlici, a zbog nedefiniranih odgovornosti dvaju kapetana znalo je doći do propusta. Tako se u ožujku 1541. senjski kapetan Ivan Lenković žalio da su dvije godine zaredom Osmanlije provalili na zapad preko Vrhovine, a da u Bihaću za posljednju provalu nisu ni znali dok se neprijatelj nije počeo vraćati s kranjskog prostora. Lenković je zato tražio da se bihaćkom kapetanu Mertu Gallu naredi da u svom dijelu Vrhovine namjesti straže te da straže međusobno komuniciraju. ${ }^{1209}$

U sljedećim mjesecima odvijala se intenzivna rasprava o odgovornosti senjskog $\mathrm{i}$ bihaćkog kapetana za straže na Vrhovini. Bihaćkom kapetanu zaista je naređeno da postavi straže na svoju polovicu Vrhovine što je i učinio do 19. travnja. Međutim, tvrdio je da se informirao o navedenom pitanju te da je doznao da je od tamo mnogo bliže dostaviti obavijesti (kundstschafften) prema Otočcu nego prema Bihaću te da Landkhomenteur, dakle Erasmo Thurn, na toj lokaciji nikada nije držao straže, a ni on nije dobio sredstva za njihovo održavanje. Unatoč svemu navedenom, odlučio je na mjesec dana iz vlastitih sredstava platiti

\footnotetext{
${ }^{1206}$ SI AS 2, DSK, kutija 194, fascikl 122, 1540., 4r-4v, rbr. 183-184. Naslov spisa „Die Türkhen Khündschafft betreffendt".

1207 SI AS 2, DSK, kutija 194, fascikl 122, 1540., 5v, rbr. 186. Naslov spisa „Die Türkhen Khündschafft betreffendt".

${ }^{1208}$ Ovdje se nesumnjivo misli na današnje Vrhovine u Lici, a ne na prostor južno od Bihaća prema izvoru Une i na zapad do Bilaja, Petrovca, Ključa i Unca koji se u predosmanskom dobu zvao Vrhovje, Vrhovina i Vrhriekom. LOPAŠ́IĆ, Bihać, 15.

${ }^{1209}$ SI AS 2, DSK, kutija 198, fascikl 123a, Ljubljana, 15.3.1541., 1r, rbr. 1259.
} 
povjerljive stražare koje će namjestiti na navedenoj lokaciji te im narediti da komuniciraju sa stražarima pod senjskim kapetanom. Molio je Lenkovića da to naredi i sa svoje strane. ${ }^{1210}$ Početkom svibnja bihaćki kapetan Mert Gall navodi da je za straže i poštanske konje primio iznos od 150 rajnskih guldena, a to je manje od iznosa kojim je raspolagao Landkhomentur Erasmo Thurn, jer je on imao mjesečno na raspolaganju 92 rajnska guldena dok se on mora snalaziti sa 75 rajnskih guldena mjesečno. Očito se referirao na mjesečni izdatak na straže koji je dakle iznosio pola od doznačene svote. Ipak, na Vrhovine i Muchla Polje postavio je četiri stražara iako je ponovno konstatirao da je Otočac bliže, a tražio je i da se pucačima signala (kreidschussen) i stražama dopremi nekoliko mužara. ${ }^{1211}$

Lenković je pak u svome odgovoru uzvratio da je prije 8 ili 10 (vor viii oder c Jaren) u Bihaću služio kao „Landkhomenteur Leytenand“ te da zna na kojim su se mjestima držale straže, a budući da je prije par godina zapovijedao i „Bihaćem i Senjom“, zna kako su se i tada držale straže. Konstatirao je da već četvrto ljeto drži straže od Jadranskog mora do Vrhovine. Čini se da su osnovni problem bile straže na Muchlovom Polju (udaljenom pet milja od Ripča ${ }^{1212}$ ) koje Lenković nije htio ni držati ni preuzeti odgovornost za ono što eventualno pođe po zlu. Također, znakovito je što je naveo da su oboje svjesni da novac koji primaju nije namijenjen financiranju „uobičajenih straža utvrda pod našim zapovjedništvom“ (die gmeier oder Skarten der Ortfleckhenn vnnser verawlttung), već straža na komunikacijama kojima Osmanlije prodiru u zemlju. Budući da je Muhlo Polje mnogo bliže Bihaću, a on ima više smjerova koje mora obavještavati i držati više ljudi, nema sredstava za tu stražu. Na kraju je tražio da stražari na Vrhovini surađuju jer je to za zajedničko dobro. ${ }^{1213}$

U periodu od tih mjeseca dana, od 19. travnja do 19. svibnja, bihaćki kapetan držao je straže na sljedećim mjestima: 2 stražara iznad Ripča na Željeznoj Glavi, zatim po 2 stražara na Na Newuize i Vražjem Vrtlu te po 4 stražara ,in der Coranize“ i Muhlo Polje. ${ }^{1214}$ Međutim, Lenković se i dalje žalio jer je morao držati stražare na tolikoj distanci, a primao je identične novčane iznose kao i bihaćki kapetan čije straže nisu pokrivale polovicu tolikog prostora. ${ }^{1215}$

Nažalost, te mikrolokacije trenutno je vrlo teško locirati. Na koncu je problem riješen tako da je senjski kapetan u brdima i šumama do pola Vrhovine držao 12 stražara dok je

\footnotetext{
${ }^{1210}$ SI AS 2, DSK, kutija 198, fascikl 123a, 20.4.1541., 1r, rbr. 1279.

1211 SI AS 2, DSK, kutija 198, fascikl 123a, Bihać, 2.5.1541., 1v-2v, rbr. 1440-1442. Mert Gall na Nikolu Jurišića.

${ }^{1212}$ HDA, Militaria, kutija 4, 1553., 2. Naslov spisa „Hannsen Lennkhowitsch Beyleüffige auffzaichunng“.

1213 SI AS 2, DSK, kutija 198, fascikl 123a, Bihać, 11.5.1541., 1r-1v, rbr. 1281-1282. Ivan Lenković na Merta Galla.

${ }^{1214}$ SI AS 2, DSK, kutija 198, fascikl 123a, Bihać, 19.5.1541., 1r, rbr. 1525.

1215 SI AS 2, DSK, kutija 198, fascikl 123a, Bihać, 22.5.1541., 2v, rbr, 1286. Ivan Lenković na Nikolu Jurišića.
} 
bihaćki kapetan trebao namjestiti stražare od pola Vrhovine, na putove i prolaze prema Mrsinju, Korani i Petrovom Gvozdu (die stra $\beta$ vnd den Paß auf Merschin, Khorana Petrougu $\beta$ ) te na putove i staze prema Bihaću, Ripču i „tim krajevima“. Trebao je odmah javiti koliko ljudi mu je potrebno kako bi se mogla donijeti odluka, a stražarima osigurati međusobna komunikacija. ${ }^{1216}$

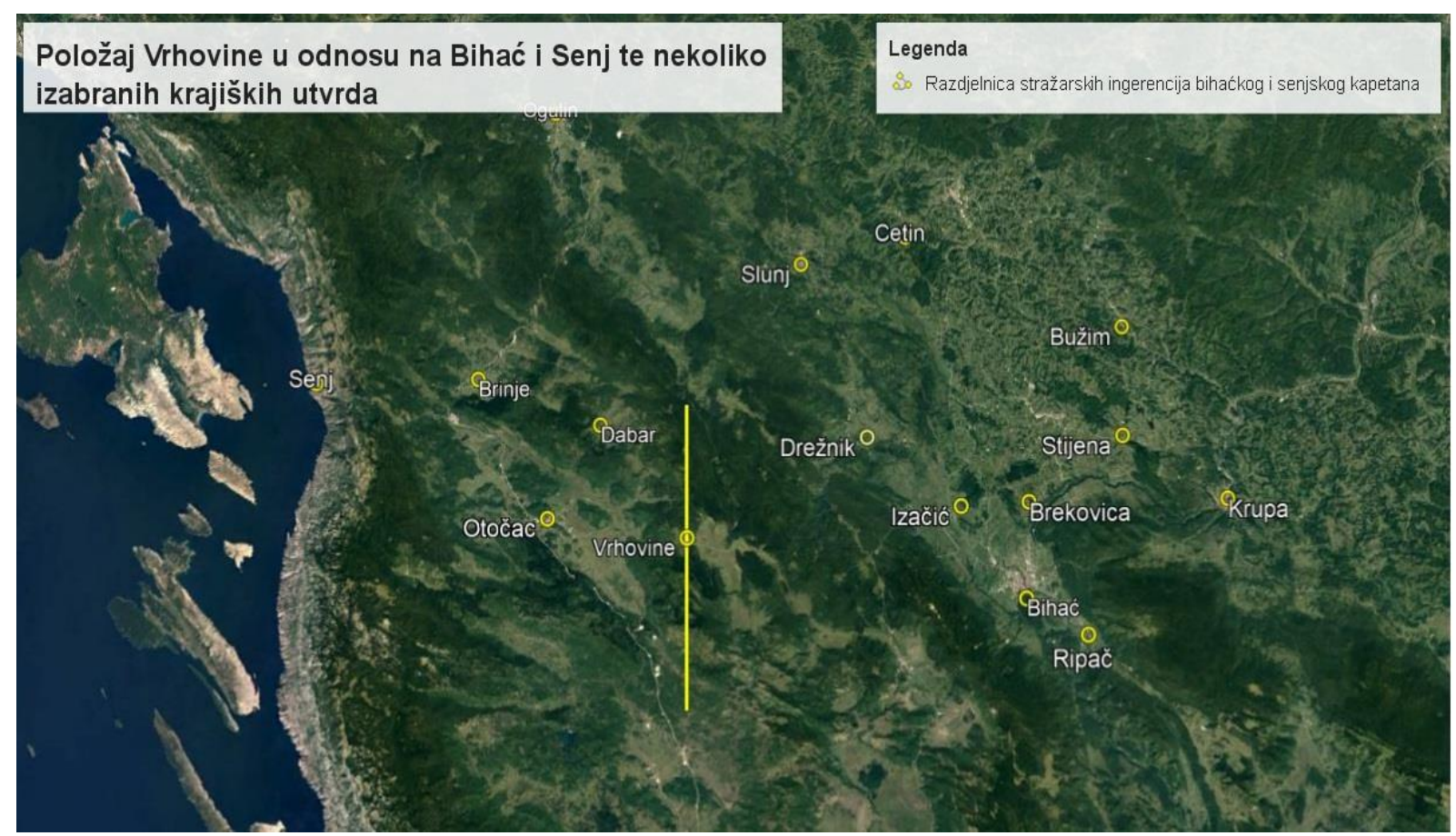

Slika 37. Položaj Vrhovine u odnosu na Bihać i Senj te nekoliko izabranih krajiških utvrda

Iako je tada očito utvrđena zona odgovornosti bihaćkoga kapetana, međusobna je komunikacija i u kasnijem periodu znala biti problematična pa se tako Ivan Lenković u kolovozu 1554. žalio da je prekasno primio obavijesti o osmanskom upadu na Zavalje iznad Bihaća (an Sauälle oberhalb Wihitsch). ${ }^{1217}$ Takve pojave nisu predstavljale osobitu iznimku jer su obje strane znale pronaći način da neopaženo upadnu na neprijateljski teritorij iako je s vremenom to postajalo sve teže. U napetome krajiškom ambijentu svaki je potencijalni neprijateljski pokret trebalo ozbiljno shvatiti, pa makar se „puhalo i na hladno“.

Tako u prosincu 1557. zapovjednik Hrvatske krajine Georg Sauer opisuje da je jedna velika osmanska vojska pješaka i konjanika prodrla u unutrašnjost neopaženo od senjskih i bihaćkih stražara, ali da ih je uočio jedan ogulinski vojnik koji se kretao prema Jesenici. Iako

\footnotetext{
${ }^{1216}$ SI AS 2, DSK, kutija 198, fascikl 123a, 1541., 1r-1v, rbr. 1341-1342.

1217 SI AS 2, DSK, kutija 200, fascikl 124, Ogulin, 18.8.1554. 1r, rbr. 165. Ivan Lenković na Herbarta Auersperga.
} 
su hitno poslane obavijesti na sve strane, oglašeni mužari i upaljenje vituljače, osmanska je vojska napala Ogulin i spalila sve osim utvrde (befestigung). ${ }^{1218}$ Sauer se čudio što se osmanska vojska mogla okupiti neopaženo, bez znanja habsburških špijuna, te je pisao senjskom kapetanu da to ozbiljno istraži. ${ }^{1219}$

Početkom rujna 1558. bihaćki kapetan Georg Zoblsperg javio je da su njegovi stražari u Lici ugledali vatru u dužini od pola milje za koju su pomislili da je velika osmanska vojska koja će na Kočevje ili Metliku te su započete opsežne pripreme za obranu Kranjske. Zoblsperg je odmah poslao svoje ljude u prostor na kojem su vidjeli vatre da ispitaju stvari i hitno (bei tag vnd naht) dojave. Budući da mu neko vrijeme nisu stizala nikakva objašnjenja, Zoblsperg je kranjskim staležima javio da se možda radilo o katunu (Khadtun) koji se zadržavao kod Gračaca, a koji je sa stokom krenuo prema moru. ${ }^{1220}$

Do sredine sljedećeg desetljeća došlo je do određenih promjena u broju stražara pa je do 1553. na osam ugarskih milja između Senja i Bihaća 20 stražara s mjesečnim primanjima od 3 rajnska guldena, angažiranih na period od devet mjeseci godišnje. ${ }^{1221}$ No, u nedatiranom iskazu troškova, koji je oko 1553. sastavio Ivan Lenković, stoji da je na potezu od Jadranskog mora do Ripča u planinama 36 stražara koji su primali 3 ili 4 rajnska guldena mjesečno. ${ }^{1222} \mathrm{U}$ jednom drugom izvoru stoji pak, da je od Bihaća do iznad Vražjeg vrtla odnosno Plitvičkih jezera te „s druge“ strane na Ripač (bis vber den Teufels gartten, vnnd von der anndern seytten auf Ripač), dakle na potezu s kojeg se moglo nadgledati i prilaze s bosanskog i krbavsko-ličkog prostora, u rasponu od četiri ugarske milje, 1553. bilo čak 16 stražara koji su također angažirani devet mjeseci u godini. Budući da je oko Bihaća bilo mnogo opasnije stražariti jer kranjski staleži navode da je tamo neprijatelj zarobljavao stražare na dnevnoj bazi, nije se nikoga moglo uzeti u službu za manje od 4 rajnska guldena mjesečno. ${ }^{1223}$ Primjerice, kada su početkom rujna 1555. Osmanlije napali selo Suče, i to kada je ,sunce bilo

\footnotetext{
${ }^{1218}$ Budući da se sve stanovništvo sa stokom sklonilo u utvrdu, zarobljeno je tada tek 6 osoba i nešto malo stoke. Međutim, na prostoru između rijeke Korane i Mrežnice zarobljeno je navodno do 400 ljudi Na kraju su Osmanlije naletjeli na konjanike hrvatskih grofova, koji su kretali na svoja mjesta na krajištu, te su se povukli prema Bihaću misleći da se radi o većoj kršćanskoj sili. Dvadesetak zarobljenih osmanskih vojnika izjavilo je da ih je bilo oko 8000 te da im nikakve informacije o primirju nisu stigle ni od Porte ni od budimskog paše. SI AS 2, DSK, kutija 201, fascikl 124, Črnomelj, 14.12.1557., 1v-2r, rbr. 530-532. Georg Sauer na Ivana Lenkovića.

${ }_{1219}$ SI AS 2, DSK, kutija 201, fascikl 124, Črnomelj, 14.12.1557., 2r, rbr. 532. Georg Sauer na Ivana Lenkovića.

${ }^{1220}$ SI AS 2, DSK, kutija 201, fascikl 124, Bihać, 5.9.1558., 1r, rbr. 755. Georg Zoblsperg na predstavnike kranjskih staleža.

${ }^{1221} \mathrm{U}$ izvorima se navodi da stražari u zimskim mjesecima zbog snijega nisu služili ili je njihov broj reduciran. Hans Gall upozorava brata, kapetana Merta Galla da treba riješiti pitanje novca za stražare ,jer se snijeg sasvim topi“. SI AS 2, DSK, kutija 198, fascikl 123a, Bihać, 2.3.1541., 2r, rbr. 1188.

${ }^{1222}$ HDA, Militaria, kutija 4, 1553., bez paginacije.

${ }^{1223}$ SI AS 2, DSK, kutija 229, fascikl 136., 1v, 1553. Početkom listopada 1558., prilikom priprema za provalu na habsburški teritorij, osmanski martolozi zarobili su troje stražara ponad Ripča. SI AS 2, DSK, kutija 201, fascikl 124, Bihać, 8.10.1558., 1r, rbr. 322.
} 
visoko na nebu pa nije bilo straža na rijeci“‘!, stražari s druge rijeke Une bili su napadnuti i sasječeni. ${ }^{1224} \mathrm{Na}$ krajini je trebalo permanentno biti na oprezu, osobito kada je bilo riječ o izloženim stražarskim postajama koje su često prve stradavale u provalama.

Kranjski staleži planirali su 1553. povećanje broja stražara na hrvatskom prostoru pa je oko Ogulina, Modruša, Slunja, Tržca okolici Drežnika, Topličkog Turnja i Izačića trebalo angažirati 47 stražara s mjesečnom plaćom od 3 rajnska guldena. ${ }^{1225}$ No, broj je stražara ipak varirao zato što se iste te godine navodi da je oko Bihaća stacionirano oko 16 stražara. ${ }^{1226}$ Straže izvan grada držali su domaći ljudi, haramije, pa je tako njih 20 trebalo 1563. stražariti na položajima izvan grada. ${ }^{1227}$ Važna stražarska lokacija bio je Ripač gdje je 1537. bilo 6 stražara $^{1228}$, a 1540. i 1545. tamo su bila stacionirana 3 stražara. ${ }^{1229}$ To su bile tzv. „,straže na vodi“", dakle na rijeci Uni, gdje su 1540. stražarili Matija i Juraj Filipović te Martin Kralj. ${ }^{1230}$ Nešto kasnije, 1555., na rijeci Uni kod Ripča i dalje su stacionirana trojica stražara - Mihovil Dudić, Matija Petrašić i Martin Matolinić. Oni su pak primali mjesečnu plaću od samo 1 rajnskoga guldena i 30 krajcara. ${ }^{1231}$

Prema vojnom proračunu iz 1556., pod bihaćkim je kapetanom 16 stražara na koje je mjesečno otpadalo 64, a godišnje 768 rajnskih guldena. Pod senjskim kapetanom bilo ih je 20, mjesečno su primali 60 , a godišnje 720 rajnskih guldena. ${ }^{1232}$ Dakle, stražara pod senjskim kapetanom bilo je više, ali su mjesečno primali manje. Prema vojnom proračunu iz 1559., na potezu od Senja do Jezera iznad Plitvičkih Jezera bilo je opet 20 stražara. Oko Bihaća ih je i dalje bilo stacionirano 16 i to po dvoje na sljedećim lokacijama: Nova Cesta, Petrov Gvozd, Jolina Jama, Podvrška Staza, Željezna Glava, Na Vkhrettw, Na Reyuoy, Na Paruintscha Khlannza. ${ }^{1233}$ Dakle, prijedlog povećanja broja stražara iz 1553. ili nije realiziran ili je u narednim godinama ponovno vraćen stari raspored.

Slične brojke nalaze se i u godinama koje su slijedile. Tako je 1564. na „najisturenijim prolazima i šumama“" na Hrvatskoj krajini bilo 27 stražara. ${ }^{1234}$ Znamo da su 1566. straže stajale na brdu Somišlju kod Bihaća gdje su u ožujku te godine Osmanlije uništili stražarske

\footnotetext{
${ }^{1224}$ HDA, Militaria, kutija 4, Bihać, 3.9.1555., 1r, rbr. 210. Georg Sauer na Ivana Lenkovića.

${ }^{1225}$ SI AS 2, DSK, kutija 229, fascikl 136, 1553., 3r.

${ }^{1226}$ SIMONITI, Vojaška organizacija, 166.

${ }^{1227}$ KRUHEK, Krajiške utvrde, 212.

${ }^{1228}$ LOPAŠIĆ, Bihać, 60;213; LOPAŠIĆ, SHK, knjiga III, dodaci, dok. III, 390.

${ }^{1229}$ SI AS, DSK, kutija 244, fascikl 143, 1540., 3v, rbr. 257. Popis vojnika u utvrdama Bihaćke kapetanije. LOPAŠIĆ, Bihać, 213; LOPAŠIĆ, SHK, knjiga III, dodaci, dok. III, 391.

${ }^{1230}$ SI AS, DSK, kutija 244, fascikl 143, 1540., 3v, rbr. 257. Popis vojnika u utvrdama Bihaćke kapetanije

${ }^{1231}$ LOPAŠIĆ, Bihać, dodatak, dok. IX, 304.

${ }^{1232}$ SI AS 2, DSK, kutija 201, fascikl 124, 2.3.1556., 6v, rbr. 248.

1233 ŠTEFANEC, Država ili ne, 468-469.

${ }^{1234}$ IBID., 477-482.
} 
kolibe (Wacht Hütten). ${ }^{1235}$ Izloženost osmanskim napadima izazivala je velike probleme jer su ljudi oklijevali služiti na takvim isturenim lokacijama. U navedenom izvoru kapetan Matiasch Mori javio je da od pada Krupe nitko ne želi stražariti ni u Svetom Jurju ni u Ostroškom polju, pa tamo tada nije ni bilo stražara. Četiri stražara između Mača i Topličkog Turnja, gdje su se straže držale od studenog prethodne godine, Osmanlije su zarobili, pa su postavljeni novi ljudi. ${ }^{1236}$ Stražarenje na pograničju bilo je riskantan posao.

Sredinom 1570-ih broj stražara u sastavu Bihaćke kapetanije osjetno je narastao pa se 1576. i 1577. navode 44 stražara. ${ }^{1237}$ No, do 1580. taj je broj pao pa je krajem srpnja te godine bihaćki kapetan Sebastian Lamberg javljao da sa sadašnjim stražarima na adama (Wördt), šumama i gorama (Gebürgen), kojih je ranije bilo 36, može pokriti jedva četvrtinu prijašnjeg prostora te se ne može štititi ljude pri poljoprivrednim radovima, a izlazak po sijeno, drva i druge potrepštine opasan je po život. Naime, Osmanlije ih neopaženo napadaju i zarobljavaju. $^{1238}$ No, ubrzo nakon Lambergova zahtjeva za povećanjem broja stražara nadvojvoda Karlo odgovara da nije moguće udovoljiti kapetanu jer se zbog velikih troškova i potreba za uštedom namjeravalo ukinuti navedene straže na cijeloj krajini. Stražarska dužnost, naveo je nadvojvoda Karlo, uz vojne akcije i straže u gradu, obaveza i dužnost svakoga plaćenog vojnika. ${ }^{1239}$ Dakle, tada je postojala tendencija da se te specifične straže ukinu te da tu dužnost izvršavaju plaćeni vojnici, a to korespondira i s povlačenjem terenske vojske u utvrde, o čemu je bilo riječi u tekstu. U kasnijim izvorima i popisima broj i položaj stražara se ne specificira, ali sve straže svakako nisu ukinute. Štoviše, 1581. godine Sebastianu Lambergu isplaćeno je prvo 500, a zatim 100 rajnskih forinti za straže dok mu je u kolovozu 1582. na nadvojvodin nalog isplaćeno visokih 797 rajnskih forinti. ${ }^{1240}$

\subsection{Poštanski sustav}

Jednom pristigle obavijesti dalje bi raznosili poštanski konji i pješaci. I u ovom je segmentu Bihać bio ključna točka sustava koji su kranjski staleži organizirali na Hrvatskoj krajini. ${ }^{1241}$

\footnotetext{
1235 SI AS 2, kutija 415, fascikl 285, Bihać, 17.3.1566., 1r, rbr. 55. Matiasch Mori na Ivana Lenkovića.

${ }^{1236}$ SI AS 2, kutija 415, fascikl 285, Bihać, 17.3.1566., 1v, rbr. 56. Matiasch Mori na Ivana Lenkovića.

1237 ŠTEFANEC, Država ili ne, 477-482.

1238 SI AS 2, DSK, kutija 202, fascikl 124a, Bihać, 9.7.1580., 1r-1v. Sebastian Lamberg na vojne povjerenike i zapovjednika Hrvatske i Primorske krajine.

${ }^{1239}$ SI AS 2, DSK, kutija 287, fascikl 164, Graz, 25.7.1581., 2v, rbr. 873. Nadvojvoda Karlo na kranjske staleže.

${ }^{1240}$ HDA, Croatica, kutija 2, svežanj 4, 1584., 436-437.

${ }^{1241}$ HOZJAN, Die ersten steirischen, 276.
} 
Koliko je zapravo Bihać bio važna točka poštanskog, ali i generalno obavještajnog sustava, pokazuje i činjenica da se termin „Bihaćki konji“ (Wihitscher Pferde) za poštanske konje, zadržao u krajiškoj nomenklaturi i nakon pada grada pod osmansku vlast. Primjerice, tako su prema popisu vojske na Hrvatskoj i Primorskoj krajini 1657. navedena su četiri tzv. „Bihaćka ili poštanska konja“" (so genante Wichatspferdt oder post pferdt). ${ }^{1242}$

Poštanska služba na Hrvatskoj krajini organizirana je na isti način kao poštanska služba na Slavonskoj krajini koju su ustrojili i financirali štajerski staleži, s tim da je Hrvatska krajina bila površinom veća i neprohodnija pa se na njezinu teritoriju nalazilo više postaja i plaćenih poštanskih konja. ${ }^{1243}$ Integrirani poštanski sustav na hrvatskom i kranjskom prostoru također je ustrojen do početka 1540-ih. U proljeće 1541. izgledao je ovako - obavijesti s krajišta prenosila su po dva konjanika stacionirana u Bihaću, Cetinu i Ogulinu. Jedan od konjanika iz Cetina imao je zadaću prenositi obavijesti u Ogulin odakle su ih navedena dvojica konjanika pod zapovjedništvom Ivana Lenkovića prenosila dalje. Za prijenos obavijesti (khundtschafft) na području Žumberka i Metlike angažirani su pak uskoci pod zapovjedništvom Hansa Wernekha. ${ }^{1244}$

Poštu su također pratili uobičajeni problemi. Početkom ožujka 1541. Hans Gall pisao je iz Bihaća svom bratu bihaćkom kapetanu Mertu da Postfuerer ne žele više raznositi poštu dok im se ne podmiri plaća, ali da je dogovorio s njima da nastave služiti dok ne stigne njegov odgovor. ${ }^{1245}$ Do svibnja su im već bili dužni plaću za tri mjeseca pa je tražio da ih se isplati jer se bojao da nitko više neće služiti. ${ }^{1246}$ Par dana kasnije navodi da su služili osam mjeseci, a da su im plaćena tek četiri, pa moli da se to podmiri - , da mi stalno ne vise za vratom“. ${ }^{1247}$ Jedan od tih koji su tražili isplatu bio je i stanoviti Rugsitsch kojeg je kapetan opisao kao

\footnotetext{
${ }^{1242}$ LOPAS̆IĆ, SHK, knjiga II, dok. CLXXXVI, 296.

${ }^{1243}$ Hozjan je na primjeru Slavonske krajine ustanovio da su tu službu obnašali ljudi raznih profila i narodnosnog porijekla (Hrvati, Vlasi, Slovenci, Nijemci, Talijani). Socijalni je status također poprilično varirao - od nepismenih građana, propalog plemstva, udovica, zanatlija, sitnih i krupnih trgovaca, vojnika i časnika pa sve do najviših plemićkih ešalona. Iako su poštari na štajerskom području morali poznavati njemački jezik, na Slavonskoj krajini čak ni to nije bio uvjet - mnogi poštari njemački jezik uopće nisu znali ili su ga poznavali tek rudimentarno. U opis poslova poštara spadala je otprema raznih pošiljki koje su staleži slali na pojedine osobe, obvezatna posudba poštanskih konja za Verordnenten i časnicima za razna putovanja, odnosno inspekcije, vođenje registraturnih knjiga o otpremljenim pismima, otprema pisama civilne provenijencije, sastavljanje izvještaja o situacijama u njihovima mjestima. Za obavljanje efikasne poštanske službe osobito je opterećenje bila obaveza dodjeljivanja konja putnicima kojima je, pri uručivanju naloga koji je potpisao nadređeni ili staleški odbor, poštarski službenik morao staviti na raspolaganje jednog konja ili više njih do sljedeće postaje. IBID., Die ersten steirischen, 273-275.

${ }^{1244}$ SI AS 2, DSK, kutija 804, fascikl 539 ili 540, Ljubljana, ožujak 1541.

1245 SI AS 2, DSK, kutija 198, fascikl 123a, Bihać, 2.3.1541., 1v-2r, rbr. 1187-1188. Hans Gall na Merta Galla.

${ }^{1246}$ SI AS 2, DSK, kutija 198, fascikl 123a, Bihać, 2.5.1541., 1r, rbr. 1304. Mert Gall na Ivana Jurišića.

1247 "damit Sy mir nit stats auf den Halss ligen." SI AS 2, DSK, kutija 198, fascikl 123a, Bihać, 16.5.1541., 1v2r, rbr. 1440-1441. Mert Gall na Ivana Jurišića.
} 
„jednog siromašnog čovjeka“ (ein Armer gesell), te je u potpunosti podržao njegov zahtjev. $^{1248}$

U Bihaću su od 19. travnja do 19. svibnja bila 2 poštanska konjanika koja su nosila poštu prema Slunju gdje su također bila 2 konjanika koja su dostavljala poštu u Ogulin odakle je išla na Kranjsku. Primali su 4 guldena mjesečno. ${ }^{1249}$ Pod zapovjedništvom bihaćkoga kapetana bila su 4 poštanska konja, navedena 2 u Bihaću i 2 u Cetinu, dok su 2 konjanika u Ogulinu bila pod zapovjedništvom senjskoga kapetana. ${ }^{1250} \mathrm{U}$ više puta citiranom diskursu kranjskih staleža iz 1553. navedeno je da se, budući da je bez uredne poštanske službe svaki napor uzaludan, nije smjelo na godišnjoj razini držati ispod 48 poštanskih konja koji su pak u svako doba pisma i upozorenja prenosili od Senja preko Krasa na Ljubljanu i Goričku grofoviju te od Bihaća kroz Hrvatsku prema Metlici, Slovenskoj Marki i prema potrebi na razna druga mjesta. Tada je očito postojala tendencija da se broj poštanskih konja smanji jer su staleži tražili upravo suprotno, odnosno da se njihov broj prije poveća nego reducira. ${ }^{1251}$ Prema prijedlogu Ivana Lenkovića iz te godine, u Bihaću su trebala biti 2 poštanska konja s plaćom od 4 rajnska guldena mjesečno za svakog konjanika. U Drežniku su također bila 2 poštanska konja, u Donjoj Kladuši 2 s plaćom od 4 rajnska guldena mjesečno te u Mlaču kod Bihaća 2 poštanska konjanika koja su mjesečno primali 3 rajnska guldena plaće. ${ }^{1252}$ Početkom ili u prvoj polovici 1556. na krajištu je bilo 40 poštanskih konja (Lenković samo kaže da ih se isplati i prema potrebi dio otpusti). ${ }^{1253} \mathrm{U}$ ljeto te godine bili su na hrvatskom i slovenskom prostoru stacionirani u Senju, Otočcu, Brinju, Modrušu, Jesenici, Ogulinu, Svetom Vidu na Rijeci ili Trsatu, Krasu, Poljani, Bihaću, Hojsić Gradcu, Skradu, Khunitschu, Petrovini, Pobrežju, Mehovu i Žužemberku. Dio je poštanskih konja tada bio otpušten. ${ }^{1254}$

\footnotetext{
${ }^{1248}$ SI AS 2, DSK, kutija 198, fascikl 123a, Bihać, 19.5.1541., 1r, rbr. 1525.

1249 SI AS 2, DSK, kutija 198, fascikl 123a, Bihać, 19.5.1541., 1r-1v. rbr. 1257-1258.

1250 SI AS 2, DSK, kutija 198, fascikl 123a, 1541., 1r-1v, rbr. 1391-1392. U ljeto 1543. dogovarano je da dva poštanska konja u Cetinu drži knez Babonožić. HDA, Militaria, kutija 2, 113.

${ }^{1251}$ SI AS 2, DSK, kutija 339, fascikl 136., 1v-2r, 1553.

1252 HDA, Militaria, kutija 4, 1553., 4. Spis pod naslovom „Hannsen Lennkhowitsch Beyleüffige auffzaichunng“.

1253 SI AS 2, DSK, kutija 201, fascikl 124, 1v. Lenkovićev memorijal za zasjedanje kranjskih staleža 1556. Bez broja iako su ostali spisi numerirani.

${ }^{1254}$ SI AS 2, DSK, kutija 201, fascikl 124, 14.8.1556., 1r-1v, rbr. 228-229.
} 
Tablica 15. Raspored poštanskih konja 1556.

\begin{tabular}{|c|c|c|c|c|}
\hline 1556. & $\begin{array}{l}\text { poštanskih } \\
\text { konja }\end{array}$ & $\begin{array}{l}\text { pješaka } \\
\text { poštara }\end{array}$ & mjesečna plaća & opaska \\
\hline Senj & & 4 & $\begin{array}{r}3 \text { rajnska } \\
\text { guldena }\end{array}$ & \\
\hline Otočac & 4 & & $\begin{array}{r}3 \text { rajnska } \\
\text { guldena }\end{array}$ & tada otpušteni \\
\hline Brinje & 2 & & $\begin{array}{r}5 \text { rajnska } \\
\text { guldena }\end{array}$ & \\
\hline Modruš & 2 & & $\begin{array}{r}4 \text { rajnska } \\
\text { guldena }\end{array}$ & tada otpušteni \\
\hline Jesenica & 2 & & $\begin{array}{r}4 \text { rajnska } \\
\text { guldena }\end{array}$ & tada otpušteni \\
\hline Ogulin & 2 & & $\begin{array}{r}5 \text { rajnska } \\
\text { guldena }\end{array}$ & \\
\hline na Krasu & 2 & & $\begin{array}{r}3 \text { rajnska } \\
\text { guldena }\end{array}$ & \\
\hline $\begin{array}{l}\text { Sveti Vid na Rijeci } \\
\text { ili Trsat }\end{array}$ & & 2 & $\begin{array}{r}4 \text { rajnska } \\
\text { guldena }\end{array}$ & tada otpušteni \\
\hline Poljana & 2 & & $\begin{array}{r}3 \text { rajnska } \\
\text { guldena }\end{array}$ & \\
\hline Bihać & 2 & & $\begin{array}{r}4 \text { rajnska } \\
\text { guldena }\end{array}$ & \\
\hline Hojsić Gradac & 2 & & $\begin{array}{l}4 \text { rajnska } \\
\text { guldena }\end{array}$ & tada otpušteni \\
\hline Skrad & 2 & & $\begin{array}{r}4 \text { rajnska } \\
\text { guldena }\end{array}$ & \\
\hline $\begin{array}{l}\text { Khunitsch } \\
\text { (neubicirano) }\end{array}$ & 2 & & $\begin{array}{r}4 \text { rajnska } \\
\text { guldena }\end{array}$ & \\
\hline Petrovina & 2 & & $\begin{array}{r}4 \text { rajnska } \\
\text { guldena }\end{array}$ & \\
\hline Pobrežje & 2 & & $\begin{array}{r}4 \text { rajnska } \\
\text { guldena }\end{array}$ & \\
\hline Mehovo & 2 & & $\begin{array}{r}4 \text { rajnska } \\
\text { guldena }\end{array}$ & \\
\hline Žužemberk & 2 & & $\begin{array}{r}4 \text { rajnska } \\
\text { guldena }\end{array}$ & \\
\hline
\end{tabular}




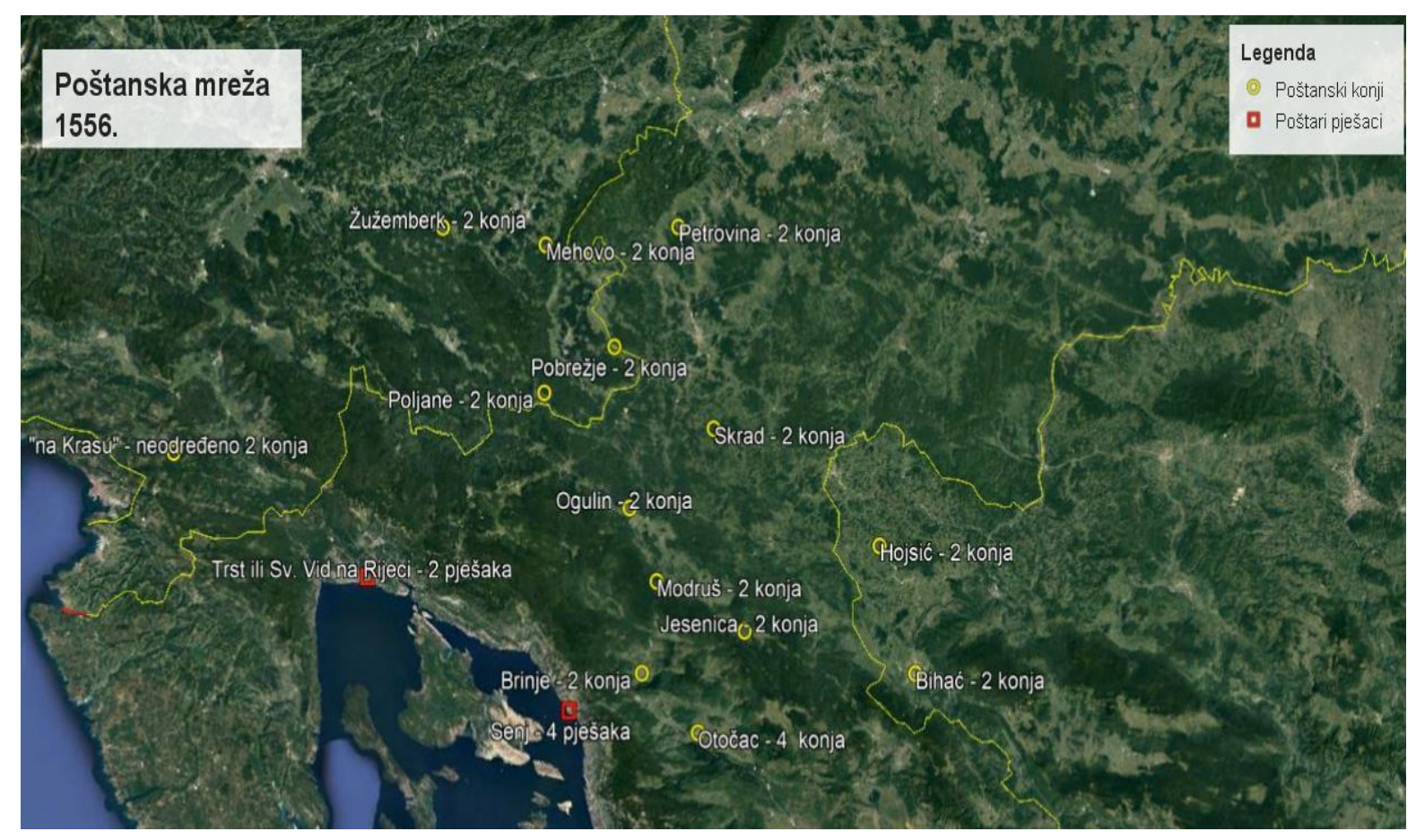

Slika 38. Prostorni raspored poštanskih konja i pješaka $1556 .{ }^{1255}$

Krajiško povjerenstvo iz 1563. bilo je krajnje kritično prema dotadašnjemu poštanskom sustavu. Naime, naveli su da su se na poštanski sustav godišnje trošila 2892 rajnska guldena, a da je bio prespor. Zato su predložili da se potpuno ukine te da se umjesto konjanika angažira nekoliko pješaka (fuess potten) s godišnjom provizijom, a koji bi prilikom prijenosa pisama bili isplaćivani prema dogovoru ili prema udaljenosti koju su prešli. Smatrali su da bi trošak takvog sustava pošte bio mnogo niži - godišnje 1500 rajnskih guldena. ${ }^{1256}$ No, čini se da je raspored poštanske službe ostao sličan i u sljedećim desetljećima, iako se i u izvorima s kraja 1570-ih navodi da je iskustvo pokazalo da je mnogo razboritije da umjesto konjanika poštansku službu vrše pješaci, konjanici su i dalje (primarno) prenosili obavijesti s pograničja u unutrašnjost. ${ }^{1257}$

Važne obavijesti ponekad su prenosili i sami zapovjednici pojedinih utvrda. Tako je između tri i četiri sata u noći 21. veljače 1585. ripački porkulab Christoph Schirk osobno u Bihać donio informacije o osmanskim namjerama, a zatim je bihaćki leütenandt Gregor Allmeyer ubrzo poslao dvojicu konjanika s obavijestima prema Karlovcu. Budući da se zapovjednik Hrvatske krajine tada nalazio na osmanskom prostoru, negdje između Udbine i

\footnotetext{
${ }^{1255}$ Khunitsch nije prikazan jer je neubiciran.

${ }^{1256}$ AHAZU, Lopašić, E. Prijepisi iz austrijskih arhiva, br. 15, str. 43.

1257 „,weil je die erfahrung mit sich bringt, das derselben orten die fueßpoten, vil fürdersamer als die Roßposten, solchen uncossten von Laibach auß nach der Gränizen allenthalben zu fueß anzurichten“. HDA, Croatica, kutija 1, svežanj 2, 54. Dvorsko ratno vijeće u Grazu na nadvojvodu Karla.
} 
Bunića, nastojao je dostaviti informacije i njemu. ${ }^{1258}$ U Bihaću su i dalje očito služila dva poštanska konjanika sve do pada grada u osmanske ruke.

Zaključno gledano, može se konstatirati da je Bihać kao najveći urbani centar i sjedište kapetanije bio i ključno obavještajno-stražarsko-poštansko sjedište na Hrvatskoj krajini. Velik i dobro naseljen grad predstavljao je važno regionalno informacijsko čvorište u kojem su se susretali razni interesi, društvene skupine i pojedinci, koji su ili sudjelovali u habsburškom, ali i osmanskome obavještajnom aparatu ili raspolagali informacijama na kojima se moglo financijski ili na neki drugi način profitirati. Informacija je svakako bila ključan aspekt pograničnog ratovanja i imala je izrazito veliku vrijednost. Isprva su obavještajno-poštanski sustav plaćale unutrašnjeaustrijske pokrajine, a njime rukovodili ban i domaće plemstvo. Nakon formiranja Bihaćke kapetanije njime je upravljao bihaćki kapetan. Iako je obavještajni sustav inherentno konspirativan i nije ga lako analizirati, vjerujem da sam demonstrirao njegovu kompleksnu strukturu i specifične pogranične karakteristike. Treba naglasiti da je Bihać bio i jedan od centara osmanskih špijunskih i drugih konspirativnih aktivnosti u kojima su participirali i doseljenici i pojedinci iz starosjedilačkoga društvenog miljea.

Što se straža tiče, Bihaćki je kapetan uz stražarska mjesta oko samog grada, imao ingerencije nad stražama na potezu od grada do Vrhovine dok je od druge polovice Vrhovine do Jadranskog mora njima upravljao senjski kapetan. Ovakva shema demonstrira važnost tih dvaju kapetana na prostoru Hrvatske krajine. Straže su držane oko grada i utvrda, na riječnim prijelazima i brdima, odnosno na najfrekventnijim komunikacijama kojima su Osmanlije prodirali prema zapadu. Stražarska dužnost bila je izrazito bitna, ali i opasna jer su pozicionirani stražari često na isturenim mjestima padali kao prve žrtve osmanskih prodora i upada. Stražarske dužnosti izvan grada obavljali su domaći pješaci haramije dok su pripadnici njemačke postrojbe morali stražariti unutar grada te na gradskoj Otoci.

Obavijesti koje su prikupljene špijunskom i stražarskom aktivnosti dalje su prenošene razrađenim poštanskim sustavom koji je spajao hrvatski i kranjski prostor, a u kojem je Bihać opet jedna od ključnih točaka. Njegovo značenje pokazuje činjenica da se termin „Bihaćki konji“ za poštanske konje koji su prenosili obavijesti iz Bihaća, a kasnije i iz Karlovca, zadržao još desetljećima nakon pada grada pod osmansku vlast u lipnju 1592.

${ }^{1258}$ SI AS 2, DSK, kutija 203, fascikl 124a, Bihać, 21.2.1585., 1r. Gregor Allmeyer na zapovjednika Hrvatske krajine. 


\section{SLOBODNI KRALJEVSKI GRAD BIHAĆ NA POGRANIČJU}

\subsection{Srednjovjekovno nasljeđe - ustroj i promijene}

Slobodni kraljevski grad Bihać bio je jedan od najvažnijih gradova na hrvatskom prostoru. Južno od grada, jedino je Knin imao sličnu/višu sociopolitičku važnost, ali ne status i strukturu slobodnoga kraljevskog grada. Ako izuzmemo priobalne komune sa svojim specifičnim ustrojem i kontekstom, u srednjovjekovnoj Hrvatskoj nije bilo urbanih naselja sličnog profila. Kao što to navodi Neven Budak, u ekonomskom je pogledu Bihać „za hrvatsko zaleđe predstavljao centralno mjesto prvog reda“". ${ }^{1259}$

Budući da srednjovjekovni razvoj bihaćke gradske općine nije do sada adekvatno rasvijetljen, a u fokusu ovog istraživanja kasniji je vremenski period, u ovom ću se poglavlju fokusirati na one aspekte razvoja bihaćke gradske općine važne za prezentaciju transformacija prouzročenih ustrojavanjem krajiškog sustava na hrvatskom prostoru, prvenstveno na odnos između vojnih i civilnih struktura u gradu, demografska kretanja te problematiku egzistencije i opskrbe grada na isturenom pograničju.

Do zasjedanja nadvojvode Ferdinanda na hrvatsko prijestolje 1527. bihaćka je gradska struktura postojala već skoro tristo godina. Samo bihaćko naselje prvi je put spomenuto 26 . veljače 1260. u ispravi kralja Bele IV. u kojoj se navodi da je opat cistercitske opatije u Topuskom molio kralja da redu dodijeli kraljevski posjed Kralje (Krala) pored grada. Navodi se i da su cisterciti uz kraljevsku dozvolu na Otoku Sv. Ladislava, na kojem se već nalazila granđa (grangia ${ }^{1260}$ ) topuske opatije, a koji se ranije nazivao Bihać, podizali kuće i toranj. Posjed Kralje do tada su držali kraljevski vitezovi Bridislav i Ludugar. ${ }^{1261}$ Dakle, već tada se spominju posjed Kralje koji je izrazito važan za Bihać te građevinske aktivnosti na Otoku sv. Ladislava koje cistercitsko naselje očito podižu na jedan viši stupanj urbanog razvoja. Naziv riječnog otoka, Otok Sv. Ladislava, vjerojatno treba vezati uz ugarskoga kralja Ladislava I. (vladao 1077. - 1095.) i njegov prodor kroz Slavoniju do Hrvatske nakon smrti hrvatskog kralja Stjepana II.1091. Budući da se Bihać nalazio na prostoru srednjovjekovne Hrvatske te

\footnotetext{
${ }^{1259}$ BUDAK, Uloga Bihaćke komune, 164.

1260 Tadija SMIČIKLAS, Diplomatički Zbornik kraljevine Hrvatske, Dalmacije i Slavonije, V, JAZU, Zagreb, 1907., dok. 664, 156. Granđe (lat. Grangia) bile su gospodarske jedinice, odnosno najvažniji posjedi cistercita. Ana NOVAK, Gorski arhiđakonat Zagrebačke biskupije od 1334. do 1501. godine, doktorska disertacija, Hrvatski studiji Sveučilišta u Zagrebu, Zagreb, 2011., 132.

${ }^{1261}$ „,in insula sancti Ladizlai que prius Wyhugh nuncupabatur“. Ivan Krstitelj TKALČIĆ, Povjestni spomenici Zagrebačke biskupije XII. i XIII. stoljeća, knjiga I, Zagreb, 1873., dok. CVIII, 124-125.
} 
da je spadao pod ingerenciju psetskog župana i kninskog biskupa, Ančić smatra da je do određene promjene došlo ugarskim zauzimanjem Slavonije 1091. nakon čega je na unskom otoku vjerojatno podignut castrum. Dakle, posjed Kralje (Crala) bio bi posjed kraljevske posade navedenog castruma. ${ }^{1262}$

Iako nema izravnih pisanih dokaza, može se pretpostaviti da je i prije katastrofalne provale Tatara 1242. na unskom otoku postojalo (razvijenije) naselje. Slično razmišlja i Pavao Ritter Vitezović, koji u svojem djelu Oživljena Hrvatska, raspravljajući doduše o sasvim drugoj temi, navodi da je od Tatara progonjeni kralj Bela IV. došao u „Središnju Hrvatsku (gdje je zidinama utvrdio gradove Modruš i Bihać)“. ${ }^{1263}$ Zidine vjerojatno tada još nisu podignute - možda je grad zaštićen nekim skromnijim fortifikacijskim sustavom, ali je dvadeset godina kasnije privilegijem kraljice Marije Bihać zadobio status slobodnoga kraljevskog grada. ${ }^{1264}$

Bihać je proglašen slobodnim kraljevskim gradom 1262. za vrijeme boravka kralja Bele IV. i kraljice Marije u gradu. ${ }^{1265}$ Ančić smatra da je kraljevski par relativno dugo boravio u Bihaću, od kraja veljače do 9. travnja navedene godine, te da je Marija, a ne kralj, izdala privilegij zato što su riječni otoci prema ugarskome srednjovjekovnom pravu bili u posjedu kraljica. ${ }^{1266}$ I Toma Arhiđakon u svojoj kronici pisanoj do 1266., pri opisu sukoba kraljice Marije sa splitskom komunom, navodi da su 1262. kralj i kraljica stigli u Bihać gdje su im Splićani predali taoce, a za splitskog gradskoga kneza postavljen im je ban Roland. ${ }^{1267}$

\footnotetext{
${ }^{1262}$ ANČIĆ, Bihać - slobodna kraljevska, 131.

${ }^{1263}$ Pavao RITTER VITEZOVIĆ, Oživljena Hrvatska, prevela i priredila Zrinka Blažević, Hrvatski institut za povijest, Zavod za hrvatsku povijest Filozofskog fakulteta u Zagrebu, Zagreb, 1997., 101.

${ }^{1264}$ U 13. i 14. stoljeću na području Ugarske, dakle sjeverno od rijeke Drave, pedesetak je naselja dobilo privilegij slobodnoga kraljevskog grada, s tim da se mnoga od tih naselja neće uopće transformirati u stvarne gradove. Do početka 15. stoljeća tek će trideset gradova imati status slobodnoga kraljevskog grada (royal free towns), a s hrvatskog prostora tek Gradec. Najekskluzivniji sloj činilo je pak osam gradova koji su okruženi zidinama (free royal or tavernical towns) i koji su spadali pod ingerenciju tavernika Ugarskoga Kraljevstva. U toj kategoriji nije bio nijedan grad s hrvatsko-slavonskog prostora. U 15. stoljeću na ugarskom prostoru bilo je tek 180-200 naselja urbanog tipa. Od toga njih oko 150 može se smatrati gradom, prvenstveno u ekonomskom pogledu. István PETROVICS, King Matthias and the Towns of the Realm, Analele Banatului, serie nouă. Arheologien. Istorie, XXI, Cluj-Napoca, 2013., 285-286. Prvi kraljevski privilegij generalno dodijeljen je Trogiru 1108., no to je dakako jedan sasvim drugačiji kontekst. István PETROVICS, The role of towns in the defence system of medieval Hungary, u: La guerre, la violence et les gens au Moyen Âge, ur. Philippe Contamine i Olivier Guyotjeannin, Éditions du CHTS, 1996., 264. Madžarska historiografija primarno je fokusirana na ugarski i slavonski prostor te se rijetko referira na gradove i urbani razvoj na prostoru Hrvatskoga Kraljevstva. Bihać se uopće ne spominje u konzultiranim radovima madžarskih urbanih povjesničara.

${ }^{1265}$ Privilegij je objavljen u THALLÓCZY, HORVÁTH, Also-Szlavoniai, dok. VII, 8-9.

${ }^{1266}$ ANČIĆ, Da li je srednjovjekovni Bihać, 238. Ranije je Ančić smatrao da nije bilo pravne zapreke da kraljica izda privlegij zato što je u ime malodobnog sina Bele obnašala čast slavonskog hercega. Također, smatrao je da je privilegij izdala kraljica jer kralj kod sebe nije imao svoj pečat. ANČIĆ, Bihać - slobodna kraljevska, 127128.

${ }^{1267}$ Toma navodi da su se kralj Bela i kraljica Marija 1262. „spustili preko Slavonije, došli i smjestili u gradu koji se zove Bihać“. Toma ARHIĐAKON, Historia Salonitana, Kniževni krug, Split, 2003., 315.
} 
Iako je na promatranom prostoru očito već ranije postojalo naselje, privilegij slobodnoga kraljevskog grada izdan je posebnoj kategoriji stanovništva - hospites, gostima. Termin hospites odnosi se na strance što pokazuje da se radilo o kolonistima, a uklapa se u kontekst razvoja gradova na ugarsko-slavonskom prostoru. I Neven Budak navodi da početak bihaćkog naselja ,valja tražiti u onom istom vremenu kolonizacije u kojemu nastaju i gradovi u Slavoniji“ “ ${ }^{1268}$ Nastanak i razvoj gradova na ugarskom i slavonskom prostoru neraskidivo je vezan uz kategoriju hospites, strance i koloniste koji su se nastanjivali u (proto)urbanim sredinama, a zatim ih socieokonomski razvijali. U 11. i 12. stoljeću doseljenici su dolazili primarno iz Flandrije, Valonije, pokrajine Lorraine i Lombardije dok su od 12. i 13. stoljeća dominirali Nijemci (Teutonci i Sasi). Period vladavine kralja Bele IV. (1235.-1270.) obilježavaju intenzivno osnivanje gradova i izdavanje gradskih privilegija, a u tome su veliku ulogu imali upravo njemački kolonisti, osobito nakon Mongolske invazije 1242. ${ }^{1269}$

Ipak, treba biti oprezan jer termin hospites u periodu kada je Bihać proglašen slobodnim kraljevskim gradom više nije nužno označavao stranca, odnosno njihovo etničko porijeklo, već osobu specifičnog statusa. ${ }^{1270}$ Budući da se u kasnijim izvorima (gotovo i) ne pojavljuje strana (njemačka, madžarska, talijanska) onomastika, možemo ipak zaključiti da nekog osobito masovnog i utjecajnog priljeva stranaca nije bilo. Vjerojatno se primarno radilo o okupljanju i privilegiranju domaćeg stanovništva. Trebalo bi podrobnije istražiti taj aspekt rane povijesti Bihaća.

Privilegijem slobodnoga kraljevskog grada bihaćki su hospites stekli pravo slobodnog izbora gradskog suca (vilicus, maior villae, judex) koji je autonomno sudio u internim sporovima gradske općine dok je u slučajevima kada su u spor bili uključeni stranci sudski postupak provodio s kraljevskim sucem. Bišćani su imali slobodno pravo iseljavanja i raspolaganja vlastitom imovinom, razne porezne egzempcije na trgovačku robu u vrijednosti do pet maraka, a potvrđene su im i neke već postojeće, ali neprecizirane trgovačke povlastice na svim trgovima Kraljevstva te pravo na izbor župnika. U sporovima sa stanovnicima drugih mjesta Bišćani su imali pravo na postupak kakav su uživali stanovnici Gradeca i drugi kolonisti s ove strane Drave. To su prava koja Ančić stavlja u kategoriju općih prava koja su izdavana kolonistima na slavonskom prostoru. U kategoriju specifičnih prava, koja nisu izdavana drugima gradovima, isti autor stavlja pravo svećenika i klerika da pređu u redove

\footnotetext{
${ }^{1268}$ BUDAK, Uloga Bihaćke, 163.

${ }^{1269}$ Neven BUDAK, Budući da smo htjeli u Zagrebu na brdu Gradecu sagraditi slobodni grad..., Rađanje Gradeca - okolnosti, poticaji, slijed, u; Zlatna bula 1242-1992, ur. Zlatko Stublić, Zagreb 1992, 24.

${ }^{1270}$ István PETROVICS, King Matthias, 283-284; PETROVICS, The role of towns, 263. O kolonizaciji i postanku gradova na slavonskom prostoru vidi Neven BUDAK, Gradovi Varaždinske županije u srednjem vijeku, Nakladna kuća „Dr. Feletar“ Koprivnica, Zagreb-Koprivnica, 1994., 38-45.
} 
vojne posade castruma te da tada uživaju sva prava hospita, kao i pravo da u laičkim sudskim sporovima dođu pod ingerenciju suca (vilicusa). Bihaćki hospites imali su pravo potpunog oslobađanja od plaćanja poreza na gradskom trgu te potpunog izuzeća od vlasti bana i dužnosti ukonačivanja. ${ }^{1271}$

Ovdje se osobito ističe egzempcija od dužnosti ukonačavanja, odnosno davanja kuće za boravak bana i pratnje u gradu. Bišćani ipak nisu bili oslobođeni davanja dužnosti ukonačivanja (zalaznine) kralja. ${ }^{1272}$ Privilegij od oslobađanja dužnosti pružanja ukonačivanja bana na slavonskom je prostoru posjedovala još jedino Virovitica, i to tijekom kraćeg perioda. Ta povlastica, u kombinaciji s izborom samostalnog suca, predstavljala je instrument autonomije grada u odnosi na lokalnu vlast i značila je direktno podvrgavanje kraljevskom sudu. Budući da je obveza davanja zalaznine predstavljala jednu od „vrlo teških dužnosti““, oslobađanje od takvih obaveza (ona se mogla limitirati ili sasvim ukinuti) zasigurno je moralo pozitivno djelovati na materijalni pa i politički status grada. ${ }^{1273}$

Iako u odnosu na druge važne gradove broj kasnosrednjovjekovnih isprava vezanih uz Bihać nije osobito velik, predstavnici bihaćke gradske općine nosili su svoj privilegij na potvrdu (gotovo) svakom novom vladaru. U kontekstu slabljenja središnje vlasti i rasplamsavanja internih konflikta tijekom vladanja kontroverznoga kralja Ladislava IV. Kumanca (vladao 1272. - 1290.) Bišćanima je čak izdan novi privilegij s nešto širim povlasticama nego ranije. ${ }^{1274}$

Dobivanje statusa slobodnoga kraljevskog grada impliciralo je povlašteni položaj građana pomoću kojeg oni funkcioniraju kao samoupravna općina. ${ }^{1275}$ Takva samoupravna, odnosno gradska općina (communitas) obuhvaćala je osim teritorija samoga grada i sve gradske posjede te je predstavljala pravnu zajednicu svih građana koji su živjeli unutar njezinih granica. ${ }^{1276}$ Odredbe privilegija odnosile su se pak samo na punopravne građane (cives), odnosno na one koji su u gradu posjedovali nekretninu dok preostali stanovnici (habitatores, inquilini) nisu bili dio gradske zajednice. ${ }^{1277}$

Osim formalno-pravnim putem (preko privilegija), status grada u srednjovjekovnom periodu definirali su i prisutnost obrtnika i trgovaca u ukupnoj gradskoj populaciji od

\footnotetext{
${ }^{1271}$ ANČIĆ, Bihać - slobodna kraljevska, 128-129.

1272 IBID., 132.

${ }^{1273}$ N. KLAIĆ, Prilog pitanju postanka, 51.

${ }^{1274}$ ANČIĆ, Bihaćki kraj, 196; THALLÓCZY, HORVÁTH, Also-Szlavoniai, dok. XIV, 19-21.

1275 Danijel JELAŠ, Gradovi Požeške, Vukovske i Srijemske županije u srednjem vijeku, magistarski rad, Filozofski fakultet Sveučilišta u Zagrebu, 2011., 24.

${ }_{1276}$ Bruno ŠKREBLIN, Etničke i političke skupine u srednjovjekovnom gradu. Primjer gradečkih lingu, Povijesni Prilozi, 25, 2008., 94.

1277 JELAŠ, Gradovi Požeške, 81.
} 
prosječno 25-30 \%, postojanje cehova, održavanje redovitih tjednih tržnih dana i do nekoliko godišnjih sajmova te razvijena urbana infrastruktura, odnosno mreža ulica i tržni prostor. Jedna od bitnih karakteristika gradova je i brojnost stanovništva, a većina ugarskih gradova u 15. stoljeću broji oko 2000-3000 stanovnika. Pojedini povjesničari kao važan indikator gradskog statusa navode i prisutnost prosjačkih redova koji su u pravilu svoje samostane osnivali u razvijenijim gradovima koji su ih mogli uzdržavati i gdje su mogli propovijedati većem broju ljudi. Zato je i broj crkvi i crkvenih institucija (hospitali, hospicij, bratovštine itd.) također važan pokazatelj urbanog razvoja. ${ }^{1278}$

I ovdje se pokazuje važnost Bihaća jer je u gradu bilo sedam crkava s dva samostana dominikanskim i franjevačkim. Zidine nisu predstavljale apsolutni preduvjet urbanog razitka, ali su bile, kao što to navodi Katalin Szende, ,an unmistakable manifestation of urbanity, and its image was often proudly included as a symbol on town seals and coats of arms"“. ${ }^{1279}$ Kao što je već navedeno, kaštel s tri kule prikazan je na gradskom pečatu iz 14. stoljeća. ${ }^{1280}$ Vjerojatno su već tada postojale i zidine oko grada.

Neven Budak pak kao kriterije utvrđivanja centraliteta, odnosno važnosti srednjovjekovnoga grada navodi sustav župa koji se izgrađuje tijekom 12. stoljeća i kojim se „u potpunosti dovršava mreža crkvenih veza“, zatim prisutnost i položaj samostana, mjesta hodočašća, trgovačke sajmove, prisutnost i razvijenost obrta, položaj na prometnicama, teritorijalni opseg gradskih povlastica te utjecaj gradskoga zemljišnog posjeda i posjeda gradskih institucija i građana na okolicu. Također, Budak navodi i posredne i neposredne funkcije - posredne poput održavanja sabora ili sazivanja banskog suda koje nisu stalne, ali su uglavnom rezervirane za uglednija i veća mjesta te neposredne poput sjedišta županija i vlastelinstva. Zidine i obrambene fortifikacije predstavljaju važan element utvrđivanja stupnja urbaniteta iako nisu svi gradovi bili utvrđeni. Zidine su postale presudan kriterij za utvrđivanje statusa grada tek nakon odluke kralja Žigmunda Luksemburškog 1405. u dokumentu Decretum minus. ${ }^{1281}$ Naposljetku, kulturna produkcija također je jedan od kriterija utvrđivanja važnosti grada. ${ }^{1282}$

U Marijinu privilegiju navedeno je pravo na izbor župnika, a već u 13. stoljeću podignuti su dominikanski i franjevački samostani. Budući da su se ti redovi „intenzivnije uključivali u društveni život regije“, činjenica da su podignuti u Bihaću upućuje na njegovu

\footnotetext{
${ }^{1278}$ IBID., 26-27.

${ }^{1279}$ Katalin SZENDE, The Urban Economy in Medieval Hungary, u: The Economy of Medieval Hungary, ur. József Laszlovszky,Balázs Nagy, Péter Szabó, András Vadas, Brill, Leiden-Boston, 2018., 342.

${ }^{1280}$ Vidi stranicu 212.

${ }^{1281}$ BUDAK, Gradovi Varaždinske, 23.

${ }^{1282}$ IBID., 16-18.
} 
regionalnu važnost. ${ }^{1283}$ Što se sajmova tiče, za Bihać nema podataka, kao ni za obrte. Međutim, činjenica da su nadgrobni spomenici iz 16. stoljeća pronađeni u džamiji Fethiji proizvod lokalne radionice pokazuje određeni stupanj razvijenosti obrta i kulturne proizvodnje. ${ }^{1284}$ Nadalje, pravo Bišćana o oslobađanju od plaćanja nameta na prostoru od Drave do Jadrana također je važan indikator važnosti grada. Što se veličine gradskog posjeda tiče, čini se da on nije osobito velik, barem ne u periodu funkcioniranja habsburške Bihaćke kapetanije, ali o tome će biti riječi dalje u tekstu. U gradu je bilo sjedište kraljevskog suda te je bio mjesto održavanja hrvatskih sabora i kasnije središte kapetanije. Također, ovdje su stolovali banovi i herceg Ivaniš Korvin. Upravo se u Bihaću 10. travnja 1494. okupio hrvatski sabor na kojem su „devotissimi filii prelati et magnates potioresque nobiles et proceres universi, totus infelix regnum Croatie representantes“ uputili dramatičan apel za pomoć caru Maksimilijanu I. i carskim staležima te papi. ${ }^{1285}$

O kulturnoj produkciji nema mnogo izvora, ali onih malo koji nam (trenutno) stoje na raspolaganju povezuju Bihać s važnim povijesnim događajima, procesima i osobama. Tako je Primož Trubar oko 1562. dao na uvid stanovitom fra Ivanu iz Bihaća, koji je tada živio u Novom Mestu, a zbog bolesti boravio u franjevačkom samostanu u Ljubljani, hrvatski prijevod Biblije koju su u važnoj protestantskoj tiskari u Wurtembergu načinili Stjepan Konzul i Antun Dalmatin. Fra Ivan bio je vješt hrvatskom jeziku i pismu te je zaključio da ,je prievod dobar, ali da je stil i jezik slab“ dok je za katekizam konstatirao da je ,još lošije preveden te da će se takove knjige teško moći prodavati“. Ovakva recenzija izazvala je veliku buru. ${ }^{1286} \mathrm{U}$ gradu je djelovala i neka škola jer je u jednom propalom pokušaju hvatanja osmanskih podanika 1562. zarobljen i neimenovani „mladi vojnik“, dakle pripadnik gradske posade koji je bio „učiteljev sin“ (des schulmaisters Son). ${ }^{1287}$ Kao kuriozitet možemo dodati i da je i veliki Juraj Križanić, rođen 1618. u Obrhu na Ribničkom vlastelinstvu, naveo da je njegov otac porijeklom iz Bihaća. ${ }^{1288}$

Istaknut status potvrđuje i terminologija, pa dok se u privilegiju iz 1262. navode termini castrum i villa, 1271. građani se nazivaju tota communitas. ${ }^{1289} \mathrm{U}$ potvrdi gradskog privilegija za „hospitibus de Byhag“ iz 1279. korišteni su termini ,idem cives “, ,ipsi cives “ te

\footnotetext{
1283 IBID., 16.

${ }^{1284}$ VEGO, Srednjevjekovni bihaćki, 255-272.

1285 Ferdo ŠIŠIĆ, Rukovet spomenika o hercegu Ivanišu Korvinu i borbama Hrvata s Turcima (1473-1496), Starine, JAZU, knjiga 38, Zagreb, 1937., dok.b178 i 179; 232-237.; LOPAŠIĆ, Bihać, 50.

${ }^{1286}$ Franjo BUĆAR, Odnošaji Primoža Trubara prama hrvatskoj tiskari u Würtemberškoj, Trubarjev zbornik, ur. Fran Ilešič, Matica Slovenska, Ljubljana, 1908., 34-35.

${ }^{1287}$ HDA, Militaria, kutija 7, Bihać, 20.4.1562., 1v. Herbart Auersperg na Ivana Lenkovića.

1288 ŠARIĆ, Etnokulturna kretanja, 21.

1289 BUDAK, Uloga Bihaćke, 164.
} 
"predictis civibus ". ${ }^{1290}$ Dakle, iako srednjovjekovna terminologija može biti nekonzistentna, sve navedeno upućuje na to da je Bihać smatran slobodnim kraljevskim gradom u punom srednjovjekovnom značenju. Nadalje, u regesti isprave kojom je Nikoli Krčkom 1431. založen niz gradova, uključujući Bihać, on se naziva „civitate Bihigy“ dok je Sokol castro, a Ripač castella. U regesti pak prijepisa te iste darovnice, koju je dvije godine kasnije izdao kninski kaptol, opet se navode „,civitatibus Bihigy“, „,castris Szokol“ i „,castello Ripach“. ${ }^{1291}$ Važnost Bihaća pokazuje i činjenica da je Bihać, kao i Gradec, jedno od rijetkih gradskih naselja koje se nije nalazilo u sastavu nekog vlastelinstva ${ }^{1292}$ te je jedan od rijetkih gradova na prostoru Hrvatskoga Kraljevstva koji je uspio zadržati svoj urbani karakter i administrativnu strukturu sve do osmanskog osvajanja grada 1592.

\subsection{Struktura bihaćke gradske općine}

Struktura bihaćke gradske općine bila je identična strukturi slobodnih kraljevskih gradova na slavonskom prostoru. ${ }^{1293} \mathrm{Na}$ čelu gradske općine nalazio se gradski sudac (villicus, maior villae, judex) koji je obnašao sudsku i upravnu vlast na području gradske općine, a kojeg su, kao što je vidljivo i iz Marijina privilegija, birali sami građani dok ga je morao potvrditi kralj. Sudac je imao široka prava uključujući i izricanje najtežih presuda, a viša instanca bio je kraljevski sud. ${ }^{1294}$ Funkciju gradskog suca (major vile) 1271. obnašao je stanoviti Jakov. ${ }^{1295}$ Gradskog suca mijenjao je podsudac, utjecajan je bio i „stari sudac“, a u donošenju odluka participirala je i cijela gradska općina. ${ }^{1296}$ Važnu ulogu imao je i župnik što se vidi iz redoslijeda jednog spisa iz 1488. u kojem su redom navedeni župnik, sudac, drugi sudac, podsudac i dva prisežnika. ${ }^{1297}$ Gradsko vijeće (magistrat) činili su pak gradski sudac i šest do dvanaest zakletih prisjednika (jurati). Gradska su se vijeća u 15. stoljeću bavila općinskim, sudskim, vojnim i financijskim poslovima kao što su izbor službenika, rješavanje upravnih

\footnotetext{
${ }^{1290}$ THALLÓCZY, HORVÁTH, Also-Szlavoniai, dok. XIV, 19-21.

${ }^{1291}$ Ferdo ŠIŠIĆ, Iz Arkiva u Željeznom, Vjesnik Kr. Hrvatsko-slavonsko-dalmatinskog zemaljskog arkiva, god. VII, Zagreb, 1905., dok. XX i XIV, 172.

${ }^{1292}$ ADAMČEK, Agrarni odnosi, 177.

${ }^{1293}$ BUDAK, Uloga Bihaćke, 164

${ }^{1294}$ ANČIĆ, Bihać - slobodna,132. Margetić navodi da je sporove sa strancima u Bihaću vodio vilicus zajedno s kraljevskim sucem. Za komparaciju, gradonačelnik Križevaca sudio je i stranicima na gradskom prostoru, a Gradec i Koprivnica imali su još povoljniji položaj jer su građani tih gradova mogli biti tuženi samo pred gradskim vlastima tih gradova. Lujo MARGETIĆ, Zagreb i Slavonija. Izbor studija, HAZU-Vitograf-Adamić, Zagreb-Rijeka, 2000., 223-224.

${ }_{1295}$ TKALČIĆ, Povjestni spomenici, dok. CLIII, 160-161; LOPAŠIĆ, Bihać, 44.

1296 IBID., 51

${ }^{1297}$ BUDAK, Uloga Bihaćke, 164.
} 
pitanja i zastupanje interesa građana. ${ }^{1298} \mathrm{U}$ konzultiranom gradivu gotovo nema osobitih podataka o gradskom vijeću Bihaća, osim da su krajem listopada 1543. stigle vijesti da građani u vijeće ne žele primiti nijednog vojnika što su vojne vlasti promatrale kao „loš znak“. $^{1299}$

Navedena srednjovjekovna struktura održala se sve do pada Bihaća pod osmansku vlast. U promatranom periodu predstavnici grada $\mathrm{u}$ izvorima navode se kao „sudac i vsa općina Bihaćska“ ili „Luka zlatar, sudac Bihaćki, i vsa općina varoša Bihaćkoga vazda verni k.s. i vam gospodi““ itd. ${ }^{1300}$ Kada je gradska općina početkom svibnja 1531. poslala župnika i gradskog suca Hansu Katzianeru potpisali su se s „Comunitas(!) sew vniuersitas ciuium oppidi Bihigiensis, subditi et fideles incliti regis Ferdinandi. ${ }^{1301} \mathrm{U}$ zasad posljednjem poznatom spisu, koji je izdao predstavnik gradske općine pred osmansko osvajanje kojim se 21. svibnja 1592. preporučuje Katarinu, udovicu kneza Ivana Čiračanina, koja je napuštala grad, potpisani su Mikula Zemlić, „sudac slobodnoga varoša Bihaća, i vsi ostali purgari općine varoša ovoga“. ${ }^{1302} \mathrm{Na}$ kraju je Bihać i predan Osmanlijama na nagovor suca, starog suca i podsuca. ${ }^{1303}$

$\mathrm{Na}$ temelju jednog spomena burgermeistera, to jest gradonačelnika, u kasnom periodu 16. stoljeća, Neven Budak sugerirao je da daljnji razvitak bihaćke gradske općine mogao pratiti razvoj na njemačkom i austrijskom području. ${ }^{1304}$ No, za takvo što za sada ipak nema nikakvih drugih potvrda u izvorima pa se taj slučaj vjerojatno može pripisati možda pogreški pisara ili nepravilnom prijevodu naziva gradskih službenika s hrvatskog/latinskog jezika na njemački jezik. ${ }^{1305}$

Od 1527. Bihać je sve više ulazio u interesnu sferu staleža Unutrašnje Austrije, primarno Kranjske, iako je nadzor nad upravljanjem slobodnim kraljevskim gradovima i dalje (načelno) imala Ugarska komora, podređena Dvorskoj komori u Beču. ${ }^{1306}$ Već je u srpnju 1527. Nikola Jurišić, kao jednu od mjere obrane grada, kralju predložio da se za kapetana (haubtman) nad kaštelom i gradom (uber die stat und gschloss verordnen) imenuje sposoban

\footnotetext{
1298 JELAŠ, Gradovi Požeške, 83.

1299 „,Wan die Purger In Iren Ratt khain diennstman nemen wollen, das ist ain bo $\beta$ zaichen“ HDA, Militaria, kutija 2, 1543., str. 187.

${ }^{1300}$ LOPAŠIĆ, Bihać, 301, dodatak VII.; dodatak VIII.

${ }^{1301}$ LAZSOWSKI, HSKHDS, knjiga II, dok. 43, 32.

${ }^{1302}$ LOPAS̆IĆ, Bihać, dodatak XV. 308,

${ }^{1303}$ Vidi poglavlje „Početak kraja i kontroverzno osmansko osvajanje Bihaća“.

${ }^{1304}$ BUDAK, Uloga Bihaćke, 164; HDA, Croatica, mikrofilm D-1916, br. 165, listopad 1587.

${ }^{1305}$ V. KLAIĆ, Povijest Hrvata, knjiga 5, 479.

1306 ŠTEFANEC, Država ili ne, 95.
} 
plemić iz zemalja Njegovog Veličanstva koji bi zapovijedao nad Bišćanima i „drugima“. ${ }^{1307}$ Vezivanje uz zemlje Unutrašnje Austrije ubrzano se nastavilo pa u srpnju 1528., kada se pojavila opasnost od velikoga osmanskog napada na Bihać, kralj Ferdinand piše kranjskim staležima da preuzmu obranu grada dok se ona već nekako drugačije ne uredi. ${ }^{1308}$ Simoniti navodi da je kralj naredio da se ,z denarjem od cerkvenih dragocenosti pokrijejo plače za najmanj sto mož bihaške posadke, poleg tega pa Bihač preskrbijo s hrano in drugimi potrebščinami“. ${ }^{1309}$

Kao što je prezentirano u prethodnim poglavljima, ta je ovisnost o kranjskim staležima sve više rasla, osobito u vojno-upravnom pogledu. Nažalost, zasad nije pronađeno dovoljno izvora da bi se sasvim precizirao specifičan položaj Bihaća. Iako formalno pravna podređenost ugarskoj kruni nije dovedena $u$ pitanje, $u$ realnosti obrana grada gotovo je $u$ potpunosti ovisila o staležima Unutrašnje Austrije, podređenima pak caru Svetog Rimskog Carstva Njemačke Narodnosti. To potvrđuje spis kranjskih staleža iz 1579. u kojem navode da je mnogo staleških sredstava i sredstava zemaljskog kneza utrošeno u obranu Bihaća, čvrstog predziđa Kranjske, koji je smješten na Hrvatskoj krajini koja je podređena ugarskom kralju, a samim time i caru Rudolfu II. ${ }^{1310}$ Ta hijerarhija vidljiva je u molbama i predstavkama koje su adresirane visokim krajiškim dužnosnicima, nadvojvodi i/li caru. U predstavci, koju je početkom srpnja 1573. Jobstu Josephu Thurnu uputili predstavnici bihaćke gradske općine na čelu sa sucem Lovrom Kozlovićem, stoji da su „Carskom Veličanstvu etc. i Vama uvijek vjerna““. ${ }^{1311}$ Dakle, vjernost se iskazuje caru i Jobstu Josephu Thurnu, nadvojvodinom savjetniku i kapetanu nad uskocima koji je tada upravljao Hrvatskom krajinom.

Kako je rasla dominacija unutrašnjeaustrijskih (kranjskih) staleža, tako je u vojnom i administrativnom pogledu padao angažman bana i hrvatskih staleža. S druge strane, sudbena vlast na cijelom preostalom teritoriju Hrvatsko-slavonskoga Kraljevstva (načelno) nije dovedena u pitanje. Kada je u svibnju 1540. izbio sukob između hrvatskog plemića Mihaela Budošića (Michel Wudoschitz) i bihaćkih građana (hieygen Burger) oko nekih podanika (von wegen etlich Vnnderthannen verloffen), predstavnici kranjskih staleža i kranjski vicedom

\footnotetext{
1307 „, das er dasselbs denen von Wichitsch und anderer das recht besitz“. THALLÓCZY, HODINKA, A horvát véghelyek, dok. DXLIV, 693.

${ }^{1308}$ SI AS 2, DSK, kutija 194, fascikl 122, Beč, 13.7.1528., 2v, rbr. 108. Kralj Ferdinand na Niclasa Thurna, upravitelja Kranjske.

${ }^{1309}$ SIMONITI, Turki su, 125.

1310 SI AS 2, DSK, kutija 287, fascikl 164, Ljubljana, 14.11.1579., 2r, rbr. 819. Staleške instrukcije kranjskim poslanicima.

1311 „Lourinatz Khoslouitsch Richter Zw Wihitsch, vnd die Gantz gemain deselben Flekhens, Allzeyt der Khayserlichen Mtt. etc vnd eur Allß die getrewen “. SI AS 2, DSK, kutija 286, fascikl 164, Bihać, 2.7.1573., 1r, rbr. 128.
} 
konstatirali su da oni o tom sukobu ne znaju ništa te da je to slučaj koji spada pod bansku ingerenciju. ${ }^{1312}$ Radilo se zapravo o sukobu oko posjeda Velihovo koji je prema kraljevskoj zapovjedi krajem prosinca 1545. trebalo vratiti u posjed Mihaela Budišića, ali su Bišćani to odbijali. Kraljevsku odluku trebali su provesti Stjepan prezbiter Ivanićki i zagrebački prebendar. ${ }^{1313}$ Nadalje, u veljači 1547. kraljevski izaslanici i predstavnici kaptola saslušavali su svjedoke oko pitanja statusa podčinjenosti plemenite općine Menića, između ostalog i u Bihaću. ${ }^{1314}$ Krajem prosinca 1551. Gašpar Kobasić žali se pred zagrebačkim kaptolom zbog pretenzija bana Nikole Zrinskog, topuskog opata Franje Keglevića i Bišćana na predij Kralje. ${ }^{1315}$ Hrvatsko-slavonski sabor još 1570 . navodi da hrvatski staleži obitavaju na prostoru nekadašnje Zagrebačke županije južno od Kupe te u Bihaću i Ripču. ${ }^{1316}$ Zanimljivo je da hrvatsko-slavonski sabor 1582. navodi da je u Hrvatskoj tek jedna utvrda u kršćanskim rukama i to Ripač ! ${ }^{1317}$ Dakle, ako je Bihać u vojno-administrativnom pogledu potpuno ovisio o staležima Unutrašnje Austrije, odnosno kralju/caru, u „civilnom“ pogledu, primarno sudbenom pogledu, i dalje je bio pod ingerencijom domaćih institucija, prvenstveno naravno bana. ${ }^{1318}$ Pitanje je samo u kojoj je mjeri ban mogao manifestirati svoje ingerencije na ovom prostoru od sredine stoljeća, a potom od 1570-ih kada su okolnosti poprilično degradirale. Izvori krajiške provenijencije ne referiraju na tu temu.

Iako se na Hrvatsko-slavonskom saboru u drugoj polovici 16. stoljeća rijetko raspravljalo o Bihaću, hrvatsko plemstvo svakako nije potpuno zanemarilo grad. Ivan Steklasa tako navodi da je Herbart Auersperg na okupljanju unutrašnjeaustrijskih staleža u Grazu 1574. zagovarao molbu grofa Zrinskoga da se odmah utvrde Bihać i Hrastovica. ${ }^{1319}$ Međutim, predstavnici Bihaća nisu, kao predstavnici Zagreba, Varaždina i Križevaca, sudjelovali u radu hrvatsko-slavonskog sabora, no nema ni izvora koji bi pokazivali da im je nametnut dodatan porez, kao što je to učinjeno navedenim gradovima. Pitanje tog poreza rješavalo se preko Ugarske komore. ${ }^{1320}$ Od plaćanja poreza Bihać je mogao biti oslobođen zbog osmanske

\footnotetext{
1312 „So ist es auch ain sach die dem Waan zurichten gepurt“. SI AS 2, DSK, kutija 193, fascikl 119/120, Bihać, 24.5.1540., 4v. Predstavnici kranjskih staleža i vicedom na Merta Galla.

${ }^{1313}$ LASZOWSKI, HSKHDS, knjiga III, br. 216, 247.

${ }^{1314}$ IBID., dok. 239, 275.

${ }^{1315}$ IBID., dok. 358, 410 .

${ }^{1316}$ KLAIĆ, Povijest Hrvata, knjiga 5, 594. Usporedi ŠIŠIĆ, HSS, knjiga III, 290-291. Riječ je o zaključcima hrvatsko-slavonskog sabora od 12. travnja 1570.

${ }^{1317}$ ERCEG, Šišićeve biljeske, 448.

${ }^{1318}$ Kralj Žigmund je 1405. dokumentom Decretum minus "podredio gradska naselja, civitas, oppidum i libera villa, prizivnoj nadležnosti kraljevskog tavernika. Danijel JELAŠ, Tipologija srednjovjekovnih gradskih naselja u donjem međurječju Drave i Save, Povijesni zbornik: godišnjak za kulturu i povijesno naslijeđe, vol. 4, br. 5, 2012., 36.

${ }_{1319}$ STEKLASA, Kako so Turki, 407.

${ }^{1320}$ ERCEG, Šišićeve biljeske, 434-435.
} 
opasnosti i teškog položaja, ali možda i zbog činjenice da je teritorij preko rijeke Kupe i bio oslobođen od plaćanja poreza zbog osmanskih pustošenja. ${ }^{1321}$ Vjerojatno je riječ o kombinaciji navedenih faktora.

Što se lokalnog stanovništva u Bihaću odnosno na gradskim posjedima u promatranom periodu tiče, ono nije bilo homogeno, već je bilo prisutno nekoliko kategorija stanovništva. Osnovna podjela bila je na građane i stanovnike, one koje u listopadu 1556. Ivan Lenković oslovljava kao „Burger vnd Inwoner $“{ }^{1322}$ O građanima zapravo nema mnogo podataka koji bi nam omogućili dubinsku analizu njihova društvenog i upravnog položaja, problematike imovine, gospodarskih i/ili trgovačkih djelatnosti, kao što generalno nema osobitih izvora koji bi pokazali kakva je bila društvena dinamika u gradskom kontekstu. U pronađenim izvorima uglavnom se navode imena osoba koje su obnašale upravne funkcije (suca, podsuca ili prisjednika) te imena građana i stanovnika. Nije sačuvan ili spomenut eventualni gradski statut, a ne navodi se ni lokacija gradske vijećnice, lokacije trga/trgova na kojima se trgovalo (što je za gradsku općinu bilo vrlo važno), bratovštine, dakle svih onih faktora koji su činili jedan srednjovjekovni grad.

Lopašić u svom djelu donosi popis sudaca, građana i stanovnika koji, reduciran na period 15. i 16. stoljeća, izgleda ovako: oko 1480. gradski sudac je Tomo Kosavić, 1488. Benko Radošević (bio je literat i prisežnik Zagrebačke županije), 1531. stanoviti Juraj, 1543. - 1547. Luka zlatar, 1549. Ivan Glavić, 1566. Juraj Grda/ović, 1573. Lovro Kozlović ${ }^{1323}$, a zatim i Lovrinac Vukoslavić, 1576. Franko Kaptolović, 1588. Mikula Zemlić, 1590. Ivan Vranić i podsudac Matej Beličić te 1592. ponovno Mikula Zemlić. ${ }^{1324}$ Međutim, izvori pokazuju da su bivši podsudac Matej Beličić te stanoviti Sebelić bili suci u ožujku 1592. (beede Richter zu Wihitsch, Sebelitsch vnd Welitschiz). Navedeni su se zajedno s bihaćkim kapetanom uputili u Ljubljanu kako bi u ime cijele gradske općine (burgerschafft) okupljene staleže zamolili za pomoć. ${ }^{1325}$ Mikula Zemlić bio je očito posljednji (imenovani) sudac u Bihaću i vjerojatno onaj koji je sudjelovao u predaji grada Osmanlijama.

Jedna od uglednijih obitelji zasigurno je bila obitelj Kaptolović. Već se u popisu pješaka (martologa) koje je Kranjska unajmila u travnju 1530. navodi jedan „, Kaptolowitsch

\footnotetext{
${ }^{1321}$ IBID., 435.

1322 SI AS 2, DSK, kutija 201, fascikl 124, logor pod Thurgo(?), 6.10.1566., 1r, rbr. 252.

${ }^{1323}$ Početkom srpnja 1573. spominje se sudac Lovrinac Kozlović - „Lourinatz Khoslouitsch Richter Zw Wihitsch, vnd die Gantz gemain deselben Flekhens, Allzeyt der Khayserlichen Mt. etc vnd eur All $\beta$ die getrewen. SI AS 2, DSK, kutija 286, fascikl 164, Bihać, 2.7.1573., 1r, rbr. 128.

${ }^{1324}$ LOPAŠIĆ, Bihać, 253, fusnota 69.

${ }^{1325}$ SI AS 2, DSK, kutija 805, fascikl 540, Karlovac, 5.3.1592. Andreas Auersperg na predstavnike kranjskih staleža.
} 
von Wihitsch“ kojemu na žalost nije zapisano ime. ${ }^{1326} \mathrm{U}$ popisu vojske Bihaćke kapetanije iz 1553. navode se dvojica Kaptolovića, pješaka gradske posade. Marko Kaptolović primao je mjesečnu plaću od 4 rajnska guldena, a Mihovil Kaptolović primao je plaću od 3 rajnska guldena mjesečno. ${ }^{1327}$ Nadalje, Lopašić je naveo Franka Kaptolovića kao suca 1576., ali je on (Franko Kuptholowych) bio je jedan od sudaca i oko/prije 1570. jer ga je „opchyna warossa byhachkoga“" poslala zagrebačkom sucu Teletiću radi pitanja stoke njegova pokojnog brata Mikule dijaka. Kaptolović je dvaput putovao u Zagreb, a bihaćki suci i općina molili su da se stvar riješi „zasto ny nasemw zwdczw prohoda wazdar yz warosa, ny (tako) drwgym owdy zthoyechym“. ${ }^{1328}$ Njegov brat očito se bavio trgovinom stokom, a bio je i obrazovan čovjek jer je naveden kao dijak. Franko Kaptolović bio je i dio krajiške strukture pa je tako 1587. zapovjednik stražara u šumama oko Bihaća. ${ }^{1329}$ Kaptolovići su dobar primjer isprepletenosti civilne i vojne strukture u kojima su obnašali važne funkcije.

Još jedan potencijalni primjer takvih međuodnosa jest Paul Mili koji je, kao istaknuti vojni zapovjednik, autor nekoliko pisama na više instance. Mili je možda bio i ugarskog porijekla jer se u upozorenju o osmanskom napadu koji je sastavio u Bihaću sredinom svibnja 1531. oslovljava kao Mili Paul, dakle prvo prezime pa ime, što je bilo uobičajeno za osobe ugarske narodnosti ili barem one koje su potjecali s ugarskog prostora. ${ }^{1330}$ Međutim, krajem listopada 1533. kralj Ferdinand traži od bihaćkoga kapetana Erasma Thurna da pusti iz tamnice, Paula Milija, ,iudicem ciuitatis nostre Bihigiensis“ ${ }^{1331}$ Izvori ne govore zašto je Mili zatvoren, ali sam čin utamničenja suca upućuje na sve izraženiju asimetriju moći između krajiške i civilne strukture u gradu.

Nadalje, u izvorima se navodi i obitelj Cvitković koja je bila plemićkog statusa, a čiji su članovi obnašali dužnost gradskih sudaca. Na nadgrobnoj ploči koja je stajala u crkvi sv. Antuna, a koju je 1524. podignuo gradski sudac Luka Cvitković za sebe i svoje potomke urezan je natpis - „ivdicis. Bihic(ensis) (Ivd)ex Civitatis p(re)fate“. Par godina kasnije, 1530., gradski sudac Juraj Cvitković (Georgium Czwythkowych) bio je poslanik kod cara/kralja Ferdinanda. S njim je bio i sugrađanin (concives) Nikola. ${ }^{1332}$ Paval Cvitković je jedan od gradskih prisjednika 1547., a uz njega se navode još i Matija Brizović, Nikola Grgić, Mikula

\footnotetext{
${ }^{1326}$ SI AS 2, DSK, kutija 230, fascikl 136, Vinica, 8.4.1531., stranica 22 u maloj knjižici.

${ }^{1327}$ LOPAŠIĆ, Bihać, dodatak, dok. IX, 303.

${ }^{1328}$ Ivan KUKULJEVIĆ SAKCINSKI, Acta Croatica, Monumenta historica Slavorum meridionalium, Zagreb, 1863., dok. 39, 333.

${ }^{1329}$ LOPAŠIĆ, SHK, knjiga I, dok. CII, 147.

${ }^{1330}$ LASZOWSKI, HSKHDS, knjiga II, dok. 45, 34.

${ }^{1331}$ IBID., knjiga II, dok. 193, 178.

${ }^{1332}$ LASZOWSKI, HSKHDS, knjiga I, dok. 269, 261-262; VEGO, Srednjevjekovni bihaćki, 265-266.
} 
Jurmanić, Juraj Jurlinović, Bartol Kružić, Juraj Peršić, Nikola Radičević, Grgur Tomasović, Ivan Vladić i Mihovil Zvirčić. ${ }^{1333}$

Kao građani bez određene funkcije 1547. navode se Ivan Barbirić, Marko Brizovčić, Jandrej Čvrstičić, Martin Ivinović, Paval Mršljenović, Luka Udrinić i Petar Zoranić. ${ }^{1334}$ Osim Paula Milija, čije porijeklo zasad ipak nije moguće precizno utvrditi, sva navedena onomastika pokazuje da je gradski sloj sačinjen isključivo od domaćega hrvatskog stanovništva.

Nažalost, nemamo izvora koji bi pokazivali kako su se određeni pojedinci birali na navedene funkcije te da li su potjecali iz specifičnoga kruga osoba, jesu li službe bile nasljedne itd., osim što je vidljivo da je Mikula Zemlić bio sudac 1588. i 1592., a Matej Beličić podsudac 1590. i sudac 1592. te da je Franko Kaptolović također (barem) dvaput bio gradski sudac. Možda je zaista postojala stanovita kategorija uglednijih građana iz koje su se imenovali gradski suci i druge upravne instance.

Međutim, društvene promjene uzrokovane osmanskom ekspanzijom i ustrojavanje krajiškog sustava rezultirale su formiranjem jedne specifične društvene kategorije koja se pojavljuje u gradu, a to je kategorija plemića i krajiških časnika, odnosno osoba u vojnoj službi. U toj se kategoriji u promatranom periodu uglavnom nalaze hrvatski plemići iz bliže ili dalje okolice, kao i pojedini ugledni uskočki časnici/zapovjednici poput Radića Šišmanovića. Kada je ta krajiška struktura slala svoje izvještaje, apele i molbe na više instance, potpisivali su se kolektivno, kao „vsi Bihaćki soldati, pišci i konici, porkulabi okolašni““. ${ }^{1335}$ Uz ranije prezentirane popise vojnika u Bihaću, te osoba poput Gašpara, Mikule i Jurja Križanića te Ivana i Gašpara Kobasića, o sastavu te društvene kategorije svjedoči i popis plemića i vojnika koji su kao svjedoci jednog spora ispitani 1547. i 1549. Prema pravilu, u takvim slučajevima svjedočili su ugledniji i stariji članovi društva. Tako su 1547. u kategoriju plemića i vojnih časnika Petar Bučković, Paval Heraković, Ivan Hlapčić od Knina, Marko Hrinčić, Ivan Izačić,

\footnotetext{
${ }^{1333}$ LOPAŠIĆ, Bihać, 54-55.

${ }^{1334}$ IBID. Navedenog Petra Zoranića se ponekad, bez osobitih dokaza izvan istovjetnosti imena i prezimena, identificira s proslavljenim hrvatskim knjiženikom Petrom Zoranićem.

${ }^{1335}$ LOPAŠIĆ, Bihać, 306, dodatak XI. I na ugarskom prostoru dogodilo se slično. Szelényi navodi: „Towns that lay within the stretch of territory that is commonly referred to as the "military border zone" underwent a further unique urban evolution in the sixteenth century, as exemplified by Tata, Gyor, Papa, Veszprem, Keszthely, and Zalaegerszeg. A high proportion of these towns' urban dwellers were professional soldiers. In sixteenth-century Gyor, for instance, 265 of the 731 houses were occupied by soldiers, and next to the 3,000 burghers lived a soldier population of 2,000. Furthermore, because of the length of military conflict (the region remained a military border zone for 150 years) in these border castle towns, resembling Spartan-like urban fortresses with the core of their identity centered on the soldier-burgher ideal, a distinct military caste-like element emerged. The Kuruc Army, used by Emmerich Thököly and Ferenc Rakoczy II in their struggles for Hungarian independence against Habsburg rule in the late seventeenth century, was recruited from this soldierburgher population. Balázs A. SZELÉNYI, The Dynamics of Urban Development: Towns in Sixteenth and Seventeenth-Century Hungary, American Historical Review, 109(2), 2004., 382.
} 
Stjepan Jurjević, Ivan Katalenić od Knina, Bogdan Knezić, Petar Kučković, Martin Rošković, Radić Šišmanović i Vid Tehojević od Obrovca. Dvije godine kasnije, 1549., u kategoriji plemića i vojnika su Bariša Batičić, Marko Hrinčić, Grgur Kohmanović, Ivan Kolurić, Mate Krušelić, Pavao Medošić, Ivan Rebrović, Stjepan Retković i Luka Roginić. ${ }^{1336}$ Zanimljivo je da se navodi i Pavao Medošić, budući da je bihaćki građanin Pavao Medošić jedan od onih koji su nakon pogibije bana Petra Berislavića na Plješevici 1520. donijeli tijelo u Bihać. ${ }^{1337}$ Bez obzira radi li se o istoj osobi ili različitim generacijama iste obitelji, i ovaj podatak ukazuje na isprepletenost civilne i vojne strukture u Bihaću. U sastavu bihaćke posade nalazile su se i osobe koje nisu potjecale iz neposredne blizine, već su prisiljene osmanskim napredovanjem u Bihać pristigle iz udaljenijeg područja. Od početka 1540-ih do 1550-ih u sastavu bihaćke posade kao konjanik, služio je Stjepan Kecerić - pripadnik bogate baranjske obitelji koja se, nakon što su im posjede početkom 16. stoljeća zauzeli Osmanlije, doselila u Slavoniju. Kecerić je bio u bliskim obiteljskim vezana s članovima obitelji Vragović. ${ }^{1338}$

Dakle, ova je društvena kategorija do sredine stoljeća zauzela istaknutu ulogu u gradskom ambijentu, a to ne bi trebalo iznenađivati s obzirom na važnost i snagu vojne strukture te činjenicu da se radilo u uglednim plemićima i krajiškim zapovjednicima. No, postavlja se pitanje da li su pripadnici vojnog kruga, izvan kategorije bihaćkih građana u vojnoj službi, i formalizirali svoj istaknuti položaj, odnosno da li su imali pristup gradskim institucijama? O tome ima zaista malo podataka, ali već spomenuti navod iz 1543. prema kojem građani nisu željeli primiti nijednog vojnika u gradsko vijeće možemo protumačiti ili kao odbijanje da se uvedu noviteti ili možda kao pokušaj sprječavanja već postojeće prakse. ${ }^{1339}$ Zbog deficitarnih izvora teško je decidirano zaključiti, ali navedeni slučaj svakako pokazuje proces transformacija gradske strukture te proces postupne infiltracije sve dominanntije vojnog elementa u civilnu gradsku strukturu.

Za kraj ovog poglavlja treba navesti da je u bihaćkoj džamiji Fethiji, nekadašnjoj crkvi sv. Antuna, pronađeno devet nadgrobnih ploča iz 16. stoljeća koje svjedoče o kompoziciji gradske elite i karakteru života na isturenom krajištu. Od bihacita, lokalnog kamena koji je korišten i za gradnju crkve sv. Antuna, isklesani su nadgrobni spomenici Luke Krojača, Petra Rebrovića, Bernardina Stifkovića, Ivana i Gašpara Kobasića, Ivana Izačića, Luke Cvitkovića, Nikole Farkašića, Ivana Bukovića i stanovitog Jurja. Radi se o pokojnicima koji su bili dio

\footnotetext{
${ }^{1336}$ LOPAŠIĆ, Bihać, 254, fusnota 69.

${ }^{1337}$ Matija MESIĆ, Banovanje Petra Berislavića, RAD JAZU, Zagreb, knjiga 3, 1868., Zagreb, 53.

${ }^{1338}$ Ivan JURKOVIĆ, Prozopografska analiza „Teštamenta“ gospe Jeleni, sestri pokojnoga kneza Petra Kružića, u: Raukarov zbornik, ur. Neven Budak, FF Press, Zagreb, 2005, 401-402.

${ }^{1339}$ HDA, Zbirka preslika, Militaria, kutija 2, 1543., str. 187.
} 
gradske strukture poput suca Luke Cvitkovića te uglednih hrvatskih plemića i vojnih zapovjednika u gradu i okolici. U crkvi sv. Antuna pokopani su tako bihaćki vicekapetan Petar Rebrović, istaknuti krajiški časnici i hrvatski plemići Ivan i Gašpar Kobasić, kao i Ivan Izačić i Bernardin Stifković.

Natpisi na spomenicima upućuju i na izraženu prisutnost nasilja na isturenom pograničju, a to se posebno ističe u slučaju „strenui militis nobilis“ Bernardina Stifkovića za kojeg je navedeno da je pokopan bez glave nakon što je 1523. poginuo u borbi ,za kršćansku vjeru“. U istom su grobu počivali i „etiam alia corpora egregiourm militum gentis Stivchovich“. ${ }^{1340}$ Stifkovići se u Bihaću spominju još 1488. kada se navode Antun i Marko Stifković (Anthonius et Marcus Stefkowich). ${ }^{1341}$ Radilo se dakle o uglednome plemićkom i vojničkom rodu čiji će jedan član, Petar Stifković, još 1583. biti spomenut kao nekadašnji konjanički kapetan u Bihaću. ${ }^{1342}$ I za Nikolu Farkašića na ploči stoji da je poginuo 1519. u borbi za katoličku vjeru. ${ }^{1343} \mathrm{Na}$ nadgrobnoj ploči Ivana Izačića zapisano je pak da je ovdje pokopan „Nobilis Egregiique Militis Iohanis Isatsich Ces. M. Capitanei in Repats et heredvm“. ${ }^{1344}$ To su članovi obitelji koje su u višedesetljetnom kontinuitetu bile prisutne u krajiškoj vojnoj službi u kojoj su mnogi od njih i ostavili svoje živote boreći se na isturenom pograničju.

\subsection{Unutrašnje napetosti u pograničnom gradu. Civilna i vojna vlast u ,klinču“}

Jedna od najvažnijih i još uvijek uglavnom neistraženih tema razvoja krajiškog sustava na hrvatskom prostoru u promatranom periodu jest i problematika konfliktnih epizoda i procesa u odnosima civilnih i krajiških struktura te napetosti unutar samoga vojnog elementa na krajištu. U ovom poglavlju analizirati ću navedenu problematiku, prvo referirajući na nesuglasja i sukobe između krajiške i gradske instance, a zatim i na interne trzavice unutar vojnog sustava u gradu.

U Bihaću je dakle, s jedne strane stajala tradicionalna gradska administracija opisana u prethodnom poglavlju, a s druge strane (relativno) nova i sve dominantnija vojna struktura.

\footnotetext{
${ }^{1340}$ VEGO, Srednjevjekovni bihaćki, 263. Vego donosi fotografije nadgrobnih spomenika. Prije desetak godina u Bihaću je postavljena replika sarkofaga u kojem su pokopani ostaci navedenih osoba. Na vanjskoj strani sarkofaga isklesani su grbovi pokojnika.

${ }^{1341}$ THALLÓCZY, HORVÁTH, Also-Szlavoniai, dok. XIV, 338.

${ }^{1342}$ HDA, Croatica, mikrofilm D-1914, br. 19. prosinac 1583.

${ }^{1343}$ VEGO, Srednjevjekovni bihaćki, 266.

${ }^{1344}$ IBID., 264.
} 
No, budući da su obje instance u Bihaću bile isprepletene ne bi se smjele promatrati kao zasebni entiteti, jer su dugotrajni procesi pograničavanja uvelike militarizirali stanovništvo Bihaća.

Bihaćka gradska općina je u promatrani period ušla ugrožena zbog Osmanlija, ali sa svojim naslijeđenim pravima i privilegijama. Građani Bihaća i Ripča su u srpnju 1527. prisegli na vjernost Nikoli Jurišiću, koji je nastupao u ime vladara, a on im je pismeno obećao potvrdu starih privilegija te da će se moći voditi svojim starim slobodama i običajima. Vladar je pak trebao potvrditi i sankcionirati dogovoreno. ${ }^{1345}$ Također, udovica ugarsko-hrvatskog kralja Ludovika II, kraljica Marija trebala je poslati pismo Bišćanima i Ripčanima u kojem bi izrazila zadovoljstvo zbog njihove odluke da se podrede njezinu bratu, kralju Ferdinandu. ${ }^{1346}$ Teško je utvrditi o kojim se privilegijama točno radi, ali znamo da je u lipnju 1531. kapetan Erasmo Thurn tvrdio da su bihaćki građani (purgger, purggerschaft) oslobođeni obaveze sudjelovanja u građevinskim radovima. ${ }^{1347}$ Ovdje je možda riječ o sudjelovanju u neplaćenim građevinskim radovima, odnosno o dužnosti od koje su stanovnici gradova uglavnom bili izuzeti. ${ }^{1348}$ Treba napomenuti da Katalin Szende navodi da su, prema sačuvanim računskim knjigama gradova na ugarskom prostoru, najveći financijski trošak, osim plaćanja poreza, otpadao na građevinske radove održavanja (primarno) obrambene infrastrukture, te da je sudjelovanje u obrani grada bila druga najvažnija obaveza građana nakon oporezivanja. ${ }^{1349} \mathrm{U}$ periodu permanentne ratne opasnosti taj je aspekt silno potenciran i prema tome postao još veći financijski uteg.

Za razliku od senjske gradske općine, kojoj kralj Ferdinand 1528. i kralj Rudolf II. 1582. potvrđuju stara prava i slobode, takve potvrde nakon 1527. nisu pronađene za Bihać. ${ }^{1350}$ Superiorni položaj kapetana svakako je bio generičke prirode, posljedica realnog stanja odnosa uzrokovanih osmanskom ekspanzijom, ali je bio i (u određenoj mjeri) pravno formaliziran. Već je navedeno da je Nikola Jurišić savjetovao kralju u srpnju 1527. da se za kapetana nad kaštelom i gradom imenuje sposoban austrijski plemić koji bi zapovijedao nad

\footnotetext{
1345 „,hei iren alte privilegi behalten“ odnosno „auch bei iren alten freihaiten und gepreuchen zu handthaben welle“. THALLÓCZY, HODINKA, A horvát véghelyek, dok. DXLIV, 694.

${ }^{1346}$ IBID., dok. DXLIV, 695-696.

${ }^{1347}$ LASZOWSKI, HSKHDS, knjiga I, dok. 57, 44.

${ }^{1348}$ Katalin Szende navodi da je „The basis of the towns' own enterprises was a series of privileges transferring the king's rights as landlord over the town and fields around it, so that the land became the property of the community of burghers. Apart from some isolated cases, towns were also exempted from the unpaid labor, because they held the rights of landownership to their own land." SZENDE, The Urban Economy, 339.

1349 IBID., 342.

${ }^{1350}$ KLAUŽER, Ustrojstvo i djelovanje, 48.
} 
Bišćanima i „drugima“. ${ }^{1351}$ Krajem kolovoza 1531. predstavnici gradske općine, a to su župnik, prior, gvardijan, sudaci te „uniuersa comunitas Bichigiensis“ šalju obavijest o osmanskom napadu na Krupu kapetanu Thurnu oslovljavajući ga s „Magnifico domino Erazmo de Turn, capitaneo Bihachiensi, domino nostro semper gratiosissimo“. ${ }^{1352}$ Ovakvo oslovljavanje pokazuje koliki je već tada njegov ugled i status iako treba voditi računa da su na mjestu kapetana, a osobito kada je riječ o osobama poput Erasma Thurna, namješteni ugledni i visokopozicionirani plemići koji bi i bez funkcije koju su obnašali generirali veliki respekt u regiji. Kada je pak Mert Gall u svibnju 1540. preuzeo kapetaniju, on je od Barthlmea Raunacha preuzeo „kaštel Bihać, grad i druge podređene utvrde“. ${ }^{1353}$

U Senju je odnos kapetana i gradske općine bio reguliran na način da je prilikom postavljanja kapetana vladar o izboru obavijestio građane te od njih tražio poslušnost i vjernost obvezujući se da će poštivati njihova prava i obaveze. Izdavana su i pisma garancija (littere credentiales). ${ }^{1354}$ Identično je bilo i u Bihaću, barem od 1540. nadalje. Naime, kraljica Ana je u srpnju 1540. poslala na predstavnike kranjskih staleža i vicedoma pismo u kojem navodi da im dostavlja „pismo pokornosti“ (Gehorsamb=Brieff) koje je upućeno bihaćkim građanima (Burger zu Wichitsch), a u njemu se nalaze i instrukcija te pismo postavljanja (Bestallung) za Merta Galla. ${ }^{1355}$ Kraljica je dakle poslala pismo ,pismo pokornosti“ i na Bišćane u kojem je navedeno da se moraju pokoraviti kapetanu Gallu. ${ }^{1356}$ Valvasor je to protumačio kao podređivanje grada Kranjskoj, ali to je bio uobičajen postupak - izdavala su se pismo postavljanja i instrukcije za kapetana te pismo pokornosti upućeno građanima $\mathrm{u}$ kojem se traži poslušnost i vjernost. Dakle, građani su trebali biti poslušni kapetanu koji je pak trebao poštivati njihova naslijeđena prava i obaveze. Jedna od obaveza gradske općine vjerojatno je bila držanje straža u gradu ili neposrednoj blizini, primarno na Otoci. Međutim, i to je u kasnijem periodu postalo problematično, pa su građani 1571. molili kralja da podmiri troškove držanja četvorice stražara koje su do tada plaćali. ${ }^{1357}$ Ova molba pokazuje degradaciju moći gradske općine koja više nije mogla izvršavati naslijeđene obaveze, a u takvom kontekstu ovisnost o krajiškom sustavu bila je sve izraženija.

\footnotetext{
1351 „, das er dasselbs denen von Wichitsch und anderer das recht besitz”. THALLÓCZY, HODINKA, A horvát véghelyek, dok. DXLIV, 693.

${ }^{1352}$ LASZOWSKI, HSKHDS, knjiga I, dok. 57, 44.

1353 „,das schloss Wihitsch, Stat vnd etliche andere zugeherundt fleckhen“. IBID., knjiga II, dok. 493, 487-488.

1354 KLAUŽER, Ustrojstvo i djelovanje, 45-46.

1355 SI AS 2, DSK, kutija 244, fascikl 143, Beč, 1r, rbr. 236. Kraljica Ana na predstavnike kranjskih staleža i vicedoma Kranjske. VALVASOR, Die Ehre, svezak IV, knjiga XII-XV, 12.

${ }^{1356}$ LASZOWSKI, HSKHDS, knjiga II, dok. 501, 498-489.

1357 SI AS 2, DSK, kutija 286, fascikl 164, Beč, 20.11.1571., 1r-1v, rbr. 47-48. Car Maksimilijan na Herbarta Auersperga. Stanovnici Senja imali su od kraja 15. stoljeća obavezu davati šestoro stražara na gradskim zidinama. KLAUŽER, Ustrojstvo i djelovanje, 73.
} 
No, nema izvora koji bi potvrđivali da je u Bihaću, kao u Senju, kapetan, a ranije i ban, birao jednog gradskog suca, a drugog nakon izbora potvrđivao. U Senju je kapetan imao i određenu arbitrarnu ili prizivnu funkciju međuinstance prije kraljevskog suda. ${ }^{1358}$ Nažalost, nema ni izvora koji bi pokazivali kako je točno tekao proces izbora gradskih sudaca, odnosno je li kapetan u bilo kojoj mjeri utjecao na izbor ili ga čak monopolizirao kao što se (kasnije) znalo događati u drugim gradovima na pograničju. ${ }^{1359}$

Veliki broj predstavki, molbi i apela, kojima su predstavnici gradske općine tražili od kranjskih staleža i središnje vlasti pomoć, svjedoči o sve izraženijoj ovisnosti o vladaru i unutrašnjeaustrijskim staležima. Bez njihove asistencije bihaćka gradska općina bi se vrlo teško toliko dugo održala na isturenom krajištu. Iako su kranjski staleži i središnja vlast uglavnom revno pomagali ili barem nastojali pomoći, okolnosti su često bile takve da su apeli za pomoć ostali (određeno vrijeme) neuslišani. To je pak generiralo nezadovoljstvo, a nezadovoljno stanovništvo u nestabilnome krajiškom kontekstu predstavljalo je potencijalno veliki sigurnosni problem za vojne vlasti. Tako je krajem srpnja 1576. bihaćki kapetan Sebastian Lamberg naveo da cijelo građanstvo (die gannz burgerschafft) negoduje jer sve njihove molbe i poslanstva upućena predstavnicima kranjskih staleža i vojnim zapovjednicima, nisu imala nikakav efekt. Budući da je to bio period kada su Osmanlije napadali jednu utvrdu za drugom, kapetan je tražio momentalnu isplatu plaća i dopremu platna za plaću jer se bojao pobune vojnika, građana i seljaka koji bi mogli napustiti grad. ${ }^{1360}$ Prije samog pada grada, početkom ožujka 1592., bihaćki kapetan uputio se pak u Ljubljanu s oba bihaćka suca kako bi okupljene staleže u ime cijele burgerschafft zamolili za pomoć. Andreas Auersperg molio je nadvojvodu da ih se ne samo sasluša u njihovoj potrebi nego da ih se otpratiti s odlukom kojom bi svojim sunarodnjacima pokazali da njihovo putovanje ne samo da nije bilo beskorisno već da se mogu nadati da im neće propustiti priskočiti u pomoć. ${ }^{1361}$

Izvori svjedoče o napetosti, a u nekim trenucima i pravom neprijateljstvu između predstavnika bihaćke gradske općine i krajiške strukture koja je raspolagala s vojnim formacijama unutar grada, širim teritorijem pod svojom upravom, većim financijskim

\footnotetext{
${ }^{1358}$ IBID., 49-55.

${ }^{1359}$ Primjerice, u Koprivnici su se u sljedećem stoljeću kapetani nametali i za suce. Neven BUDAK, Pogranična gradska naselja sjeverne Hrvatske u 17. stoljeću, Radovi Zavoda za hrvatsku povijest Filozofskog fakulteta u Zagrebu, vol. 15, Zagreb, 1992., 30-31. U Križevcima je u 17. stoljeću vojna vlast nastojala preuzeti upravu nad cijelim gradom, a ti su se pokušaji zbog degradacije važnosti grada nastavili i nakon što je 1635. civilna vlast potpuno izuzeta ispod vojničke. IBID., 34.

${ }^{1360}$ SI AS 2, DSK, kutija 287, fascikl 164, Bihać, 20.7.1576., 1r, rbr. 562. Sebastian Lamberg na kranjske Verodneten.

${ }^{1361}$ SI AS 2, kutija 805, fascikl 540, Karlovac, 5.3.1592. Andreas Auersperg na predstavnike kranjskih staleža.
} 
sredstvima te logistikom. Čini se da je u prvoj polovici 16. stoljeća, kada je gradska općina još uvijek u povoljnijem položaju nego što će to biti kasnije, prisutan nešto izraženiji rivalitet između krajiške i gradske strukture. Iako Lopašić uzrok sukoba vidi u osobnom antagonizmu, vjerojatno je ipak riječ o dubljem, strukturalnom problemu koji je prvenstveno povezan s pauperizacijom gradske općine i sve izraženijom ovisnošću o krajiškoj upravi. U takvom kontekstu građani su teško mogli biti ravnopravni kapetaniji, bez obzira na to što je potonja i sama bila opterećena različitim manjkavostima.

U prvoj polovici stoljeća postoji i poneka eksplicitna potvrda da se mišljenje lokalnog stanovništva, a prije svega predstavnika gradske općine, uzimalo u razmatranje, i kada se radilo o vojnim temama. Jedan od visokopozicioniranih časnika u kapetanijskoj strukturi i ugledni hrvatski plemić Petar Rebrović javio je tako krajem kolovoza 1531. kapetanu Thurnu da se savjetovao s bihaćkim građanima (mein vnd der purger Rat gewesen) u vezi određenih pitanja. ${ }^{1362}$ No, treba uzeti u obzir da je Rebrović bio i domaći čovjek odnosno hrvatski plemić. Takvih navoda kasnije gotovo da i nema iako nema sumnje da je razmjena mišljenja svakako morala postojati. S određenim nezadovoljstvom susreo se u lipnju 1530. vicekapetan Ivan Lenković koji je naveo da „siromašan puk“ očajava, teži podrediti se Osmanlijama i predati grad. Lenković čak komentira da je domaće stanovništvo tri ili četiri puta snažnije nego oni (schterkher hinein den wir), dakle krajiška struktura, a da kaštel nije toliko čvrst kao što svi misle. Da je „,snažniji“, piše Lenković, ne bi se obazirao na njihove riječi i djela, ali budući da nije primio nikakve pomoći (vojnike, barut i novac) te da kapetan nije u Hrvatskoj, molio je da ga se instruira kako postupiti u tako kompleksnoj situaciji kada je prijetio i osmanski napad. ${ }^{1363}$ Unatoč Lenkovićevim strahovima od „nekoliko puta“ snažnijih građana, krajiška vlast bila je dovoljno snažna da tri godine kasnije, u listopadu 1533., utamniči bihaćkog suca Paula Milija. ${ }^{1364}$

Prvi nešto iscrpniji izvor o konfliktnim situacijama na navedenoj relaciji potječe iz 1543. i odnosi se na pokušaj intervencije bihaćkoga kapetana Merta Galla u spor između bihaćkog gradskog suca (vjerojatno Luke zlatara) i hrvatskog plemića Mikule Križanića. U pozadini spora jest Križanićev stav da su on i ostali stanovnici na otoku (očito bihaćka ada Otoka) kraljevski slobodnjaci te stoga ne podliježu pod ingerenciju bihaćke gradske općine. Međutim, gradski je sudac kapetanu Gallu porekao bilo kakve ingerencije u navedenom pitanju, ali nije se zaustavio pri tome, već je nadredio da mora platiti 500 guldena kazne onaj

\footnotetext{
1362 SI AS 2, DSK, kutija 191, fascikl 119, Bihać, 22. kolovoz 1531., 1v. Petar Rebrović na Erasma Thurna. ${ }^{1363}$ LASZOWSKI, HSKHDS, knjiga I, dok. 367, 352.

${ }^{1364}$ IBID., knjiga II, dok. 193, 178.
} 
tko se pokori nenavedenoj kapetanovoj odluci. Gall ga je pak sa svoje strane optužio da ne poštuje autoritete Cara i bana te da je čak etiketirao vojnike kao drvosječe i stražare. ${ }^{1365} \mathrm{U}$ osnovi ovog spora zapravo je bio sukob između hrvatskog plemstva, koje je doseljeno na prostor grada, i bihaćke gradske općine, dakle još jedna razina internih preslagivanja unutar domicilnog elementa koja nije rijetkost i u drugim gradovima Ugarsko-hrvatskoga Kraljevstva. Proces useljavanja plemstva u gradove nije nužno morao biti direktno vezan uz osmansku prijetnju, ali na hrvatskom prostoru u promatranom periodu on je ipak primarno posljedica osmanskog napredovanja pred kojim se i plemstvo povlačilo u gradove unutar kojih su mogli pronaći zaklon te osigurati egzistenciju služeći u plaćenoj vojnoj službi. Useljavane privilegirane plemićke kategorije na prostor grada moglo je generirati sukobe jer se plemstvo nije osjećalo dužnim podrediti se gradskim zakonima. Na temelju svojeg statusa, a vjerojatno i vojne službe, smatrali su se izuzetim od dužnosti, prije svega novčanih davanja, koje su obvezivale gradsko stanovništvo. ${ }^{1366}$

U ovom se slučaju ocrtava kompleksnost odnosa raznih instanci, svaka sa svojim pravima, tradicijom, autopercepcijom i autonomnom logikom na malom gradskom prostoru. Da je ta godina bila „burna“, pokazuje i činjenica da je krajem listopada 1543. Wilhelm Schnizenbaum izvještavao da su primili obavijesti o izdajničkim namjerama „unutar grada“. Tada je javio i da građani ne žele primiti nijednog vojnika u gradsko vijeće, o čemu je bilo riječi ranije. Štoviše, Schnizenbaum se bojao da, ako su obavijesti točne, građani u grad neće pustiti čak ni pojačanje. Ipak, konstatirao je da je kapetan u kaštelu ,jak“ te da noću može kroz mala vrata Zavala (Zabala) unutra pustiti vojnike ili izaći u vojnu akciju (Raiß). ${ }^{1367}$ Dakle, napetost je dosegla takvu razinu da se moralo razmišljati kako da se kapetan obrani od eventualne ugroze iznutra. Ono što je izrazito važno ponoviti jest da izvor implicira da su osobe u plaćenoj vojnoj službi (diennstman) mogle biti/bile dio gradskog vijeća, a to pak pokazuje procese amalgamizacije gradskog društva u promatranom periodu. Ako je pak ulazak vojnika u gradsko vijeće bio tada tek planiran, onda ovaj izvor upućuje na pokušaj

\footnotetext{
${ }^{1365}$ IBID., knjiga III, dok. 171, 164; LOPAŠIĆ, Bihać i Bihaćka, 65.

${ }^{1366} \mathrm{Na}$ ugarskom prostoru gradovi su zatvorili vrata plemstvu koje se masovno htjelo useliti u gradove. Plemstvo je potom na Ugarskom saboru htjelo izglasati zakone koji bi prisili gradove da ih puste, ali su to spriječili delegati slobodnih kraljevskih gradova. Stoga je plemstvo 1552. kralju uputilo peticiju u kojoj su, prema Szelényjevim riječima, tražili od „your Highness to give the command to the royal free towns and the mining towns, that those nobles and others who are escaping from the war, who can no longer live in the safety of their home, be allowed to settle“, a 1562. ponovno su uputili peticiju kojom su molili da im se dozvoli kupovina kuća u gradovima. Međutim, tek je 1647. plemićima dozvoljeno da se u ograničenom broju naseljavaju u slobodnim kraljevskim gradovima. Balázs A. SZELÉNYI, The Dynamics of Urban Development: Towns in Sixteenth and Seventeenth-Century Hungary, American Historical Review, 109(2), 2004., 377-378. Vidi i PALFFY, Povijest Madžarske, 86-87.
}

${ }^{1367}$ HDA, Militaria, 1543., kutija 2, str. 187. 
gradske općine da se barem u institucionalnom pogledu zatvori prema dominantnoj krajiškoj strukturi.

Međutim, već krajem 1543. gradski sudac i „,vsa općina varoša Bihaćkoga“ šalje Anthonu Thurnu, „gospodinu i ostaloi gospodi, ku su priglednici k.s. (kraljevske svitlosti, op.a.) rusagov“ pismo u kojem se žale na objedu neimenovanog/ih koja „mrazi našu ubogu službu vam gospodi“, a radilo se o optužbama za malverzacije oko živeži. Bišćani su odbijali bilo kakvu krivnju te kontrirali da su oni ti koji bi ,imili tužiti, zač bismo mogli doistiniti, da nam e učineno škode za stov dukat u senu i u slamah i u grajah vartlenih, ča ni plaćeno, i oše zato ovi ubozi ludi nisu k nim niedne zle vole ni zle riči skazali“. Završetak rečenice, u kojem stoji „zač mi liti i v zimi prez vašega prigledanja i pomoći biti nemoremo“, pokazuje zašto se Bišćani ipak nisu tužili na očito neke/oga iz krajiške strukture. ${ }^{1368}$

Bez dodatnih izvora teško je utvrditi jesu ta dva slučaja povezana, ali molba pokazuje da su, bez obzira na konflikte, okolnosti bile takve da si gradska općina nije mogla dopustiti luksuz sukobljavanja s instancama o kojima je ovisila obrana grada. Ipak, nisu se libili (oštrije) upozoravati krajiške strukture o potrebi obrane grada pa će tako sudac Franko Kaptolović početkom srpnja 1576. tražiti hitnu pomoć od Hansa Auersperga riječima da „ye bolye pomochy zuzednye kuche gaziti, nego kada k zuoyoi pozar doyde“. ${ }^{1369}$ Nakon tih događaja još dva izvora direktno upućuju na sukobe između vojne i civilne strukture u gradu. Prvi je vrlo kratak navod iz 1582. da je kapetan zbog neposlušnosti bihaćkih građana suca bacio u tamnicu, odnosno ,in Thurn werfen lassen“. ${ }^{1370}$ Dakle, gradski je sudac (privremeno) podijelio sudbinu osmanskih zarobljenika koji su tamo zatvarani.

Drugi slučaj odvio se nekoliko godina kasnije. U prosincu 1586. vojni povjerenik Jobst Langenmantel održao je prilikom muštre u Bihaću, a u nazočnosti vojnih zapovjednika i vojnog suca (regiments schuldtheis) saslušanje (das pro et contra gehört) u vezi žalbi koje je protiv kapetana Franza Hörnera uputilo građanstvo. Stanovnici su se žalili da se već petnaest dana ne drže straže te da sadašnji zapovjednik ne poduzima nikakve građevinske aktivnosti. Nadalje, žalili su se da im je preko profosa oduzeo jednu bačvu rakije i jednu bačvu „zwespen“ koje je prodao te da nemaju pravo prvootkupa u slučajevima kada zarobljenici radi

\footnotetext{
${ }^{1368}$ LOPAŠIĆ, Bihać, dodatak, dok. VIII, 301; SZELÉNYI, The Dynamics, 382. No, 1546. donesena je zakonska odredba prema kojoj su plemići, koji su izgubili imovinu u sukobima s Osmanlijama, oslobođeni plaćanja gradskih nameta, a 1563. donesen je zakon prema kojem je osmanska prijetnja opravdanje plemićima za stjecanja imovine u gradu. Blanka SZEGHYOVÁ, Coexistence of Diversities: Social, Ethnic and Religious Frontiers and Identities in Early Modern Hungarian Towns. u: Frontiers and Identities. III. Thematic work group 5. Cities in Regions and Nations., ur: Klusáková, Lud’a - Teulières, Laure. Pisa : Edizioni Plus Pisa University Press, 2008, 128.

${ }^{1369}$ LOPAŠIĆ, Bihać, dodatak, dok. XIII, 307.

${ }^{1370}$ HDA, Croatica, mikrofilm D-1914, br. 6, studeni 1582; BUDAK, Uloga Bihaćke, 169.
} 
otkupa iz sužanjstva dovedu stoku u grad. No, predstavnici građana su u nazočnosti povjerenika i drugih vojnih zapovjednika ipak promijenili iskaz i izjavili da im je Hörner uvijek bio poput oca te da u pogledu straža nije učinio ništa loše. Što se straža tiče, Hörner se pravdao da je tako postupio jer više nije bilo živeži, a građani im nisu željeli pomoći novcem, suknom i žitom. U pogledu građevinske djelatnosti, naveo je da kada je i nešto htio graditi građani nikada nisu mogli financijski pomoći. ${ }^{1371}$

No, najzanimljiviji dio ovog spora jest onaj u kojem Langenmantel navodi da je kapetan imao pravo oduzeti rakiju (zbog koje su se vojnici opijali pa su izbijali problemi) i raznu drugu „kvarljivu robu“ jer je to praksa na krajini te da je postupak kapetana sasvim opravdan jer je kapetan nadređen građanima (alls derzeit irer fürgeseczten obrigkheit)! Također, Langenmantel je smatrao ispravnim da kapetan i podređeni mu vojnici imaju pravo provotkupa stoke i „drugoga“ zato što građani nisu kupovali za svoje „kuće i čeljad“, nego kako bi tu istu stoku kasnije prodavali njemačkim vojnicima po dvostrukoj cijeni. ${ }^{1372}$ Dakle, u ovom slučaju Langenmantel sasvim jasno konstatira da je kapetan nadređen građanima. Dok visoko pozicionirana krajiška svita nije stigla u grad, gradska općina je možda (pismeno) mogla oponirati ili barem prigovarati kapetanu, ali suočena s kapetanu nadređenim vojnim instancama, o kojima je uostalom i ovisila njihova obrana, uslijedilo je naglo reteriranje u korist kapetana. Ovaj slučaj vrlo plastično prikazuje realnost odnosa između krajiške i gradske strukture prije pada grada u osmanske ruke.

I plemićke obitelji, čiji su članovi također bili visokopozicionirani u krajiškoj strukturi i koje su imale ili stekle posjede u neposrednoj okolici grada, sukobljavale su se (ponekad) s gradskom općinom jer su imale tendenciju zauzimati zemlje u gradskom vlasništvu ili posjede na koje je gradska općina pretendirala, kao što se dogodilo s Kobasićima kojima je dodijeljen posjed Kralje. Bišćani su protiv Kobasića protestirali 1530. jer ne samo da su im pričinjavali probleme već je navodno ,vlastelin Kobasić“ nasrnuo mačem na gradskog suca koji je branio gradske međe. ${ }^{1373}$ Kapetan Mert Gall je u svibnju 1540. spomenuo već navedeni sukob između hrvatskog plemića Mihaela Budošića (Michel Wudoschitz) i građana (hieygen Burger) oko nekih podanika (von wegen etlich Vnnderthannen verloffen). Naime, Gall je naveo da je njegov prethodnik Bartlme Raunach od nadređenih dobio pismeni nalog da spomenute „podanike“ (Vnnderthannen) podredi Budošiću što je namjeravao provesti, ali su se građani tome usprotivili i nisu to dopustili, već su tražili da im se pokaže kraljevska (khuniglichen)

\footnotetext{
${ }^{1371}$ LOPAŠIĆ, SHK, knjiga I, dok. CII, 150.

1372 IBID.

${ }^{1373}$ LOPAŠIĆ, Bihać, 55.
} 
odluka. Kada je to ponovno pokušao provesti, građani su se opet usprotivili i ponovo tražili da im se prezentira kraljevska odluka. Kapetan je stoga tražio daljnje upute jer su građani dali do znanja da nikome neće ,predati“ podanike, pa i pod gubitkom života. Gall je sa svoje strane strahovao da se iz toga ne izrodi još veći problem. ${ }^{1374}$ Međutim, kao što je navedeno, predstavnici kranjskih staleža i vicedom smatrali su da to treba rješavati ban. ${ }^{1375}$ Očito se radilo o podanicima s posjeda Velihovo za koji je kralj krajem prosinca 1545. naredio da se vrati u posjed Mihaela Budošića, ali kada su kraljevski delegati pokušali provesti odluku, „,constitutis iudice et ciuibus“ Bihaća izjavili su da će se radije podčiniti Osmanlijama nego dopustiti da se to izvrši. ${ }^{1376}$ Velihovo je bio važan posjed u gradskom arealu, od prvih spomena vezan uz Bihać, i nije iznenađujuće da su ga građani s tolikim žarom branili. Bitka za posjede i podanike bjesnila je i između domaćih instanci na hrvatskom pograničju.

Treba napomenuti da nema naznaka konfesionalnog antagonizma u Bihaću iako su kranjski plemići i dio vojne posade na krajini uglavnom bili protestanti, a u gradu su služili i martolozi, odnosno uskoci od kojih je dio svakako bio pravoslavne vjeroispovijesti. Zna se da je kapetan Mihael Spalatin u grad pozvao poznatoga hrvatskog protestantskog propovjednika Gregora Vlahovića te da je karlovački predikant Sebastian Folberger djelovao i u Bihaću. ${ }^{1377}$ No, taj aspekt gotovo se i ne navodi u izvorima što znači da on nije imao osobit utjecaj na međusobne odnose na krajini te da je borba protiv zajedničkog neprijatelja „kršćanskog imena" očito relativizirala međukonfesionalne prijepore.

Jedan drugi uzrok potencijalnih sukoba mnogo se češće pojavljuje u izvorima prevratničke namjere lokalnog stanovništva. Još je Lopašić konstatirao da se mnogo naroda iz bihaćkog kraja tijekom 16. stoljeća iselilo, ali da je većina ostala i islamizirala se, a tim i lakše jer su se „mnogi kmetovi, tlačeni do zla boga od svoje vlastele, bili uzrujali i naginjali turskoj vlasti samo da budu u životu i imetku što više poštedjeni.“1378 Još je uvijek otvoreno pitanje koliko je domicilnog stanovništva zaista ostalo, a koliko se islamiziralo. No, nesumnjivo je da je egzistencija na nesigurnome isturenom pograničju bila opterećena svakojakim izazovima, a jedan od njih predstavljali su i domaći velikaši koji su ponekad nastojali pretrpljene gubitke

\footnotetext{
1374 „sy lasen sich auch horn, das sy dieselben Vnnderthannen niemandt abtrettenn, sonder sy wellen ir Leben bey inen lassen, vnnd ist grosslich zu besorgen, damit nit etbo ain merer Vnrat daranste“. LASZOWSKI, HSKHDS, knjiga II, dok. 493, 491.

${ }^{1375}$ „So ist es auch ain sach die dem Waan zurichten gepurt“. SI AS 2, DSK, kutija 193, fascikl 119/120, Bihać, 24.5.1540., 4v. Predstavnici kranjskih staleža i vicedom na Merta Galla.

${ }^{1376}$ LASZOWSKI, HSKHDS, knjiga III, br. 216, 247.

${ }^{1377}$ Ivan STEKLASA, Protestantizem v Istri, v metliški in hrvatski Krajini, u: Trubarjev zbornik, ur. Fran Ilešič, Matica Slovenska, Ljubljana, 1908., 83;87.

${ }^{1378}$ LOPAŠIĆ, Bihać, 8.
} 
zbog Osmanlija kompenzirati raznim nasrtajima i pritiskom na domaće stanovništvo koristeći dominantan položaj da na urušenom krajištu steknu posjedovne, financijske i druge koristi. ${ }^{1379}$

Nadalje, u ratu stasalo i obrambenim mjerama nezadovoljo lokalno stanovništvo, zasigurno je imalo jednu temperamentniju crtu, a to potvrđuje i strahovanje kapetana Sebastiana Lamberga 1577. da je bihaćke Hrvate, kada se jednom uznemire, vrlo teško primiriti, te ukoliko započne iseljavanje, neće ih moći ovdje zadržati. ${ }^{1380}$ Krajem 1543. strahovalo se o izdaji unutar grada u čijoj je u pozadini stajalo uhićenje jednog građanina čiji je brat služio kod ,jednog turskog paše“, a koji je navodno šurovao s Osmanlijama te obećao predati grad. ${ }^{1381}$ Nadalje, početkom listopada 1556. Ivan Lenković javljao je da mu je bihaćki kapetan dojavio o otvorenoj pobuni građana i stanovnika Bihaća koji prijete predajom grada. Da bi smirio napetosti i osigurao grad, Lenković je tražio da se u gradsku posadu odmah namjeste njemački vojnici. ${ }^{1382}$

Do koje mjere je to nepovjerenje moglo eskalirati, pokazuje činjenica da je $\mathrm{u}$ kontekstu pripreme spomenute „Hrvatske ekspedicije“ 1578. nadvojvoda tražio da ga se savjetuje o tome da li je moguće iz grada odstraniti bihaćke građane (burger) zbog dugotrajne sumnje (lanwirigen verdacht) i više puta pristiglih pouzdanih obavijesti da više naginju Osmanlijama nego habsburškoj strani! Ako bi to bilo izvedivo, postavilo se pitanje tko će obrađivati polja i vinograde - vojnici ili ono malo podanika (unthertanen) koji i dalje prebivaju na Otoci (in der insel). ${ }^{1383}$ Kada se par mjeseci prije pada Bihaća raspravljalo o obnovi Ripča, pa i napuštanju samog Bihaća, Dvorsko ratno vijeće u Grazu strahovalo je da bi u tom slučaju lokalno stanovništvo radije optiralo za Osmanlije! ${ }^{1384}$ U konačnici će domaće stanovništvo igrati važnu ulogu pri osmanskom osvajanju grada jer će na njihov nagovor kapetan pristati na predaju. Međutim, iako su vojne instance strahovale zbog potencijalnih izdaja unutar gradske strukture, treba napomenuti da nije uočljiv nijedan iole ozbiljniji pokušaj nečega sličnog. Postojali su pojedinci, a možda čak i male klike, koji su zavjerenički djelovali na strani Osmanlija ili su ih barem simpatizirali, ali to je očito ostalo na toj razini.

\footnotetext{
1379 Tako su Karlovići zagospodarili plemenom Novigradskim (Todorovo), Zrinski plemenom Kreščićima i Krupskom Kostajnicom, a Blagajski djelomično plemenom Menića. LOPAŠIĆ, Bihać, 22.

1380 SI AS 2, DSK, kutija 286, fascikl 164, Bihać, 26.11.1577., 1v, rbr. 303. Sebastian Lamberg na kranjske Verordneten.

${ }^{1381}$ HDA, Militaria, kutija 2, str. 185.

1382 ,gefur, Meitterey, vnnd offentliche muettungen, der Burger vnnnd Inwoner daselbst, zur ubergebung berüerten Fleckhen Wihitsch“. SI AS 2, DSK, kutija 201, fascikl 124, logor pod Thurgo(?), 6.10.1566., 1r, rbr. 252.

${ }^{1383}$ LOPAS̆IĆ, SHK, knjiga I, dok 39, 72.

${ }^{1384}$ SI AS 2, DSK, kutija 285, fascikl 163, Graz, 10.2.1592., 2r, rbr. 1048. Dvorsko ratno vijeće u Grazu na nadvovjodu Ernesta.
} 
Čak ni predaju grada u lipnju 1592. ne bi trebalo promatrati kao zavjeru ili izdaju, već prvenstveno kao čin očajnika.

\subsection{Problemi unutar vojne strukture}

U izvorima se pojavljuju i razne konfliktne situacije unutar same krajiške strukture, prvenstvo na relaciji časnici-plaćena posada, koje su uglavnom bile potaknute neurednom isplatom plaća i manjkavom opskrbom. U promatranih šezdesetak godina svakako je moralo dolaziti do razmimoilaženja, odnosno konflikta i unutar zapovjedne strukture kapetanije, ali o tome nema mnogo sačuvanih izvora ili barem do sada pronađenih podataka. Niti dostupni izvori ne otkrivaju mnogo. Tako je u protokolu Dvorskoga ratnog vijeća u Grazu u listopadu 1580. evidentirano nesuglasje (unainigkheit) između kapetana Lamberga i zastavnika (fendrich) Hansa Feyelwarta. ${ }^{1385}$ Nažalost, povod „nesuglasju“ nije nenaveden.

Prvi problemi na relaciji zapovjedni kadar-vojnici pojavljuju se već na samom početku Ferdinandove vladavine kada je u veljači 1527. kralj u Bihać poslao vojnike i oružje, a viceban Ivan Svetački nije ih htio pustiti unutra bez banova naloga. ${ }^{1386}$ Iako su kraljevski vojnici u konačnici pušteni u grad, ovaj primjer pokazuje potencijalni probleme formiranja krajiškog sustava na hrvatskom prostoru, odnosno konflikte koji su mogli eskalirati zbog djelovanja raznih instanci pod različitim zapovjedništvom na istom prostoru.

Mnogo češći problemi pojavljivali su u internim krajiškim strukturama - između plaćene vojske i krajiških zapovjednika. Izljevi nezadovoljstva pa i (ozbiljniji) sukobi najčešće su bili posljedica egzistencijalnih problema s kojima se morala nositi (plaćena) vojna posada. Manjkavosti krajiškog sustava manifestirale su se u raznim aspektima pa se tako posada konstantno žalila na lošu opskrbljenost hranom, ali i loše građevno stanje grada, na deficit vatrenog naoružanja i streljiva, na premalo vojnika u posadi itd. Često nisu bile osigurane ni najosnovnije stvari, a to je osobito predstavljalo problem u hladnim zimskim mjesecima. Zato ne iznenađuje da je, bihaćka posada, očito poučena ranijim iskustvima, već u rujnu 1582. tražila da ih se prije zime svakako opskrbi odjećom, drvom i živeži. ${ }^{1387}$

Ključni problem bila je neredovita isplata plaća, odnosno nesustavna opskrba koja je pak mogla rezultirati i pojavom gladi. Početkom ožujka 1541. posada je prijetila da će

\footnotetext{
${ }^{1385}$ HDA, Croatica, mikrofilm D-1913, br. 30, listopad 1580.

${ }^{1386}$ Vidi stranice 51-54.

${ }^{1387}$ SI AS 2, DSK, kutija 244, fascikl 143, Bihać, 12.9.1581., 1r-1v, rbr. 512 Sebastian Lamberg na kranjske Verordneten.
} 
napustiti službu ako im se ne isplate plaće navodeći da ih je malo te da su neisplaćeni. Predstavku su završili dramatičnim vapajem kako nije pošteno da besplatno služe. ${ }^{1388}$ Tadašnji upravitelj Hans Gall molio je Jurišića da se krajiški poslanici i blagajnik nakon povratka s muštre iz Senja pošalju u Bihać isplatiti plaće. Čini se da je određen iznos novca i količina platna osigurana, no da bi umirio posadu, Gall je i sam dao „sve što je imao“. Međutim, pripadnici gradske posade bili su upoznati s kretanjem poslanika i blagajnika te činjenicom da su već dosta ranije napustili Senj, pa su i dalje inzistirali da im se objasni što je to spriječilo dosadašnju isplatu. Gall je ustvrdio da zbog velikog siromaštva vojnici ne mogu više ostati u Bihaću i da odlaze na dnevnoj bazi, a jedan dio čak i uskače u Osmansko carstvo (einstails aber endspringen gar In die Tirkgkhey). Gall je zaključilo da može nastati golema šteta ako im se ubrzo ne isplati plaća. ${ }^{1389}$

No, nezadovoljstvo se nastavilo, a kao glavni kolovođa označen je jedan domaći čovjek. Naime, u svibnju 1541. bihaćki kapetan Mert Gall javio je da svi vojnici koji su još ostali u gradu slušaju (an Im hangen) Marka Frinčića (Markho Frinzitsch) pa da bi se spriječio njihov odlazak morao je s njim ispregovarati da ostane u službu još jedan mjesec te mu obećao da će ponovo dobiti svoje mjesto. ${ }^{1390}$ Frinčić je očito bio dovoljno utjecajan da utječe na nezadovoljnike, ako se pristane na njegove zahtjeve. Ipak, svega par dana kasnije Gall ponovno izvještava da je još šestero pješaka otišlo te da je konjanika ostalo sasvim malo, ali da su ,najbolji““ otišli. ${ }^{1391}$

Međutim, treba napomenuti da je senjski kapetan Ivan Lenković krajem srpnja 1544., tražeći da mu se isplati obećana svota od 1500 rajnskih guldena, tvrdio da su Bišćani nedavno primili više nego što su zaslužili, ali da su i oni dobili svojih 1500 rajnskih guldena. Najzanimljiviji dio je onaj u kojem Lenković ironizira da bi možda najproduktivnije bilo da i on ratnog blagajnika i gospodu koju vladar pošalje u utvrdu baci u okove ili čak usmrti, kao što to Bišćani uvijek! čine, pa bi se onda i s njime drugačije postupalo. ${ }^{1392}$ Dakle, Lenković, a radi se o jednom od najvažnijih i najupućenijih zapovjednika na krajini, tvrdio je da su Bišćani krajiške časnike koji su pristizali u grad ne samo bacali u okove nego ih čak znali i likvidirati. Doduše, kao i u slučaju držanja straža na Vrhovini, i ovdje su očito prisutni

\footnotetext{
1388 Špijuni su tada donijeli obavijesti da se 400 Osmanlija okuplja u Udbini, da će napasti Bihać i druge utvrde te da znaju da je posada mala. SI AS 2, DSK, kutija 198, fascikl 123a, Bihać, 2.3.1541., 1r-1v, rbr. 1186-1187. Hans Gall na Merta Gall.

${ }_{1389}$ SI AS 2, DSK, kutija 198, fascikl 123a, Bihać, 2.5.1541., 1r-1v, rbr. 1239-1240. Mert Gall na Nikolu Jurišića.

${ }^{1390}$ SI AS 2, DSK, kutija 198, fascikl 123a, Bihać, 16.5.1541., 1v-1r. Mert Gall na Nikolu Jurišića.

${ }^{1391}$ SI AS 2, DSK, kutija 198, fascikl 123a, Bihać, 22.5.1541., 1r, rbr. 1290. Mert Gall na Nikolu Jurišića.

1392 SI AS 2, DSK, kutija 804, fascikl 549/540, Senj, 20.7.1544., 1r. Ivan Lenković na predstavnike kranjskih staleža.
} 
nezadovoljstvo i kompeticija za uvijek nedostatne resurse između dvaju najvažnijih krajiških zapovjednika na Hrvatskoj krajini pa je Lenković vjerojatno pretjerivao zbog očaja ili radi dojma. Možda je i uopćio neki događaj kojem za sada nema spomena u izvornom gradivu, iako vjerujem da bi nasrtaji na visokopozicionirane krajiške časnike rezultirali produkcijom velikog broja spisa od kojih bi se dio svakako sačuvao. No, ovaj izvor pokazuje da je bihaćka posada, unatoč manjkavostima, bila visoko na listi prioriteta krajiške uprave.

Unatoč prioritetima, egzistencijalni uvjeti i dalje su često bili loši. U srpnju 1557. upravitelj kapetanije Georg Zoblsperg javljao je o velikoj gladi koja je zavladala, a budući da nije primio ni pfeninga za opskrbu, sve žito kojim je raspolagao podijelio je dvojici vojvoda (koji ni sami nisu primili novac i živež) te stranim vojnicima (außlandischen knecht) koji drugačije nisu mogli opstati. Tražio je da se pošalje novac za plaće ili da im se nešto doznači da bi vojnici mogli ostati na položajima, a on održati disciplinu. ${ }^{1393}$ Situacija je i sljedeće godine bila kritična pa Zoblsperg početkom svibnja 1558. javljao da je zavladala glad kakvu nitko ne pamti te da mu vojnici odlaze na dnevnoj bazi. Pristižu vojnici koji nisu tri, četiri pa čak i pet punih dana okusili „,zalogaj kruha“ te apelira da im se odmah pošalju plaće jer ih on nikako ne može uzdržavati, s obzirom na u slučaju napada raspolaže sa živeži za samo tri dana. ${ }^{1394}$ Posada se u takvim kritičnim trenucima, koji nisu bili rijetkost, morala zadovoljavati sa suhim prosenim kruhom. ${ }^{1395}$

Takav kontekst bio je plodno tlo za izbijanje konflikta. Zato su vojne vlasti često donosile ad hoc mjere o isplatama dijela dugova. Kada je Mert Gall 1540. imenovan bihaćkim zapovjednikom iz kancelarije kraljice Ane konstatirano je da se on ne može vratiti u grad praznih ruku već da mu se mora doznačiti 750 rajnskih guldena koje je trebao raspodijeliti između 40 konjanika i 125 pješaka. ${ }^{1396}$ Budući da se tada u Bihaću nalazilo čak 126 konjanika, središnje vlasti odlučile su otpuštenim konjanicima, za koje su pretpostavili da neće biti zadovoljni bez isplate zaostataka, podijeliti određenu količina platna koje se tada nalazilo u Ptuju. ${ }^{1397}$

Takve isplate parcijalnih (primjerice, jednomjesečnih plaća) iznosa nastavile su se tijekom cijelog stoljeća. Nakon pada Krupe, odnosno nakon predstavki bihaćke posade i

\footnotetext{
${ }^{1393}$ SI AS 2, DSK, kutija 201, fascikl 124, Bihać, 29.7.1557., 1r-1v, rbr. 462-463. Georg Zoblsperg na Georga Sauera.

${ }^{1394}$ SI AS 2, DSK, kutija 201, fascikl 124, Bihać, 5.5.1558., 2r, rbr. 739. Georg Zoblsperg na Georga Sauera.

1395 SI AS 2, DSK, kutija 286, fascikl 164, Bihać, 26.11.1577., 2v, rbr. 305. Sebastian Lamberg na kranjske Verordneten.

${ }^{1396}$ SI AS 2, DSK., kutija 244, fascikl 143, Beč, 19.4.1540., 3r, rbr. 246. Kraljica Ana na predstavnike kranjskih staleža.

${ }^{1397}$ SI AS 2, DSK., kutija 244, fascikl 143, Beč, 19.4.1540., 1r, rbr. 248. Kraljica Ana na predstavnike kranjskih staleža.
} 
zapovjednika, kranjski su staleži nastojali privoljeti koruške staleže da što prije osiguraju sredstva za isplatu zaostalih plaća. Planirali su isplatiti četveromjesečnu plaću (dva mjeseca u novcu ili platnu) te određenu količinu živeži. No, onima koji su već primili nešto živeži trebalo je pri isplati odbiti jednu mjesečnu plaću i s tim sredstvima ponovo kupiti svježu živež. ${ }^{1398}$ U ljeto 1577., kada se činilo da će Osmanlije zaposjesti Bihać, tamošnjim je vojnicima isplaćena jednomjesečna plaća u iznosu od visokih 2469 rajnskih guldena! ${ }^{1399}$

Ni takve vatrogasne mjere nisu uvijek bile dostatne. Za sada najdramatičniji poznati iskaz nezadovoljstva dogodio se 1573. Naime, krajem veljače, dakle neposredno nakon pogibije kapetana Daniela Lassera u sukobu s pobunjenim seljacima kod Krškog, konjanici i pješaci u Bihaću, zapovjednici (phleger) u svim okolnim utvrdama te ukupna tamošnja vojska (prvo je upisano plaćena - pesoldner, a onda prekriženo i upisano je samo vojnici dienstleut) sastavili su pismo u kojem su se žalili na odnos krajiških vlasti i uvjete u kojima služe. Naveli su da su već nekoliko puta pisali u vezi plaća koje su zavrijedili teškom i mukotrpnom službom te da su, čekajući isplatu, gubili glave i svu imovinu (hab, guett). Oni koji nisu izgubili glave, izgubili su pak „sve živo“ (lebendig) što su imali, poput konja i stoke. „Bog nam je svjedok, da tako više ne možemo“, konstatirali su i nastavili da umiru od gladi i bijede te da si više nikako ne mogu pomoći i kako ovdje nemaju sredstva za daljnji ostanak. Osobito su ugroženi bili oni koji oko Bihaća nisu imali ni vrtova ni „Pifanckh“ na kojima bi uzgajali zelje ili „Laugkh“. Uza sve navedeno, Osmanlije ih ometaju sa svih strana, osobito u šumi pod Pokojem, dok se osmanski konjanici zalijeću sve do mostova, tako da ne mogu ni „proviriti van“. ${ }^{1400}$ Tvrdili su da plaću nisu primili već tri godine, osim četiri polumjesečna iznosa u gotovini i za četiri mjeseca trulog platna koje su mogli tek jeftino prodati pa je bilo dobro ako su uspjeli kupiti išta žitarica. ${ }^{1401}$

Naglasili su da su o svemu izvijestili nadređene i molili isplatu te apostrofirali da im se ne može prigovoriti da bježe zbog straha. Tražili su da im se u roku od mjeseca dana isplati dvomjesečna plaća preko kapetana Bernardina i kapetana Ivana Bogdanića dok će se za ostatak zasad strpjeti i odrediti daljnji termin isplate. Ako im se ne pošalje plaća, odnosno ostatak ne isplati do danog termina, svi zajedno su se usuglasili da neće dalje služiti, već će

\footnotetext{
1398 SI AS 2, DSK, kutija 249, fascikl 146a, 24.10.1565., 1v, 301. Predstavnici kranjskih staleža na Georga Kronschala te zapovjednike i gradsku posadu.

1399 SI AS 2, DSK, kutija 286, fascikl 164, Ljubljana, 29.7.1577., 1r, rbr. 362. Christoph Auersperg i Verordneten na kranjskog zemaljskog kapetana.

${ }^{1400}$ SI AS 2, DSK, kutija 286, fascikl 164, Bihać, 22.2.1573., 1r, rbr. 217. Navedeni na Herbarta Auersperga i u njegovoj odsutnosti na Jobsta Josepha Thurna.

${ }^{1401}$ SI AS 2, DSK, kutija 286, fascikl 164, Bihać, 22.2.1573., 1v, rbr. 218. Navedeni na Herbarta Auersperga i u njegovoj odsutnosti na Jobsta Josepha Thurna.
} 
otići u kaštel i upravitelju Scheyeru (u spisu prekriženo Suerer!) predati zastave, napustiti vojnu službu te otići u carske zemlje kamo će koji već moći. Radije će otići i služiti kod „dobre gospode“ nego ovdje umirati od gladi, a to osobito vrijedi za one sirote koji ovdje nemaju ništa svojega. ${ }^{1402}$

Tih dana sastavljen je njemački prijepis već spomenutog pisma na hrvatskom koje su Herbartu Auerpsergu poslali bihaćki sudac Lovro Vukoslavić i cijela gradska općina, a u kojem navode da su ih Osmanlije ove godine dvaput napali te traže namještanje straža i vojnika (Wacht vnd Leütten). ${ }^{1403}$ Početkom ožujka predstavnici kranjskih staleža primaju dva pisma na hrvatskom jeziku koja su im poslali svi vojnici, konjanici i pješaci u Bihaću, posade svih utvrda podređenih bihaćkom kapetanu te sudac i cijela gradska općina. ${ }^{1404}$ Dakle, radilo se o općem nezadovoljstvu koje nije zahvatilo samo bihaćku vojnu posadu već i građane te vojne posade u utvrdama Bihaćke kapetanije.

Nadvojvoda Karlo promptno je reagirao i tražio da se odmah osiguraju financije za plaće i opskrbi grad. ${ }^{1405}$ Caru je pak javio da u slučaju gubitka Bihaća može doći do velikih šteta, a granična bi se fronta pomakla nekoliko milja u unutrašnjost. ${ }^{1406}$ Nadvojvoda je paralelno slao pisma i na Dvorsko ratno vijeće u Beču i Dvorsku komoru tražeći da također interveniraju kod Cara kako bi se ova opasna situacija razriješila na jedini mogući način, a to je isplatom plaća. ${ }^{1407}$ I car Maksimilijan smatrao je da se zbog opasnosti više ne smije čekati pa je naredio Dvorskoj komori da na Hrvatsku krajinu pošalje 10000 rajnskih guldena da bi se posada mogla održati još koji mjesec do potpune isplate. ${ }^{1408}$ No, molio je brata da, ako Komora oduži sa slanjem novca, urigira kod kranjskih staleža da doznače 8000 ili 10000 rajnskih guldena, a da će im ta sredstva vrlo brzo biti refundirana. ${ }^{1409}$ Čini se da su kranjski staleži već bili poslali tek 2500 rajnskih guldena i nešto živeži jer više nisu bili u stanju zbog uobičajenih izdataka. ${ }^{1410}$

\footnotetext{
${ }^{1402}$ SI AS 2, DSK, kutija 286, fascikl 164, Bihać, 22.2.1573., 2r-2v, rbr. 219-220. Navedeni na Herbarta Auersperga i u njegovoj odsutnosti na Jobsta Josepha Thurna.

${ }^{1403}$ SI AS 2, DSK, kutija 286, fascikl 164, Bihać, den dritten Montag in der Fassten 1573., 1r-1v, rbr. 215-216.

${ }^{1404}$ SI AS 2, DSK, kutija 286, fascikl 164, Ljubljana, 2.3.1573., 1r, rbr. 191. Jobst Joseph Thurn na kranjskog zemaljskog kapetana.

${ }^{1405}$ SI AS 2, DSK, kutija 286, fascikl 164, Graz, 9.3.1573., 1r, rbr. 209. Nadvojvoda Karlo na kranjske staleže.

${ }^{1406}$ SI AS 2, DSK, kutija 286, fascikl 164, Graz, 9.3.1573., 2r, rbr. 211. Nadvojvoda Karlo na kranjske staleže.

${ }^{1407}$ SI AS 2, DSK, kutija 286, fascikl 164, Graz, 9.3.1573., 1r, rbr. 213. Nadvojvoda Karlo na Dvorsko ratno vijeće u Beču i Dvorsku komoru. O Dvorskoj komori vidi ŠTEFANEC, Država ili ne, 92-95.

${ }^{1408}$ SI AS 2, DSK, kutija 286, fascikl 164, Beč, 18.3.1573., 1v, rbr. 183. Car Maksimilijan na nadvojvodu Karla.

${ }^{1409}$ SI AS 2, DSK, kutija 286, fascikl 164, Beč, 18.3.1573., 1v-2r, rbr. 183-184. Car Maksimilijan na nadvojvodu Karla.

${ }_{1410}$ SI AS 2, DSK, kutija 286, fascikl 164, Ljubljana, 14.3.1573., 1v-2r, rbr. 205-206. Kranjski staleži na nadvojvodu Karla.
} 
Krajem ožujka nadvojvoda je ponovno upozorio Cara da vojnici stalno protestiraju zbog dugotrajne neisplate plaća, da tvrde da više ne mogu ostati u tim krajevima te da ih nužda nagoni da napuste svoje pozicije. Također, zapovjednika Hrvatske krajine već duže vrijeme nije bilo što također predstavlja veliku opasnost. ${ }^{1411}$ Sljedeći se mjesec pokušalo unijeti veću količinu živeži u Bihać, ali je taj pokušaj neslavno propao pa je opskrbnik Saloman lamentirao da više ništa neće pomoći to što je njemačke vojnike do sada ohrabrivao „dobrim“ "riječima. ${ }^{1412}$

Problemi očito i dalje nisu bili riješeni, a sredinom 1573. bihaćka posada dovedena je do ruba izdržljivosti. Živež nije stizala mjesecima pa su bili izloženi velikoj gladi i pogibelji. U jednom trenutku hrvatski vojnici (Crabatischen dienstleut), uzrujani zbog neopskrbljenosti i neisplaćenih plaća, odbili su ići na položaje, straže i četovanja. Također, odbili su uopće djelovati protiv Osmanlija izvan zidina. Čak su počele stizati i vijesti o izdajničkim dogovorima s neprijateljem u Vinodolu. ${ }^{1413}$ Iskaz bihaćkog upravitelja Paula Scheyera otkriva da su problemi eskalirali kada se u srpnju vratio u grad bez sredstava za plaće, a na to su vojnici sa svojim zapovjednicima i vojvodama jednoglasno odstupili iz službe te predali vojne zastave na vratima kaštela. Pobunjena posada žalila se da već tri godine u carskoj službi održavaju krajinu s nemalim gubicima, a niti primaju plaću niti ih se opskrbljuje. Nisu urodili plodom Scheyerovi pokušaji da ih skloni da ostanu na svojim mjestima dok nadvojvoda ne pošalje plaće i dodatne snage. Vojnici i njihovi zapovjednici ostali su pri svome te ostavili zastave ležati na podu pred gradskim vratima. ${ }^{1414}$ Takav postupak predstavljao je izrazito potentan čin nezadovoljstva jer je zastava za vojnu postrojbu imala veliko simbolično značenje. ${ }^{1415} \mathrm{U}$ tako dramatičnoj situaciji kapetan je strahovao od „velike izdaje“ jer je smatrao da se građanima ne može vjerovati te da se na njih ne može osloniti ako tamo nisu prisutni njemački vojnici. ${ }^{1416}$ Ovu kompleksnu situaciju dodatno je komplicirala činjenica da

\footnotetext{
1411 „Eur. Mt. Leüttenambt nun lange Zeitt abwesig“. SI AS 2, DSK, kutija 286, fascikl 164, Graz, 24.3.1573., 1r, rbr. 188. Nadvojvoda Karlo na cara Maksimilijana.

1412 SI AS 2, DSK, kutija 286, fascikl 164, Bihać, 15.4.1573., 1v, rbr. 153. Burckhardt Saloman na Jobsta Josepha Thurna.

${ }_{1413}$ SI AS 2, DSK, kutija 286, fascikl 164, 24.7.1573., 1r-1v, rbr. 66-67. Predstavnici kranjskih staleža na nadvojvodu Karla.

${ }^{1414}$ SI AS 2, DSK, kutija 286, fascikl 164, Bihać, 20.7.1573., 1r, rbr. 80. Paul Scheyer na kranjske staleže.

${ }^{1415} \mathrm{Za}$ izradu jedne zastave za njemačke vojnike i četiri uskočke zastave u Bihaću je oko 1566. isplaćeno visokih 55 rajnskih guldena i 15 krajcara. HDA, Militaria, kutija 7, 1565./1567., 18v. Iskaz financijskih izdataka Hansa Khiesla, ratnog blagajnika na Hrvatskoj krajini za 1565. i 1566. Preslike ovoga opsežnog iskaza nalaze se među preslikama spisa za 1561. Tada je Michaelu Semenitschu isplaćeno 8 rajnskih guldena i 44 krajcara za izradu samo jedne konjaničke zastave. HDA, Militaria, kutija 7, 1565./1567., 17v.

${ }^{1416}$ SI AS 2, DSK, kutija 286, fascikl 164, Bihać, 20.7.1573., 1r, rbr. 81. Paul Scheyer na kranjske staleže.
} 
se sve odvijalo za vrijeme osmanskoga vojnog okupljanja kojem je navodni cilj bio Bihać. ${ }^{1417}$ No, povratkom bosanskog paše u Bosnu situacija se primirila pa su vojne vlasti odustale od planiranog slanja Mathiascha Morija s 200 unajmljenih strijelaca u Bihać. ${ }^{1418}$

Izvori ne pokazuju što se dalje te godine događalo po tom pitanju, ali čini se da se situacija smirila. No, okolnosti se nisu uvelike promijenile ni sljedeće godine jer je sva terenska vojska (Extraordinary), konjanici i pješaci, pismeno i usmeno protestirala zbog činjenice da nisi primili nikakvu plaću od studenog 1572. do kraja veljače 1574., odnosno za cijelih petnaest mjeseci službe. ${ }^{1419}$ Dakle, prema toj tvrdnji ništa nije isplaćeno ni prethodne godine, a to djeluje iznenađujuće i otvara pitanje pregovaračkog diskursa na liniji vojnicikrajiške upravne instance. U studenom i prosincu 1574. u Bihaću su ponovno „velika nestašica i opasnost“", a to je osobito pogodilo hrvatske vojnike (Crabatischen dienstleut). ${ }^{1420}$ Žalili su se i zbog neisplate plaća i lošega građevnog stanja te prijetili ,,predajom zastava te odbijanjem odlaska u vojne akcije i na stražu". ${ }^{1421}$ Sredinom studenog 1574. kapetan Sebastian Lamberg javlja da među njemačkim vojnicima vladaju velika glad i krajnja oskudica te da najbolji vojnici odlaze protivno njegovoj volji dok se veliki broj drugih razbolijeva zbog jake zime i loše odjeće te umire od gladi. ${ }^{1422}$

U takvim nepovoljnim okolnostima interni konflikti bili su neizbježni. Da vojnici ne bi stradali od gladi, zapovjednici su bili prisiljeni (ili su barem tako opravdavali svoj postupak) u siječnju 1577. nasilnim putem oduzeti žitarice od „Kobasićeva suca“ (Kowaschitschen

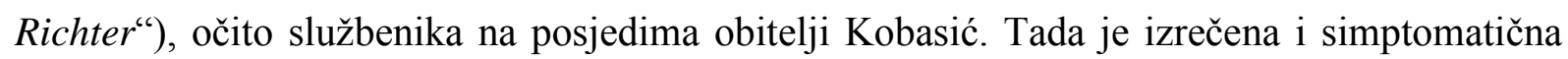
rečenica - glad razrješuje svih zakletvi. Situacija je ponovo poprimila krajnje dramatičnu notu jer su Hrvati prijetili da, ako njemački vojnici zbog gladi napuste grad, da će i oni, i staro i mlado, napustiti grad i ostaviti ga praznim. ${ }^{1423}$

I u kasnijim su se godinama takve situacije ponavljale. U rujnu 1581. svi zapovjednici, časnici, njemački i hrvatski vojnici, pješaci i konjanici šalju molbu da im se ispate dugovanja jer više ne mogu služiti u ovakvim okolnostima - danonoćno pri studeni, snijegu, kiši i

\footnotetext{
1417 SI AS 2, DSK, kutija 286, fascikl 164, Graz, 9.7.1573., 1r, rbr. 93. Jobst Joseph Thurn na predstavnike kranjskih staleža.

${ }^{1418}$ SI AS 2, DSK, kutija 286, fascikl 164, Graz auf Motling Boden, 9.7.1573., 1r, rbr. 92. Jobst Joseph Thurn na predstavnike kranjskih staleža.

${ }^{1419}$ HDA, Croatica, kutija 1, svežanj 1, 1575., 150.

${ }^{1420}$ SI AS 2, kutija 286, fascikl 164, Graz, 8.12.1574., 1r, rbr. 227. Nadvojvoda Karlo na kranjske Verodneten.

${ }^{1421}$,, mit vberanntwortung der Fanen, auch waigerung de Zeüg vnd Wacht“. SI AS 2, kutija 286, fascikl 164, Ljubljana, 3.12.1574., 1r-2r, rbr. 231-233. Kranjski Verodneten i blagajnik na nadvojvodu Karla.

1422 SI AS 2, kutija 286, fascikl 164, Bihać, 16.11.1574., 1r, rbr. 234. Sebastian Lamberg na kranjske Verordneten.

${ }^{1423}$ SI AS 2, kutija 286, kutija 244, fascikl 143, Bihać, 8.1.1577., 1r-1v, rbr. 431-432. Časnici u Bihaću na kranjske Verordneten.
} 
vjetru. $^{1424}$ Te prijetnje zapravo nikada nisu realizirane, barem ne potpuno, a unatoč nesumnjivoj utemeljenosti njihovih prigovora, svakako ih treba promatrati i kao diskurzivno sredstvo pritiska na više krajiške instance.

Plaćena vojska bila je zato prisiljena zaduživati se kod lokalnih stanovnika, odnosno trgovaca. Kada bi napokon pristigao novac za plaće, tim bi se sredstvima često odmah pokrivali akumulirani dugovi. ${ }^{1425}$ To je osobito dolazilo do izražaja kod privremeno stacioniranih postrojbi u gradu koje su ovisile o doznačenim sredstvima i krajiškome opskrbnom sustavu. Tako se Mathiasch Mori 1566. žalio da više ne mogu ostati u Bihaću jer poslane novca odmah moraju prosljeđivati kramarima (sitnim trgovcima) koji su im dali robu na dug, pa im ne ostane ništa ni od sljedeće isplate. ${ }^{1426} \mathrm{~S}$ druge pak strane, i domaći vojnici mogli su biti u neugodnoj poziciji jer su prioritet pri isplati zaostalih plaća i opskrbi imali njemački vojnici u gradskoj posadi, odnosno pojačanja koja su u gradu privremeno stacionirana.

Nezadovoljstvo i neriješeno egzistencijalno pitanje otvarali su prostor za prevratničke namjere i među vojnicima u plaćenoj službi. Zato ću na kraju ovog poglavlja prezentirati jedan slučaj koji pokazuje konspirativnu umreženost raznih skupina pograničnog stanovništva, pa tako i plaćenih vojnika u krajiškoj službi. ${ }^{1427}$ Riječ je o zapisnicima saslušanja osmanskih zarobljenika i nekolicine osoba uhićenih pod optužbom da su špijunirali za Osmanlije te izveli neke pljačke na kršćanskom teritoriju. Izvori su nastali sredinom 1558. kada su počeli pristizati špijunski izvještaji o pripremama dviju velikih osmanskih vojski za provalu na habsburški teritorij. Jedna je trebala krenuti iz Udbine, druga iz Kostajnice, a obje sile namjeravale su se spojiti kod Zrina te napasti rudnike kod Gvozdanskog i Pedlja, a zatim ostaviti konje na paši kod Blagaja i napasti Bušević, Otoku ili Lišnicu na Uni te obnoviti Novi na Uni. Navodno su bili dobro naoružani i opskrbljeni te na raspolaganju imali brodove pa je postojala opravdana bojazan da će udariti na bihaćku ili ripačku adu. ${ }^{1428}$ Problem je dodatno komplicirala činjenica što je tada u Bihaću vladala glad „kakvu ljudi nisu pamtili“ pa je zbog jedne takve „skupe“ godine bihaćki zapovjednik imao velikih problema s isplatom novaca za špijune i stražare. ${ }^{1429}$ I stanoviti Mihal Maslak iz Ogulina, tada pritvoren i saslušan zbog

\footnotetext{
${ }^{1424}$ SI AS 2, kutija 286, kutija 244, fascikl 143, rujan 1581., 1r, rbr. 506. Adresirano na kranjske Verordneten.

${ }^{1425}$ SI AS 2, kutija 286, fascikl 164, Ljubljana, 29.7.1577., 1r, rbr. 365. Christoph Auersperg i kranjski Verordneten na nadvojvodu Karla.

${ }^{1426}$ SI AS 2, kutija 286, fascikl 164, Bihać, 6.5.1566., 1r-1v, rbr. 41-42. Matiasch Mori prijevod s hrvatskog.

${ }^{1427}$ Izvori korišteni i u radu: Damir STANIĆ, Ambivalentna lojalnost, 136-140.

${ }^{1428}$ SI AS 2, DSK, kutija 201, fascikl 124, Bihać, 21.4.1558., 1r, rbr. 613. Georg Zoblsperg na Georga Sauera.

${ }^{1429}$ SI AS 2, DSK, kutija 201, fascikl 124, Bihać, 5.5.1558, 1v-2r, rbr. 738-739. Georg Zoblsperg na Georga Sauera.
} 
sumnje da je obavijestio Osmanlije o nekom ranijem habsburškom planu napada na Udbinu, tvrdio je da su on, supruga i četvero djece često po 10, 14 ili 20 dana bez zalogaja kruha u kući. ${ }^{1430}$ Paralelno s gladi i osmanskim pripremama, problem „,curenja informacija“ dosegao je takve razmjere da su Osmanlije navodno iz Bihaća, ali i s cijele krajine, primali tako točne informacije da se „nije mogao osedlati konj, a da oni prije o tome ne bi bili obaviješteni“ ${ }^{1431}$

Nadalje, Mustafa Poporšen, zarobljeni osmanski vojnik, na svojem saslušanju apostrofirao je Bogdana Košića (Wogdan Khossitsch) i Ivana Sokolana (Juan Socollan), oba iz Bihaća, kao osobe koje su slale obavijesti u Ostrovicu (Osterbiz) odakle su one stizale u Udbinu. ${ }^{1432}$ Iako ih spomenuti nikada osobno nije vidio, tvrdio je da je bio prisutan u trenutku kada je Bajazid-aga (Paiassit aga, očito iz Udbine) naveo njih dvojicu kao izvore. ${ }^{1433}$ Također, zarobljeni osmanski vojnik Sula Kapičić iz Udbine naveo je stanovitog (Petra) Babulana iz Bihaća kao osobu koja je prebjegla u Udbinu, pritom namamivši sedmoricuosmoricu kršćana u zasjedu iz koje su se samo dvojica spasila. Pred udbinskim je dizdarom Babulan navodno izjavio da je u Bihaću ostavio ženu i djecu koji „da mu nisu potrebni“ te da je kod supruge ostavio dizdarov bestelbrieff koje pak uvijek može preuzeti u njihovu vrtu na adi pored Bihaća. Navodno je u Bihaću ostala i njegova „družina“ (gesellen) za koju je garantirao da će mu prema potrebi dostavljati bilo kakve novosti. Iako se ne zna sastav te „družine“, Babulan je Kapičiću navodno spomenuo uskoka Matiju (Mathy) koji je nekoliko godina ranije uskočio iz Livanjskog polja i s kojim je služio kod pokojnog Stipana Jurjevića (Stypnnytsch Jurjowitsch). ${ }^{1434}$ Kasnije je uvidom u Muster Register utvrđeno da se spomenuti Matija vodi pod prezimenom Vlah te je naloženo da se privede. ${ }^{1435}$ Kapičić je dalje izjavio da ga mogu „rezati, peči ili rastrgati, ali o (ostalim kršćanskim šijunima, op.a.) ne zna više ništa

\footnotetext{
${ }^{1430}$ SI AS 2, DSK, kutija 201, fascikl 124, 2.5.1558., 1r, rbr. 631. Svjedočenje Michala Masslagkha iz Ogulina.

1431 SI AS 2, DSK, kutija 201, fascikl 124, Ljubljana, 7.8.1558., 1r, rbr. 623. Georg Sauer na zemaljskog kapetana u Kranjskoj.

${ }^{1432}$ Bogdan Košić plaćeni je pješak u Ripču 1551. LOPAŠIĆ, Bihać, prilog IX, 243. Oko Jure Košića iz Bihaća vodio se pravni spor početkom 1580-ih. LOPAŠIĆ, SHK, knjiga I, dok. LXXVIII, 115-116.

${ }^{1433}$ SI AS 2, DSK, kutija 201, fascikl 124, 2.5.1558., 1r-1v, rbr. 626-627. Iskaz Mustafe Poporšena pred Krstom Gušićem, Hansom Welzerom i Hansom Weichselbergom.

${ }^{1434}$ U registru vojske Bihaćke kapetanije iz 1551. Stipan Jurjević iz Bihaća drži pet konjanika i prima ukupnu plaću od 18 rajnskih guldena. LOPAŠ́Ć, Bihać, prilog IX, 242.

${ }^{1435}$ SI AS 2, DSK, kutija 201, fascikl 124, Pobrežje, 22.7.1558., 1r, rbr. 632. Ispitivanje Sule Kapičića iz Udbine, čini se od strane Georga Sauera, uz prisutnost Krste Gusića, Mihaela Spalatina, Andrije Tadiolovića i Antuna Stipšića.
} 
kazati““ ${ }^{1436} \mathrm{Na}$ kraju je predan kranjskim vlastima uz opasku „da jedan tako iskusni pljačkaš ove jadne krajine, od tamo nikako ne smije biti živ pušten“. ${ }^{1437}$

Već ovih nekoliko navoda, prema kojima ipak treba biti oprezan jer su iznuđeni torturom, pokazuje kapilarni karakter špijunaže i ambivalentnih lojalnosti na pograničju. Nadalje, bihaćki kapetan Georg Zoblsperg javio je krajem kolovoza 1558. da se Mikula Štrbac (Micula Schterbatz), koji je služio u šeregu pod Spalatinom, vratio iz Osmanskog Carstva sa zarobljenikom koji je tvrdio da je od povjerljivog prijatelja doznao da jedan ovdašnji konjanik (reidter) imena Petar (Pedter) Mulier odaje obavijesti neprijatelju. Zoblsperg je apostrofirao da neće štedjeti truda da mu, s Božjom pomoći, uđe u trag. ${ }^{1438}$

U drugom pismu datiranom isti dan Zoblsperg navodi da je primio dva pisma u kojima stoji da mora uhititi ranije spomenutog Ivana Sokolanina (Ifan Sockholanyn). ${ }^{1439}$ Čini se da ga ipak nije uspio privesti jer Zoblsperg 17. rujna javlja da je kalauz (furer) osmanske čete koja je upala u selo $S a \beta$ pod Sokolom bio Ivanić Sokolanin ( Iwanitz Socolanin) - očito se radi o istoj osobi. ${ }^{1440}$ Uhićeni Petar Babulan (Wawullan) tvrdio je pak na ispitivanju da ne zna za nijednog drugog osmanskog špijuna osim Marka Sokolanina (Marco Sokollanin). ${ }^{1441}$ Dakle, dva člana očito iste obitelji te nekoliko drugih vojnika iz Bihaća sudjelovalo je u osmanskim napadima ili su bili osumnjičeni za špijuniranje.

Navedeni primjeri upućuju na činjenicu da je pogranično stanovništvo, pa tako i bihaćki građani te vojna posada, često slijedilo svoje autonomne strategije preživljavanja na krajištu koje su iskorištavale razne mogućnosti manevriranja na isturenim pograničjima zaraćenih carstava. U nestabilnome krajiškom ambijentu, suočeni $\mathrm{s}$ permanentnom osmanskom prijetnjom te opterećeni neurednim opskrbnim sustavom i neredovitom isplatom plaća, pojedini su vojnici egzistencijalno rješenje pronalazili su suradnji s neprijateljskom stranom.

\footnotetext{
${ }^{1436}$ SI AS 2, DSK, kutija 201, fascikl 124, Pobrežje, 22.7.1558., 1v, rbr. 633. Ispitivanje Sule Kapičića iz Udbine, čini se od strane Georga Sauera, uz prisutnost Krste Gusića, Mihaela Spalatina, Andrije Tadiolovića i Antuna Stipšića.

${ }^{1437}$ SI AS 2, DSK, kutija 201, fascikl 124, Pobrežje, 22.7.1558., 1r, rbr. 632. Ispitivanje Sule Kapičića iz Udbine, čini se od strane Georga Sauera, uz prisutnost Krste Gusića, Mihaela Spalatina, Andrije Tadiolovića i Antuna Stipšića. Za „rođene Turke“ Sulu Kapičića i Mustafu Popršana (Mustapha Poporschan), koji su izgleda služili u konjici, ali su se bavili i „martološtvom“, konstatirano je da ne bi bilo nečasno prema običaju ove krajine pogubiti ih mačem (mit dem Schwerdt zuuerfaren). SI AS 2, DSK, kutija 201, fascikl 124, Ljubljana, 7.8.1558., 2r, rbr. 625.

${ }^{1438}$ SI AS 2, DSK, kutija 201, 31.8.1558., rbr. 712. Nije sačuvana zadnja stranica, ali očito na predstavnike kranjskih staleža.

1439 SI AS 2, DSK, kutija 201, Bihać, 31.8.1558., 1r, rbr. 708. Na kranjskog zemaljskog kapetana i kranjske Verodneten.

${ }^{1440}$ SI AS 2, DSK, kutija 201, Bihać, 17.9.1558., 1v, rbr. 770. Georg Zoblsperg.

${ }^{1441}$ SI AS 2, DSK, kutija 201, Bihać, 22.9.1558., 1r, rbr. 772. Georg Zoblsperg.
} 
No, iako je nezadovoljstvo manjkavošću sustava bilo endemsko te je stvaralo permanentno napetu situaciju, nekakvi neposredni i ozbiljniji izljevi nasilja prema nadređenima nisu zabilježeni. Autoritet kapetana i krajiških struktura morao je biti jak kao što pokazuje primjer izvještaja koji je nakon muštre i inspekcije Bihaća u studenom 1587. sastavio krajiški komesar Langenmantel. U njemu stoji da je prilikom njegova boravka u gradu kapetan Hörner, a zbog „,neprestanih prigovora“ protiv njega, u zatvorenom krugu (geschlossnen ring) okupio podređene njemačke i hrvatske vojnike te zatražio da onaj koji ima nešto protiv njega, odnosno da onaj kome je nešto loše učinio, istupi i iznese prigovor pred povjerenikom. Međutim, ne da nitko nije istupio već su svi zajedno ustvrdili da im je bio kao otac i kapetan u svim kriznim situacijama. ${ }^{1442}$

Bez obzira na svu manjkavost krajiškog sustava, plaćena vojna služba bila je aspiracija mnogih i oni koji su stupili u taj povlašteni krug nisu ga, bez obzira na dramatičnost diskursa, samo tako htjeli napustiti. Usprkos svim problemima, solidarnost i zajednički interes nedvojbeno su prisutni, kako između krajiške i civilne strukture, tako i među gradskom posadom. Tome svjedoče i pojedinačni slučajevi poput slučaja bihaćkog vojnika Galla Hartera za čiji je otkup iz osmanskog zarobljeništva bihaćka posada podmirala obavezu isplate (verehrt, vereherung) određene svote koju je navedeni Harter molio da se doznači iz Blagajničkog ureda (Zallambt). Također, Harter je molio da mu zapovjednik Hrvatske krajine izda propusno pismo kako bi mogao sakupiti ostatak traženog iznosa. ${ }^{1443}$ Da je bilo drugačije, Bihać se sigurno ne bi tako dugo održao pred osmanskom silom.

Napetosti na relaciji gradska općina-krajiška uprava posljedica su strukturalnih preslagivanja koja su izazvana osmanskom ekspanzijom na hrvatskom prostoru. U Bihaću, kao jednom od najvažnijih gradova na hrvatskom prostoru, formiran je i jedan od centara protuosmanske obrane, a od dolaska Habsburgovaca 1527. i sjedište kapetanije. Bihaćka kapetanijska struktura raspolagala je s mnogo jačom „pozadinom“ u vojno-političkom i financijsko-logističkom pogledu od gradske općine koja je sve više ovisila o kapetaniji. Zato je i asimetrija moći u konačnici prevagnula na stranu bihaćkoga kapetana. Uostalom, iako su gradskoj općini zajamčena njezina naslijeđena prava, od samih početaka postojanja Bihaćke kapetanije smatrano je da bihaćki kapetan ima ingerencije nad obranom kaštela, grada i podređenih utvrda te da mu lokalno stanovništvo, uključujući i građane, mora biti poslušno.

\footnotetext{
${ }^{1442}$ LOPAŠIĆ, SHK, knjiga I, dok. CII, 147.

${ }^{1443}$ HDA, Croatica, mikrofilm D-1918, br. 3, prosinac 1589.
} 
Iako su građani, odnosno predstavnici gradske općine, u nekim trenucima ulazili su sukobe s kapetanima, superioran položaj krajiške strukture nije doveden u pitanje. Sociopolitičke i vojne okolnosti nametnule su takve relacije, osobito u drugoj polovici 16. stoljeća.

Gradska općina sukobljavala se i s hrvatskim plemstvom zbog posjeda i podanika koji su u krajiškom ambijentu bili izrazito važni, ali i zbog plemićkog stava da se jednom naseljeni u grad ili na gradske posjede nisu željeli podrediti gradskim zakonima i obvezama. To je proces koji je imao ekvivalente na čitavome ugarsko-hrvatskom prostoru. Formiranjem kapetanijskog sustava i ulaskom lokalnog plemstva u krajišku službu formirana je i nova društvena kategorija u gradu, a to je kategorija istaknutih plemića i uskočkih starješina $u$ krajiškoj službi. Još će trebati pronaći dodatne izvore koji bi pokazivali kakav je bio međuodnos ove društvene kategorije i gradske općine.

Što se krajiške strukture tiče, interni sukobi primarno su povezani s egzistencijalnim deficitima krajiškog sustava, prvenstveno s neredovitom isplatom plaća i manjkavom opskrbom. Gradska posada znala je mjesecima, pa i duže, ne primiti plaću, a kada se dopremljeni živež potrošio, morali su se zaduživati kod lokalnih trgovaca i građana. Time su generirana visoka zaduženja pa su i jednom isplaćenim plaćama odmah zatvarana dugovanja. Često ni taj iznos nije bio dostatan da se pokrije dug koji je „pojeo“ čak i buduće isplate. Njemački vojnici stacionirani u gradu bili su u nepovoljnoj poziciji, jer „pravi“ stranici među njima nisu imali lokalne posjede s kojih bi dobivali hranu. Međutim, kao i u gradu privremeno stacionirana pojačanja, oni su imali prioritet pri isplati kada su napokon stigla sredstva. Hrvatski vojnici imali su pak (djelomično) posjede u okolici, ali ne i prioritet pri isplati zaostataka, a to je predstavljalo problem kada je zakazala poljoprivredna proizvodnja zbog nepovoljnih vremenskih uvjeta, elementarnih nepogoda, osmanskih napada i sl. Loše građevinsko stanje, manjak opreme, oružja i drugih potrepština dodatno su opterećivali vojnu posadu. U takvom ambijentu tinjalo je stalno nezadovoljstvo koje je sredinom 1570-ih poprimilo i ozbiljniju notu. U budućnosti će trebati detaljnije istražiti suodnos između navedenih procesa na Hrvatskoj krajini i velikih osmanskih osvajanja tih godina. Očito je da su određeni pojedinci i krugovi ulazili u konspirativne dogovore s Osmanlijama iako je bihaćka vojna posada, kao i građanstvo generalno, ipak ostala vjerna vladarskoj kući i kršćanstvu. 


\section{DEMOGRAFSKI KONTEKST POGRANIČNOGA GRADA}

Kao najveće gradsko naselje i najnapučenije mjesto na Hrvatskoj krajini, Bihać je pograničnom stanovništvu predstavljao jednu od rijetkih oaza kakve-takve sigurnosti na isturenom krajištu. Nema sumnje da su se mnogi sklonili u Bihać povlačeći se pred Osmanlijama, dok su pak drugi i kapilarno i masovnije napuštali grad i sigurnost tražili dublje u pozadini - od neposrednoga hrvatskog zaleđa pa do Kranjske, Štajerske, Gradišća i raznih dijelova Ugarske. Tako se, primjerice, između 1533. i 1543. u Šopronjsku županiju i grad Kiseg iselila „,veća skupina Hrvata iz Pounja“. ${ }^{1444}$ Istodobno, Bihać je imao važnu tranzitnoorganizacijsku ulogu u kontekstu migracija bivših osmanskih podanika na habsburški teritorij. U tom je pogledu Bihać igrao ključnu ulogu jer je bio velik grad koji je mogao privremeno ili trajno primiti nemali broj izbjeglica i prognanika, a imao je i gradsku administraciju, odnosno krajišku upravu koje su mogle dogovarati prelaske kršćana s osmanskog na habsburški teritorij, što se osobito manifestiralo pri uskakanju prvih uskočkih zajednica „u kršćanstvo“. ${ }^{1445}$ Upravo je ovaj aspekt jedna od temeljnih karakteristika grada u referentnom periodu kada se naslijeđena srednjovjekovna društvena infrastruktura hrvatskog prostora urušavala i/ili transformirala i kada je, upravo i procesima migracija stanovništva raznog profila, ustrojen specifični pogranični ambijent.

U predosmanskom periodu prostor koji će zauzeti Bihaćka kapetanija u demografskom je pogledu bio gusto naseljeno područje s razvijenom društvenom (osobito je brojno bilo plemstvo - magnati, srednje i niže plemstvo, plemićke zajednice), eklezijalnom, urbanom, fortifikacijskom i drugom infrastrukturom. Iako su kontinuirani osmanski napadaji od druge polovine 15. stoljeća demografski devastirali ovaj prostor, neka su područja u interesu ovog rada, manje stradala (ili su se opetovano obnavljala) sve do druge polovice 16. stoljeća. Naravno, ova konstatacija vrijedi tek u komparaciji s onim prostorom koji je potpuno devastiran $\mathrm{u}$ ratnim operacijama, a ne u odnosu na demografski stabilne prostore $\mathrm{u}$ unutrašnjosti.

Promatrani period jest primarno period masovnog iseljavanja i povlačenja starosjedilačkoga hrvatskog stanovništva s onodobnoga hrvatskog prostora, ali je simultano i period masovnih kretanja stanovništva s jedne na drugu stranu pograničja. Imajući to u vidu, može se konstatirati da kruta primjena Antemurale Christianitatis sintagme kreira odviše

\footnotetext{
1444 ŠARIĆ, Etnokulturna kretanja, 19.

${ }^{1445}$ O klasifikaciji raseljenika u kontekstu osmanske ekspanzije vidi: Ivan JURKOVIĆ, Klasifikacija hrvatskih raseljenika za trajanja osmanske ugroze, Migracije i etničke teme, vol. 19, No. 2-3, 2003., 147-174.
} 
statičnu društvenu sliku koja ne odgovara realnom i kompleksnom stanju na terenu. Iako na generalnoj razini nema nikakve dvojbe da su se na hrvatskom prostoru sukobila dva načelno krajnje neprijateljska i oprečna civilizacijska kruga, kada se istraživački fokus spusti na mikrorazinu, otvara se kompleksan svijet autonomne pogranične logike koji se ne može interpretirati u pojednostavljenim imperijalnim kategorijama.

Na pograničju je permanentno trajala borba za ljude koja je često bila važnija od borbe za fortifikacije i prazan teritorij. Tek kada je određeni prostor koloniziran, mogao se ustrojiti administrativni aparat i osigurati njegova sigurnost. Domaći posjednici nastojali su demografski obnoviti svoje posjede kolonizacijom izbjeglog stanovništva, a slično su činili i plemići iz okolnih zemalja i to do te mjere da je taj proces prerastao u politički problem. Tako se 1553. Hrvatski sabor žalio da su se mnogi kmetovi odselili u Slavoniju ili na prostor okolnih zemalja te je optužio kranjsko plemstvo da nastoji privući kmetove hrvatskih plemića. ${ }^{1446}$ Radikalan prijedlog, koji je Ivan Lenković uputio banu, pokazuje koliko je iseljavanje ugrožavalo obranu krajiškog prostora. Lenković je, naime, tražio javnu objavu zabrane iseljavanja te prijetnju vješanjem muškaraca, a utapanjem žena i djeca koji su uhvaćeni u odlasku! ${ }^{1447}$

Osobito je zanimljiv proces reverzibilnih migracija izbjeglog stanovništva na nekadašnji domicil. Poticaj za povratak izbjeglog stanovništva na nekadašnje posjede mogao je biti iniciran političkim, ekonomskim, kulturološkim, ali i emocionalnim pobudama - nisu se, naime, svi uspjeli uklopiti u novu običajno-jezičnu sredinu. ${ }^{1448}$ Primjera reverzibilnih kretanja ima i kada je riječ o Hrvatskoj krajini i to pomalo začuđujuće, ali svakako indikativno, u periodu najintenzivnijih osmanskih osvajanja 1570-ih. To pak pokazuje da je dio izbjeglog stanovništva bilo spremno za povratak čim su se za to otvorile i najmanje mogućnosti.

Naime, izvori pokazuju da je nakon potpisivanja primirja početkom 1577. počeo proces povratka „mnogobrojnog“ (hauffenweis) stanovništva na Hrvatsku krajinu. Zanimljivo je da se navodi da se počelo vraćati stanovništvo koje je prije „mnogo godina“ otišlo u strane zemlje, kao i ono koje je svoje domove napustilo nedavno. I jedni i drugi sada su se u velikom broju počeli vraćati sa svime što su posjedovali na svoje stare posjede, u gradove i sela, čak na najisturenije pograničje. Radilo se o stanovništvu za koje se u izvorima navodi da je izbjeglo

\footnotetext{
${ }^{1446}$ V. KLAIĆ, Povijest Hrvata, knjiga 5, 617.

${ }^{1447}$ N. KLAIĆ, »Ostaci ostataka«, 275.

${ }^{1448}$ Nisu se svi uspjeli prilagoditi životu u novoj sredini pa su se, poput iseljenoga zadarskog stanovništva u Apuliju i Abruzzi koje se nije uspjelo prilagoditi ni običajima ni jeziku, odlučili na povratak u rodni kraj ili barem na poznat teritorij. BRACEWELL, Senjski Uskoci, 25.
} 
u okolne „Prouinzen“, najvjerojatnije na prostor Slavonije te u pokrajine Unutrašnje Austrije. To pokazuje da su se te reverzibilne migracije mogle odvijati na širem području, odnosno da nisu bile rezervirane samo za prognanike u neposrednom zaleđu. No, slavonskom i drugom plemstvu nije bilo u interesu gubiti podanike pa su ti ljudi na raznim mjestima zaustavljeni te čak i opljačkani ne bi li ih se prisililo da odustanu od svojih namjera. Takva reakcija navela je zapovjednika Hrvatske krajine Hansa Auersperga da uputi apel caru i nadvojvodi da interveniraju kod bana kako bi se izdao Patent koji bi spriječio takva nasilja te kojim bi se dopustilo „starom stanovništvu ove siromašne krajine“ da se može vratiti bez ikakve smetnje i zapreka ako to žele. Ipak, kranjski su se staleži bojali da će slavonsko i drugo plemstvo, na čijim su se posjedima ti prognani Hrvati „prije mnogo ili malo godina naselili“, teško dozvoliti da ih napuste sa svojom imovinom. ${ }^{1449}$

Ovaj slučaj pokazuje da se izbjeglo stanovništvo, bez obzira na prostornu i temporalnu udaljenost, masovno odlučilo vratiti na još uvijek krajnje nesigurna područja čim su se za to stvorili određeni preduvjeti, konkretno čim je potpisano primirje. Činjenica da se to masovnije vraćanje dogodilo 1577., odnosno u jeku najvećih osmanskih osvajanja na prostoru Hrvatske krajine, dodatno apostrofira spremnost izbjeglog stanovništva na povratak u još uvijek krajnje nepovoljnom kontekstu. To su izrazito važne činjenice kada je riječ od demografskim kretanjima na isturenom krajištu.

No, koliko je uopće stanovnika mogao imati grad poput Bihaća? Na temelju raspoloživoga arhivskog materijala teško je dati precizan broj, ali se mogu napraviti neke procjene broja stanovnika Bihaća u 16. stoljeću. Lopašić je na temelju jednog izvještaja naveo da je u gradu neposredno prije osmanskog zauzimanja bilo oko 5000 ljudi. Ako tu brojku kompariramo s brojem stanovnika drugih gradova iz tog perioda, primjećuje se da bi ona bila zaista visoka. Naime, krajem 16. stoljeća broj stanovnika Gradeca procijenjen je na 15002000 dok je s okolicom taj broj mogao narasti do 3200 ljudi. Varaždin je s druge strane 1543. navodno brojao 250 kuća, a na temelju toga je Neven Budak procijenio gradsku populaciju na 1200-1400 ljudi. Krajem 16. i početkom 17. stoljeća stanovništvo Varaždina procjenjuje se na 2400-3200 ljudi, ovisno o autoru. ${ }^{1450}$ Senj je pak 1538. imao oko 1000 stanovnika, a u prvoj

\footnotetext{
1449 SI AS 2, DSK, kutija 205, fascikl 125b, Steničnjak, 18.3.1577., 1r-2r.

1450 Hrvoje PETRIĆ, O ukupnom broju stanovnika slobodnih kraljevskih gradova Hrvatsko-slavonskog Kraljevstva od sredine 16. do početka 18. stoljeća, u: Raukarov zbornik, u: Neven Budak, FF Press, Zagreb, 2005, 262-265.
} 
dekadi 17. stoljeća oko 2000 ljudi. ${ }^{1451}$ Koprivnica je 1580 . brojala tek oko stotinu civila unutar grada te 440 vojnika. ${ }^{1452}$

U izvorima se zaista koriste fraze i termini koji upućuju da je prije kraja u Bihaću zaista moglo biti tisuće ljudi. Dakako, to nisu bili samo građani, već ukupan broj ljudi koji se u trenutku opasnosti mogao naći na prostoru grada - možda i neposredne okolice. Uostalom, samo je gradska posada brojala nekoliko stotina ljudi, s time da se ne zna koliko ih je imalo obitelji u gradu, iako izvori pokazuju da je to bio slučaj. Krajiško povjerenstvo iz 1563. apostrofiralo je upravo problem depopulacije isturenih krajiških utvrda navodeći da, uz iznimku Bihaća i Senja, u drugim utvrdama nisu vidjeli „ljudsko stvorenje“ (menschliche creatur) osim nešto žena i djeca vojnika. ${ }^{1453}$ Ova dva grada bili su ipak bitno drugačiji slučaj od manjih utvrda na opustjelom pograničju. Tako krajem srpnja 1565. vojni opskrbnik Gallenberg navodi da je u gradu više od 500 udovica i njihove djece koje treba uzdržavati jer nemaju posjede. ${ }^{1454}$ Već zbroj tih dviju kategorija iznosi skoro tisuću ljudi! Lopašić pak navodi da je kapetan Franz Hörner u listopadu 1586. ustvrdio da je 1577. i 1578. iz Bihaća otišlo 2000 do 3000 ljudi. ${ }^{1455}$ No, ipak se u srpnju 1580. kapetan Sebastian Lamberg žalio da im je potrebno krmivo za konje i stoku koji su potrebni za obradu zemlje, ratne aktivnosti i prijevoz te da o tome ovisi preživljavanje ,nekoliko tisuća ljudi, starih i mladih, muškaraca i žena“. Nadalje, Lamberg tvrdi da je u Lenkovićevo vrijeme bilo nekoliko stotina vojnosposobnih muškaraca više nego sada dok sada nitko ni ne pomišlja na otpor zbog svakodnevnih neprijateljskih napada. ${ }^{1456}$ Ranije je broj stanovnika bio i veći. No, nakon gubitka Ripča 1591. bihaćki kapetan ipak traži pomoć jer će u protivnom „mnogo tisuća duša“ dospjeti „u đavolje ždrijelo“. ${ }^{1457}$

Treba biti osobito oprezan i s publikacijama o padu grada tiskanima na europskom zapadu u kojima se navodi da je paša likvidirao 5000 kršćana, a 800 djece poslao u

\footnotetext{
${ }^{1451}$ IBID., 271.

1452 BUDAK, Pogranična gradska, 351.

1453 AHAZU, Lopašić, E. Prijepisi iz austrijskih arhiva, br. 15, str. 75-76.

1454 SI AS 2, kutija 414, fascikl 284, Črnomelj, 24.7.1565.,1v, rbr. 1098. Glavni opskrbnik Gallenberg na predstavnike kranjskih staleža.

1455 LOPAŠIIĆ, Bihać, 73.

1456 „etlich Tausent Alt vnd Jung, Mens vnnd Weibs“. SI AS 2, DSK, kutija 287, fascikl 164, Bihać, 9.7.1580., 1r1v. Sebastian Lamberg na vojne povjerenike i Waikharda Auersperga zapovjednika Hrvatske i Primorske krajine.

${ }^{1457}$ „,vil taussent seeln ins Teüfelsrachen geriechen“. SI AS 2, DSK, kutija 805, fascikl 540, Bihać, 8.11.1591., 1v. Christoph Obritschan na Andreasa Auersperga. U Ripču, odnosno naselju na unskom otoku, 1550. je i dalje pedesetak kućeraka. Budući da Ivan Lenković navodi da je veličina naselja smanjena za trećinu, ono bi ranije brojalo oko 150 kuća/eraka. Tamo se tada nalaze pretežno žene i djeca jer su muškarci poginuli ili su zarobljeni. KRUHEK, Krajiške utvrde, 168-169.
} 
Carigrad. ${ }^{1458}$ Ovakvi izvještaji vjerojatno su pretjerani, ali upućuju na percepciju Bihaća kao dobro napučenoga grada, barem u tom trenutku. Iako nema preciznijih izvora, vjerujem da sve navedene tvrdnje nisu tek fraze kojima se opisivala potencijalna opasnost i kojima se nastojalo osigurati pomoć, već da upućuju na realnu demografsku situaciju u gradu u tom trenutku. Vjerojatno je broj stanovnika tijekom opsade umnožen priljevom okolnog stanovništva koje je nastojalo pronaći sigurnost iza gradskih zidina.

Dakle, na temelju sačuvanih izvora procjenjujem da je na području grada Bihaća i neposredne okoline prije 1570-ih moglo biti nekoliko tisuća ljudi, a da je prilikom opsade grada u lipnju 1592., možda i zbog priljeva stanovništva iz okolice, taj broj mogao biti na sličnoj razini. Teško je decidirano potvrditi je li se radilo baš o brojci od oko 5000 ljudi prije osmanske opsade zbog amplituda broja stanovnika kao posljedice (privremenog) iseljavanja i useljavanja u grad. Nedvojbeno je pak da je Bihać za onodobne prilike, te nalazeći se u praktički u okruženju, i dalje bio dobro naseljen grad.

Što se depopulacije Bihaća i okolnog prostora tiče, stradanje i iseljavanje domaćeg stanovništva u referentnom je periodu permanentno, ali je do sredine stoljeća demografska situacija na promatranom prostoru relativno stabilna za istureno pograničje. Popis prihoda na posjedima utvrde Sokol iz 1548. pokazuje da je u selima, odnosno na prostoru Sokola, Golubića, Ribića $^{1459}$, Omršla, Suča i Turije živjelo 145 vlasnika posjeda, a od toga je do 15 otpadalo na žene koje su navedene kao glave kuće. ${ }^{1460}$ Kada se tom broju pridodaju i članovi obitelji, čak bi i oprezna procjena nesumnjivo bila preko 400 osoba. Zasigurno nisu evidentirani svi koji su živjeli na tom prostoru, kao ni svi koji su živjeli unutar navedenih sela, pa je ukupan broj stanovnika morao biti (dosta) viši.

Proces depopulacije Bihaća nije pravocrtan proces, već je uvelike ovisio o sociopolitičkim okolnostima određenog trenutka. Marko Šarić navodi da osmanski defter iz 1604. za nahiju Bihać donosi „sliku prave pustoši i demografskog diskontinuiteta“ te da, osim muslimanskog i vlaškog stanovništva, nema druge populacije jer je raja pobjegla na habsburšku stranu pograničja (preko). Budući da je od 65 prisutnih muslimanskih domaćinstva tek pet domaćinstava novih muslimana, a da se prvi spomen katolicima pojavljuje tek 1650., Šarić zaključuje da sve „ukazuje na zaključak da je starosjedilačko

\footnotetext{
${ }^{1458}$ V. KLAIĆ, Povijest Hrvata, knjiga 5, 479-480.; „Historicae Relationis Continvatio: das ist warhafftige Beschreibunge aller fürnemen vnd gedenckwirdigen sachen, so sich hin vnd wieder in Europa....", 48. Izvještaj je dostupan na http://books.google.com, pristup 13. prosinac 2018.

${ }_{1459}$ Selo Ribić nalazilo se na povećoj riječnoj adi (Ottogkh) koja se danas naziva Ribićka otoka. HDA, Militaria, kutija 8, pismo sastavljeno ,pri pokretu“, 28.7.1565., 1r. Herbart Auersperg na Ivana Lenkovića.

1460 ÖeStA, HKR, Hoffinanz in Ungarn, kutija 5, Rote nr 2 fol. 126-135.
} 
stanovništvo Bihaća i okolice bilo desetkovano i da se nije održalo u većemu broju““ ${ }^{1461}$ Ova tema zaslužuje detaljniju analizu utemeljenu na arhivskim izvorima, ali do depopulacije je očito došlo tek nakon osmanskog osvajanja grada 1592., odnosno tijekom Dugog rata koji se vodio od 1593. do 1606. Ključni događaj bio bi napad krajiške vojske pod zapovjedništvom Jurja Lenkovića 1594. na Bihać kada je zauzeti cijeli grad osim kaštela, a s habsburškom se vojskom povuklo 1200 kršćana. ${ }^{1462}$

Iako su iseljavanja mogla biti i privremena pa se stanovništvo nakon prestanka neposredne opasnosti vraćalo na svoj domicil, nema sumnje da je tijekom čitavoga promatranog perioda Bihać jedan od većih iseljeničkih centara na hrvatskom prostoru. ${ }^{1463}$ Premda su Bišćani i stanovnici iz neposredne okolice grada participirali u seobama sve do Gradišća, većina iseljenika svoje nove domove vjerojatno je pronašla u zaleđu ugroženog područja, primarno južno od Zagreba, oko Karlovca, Ozlja, u Kranjskoj itd. Tako su se 1541. na Frankopanski posjed oko Ozlja naselili „,dobro oborusni plemeniti posteni musi Mikula Radichich, Fabyan Vlassich, y Petar Bendekovich“ koji „pred szilum Turskom“ sa svojom „drusinum od on kraj Bischa iz mesta Verhovia vu kerschanstvo doidose“. Radičić je prebjegao s suprugom Lucijom te sinovima Tomašem, Ivanom, Jurjem, Petrom i Stipanom te kćeri Agicom, Vlašić je prebjegao sa suprugom Dorotejom, sinovima Grgurom i Ivanom, kćerima Barbarom i Helenom te dva konja, a Bendeković sa sinovima Lukačem i Tomašem. Navedeni „vse zsvoie ubosstuo pred szillum Turskum pobubisse“ te im je Stjepan Frankopan dozvolio naseljavanje. Bili su dužni nositi poštu te ,ako bi namsze vkrainu szpotribillo, da znami ob nasem sztrosku dusni budu oborusni poitti““. ${ }^{1464}$ Dakle, radilo se o stanovništvu koje je bilo vično ratovanju.

U ispravi na hrvatskom jeziku iz 1562. stoji pak da se na Erdödyjevo imanje u današnjoj Donjoj Zdenčini (Zdenčina, Rakov Potok i Horvati) pod Okićem „,naselil sto kuć Hrvatov (prezimena su Šimanovići, Malčići, Juratovići ), ki su od turske sile od Bišća uskočili, i pri svićah i pri zvizdah u naše kraje prišli“. ${ }^{1465}$ Očito se radilo o većem iseljavanju. Još 1599. Byschany su se naselili u Hrašću, na posjedu zagrebačkoga Gradeca. Imali su

\footnotetext{
${ }^{1461}$ ŠARIĆ, Etnokulturna kretanja, 23.

${ }_{1462}$ V. KLAIĆ, Povijest Hrvata, knjiga 5, 509; Hamdija KREŠEVLJAKOVIĆ, Kapetanije u Bosni $i$ Hercegovini, Svjetlost, Sarajevo, 1980., 102.

${ }^{1463}$ U drugoj polovici 15. stoljeća u Zadru je veliki priljev useljenika iz šireg Pounja, uključujući i Bihać. Uglavnom se radilo o osobama koje su radile na tuđim posjedima, kao kućna posluga ili u sitnom obrtništvu. Borislav GRGIN, Počeci raspada. Kralj Matijaš Korvin i srednjovjekovna Hrvatska, Ibis grafika, Zagreb, 2001., 273, fusnota 794.

${ }^{1464}$ Prijepisi ovog spisa postoje na raznim fonodovima. Ja sam koristio sljedeći prijepis. HR-HDA-22. Ugarska dvorska komora. Urbarski spisi i popisi posjeda, kutija 30, br. 395.

${ }^{1465}$ KLAIĆ, Povijest Hrvata, knjiga 5, 303; LOPAŠIĆ, Bihać, 81.
} 
obavezu vojno služiti, davati desetinu i od svake kuće četiri pilića, deset jaja i kopuna, a cijelo selo godišnje dva ovna i jedno tele. Adamček navodi da su dobili status „svojevrsnih slobodnjaka“. ${ }^{1466}$ Iste je godine gradačka općina u Gračanima kod Zagreba naselila bihaćke izbjeglice prezimena Stepković, Keglević, Lovreković, Novak, Glazina, Fabijanić, Hamšak i Novosel. ${ }^{1467}$ Dakle, iseljavanja su dakle trajala i godinama nakon pada Bihaća, a jedino je pitanje je li to stanovništvo tada pristiglo direktno iz osmanskog Bihaća ili su već ranije bili naseljeni na nekom drugom hrvatsko-slavonskom području s kojeg sada dolaze u okolicu Zagreba.

Jedan od presudnih momenata u depopulaciji unskog prostora definitivno je pad Krupe 1565. U izvještaju koji je krajem lipnja Ivan Lenković uputio caru i nadvojvodi stoji da je zbog pada Krupe strava uhvatila sav puk u Hrvatskoj, a prije svega u Bihaću i utvrdama promatranog prostora. ${ }^{1468}$ I zapovjednik Hrvatske krajine Herbart Auersperg strahovao je da će nakon toga dramatičnog gubitka, „ubrzo cijela zemlja opustjeti““ ${ }^{1469}$ Među Hrvatima na krajini zaista je zavladala tolika bojazan da su muškarci iz Ostrožca pisali Auerspergu da će se vjerno i časno ponašati, samo kada bi njihove žene i djeca bili negdje drugdje na sigurnom. No, Auersperg im nije osobito vjerovao jer je smatrao da bi oni radije otišli tamo gdje su/bi poslali svoje obitelji. ${ }^{1470}$ Auerspergu je javljeno da je Mumin-aga naredio „sirotim ljudima“ oko Blažuja (kod Bihaća) da se moraju dobrovoljno podrediti osmanskoj vlasti ili će još istog dana biti skroz uništeni pa ti „siroti ljudi, s ženama, djecom, stokom i svim dobrima“ od tamo bježe. ${ }^{1471}$ Slično se odvijalo i u Bihaću iz kojeg je počelo iseljavanje stanovnika koji su, kako tvrdi Auersperg, sa sobom nosili svu imovinu koju su mogli. Kada se Auersperg vraćao prema Bihaću, na Maču su ga sačekali gradski suci i „drugi građani“ te ga ustrašeni zamolili za pomoć prije nego što dopadnu u ruke neprijatelja. Zatražili su da im sugerira neko mjesto u

\footnotetext{
1466 ADAMČEK, Agrarni odnosi, 530-531.

${ }^{1467}$ Domagoj NOVOSEL, Stanovništvo Upravne općine Gračani - Remete između dva svjetska rata, doktorska disertacija, Hrvatski studiji Sveučilišta u Zagrebu, 2015., 23.

1468 „,alles gemain volkh, des gannzen Crabat Lanndts, vnd zuuorderst aus Wichitsch vnnd merrern Orttflegkhen der Ennden, erschragkhlichen anfanng gemacht“. SI AS 2, DSK, kutija 209, fascikl 126, Črnomelj, 27.6.1565., $1 \mathrm{v}$, rbr. 75. Ivan Lenković na cara i nadvojvodu.

${ }^{1469}$ SI AS 2, DSK, kutija 209, fascikl 126, Stijena, 23.6.1565., 2r, rbr. 52.

${ }^{1470}$ SI AS 2, DSK, kutija 209, fascikl 126, logor kod Cetina, 24.6.1565., 1v, rbr. 79. Herbart Auersperg na Ivana Lenkovića.

1471 „wie Mumin Aga, denen armen Leütten auf Blasay, zugeschrieren, Sy sollten sich guettwillig Ergeben, oder man werde es dise tag gannz vnnd gar zörsteren, sein, also darauf all derselben arm Leütt, weib vnnd Khinder, sambt viech, vnnd allem Guett, daruon vnnd heraus gezogen“. SI AS 2, DSK, kutija 209, fascikl 126, logor kod Cetina, 24.6.1565., 1v, rbr. 79. Herbart Auersperg na Ivana Lenkovića.
} 
unutrašnjosti kamo bi mogli poslati svoje žene i djecu, uz obećanje da će muškarci ostati u gradu kako to časnim ljudima i pristoji. ${ }^{1472}$

Dakle, i na ovim se primjerima vidi da je iseljavanje moglo biti privremeno, odnosno da su zbog neposredne opasnosti najranjivije kategorije sklanjane iz grada dok ne prođe opasnost. Također, i na ovom primjeru pokazuje se uključenost domaćeg stanovništva u ratne operacije i razvijeni krajiški etos kojeg iskazuju građani zaklinjujući se ostati braniti svoje domove kako to pristoji časnim ljudima, dakle ratnicima. No, sva ova drama rezultirala je najgorim mogućim scenarijem - svoje položaje započeli su napuštati plaćeni vojnici. Lenković je stoga tražio da im se odmah isplati zaostatak, da se grad ojača dodatnim snagama te da se dostave vatreno naoružanje, streljivo, živež i druge potrepštine. ${ }^{1473}$

Iako je Auersperg u Bihać poslao Matiascha Morija s 200 unajmljenih strijelaca, a kapetan Rab dvojicu uskočkih vojvoda te još jednog vojvodu u Ostrožac, time nisu bili zadovoljni ni kapetan Kronschall ni bihaćki građani, već su tražili da se u grad pošalje još ljudi. ${ }^{1474}$ Štoviše, čak ni dolazak pojačanja nije rezultirao smirivanjem situacije zato što su, prema Kronschallovu iskazu, Morijevi strijelci stigli samo do brda Mač, a onda od tamo jednostavno pobjegli. Taj čin izazvao je takvu eksploziju nezadovoljstva, pobunu, galamu i svađu da su građani i običan puk zajedno s ženama i djecom smjerali napustiti grad. Kronschall ih je s teškom mukom i velikim trudom uspio smiriti i zadržati u gradu iako je tvrdio da je zapravo većina već otišla iz grada te da, osim njemačkih vojnika i konjanika, nema više od oko četrdesetak Bišćana na raspolaganju. Još je i strahovao da se neki od njih neće podrediti Osmanlijama. Kapetan je molio pomoć pritom navodeći „cijeli svijet moći vidjeti da ću časno i viteški postupati, sve dok nam Bog svemogući ne pomogne“. Ipak, nakon što je još jednom zatražio dostavu novčanih sredstva i pojačanja, gotovo je zavapio da, ako mu se ne pomogne, samo s ,„časti na ovom svijetu među ovim ljudima ne mogu živjeti““ ${ }^{1475}$

\footnotetext{
${ }^{1472}$ „Ee sy sich, also in der Feindt hennden pegeben muessen, vnnd haben angelanngt, Innen im lanndt, etwo an Einen ortt, außzuzaigen, wohin sy irer weiber vnnd khinder schigkhen mochten, mit erpieten, das sy die männer im flegkhen peleiben wöllen, wie es erlichen Leütten zuthuen gepuertt“. SI AS 2, DSK, kutija 209, fascikl 126, logor kod Cetina, 24.6.1565., 1v, rbr. 79. Herbart Auersperg na Ivana Lenkovića.

${ }_{1473}$ SI AS 2, DSK, kutija 209, fascikl 126., Črnomelj, 27.6.1565., 1v, rbr. 75. Ivan Lenković na cara i nadvojvodu.

${ }^{1474}$ SI AS 2, DSK, kutija 209, fascikl 126, logor kod Cetina, 24.6.1565., 2v, rbr. 81. Herbart Auersperg na Ivana Lenkovića.

1475 „die gannze Wellt solt sehen, das Ich erlich vnnd redlich hie will hanndlen, bis vnns Gott der Allmechtig weitter helfen wierdt“ i ,dann Ich sonnst mit Eern hie auf dieser Wellt, bey disen volckh nit leben khann “. SI AS 2, DSK, kutija 209, fascikl 126, Bihać, 24.6.1565., rbr. 89. Georg Kronschall na Herbarta Auersperga.
} 
Sljedeći veliki val iseljavanja dogodio se 1570-ih te je, uz Bihać, zahvatio cijeli prostor Hrvatske krajine. ${ }^{1476} \mathrm{U}$ ožujku 1576., a u kontekstu intenzivnoga osmanskog četovanja i priprema za napad na grad, oko 50 Hrvata sa ženama i djecom namjeravalo je napustiti grad s dolaskom opskrbnog konvoja, što je pak kod ostalih izazvalo uzbuđenje i strah (auffruer vnd forcht). Očito je namjera bila izaći iz grada u relativnoj sigurnosti opskrbnog konvoja, a možda pritom odnijeti i (dio) imovine. Bihaćki časnici koji su sastavili izvještaj pisali su da više ne znaju kako se prema njima postaviti. ${ }^{1477}$ Već sljedeći mjesec Georg Haller javlja da su cijela gradska općina (burgerschafft) i vojna posada poslale pismo na hrvatskom jeziku u kojem stoji da zbog neprijateljske opasnosti, gladi, neisplate plaća i nedostatka pomoći više nisu u stanju ostati u gradu te da se grad sprema napustiti još 25 kuća nakon što su to učinili najugledniji i najimućniji građani. ${ }^{1478}$ Krajem srpnja 1576., kada su izgubljeni Cazin i Bužim, napadnut Ostrožac, a ugrožen Bihać, kapetan Sebastian Lamberg javlja da je cijela bihaćka gradska općina zbog velike nestašice i predstojeće opasnosti odlučila otići te da u grad odmah treba poslati jednu mjesečnu plaću za vojnike, sredstva za straže, nešto platna i još ljudi. ${ }^{1479}$ I krajem srpnja kapetan navodi da građani (burgerschafft) $\mathrm{i}$ dalje prijete napuštanjem grada jer sva njihova poslanstva i molbe nisu urodili plodom. Tada je već preko trideset kuća stajalo prazno (ödt vnd lör) jer su njihovi stanovnici napustili grad s opskrbnim konvojima. Također, Lamberg je naveo da je dio građana kolektivno sklonio najveći i najbolji dio svoje imovine na neka sigurna mjesta izvan grada dok su drugi napustili svoje posjede, kuće, vinograde te otišli iz grada. ${ }^{1480}$ Do kraja prosinca, a u trenutku izglednoga osmanskog napada, nadvojvoda Karlo konstatirao je da su građani Bihaća u najvećoj mjeri od tamo otišli. ${ }^{1481}$

Iako brojke variraju, te je godine očito došlo do jednog masovnijeg odlaska iz grada. Zanimljivo je da izvori pokazuju da su se u tom valu iselili najugledniji ili barem najbogatiji stanovnici, iako se ne može znati je li to bilo privremeno ili trajno. Doduše, to što su iz grada

\footnotetext{
${ }^{1476}$ Tako Thomas Naglić u travnju 1573. javlja da je iz Cetina već otišlo 30 kuća pa tamo više nema nikoga osim vojnika, te da su svi otišli iz Topuskog (zeucht auch Jeder man weckh). SI AS 2, DSK, kutija 286, fascikl 164, Črnomelj, 27.4.1573., 2v-3r, rbr. 53-54. Thomas Naglić na Jobsta Josepha Thurna.

${ }^{1477}$ SI AS 2, DSK, kutija 287, fascikl 164, Bihać, 30.3.1576., 1r-1v, rbr. 515-516. Bihaćki časnici na Hansa Auersperga.

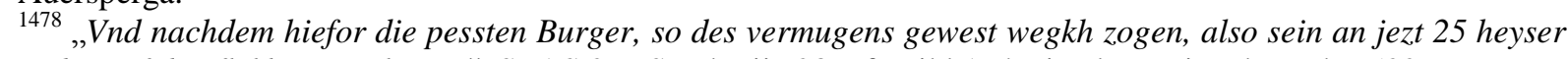
wider auf den flekhen zuerlassen". SI AS 2, DSK, kutija 287, fascikl 164, sine loco, sine dato, rbr. 522.

${ }^{1479}$ SI AS 2, DSK, kutija 287, fascikl 164., Ljubljana, 24.7.1576.,1r-1v, rbr. 575-576. Kranjski staleži na nadvojvodu Karla.

${ }_{1480}$ „dan sy nun sambtlich den mehren vnnd besten thaill Ires guets an anndere Ort Irer gwarsamb nach verseckht, des andern aber alles als Ir grundt heüer wein gärten sambt allen verwegen, vnnd wo die hinwegkh ziehen “. SI AS 2, DSK, kutija 287, fascikl 164, Bihać, 20.7.1576., 1r, rbr. 562. Sebastian Lamberg na kranjske Verodneten.

${ }_{1481}$ „,nnnd darzue die Burger merers tails daruon gezogen sein“. SI AS 2, DSK, kutija 244, fascikl 143, Graz, 28.12.1576., 1r-1v, rbr 347-348. Nadvojvoda Karlo na Hansa Auersperga.
} 
izvukli svoju imovinu sugerira da se radilo o trajnom iseljavanju, ali s obzirom na sve ranije navedeno, treba biti oprezan pri decidiranim zaključcima. Također, ovi procesi pokazuju da je lokalno stanovništvo koristilo opskrbne konvoje, zapravo slamku spasa, za izlazak iz ugroženoga grada. Iako nedvojbeno nisu ni približno svi napustili grad, prijetnje i upozorenja lokalnog stanovništva da će napustiti Bihać pojavljuju se sve do pada pod osmansku vlast. Iseljavanje je trajalo sve do samog pada grada pod osmansku vlast, kao što pokazuje i slučaj Katarine, udovice kneza Ivana Čiračanina, koja se iz grada iselila krajem svibnja 1592., a kao uzrok se navodi ,ni za drugi uzrok, nego za strah turski, da ne bi služila vere kršćanske neprijateljske.“1482 No, bez obzira na permanentna iseljavanja, Bihać je kao najveći grad i najsnažnije vojno uporište na prostoru Hrvatske krajine bio dobro napučen sve do pada pod osmansku vlast.

Što se pak demografskih gubitaka prouzrokovanih ratom tiče, njih, naravno, nije moguće točno utvrditi, ali budući da se u izvorima na raznim mjesta spominju upravo takvi podaci, vrijedi ih prezentirati. Prije svega treba napomenuti da ti brojevi uglavnom nisu onako dramatični kao što bi se moglo očekivati, ali je njihov kumulativni efekt bio devastirajući. Već u peticiji upućenoj kralju Ferdinandu 1530. Bišćani navode da je u gradu 170 udovica čiji su muževi poginuli ili su zarobljeni. ${ }^{1483}$ Kao što je već spomenuto, krajem srpnja 1565. spomenuti vojni opskrbnik Gallenberg javlja o preko 500 udovica i djece u gradu. ${ }^{1484} \mathrm{I}$ gradski sudac Fanko Kaptolović jadao se u veljači 1576. da u gradu jedva ima onih koji u svakodnevnim sukobima nisu izgubili oca, brata ili rođaka te da je mnogo djece odvedeno u roblje. $^{1485}$

U nastavku donosim tek izbor izvora koji demonstriraju koliko je opasan bio život u stalnoj sjeni rata. Početkom rujna 1555. Osmanlije su zbog niskog vodostaja uspjeli prijeći rijeku Unu te iz „gornjeg sela“ kod Suča (Ober Dorff zu Sutsche) odvesti 38 žena i djece, pa je selo potpuno ostalo bez žena i djece. ${ }^{1486}$ Početkom rujna 1558. tristotinjak osmanskih konjanika i pješaka neopaženo je prešlo Unu iznad Ripča te kod Sokola iz dvije kuće odvelo 15 žena i djece. ${ }^{1487}$ Krajem kolovoza 1576. odvedeno je 32 ljudi. ${ }^{1488}$ Krajem srpnja 1577. tristotinjak Krupljana napalo je grad te odvelo 18 mladića, 50 konja (paripa) i 180 komada

\footnotetext{
1482 LOPAŠIĆ, Bihać, 308, dodatak, dok. XV.

${ }^{1483}$ KRUHEK, Krajiške utvrde, 88; LASZOWSKI, HSKHDS, knjiga I, dok. 269, 261.

${ }^{1484}$ SI AS 2, DSK, kutija 414, fascikl 284, Črnomelj, 24.7.1565., 1v, rbr. 1098. Glavni opskrbnik Gallenberg na predstavnike kranjskih staleža.

${ }^{1485}$ LOPAŠIĆ, Bihać, 69.

${ }^{1486}$ HDA, Militaria, kutija 4, Bihać, 3.9.1555., 1r, rbr. 210. Georg Sauer na Ivana Lenkovića.

1487 SI AS 2, DSK, kutija 201, fascikl 124, Bihać, 5.9.1558., 1r, rbr. 756. Georg Zoblsperg na Baltazara Katzianera, carskog ratnog savjetnika na Slavonskoj i Hrvatskoj krajini.

${ }^{1488}$ LOPAŠIĆ, SHK, knjiga I, dok. XVI, 24.
} 
krupne stoke. ${ }^{1489}$ Krajem studenog te godine tristotinjak osmanskih konjanika četovalo je skroz do gradskih vrata i odvelo 8 osoba. ${ }^{1490}$ Početkom svibnja ili krajem travnja 1588. Osmanlije napadaju Kralje i Velihovo te odvode 7 žena i djece. ${ }^{1491} \mathrm{U}$ prosincu 1589. pri sječi drva negdje između Bihaća i Ripča, navodno radi neopreznosti, zarobljeno je 28 osoba. ${ }^{1492}$ Ovo su samo fragmentarni podaci o stradanjima kojima je bilo izloženo stanovništvo Bihaća. Stvarni brojevi bili su mnogo viši, ali do pada pod osmansku vlast Bihać je bio dobro napučen što pretpostavlja da se odseljeno stanovništvo ponekad vraćalo ili da je praznina popunjavana doseljavanjima iz okolice i s osmanskog prostora, a vjerojatno oboje.

Treba naglasiti da je bilo slučajeva i individualnog, ali i kolektivnog iseljavanja $\mathrm{s}$ habsburškog na osmanski teritorij te da takve strategije preživljavanja još uvijek nisu adekvatno istražene. Iseljavanja tog tipa primarno su posljedica nepovoljnih egzistencijalnih uvjeta pa su tako već na cetinskom saboru u travnju 1527. hrvatski staleži lamentirali da su zbog prestanka uvoza u Hrvatskoj zavladale nečuvena glad i skupoća te kmetovi sami bježe na osmansku stranu. ${ }^{1493}$ I u ovom kontekstu spominje se bihaćki prostor. Naime, sačuvani regest jedne sultanske naredbe datirane 15. studenog 1568. navodi da je u blizini Knina naseljeno 200 kuća Vlaha Istrije koji su se vratili s „neprijateljskog područja“, a da je dogovoreno „da na teritorij štićene države (Osmanskog Carstva, op.a.) iznova prijeđe sedam stotina kuća iz Bihaćke doline i okolice, da ih se naseli oko Obrovca, u nahiji Podgorje i u nahiji Lika koja pripada utvrdi Gradčac; u nahijama Karin i Bukovica zatraženo je da se od starih vlasnika izdvoji višak mjesta te da se odgovarajuća dadnu spomenutima za

\footnotetext{
1489 IBID.

${ }^{1490}$ SI AS 2, DSK, kutija 286, fascikl 164, Črnomelj, 30.11.1577., 1v, rbr. 316. Hans Auersperg na kranjske Verordneten.

${ }^{1491}$ SI AS 2, DSK, kutija 201, fascikl 124, Bihać, 5.5.1588., 13r, rbr. 741. Georg Zoblsperg na Georga Sauera.

1492 HDA, Croatia, mikrofilm D-1918, br. 1, prosinac 1589.

1493 N. KLAIĆ, »Ostaci ostataka«, 262.; „Za pridobivanje novih podanika prilikom kolonizacije krajišta osmanske su se vlasti ponajviše koristile metodom ,jamstva“ (istimalet). Protivničke podanike nagovarale su na preseljenje i prihvaćanje osmanske vlasti, uz garanciju da će im biti jamčena određena prava, poput plaćanja filurije, nekih poreznih olakšica za obavljanje poluvojnih dužnosti i provođenje samouprave. Ovo je posebno bio slučaj kod reverzibilnih migracija kada se pozivalo izbjeglo stanovništvo da se vrati u svoj stari zavičaj"“. JURIN-STARČEVIĆ, Osmanski krajiški, 173.; „Onima koji su se željeli vratiti, a mogli su dokazati da je određena baština bila njihova, ona bi bila vraćena, kao i zemlja za obradu. U Carstvu je vrijedilo pravilo ako je zemlja tri godine nenaseljena $i$ zapuštena, treba je revitalizirati $i$ naseliti. Vlast je uvijek imala $u$ interesu repopulaciju pustih područja pa su ona s naseljavanjem stanovništva gubila status zakupnih posjeda, čiftluka $i$ mezri“. IBID., 176. Politika istimaleta, kojom su osmanske vlasti barem privremeno i djelomično potvrđivale zatečeno stanje, postigla je veliki uspjeh među kršćanskim stanovništvom na prostoru Osmanskog Carstva. Osmanlije su zadržavali u upotrebi neke predosmanske zakone i običaje, očuvali su statuse i privilegije, inkorporirali određene vojne grupe u svoj vojni sustav, a dijelu stanovništva dodijeljene su privremene porezne egzempcije. U nekim dijelovima Carstva, prema izvorima područje srednjovjekovne Srbije, u drugoj polovini 15. stoljeća, spahije kršćanske konfesije držali su i do 50\% timara. Vjeran KURSAR, Being an Ottoman Vlach: On Vlach Identity(ies), Role and Status in Western Parts od the Ottoman Balkans $\left(15^{\text {th }}-18^{\text {th }}\right.$ Centuries), OTAM, 34, 2013., 133
} 
naseljavanje“. ${ }^{1494}$ Brojevi su očito pretjerani, ali čini se da bi to moglo biti riječ o vlaškom stanovništvu koje je prešlo na habsburški teritorij pa opet pregovaralo o povratku na osmanski prostor. Međutim, ne treba isključiti mogućnost da je riječ (djelomično) o izbjeglome starosjedilačkom stanovništvu koje je pregovaralo o povratku na stare posjede pod osmanskom vlašću.

\subsection{Vlasi i uskoci}

Kada je o migracijama s osmanskog prostora riječ, uskočka su kretanja vrlo zanimljiv i važan demografski fenomen koji se u velikoj mjeri doticao i Bihaća. O uskocima je zaista mnogo pisano te bi opširne elaboracije izlazile iz okvira ovog rada, no treba apostrofirati da uskoci nisu bili homogena etnokonfesionalna skupina već heterogene zajednice koje su mogle, ali često nisu imale osobito bliske međusobne veze. Nada Klaić ispravno je zaključila da terminologija kojom se referiralo na bjegunce s osmanskog teritorija nije odavala njihovo porijeklo pa je proces naseljavanja Vlaha odnosno prebjega generalno nužno rješavati bez uopćavanja, na pojedinačnoj razini. ${ }^{1495}$ Iako je svakako veći dio prebjeglih uskoka bio vlaškog porijekla, svaki onaj koji je „uskočio“ s osmanskog teritorija te na temelju toga i vojne službe na habsburškoj strani zadobio specifičan pravni status postajao je uskok. ${ }^{1496}$

Bihaćka gradska općina nesumnjivo je još od srednjeg vijeka bila u dodiru s vlaškim svijetom, osobito brojnim na prostoru oko Une i Zrmanje, oko južnog Velebita itd. ${ }^{1497}$ Na taj

1494 JURIN-STARČEVIĆ, Osmanski krajiški, 173.

${ }^{1495}$ N. KLAIĆ, »Ostaci ostataka«, 283. Primjerice, tako je u studenom 1580. na habsburški teritorij prebjegla jedan grupa Vlaha kojoj je na čelu bio Mikula Brkanović (Micula Werkhanouitsch). Ime Mikula vjerojatno upućuje na njihovo katoličko porijeklo. HDA, Croatica, mikrofilm D-1913, br. 20, studeni 1580. Čini se da su smješteni ili planirani biti smješteni na pet posjeda oko Slunja kamo je trebalo ,, auch den andern VBgoggen ain Refier vmb Slun außgezeigt werde“. IBID., prosinac 1580.

${ }^{1496}$ Fedor Moačanin konstatirao je da se pojam Vlah odnosi „na kršćansko stanovništvo u Turskoj koje zbog vršenja vojne službe uživa specifične vlaške povlastice i koje i poslije preseljenja na kršćansku stranu nastoji zadržati sličan status“. F. MOAČANIN, Vojna krajina do kantonskog uređenja, 26-27. U izvorima se to stanovništvo često naziva „entsprungnen Turken“, „,herubergefallenen Turken“ itd. Sadržaj kânûnnmâe za Požeški sandžak iz 1545. najbolje pokazuje što su te zajednice značile na (osmanskom) pograničju. Na engleski jezik ga je preveo Vjeran Kursar: „Vlachs are settling in desolated arable fields in the border-province, making them inhabited and prosperous. Some Vlachs are cultivating fields, while others are pasturing goats and sheep... If this records in the register, these hearths will become contractors for the performance of the imperial services, defence and security. Indeed, if there were no Vlachs in the border-province, there would be no possibility for settlement and prosperity, and infidel robbers would be coming and going regulary". KURSAR, Being an Ottoman Vlach, 132.

${ }^{1497}$ Pitanje autohtonosti vlaških zajednica izlazi iz okvira ovog rada te je dovoljno navesti da je vlaška populacija, i to primarno ona iz kategorije „kraljevskih Vlaha“, već od kraja 14. i početka 15. stoljeća osobito brojna na kraljevskim posjedima oko Ervenika kod Zrmanje i Suhače u Kninskoj županija. BOTICA, Krbavski knezovi, 200. Vlaške zajednice obitavale su i na području krbavske biskupije, a o tome krajem 14. stoljeća 
(kasno)srednjovjekovni sloj vlaškog stanovništva, u onoj mjeri u kojoj je opstao na tom prostoru, nadovezale su se nove vlaške skupine pristigle $\mathrm{s}$ istoka i jugoistoka. ${ }^{1498}$ Prema istraživanjima Milana Vasića, prve veće vlaške skupine iz jugoistočnih krajeva „Turskog carstva“" prelaze preko gornjeg toka Vrbasa i Rame na razmeđu 15. i 16. stoljeća te naseljavaju planinski prostor oko Kupresa, Glamoča, Unca, izvorišta Plive i Sane. ${ }^{1499}$ Slažem s tvrdnjom Drage Roksandića koji smatra da su gornjopounski, zrmanjski i cetinski Vlasi, koji su od 1530-ih počeli prelaziti na habsburšku stranu, barem parcijalno Vlasi koji su tamo obitavali i u 14. i 15. stoljeću, a koji emigriraju u godinama nakon Mohačke bitke kada njihov socioekonomski status postaje ugrožen. ${ }^{1500}$ Iz tog prostora, iz okolice Srba, srednjeg toka Unca i Glamoča, dolaze i žumberački uskoci koji su u promatanom periodu imali važnu ulogu na Hrvatskoj krajini te oko Bihaća. ${ }^{1501}$

svjedoči krbavski biskup Nikola navodeći da Vlasi ili Morlaci ne plaćaju nikakvu desetinu, a da je nisu plaćali ni u vrijeme njegovih prethodnika. IBID., 163. Takav raspored vlaške populacije potvrđuje i činjenica da su dušebrižništvo nad Vlasima od 1340. preuzeli bosanski franjevci koji su bili organizirani u okviru bosanske vikarije koja se prema popisu iz 1385. sastojala od sedam kustodija od kojih je tek jedna obuhvaćala prostor prave Bosne. Tek je manji dio od ukupno 36 samostana pokrivao prostor na kojem je funkcionirala crkva bosanska. Za pitanje vlaške populacije najvažnija je Duvanjska kustodija sa šest samostana u Stonu, Novom na obali Neretve kod današnje Čapljine, Imotskog, Cetini kod vrela, Livnu i Glamoču, a područje koje su pokrivali ti samostani, prema Mladenu Ančiću, jest prostor „najintenzivnijeg vlaškog naseljavanja već do sredine 80-tih godina 14. stoljeća“. Mladen ANČIĆ, Srednjovjekovni Vlasi kontinentalne Dalmacije, u: Dalmatinska Zagora nepoznata zemlja, ur. Vesna Kusin, katalog izložbe, Zagreb, 2007, 166.

${ }^{1498}$ Manojlo Sladović tvrdio je da se na području Krbave, a osobito uz rijeku Unu, moglo pronaći mnoge Srbe već tijekom vladavine kralja Žigmunda (1387. - 1437.). Drago ROKSANDIĆ, Rmanj, an Orthodox monastery on the Triplex Confinium, u: Tolerance and Intolerance on the Triplex Confinium, ur. Egidio Ivetic i Drago Roksandić, Padova,103. Za tu tvrdnju ipak nisu navedeni nikakvi konkretni izvori. U historiografiji se pojavljuju navodi da su već u vrijeme Matijaševih kampanja u Bosnu na prostoru Ugarske i Hrvatske naseljene „tisuće srpskih izbjeglica“. Na hrvatskom su se teritoriju navodno naselili na prostoru Like i Krbave. ROTHENBERG, The Military Border, 6. Prema Rothenbergu, te su zajednice nestale u kaosu nakon propasti ugarskoga državnog aparata. IBID., 28. Carl Bernhard von Hietzinger pak tvrdi da su srpski i bosanski prebjezi dobili vjerske slobode i oslobođenje od plaćanja desetine u zamjenu za vojnu službu te da su bili podređeni senjskom kapetanu. No, izgleda da je Hietzinger smatrao da su Lika i Krbava tada bile oslobođene od osmanske vlasti, a da je spomenuto uređenje propalo kada su ubrzo „ponovno“ potpale pod Osmanlije. Carl Bernhard Edlen von HIETZINGER, Statistik der Militärgränze des österreichischen Kaiserthums, vol. 1, Beč, 1817., 15-16. Ni za te tvrdnje navedeni autori nisu naveli nikakve konkretne izvore pa ih treba promatrati s velikom rezervom.

${ }^{1499}$ Mirko VALENTIĆ, Turski ratovi i hrvatska dijaspora, Senjski zbornik, 17, 1990., 47.

${ }^{1500}$ Drago ROKSANDIĆ, Dalmatinska zagora u ranome novom vijeku: pitanja za raspravu, u: Dalmatinska zagora nepoznata zemlja, ur. Vesna Kusin, Zagreb, 2007., 190. Tome u prilog ide i činjenica da su, prema osmanskim izvorima, 1528. na području „vilajeta Hrvati“ od četrdesetero spahija njih 23 kršćanske vjeroispovijesti, s tim da je i među muslimanima bilo nedavno preobraćenih osoba. Svi navedeni kršćani pripadali su skupini vlaških knezova, a neki su bili u statusu vojvoda. Raspolagali su manjim timarima nadarbine do 2000 akči preko kojih je zapravo priznata njihova ranija baština. Kornelija Jurin-Starčević konstatirala je da činjenica „da se knezovima dinarsko-jadranske regije priznaju njihove ranije baštine u obliku malih timara te spoznaja da im se povjerava obrana granica navodi nas na pomisao da su ti vlaški knezovi, zajedno s vlaškom populacijom u čijem su okruženju živjeli, autohtona populacija iz predosmanskog perioda, a ne novodoseljeno vlaško stanovništvo“. Te autohtone kasnosrednjovjekovne vlaške skupine očito su se kasnije asimilirale s Vlasima koji su u valovima pristizali na promatrani prostor tijekom 1540-ih i 1550-ih. JURIN-STARČEVIĆ, Osmanski krajiški,111-112.

${ }^{1501}$ KASER, Slobodan vojnik, knjiga I, 55. 
Nema sumnje da je širi osmanski unski prostor bio, u kontekstu imperijalnih višegraničja, dobro napučen prostor tijekom ovoga čitavog perioda. ${ }^{1502}$ Prvi evidentirani masovni prelasci vlaških zajednica s osmanskog na habsburški teritorij u okolici Bihaća zbili su se oko 1530. kada je ban Ivan Karlović javio Ivanu Katzianeru da su iz Osmanskog Carstva pristigli Vlasi (,mnogi ili pedesetorica“) koji bi željeli prijeći na habsburški teritorij. Karlović nije imao sredstva za njihovo uzdržavanje, a radilo se najuglednijim glavarima (principales milites et capitales inter Wlahos, qui multa damna fecerunt huic regno Carinthie donec fuerunt inter Thurcis). Usto, smatrao je da će njihov uspješan prelazak rezultirati lančanim seobama vlaških zajednica na kršćansku stranu. Zato je od Katzianera tražio da im se pronađe smještaj i da im se osigura opsrkba. Predstavnici prebjeglog stanovništva tražili su da im se dozvoli ostanak u kraljevskoj službi te da ih se ne stavlja pod ingerenciju plemstva. ${ }^{1503}$

Na čelu tih vlaških zajednica, koje su s imovinom prebjegle s područja Srba, Unca i Glamoča, stajao je glamočki vojvoda Vladislav Stipković, očito istovjetan knezu Vladislavu koji se navodi u osmanskom defteru iz 1528. - 1530. kao starješina glamočkih Vlaha. Uz njega se spominju i njegov bratić Radman, vojvoda Perlo(a) sin Radosava i još jedna osoba (čije ime Vasić nije mogao pročitati, op.a.) kao starješine zajednice glamočkih Vlaha i

\footnotetext{
${ }^{1502}$ Osmanski defteri pokazuju da je između Zrmanje i Krke od 1528. do 1530. u devedesetak seoskih imanja popisana 681 porezna jedinica takozvanih „Vlaha zemlje Istre“. U nahijama Ostrovica, Popina, Plavna i Strumica vlaška populacija broji 218 kuća u 17 sela. Prema Jurin-Starčević, te vlaške zajednice činili su Vlasi doseljeni iz prekodinarskih nahija Uskoplje i Unac, zatim jedna grana Vlaha zemlje Istre te domaći katolički Vlasi. Uz antroponimiju, autohtonost tih Vlaha sugeriraju i spomenuti mali timari u vlasništvu starješina jer, kada su osmanske vlasti poticale kolonizaciju, jedna od metoda kojom su motivirale vlaške starješine na preseljenje bili su i viši iznosi timara. JURIN-STARČEVIĆ, Osmanski krajiški, 168-170. S druge pak strane, prema Milanu Vasiću, defter iz 1528. pokazuje da je nahija Unac izgubila svoje starosjedilačko stanovništvo, da su u prvim godinama osmanske vladavine organizirano naseljeni stočari nomadi (hajmaneler) te da su privremeno naseljeni u tri sela koja su brojala 159 kuća. Vasić pretpostavlja da je daljnja kolonizacija tog prostora išla iz ta tri sela. VASIĆ, Etnička kretanja, 242. Interesantno je da prema istome osmanskom defteru u nahijama Kupres, Ključ, Kamengrad, Srb uopće nema naselja i kuća. Uz nahiju Unac, samo se u nahiji Grahovo pojavljuju dva sela s 39 kuća. IBID., 240. Već deset godina kasnije u nahiji Unac nalazi se 30 novih naselja i sveukupno 366 kuća. IBID., 243. U nahiji Grahovo tada se nalazi 14 sela s 246 kuća, u nahiji Ključ 11 sela s 93 kuće dok je u nahiji Kamengrad upisan samo grad s 65 kuća. IBID., 240. Dakle, to je dobro naseljen prostor, osobito kada je riječ o isturenom pograničju. Osmansko-mletački rat (1537. - 1540.) negativno je utjecao na demografiju promatranog prostora pa se 1540. između Zrmanje i Krke broj „Vlaha zemlje Istre“ prepolovio na 322 kućanstva. JURIN-STARČEVIĆ, Osmanski krajiški, 170. Nakon smirivanja ratnih operacija započeo je proces demografskog opravka. Prema istraživanjima Jurin-Starčević, osmanske su vlasti između 1540. i 1550. na području nahija Unac i Srb naselili 141 kuću kršćana čija je dužnost bila obnašati službu derbendžija i štititi pograničje prema habsburškoj strani. IBID., 178. U nahijama Strmica, Plavna, Zrmanja i Popina, Zrmanja Istrija, Ostrovica Istrija, Bukovica i nahija Kosovo bilo je 1550. 98 sela sa 783 kuće. IBID., 171. Dakle, krajevi oko rijeke Une bili su dobro napučeni barem od 1520-ih nadalje, a prostor oko Une, Unca i Glamoča očito je funkcionirao kao permanentno ishodište vlaških migracija na zapad. Tako je dobar dio, a možda i svi od 3500 Vlaha naseljenih na područje Like i Krbave 1570-ih pristigao s prostora oko rijeke Une. SI AS 2, DSK, kutija 205, fascikl 125b, Hoffenbach, 26.2.1577., 1v. Hans Auersperg.

${ }^{1503}$ N. KLAIĆ, »Ostaci ostataka«, 284.; LASZOWSKI, HSKHDS, knjiga I, dok. 442, 415-416.
} 
korisnici zajedničkog timara. ${ }^{1504}$ Što se tiče karaktera odnosa između Bišćana i spomenutih vlaških zajednica, interesantna je činjenica da su Bišćani vojnim vlastima preporučili spomenute vlaške zajednice iako su u svom zarobljeništvu držali brata „glavara Vukmana“ za čije oslobađanje ili otkup ban Karlović moli Katzianervu asistenciju. ${ }^{1505} \mathrm{Na}$ molbu Ivana Katzianera Vlasi koji su imali obitelji i stoku smješteni su na žumberački posjed koji je kralj za vjernu službu dodijelio Ivanu Kobasiću. Pojedinci bez obitelji smješteni su u sam castrum, a Kobasić je od Katzianera tražio da ih primi u kraljevsku službu jer će inače teško samostalno preživjeti. Jedan dio smješten je, unatoč protivljenju jaskanskoga kaštelana, na Erdödyjev posjed Tihočaj u sklopu jaskanskog vlastelinstva. ${ }^{1506}$

Vjerojatno su postojale veze između Ivana Kobasića i vlaških starješina. Naime, kao što je već rečeno, Kobasić je imao razgranatu obavještajnu mrežu na osmanskom teritoriju koja je nesumnjivo uključivala i vlaške skupine. Usto, uskoci su silno željeli biti naseljeni na žumberačkom području navodeći da tamo ima dovoljno zemlje i površina za ispašu te da je dovoljno udaljeno od krajine. Taj je posjed pak bio u zakupu obitelji Kobasić čiji su se obiteljski posjedi nalazili i oko Bihaća. No, pristigli uskoci bezrezervno su tražili da ne budu podložni Kobasićima.

Postavlja se pitanje je li netrpeljivost između Kobasića i uskočkih skupina proizašla iz sukoba oko naseljavanja na Žumberku ili je u cijeloj toj drami bilo i drugih uzroka. Izvori demonstriraju neprijateljski stav uskoka prema hrvatskom plemstvu, a osobito prema obitelji Kobasić. Naime, kada su uskoci 1533. upitani gdje žele biti naseljeni, odgovorili su na Žumberak, oko Metlike i okolnim planinama, a pritom su naglasili da nikako ne žele biti podložni Kobasiću ,jer im je ove godine mnogo nepravde i nasilja učinio“. Tražili su da kralj ponovo preuzme Žumberak u svoje ruke ili da ga preda nekom drugom kranjskom plemiću. ${ }^{1507}$ Predstavnici kranjskih staleža od kralja su tražili da imenuje kapetana nad uskocima koji bi rezidirao u utvrdi Žumberak, a koji bi bio kranjski plemić jer uskoci „radi raznih razloga“ ne žele biti podređeni nijednom Hrvatu ili Kobasićima koji sada posjed drže u zakupu. ${ }^{1508}$ Neprijateljski stav prema hrvatskom plemstvu može se djelomično opravdati

\footnotetext{
${ }^{1504}$ VASIĆ, Etnička kretanja, 243. Vojvoda Perla past će 1543. u zarobljeništvo bihaćke posade. LASZOWSKI, HSKDHS, knjiga III, dok. 149, 144.

${ }^{1505}$ N. KLAIĆ, »Ostaci ostataka«, 284.

${ }^{1506}$ IBID., 284-285.

1507 „aber vnder dem Khobaschitz wolten sy nicht sein, dan er inne dise Jar vill vnd gross Vngerechtigkhait auch Gezwang bewisen vnd gethan, sonnder damit dit Kh. Mt. Solichen Flekhl Sichelberg widerumben zw Hennden namb oder ainem andern Landtman gab“. IVIĆ, O prvoj srpskoj, dok. 6, 263.

1508 „In sonnder wäre euch ain. Noturfft, das E. Mt. innen ain Haubtman ordnet, der zu Sichlberg im. Gsloss wonet. Der Gericht vnnd Recht von E. kn. Mt. wegen vnder innen hielte vnnd Ordnung gäbe, doch das der ain
} 
permanentnim ratovanjem na krajištu te nastojanjem da se sačuva specifični društveni položaj, s tim da u slučaju Kobasića ne bi trebalo zanemariti njihove obavještajne mreže. Može se pretpostaviti da su se Kobasići i prebjegli Vlasi ranije ,poznavali“ te da je animozitet mogao nastati i prije same seobe u tom kontekstu. Za kasniji period nisu pronađeni slični izvori iako su se prelasci s osmanskog na habsburški teritorij nastavili.

Teško je detektirati prisutnost (privremeno) naseljene uskočke populacije u Bihaću i neposrednoj okolici. Kada je 1540. buknuo požar u gradu koji je uništio župnikovu kuću/župni dvor i sedam drugih kuća, Bišćani su uskoke smatrali odgovornima za ovu „izdaju“. ${ }^{1509}$ Već je navedeno da je u Bihaću bio rođen Vlah prezimena Sišnavić koji je kasnije bio istaknuti osmanski martolog i kalauz. ${ }^{1510}$ Početkom 1570-ih u gradu je barem na određeno vrijeme boravila jedna grupa uskoka. Naime, u travnju 1573. Thomas Naglić piše o smještaju „der Vßkhockhen zw Wihitsch“ na posjed Mikule Batine u Čemernici. ${ }^{1511} \mathrm{Na}$ tom je posjedu Batina tri godine ranije uz pomoć i savjet zagrebačkog biskupa, na jednom zgodnom mjestu, s dovoljno drva i polja u blizini i prikladnom za stoku, podigao Plochhauß zaštićen ogradom (Zaun). No, Naglić je napomenuo da je od Bišćana saznao da su uskoci izjavili da žele dobiti carsku odluku (beschaidt) i slobode te da žele služiti na isturenoj granici. Prema njihovima izjavama, nisu htjeli biti izmješteni iz Bihaća iako je Naglić napomenuo da im Hrvati neće mnogo vjerovati i biti na ispomoć. U istom pismu Naglić je naveo da oni zapravo bihaćkoj gradskoj općini ne koriste, već čine štetu te da ne žele biti ni pratnja pri transportu živeži. U tom se trenutku raspravljalo i o smještaju nedavno prebjeglih uskoka na područje Podbrežja. Ti ,heruber gefallnen Vßkhockhen“ trebali su biti naseljeni na raspoložive puste posjede oko Podbrežja, no Naglić je strahovao da kranjski zemaljski kapetan neće biti presretan zbog njihova naseljavanja jer „oni žele biti potpuno slobodni“. ${ }^{1512}$

Nakon osvajanja Bihaća Osmanlije su nastojali čim prije kolonizirati čitav tok rijeke Une. To je vidljivo iz iskaza Osmanlije iz Bihaća koji su zarobljeni pod Modrušom (Wihitscherischen Tschetta) i koji su otkrili da su do sredine sljedeće godine Vlasi već naseljeni oko Bihaća, od Mača pored Brekovice (Bregkhouaz) s one strane Une do Ripča, i od

Lanndtman sey, dann sy khain Krabaten noch den Khowatschitschen, so yetzo Sichlberg innen hat, aus vill Vrsachen nit leiden möchten....“. IBID., dok. 13, 275.

${ }^{1509}$ SI AS 2, DSK, kutija 286, fascikl 164, Bihać, 17.4.1540., 1r, rbr. 7. Bartlme Raunach na Nikolu Jurišića.

1510 SI AS 2, DSK, kutija 414, fascikl 284, Črnomelj, 28.9.1565., 2r, rbr. 1375. Balthasar Katzianer na Ivana Lenkovića.

${ }^{1511}$ Kuća/e kneza Mikule Batine iz Opatije (Mykwle Bathyne yz Oppathye) u Steničnjaku spominje/u se u jednoj ispravi iz 1572. Radoslav LOPAŠIĆ, Oko Kupe i Korane, Matica Hrvatska, Zagreb, 1895., 23, fusnota 3.

${ }_{1512}$ SI AS 2, DSK, kutija 286, fascikl 164, Crnomelj, 14.4.1573., 1r-3r. 50-53. Thomas Naglić na Jobsta Josepha Thurna. 
Ostrovice ili Ostrožca do Werla Draga pod Sokolom s ove strane Une te da se na dnevnoj razini naseljevaju u te krajeve i podižu mnogo kuća. ${ }^{1513}$

Bihać je, dakle, nastavio biti jedan od najvećih gradova u regiji i u promatranom periodu. Cijeli prostor današnje Bosanske krajine te Banije i Korduna bio je do osmanske ekspanzije demografski gusto naseljeno područje pa je, unatoč iseljavanjima iz grada i okolice, dio tog stanovništva nedvojbeno pronašao privremeno $\mathrm{i} / \mathrm{ili}$ trajno utočište $\mathrm{u}$ samome Bihaću, kao najsigurnijem refugiju na isturenom krajištu. Broj stanovnika u samom gradu u promatranih šezdesetak godina teško je precizno utvrditi, ali izvori su dovoljno sadržajni da se može zaključiti da se radilo o nekoliko tisuća osoba. U trenutku osmanske opsade 1592. taj se broj mogao popeti blizu navedene brojke od 5000 ljudi. Naravno, nisu svi bili građani, dakle i članovi gradske općine, već je tu bilo i „običnih“ stanovnika, onih bez prava građanstva, zatim pripadnika plaćene vojne posade i njihovih obitelji, u grad doseljenog plemstva, od kojih su mnogi bili u plaćenoj vojnoj službi i uskočke populacije. Naime, u gradu su se naseljavale i uskočke, odnosno vlaške skupine. Ponekad se radilo o trajnom boravku, a često o privremenom boravištu do preseljenja na neke druge prostore na krajištu i u unutrašnjosti. U tom pogledu Bihać je bio važno regionalno središte. Može se konstatirati da je za onodobne hrvatske, a osobito krajiške prilike, Bihać praktički bio velegrad. Dobro naseljen grad ostao je usprkos kontinuiranim iseljavanjima s promatranog prostora koja su se intenzivirala kako je rasla osmanska opasnost, s maksimumom nakon pada Krupe 1565. Nakon dramatičnih poraza na unskom frontu 1570-ih iseljavanje je još dobilo na zamahu pa nalazimo i podatake o bijegu najbogatijih građana/stanovnika, praznim kućama, prijetnjama s odlaskom i slično. No, unatoč svoj drami i opasnostima života u praktički neprijateljskom okruženju, Bihać i neposredna okolica ostali su dobro naseljeni prostori sve do pada pod osmansku vlast 1592 . To je jedan od elemenata koji nije dostatno istražen kada je riječ hrvatskom pograničju u periodu 16. stoljeća. Postavljaju se pitanja o tome koliko je stanovništva ostalo na tom prostoru, kako su se održali i kada su bili spremni za povratak na domicil. Iz prezentiranog izvora s početka 1577. jasno je vidljivo da je izbjeglo stanovništvo bilo spremno vratiti se na svoje posjede na najisturenijem pograničju čim su postojale indicije da će se ratne aktivnosti

1513 „Zaigt verer an, das siche die Wallachen aldort bey Wihitsch von den Matsch bey Gregkhouaz inseit der Vna, biß auf Repitsch also auch von Ossteruiz biß auf Werlau(d)roga (Werla Draga) vndter Sagkhol diser Seits der Vna allenthalben woll alberait angesezt vnd sich noch taglichen mit erpaunug viler heüser derselben Enden hin vbersidlen.“. SI AS 2, DSK, kutija 805, fascikl 540, 24.5.1593., 1v. 
smiriti - konkretno odmah nakon potpisivanje primirja koje uostalom ni nije garantiralo apsolutni mir. Taj je podatak jasan pokazatelj višegeneracijskog procesa adaptacije pograničnog stanovništva na permanentno stanje rata te sposobnosti odnosno spremnosti pograničnog stanovništva da nastavi egzistirati na prostoru koji je čak i za neke viteške redove tada već postao preopasno mjesto za obavljanje bogougodne dužnosti borbe protiv „nadneprijatelj kršćanske vjere“. Iza bihaćkih zidina moglo se pronaći više sigurnosti u odnosu na ostatku pograničja. Naravno, sve to imalo je visoku ljudsku cijenu, a to se očituje u broju poginulih te stalnom zarobljavanju pojedinaca, odnosno manjih ili većih grupa stanovništva u osmansko zarobljeništvo. Kumulativni efekt „malog rata“ bio je dramatičan pa je tako Bihać dobrim dijelom postao i grad udovica i siročadi o čijoj se prehrani morala starati (i) vojna vlast. To je najbolji pokazatelj cijene rata koju je plaćalo stanovništvo na isturenom pograničju u jednom od najdramatičnijih razdoblja hrvatske, ali i regionalne povijesti. 


\section{1. ŽIVOT NA ISTURENOM POGRANIČJU - „BOG NAM JE SVJEDOK, DA MI DALJE OVAKO NE MOŽEMO“61514}

\subsection{Posjedi bihaćke gradske općine}

U ovom poglavlju pokušat ću odgovoriti na nekoliko intrigantnih pitanja promatranog perioda. Kako je stanovništvo na isturenom pograničju poput bihaćkog uspjelo osigurati egzistenciju u stanju neprekidnog ratovanja? Na kojim su posjedima ili arealima proizvodili hranu, odnosno kako je izgledala opskrba jednog za ono doba velikog grada na pograničju s Osmanskim Carstvom? Odakle se dopremala živež i kojim se trasama unosila u grad? Može li se nešto reći o trgovačko-gospodarskoj aktivnosti gradske općine?

$\mathrm{Na}$ početku treba naglasiti da je Bihaćka dolina bila jedan od najproduktivnijih poljoprivrednih areala na onodobnom hrvatskom prostoru što je konstatirano i na saboru $u$ Brucku 1578. gdje je povlačenje obrambene linije s rijeke Une na rijeku Glinu promatrano kao „napuštanje najplodnije doline u Hrvatskoj s ove strane Une“. ${ }^{1515}$ Međutim, u promatranom periodu poljoprivredni potencijal nije mogao biti maksimaliziran zbog permanentnih osmanskih pustošećih napada koji su se osobito često odvijali u razdobljima izvođenja poljoprivrednih radova. Njihov je cilj bio devastirati agrarnu proizvodnju te prisiliti domaće stanovništvo na bijeg, predaju ili podčinjavanje. To je poznata ratna taktika ,spaljene zemlje“.

Budući da je u ratnim okolnostima bilo teško osigurati dovoljno hrane za preživljavanje vojnih posada, ali vidjeli smo i (dijela) gradskog stanovništva, kao nužnost se nametala doprema živeži na krajište. Na saboru u Steničnjaku 1558. hrvatsko-slavonski staleži Žalili su se kako su se osmanski napadi počeli odvijati i zimi, pa se na tom gorskom i neplodnom prostoru, koje je izloženo neprijateljskim upadima, ne može obrađivati zemlja, već se živež mora dopremati izvana. ${ }^{1516}$ Izjava je ponešto pretjerana jer se zemlja u određenoj mjeri obrađivala gdje god je ostalo stanovništva, ali suština je točna - proizvodnja nije dostajala za sustavnu opskrbu te je živež bilo potrebno uvoziti s raznih strana. ${ }^{1517}$

\footnotetext{
1514 SI AS 2, DSK, kutija 286, fascikl 164, Bihać, 22.2.1573., 1v-2r, rbr. 218-219. Vapaj predstavnika bihaćke vojne posade upućen Herbartu Auerspergu i Jobstu Josephu Thurnu.

1515 ŠTEFANEC, Država ili ne, 295.

1516 IBID., 174.

${ }^{1517}$ Zbog klimatskih promjena došlo je do promjene tipa usjeva i jačanju stočarstva u odnosu na poljoprivredu. Jelena MRGIĆ, Wine or Raki - The Interplay of Climate and Society in Early Modern Ottoman Bosnia, Environment and History, 17, 2011., 614. Društvene posljedice klimatskih promjena mogle su biti goleme.
} 
Jedan od povoda manjim, češćim osmanskim upadima svakako su i klimatske promjene u periodu tzv. „Malog ledenog doba“ čiji se početak može tražiti već u drugoj polovici 15. stoljeća, ako ne i ranije. Hladnije i kišnije vrijeme snažno je utjecalo i na tip i na obujam poljoprivredne proizvodnje, a ako se tome pridodaju i epidemije, navodi Ivan Jurković, radilo se o ozbiljnim udarcima na već ekonomski i društveno devastiran hrvatski prostor. Kada se u tu ,jednadžbu“ ubace i osmanski napadi, dobivamo shemu koju Jurković prikazuje na sljedeći način: ,prirodne klimatske katastrofe $\rightarrow$ period gladi $\rightarrow$ osmanski napad $\rightarrow$ epidemija $\rightarrow$ novi period gladi““. ${ }^{1518}$ Problem osiguravanja dodatne količine hrane osobito je dolazio do izražaja kada se radilo o velikim vojnim centrima poput Bihaća koji su posjednuti brojnom vojnom posadom koju je trebalo prehraniti.

Što se opskrbnog sustava tiče, dominantnu ulogu imala je središnja vlast, odnosno unutrašnjeaustrijski staleži, a živež je nabavljana na hrvatsko-slavonskom prostoru i prostoru zemalja Unutrašnje Austrije, ali ponekad i u okolnim zemljama. Iako je glavnu ulogu i u ovom segmentu imalo unutrašnjeastrijsko plemstvo, u opskrbnom sustavu participirale su razne instance. Lokalno stanovništvo i plemstvo prodavalo je vlastite proizvode vojnoj posadi, a hrvatsko-slavonski staleži uključili su se u trgovinu namirnicama i opskrbu krajiških gradova kada je sabor to odlučio. Magnati su tom trgovinom ostvarivali visok profit. Često se radilo o tržišnoj manipulaciji, umjetnom dizanju cijena ciljanim skladištenjem robe, iskorištavanju prava prvokupa od seljaka itd., na što su se krajiški zapovjednici često žalili. Namirnice su od kmetova prikupljane besplatno, i to po mnogo nižoj cijeni od prodajne ili prema cijeni koju je definirao sabor. ${ }^{1519}$ Koliki su problem te makinacije izazivale pokazuje i tužba bihaćkoga kapetana Zoblsperga predstavnicima kranjskih staleža krajem kolovoza 1558. protiv hrvatskih velikaša koji su podanicima zabranili prodaju žita pa vojnici danima lutaju u potrazi za hranom. Kapetan je tražio da se intervenira kod grofova Blagajskog, Tržačkog i Slunjskog da prestanu s tom praksom jer su i sami u kranjskoj plaćenoj službi. ${ }^{1520}$

Hrvatsko-slavonski sabor odupirao se prijedlogu kralja da se zabrane otkup hrane od seljaka i preprodaja vojsci (naravno, po višim cijenama) te da se plemstvo primora da na

\footnotetext{
Padom temperature i raznim drugim klimatskim anomalijama padale su produkcija i vrste poljoprivredne proizvodnje. Osim toga, padale su i nadmorska visina na kojoj se mogla proizvoditi hrana, kvaliteta usjeva, raznolikost, a to je pak znatno utjecalo na dostupnost hrane za ljude i za životinje. To je dovodilo do porasta cijena hrane i stoke te manjka radno sposobnih ljudi i radne stoke, deficita sredstava za ulaganje u poljoprivredu, što je pak uzrokovalo neishranjenost, glad, višu stopu smrtnosti i slabiji fertilitet, migracije te socijalne nemire. Mrgić zaključuje da su od 1580. do 1606. klimatske anomalije pogodile proizvodnju žitarica (wheat) i vina u osmanskoj Bosni, Ugarskoj i cijeloj srednjoj Europi. IBID., 628-629.

1518 JURKOVIĆ, The Fate, 43-44.

1519 ŠTEFANEC, Država ili ne, 341.

1520 SI AS 2, DSK, kutija 201, fascikl 124, Bihać, 31.8.1558., 1v, rbr. 709.
} 
zahtjev vrhovnoga kapetana prodaje žito po cijeni koju će odrediti četiri zapovjednikova povjerenika. Smatrali su da bi to nepovoljno djelovalo na stanovnike koji se ne bi mogli održati te da plaćeni vojnici za adekvatnu cijenu mogu kupovati na nedjeljnim sajmovima. ${ }^{1521}$ Kada je Sabor u proljeće 1560. pristao sudjelovati u opskrbi krajiških gradova, odlučeno je da se u Slavoniji od svakog dima, a u Hrvatskoj od svakog puškara (jedan se puškar dizao na pet dimova) doznačuje jedna „četvrtinka“ pšenice i jedna „četvrtinka“ prosa. Podanici između Save i Kupe prikupljeno su trebali dopremiti u Topusko, a oni iz Hrvatske, dakle južno od Kupe, u Cetin. U tim mjestima živež je trebao biti predan osobama koje je delegirao Ivan Lenković. Naknadno je određeno da ban na zahtjev vrhovnoga kapetana mora osigurati ljude koji će živež iz Topuskog i Cetina prevoziti na samu krajinu te za to biti adekvatno plaćeni. $^{1522}$

Kada je riječ o egzistencijalnim uvjetima u Bihaću, svakako treba načiniti distinkciju između civilne i vojne strukture u gradu. Naime, građani i stanovnici koji su (trajno) živjeli na ovom prostoru imali su svoje posjede s kojih su osiguravali određene prinose (žitarice, vino itd.), a koji su im u stanovitoj mjeri bili dostatni za život, možda i lokaliziranu trgovinu. Gradska je općina već tradicionalno imala svoje posjede u okolici grada o kojima je prehrambeno ovisila, a koji su zbog osmanske opasnosti s vremenom sve slabije obrađivani. Određene razlike možda postoje između građana koji su uživali općinske posjede naslijeđene još iz srednjovjekovnog perioda te stanovnika, koji nisu uživali taj pravni status, a živjeli su na prostoru grada, i za koje je teško ustvrditi kojim su zemljištima raspolagali. Izvori jasno pokazuju da agrarna proizvodnja lokalnog stanovništva nije zamrla do pada pod osmansku vlast.

$\mathrm{Na}$ temelju trenutno dostupnih izvora čini se da $\mathrm{u}$ promatranom periodu posjedi gradske općine nisu bili osobito prostrani. U izvorima se kao jedan od najvažnijih posjeda navodi Velihovo gdje su se u promatranom periodu nalazile livade. ${ }^{1523}$ Bihaćka gradska općina na čelu s Jacobom (major vile et tota communitas) sporazumjela se već 1271. s topuskom opatijom da neće biti dozvoljeno međusobno preseljenje kmetova iz Velihova u Kralje. ${ }^{1524}$ Kralj Žigmund 1387. dodijelio je Petru, sinu kneza Novaka od Ostrovice, „kraljevska sela“ Velihovo, Stuguchawcha, Založje, Tolzth, Brakovicha, in pertinentiis de Byhichio existentes, ad regnum nostrum Sclavonie et ad domun nostram Palata spectantes. ${ }^{1525}$

\footnotetext{
${ }^{1521}$ Navedeni su uglavnom slavonski sajmovi te Steničnjak.V. KLAIĆ, Povijest Hrvata, knjiga 5, 301.

1522 IBID., 287-288.

${ }^{1523}$ ANČIĆ, Bihaćki kraj, 205; LOPAŠIĆ, Bihać, 54.

1524 TKALČIĆ, Povjestni spomenici, dok. CLIII, 160-161; LOPAŠIĆ, Bihać, 44.

1525 THALLÓCZY, HORVÁTH, Also-Szlavoniai, dok. LXXIII, 112-113.
} 
No, u promatranom razdoblju Velihovo je barem djelomično u posjedu gradske općine jer su se Bišćani vrlo žustro opirali predati podložnike“s tog posjeda plemiću Mihaelu Budošiću $1545 .^{1526}$

Bihaću je pripadalo i selo Hotinac (Hatinac) u neposrednoj blizini grada. Budući da je selo već rano stradalo u osmanskim napadima, ban Petar Berislavić 1515. darovao je ,jedan pusti dvorac hotinački“ bihaćkom vicekaštelanu Petru Rebroviću ne bi li ga revitalizirao. ${ }^{1527}$ Poljoprivredne površine nalazile su se u Pokoju ${ }^{1528}$ i na području Zavalja te na riječnim otocima sjeverno od grada.

Pod bihaćku gradsku općinu potpadali su stanovnici sela Kralje koje se u promatranom periodu nalazilo i u vlasništvu obitelji Kobasić. ${ }^{1529}$ Teško je procijeniti površinu posjeda gradske općine, ali, prema pronađenim izvorima, nije bio osobito velik. To bi zaista moglo upućivati na primarnu orijentaciju prema trgovini i obrtu, ali jednako tako može biti indikator svojevrsnoga teritorijalnog sažimanja njihova posjeda kao posljedice osmanskih napada, ali i preuzimanja okolnih posjeda od strane krajiške strukture. Nadalje, promatrani prostor bio je u kasnosrednjovjekovnom periodu dobro naseljen, a ovdje su svoju egzistenciju pronašli i razni protjerani hrvatski plemići koji su u vojnoj službi i na druge načine nastojali osigurati nove posjede, često na štetu gradske općine. Isprva je vjerojatno bilo premalo zemljišnih posjeda za sve zainteresirane, a nakon što su Osmanlije u drugoj polovici stoljeća demografski devastirali taj prostor, okolnosti su se promijenile pa je ostalo premalo ljudi koji bi te posjede obrađivali. Isprva je vrijednost predstavljala zemlja, a kasnije čovjek.

\footnotetext{
${ }^{1526}$ LASZOWSKI, HSKHDS, knjiga III, dok. 216, 247.

${ }^{1527}$ IBID., 54.

${ }_{1528}^{15}$ LOPAS̆IĆ, SHK, knjiga I, dok. CII, 152.

${ }^{1529}$ IBID., dok. LXIVI, 107-108.
} 


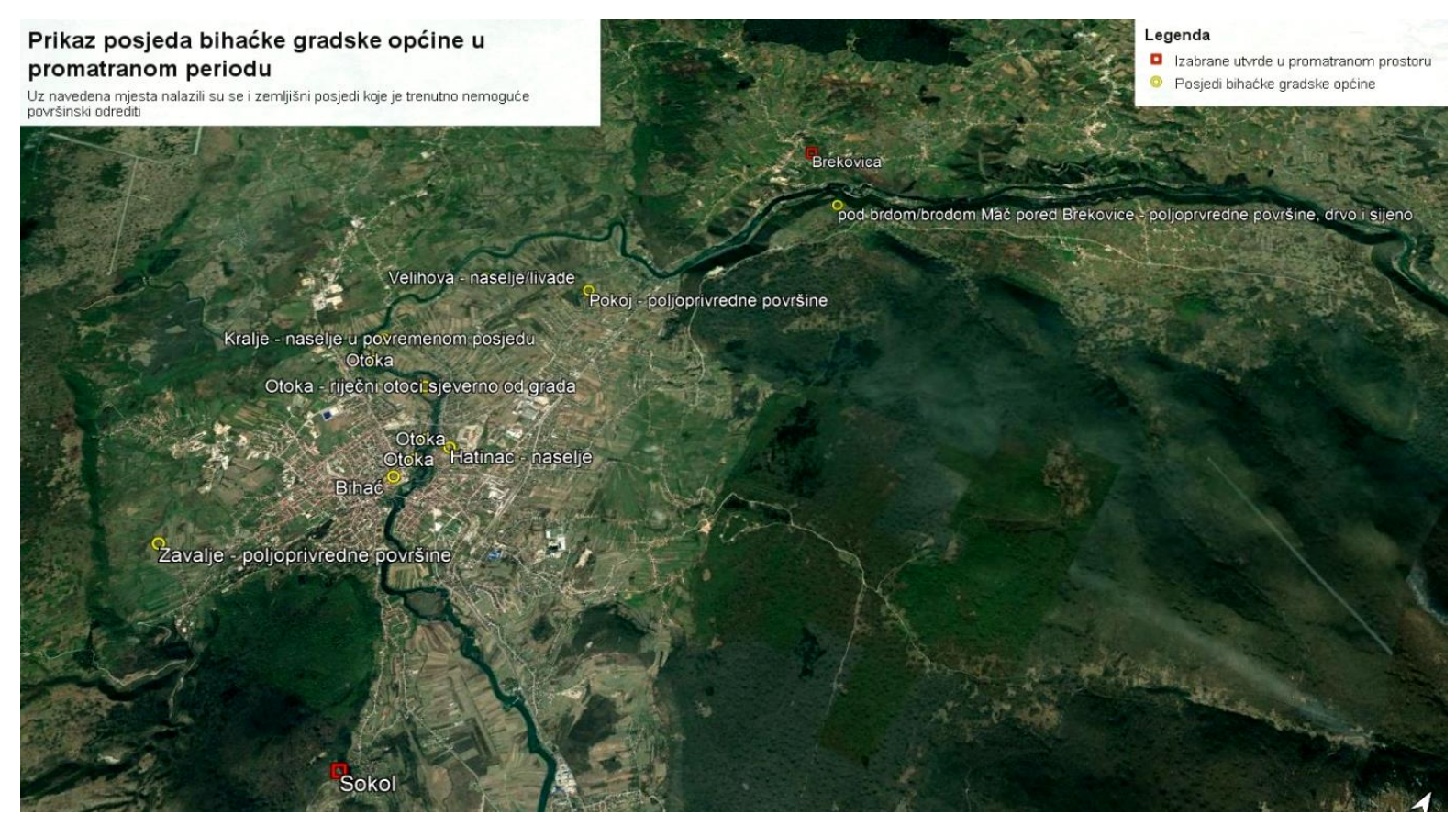

Slika 39. Prikaz posjeda bihaćke gradske općine u promatranom periodu.

Za razliku od danas, oko Bihaća je tada bilo i vinograda. Lopašić tako navodi lokalitet Vinica zapadno od grada te vinograde na oplazi brda Somišlja koji da su podsjećali na nekadašnju lokalnu vinogradarsku kulturu. ${ }^{1530}$ Vinograda je bilo oko Ripča iako Lenkovć 1550. navodi da je tamo ostalo tek ,nešto“ vinograda. ${ }^{1531}$ Vinogradi oko Bihaća spominju se još prilikom pripreme „Hrvatske ekspedicije“ 1578. pa se može pretpostaviti da se vino proizvodilo sve do pada grada po osmansku vlast. ${ }^{1532}$ I Adamček navodi da je oko Bihaća bilo posjeda s dobro razvijenim vinogradarstvom“. ${ }^{1533}$

Kada je riječ o obujmu poljoprivredne proizvodnje, izvori su nažalost rijetki i sporadični. Prema popisu crkvene desetine iz 1520. u Bihaću i njegovim posjedima (pripadnostima) dobiveno je 760 kvarti pšenice, 300 kvarti zobi, 1014 kvarti prosa i 262 vedara (cubic) vina. Na ostalim posjedima oko Bihaća dobiveno je sljedeće: u Homljanu „S ove strane brda“" proizvedeno je 195 kvarti pšenice, 40 kvarti zobi, 231 kvarti prosa i 127 vedara vina dok je u Homljanu „s one strane brda“ prikupljeno 216 kvarti pšenice, 36 kvarti zobi, 250 kvarti prosa i 90 vedara vina. U „provinciji“ Sokol tada je proizvedeno 80 kvarti pšenice, 7 kvarti zobi, 96 kvarti prosa i 87 vedara vina. Adamček je izračunao da je desetina

\footnotetext{
${ }^{1530}$ LOPAŠIĆ, Bihać, 54.

${ }^{1531}$ KRUHEK, Krajiške utvrde, 169.

1532 LOPAŠIĆ, SHK, knjiga I, dok. XXXIX, 73.

1533 ADAMČEK, Agrarni odnosi, 200.
} 
za Bihać, Sokol i Stešković iznosila 60 florena, a za Ripač 30 florena. ${ }^{1534}$ To znači da su se u Bihaću i okolici tada uzgajali pšenica, zob i proso te da se proizvodilo vino. No kako su osmanski napadi postajali češći, tako je i bihaćka okolica postajala sve nesigurniji prostor pa su se Bišćani već 1530. žalili da se ne usuđuju izlaziti iz grada jer ih napadaju Vlasi, osmanski konjanici i pješaci. ${ }^{1535}$ To je predstavljalo veliki problem za opće funkcioniranje grada jer je obrada zemlje implicirala kontinuiran i dugotrajan boravak na otvorenom, a to je otvaralo prostor osmanskim postrojbama za napad. Zato je vojska trebala osiguravati poljoprivredne radove i sječu drva, odnosno bilo kakve druge aktivnosti izvan zidina.

Ipak, unatoč snažnome osmanskom pritisku na Bihać i okolicu, promatrani prostor će još desetljećima biti demografski relativno stabilan, barem kada se promatra iz perspektive habsburškoga krajišta. U jednoj predstavci iz 1541. Senjani su se žalili da Bišćani ne trpe ni desetinu nužde, siromaštva i dnevnih opasnosti kao oni te su potpuno isplaćeni i zadovoljeni. ${ }^{1536}$ Jasno je da situacija nije bila tako stabilna kao što su Senjani tvrdili, ali izvor, unatoč diskurzivim mehanizmima, pokazuje kako je Bihać promatran iz krajiškog očišta. Već dvije godine kasnije Bišćani su kralju Ferdinandu uputili molbu u kojoj su naveli da oni, kao najistureniji grad prema Osmanlijama, već mnogo godina gube svoje očeve, sinove, žene, djecu, živote (leib) i dobra, da je u ispražnjenom gradu preko 60 siromašnih udovica te da je mnogo njihovih sugrađana zarobljeno ili ubijeno. Ono malo preostalih građana, zajedno s vojskom nema druge hrane osim ,das ploss velld paw“ te zbog osmanske opasnosti ne mogu obrađivati polja. Budući da je zbog opasnosti obrada zemlje djelomično morala biti napuštena, molili su da im se za njihovu sigurnost osigura šest stražara. ${ }^{1537}$

Do sredine 1570-ih životni prostor stanovnika Bihaća već je toliko reduciran da je obavljanje poljoprivrednih radova doslovno značilo nositi glavu u torbi i rijetko se moglo izvoditi bez oružanje pratnje. Zato je u rujnu 1577. zapovjednik Hrvatske krajine Hans Auersperg smatrao mudrim u gradu ostaviti unajmljene strijelce mjesec dana duže od predviđenog jer su se, između ostalog, sadile ozimice i jer su trajali poljoprivredni radovi. ${ }^{1538}$ Situacija je bila takva da je i oružana pratnja morala sudjelovati u agrarnim aktivnostima i/ili prikupljanju drvne građe. Osmanlije su znali iskoristiti takve situacije pa su tako dva dana

1534 HR-HDA-995. Osobni fond Josip Adamček, kutija 18. III/63; ADAMČEK, Agrarni odnosi, 200; THALLÓCZY, HORVÁTH, Also-Szlavoniai, dok. XXVII, 354-355. Adamček navodi da je riječ o nedatiranom obračunu desetine iz druge polovice 15. stoljeća, ali u Thallóczyjevu i Horváthovu zborniku izvora datiran je 1520.

${ }^{1535}$ LASZOWSKI, HSKHDS, knjiga I, dok. 269, 261.

${ }^{1536}$ IBID., knjiga III, dok. 76, 74.

${ }^{1537}$ IBID., dok. 174, 166-168.

1538 SI AS 2, DSK, kutija 286, fascikl 164, Pobrežje, 27. 9.1577., 1r, rbr. 350. Hans Auersperg na predstavnike kranjskih staleža. 
napadali Ostrožac krajem srpnja 1576. kada je bihaćki kapetan Sebastian Lamberg s cijelom posadom bio u žetvi kod „broda“ odnosno brda Mač (Am Matsch ili Säbl) pored Brekovice. ${ }^{1539} \mathrm{Na}$ Maču se skupljalo i sijeno i drvo (hey vnnd holz), ali je i to postajalo sve riskantnije, kao što pokazuje slučaj s kraja studenog 1577. kada su građanstvo i posada namamljeni u zasjedu pri čemu je zarobljeno šestero ljudi, a jedna osoba ubijena. Osmanlije, odnosno njihovih oko 150-200 konjanika, nakon napada iz zasjede brzo su se povukli prema Cazinu. ${ }^{1540}$ Upitno je da li je koji dio Mača kod Brekovice bio u posjedu gradske općine, ali je i gradsko stanovništvo sudjelovalo u tamošnjim poljoprivrednim radovima.

Zbog permanentne opasnosti vojni povjerenik Jobst Langenmantel predložio je krajem 1587. da se na Pokoju podigne jedan čardak kako bi se tamo držala straža u vrijeme siječe drva ili kada bi se tamo obrađivala polja (in schnitt zeitten vnd wen sy sonnsten derselben ennden pauen vnd ansäen thete). Prema mišljenju Bišćana to bi godišnje uštedjelo nekoliko stotina rajnskih guldena za opskrbu. ${ }^{1541}$

Unatoč devastaciji i depopulaciji, čini se da je lokalno stanovništvo ipak raspolagalo većim količinama žitarica sve do samog pada pod osmansku vlast. To pokazuje i činjenica da su dvije godine prije osmanskog zauzimanja Bihaća građani vojnoj posadi (pro)dali na dug 138,5 kvarti ječma. ${ }^{1542}$ Dakle, agrarna proizvodnja na posjedima gradske općine održala se na relativno dobrom stupnju za krajište, sve do pada grada pod osmansku vlast u lipnju 1592. Da je bilo drugačije, u Bihaću ne bi moglo živjeti toliko brojno stanovništvo. Ova je činjenica važna za razumijevanje života na isturenom pograničju u periodu intenzivnih sukoba jer pokazuje da se i u takvom dramatičnom i nasilnom kontekstu mogla proizvesti veća količina žitarica. Bez obzira na ratne okolnosti, lokalno je stanovništvo i dalje nastavilo funkcionirati u reduciranom i modificiranom ritmu.

$\mathrm{Na}$ kraju, treba napomenuti da je lokalno stanovništvo dio svojih namirnica dobivalo iz rijeke Une, ribolovom ili lovom na rakove, kao što je to napomenuo kapetan Georg Kronschall krajem travnja 1565. kada je, dolazeći u grad, vidio 40-50 osoba koje su pod mostovima prema Zavalju (Saulle) lovili rakove pri vrlo niskom vodostaju. ${ }^{1543}$

\footnotetext{
${ }^{1539}$ SI AS 2, DSK, kutija 287, fascikl 164, Bihać, 20.7.1576., 1r, rbr. 562. Sebastian Lamberg na kranjske staleže i kranjske Verodneten.

1540 SI AS 2, DSK, kutija 286, fascikl 164, Bihać, 26.11.1577., 1r, rbr. 302. Sebastian Lamberg na kranjske Verordneten.

${ }^{1541}$ LOPAS̆IĆ, SHK, knjiga I, dok. CII, 152.

1542 ,vergleichen 138 1/2 quarten Waiz, so di Burger zu Wihitsch fergeliehen, vnnd Innne dieselb mit gelt wolten bezalen lassen“. HDA, Croatica, mikrofilm D-1918, br. 2, siječanj 1590; BUDAK, Uloga Bihaćke, 167.

${ }^{1543}$ SI AS 2, DSK, kutija 282, fascikl 162, Bihać, 25.4.1565., 1r, rbr. 146. Georg Kronschall na Herbarta Auersperga.
} 


\subsection{Trgovinska aktivnost bihaćke gradske općine}

Bihać je u srednjovjekovnom periodu nedvojbeno bio značajna postaja na važnoj trgovačkoj ruti koja je pratila tok rijeke Une, iako se, primjerice, u kancelarijskim i notarskim knjiga dalmatinskih komuna rijetko spominje. U kronikama i ljetopisima autora s dalmatinskog prostora mnogo se češće spominje u političkom i vojnom nego u gospodarskom kontekstu. ${ }^{1544}$ No, da je trgovina bila jedna od ključnih djelatnosti bihaćke gradske općine od njezinih samih početaka pokazuje i činjenica da je prilikom izdavanja Marijina privilegija 1262. navedeno da su bihaćki hospites i ranije posjedovali neka trgovačka prava. Mladen Ančić naglasak na gospodarskoj komponenti prilikom proglašenja slobodnim kraljevskim gradom interpretira kao dio šire političke zamisli ciljanog jačanja Bihaća kao kraljevskog uporišta kojemu temelj egzistencije nije agrarna djelatnost već trgovina i obrt. Zato kralj od Bišćana i nije zahtijevao nadoknadu za ustupljeno pravo trgovanja iako takvu nadoknadu plaćaju stanovnici svih slobodnih kraljevskih gradova. ${ }^{1545}$ Prema sadržaju gradskog privilegija, koji je 1279. potvrdio kralj Ladislav IV. Kumanac, Bišćani su bili izuzeti od bilo kakvih podavanja na prostoru od Jadranskog mora do rijeke Drave, odnosno na prostoru koji je očito bio primarni trgovački areal bihaćke gradske općine. ${ }^{1546}$ Nadalje, domaći i strani trgovci bili su oslobođeni plaćanja daća na gradskom trgu dok su Bišćani bili dužni plaćati samo carinu, tridesetinu, ako je uvozna roba prelazila vrijednost od pet maraka. ${ }^{1547}$ Nažalost, trenutno je nemoguće odrediti koji gradski trg izvori spominju.

U promatranom periodu trgovačka aktivnost bihaćke gradske općine morala je biti bitno reducirana zato što su Osmanlije zauzeli velike dijelove okolnog teritorija i prekinuli dotadašnji promet ključnim srednjovjekovnim komunikacijama, primarno Kraljevskom

\footnotetext{
1544 ANČIĆ, Bihaćki kraj, 195.

1545 ANČIĆ, Bihać - slobodna, 133-134; Katalin Szende navodi: „The function of the early centers primarily involved control/administration and church/cultic activity, and it was to these that economic activities were connected, often in a loose spatial arrangement. By contrast, the new model of urbanization took its direction from the economy, which was the driving force for settlement and determined how the other central functions arose“. SZENDE, The Urban Economy, 366.

1546 BUDAK, Uloga Bihaćke, 163; Mladen ANČIĆ, Bihaćki kraj, 204. Treba naglasiti da u gradovima na ugarskom prostoru nije, kao na zapadu, dominiralo obrtništvo već trgovina, a to se očituje u sadržaju gradskih privilegija u kojima se obrtnici rijetko spominju. PETROVICS, The role, 266.

${ }_{1547}$ ANČIĆ, Bihaćki kraj, 205. Intenzitet trgovanja s talijanskim poluotokom porastao je u kasnom srednjem vijeku, a dvije glavne rute za uvoz talijanske robe na današnjem hrvatskom prostoru bile su Senj i Zadar odakle je roba na sjever transferirana Kraljevskom cestom. Iako Katalin Szende smatra da je najvažnija postaja na toj ruti Zagreb, mislim da je opravdana pretpostavka da je izrazitu važnost imao i Bihać. Katalin SZENDE, Towns along the way. Changing patterns of long-distance trade and the urban network of medieval Hungary, u: Towns and communication. Volume 2; Communication between Towns, ur. Hubert Houben, Kristjan Toomaspoeg, Proceedings of the Meetings of the International Commision for the History of Towns (ICHT), Lecce, ut. Mario Congedo, 2011., 178.
} 
cestom uz rijeku Unu. No, treba naglasiti da se i u periodima najžešćih sukoba odvijala određena trgovačka aktivnost između habsburške i osmanske strane. ${ }^{1548}$ Razni proizvodi, osobito žito i stoka, dopremani su, a često i krijumčareni s osmanske strane jer, iako je Porta u određenim periodima uvodila zabrane na izvoz žita izvan granica države, lokalni su se spahije uz dozvolu sandžak-begova te sami sandžak-begovi znali oglušiti na te zabrane. ${ }^{1549}$ Slavonski sabor je 1537. donio odluku da se kapetanu Kraljevine moraju živi ili mrtvi predati oni koji živež i „ratnu zairu“ prodaju Osmanlijama te da se roba mora zaplijeniti. ${ }^{1550}$ Usprkos ratovanju, trgovačka aktivnost i dalje je nastavljena, iako u smanjenom intenzitetu i vjerojatno lokaliziranija. Iako je bihaćko gospodarstvo stradavalo prvenstveno zbog osmanske ekspanzije, izvori pokazuju da se to događalo i kao posljedica internih konflikta. Tako se 1543. gradski sudac žalio na probleme koje su imali s banom i na odnos vlasti prema njima što je, navodi sudac, ništa manje od Osmanlija ograničavalo njihovu slobodnu trgovinu i u konačnici preživljavanje. Žalili su se da ih s jedne strane uništavaju „Turci“ dok ih s druge strane blokiraju kršćani. ${ }^{1551}$

U nesigurnim ratnim okolnostima porasla je važnost stoke koju se ipak moglo lakše zaštiti od neprijateljskih napada, bez obzira na činjenicu da je upravo stoka, uz ljude i dragocjenosti, bila primarni ratni plijen. Stokom se na krajištu i u unutrašnjosti ekstenzivno trgovalo. Zato se ne radi o stilskoj figuri kada Ivan Lenković za ripačko stanovništvo 1550. navodi da posjeduje nešto stoke koja je „ostatak njihova siromaštva““ ${ }^{1552}$ U kolovozu 1591. bihaćka je posada napala Bunić u Krbavi i otela 1500 ovaca i 250 goveda, a to je bio velik plijen. ${ }^{1553}$ Bišćanima je također morala biti nanesena velika šteta kada im je krajem srpnja 1577. tristotinjak Krupljana otelo 50 konja i 180 komada krupne stoke. ${ }^{1554}$ Taj vid trgovačke aktivnosti Bišćana nastavio se i tijekom najintenzivnijih perioda sukoba. Već je navedeno da

\footnotetext{
${ }^{1548}$ I razni hrvatski plemići održavali su trgovinske/gospodarske veze s osmanskom stranom. Krajem travnja 1522. Osmanlije su navodno cijeli dan na Modruškom polju trgovali i „dijelili vjeru“ s Hrvatima, a čini se da su od Hrvata dobili vino, kruh i sl. Hrvatsko pučanstvo nije bježalo, a nisu se čuli ni pucnjevi za uzbunjivanje. THALLÓCZY, HODINKA, A horvát véghelyek, dok. LXI, 97. Relativno brzo nakon pada Udbine 1527. pristižu i optužbe da Krsto Frankopan trguje s tamošnjim Osmanlijama, a isto je nešto kasnije u Pounju činio Nikola Zrinski. Osmanski podanici slobodno su trgovali na sajmu u Gvozdanskom. KRUHEK, Krajiške utvrde, 87. Nadalje, zna se da su se trgovinom manjeg intenziteta bavili osmanski zarobljenici koji su se, barem ponekad, poprilično slobodno kretali hrvatskim i unutrašnjeaustrijskim teritorijem. Središnje vlasti nastojale su eliminirati takvu praksu jer su opravdano strahovale da će neprijatelj na taj način doći do vrijednih informacija. HDA, Croatica, kutija 1, svežanj 2, 5.2.1579., 73-74. Tracy također navodi da su u Hrvatskoj i Bosni trgovci posjećivali sajmove čak i u periodima ratovanja. TRACY, Balkan Wars, 4.

${ }_{1549}$ JURIN-STARČEVIĆ, Osmanski krajiški, 101.

${ }^{1550}$ ERCEG, Šišićeve biljeske, 421.

${ }^{1551}$ LASZOWSKI, MHSKHDS, knjiga II, dok. 174, 167-168.

${ }^{1552}$ KRUHEK, Krajiške utvrde, 169.

${ }^{1553}$ LOPAŠIĆ, Bihać, 76.

${ }^{1554}$ LOPAŠIĆ, SHK, knjiga I, dok. XVI, 24.
} 
je oko 1570. „opchyna warossa byhachkoga“ poslala Franka Kaptolovića zagrebačkom sucu Teletiću u vezi (vjerojatno povrata) stoke njegova pokojnog brata Mikule dijaka. ${ }^{1555}$ Trgovalo se i stokom koju su u grad dopremali zarobljenici za otkup, kao što pokazuje već navedeni spor između kapetana Hörnera i bihaćkih građana s kraja 1587. kada su se građani žalili da im kapetan ne dozvoljava pravo prvokupa takve robe. Krajiški povjerenik Jobst Langenmantel tada je konstatirao da je prikladno da kapetan i podređeni vojnici imaju pravo prvokupa jer građani tu stoku otkupljuju i kasnije prodaju njemačkim vojnicima po dvostrukoj cijeni. ${ }^{1556}$

Dakle, vojna je posada predstavljala stalno tržište za lokalno stanovništvo. Riječ je o tipičnoj ratnoj ekonomiji čiji je opseg teško utvrditi na temelju postojećih izvora, ali je unatoč tome sasvim jasno da je ta aktivnost zauzimala važno mjesto na gospodarskom horizontu pograničja. Već je navedeno da je bihaćki kapetan u proljeće 1573. po nepovoljnoj cijeni morao prodati neke svinje koje je u Bihać kao otkup dopremio zarobljenik njegova šogora (schwager), a koje je kapetan namjeravao poslati „van“ (hinauss - dakle, u unutrašnjost) i to kako bi gladnim i neisplaćenim njemačkim vojnicima mogao doznačiti 30 krajcara po osobi. $^{1557}$

Unatoč osmanskoj prijetnji, trgovina generalno nikada nije potpuno prestala iako se očito radilo o sitnijoj trgovini (crammer) koja se primarno odnosila na prodaju hrane i drugih potrepština vojsci. Prisutnost vojnih postrojbi, osobito onih koje nisu imali stalno boravište u gradu i okolici, predstavljala je dobru priliku za zaradu samim Bišćanima, ali i regionalnim trgovcima. Može se ponoviti izjavu Matiascha Morija s početka svibnja 1566. da oni sav novac koji im se dostavi moraju proslijediti trgovcima za dugovanje pa im ništa ne ostaje ni od budućih isplata. ${ }^{1558}$

Izgladnjela i neplaćena posada često je ovisila o kupovini na dug od bihaćkih građana. No, ni takva trgovina nije uvijek bila moguća jer je poljoprivredna proizvodnja stradavala zbog osmanskih napada i klimatskih uvjeta te zato što je potražnja očito bila velika. Tako je u travnju 1573. bihaćki opskrbnik Burckhardt Saloman zdvajao nad gladnim njemačkim vojnicima koje nema odakle opskrbiti. Od građana se tada ništa nije moglo otkupiti jer sve što su imali već je proslijeđeno „novim uskocima“, a bio im je već dosta i dužan te nije znao kako

\footnotetext{
${ }^{1555}$ KUKULJEVIĆ SAKCINSKI, Acta Croatica, dok. 39, 333.

${ }^{1556}$ LOPAŠIĆ, $S H K$, knjiga I, dok. CII, 151.

1557 SI AS 2, DSK, kutija 286, fascikl 164, Bihać, 17.4.1573., 1r-1v, rbr. 155-156. Paul Sheyer na Jobsta Josepha Thurna.

${ }^{1558}$ SI AS 2, DSK, kutija 286, fascikl 164, Bihać, 6.5.1566., 1r-1v, rbr. 41-42. Matiasch Mori, prijevod s hrvatskog.
} 
će i to podmiriti. ${ }^{1559}$ I bihaćki kapetan tada je naveo da će posada teško išta kupiti jer je građanima propao urod žitarica. ${ }^{1560}$ Vjerojatno se radi o posljedicama jakih zima 1570./1571. te 1572./1573. koje su rezultirale i pojavom gladi na području susjednoga Kliškog sandžaka. To je nesumnjivo moralo imati utjecaj i na intenzitet osmanskih provala sredinom 1570-ih na hrvatskom prostoru. ${ }^{1561}$

U trgovini su sudjelovali i regionalni trgovci koji su u grad dolazili unatoč velikoj opasnosti i riziku, ponekad s opskrbnim konvojima, a ponekad u periodu između opskrbnih konvoja. Prodavali su alkoholna pića, vino i rakiju za gotovinu, a znali su im se pridružiti i neki dubovački građani. ${ }^{1562}$ Uz trgovce s hrvatskog odnosno regionalnog prostora, u Bihaću i na promatranom prostoru djelovali su i trgovci s osmanskog prostora. Iako nema mnogo izvora koji pokazuju kakav je bio intenzitet prekogranične trgovine u promatranom periodu, sačuvan je jedan prvorazredni izvor s početka 1577. koji pokazuje kako je to moglo izgledati. Naime, nakon što je nastupilo habsburško-osmansko primirje $1577 .{ }^{1563}$, bihaćki kapetan Sebastian Lamberg javlja 10. veljače da su „die Turckhen“ iz Krupe, Cazina i tamošnjih utvrda „na vjeru“ (auff glauben) stigli „do oraha“ kod Ripča gdje se trgovalo. Peta dana kasnije uputili su se u Ostrožac gdje su trgovali na zalog (Pfantiert) i opskrbili se drvom. U Ostrožac su pristigli i Cazinjani, a sve je proteklo u miru i bez ikakvog sukoba. Dva dana kasnije u Ripač su došli trgovati Osmanlije s Belajskog polja, a među njima i vojvoda iz Srba te više drugih pograničnih aga. Navedeni Osmanlije naglašavali su predanost miru, ali su ozbiljno tražili da se oslobode petorica Vlaha i stražara koje su Ripčani i Sokolani (među habsburškim vojnicima navodi se Mate vojvoda - Mathä Vayuoda) nedavno zarobili kod Nebljuha prijeteći da će se inače brzo vratiti i osvetiti. Iako su im se Ripčani i Sokolani ispričavali/kontrirali time što su Osmanlije nedugo prije toga u Ripču i Sokolu zarobili nekoliko osoba, ipak su izjavili da će se ravnati prema odluci zapovjednika Hrvatske krajine Hansa Auersperga jer se zbog osmanske prijetnje ne može izaći iz grada ni po drva ni po druge potrepštine. No, Lamberg na kraju zaključuje da „Turci“ koji su bili pod Ripčem nisu imali daljnje zahtjeve, ali nisu bili skloni ni čarkanju, odnosno „lomljenju kopalja“. ${ }^{1564}$

\footnotetext{
${ }^{1559}$ SI AS 2, DSK, kutija 286, fascikl 164, Bihać, 15.4.1573., 1r, rbr. 152. Burckhardt Saloman na Jobsta Josepha Thurna.

${ }^{1560}$ SI AS 2, DSK, kutija 286, fascikl 164, Bihać, 17.4.1573., 1r-1v, rbr. 155-156. Paul Sheyer na Jobsta Josepha Thurna.

${ }^{1561}$ JURIN-STARČEVIĆ, Osmanski krajiški, 102.

${ }^{1562}$ LOPAS̆IĆ, SHK, knjiga I, dok. CII, 149.

${ }^{1563}$ Novo primirje ratificirano je u siječnju 1577. TRACY, Balkan wars, 252.

${ }^{1564}$ SI AS 2, DSK, kutija 205, fascikl 125b, Bihać, 20.2.1577. Sebastian Lamberg. Izvještaj je umetnut u spis pod datumom 26. veljače 1577. u kojem o istoj temi nadvojvodu izvještava Hans Auersperg.
} 
Istodobno, Auersperg javlja nadvojvodi Karlu da Osmanlije ne samo da poštuju primirje već da njihovi zapovjednici i vojnici često dolaze u pogranična mjesta i unutrašnjost, a osobito u važna mjesta poput Bihaća, Hrastovice i Ripča, „na vjeru razgovarati“ (auf glauben sprachzuhalten) te trgovati stokom i drugom robom (vnd andern Wahren). Jednako tako, Auersperg navodi da „naši“, dakle habsburška strana, slobodno prolaze osmanskim teritorijem, a navodi da čak odlaze u lov, pri čemu nema sukoba ako se susretnu s Osmanlijama ili Vlasima. Osmanlije su čak pustili nekoliko zarobljenika kao simboličan znak predanosti miru. $^{1565}$

Dakle, ovaj zanimljiv slučaj pokazuje kako su se brzo nakon smirivanja otvorenih sukoba mogle uspostaviti normalnija komunikacija i određena gospodarska aktivnost iako se postavlja pitanje je li uopće prestajala tijekom ratovanja. Naime, na pograničju su unatoč sukobima i destrukciji djelovali i profesionalni trgovci čija aktivnost očito nije bila sporadične naravi, već je implicirala uhodan posao s razvijenom mrežom klijenata i suradnika pa su, kao što je već rečeno, upravo takve osobe predstavljale dragocjene izvore informacija o neprijateljskim namjerama. Iako se u izvorima i literaturi uglavnom spominju osobe s dalmatinskog ili slavonskog prostora, takvih je pojedinaca i trgovačkih mreža bilo i na unskom prostoru. Upravo je trgovac pod pseudonimom Sveti Franjo (S. Franncisckh) krajem veljače 1566. dostavio jedan špijunski izvještaj u kojem navodi da je trgovao na nekoliko mjesta u „Turskoj““, a zbog stoke i žitarica (getraid) došao je sve do Krupe na rijeci Uni. ${ }^{1566}$ Treba naglasiti da tada nije prošla ni godina dana od osmanskog osvajanja Krupe.

Jedan od važnijih opskrbnih kanala bila je i vlaška trgovačka aktivnost u gradu. Iako su i ovom aspektu izvori skromni, u predstavci, koju je kompletna vojna struktura Bihaća uputila u rujnu 1581. u vezi teškoga egzistencijalnog stanja posade, jasno stoji da su im Vlasi ranije dopremali raznu robu i stoku pomoću koje su se mogli održati, ali su tu praksu nadređeni prekinuli i najstrože zabranili pa trpe veliku nestašicu. Može se pretpostaviti da je riječ o Vlasima s osmanskog prostora te da su zbog toga nadređeni strogo zabranili tu trgovačku aktivnost.

Zbog posljedica osmanske ekspanzije, odnosno manje-više permanentnoga ratnog stanja i opće nesigurnosti na hrvatskom prostoru, ranije nedvojbeno izrazito važna trgovačka aktivnost bihaćke gradske općine degradirala je. Ključne prometnice izgubile su na važnosti, mnoga su sela i trgovišta uništena, procesi ekstenzivne depopulacije uzeli su maha, a sve je to sasvim izmijenilo tradicionalni trgovačko-gospodarski okvir. Međutim, ipak nije potpuno

\footnotetext{
1565 SI AS 2, DSK, kutija 205, fascikl 125b, Hoffenbach, 26.2.1577., 1r.

${ }^{1566}$ SI AS 2, DSK, kutija 415, fascikl 285, sine loco, 23.2.1566., rbr. 21
} 
uništilo trgovačku djelatnost gradske općine i gradske posade. Bišćani su i dalje trgovali izvan matičnoga lokalnog prostora, očito primarno stokom što se uklapa u okvir ratne ekonomije u kojem je stoka bila izrazito važna u gospodarskom pogledu. Stoka je gonjena i do Zagreba, a vjerojatno i dalje, a to pokazuje da se nije radilo samo o trgovini lokalnoga karaktera. U grad su također stizali i profesionalni trgovci te Vlasi koji su potjecali s osmanskog prostora ili na njemu djelovali, a to demonstrira kompleksnost života na pograničju na kojem su zaraćene strane ponekad međuovisne u egzistencijalnom pogledu. Važan izvor prihoda bihaćkim stanovnicima bila je brojna gradska posada jer je dio tih vojnika bio prisiljen opskrbljivati se na lokalnom tržištu. U toj (sitnoj) trgovini participirali su i trgovci koji su s opskrbnim konvojima pristizali u grad te građani iz Dubovca, a na isturenom krajištu djelovali su i profesionalni trgovci koji su svoju djelatnost obavljali na širem regionalnom prostoru. Izvori dakle pokazuju da je na isturenom pograničju u određenoj mjeri preživjela trgovačka aktivnost $\mathrm{u}$ promatranom periodu te da je Bihać bio jedan o njezinih centara.

\subsection{Opskrba vojne posade s lokalnih posjeda}

Dakle, vojna posada, odnosno vojnici koji u gradu nisu imali svojih posjeda, ovisila je o krajiškome opskrbnom sustavu. Takvi vojnici kao, primjerice, jednom prilikom navedeni stražari u šumama oko Bihaća i haramije koji su ,izvana“ namješteni u Bihaću, nisu imali ni oranica ni polja (akher noch felder) te su potpuno ovisili o krajiškoj opskrbi. ${ }^{1567}$ Posada se generalno često morala zaduživati na lokalnom tržištu ili kod samih građana i/ili regionalnih trgovaca, a dio potreba osiguravan je ratnom ekonomijom (pljačkom, otkupom itd.). Žitarice su često uzimane na dug pa je u nekim slučajevima, nakon unošenja žita u grad, građanima odmah trebalo predati više od polovice unesenog kako bi im se vratilo posuđeno ili dugovano. $^{1568}$

Razni apeli očajne posade već su više puta prezentirani, ali vrijedi ipak spomenuti da je u srpnju 1581. kompletna vojna posada (zapovjednici, časnici, njemački i hrvatski vojnici, konjanici i pješaci) molila da im se pomogne novcem i živeži navodeći da više od polovice vojnika leži bolesno i polumrtvo. ${ }^{1569}$ Nešto ranije, krajem ožujka 1578., Ivan Štrbac (Sterbac) iz Bihaća piše Hansu Auerspergu, „chapittanu generallu chraine herua(c)che i primorsche“, da

\footnotetext{
${ }^{1567}$ LOPAŠIĆ, SHK, knjiga I, dok. CII, 147.

${ }_{1568}$ SI AS 2, DSK, kutija 246, fascikl 145, 1574., 2v, rbr. 176. Herbart Auersperg, primatelj nije naveden.

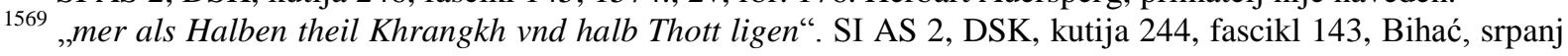
1581., 2r, rbr. 508. Upućeno kranjskim Verordneten.
} 
pošalje „odlucak i pinezi““ za vojsku koja je stacionirana u gradu. Budući da ne mogu izaći izvan grada, Štrbac je od bihaćkoga kapetana namolio 62 kvarti živeži (profuntta). ${ }^{1570}$

Uz veliku gradsku posadu, u Bihaću su prema potrebi namještane i druge vojne postrojbe pa je broj vojnika koje je trebalo opskrbiti mogao biti poprilično visok. Krajem srpnja 1565. u Bihaću se našlo čak 900 vojnika - konjanici i pješaci iz posade, kranjski te koruški unajmljeni strijelci. Glavni opskrbnik Gallenberg smatrao je da za takvu silu mjesečno treba osigurati 450 metliških vedara pšenice (Metlinger Schaff weiz). Budući da, uz 150 tovara živeži koje je također poslao u Bihać, opskrbnik nije raspolagao s više od 600 metlinških vedara žitarica, uključujući 25 volova koje je dao goniti u grad, procjenjivao je da hrane ima za samo pet tjedana. Još je morao i posuditi novac od ratnog blagajnika. Tražio je da se kupi još živeži te izrazio zabrinutost da će se za eventualne probleme ponovno kriviti njega. Od Bišćana je planirao nešto kupiti, ali je smatrao da će to biti malo. ${ }^{1571}$ Već je spomenuto da je, uz vojsku, morao opskrbiti i preko 500 udovica i njihove djece koji nisu posjedovali ni oranice ni vrtove. Mjesečni trošak unosa pšenice i samara iznosio je 900 talira, a volova i stoke (Oxen vnd Vieh) 1070 talira pa nužna opskrba za navedeni period, prema Gallenbergovoj procjeni nije moguća ispod 12000 talira. ${ }^{1572}$ To su za ono vrijeme golemi iznosi.

Treba naglasiti da su kraljevske utvrde, odnosno u ovom slučaju i krajiške, uobičajeno raspolagale vlastitim posjedima s kojih se uzdržavala vojna posada. Utvrde na ugarskom prostoru imale su podanike, oranice, pašnjake, ubirala se desetina te su se sastavljali urbari i obračunavali godišnji prihodi. ${ }^{1573}$ Slično je bilo i na hrvatskom prostoru. Nedugo nakon što je izabran za kralja, Ferdinand je savjetovao plemićima da središnjoj vlasti predaju pogranične gradove koje nisu bili u stanju braniti, ali zajedno s njihovim pripadajućim posjedima. ${ }^{1574}$ Iako je Kruhek u pravu kada tvrdi da je hrvatskom plemstvu taj prijedlog „neprihvatljiv toliko i neobično smion i drzak.“, sa strateškog aspekta sasvim je opravdan jer je obrana pojedine utvrde uvelike ovisila o pripadajućim posjedima. ${ }^{1575}$ Jedan od ključnih razlog imenovanja Petra Keglevića bihaćkim kapetanom bila je tendencija da se za obranu Bihaća i Ripča iskoriste prihodi s posjeda topuske opatije. Keglević se stoga prilikom postavljanja za

\footnotetext{
${ }^{1570}$ BOJNIČIĆ, Izvješća, dok. XL, 95.

1571 SI AS 2, DSK, kutija 414, fascikl 284, Črnomelj, 24.7.1565., 1r, rbr. 1097. Glavni opskrbnik Gallenberg na predstavnike kranjskih staleža.

${ }_{1572}$ SI AS 2, DSK, kutija 414, fascikl 284, Črnomelj, 24.7.1565., 1r-1v, rbr. 1097-1098. Glavni opskrbnik Gallenberg na predstavnike kranjskih staleža. Prema Jeleni Mrgić, za prehranu jedne osobe na godišnjoj je razini bilo potrebno osigurati 300 kilograma hrane. MRGIĆ, Wine or Raki, 629.

1573 ŠTEFANEC, Država ili ne, 442.

${ }^{1574}$ KRUHEK, Krajiške utvrde, 81.

${ }^{1575}$ IBID., 81, fusnota 81.
} 
gubernatora topuske opatije 1533. obvezao njezinim prihodima tri godine uzdržavati posade u Bihaću i Ripču. ${ }^{1576}$

$\mathrm{U}$ predosmanskom periodu kraljevskom kaštelanu u Bihaću bile su podređene plemenite općine Vrtek, Su(d)čani i Omršal. ${ }^{1577}$ No, njih je još kralj Žigmund (vladao 1387.1437.) oslobodio sudbenosti banu i bihaćkom kaštelanu te ih podredio neposredno Zagrebačkoj županiji. ${ }^{1578}$ Kraljevskom kaštelanu u Bihaću također su bili podređeni plemići Humljani koji su se već 1531. žalili da nemaju mogućnosti sami stražariti zato što su svi odrasli muškarci ili poginuli u borbi ili zarobljeni. ${ }^{1579} \mathrm{U}$ srednjovjekovnom periodu podređena mu je i plemićka općina Berišić oko Izačića. ${ }^{1580}$ Kao što je ranije navedeno, pod kapetanijom su se u promatranom periodu nalazili podanici u selima Omršal, Suče i Turija dok su Golubić i Ribić spadali pod utvrdu/vlastelinstvo Sokol koje je ionako većinu vremena bilo pod zapovjedništvom bihaćkoga kapetana.

Ključni posjed Bihaćke kapetanije bila je upravo utvrda Sokol s pripadajućim posjedima u okolici grada te prihodima od desetine na posjedima navedene utvrde koju su bihaćki kapetani zakupili od topuskog opata. Već od sredine 14. stoljeća vojna posada utvrde Sokol uzdržavala se prihodima velikih posjeda u bihaćkom polju te s posjeda Brekovice i Omršla koji su smješteni s lijeve obale rijeke Une između Bihaća i Ostrožca. ${ }^{1581}$ Štoviše, na temelju jedne presude sokolskoga kaštelana iz 1380., Ančić je zaključio da je cijeli posjed „Bihaćkog polja“ služio za uzdržavanje posade u Sokolu. ${ }^{1582}$ Posjed se još i povećao nakon napuštanja utvrde Peći početkom 15. stoljeća kada je imanje, s kojeg se pećka posada uzdržavala, pripojeno Sokolu. ${ }^{1583}$ Kralj je 1510. vlastelinstvo predao obitelji Orlovčić u čijem se posjedu nalazi do pogibije Grgura Orlovića na Mohačkom Polju 1526., a onda ga na upravljanje preuzima njegov adoptivni brat Petar Kružić. ${ }^{1584}$ U darovnici kralja Ferdinanda Petru Kružiću s početka 1529. navodi se da je posjed opustošen. ${ }^{1585}$ No, to nije moralo biti

\footnotetext{
${ }^{1576}$ Josip ADAMČEK, Glina i njezina okolica u srednjem vijeku. u: Glina. Glinski kraj kroz stoljeća, ur. Drago Roksandić i Mira Kolar-Dimitrijević, Zagreb, 1988., 16.

${ }^{1577}$ LOPAŠIĆ, Bihać, 22.

${ }^{1578}$ IBID., 45. Tu odluku potvrdio je i kralj Ferdinand 1551. Ivan BOJNIČIĆ, Kraljevske darovnice odnose se na Hrvatsku. Iz kraljevskih registraturnih knjiga „Libri Regii“, Vjesnik Kr. Hrvatsko-slavonsko.dalmatinskoga Zemaljskoga arkiva, god. VIII, Zagreb, 1906., dok. CL, 29.

${ }^{1579}$ LASZOWSKI, HSKHDS, knjiga II, dok. 27, 19; LOPAŠIĆ, Bihać, 64.

${ }^{1580}$ IBID., 139.

${ }^{1581}$ ANČIĆ, Bihaćki kraj, 198-199

1582 IBID., 211.

${ }^{1583}$ IBID., 199-200.

${ }^{1584}$ Ivan JURKOVIĆ, Prozopografska analiza „Teštamenta“ gospe Jeleni, sestri pokojnoga kneza Petra Kružića, u: Raukarov zbornik, ur. Neven Budak, FF Press, Zagreb, 2005., 384.; LOPAŠIĆ, Bihać, 273.

${ }^{1585} \mathrm{U}$ regesti kraljevske darovnice kojom daje na upravu „castrum Zokol cum suis pertinenciis nadopisano je Hec bona in consilio ad suplicacionem Petri Krwsyth sunt donata, que sunt in regno Croacie et desolata ".
} 
permanentno stanje jer su depopularizirani posjedi mogli biti rekolonizirani, a devastirano gospodarstvo obnovljeno, kao što uostalom pokazuje upravo registar prihoda i desetine Sokola iz 1548. Štoviše, postavlja se pitanje je li vlastelinstvo Sokol uopće potpuno opustjelo.

Nakon Kružićeve smrti pod Klisom 1537. vlastelinstvo je naslijedio njegov šogor, ugledni slavonski plemić Juraj Vragović. ${ }^{1586}$ No, vlastelinstvo Sokol ubrzo je dospjelo pod upravu bihaćkoga kapetana jer Juraj Vragović 1540. moli kralja da mu se vrati Sokol (castro meo Zokol vocato, in Croacia habito) koji mu je uz dozvolu samog kralja zauzeo bivši bihaćki kapetan Erasmo Thurn. ${ }^{1587}$ Bihaćki kapetan Mert Gall te iste godine zaista u kraljevo ime Sokol predaje Jurju Vragoviću, ali pod uvjetom da prihodima i proizvodima s tog vlastelinstva uzdržava gradsku posadu. Vragović se obvezao sa svojim podanicima obrađivati oranice i dovoziti vino u bačvama koje je trebao sam načiniti. ${ }^{1588}$ Nadalje. među kserokskopijama gradiva iz Štajerskoga zemaljskog arhiva nalazi se i koncept carske naredbe od 28. svibnja 1545. u kojoj stoji da se treba provesti dogovor s Vragovićem, isplatiti mu 150 rajnskih guldena te u sljedeće četiri godine po 100 rajnskih guldena. Ta svota trebala se primarno isplaćivati iz prihoda tridesetnice u Trstu. ${ }^{1589}$

Kralj Ferdinand uzeo je 1550. vlastelinstvo Sokol u zakup na šest godina - i to opet primarno radi opskrbe Bihaća. Iznos godišnje zakupnine iznosio je 100 zlatnih ugarskih florena, a isplaćivan je iz prihoda tridesetnice u Nedelišću, a ne tridesetnice grada Trsta kao $u$ vrijeme Vragovića. ${ }^{1590} \mathrm{Na}$ koncu je početkom listopada 1553. kralj Ferdinand sada pak od Ladislava Kerechenyja potpuno preuzeo vlasništvo nad Sokolom, zajedno sa svim pripadnostima, koristima i pravima (singulis attinetijs, vtilitatibus et juribus suis). ${ }^{1591}$ Kerechenyjima je obećano 150 rajnskih guldena godišnje sve dok im se ne nađe drugi posjed vrijednosti Sokola. ${ }^{1592}$ Posjed Sokol teško je stradao u napadu početkom 1561. kada su Osmanlije pustošili oko Sokola, Golubića, Ripča i Privelice. Pod Sokolom je spaljeno 9, a u Ripču 1 kuća. Također, zarobljeno je 60 žena i male djece te četvero muškaraca. ${ }^{1593}$

Utvrda Sokol bila je izrazito važna i za opskrbu i sigurnost Bihaća. U jednom izvoru iz 1580. stoji da bi nastala velika pogibelj za Bihać u slučaju da Osmanlije zauzmu Sokol jer bi

Bogoljub KRNIC, Darivanja kralja Ferdinanda I. za Hrvatsku u god. 1527. do 1529., Vjesnik Zemaljskog Arkiva, 10, 1908, dok. 16, 6 .

${ }_{1586}$ JURKOVIĆ, Prozopografska analiza, 383. Autor je na kraju rada prezentirao i rodoslovlje obitelji Vragović.

1587 ,quod magnificus Erasmus de Turri, alia capitaneus Byhygiensis a me sub assecuracione maiestatis vestre regie occupauerat“. LASZOWSKI, HSKHDS, knjiga III, dok. br. 44, 43.

${ }^{1588}$ N. KLAIĆ, »Ostaci ostataka«, 273.

${ }^{1589}$ HDA, Militaria, kutija 2, 28.5.1545.

1590 JURKOVIĆ, Prozopografska analiza, 384-385; LASZOWSKI, HSKHDS, knjiga III, dok. 314, 364-366.

${ }^{1591}$ LOPAŠIĆ, SHK, knjiga I, dok. X, 17.

1592 LOPAS̆IĆ, Bihać, 219.

${ }^{1593}$ IBID., 220. 
tada mogli zarobljavati stanovništvo ,zwisen waser“ (očito na unskim otocima), a kada bi to stanovništvo bilo protjerano, ne samo da se ne bi moglo ništa prevoziti preko rijeke već ne bi bilo ni hrane. ${ }^{1594} \mathrm{~S}$ tih „mnogobrojnih otoka“ (vil Insel) između Bihaća i Ripča, koji su naseljeni hrvatskim seljacima i neplaćenim vojnicima (Crabatischen Volkh), opskrbljivan je Bihać raznom živeži sve do pada Bihaća pod osmansku vlast. ${ }^{1595}$ Bez obzira na ratne (ne)prilike i život u okruženju, oni su i prije pada grada imali plodne vrtove (vollträchtigen Gärten), polja, vinograde i druge živežne namirnice (victualien). ${ }^{1596}$ Međutim, čini se da se tada radilo o tek dvama preostalim selima jer Andreas Auersperg početkom veljače javlja da, ako Osmanlije obnove Ripač, dva se preostala sela „im Wasser“ između Ripča i Bihaća, odakle se Bišćani najbolje opskrbljuju, neće moći održati nijedan sat. ${ }^{1597}$ Vjerojatno se radilo o Golubiću i Ribiću, selima pod Sokolom koja su se nalazila na otokama.

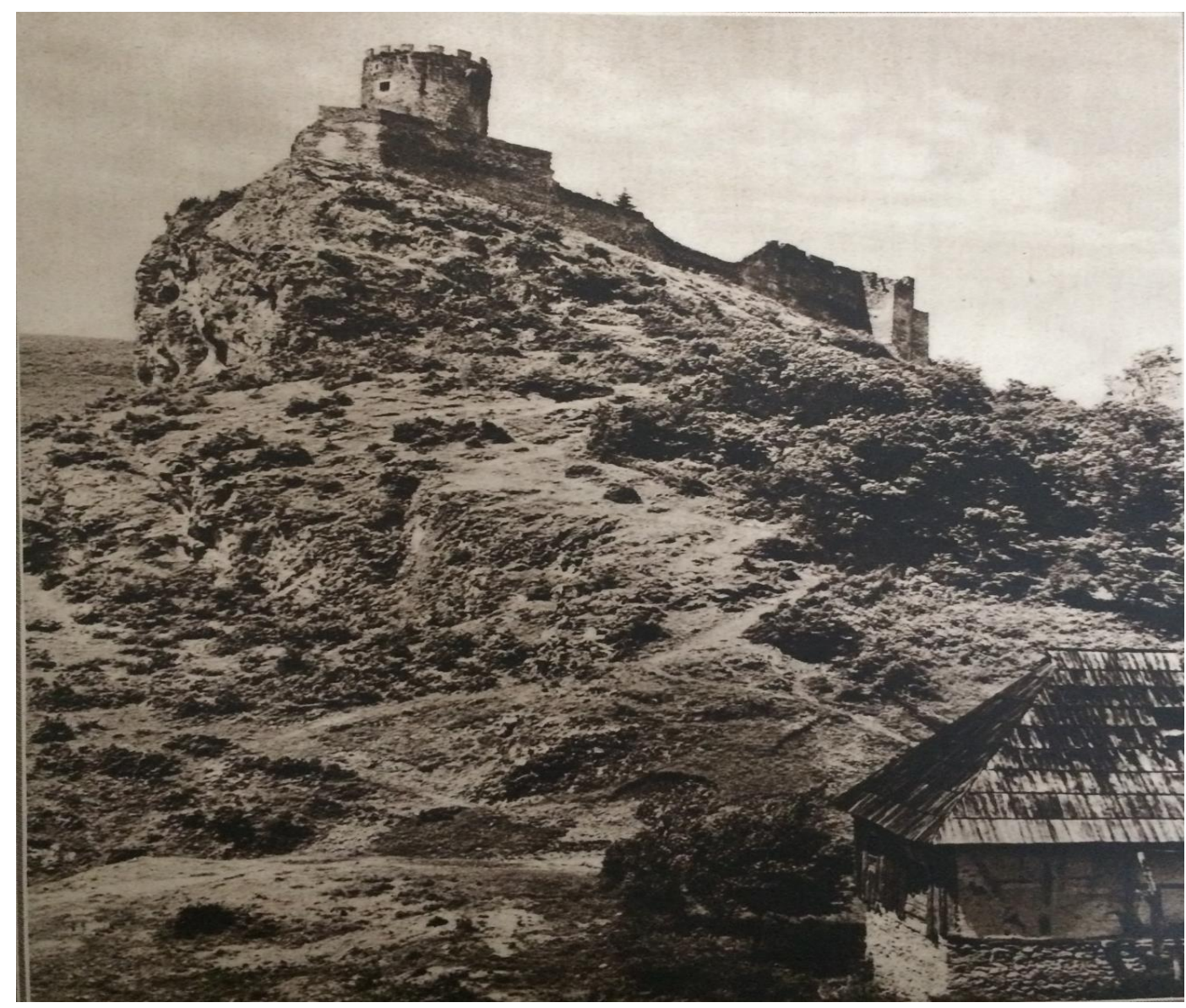

Slika 40. Sokol na naslovnici zagrebačkog časopisa „Svijet“ iz studenog $1928 .{ }^{1598}$

\footnotetext{
${ }^{1594}$ SI AS 2, kutija 202, fascikl 124a, Bihać, 9.7.1580.,1r.

1595 SI AS 2, DSK, kutija 285, fascikl 163, Beč, 5.3.1592., 2r-2v, rbr. 1038-1039.

1596 SI AS 2, DSK, kutija 285, fascikl 163, Graz, 10.2.1592., 2r, rbr. 1048. Dvorsko ratno vijeće u Grazu na nadvojvodu Ernesta.

${ }^{1597}$ SI AS 2, DSK, kutija 285, fascikl 163, Karlovac, 4.2.1592., 2v, rbr. 1053.

${ }^{1598}$ Svijet, godina 3, knjiga 6, broj 21 od 17.11.1928. Ćasopis u posjedu autora.
} 
Što se tiče kapaciteta agrarne proizvodnje s tog vlastelinstva, zna se da je 1520 . desetina žita na posjedima oko Sokola iznosila 80 kvarti, a da je do 1548. taj iznos još malo porastao - na 89 kvarti žita. ${ }^{1599}$ Dakle, bez obzira na osmanske napade, činjenicu da je krajem 1520-ih opisan kao desolata i promjene vlasnika vlastelinstva, iznos desetine je u promatranom periodu porastao.

Prema navedenom popisu ,prihoda utvrde Sokol“ iz 1548. (vidi prilog 4) Sokolu su pripadali podanici samog Sokola te sela Golubić i Ribić dok se za sela Omršal i Sučani, te barem 13 podanika u selu Turija, navodi da pripadaju Bihaćkoj kapetaniji. Podanici koji su potpadali pod Sokol bili su dužni davati „darove“ o Božiću i to svaki jednu pogaču i jednu svinjsku lopaticu (rippraten), a o Uskrsu svaki jednu pogaču i šest jaja. O Miholju je svaki morao davati jednu pogaču i jednu kokoš. Također, morali su obrađivati nekoliko ackhr zemlje te raditi „što je potrebno“ u vrtu/vrtovima (Garten) te kositi i prevoziti sijeno. Sela Golubić i Ribić bila su dužna o Miholje davati porkulabu u Ripču 6 krajcara te prevoziti porkulaba, bihaćkoga kapetana i vojnike preko rijeke Une. Stanovnici Omršla i Suča morali su o Miholje davati 10 rajnskih guldena, a podanici iz Turije 3 rajnska guldena i 30 krajcara. ${ }^{1600}$ Što se pak zakupa desetine na navedenim posjedima tiče, bihaćki je kapetan držao tu desetinu u zakupu još od ranih 1530-ih. Naime, još početkom lipnja 1531. kapetan Erasmo Thurn molio je kralja Ferdinanda da piše topuskom opatu da desetinu vina i žitarica (wein vnd traidzehendt), koja je prikupljana s posjeda pored Bihaća, a godinama se daje $\mathrm{u}$ zakup, prepusti njemu koji će isplaćivati zakupninu kako i pristoji. Thurn je apostrofirao da će na taj način biti dobro opskrbljeni Bihać, odnosno bihaćka posada. ${ }^{1601}$ Očito se to vrlo brzo i realiziralo.

Desetina se prikupljala u pšenici, prosu, zobi, painstockhu i vinu, a iznosi pokazuju da je vlastelinstvo 1548. još uvijek relativno dobro funkcioniralo. Tako je pod Sokolom, u Golubiću, Ribiću, Omršlu, selu Suče i Turiji ukupno prikupljeno 149,5 kvarti pšenice, 153 kvarti prosa, 16 kvarti zobi, 6 painstockha te 250,5 vedara vina. Uočljivo je da se proizvodilo dosta vina pod Sokolom i oko sela Ribić dok se oko Golubića i Turije uopće nije proizvodilo. Zob se pak uzgajala samo oko Ripča. Dominirale su kulture pšenice i prosa.

Količina popisanog iskazivana je $u$ domaćim mjerama jer se $u$ popisu navodi da je razlika između bihaćkog i bečkog vedra sasvim mala te da tri bihaćke kvarte čine otprilike dva ljubljanska stara. Navedene su i cijene za vino, pšenicu i proso dok se svinjske lopatice,

\footnotetext{
${ }^{1599}$ BUDAK, Uloga Bihaćke, 166.

${ }^{1600}$ ÖeStA, HKR, Hoffinanz in Ungarn, kutja 5, Rote, nr 2 fol. 126-135.

${ }^{1601}$ LASZOWSKI, HSKHSD, knjiga II, dok. 57, 44.
} 
pogače, kokoši i jaja nije prodavalo. Vino je ranije stajalo oko 20 krajcara, a sada je, budući da je prošle godine loše rodilo, stajalo preko 30 krajcara. Jedna bihaćka kvarta pšenice uobičajeno je prodavana po 20, a sada za 25-30 krajcara. Proso je pak dobro rodilo pa se bihaćka kvarta prodavala za 16-20 krajcara, a painstockh za oko 30 krajcara. Nadalje, izgleda da je tek parcijalno točna tvrdnja Josipa Adamčeka da je prikupljeno namijenjeno direktnom uzdržavanju bihaćke posade. ${ }^{1602}$ Čini se da su se prodavali vino, pšenica i proso, a dobiven novac zatim korišten za uzdržavanje vojne posade. Pitanje je samo jesu li prodani na širem tržištu ili lokalnim vojnicima. U svakom slučaju, tada se još moglo računati na solidne prinose s navedenih posjeda.

Posjed Kralje bio je važan za opskrbu gradske posade osobito od 1580. do pada pod osmansku vlast. Posjed je u srednjovjekovnom periodu pripadao cistercitskoj opatiji, a 1260. sadržavao je, između ostalog, šume, otok i pravo ribarenja. ${ }^{1603}$ Lopašić navodi da su početkom 16. stoljeća Bišćani nastojali preuzeti taj posjed, ali da je ipak pripao Ivanu Kobasiću, unatoč činjenici što je kardinal Toma Bakač 1517. od Bišćana tražio da brane Kralje od Osmanlija. Ivan Kobasić dobio je 1519. posjede u selu Suče, Otoku, Topoljanima, Omršlu i Bristovici u okolici Bihaća. ${ }^{1604}$ U vlasništvu obitelji Kobasić Kralje ostaju sve do pogibije posljednjega (muškog) člana obitelji Ivana Kobasića kod Kanjiže 30. rujna 1580. kada ga preuzima bihaćki zapovjednik Sebastian Lamberg kako bi služio kao izvor živeži za vojnu posadu grada. Iako je, odlazeći u rat, Ivan Kobasić oporučno ostavio posjede svojoj polubraći Tadiolovićima, posjede Kralje i Privilica nastojao je, osim bihaćkoga kapetana Sebastiana Lamberga, dobiti i kapetan Ivan Vojković. Ugledni krajiški zapovjednik i Ivanov očuh Andrija Tadiolović tražio je pak da se oporuka realizira. No, posjede je ipak zauzeo Lamberg pravdajući se da su Kobasići nasljeđivali Kralje samo u muškom koljenu, a da je Privelica ionako pripadala Sokolu dakle i Bihaćkoj kapetaniji. ${ }^{1605}$ Međutim, preuzimanje formalno nije realizirano sve do prosinca 1580. jer se o predmetu raspravlja još u studenom te godine. Štoviše, čini se da su pod ingerenciju kapetana planirali podrediti tek osmoricu podložnika koji su tamo i dalje obitavali dok je samo dobro Kralje trebalo biti podređeno opskrbniku koji je i sam, naravno,

\footnotetext{
1602 ADAMČEK, Agrarni odnosi, 357.

1603 „Crala cum omnibus pertinenciis suis, silvis videlicet, insula et piscacionibus“. TKALČIĆ, Povjestni spomenici, dok. CXV, 128; LOPAŠIĆ, Bihać, 44.; Tadija SMIČIKLAS, Diplomatički Zbornik kraljevine Hrvatske, Dalmacije i Slavonije, JAZU, V, Zagreb, 1907., dok. 664, 156.

${ }^{1604}$ LOPAŠIĆ, Bihać, 54-55; 106.

${ }^{1605}$ LOPAŠIĆ, SHK, knjiga I, dok. LXXIII, 106-107; dok. LXXIV, 107-109.
} 
podređen kapetanu. ${ }^{1606}$ Isti mjesec ipak se navodi da su bivša Kobasićeva imanja pripala bihaćkom kapetanu. ${ }^{1607}$

Ivanov očuh Andrija Tadiolović žalio se nadvojvodi i početkom 1581. zbog činjenice da je dobra Kralje i Privilica kod Bihaća, koja su pripadala njegovu stiefsonns, zauzeo bihaćki kapetan. Budući da je u svojoj oporuci Kobasić ostavio svoja pokretna i nepokretna dobra i imovnu svojoj majci, braći i budućoj braći, Tadiolović je tražio od nadvojvode da, na temelju njegove dugogodišnje i vjerne službe na Hrvatskoj krajini, naredi da mu se spomenuta dobra vrate te da ih brani od eventualnih daljnjih posezanja. Ako bi se pak pojavili neki koji bi iskazivali zahtjeve prema njegovoj supruzi i sinu, neka se to rješava uobičajenim pravnim putem. ${ }^{1608}$ Sebastian Lamberg replicirao je da, što se posjeda i podložnika (unterthanen) pokojnog Ivana Kobasića tiče, nije riječ o njegovu nasljednom dobru (erblich aigenthumb), već da Privilica pripada (unterworffen vnd zugehörig) utvrdi Sokol dok su podanici u selu Kralje (di aber zu Krala), kojih trenutno nema više od četvero te koji bez njegove pomoći ne mogu obrađivati zemlju zbog osmanske opasnosti, pripadali bihaćkoj gradskoj općini, ali su sada uključeni u opskrbni sustav, doduše s malom koristi. Lamberg navodi da je kralj Ferdinand te posjede dodijelio (donation) Ivanu Kobasiću za njegova „viteška djela“ (ritterlichen thaten), ali samo u muškom koljenu. ${ }^{1609}$ Dakle, Privilica je pripala bihaćkom kapetanu po zapovjednoj liniji zato što je pripadala posjedima utvrde Sokol koja je bila dio Bihaćke kapetanije dok se za Kralje navodi da je pripadala bihaćkoj gradskoj općini. Nažalost, nije poznato kada je Privelica dospjela u posjed obitelji Kobasić, a nije navedena u spomenutom popisu prihoda posjeda Sokol iz 1548. Selo Kralje je i u osmanskom periodu naseljeno katoličkim stanovništvom, a tek treba utvrditi njihovu vezu sa srednjovjekovnom hrvatskom populacijom.

Prema jednom izvještaju iz sredine 1586., većina namirnica, kao što su žito, vino, mlijeko i drvo, dopremala se iz (kraja oko) Golubića, sela koje je tada bilo spaljeno i koje je trebalo ponovno naseliti. ${ }^{1610}$ No, Golubić još krajem 1587. nije obnovljen i čekala se izgradnja dva drvena turnja ili kaštela da bi se kućama mogli vratiti preostali stanovnici i haramije koji su se djelomično zadržavali oko Sokola i Ripča. Golubić nije bio samo važan opskrbni izvor

\footnotetext{
1606 „vnnd das Khobassitschen hinderlassne Güetter eingezogen, dauon auch dem Haubtman zu Wihitsch 8 vnderthanen, die Güetter aber zu Khraill, dem Profiantmaister vndergeben werden“. HDA, Croatica, mikrofilm D-1913, br. 20, studeni 1580.

${ }^{1607}$ HDA, Croatica, mikrofilm D-1913, br. 30, prosinac 1580.

${ }^{1608}$ LOPAS̆IĆ, SHK, knjiga I, br. LXXIII, 107.

1609 „,der bürgerschft alhie in Wihitsch, aber jezundt zu dem profand wesen doch mit wenigen nutz eingezogen“ LOPAŠIĆ, SHK, knjiga I, dok. LXIVI, 107-108.

${ }^{1610}$ LOPAŠIĆ, SHK, knjiga I, dok. XCV, 140.
} 
za Bihać već se radilo i o strateški važnom mjestu na kojem se neprijatelja moglo zaustaviti te od tamo sigurnije djelovati i harati prema Ripču, osobito ako su držane straže na Klokočkoj Glavi, Vražjem Vrtlu, Železnoj Glavi (iznad Ribića prema Lopašiću ${ }^{1611}$ ) i Šiški, a za to su bila potrebno osmorica vojnika. Držanje Golubića osiguralo bi i obradu zemlje prema Zavalju te onemogućilo osmanske zasjede u krugu jedne milje. Također, u grad bi se lakše unosile žitarice. Radilo se sveukupno o trošku od 32 rajnska guldena. ${ }^{1612}$

Dakle, bihaćka posada uzdržavala se djelomično s posjeda koji su se nalazili u okolici grada, a od kojih su neki i u srednjovjekovnom periodu služili za uzdržavanje kraljevskih posada, primarno u Sokolu. Upravo je vlastelinstvo Sokol imalo velike posjede u okolici i bilo izrazito važno za gradsku posadu iako je neko vrijeme bilo u privatnom posjedu. Također, da bi se osigurala što veća količina živeži ili financijska sredstva za funkcioniranje kapetanije, bihaćki je kapetan Erasmo Thurn već početkom 1530-ih u zakup preuzeo desetinu topuskog opata koja se pobirala na posjedima oko Bihaća. To su očito bili ključni poljoprivredni prinosi i financijski prihodi. S godinama bihaćki je kapetan preuzimao i druge posjede u okolici grada, poput spomenutog sela, odnosno posjeda Kralje. Iako su navedeni posjedi zbog osmanskih napada s vremenom postajali opustošeniji i dalje su bili bitni za održavanje gradske posade. Uostalom, dio vojnika imao je zemlje u okolici grada, možda upravo na tim posjedima. S obzirom na sve navedeno, ne iznenađuje dojava habsburških špijuna iz travnja 1584. da je stanoviti Ethem-aga, nekoć zarobljenik pokojnoga bihaćkoga kapetana Obritschana, savjetovao bosanskom paši da se Bihać može osvojiti tek pomoću topova, ali samo pod uvjetom da se uništi i posiječe žito kada sazrije i vino kada rodi vino (weinbar). Kada se to učini, Bišćani će se sami predati i napustiti grad. ${ }^{1613}$ Ova konstatacija pokazuje važnost lokalne agrarne proizvodnje u krajiškom kontekstu 16. stoljeća.

\subsection{Krajiški opskrbni sustav}

Budući da lokalna proizvodnja hrane često nije bila dostatna za zadovoljavanje potreba vojne posade, opskrba grada ovisila je krajiškome opskrbnom sustavu koji su ustrojili staleži Unutrašnje Austrije. Dok su hrvatsko-slavonski staleži odgovornost za opskrbu ostavili primarno u rukama bana, staleži Unutrašnje Austrije formirali su službe i institucije za

\footnotetext{
${ }^{1611}$ LOPAŠIĆ, Bihać, 61.

1612 LOPAŠIĆ, SHK, knjiga I, dok. CII, 148.

${ }^{1613}$ IBID., dok. XCI, 133.
} 
rješavanje tih pitanja. Imenovani su glavni opskrbnici zaduženi za sustavnu brigu za kupovinu, prijenos i distribuciju živeži te za gradnju skladišta i škrinja u skladišnim mjestima što je bilo izrazito bitno. ${ }^{1614}$ Nadvojvoda Ferdinand imenovao je, primjerice, u ožujku 1523. Niclasa Wechslera glavnim opskrbnikom nadvojvodinih postrojbi na hrvatskom prostoru. ${ }^{1615}$ U kontekstu rasprave o napadu na Kamengrad 1524., jedna od glavnih stavki bilo je osiguranje živeži, a jedan od preduvjeta akcije bila je izgradnja škrinja (kastn) u Bihaću i Krupi, što je pak bilo izvedivo uz velike troškove. ${ }^{1616}$ Nikola Jurišić je preko Mikule Šiška u srpnju 1527. savjetovao kralju da glavni opskrbnik (profandtmaister) odmah pošalje živež u Bihać i Ripač kako bi se građani i posada u slučaju potrebe mogli neko vrijeme održati. ${ }^{1617}$

Količina dopremljene živeži izražavala se u količini koju je mogao nositi prosječan magarac. U njemačkim izvorima ta se mjera nazivala Saum (tovar, samar) i iznosila je 120130 kg. ${ }^{1618}$ Sama konfiguracija terena na Hrvatskoj krajini nalagala je upotrebu konja i magaraca dok su kola rjeđe upotrebljavala. ${ }^{1619}$ Konji, kola i tovari koji su prevozili živež i vojnu opremu dolazili su često s područja Unutrašnje Austrije. Tako je u drugoj polovici 1578., kada je izvedena tzv. „Hrvatska ekspedicija“, s područja Kranjske podignuto oko 2000 tovarnih konja i oko 100 kola za prijevoz živeži i razne opreme na krajinu. ${ }^{1620} \mathrm{Za}$ to vrijeme bili su to iznimni logistički pothvati.

Do 1578. i standardizacije raznih službi poslije sabora u Brucku opskrbnici su se nalazili u štabu glavnog zapovjednika, a zatim su donesene mjere za poboljšanje opskrbnih poslova koje je trebao provesti posebni opskrbni povjerenik (Obrist Prouiandt Commisary). On je trebao urediti opskrbu na krajinama i u unutrašnjaustrijskim zemljama, odnosno „sve ih povezati i osposobiti““. ${ }^{1621}$ Glavni opskrbnik (Obristen Profiantmaister) bio je podređen nadvojvodi kao glavnom zapovjedniku Hrvatske krajine, a biran je na godinu dana. Ured opskrbnika na Hrvatskoj krajini nalazio se u Karlovcu, a nabavljao je, distribuirao i prodavao namirnice te organizirao skladišta. Organizirao je dopremu živeži iz Kranjske, ponekad Štajerske, a katkad i iz Ugarske. U važnijim gradovima držao je nekoliko viših službenika jednog u Bihaću s 12, jednog u Slunju s 20 i jednog u Hrastovici s 8 rajnskih guldena

\footnotetext{
1614 ŠTEFANEC, Država ili ne, 434

1615 THALLÓCZY, HODINKA, A horvát véghelyek, dok. CXLII, 240.

${ }^{1616}$ U lipnju 1524. u Ljubljani se raspravljalo o prijedlogu Nikole Zrinskog za napad na Kamengrad, a prisutni su bili i Krabatten. Dakle, tada su još aktivno sudjelovali. IBID., dok. CCXXVII, 351.

1617 IBID., dok. DXLIV, 693.

1618 GRÜNFELDER, Vojna Krajina i reformski, 106.

${ }^{1619}$ ŠTEFANEC, Država ili ne, 436.

${ }^{1620}$ Ferdo GESTRIN, Gospodarstvo na slovenskem in Vojna krajina, Zgodovinski časopis, XXXX, br. 4, 1986., 418.

${ }^{1621}$ ŠTEFANEC, Država ili ne, 238.
} 
mjesečne plaće. Upravni opskrbnici na Hrvatskoj krajini navedeni su u Senju, Bihaću, Hrastovici, Slunju i Dubovcu. ${ }^{1622}$

Nadalje, glavni opskrbnik morao je surađivati $\mathrm{s}$ opskrbnim službenicima i skladištarima na području Unutrašnje Austrije koji su u svojem okrugu prikupljali i skladištili određenu količinu živeži (brašna, žita itd.), s tim da su skladišta za živež podizana i na unutrašnjeuastrijskom i na krajiškom prostoru. U Kranjskoj su to bila Radeče (Rattschach), Kostanjevica na Krki, Krško, Metlika, Črnomelj i Graz, u Koruškoj Velikovec i Dravograd, u Štajerskoj Bruck, Graz, Radgona, Ptuj, Brežice i Celje dok su na hrvatskom prostoru to Ogulin, Slunj, Rijeka i Senj, a na slavonskom prostoru Varaždin, Zagreb, Topusko i Steničnjak. ${ }^{1623}$ Prema prijedlogu Dvorskoga ratnog vijeća iz listopada 1578., Profanthäuser trebalo je pak podići u Slunju, Ogulinu, Pobrežju i u Dubovcu, odnosno Karlovcu. ${ }^{1624}$ Slunj je već 1566. bio važno opskrbno središte odakle su se opskrbljivale utvrde prema Bihaću i Senju, kao i prostoru između Une i Korane. Žito se mljelo u Slunju, Dubovcu i Hresnom. ${ }^{1625}$

Podizanje i uređenje skladišta na samome krajiškom području nametalo se kao prijeka potreba kako se živež kupljena na prostoru Kranjske i drugih zemalja u zaleđu, ne bi trebala skladištiti predaleko na kranjskom prostoru. ${ }^{1626}$ Skladišta na samom pograničju imala su stratešku važnost jer su omogućavala mnogo bržu opskrbu većeg broja vojnika te zato što se iz tih skladišta živež mogla mnogo brže dostaviti u slučaju nužde ili opskrbiti pojedine utvrde. ${ }^{1627}$ Uz središnje opskrbne lokacije, manja skladišta podizana su i u samim utvrdama na krajiškom teritoriju. ${ }^{1628}$ Prema prijedlogu uređenja Hrvatske krajine na saboru u Brucku 1578., živež se za Hrvatsku krajinu mogao kupovati oko Metlike, Graca i Črnomelja te transportirati u Ogulin koji bi se za tu funkciju mogao urediti pripremom škrinja i nekoliko peći. Iz Ogulina su se trebali opskrbljivati Bihać, Slunj, Modruš, Jesenice, Dabar, Mutnik i Tržac. ${ }^{1629}$

Živež je dopremana s raznih strana ne samo zato što su unutrašnjeaustrijski staleži željeli profitirati na toj unosnoj trgovini već i zbog činjenice da se na hrvatskom prostoru ponekad nije mogla nabaviti dostatna količina (povoljne) živeži. Takva je situacija naravno imala negativne posljedice za obranu, kao što se to pokazalo prlikom gubitka Krupe 1565 .

\footnotetext{
${ }^{1622}$ IBID., 241-242; KRUHEK, Krajiški, 288; LOPAŠIĆ, SHK, knjiga I, br. L, 87.

1623 ŠTEFANEC, Država ili ne, 434.

${ }^{1624}$ HDA, Croatica, kutija 1, svežanj 2, 1578., 50-51.

${ }^{1625}$ SIMONITI, Vojaška organizacija, 214.

${ }^{1626}$ HDA, Croatica, kutija 1, svežanj 2, veljača 1579., str. 89. Dvorsko ratno vijeće u Grazu na nadvojvodu Karla.

1627 ŠTEFANEC, Država ili ne, 296.

${ }^{1628}$ GESTRIN, Gospodarstvo, 417.

1629 ŠTEFANEC, Država ili ne, 297.
} 
kada ne samo da je nedostajalo novaca već se u Hrvatskoj nije mogla niti nabaviti živež. ${ }^{1630}$ Ipak, unatoč opetovanim deficitima, živež dobrim dijelom jest nabavljala na hrvatskom prostoru. Kada je početkom rujna 1576. podignut zemaljski ustanak u Kranjskoj i kada su na krajište trebale stići koruške i goričke postrojbe, Hans Auersperg javljao je da ne bi trebalo biti problema nabaviti živež i krmivo na hrvatskom prostoru. ${ }^{1631}$ Dakle, okolnosti su varirale. Prema instrukciji Lukasa Zäckela, zapovjednika Hrvatske i Slavonske krajine iz 1567., živež su na Hrvatsku krajinu morali dopremati Zagrebačka biskupija, Kaptol te opatija u Topuskom dok su se stara hrvatska mjesta od Bihaća do Jadranskog mora morala opskrbljivati s prostora vlastelinstva Steničnjak. ${ }^{1632}$

Prvorazredan izvor za problematiku nabave živeži na hrvatskom prostoru sastavio je 1566. krajiški opskrbnik Thomas Naglić. U tom se trenutku na hrvatskom prostoru za gotovinu na posjedu Gašpara Peranskog kod Perne moglo kupiti pšenice u iznosu od 100 bihaćkih kvarti, a na posjedima Petra Farkašića oko Vranograča 50 bihaćkih kvarti pšenice i 200 kvarti zobi. Još se više moglo nabaviti na prostoru velikog i dobrostojećeg vlastelinstva Steničnjaka - pšenice, zobi, sira (chass), svinja, mesa i vina. Na posjedima bana Petra Erdödyja oko Okića, Jastrebarskog i Metlike bilo je moguće nabaviti žito (getrayd), svinje, meso, sir (chass) te vino, a isti proizvodi bili su dostupni na plemićkim dvorovima te kod podanika u Turopolju. Slično je bilo i na posjedima Zrinskih oko Ozlja i Dubovca gdje se moglo kupiti svakojako žito (getraydt), vino, svinje, sir (khass) i meso. ${ }^{1633}$

Također, $\mathrm{u}$ tom je spisu prikazana shema transporta i skladištenja žitarica koje su dopremljene s unutrašnjeaustrijskog i hrvatskog prostora. Spis sadrži i transportne rute unutar same Kranjske, ali ovdje ću se zadržati na pravcima preko hrvatskoga krajiškog prostora. Pri transportu žita korišteni su i tokovi rijeka pa je tako samljeveno žito dopremano iz Gornje Kranjske rijekama Savom i Kupom do Bresta te pod Hrastovicu, a odatle se onda moglo prebaciti ili pohraniti u samoj Hrastovici i Vinodolu ili pak prebaciti Kupom do Dubovca. U Hrastovicu je stizalo žito s prostora Okića, Turopolja i Mokrica. Iz Kočevja i Vinice žito se transportiralo prema Slunju gdje se samljelo i prema potrebi upućivalo u Modruš, Ogulin i Dabar na jednu stranu te Cetin, Krstinju, Kladušu ili Bihać na drugu stranu. Iz Ozlja se žito transportiralo u Dubovac gdje je mljeveno i prema potrebi upućivano dalje u Hrvatsku, a ono

\footnotetext{
1630 „in Khrabaten khain Prouiandt verhannden sein solle“. SI AS 2, DSK, kutija 209, fascikl 126, Wordl, 23.6.1565, 2v, rbr. 59. Ivan Lenković na predstavnike kranjskih staleža.

${ }_{1631}$ SI AS 2, DSK, kutija 287, fascikl 164, Sueče na Korani, 7.9.1576., 1r, rbr. 690. Hans Auersperg na predstavnike kranjskih staleža.

${ }_{1632}$ ŠTEFANEC, Država ili ne, 293.

${ }^{1633}$ SI AS 2, DSK, kutija 249, fascikl 146a, sine loco, sine dato, 1r, rbr. 209. Nastavlja se na spis Herbarta Auersperga iz travnja 1566.
} 
s prostora Steničnjaka slalo se u Topusko, Hresno i Cazin. U Hresnu se žito mljelo i prema potrebi slalo na Stijenu, Cazin ili ,čak“ Bihać. Žito iz Perne pohranjivano je u Topuskom, a ono s prostora Vrangorača u Bihaću. ${ }^{1634}$ Dakle, na hrvatskom prostoru tada su se mogle nabaviti razne namirnice $\mathrm{s}$ još relativno dobrostojećih ili barem funkcionalnih posjeda, a ustrojen je i sustav transportnih ruta koji se protezao kroz hrvatski i unutrašnjeaustrijski prostor.

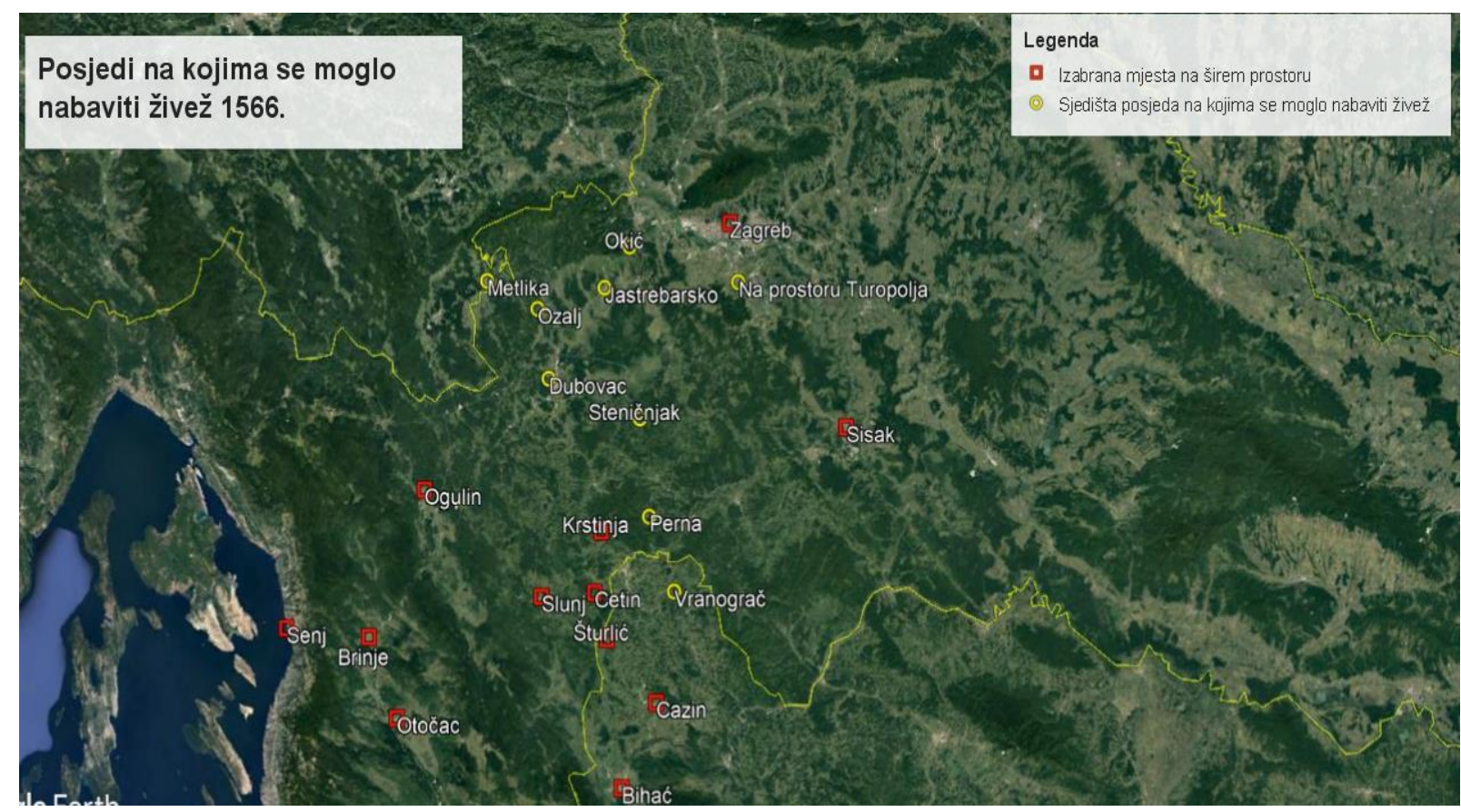

Slika 41. Posjedi na kojima se moglo nabaviti živež 1566.

Velike količine žita dopremane su s prostora Unutrašnje Austrije, osobito iz krajeva oko Maribora, Slovenske Bistrice i Celja, iz područja između Ptuja i Ormoža u Štajerskoj, zatim iz Dolenjske, Bele Krajine i oko Ljubljane u Kranjskoj. ${ }^{1635}$ Krajem travnja 1540., kada je prijetila opasnost od osmanskog napada, a stanje u gradu generalno bilo loše, kralj je naredio da se Bihać opskrbi s posjeda „obrister veldhaubtmana“ Hansa Ungnada. ${ }^{1636}$ Prema jednom izvoru s kraja 1578., Bihać se opskrbljivao žitom iz predjela Trsta i mletačkog teritorija (Venedisch), Gornje Kranjske, Vnndternmarch i Dubovca dok se to moglo (so lannges nach aufrecht gewest) te s prostora Slavonije. Tada se pojavio prijedlog da se Bihać ubuduće opskrbljuje s područja Pazina iako nije bilo jasno hoće li opskrbni konvoji proći

${ }^{1634}$ SI AS 2, DSK, kutija 249, fascikl 146a, sine loco, sine dato, 3r-3v, rbr. 213-214. Nastavlja se na spis Herbarta Auersperga iz travnja 1566.

${ }^{1635}$ GESTRIN, Gospodarstvo, 415.

${ }^{1636}$ SI AS 2, DSK, kutija 286, fascikl 164, Beč, 26.4.1540., 1r-1v, rbr. 3-4. Car Ferdinand na predstavnike kranjskih staleža. 
preko „,das Meer Gebürg“ s manje opasnosti nego da prolaze kroz Hrvatsku. Da bi ispitali tu mogućnost, glavnom opskrbniku (Obristen profiantmeisteru) i oficijalima grofa Zrinskog u Vinodolu naređeno je da pošalju „oko stotinu tovara žita“ te da dojave jesu li troškovi manji. ${ }^{1637}$ Nažalost, nisu pronađeni izvori koji bi pokazali da li je to realizirano i s kakvim uspjehom.

Treba naglasiti da je opskrbni sustav bio manjkav te da često nije funkcionirao na odgovarajući način. ${ }^{1638}$ Nedostajalo je financijskih sredstava, pojavljivale su se razne malverzacije, a nabava i transport živeži predstavljali su kompleksan poduhvat. Problemi su znali poprimiti nevjerojatne razmjere, kao što pokazuje žalba Šimuna Izačića iz lipnja 1566. u kojoj je tvrdio da je prošlo već sedam godina da mu nije dopremljena živež iako je dvaput pisao zapovjedniku Hrvatske krajine koji ga je pak tješio da izdrži još do ožujka. No, Izačić je lamentirao da su ožujak i travanj prošli te da je sada već svibanj, a odluke još uvijek nema. ${ }^{1639}$

Manjkavosti sustava i nedostatna agrarna proizvodnja osobito su dolazili do izražaja prilikom priprema rijetkih većih vojnih operacija. To se vidi iz izvještaja Achaza Thurna i Merta Galla koji su trebali prikupiti živež i organizirati opskrbne linije za „Hrvatsku ekspediciju“ 1578. Spomenuti dvojac navodi tako da se kola na ovom terenu ne mogu koristiti te da je potrebno osigurati pristojne naknade za tovare (samfahrten) koje su trebali osigurati podanici i zakupnici iz okolice Ljubljane. Predložili su nabavu velike količine žita, osobito zobi, u Celjskoj grofoviji oko Oberburga, koje bi trebalo uskladištiti i prema potrebi slati splavima do Zagreba i dalje na krajinu. Živež se nije mogla skladištiti na Hrvatskoj krajini jer Ogulin, Slunj itd. nisu imali krovove i podove, škrinje, bačve i druge posude. U takvim uvjetima živež se nije mogla držati ni nekoliko dana. Zato su odlučili samljeti brašno oko Metlike te ga dopremiti u Slunj i Ogulin, a od tamo u logore i utvrde. Ovaj izvještaj jasno pokazuje kakve su izazove morali savladavati odgovorni pojedinci unutar opskrbnog sustava kada je bila riječ o osiguravanju živeži za veće vojne operacije. ${ }^{1640}$

Dakle, prijevoz živeži na krajište predstavljao je kompleksan i opasan pothvat. Herbart Auersperg žalio se u lipnju 1569. da se za osiguranje opskrbnih konvoja mora delegirati čak

1637 „Profiandt beglaittung vber das Meer Gebürg nit vil geringer gefahr als durch Crabaten zubesorgen“. HDA, Croatica, kutija 1, svežanj 2, veljača 1579., 64. Georg Khevenhüller i ratni savjetnici na nadvojvodu. S područja Pazina opskrbljivana je Senjska kapetanija.

${ }^{1638}$ Problema je bilo i sa krmivom za konje. U travnju 1560. husari na Hrvatskoj krajini morali su se razići jer nije bilo dovoljno krmiva za konje te su ostavili konje na ispaši (Ire Ro $\beta$ auf das Graß zulassen) na krajištu što je moglo biti jako opasno. HDA, Militaria, kutija 7, Mehovo, 19.4.1560., bez numeracije. U izvorniku bi trebalo biti $3 r$, ali se u preslikama umetnuta još dva priloga pisana istoga dana

1639 SI AS 2, DSK, kutija 286, fascikl 164, Ripač, 6.6.1566., 1r, rbr. 45. Šimun Izačić na predstavnike kranjskih staleža.

1640 ŠTEFANEC, Država ili ne, 436-440. 
do 1500 ljudi, a to uključuje i vojnike s Primorske krajine. Da bi se okupio toliko velik broj vojnika, trebalo je povući dio ljudi iz utvrda, a to je pak cijelu krajinu činilo izloženom osmanskom napadu. Da bi unošenje živeži bilo uspješno, prioritet je bio da barem dva ili tri tjedna unaprijed neprijatelj ne sazna za planove jer „sandžaci Bosne, Livna i Hercegovine“ mogu u roku od osam do najviše četrnaest dana bez osobite muke skupiti i preko 10000 ljudi te pokušati napasti konvoj, oteti živež i pobiti sve u pratnji. Auersperg navodi da Osmanlije smatraju da se stranci više neće vraćati ukoliko habsburškoj strani jednom nanesu težak poraz i otmu živež. Auersperg je tada predao ratnim savjetnicima i dva pisma bihaćkoga kapetana u kojima se žali na glad te moli opskrbu jer bez živeži vojnike ne može zadržati u utvrdama. Auersperg se zalagao da se preuzme vlastelinstvo Steničnjak i da se krajina opskrbljuje s tog posjeda. ${ }^{1641}$ I u listopadu 1580. zapovjednik Hrvatske krajine Andreas Auersperg žalio se da je zbog opskrbe Bihaća i sam Karlovac često ispražnjen od vojske. ${ }^{1642}$

No, ni pratnja nije uvijek pomogla pa su Osmanlije ponekad imali uspjeha u napadima na opskrbne konvoje. Krajem listopada 1575. bihaćki kapetan javio je da je zbog gladi iz Senja u grad trebala stići živež (ulje, sol itd.), ali su Osmanlije napali opskrbni konvoj te pritom oteli četrdeset konja i zarobili petero ljudi. Također, da stvar bude gora, Osmanlije su tada napali i bihaćku Otoku (Wöhrdt) te oteli svu stoku koja se tamo nalazila. ${ }^{1643}$ Bilo je problematično osigurati i konje za prijevoz živeži i opreme pa je tako krajiško povjerenstvo iz 1563. navelo da bi se u tu svrhu, uz pristojnu plaću, mogli angažirati uskoci. ${ }^{1644}$ Opskrbne konvoje osiguravali su i unajmljeni strijelci kojima je za trebalo osigurati adekvatnu plaću. Čini se da su u proljeće 1573. upravo zbog neisplate plaće odbili pratiti opskrbni konvoj u Bihać pa je tada glavni opskrbnik Thomas Naglić konstatirao da se bez unajmljenih strijelaca Matiascha Morija živež nikako ne može dopremiti u Bihać te je tražio da im se doznače tražena sredstva. ${ }^{1645}$ Naglić je samo mjesec dana ranije za opskrbu Bihaća doznačio 364 rajnskih guldena i 26 krajcara. ${ }^{1646}$ Trenutno nije poznato što se dogodilo s tim novcima, ali početkom svibnja upravitelj Hrvatske krajine Jobst Joseph Thurn traži da se odmah doznače sredstva za straže i da bi strijelci pristali pratiti opskrbni konvoj. ${ }^{1647}$ Živež je na koncu ipak

\footnotetext{
${ }^{1641}$ HDA, Militaria, kutija 9, 12.6.1569., str. 2-5.

1642 HDA, Croatica, mikrofilm D-1913, br. 30, listopad 1580.

${ }^{1643}$ SI AS 2, DSK, kutija 419, fascikl 287, Smrčković, 28.10.1575., 1r-1v, rbr. 609-610.

${ }^{1644}$ AHAZU, Lopašić, E. Prijepisi iz austrijskih arhiva, br. 15, str. 82.

1645 SI AS 2, DSK, kutija 286, fascikl 164, 1.5.1573., rbr. 145-146. Jobst Joseph Thurn na predstavnike kranjskih staleža.

${ }^{1646}$ SI AS 2, DSK, kutija 286, fascikl 164, 1.5.1573., rbr. 143-144.

1647 SI AS 2, DSK, kutija 286, fascikl 164, 1.5.1573. rbr. 145-146. Jobst Joseph Thurn na predstavnike kranjskih staleža.
} 
poslana prema Bihaću, ali opis onog što se putem dogodilo najbolje pokazuje koliko je to riskantan pothvat bio.

Sačuvana su dva izvještaja o navedenom događaju: jedan koji je 14. travnja 1573. u Črnomlju sastavio više puta spominjani Thomas Naglić te drugi koji je isti dan sastavio opskrbnik (profantmeister) u Bihaću. Iako postoje neke sitne razlike, izvještaji svjedoče da je Naglić došao s oko 90 konja natovarenih žitaricama do Cetina te zatražio da mu se ususret pošalje (dodatna) vojna pratnja. Iz Bihaća im je ususret poslano 150 njemačkih i hrvatskih vojnika i 30 konjanika iz sastava bihaćke posade, koji su došli do Tržca. Međutim, osmanski martolozi su kod Šturlića zarobili glasnika kojeg je bihaćki upravitelj Scheyer poslao Nagliću. Ovaj događaj toliko je uplašio Naglićeve ljude, koji su se očito prepali razotkrivenih planova, da više nisu htjeli nastaviti prema Bihaću, već su ostavili teret i vratili se nazad. Naglić je, kaže, s teškom mukom uspio unijeti žitarice u cetinsku utvrdu, dok se bihaćka posada praznih ruku povukla. Čini se da je dio tereta završio, planirano ili ne, u Slunju. ${ }^{1648}$ Ovakvi događaji bili su nešto s čim su krajiški zapovjednici stalno morali računati.

Da bi se sigurnije prevozio do Bihaća, živež je dostavljan i prilikom smjena vojnika kao što je to očito bio slučaj 1574. kada je zaprijetila opasnost od osmanskog napada, pa je živež poslan zajedno s njemačkih vojnicima. No, kako je tada kao pojačanje poslano još nekoliko stotina ljudi, trebalo je dopremiti još živeži, iako se u Hrvatskoj tada ništa nije moglo nabaviti osim ono malo živeži koji se mogao dopremiti Savom i Kupom. ${ }^{1649}$

Problem su predstavljale i različite mjere za vaganje žitarica. Kapetan Mert Gall imao je 1540. problema s utvrđivanjem stanja jer opskrbnik nije donio svoje mjere (mas). Zato je pristiglo morao vagati s bihaćkom kvartom (Wihischer quartn nent) pa je od opskrbnika tražio da pošalje svoje mas da bi se moglo ponovno izvagati te da bi se mogli utvrditi prethodni i sadašnji omjeri. Tada je u gradskom skladištu bilo oko 214 kvarte pšenice, a od toga tek oko 109 kvarte dobre pšenice. ${ }^{1650}$

Što se tiče opskrbe Bihaća, uz kapetana koji je stajao na čelu lokalne hijerarhije, jedan od visoko pozicioniranih časnika unutar strukture Bihaćke kapetanije bio je opskrbnik (profandt verwalter). U izvorima se na toj poziciji ističe Burckhardt Saloman. ${ }^{1651} \mathrm{~S}$ obzirom na kompleksnu situaciju u Bihaću, o kojoj je već mnogo toga ranije rečeno, opskrbnik se

\footnotetext{
${ }^{1648}$ SI AS 2, DSK, kutija 286, fascikl 164, Črnomelj, 14.4.1573. 1r, rbr. 50. Thomas Naglić na Jobsta Josepha Thurna; SI AS 2, DSK, kutija 286, fascikl 164, Bihać, 15.4.1573., 1r, rbr. 152. Burckhardt Saloman na Jobsta Josepha Thurna; SI AS 2, DSK, kutija 286, fascikl 164, Cetin, 17.4.1573., 1r, rbr. 157.

1649 SI AS 2, DSK, kutija 286, fascikl 164, kraj svibnja 1574., 1v, rbr. 265.

${ }^{1650}$ LASZOWSKI, HSKHDS, knjiga II, dok. 493, 490-491.

1651 SI AS 2, DSK, kutija 286, fascikl 164, Ljubljana, 22.4.1573., rbr. 161. I u studenom slijedeće, 1574. Saloman je i dalje profandtmeister. SI AS 2, DSK, kutija 286, fascikl 164, Bihać, 14.11.1574., rbr. 234.
} 
susretao s raznim izazovima pri obnašanju svoje dužnosti. U rujnu 1581. cijela vojna struktura uputila je apel za pomoć u kojem su se žalili da im je problem dobiti i običan kruh, a kamoli slaninu, mast, sir i sol. ${ }^{1652}$

Dopremljene i nabavljene žitarice skladištile su se u gradskom kaštelu, kao što to $\mathrm{u}$ studenom 1574. javlja opskrbnik Saloman Burckhardt. ${ }^{1653}$ Vojni povjerenik Jobst Langenmantel također navodi da je u studenom 1587. izvršio inspekciju kula bihaćkoga kaštela (Die türnen im gschloss zu Wihitsch) u kojima se može pohraniti veća količina žitarica. Opskrbnik (Der profiant verwalter) je već u turnju pored kuhinje (khuchhl), kod „dugih stepenica“, dao postaviti novi pod pa je tada bilo potrebno tek urediti krov iznad. U svim trima kulama moglo se od nevremena i drugih nečistoća sigurno pohraniti oko 1200 starih žitarica, što je količina koja bi Bišćanima trebala dostajati za godišnju opskrbu. ${ }^{1654}$ Prema Simonitijevu izračunu, to bi iznosilo 127200 kilograma žitarica. ${ }^{1655}$ Živež se skladištila i u bihaćkim crkvama, kao što pokazuje i slučaj udara groma u samostan sv. Antuna pri čemu su uništeni pohranjeno streljivo i živež.

\subsection{Ključna opskrbna ruta - „Wyhitscherin Reiss“ ili „Beglaitung““}

Nakon velikih osmanskih osvajanja 1570-ih, Bihać se našao gotovo u okruženju. Već je više puta spomenuto da je prilikom pripreme tzv. „Hrvatske ekspedicije“ 1578. jasno apostrofirano da je jedan od njezinih glavnih ciljeva održavanje Bihaća, odnosno dopremanje toliko živeži da se grad može održati tijekom dužeg perioda. Vojnim je vlastima bilo sasvim jasno kakve će probleme predstavljati opskrba grada, osobito zato što su se Drežnik i Cazin, utvrde na za Bihać vrlo važnim komunikacijama, tada nalazile u osmanskim rukama, a cijeli kraj već toliko opustio da se vojna operacija mogla izvesti samo uz velike troškove i opasnosti pri prelasku rijeka. Tako je prilikom osmanske opsade Ostrožca bihaćki kapetan molio da se odmah pomogne slanjem pedeset ili više iskusnih strijelaca jer, ako Ostrožac padne, a Cazin je već u osmanskim rukama, neće se moći mijenjati vojsku, ali ni dostavljati živež i drugo potrebno Bihaću. ${ }^{1656}$

\footnotetext{
${ }^{1652}$ SI AS 2, DSK, kutija 244, fascikl 143, Bihać, srpanj 1581., 2r, rbr. 508. Upućeno kranjskim Verordneten.

${ }^{1653}$ SI AS 2, DSK, kutija 286, fascikl 164, Bihać, 14.11.1574., 1v, rbr. 243.

${ }^{1654}$ LOPAŠIĆ, SHK, knjiga I, dok. CII, 148.

${ }^{1655}$ SIMONITI, Vojaška organizacija, 212.

${ }^{1656}$ SI AS, DSK, kutija 287, fascikl 164, Bihać, 20.7.1576., 1v, rbr. 532. Sebastian Lamberg na kranjske Verordneten.
} 
Već je Nikola Jurišić u srpnju 1527. apostrofirao važnost Izačića za obranu grada naglasivši da, ako Izačić ostane nezaposjednut, kraljevi vojnici i podanici (ir. $\mathrm{kgl} \mathrm{Mt}$. underthanen und kriegsfolk) neće imati slobodan prolaz izvan grada, ali ni u grad. ${ }^{1657}$ Krajiško povjerenstvo iz 1563. pak navodi da Izačić leži na mjestu na kojem se mogu držati dobre straže (scarten vnd wacht), osobito prema ,grossen Türkhen pass, Petrogost“. Između Izačića i Tržca, kao i na drugu stranu prema Plješevici, Đavoljem vrtlu i iznad Petrova Gvozda, nalaze se divlje doline, grabe, vode, bare pa konji teško mogu prolaziti tim krajem. Članovi povjerenstva konstatirali su da se u takvim okolnostima ne može opstruirati kretanje neprijatelja. ${ }^{1658}$ Bio je važan i Tržac koji se nalazio na mjestu utoka Mutnice u Koranu, a smješten je uz prometnicu kojom je vodio put kojim su Osmanlije često provaljivali na zapad. $^{1659}$

Jedna od najvažnijih točaka za unošenje živeži u grad bio je Drežnik koji se također nalazio na komunikaciju prema Bihaću i gdje su se mogle držati dobre straže. Nakon tzv. „Hrvatske ekspedicije“ 1578. glavna komunikacija između zaleđa i gotovo okruženoga grada zaista je išla preko Drežnika i Izačića ili alternativnim pravcem preko Šturlića i Tržca koji je tada također osvojen i održao se do 1590-ih kada je napušten. ${ }^{1660}$ Ipak, mnogo češće je korištena komunikacija preko Drežnika gdje su Osmanlije u svibnju 1578. jakim snagama napali opskrbni konvoj zapovjednika Hrvatske krajine Ivana Ferenberga pri povratku iz Bihaća, ali su razbijeni i natjerani u bijeg, prilikom čega je poginulo i zarobljeno do 900 Osmanlija. ${ }^{1661}$ No, već početkom kolovoza, opet u kontekstu tzv. „Hrvatske ekspedicije“, okolnosti su bile drugačije pa Fernberger nije uspio unijeti živež u grad, a kada se povukao, Osmanlije su ponovno zauzeli Cazin i Ostrožac. ${ }^{1662}$

U tome opskrbnom lancu važnu su ulogu imali Cetin i Slunj, s tim da je Cetin vjerojatno bio važniji do sredine 1570-ih, a Slunj nakon toga. Krajiško povjerenstvo iz 1563. za Cetin je navelo da mora ostati posada od 10 plaćenih vojnika jer se tamo mogla skladištiti živež. ${ }^{1663}$ Isto povjerenstvo navodi da u Cetinu hrvatsko plemstvo pohranjuje živež. ${ }^{1664}$ Od

\footnotetext{
1657 THALLÓCZY, HODINKA, A horvát véghelyek, dok. DXLIV, 694.

1658 AHAZU, Lopašić, E. Prijepisi iz austrijskih arhiva, br. 15, str. 59-60.

${ }^{1659}$ IBID., str. 59.

1660 Drežnik je također bio u lošem građevinskom stanju. Kada je Feuer u lipnju 1586. obavljao muštru u Drežniku stepenica gotovo nije bilo pa se u slučaju potrebe uopće nije moglo pristupiti zidinama. No, posada je bila u punom broju, a nakon što su se pojedini zahvalili na službi, odmah su u plaćenu službu stupili drugi. LOPAS̆IĆ, SHK, knjiga I, dok. XCV, 140.

${ }^{1661}$ IBID., dok. XVI, 25-26.

1662 IBID.

1663 AHAZU, Lopašić, E. Prijepisi iz austrijskih arhiva, br. 15, str. 39.

${ }^{1664}$ IBID., str. 82
} 
Slunja do Bihaća moglo se sa tovarima doći za jedan dan. ${ }^{1665}$ No, do kraja 1583. sama krajiška uprava porušila je već opustjeli Cetin te Blagajski Turanj. ${ }^{1666}$

U opisu geografske karte hrvatsko-slavonske krajine iz 1581., koju je papinski nuncij u Grazu poslao državnom tajniku kardinalu de Comupsiu, navodi se da je Slunj izrazito važno mjesto koje ako neprijatelj zauzme zatvoriti će pristup Bihaću. ${ }^{1667}$ Slunj je bio osobito važan u kasnijem periodu. U registraturi Dvorskoga ratnog vijeća u Grazu (često) se pojavljuju upisi kako je potrebno tamo skladišten živež poslati u Bihać. ${ }^{1668}$

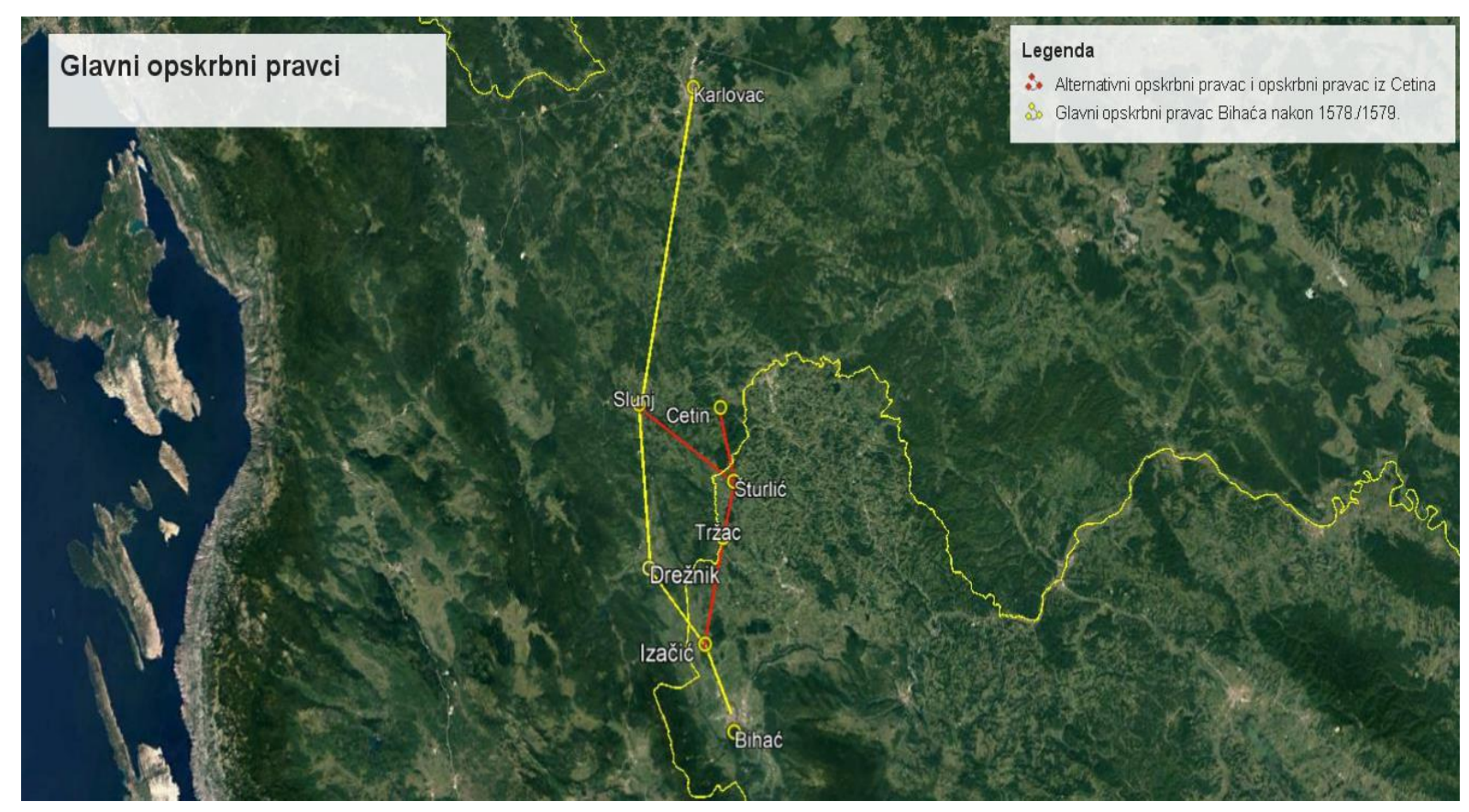

Slika 42. Glavni opskrbni pravci prema Bihaću

Koliko je važna bila navedena komunikacija najbolje se vidi iz činjenice da je Hasan paša Predojević navodno namjeravao prije opsade Bihaća ili paralelno s njom ušančiti se, odnosno podići prepreke na potezu od Klokota do Plješevice kako bi onemogućio pristizanje pomoći opkoljenom gradu. ${ }^{1669} \mathrm{U}$ proljeće 1584. Osmanlije su namjeravali naseliti stanovništvo iz Ostrovice (Ossteruitz) oko Kladuše ne bi li od tamo s 80 konja nadzirali

\footnotetext{
${ }^{1665}$ HDA, Croatica, kutija 1, svežanj 2, 5.2.1579., 72-73.

${ }^{1666}$ HDA, Croatica, mikrofilm D-1914, br. 4, prosinac 1583.

${ }^{1667}$ HORVAT, Prilozi za, dok. 5, 73.

${ }^{1668}$ Npr. HDA, Croatica, mikrofilm D-1918, br. 6, srpanj 1590.

1669 SI AS 2, DSK, kutija 805, fascikl 540, Bihać, 20.6.1592., 1r.
} 
putove radi sprečavanja bilo kakvog kretanja iz smjera Karlovca i Bihaća, sve dok se ne obnovi Tržac. ${ }^{1670}$ Dakle, u oba slučaja namjeravali su presjeći žilu kucavicu Bihaća.

Unošenje živeži podrazumijevalo je permanentnu opasnost od osmanskog napada, a to je uzrokovalo i kontinuirani oprez i uvid u eventualna okupljanja neprijateljske vojske s druge strane pograničja. Krajem studenog 1577. kasniji bihaćki kapetan Daniel Obritschan četovao je u okolici Vranograča, a zarobljenici koje je sa sobom doveo otkrili su da se u Udbini okuplja nekoliko tisuća Osmanlija koji su trebali upasti prema Bosiljevu i Črnomlju. Budući da je iz Črnomelja trebao krenuti opskrbni konvoj prema Bihaću, bihaćki kapetan Lamberg preporučao je oprez. ${ }^{1671}$

Ponekad se zbog osmanskih napada ili zbog raznih drugih nepredviđenih situacija moralo ad hoc reagirati te unijeti dodatne količine živeži i opreme u grad. Osobito kompleksan i opasan moment nastupio je nakon požara koji je izazvao udar groma u samostan u svibnju 1578. jer je uništio sve zalihe streljiva i živeži, a bilo je i ljudskih žrtava. ${ }^{1672}$ Kranjski staleži odmah su poslali pomoć, a najavili su da će poslati opskrbnih tovara koliko god je moguće. ${ }^{1673}$ Opskrba Bihaća znala je toliko opteretiti uvijek prenategnuti krajiški sustav da je zbog toga u veljači 1586. karlovačko skladište (profiandthaus) ostalo gotovo prazno, s hranom tek za nekoliko dana. ${ }^{1674}$

Osiguranje dovoljne količine hrane očito je predstavljalo jedan od ključnih aspekata opstanka pograničnog stanovništva, ali i funkcioniranja cijeloga krajiškog sustava. Problem opskrbe imao je važno mjesto u pregovorima prilikom izbora novoga kapetana, a na tu se problematiku referira cijeli niz prigovora i raznih dopisa koje su uputili predstavnici gradske posade i/ili sami građani. Taj je problem pogađao cijelu Hrvatsku krajinu, ali je posebno dolazio do izražaja na najisturenijim mjestima poput Bihaća.

\footnotetext{
${ }^{1670}$ LOPAŠIĆ, SHK, knjiga I, dok. XCI, 133. Oko Tržca još nisu sasvim jasne okolnosti, jer dok Lopašić i vojni popisi pokazuju da je još do 1590. zaposjednut, krajiška uprava u protokolu Dvorskoga ratnog vijeća u Grazu iz prosinca 1583. navodi da je zapovjednik Hrvatske krajine već dao srušiti Cetin i Blagajski Turanj (einwerffen lassen) dok je u slučaju Tržca isto u tijeku. HDA, Croatica, mikrofilm D-1914, br. 4, prosinac 1583.

${ }^{1671}$ SI AS 2, DSK, kutija 286, fascikl 164, Bihać, zadnji dan studenog 1577., 1r, rbr. 310. Sebastian Lamberg na kranjske Verordneten.

${ }^{1672}$ SI AS 2, DSK, kutija 287, fascikl 164, Ljubljana, 27.5.1578., 1r, rbr. 432. Predstavnici kranjskih staleža na nadvojvodu Karla.

${ }^{1673}$ SI AS 2, DSK, Črnomelj, 24.5.1578., 1r-2r, rbr. 425-426, 430. Krajiški povjerenici na predstavnike kranjskih staleža.

${ }^{1674}$ LOPAŠIĆ, SHK, knjiga I, dok. XCII, 134.
} 
U slučaju Bihaća postojale su dvije instance s donekle drugačijom pozicijom - gradska općina i lokalno stanovništvo koje je raspolagalo određenim posjedima na kojima su dobivali (nemale) količine poljoprivrednih proizvoda te plaćena vojna posada koja je dobrim dijelom ovisila o krajiškom sustavu, uključujući i opskrbni sustav. Gradska općina raspolagala je s posjedima u okolici grada koji očito nisu bili osobito prostrani, a s vremenom su se i smanjivali. Ipak, radilo se o jednom od najplodnijih areala na hrvatskom prostoru pa je, unatoč ratnim aktivnostima, gradska općina do pada pod osmansku vlast raspolagala $\mathrm{s}$ nemalom količinom žitarica koje su prodavale gradskoj posadi.

Krajiška uprava je pak posjedovala svoje posjede, a oni su se s vremenom čak i širili ili barem nadomještali, kao što pokazuje slučaj Golubića i Privilice koji je bihaćki kapetan Sebastian Lamberg zauzeo nakon smrti Ivana Kobasića 1580. Od 1530-ih bihaćki je kapetan u zakupu imao i desetinu topuskog opata koja se prikupljala na posjedima vrlo važnog vlastelinstva Sokol te iz nekoliko sela koja su potpadala pod samu kapetaniju. Ti su prihodi bili vrlo važni za opskrbu posade i obranu generalno, kao što je u poglavlju prikazano. Međutim, ti prinosi/prihodi nisu bili dostatni pa su namirnice nabavljane na cijelom hrvatskoslavonskom, unutrašnjeaustrijskom, mletačkom, pa čak i istočnojadranskom prostoru te su onda rijekama i prometnicama dopremane na krajište gdje su se pohranjivale i odakle su dalje distribuirane. U ovom pogledu Bihać je bio jedno od središta u kojem su djelovale posebne opskrbne instance, a u gradu je bilo dovoljno adekvatnih prostora za pohranu žita i drugih namirnica. Nakon osmanskih osvajanja 1570-ih grad se našao praktički u okruženju i tada je unošenje opskrbe u grad, a to se ranije događalo dvaput godišnje, postalo imperativ. Ti opskrbni konvoji predstavljali su žilu kucavicu Bihaća u zadnjih petnaestak godina $\mathrm{u}$ habsburškim rukama. 


\section{ZAKLJUČAK}

Povijest hrvatskih zemalja u kasnome srednjem i ranome novom vijeku prije svega je povijest imperijalnih višegraničja. Iako je hrvatsko pograničje tek jedan segment mnogo šireg pojasa razgraničenja između kršćanstva i islama, na relativno malom hrvatskom prostoru isprepletali su se i ukrštavali interesi Ugarsko-Hrvatskoga Kraljevstva, a potom Habsburške Monarhije te Mletačke Republike i Osmanskog Carstva. Tako konfigurirani hrvatski prostor poprimio je stoga i međunarodnu dimenziju te se, kao rijetko kada ranije, našao u fokusu interesa kršćanske Europe.

Osmanska ekspanzija, odnosno suodnos suprotstavljenih imperija višestoljetni je fenomen koji je imao krucijalni utjecaj na općedruštvenu fizionomiju hrvatskog i bosanskohercegovačkog prostora. Liminalnost, karakterizirana procesima pograničavanja i militarizacije krajiškog prostora jedno je od najistaknutijih obilježja hrvatskog ranonovovjekovlja, pa stoga granice i pograničja predstavljaju nezaobilazne heurističke alate za znanstvena istraživanja. Iz toga istraživačkog rakursa hrvatska se ranononovovjekovna povijest, pa tako i povijest Bihaća i Bihaćke kapetanije, nameće kao tema relevantna na međunarodnoj razini. Protuosmanski napor na hrvatsko-slavonskom odnosno ugarskom prostoru involvirao je niz međunarodnih čimbenika i u promatranom se periodu nalazio $\mathrm{u}$ centru pažnje europske javnosti. To se najbolje vidi na primjeru niza savjetovanja na regionalnoj razini (ali uglavnom bez participacije ugarskih ili hrvatsko-slavonskih staleža!) na kojima se raspravljalo o tome treba li napustiti Bihać ili ne. Paradigmatski je pak prijedlog Hansa Kobenzela o obrani Bihaća i Senja koji je uključivao i španjolskog kralja Filipa II. i Napuljsko Kraljevstvo te papu, Mlečane i Dubrovčane. Bio je to prijedlog osobe iz najviših sfera europske politike.

Dinamiku sociopolitičkog razvoja onodobnih hrvatskih zemalja diktirala je dugotrajna, ali kontinuirana ekspanzija Osmanskog Carstva koja je dominantno realizirana kroz niz opetovanih vojnih operacija, ali u određenoj mjeri i politikom privlačenja, pregovora i dogovora s lokalnim stanovništvom. Zapravo se $\mathrm{u}$ naličju sveprisutne Antemurale Christianitatis paradigme skriva pogranični svijet autonomne logike koju je nemoguće razumjeti kroz ideologizirane ,mi ili oni“ kategorije koje su na isturenom krajištu često poprimale načelnu formu dok je pogranični svijet često svoje interese, aspiracije i lojalnosti prilagođavao, a pozicije gradio u skladu s mnogo ,prizemnijim“ pobudama koje su usklađene s ritmovima svakodnevice, trenutnim odnosima moći na internoj i eksternoj razini, prilikama 
za socijalnu mobilnost $\mathrm{s}$ ove $\mathrm{i}$ one strane krajišta te sa svim onim malim i neposrednim egzistencijalnim potrebama koje su činile razliku između života i smrti, kontinuiteta i diskontinuiteta. Zato je, bez obzira na svu dramatiku rata koji je zaista imao nevjerojatnu ljudsku cijenu, pograničje uvijek i liminalna, tranzitna zona suživota, razmjene i izražene dinamike. Pograničje nikako nije granica već uvijek prostor koji je formiran u kompleksnoj dijalektici političkih, ekonomskih i kulturnih regresija i transgresija. To je zona heterotopije u kojoj se individualni i kolektivni identiteti konstantno formiraju i transformiraju, a distinktivni simbolički i politički identiteti te lojalnosti permanentno rekonfiguriraju. Habsburškoosmansko krajište simultano je i prostor suživota, zona otvorenih mogućnosti za pojedince i zajednice često heterogenog porijekla koji su u tom imperijalnom glibu imali mogućnosti zadovoljiti svoje ambicije i stremljenja jer je prije svega čovjek, najvažniji resurs krajišta. To se očituje u brojnim primjerima uskakanja s habsburškog teritorija na osmanski teritorij i obratno, kapilarnim i masovnim migracijama, razgranatoj špijunskoj aktivnosti i sl. Sve navedeno direktno se manifestiralo u bihaćkom slučaju.

No, bez obzira na brojne poveznice između društva s obiju strana pograničja, nikako se ne smije relativizirati činjenica da je hrvatsko krajište ipak prije svega prostor rata $\mathrm{i}$ stradanja, urušavanja tradicionalnih političkih, administrativnih i društvenih struktura te stvaranja modificiranih ili potpuno novih. Unatoč permanentnom ratovanju, ili upravo zbog njega, društvena je dinamika pograničja vrlo živa. Bihać je u mnogočemu točka na kojoj su se zorno manifestirale sve te promjene, kako je i prikazano u radu.

Kao što je navedeno, osmanska ekspanzija dugotrajan je proces koji je započeo već krajem 14. stoljeća, a već od prvih desetljeća 15. stoljeća uz cijeli kontaktni prostor počeli su se ustrojavati razni obrambeni sustavi - tabori, banovine, kapetanije i, naposljetku, krajine. Dakle, generacije su se rađale i umirale u pograničnom ambijentu i to je svakako imalo veliki utjecaj na njihovu autopercepciju te odnos prema Osmanlijama, odnosno prema stanovništvu s druge strane pograničja. Na isturenom pograničju, barem do početka 17. stoljeća, s habsburške i osmanske strane dominira kršćansko stanovništvo između kojeg nema osobitih jezičnih, pa čak ni konfesionalnih ili kulturoloških barijera.

U takvome dinamičnom pograničnom ambijentu gotovo dva stoljeća funkcionira jedan od najvažnijih gradova hrvatskog srednjovjekovlja - slobodni kraljevski grad Bihać. Pozicioniran uz prastaru komunikaciju, tzv. Kraljevsku ili Vojnu cestu, prometnu vertikalu koja je spajala hrvatski i ugarski prostor, u plodnoj dolini između dvaju kanjona formiranih tokom rijeke Une, natkriven Plješevicom i Grmečom te na razmeđu panonskog, 
mediteranskog i dinarskoga geografsko-kulturnog areala, Bihać je za onodobno hrvatsko zaleđe predstavljao prvorazrednu sociopolitičku točku.

Iako se u izvorima prvi puta spominje tek 1260., bihaćko naselje vjerojatno je starije jer se u sadržaju privilegija o proglašenju slobodnim kraljevskim gradom iz 1262. spominju neke tada već postojeće povlastice. Također, stečene gradske privilegije jasan su pokazatelj da je tamo već postojalo (proto)urbano naselje razvijenijeg stupnja. Bišćanima su dodijeljena i neka specifična prava, a to su prije svega potpuno izuzeće od vlasti bana i izuzeće od dužnosti ukonačivanja bilo koga osim samoga kralja. Osim Virovitice tijekom kraćeg perioda, to nije imao nijedan drugi grad na hrvatsko-slavonskom prostoru. Ta činjenica sugerira da je središnja kraljevska vlast ciljano nastojala pretvoriti Bihać u snažno uporište koje je neovisno o bilo čijoj vlasti osim kraljevskoj. Takav inicijalni impuls pridonio je društvenom uzdizanju Bihaća koji u razvijenome srednjem vijeku postaje važna strateška točka za intervencije središnje vlasti na prostoru Hrvatskoga Kraljevstva. Iako je 1420-ih založen obitelji Čupor, a zatim i Frankopanima, krajem 15. i u prvim desetljećima 16. stoljeća, kada proces urušavanja institucionalne infrastrukture Hrvatskoga Kraljevstva traje već desetljećima, Bihać još uvijek slovi kao siguran i zaštićen grad, odnosno kao važno vojno-političko središte plemićke elite i banova u kojem se povremeno održavaju hrvatski sabori te koji se u izvorima apostrofira kao „glava“ i „metropola Hrvatske“. Štoviše, od samih početaka formiranja protuosmanskih sustava u prvim desetljećima 15. stoljeća Bihać je jedno od središta, a taj je proces kulminirao pretvaranjem Bihaća u neuralgičnu točku obrane cijele Hrvatske krajine, a samim time i ostatka Hrvatsko-slavonskoga Kraljevstva, te zemalja u pozadini u habsburškom periodu nakon 1527. Iako se u historiografiji često navodi da je zborno mjesto hrvatskog pograničja Senj, Bihać je u najmanju ruku jednako važan kao i Senj.

Srednjovjekovno urbano, pa onda i političko naslijeđe, demografski potencijal (jer ovdje obitava možda i nekoliko tisuća ljudi) te povoljna geografska pozicija uvjetovali su pretvaranje Bihaća u ključnu točku hrvatskoga krajišta. Prominentni krajiški status Bihać će zadržati sve do kraja 1570-ih kada će njegovu stratešku važnost narušiti osmanska osvajanja u Pounju te podizanje Karlovca 1579. No, bez obzira na negativne posljedice navedenih događaja za status grada i kapetanije, Bihać će sve do pada pod osmansku vlast u lipnju 1592. ostati jedno od najvažnijih uporišta protuosmanskoga obrambenog sustava. Čak i u dramatičnom periodu šesnaestog stoljeća Bihać i njemu gravitirajući unski prostor još je dugo kakva-takva zona sigurnosti i svojevrsna demografska oaza na Hrvatskoj krajini u kojoj se još dugo zadržala određena staleška infrastruktura. 
U predosmanskom periodu obranom grada uglavnom će upravljati banovi, a od 1527. taj zadatak past će na leđa bihaćkih kapetana, koji će, uz neposredno zapovijedanje vojnim postrojbama, preuzeti i upravljanje obavještajnim, špijunskim i poštanskim sustavom, a morat će voditi računa o stanju fortifikacija, naoružanju, opremi i opskrbi.

Jezgro Bihaćke kapetanije činile su dvije utvrde u kraljevskom posjedu - Bihać i Ripač. S razvojem krajiškog sustava kontinuirano je rastao broj utvrda pod zapovjedništvom bihaćkoga kapetana, odnosno broj privatnih utvrda u kojima se nalazila kraljevska vojska nad kojom je bihaćki kapetan imao ingerencije. Nakon 1563. broj tih utvrda narastao je na 24, što je predstavljalo golemo opterećenje za bihaćke kapetane. Razni prigovori i žalbe pokazuju da su deficit financijskih sredstava, logistički problemi, loše građevinsko stanje obranu činili krajnje kompliciranom. Nakon velikih osmanskih osvajanja 1570-ih broj utvrda pao je na svega njih nekoliko, a na kraju promatranog perioda svedene su na sljedeću jezgru: Bihać, Ripač, Sokol, Izačić i Drežnik. Kada je izgubljen Ripač, ta integralno povezana predstraža Bihaća, vrlo brzo dogodilo se ono gotovo neizbježno - Osmanlije su zauzeli i sam Bihać.

Broj i raznovrsnost rodova plaćenih vojnika u gradskoj posadi jasno demonstrira važnost Bihaća. U gradu je smještena jedna od najbrojnijih plaćenih posada na Hrvatskoj krajini, a u drugoj polovici stoljeća i najbrojnija do podizanja Karlovca. Tu je velika postrojba elitnijih njemačkih vojnika, zatim brojni domaći pješaci haramije, domaći laki konjanici husari, a ponekad i uskoci. U jednom momentu u posadu je uveden čak i novi elitni rod teže konjice - arkebuziri. Često su u grad namještane i dodatne postrojbe, uglavnom s unutrašnjeaustrijskog prostora pa je broj vojnika stacioniranih u gradu višestruko rastao. Primjerice, jednom prilikom broj vojnika popeo se na visokih 900 ljudi. Bihać je svakako bio dobro branjen, ali je ta obrana sve više postajala financijsko, logističko i opskrbno breme.

Što se oružja i opreme tiče, u Bihaću su čuvani raznovrsno i suvremeno oružje te veća količina opreme i materijala potrebnih za rukovanje, održavanje i proizvodnju vatrenog naoružanja, primarno topova. Iako se u izvorima konstantno apostrofira problem manjka i lošeg stanja oružja i opreme, izvori pokazuju da je bihaćka posada, barem u pojedinim periodima, raspolagala većom količinom teških i standardnih bedemskih puškaka kukača dok su topovi uglavnom bili manjeg i srednjeg dometa. Međutim, u popisima je evidentirana i oprema za lijevanje i rezanje topova, a to pokazuje da su se u Bihaću topovi popravljali i proizvodili. Oružari i puškari, koji je s vremenom bilo sve više i čija je plaća rasla, brinuli su se za oružje koje je čuvano u oružarnici, koja je pak bila dio kaštela, te gradskim crkvama i samostanima. Oružje i oprema dopremali su se uglavnom s teritorija Unutrašnje Austrije, ali ponekad i s cijeloga regionalnog prostora, pa čak i iz prekojadranskih zemalja. 
Bihać je bio i ključno obavještajno-stražarsko-poštansko čvorište na Hrvatskoj krajini. Isprva su obavještajno-poštanski sustav plaćale unutrašnjeaustrijske pokrajine, a njime upravljali ban i domaće plemstvo. Međutim, nakon formiranja Bihaćke kapetanije njime je upravljao bihaćki kapetan. Bihać je bio ključno obavještajno čvorište iz kojeg je špijunima na osmanskom prostoru upravljao bihaćki kapetan, ali u kojem su i Osmanlije imali svoje špijune. Bihaćki je kapetan, uz stražarska mjesta oko samoga grada, imao ingerencije nad stražama na potezu od grada do Vrhovina dok je senjski kapetan njima upravljao od druge polovice Vrhovina do Jadranskog mora. Ovakva shema demonstrira važnost tih dvaju kapetana na prostoru Hrvatske krajine. Značenje Bihaća u poštanskom sustavu pokazuje i činjenica da se termin „Bihaćki konji“ za poštanske konje, koji su prenosili obavijesti iz Bihaća, a kasnije i iz Karlovca, zadržao još desetljećima nakon pada grada pod osmansku vlast u lipnju 1592.

Kada je riječ o rezultatima pograničavanja hrvatskog prostora, jedan od ključnih noviteta $\mathrm{u}$ vojnopolitičkom pogledu svakako je formiranje Bihaćke kapetanije te sve izraženija uloga staleža Unutrašnje Kranjske na hrvatskom prostoru. Uz civilnu upravnu strukturu gradske općine, sada se pak ustrojava paralelna krajiška upravna struktura koja s vremenom postaje sve dominantnija iako treba naglasiti kako su civilne i vojne strukture isprepletene i međuovisne. No, stvaranje krajiške upravne strukture, one vojne pod zapovjedništvom kapetana, krucijalan je indikator procesa pograničavanja. Dok civilna uprava administrira tek gradske posjede u okolici, bihaćkom kapetanu podređen je mnogo širi prostor. Na početku referentnog perioda Bihaćka kapetanija broji tek dvije-tri utvrde, a do sredine 16. stoljeća taj broj popeo se na 24. Nakon dramatičnih osmanskih osvajanja 1570-ih broj je ponovno degradirao na svega nekoliko utvrda $\mathrm{u}$ neposrednome gradskom arealu. Krajiška administracija na cijeloj Hrvatskoj krajini, pa tako i Bihaću, bila je pod ingerencijom staleža Unutrašnje Austrije, u ovom slučaju primarno Kranjske. Zbog obrambene međuovisnosti hrvatskog i unutrašnjeaustrijskog prostora te degradacije defenzivnog potencijala hrvatskog plemstva staleži Unutrašnje Austrije i središnja vlast pomagali su obrani Hrvatske i prije dolaska Habsburgovaca na ugarsko-hrvatsko prijestolje, a to se dodatno intenziviralo nakon proglašenja nadvojvode Ferdinanda hrvatskim ugarsko-hrvatskim kraljem. Sve do podizanja Karlovca 1579. Bihać ima presudnu važnost za unutrašnjeaustrijske staleže, prvenstveno kranjske.

Tu vezu najbolje ilustrira činjenica da su kapetani Bihaća u habsburškom periodu gotovo isključivo unutrašenjaustrijski, primarno kranjski plemići i da su tek jedna osoba ili eventualno dvije osobe $\mathrm{s}$ hrvatskog prostora/hrvatskog porijekla obnašale tu funkciju - Petar 
Keglević, bivši jajački ban, a zatim hrvatski ban i gubernator Topuske opatije, te čini se Mihael Spalatin, iskusni vojnik u dugogodišnjoj habsburškoj službi. Štoviše procedura izbora bihaćkoga kapetana među kandidatima s kranjskog, odnosno unutrašnjeaustrijskog prostora, do 1570-ih je već toliko formalizirana da je kranjski staleži nazivaju „ustaljenim starim običajem“. Ako pak nije bilo kandidata s prostora Kranjske, tada su u obzir dolazile osobe iz drugih pokrajina Unutašnje Austrije, a onda i stranci uključujući i osobe s hrvatskog prostora. Dakle, za grad na hrvatskom prostoru, prvorazredno hrvatsko sociopolitičko središte naseljeno hrvatskim stanovništvom, hrvatski kandidati za izbor kapetana ulaze u kategoriju stranaca, ali to tada ne izaziva prijepor među domaćom elitom i institucijama. Ovaj kratak navod pokazuje svu kompleksnost pograničavanja hrvatskog prostora, njegovu teritorijalnu redukciju i strateško-administrativnu internalizaciju koja je pak vodila formiranju novih funkcionalnih modela na krajištu.

Pograničavanje hrvatskog prostora nije podrazumijevalo samo vojno-administrativne inovacije i transformacije, već se posljedice tog procesa očituju i u snažnom utjecaju na sve sastavnice onodobnog društva. Bihać postaje važno emigracijsko i imigracijsko središte te ključna tranzitna točka. Bišćane nalazimo od neposrednog zaleđa do Gradišća u Austriji i Bele Krajine u Sloveniji, a istodobno se u grad useljava izbjeglo stanovništvo koje traži zaštitu iza još uvijek sigurnih gradskih zidina. Nadalje, prve uskočke migracije ne samo da prolaze bihaćkim prostorom već su i organizirane uz važnu participaciju Bišćana koji su poznavali osmansko pograničje i očito aktivno participirali u ključnim krajiškim procesima.

U takvom kontekstu stvoreno je jedno novo pogranično društvo u kojem se isprepleću elementi tradicionalnog - bihaćka gradska općina i starosjedilačko stanovništvo, useljeno hrvatsko plemstvo koje se mahom nalazi u plaćenoj habsburškoj vojnoj službi, strani plaćeni vojnici te uskoci koji su također u vladarskoj službi, odnosno u službi unutrašnjeaustrijskih staleža. Ta svojevrsna amalgamacija bihaćkog društva imala je svoju logiku i izazove, a formiranje novih društvenih kategorija najočitije je na primjeru peticija koje su adresirane unutrašnjeaustrijskim staležima i vladaru te koje potpisuju i predstavnici gradske općine, hrvatsko plemstvo i pripadnici uskočke elite u habsburškoj službi. Dakle, osmansko napredovanje katalizator je društvenih transformacija koje su na pograničju ustrojavale nove vertikalne i horizontalne relacije, usmjeravale pojedine dotada separirane pa i heterogene zajednice na zajednički nastup radi pronalaska načina obrane, odnosno preživljavanja na pograničju.

Napetosti na relaciji gradska općina-krajiška uprava posljedica su strukturalnih preslagivanja koje je izazvala osmanska ekspanzija na hrvatskom prostoru. U Bihaću, kao 
jednom od najvažnijih gradova na hrvatskom prostoru, formiran je i jedan od centara protuosmanske obrane, a od dolaska Habsburgovaca 1527. i sjedište kapetanije. Bihaćka kapetanijska struktura raspolagala je s mnogo jačom „pozadinom“ u vojno-političkom i financijsko-logističkom pogledu od gradske općine koja je sve više ovisila o kapetaniji. Zato je i asimetrija moći u konačnici prevagnula na stranu bihaćkoga kapetana. Uostalom, iako su gradskoj općini zajamčena njezina naslijeđena prava, od samih početaka Bihaćke kapetanije smatrano je da bihaćki kapetan ima ingerencije nad obranom kaštela, grada i podređenih utvrda te da mu lokalno stanovništvo, uključujući i građane, mora biti poslušno. Iako su građani, odnosno predstavnici gradske općine, u nekim trenucima ulazili su sukobe $\mathrm{s}$ kapetanima, superiorni položaj krajiške strukture nije doveden u pitanje. Sociopolitičke i vojne okolnosti nametnule su takve relacije, osobito u drugoj polovici 16. stoljeća.

Gradska općina sukobljavala se i hrvatskim plemstvom zbog posjeda i podanika koji su u krajiškom ambijentu bili vrlo važni, ali i zbog plemićkog stava da se jednom naseljeni u grad ili na gradske posjede ne podrede i njihovim zakonima i obvezama. To je proces koji je imao ekvivalente na cijelome ugarsko-hrvatskom prostoru. Formiranjem kapetanijskog sustava i ulaskom lokalnog plemstva u krajišku službu formirana je i nova društvena kategorija u gradu, a to je kategorija istaknutih plemića i uskočkih starješina u krajiškoj službi. Još će trebati pronaći dodatne izvore koji će detaljnije pokazati kakav je bio međuodnos ove društvene kategorije i gradske općine.

Što se krajiške strukture tiče, interni sukobi primarno su povezani s egzistencijalnim deficitima krajiškog sustava, a to su prvenstveno neredovita isplata plaća i manjkava opskrba. Gradska posada znala je mjesecima, pa i duže, ne primiti plaću, a kada se dopremljeni živež potrošio, morali su se zaduživati kod lokalnih trgovaca i građana. Time su generirana visoka zaduženja pa su i jednom isplaćenim plaćama odmah zatvarani akumulirani dugovi. Često ni taj iznos nije bio dostatan da se pokrije dug koji je „,pojeo“ čak i buduće isplate. Njemački vojnici, koji su stacionirani u gradu bili su, kao (djelomično) stranci, u nepovoljnoj poziciji jer nisu imali lokalne posjede s kojih bi dobivali hranu, ali su oni, kao i u gradu privremeno stacionirana pojačanja, imali prioritet pri isplati kada su napokon stigla sredstva. Hrvatski vojnici imali su pak (djelomično) posjede u okolici, ali ne i prioritet pri isplati zaostataka, a to je predstavljao problem kada je poljoprivredna proizvodnja zakazala zbog nepovoljnih vremenskih uvjeta, elementarnih nepogoda, osmanskih napada i sl. Loše građevinsko stanje, manjak opreme, oružja i drugih potrepština dodatno su opterećivali vojnu posadu. U takvom ambijentu tinjalo je stalno nezadovoljstvo koje je sredinom 1570-ih poprimilo i ozbiljniju notu. U budućnosti će trebati detaljnije istražiti suodnos između navedenih procesa na 
Hrvatskoj krajini i velikih osmanskih osvajanja tih godina. Očito je da su određeni pojedinci i krugovi ulazili u konspirativne dogovore s Osmanlijama iako su bihaćka vojna posada i građanstvo generalno ostali vjerno vladarskoj kući i kršćanstvu, barem do osmanske ospade 1592.

Dakle, Bihać je bio jedan od najvećih gradova na hrvatskom prostoru u promatranom razdoblju, s nekoliko tisuća stanovnika. Za vrijeme osmanske opsade 1592. taj se broj mogao popeti prema navedenoj brojki od 5000 ljudi. U tu brojku uključeni su, uz građane, i obični stanovnici, pripadnici plaćene gradske posade i njihove obitelji, plemstvo te uskoci. Unatoč kontinuiranim iseljavanjima s promatranog prostora, koja su intenzivirana nakon pada Krupe 1565. te koja su eskalirala nakon dramatičnih poraza na unskom frontu 1570-ih, može se konstatirati da je Bihać ostao dobro naseljeni grad. Za onodobne hrvatske, a osobito krajiške prilike, bio je praktički velegrad, a to je ostao i u osmanskom periodu.

Što se tiče proizvodnje i nabave dovoljne količine hrane, s jedne strane stajali su gradska općina i lokalno stanovništvo s posjedima na kojima su mogli proizvoditi hranu, a s druge strane gradska vojna posada koja je ovisila o opskrbnom sustavu i plaćama. Budući da je (dobar) dio građana bio u plaćenoj vojnoj službi, u najgoroj su situaciji bili vojnici koji su došli sa strane i koji su se zbog neredovite opskrbe i isplate morali zaduživati kod lokalnih trgovaca i građana kako bi nabavili žitarice i druge živežne namirnice. Na temelju dostupnih izvora, teško je procijeniti koliki bi postotak otpadao na one plaćene vojnike koji su raspolagali s posjedima oko grada. Čini se da posjedi gradske općine nisu bili vrlo veliki, a s vremenom su se i smanjivali zbog osmanskih napada, iseljavanja te pritisaka plemića i krajiške strukture. No, građani su i dalje raspolagali s relativno velikim količinama žitarica do pada pod osmansku vlast.

Krajiška uprava imala je svoje posjede, a oni su se s vremenom čak i širili. Bihaćki je kapetan 1530-ih u zakupu držao i desetinu topuskog opata koja se prikupljala na posjedima vrlo važnog vlastelinstva Sokol te iz nekoliko sela koja su potpadala pod samu kapetaniju. Budući da sve to nije bilo dostatno za opskrbu gradske posade, živež je nabavljana na cijelom hrvatsko-slavonskom, unutrašnjeaustrijskom, mletačkom, pa čak i istočnojadranskom prostoru. I u ovom pogledu Bihać je bio jedan od krajiških skladišnih i distributivnih centara. Nakon što se grad od druge polovice 1570-ih našao gotovo u okruženju, Bihać se mogao opskrbljivati tek preko velikih opskrbnih konvoja koji su zahtijevali velika financijska sredstva, planiranje i zaštitu, a to je pak opterećivalo cijelu Hrvatsku krajinu. Unatoč kompleksnosti i opasnosti, tim tzv. bihaćkim opskrbnim konvojima unosilo se oružje, opremu 
i namirnice te se dovodilo vojnike u grad sve do finala ove krajiške drame, odnosno do pada Bihaća u osmanske ruke 1592.

\section{IZVORI I LITERATURA}

\subsection{Neobjavljeni izvori}

\section{Arhiv Republike Slovenije, Ljubljana}

\section{SI AS 2, Deželni stanovi za Kranjsko}

Kutije i fascikli: 191/119, 193/119, 193/120, 194/122, 198/123a, 200/123b, 201/124, 202/124a, 203/123a, 203/124a, 203/124b, 205/125, 205/125b, 207/125b, 209/126, 229/136, 230/136, 244/143, 246/145, 249/146a, 285/163, 286/164, 287/164, 409/281, 411/282, $413 / 283,414 / 284,415 / 285,419 / 287,804 / 539,805 / 540$

\section{Hrvatski državni arhiv, Zagreb}

\subsection{HR-HDA-913. Zbirka preslika na papiru, Croatica et Windica, Croatica}

Kutija i svežnjevi: kutija 1, svežanj 1,2,3, kutija 2 svežanj 4,5, kutija 3, svežanj 6 Mikrofilmovi: D-1911, D-1913, D-1914, D-1916, D-1918.

2.2. HR-HDA-913. Zbirka preslika na papiru, Zbirka preslika vojnih spisa iz Štajerskog zemaljskog arhiva u Grazu, Militaria

Kutije 2,3,4,7,8,9,

\subsection{HR-HDA-22. Ugarska dvorska komora. Urbarski spisi i popisi posjeda} Kutija 30

\subsection{HR-HDA-965. Osobni fond Josip Adamček}

Kutija 18

\subsection{HR-HDA-913. Grafička zbirka. Gradovi}

Inv.br. 1358.

\subsection{HR-HDA-902. Kartografska zbirka}

A II 17

\subsection{HR-HDA-904. Zbirka planova}

Inv. br. 11 


\section{Arhiv Hrvatske akademije znanosti i umjetnosti, Zagreb}

\section{HR-AHAZU-40. Ostavština Radoslava Lopašića}

Brojevi: $14,15,16,17$

\section{4. Österreichisches Staatsarchiv, Beč}

\subsection{Kriegsarchiv. Feldakten, Altefeldakten}

Fascikl 13

\subsection{Finanz und Hofkammerarchiv. Gedenkbücher}

Svezak 65 i 72

\subsection{Finanz und Hofkammerarchiv, Alte Hofkammer, Hoffinanz Ungarn} Kutija 5

\subsection{Objavljeni izvori}

Toma ARHIĐAKON, Historia Salonitana, Knijževni krug, Split, 2003.

Ivan BOJNIČIĆ, Izvješća o kretnjama turske vojske uz hrvatsku granicu u drugoj polovici XVI. vijeka, Vjesnik Kr. Hrvatsko-slavonsko-dalmatinskoga zemaljskoga arkiva, god. 16, 1914., 60-101.

Ivan BOJNIČIĆ, Kraljevske darovnice odnoseće se na Hrvatsku. Iz kraljevskih registraturnih knjiga „Libri Regii“, Vjesnik Kr. Hrvatsko-slavonsko.dalmatinskoga Zemaljskoga arkiva, god. 7 , 1906., 1-33;105-146.

Stjepan BRODARIĆ, Mohačka bitka 1526, Dukat, Vinkovci, 1990.

Joseph CHMEL, Actenstücke zur Geschichte Croatiens und Slawoniens in den Jahren 1526 und 1527., Beč, 1846.

Danijela COFEK, Nataša ŠTEFANEC, Vojnokrajiške institucije u praksi: Slavonska krajina 1578. godine, Podravina, vol. X, br. 19, 5-44.

Georg GÖTH, Regesten aus Schazgewölbüchern des k. k. Statthalterei-Archives in Graz, Mittheilungen des historischen Vereins für Krain, 20, br. 2, 1865., 17-22.

Mislav GREGL, Neven KOVAČEV, Nataša ŠTEFANEC, Prilozi za povijest diplomacije i vojnokrajiškog ratovanja u 16. stoljeću, Historijski zbornik, godina LXIII, br. 1, 2010., 169189.

Adem HANDŽIĆ, Opširni popis Bosanskog sandžaka iz 1604. godine, sv. I/2, Bošnjački institut Züruch-Odjel Sarajevo, Orijentalni institut Sarajevo, Sarajevo, 2000., 520-531. 
HRVATSKI POVIJESNI ATLAS, ur. Krešimir Regan, Leksikografski zavod Miroslav Krleža, Zagreb, 2003.

Aleksa IVIĆ, Prilozi za povijest Hrvatske i Slavonije u XVI. i XVII. vijeku, Starine, Jugoslavenska akademija znanosti i umjetnosti, knj. 35, 1916., 295-374.

Vjekoslav KLAIĆ, Acta Keglevichiana. Najstarije isprave porodice Keglevića do boja na Muhačkom polju, Monumenta Spectantia Historiam Slavorum Meridionalium, Zagreb, 1917.

Ešref KOVAČEVIĆ, Muhimme Defteri; Dokumenti o našim krajevima, Monumenta Turcica Historiam Slavorum Meridionalium Illustrantia, Tomus quartus, Serija III, Muhimme defteri, knjiga 1, svezak 1, Sarajevo, 1985.

Bogoljub KRNIC, Darivanja kralja Ferdinanda I. za Hrvatsku u god. 1527. do 1529., Vjesnik Zemaljskog Arkiva, god. 10, 1908, 1-20.

Ivan KUKULJEVIĆ SAKCINSKI, Listine hrvatske = Acta Croatica, Monumenta Historica Slavorum meridionalium, knj. 1, Zagreb, 1863.

Emilij LASZOWSKI, Habsburški spomenici Kraljevine Hrvatske, Slavonije i Dalmacije, knjiga I, Monumenta spectantia historiam Slavorum meridionalium, sv. 35, Zagreb, 1914.

Emilij LASZOWSKI, Habsburški spomenici Kraljevine Hrvatske, Slavonije i Dalmacije, knjiga II, Monumenta spectantia historiam Slavorum meridionalium, sv. 38, Zagreb, 1916.

Emilij LASZOWSKI, Habsburški spomenici Kraljevine Hrvatske, Slavonije i Dalmacije, knjiga III, Monumenta spectantia historiam Slavorum meridionalium Zagreb, sv. 40, 1917.

Radoslav LOPAŠIĆ, Spomenici Hrvatske krajine, knjiga I, Monumenta spectantia historiam Slavorum meridionalium, sv. 15, Zagreb, 1884.

Radoslav LOPAŠIĆ, Spomenici Hrvatske krajine, knjiga II, Monumenta spectantia historiam Slavorum meridionalium, sv. 16, Zagreb, 1885.

Radoslav LOPAŠIĆ, Spomenici Hrvatske krajine, knjiga III, Monumenta spectantia historiam Slavorum meridionalium, sv. 20, Zagreb, 1889.

Matija MESIĆ, Gradja mojih razprava u „Radu“, Starine, JAZU, knjiga 5, 1873., Zagreb, 109-228.

Vladimir MOŠIN, Seid M. TRLJAIĆ, Ćirilske isprave i pisma u Arhivu Jugoslavenske akademije, Starine, Jugoslavenska akademija znanosti i umjetnosti, knj. 46, 1956., 97-144.

Paul von RADICS, Familien - Chroniken krainischer Adeliger im 16. und 17. Jahrhundert, Mitteilungen des Musealvereines für Krain, 16, sv. I i II, 1903.

Franjo RAČKI, Gradja za poviest hrvatsko-slovenske seljačke bune god. 1573., Starine, Jugoslavenska akademija znanosti i umjetnosti, knj. 7, 1875., 164-322. 
Tadija SMIČIKLAS, Diplomatički Zbornik kraljevine Hrvatske, Dalmacije i Slavonije, sv. V, Jugoslavenska akademija znanosti i umjetnosti, Zagreb, 1907.

Ferdo ŠIŠIĆ, Iz Arkiva u Željeznom, Vjesnik Kr. Hrvatsko-slavonsko-dalmatinskog zemaljskog arkiva, god. 7, 1905., 137-177.

Ferdo ŠIŠIĆ, Hrvatski saborski spisi, knjiga I, Monumenta spectantia historiam Slavorum meridionalium, sv. 33, Zagreb, 1912.

Ferdo ŠIŠIĆ, Hrvatski saborski spisi, knjiga II, Monumenta spectantia historiam Slavorum meridionalium, sv. 36, Zagreb, 1915.

Ferdo ŠIŠIĆ, Hrvatski saborski spisi, knjiga III, Monumenta spectantia historiam Slavorum meridionalium, sv. 39, Zagreb, 1916.

Ferdo ŠIŠIĆ, Rukovet spomenika o hercegu Ivanišu Korvinu i borbama Hrvata s Turcima (1473-1496), Starine, Jugoslavenska akademija znanosti i umjetnosti, knj. 37, 1937., 189-344.

Ferdo ŠIŠIĆ, Rukovet spomenika o hercegu Ivanišu Korvinu i borbama Hrvata s Turcima (1473-1496), Starine, Jugoslavenska akademija znanosti i umjetnosti, knj. 38, 1937., 157-336. Lajos THALLÓCZY, A Blagay-család oklevéltára. Codex diplomaticus comitum de Blagay. Codex diplomaticus partium regno Hungariae adnexarum, Monumenta Hungariae Historica, Diplomataria, vol. XXVIII, Budimpešta, 1897.

Lajos THALLÓCZY, Sandor HORVATH, Also-Szlavoniai Okmanytar (Dubica, Orbasz es Szana Varmegyek) 1244.-1719., Codex diplomaticus partium regno Hungariae adnexarum, Monumenta Hungariae Historica, Diplomataria vol. XXXVI, Budimpešta, 1912.

Lajos THALLÓCZY, Antal HODINKA, A horvát véghelyek oklevéltára 1490-1527., Codex diplomaticus partium regno Hungariae adnexarum, Monumenta Hungariae Historica, vol. XXXI, Budimpešta, 1903.

Lajos THALlÓCZY, Sandor HORVÁTH, Banatus, castrum et oppidum Jajcza, Codex diplomaticus partium regno Hungariae adnexarum, Monumenta Hungariae Historica, vol. XL, Budimpešta, 1915.

Ivan Krstitelj TKALČIĆ, Povjestni spomenici Zagrebačke biskupije XII. i XIII. stoljeća, knjiga I, Zagreb, 1873. 


\subsection{Literatura}

Josip ADAMČEK, Ratovi s Turcima i položaj zavisnih seljaka u Pokuplju u drugoj polovici XV i XVI stoljeća, u: Karlovac 1579-1979, ur. Đuro Zatezalo, Historijski arhiv u Karlovcu, Karlovac, 1979., 41-48.

Josip ADAMČEK, Agrarni odnosi u Hrvatskoj od XV. do XVII. stoljeća, Sveučilišna naklada Liber, Zagreb, 1980.

Josip ADAMČEK, Glina i njezina okolica u srednjem vijeku, u: Glina. Glinski kraj kroz stoljeća, ur. Drago Roksandić i Mira Kolar-Dimitrijević, Skupština općine Glina, Glina, 1988., 13-19.

Gabor AGOSTON, Habsburgs and Ottomans: Defense, Military Change and Shifts in Power, Turkish Studies Association Bulletin, Vol. 22, br. 1, 1998., 126-141.

Gabor AGOSTON, Ottoman Conquest and the Ottoman Military Frontier in Hungary, u: A Millennium of Hungarian Military History, ur. Béla Király i László Veszprémy, War and Society in East Central Europe vol. XXXVII, Atlantic Studies on Society in Change, No. 114., Boulder Co., 2002., 85-110.

Gabor AGOSTON, Where Enviromental and Frontier Studies Meet: Rivers, Forests, Marshes and Forts along the Ottoman-Hapsburg Frontier in Hungary, u: The Frontiers of the Ottoman World, ur. A. C. S. Peacock, Proceedings of the British Academy, 156. Oxford: Oxford University Press, 2009., 57-79.

Mladen ANČIĆ, Bihać - slobodna kraljevska varoš, Istorijski zbornik, Univerzitet »Đuro Pucar Stari« Banjaluka, Institut za istoriju u Banjaluci, IV/4, 1983., 125-134.

Mladen ANČIĆ, Bihaćki kraj od 1262. do početka XV stoljeća, Glasnik arhiva i Društva arhivskih radnika Bosne i Hercegovine, god. 25, 1985., 193-230.

Mladen ANČIĆ, Da li je srednjovjekovni Bihać nastao na otoku, Istorijski zbornik, Univerzitet »Đuro Pucar Stari« Banjaluka, Institut za istoriju u Banjaluci, god. VII, br. 7, 1986., 237-238.

Mladen ANČIĆ, Knin u razvijenom i kasnom srednjem vijeku, Radovi Zavoda za povijesne znanosti HAZU u Zadru, sv. 38, 1996., 53-95.

Mladen ANČIĆ, Srednjovjekovni Vlasi kontinentalne Dalmacije, u: Dalmatinska Zagora nepoznata zemlja, ur. Vesna Kusin, katalog izložbe, Galerija Klovićevi dvori, Zagreb, 2007. 161-168. 
Muhammet Zahit ATÇIL, State and Government in the Mid-Sixteenth Century Ottoman Empire: The Grand Vizierates of Rüstem Pasha (1544-1561), doktorska disertacija, University of Chicago, 2015.

Doris BACHMANN-MEDICK, Spatial Turn, u: Cultural Turns: Neuorientierungen in den Kulturwissenschaften, Rowohlt-Taschenbuch-Verlag, Reinbek bei Hamburg, 2009.

Doris BACHMANN-MEDICK, Cultural Turns. New Orientations in the Study of Culture, De Gruyter, Berlin/Boston, 2015.

János M. BAK, Hungary and Crusading in the Fifteenth Century, u: Crusading in the Fifteenth Century. Message and Impact, ur: Norman Housley, Palgrave Macmillan, New York, 2004., 116-127.

Pamela BALLINGER, „,Authentic Hybrids“ in the Balkan Borderlands“, Current Anthropology, vol. 45, br. 1, 2004., 31-60.

Maria BARAMOVA, Border Theories in Early Modern Europe, u: European History Online (EGO), izdanje Institute of European History (IEG), Mainz 2010-12-03. dostupno na http://ieg-ego.eu/en/threads/crossroads/border-regions/maria-baramova-border-theories-inearly-modern-europe

Attila BARANY, War, crown and society in the eyes of papal legate: Cardinal Campeggio in Hungary (1524.-1525.), u: The Image of States, Nations and Religions in Medieval and Early Modern Central and East Central Europe, ur. Attila Barany, Reka Bozzay, Balasz Antal Bacsa, Memoria Hungariae 5, Debrecen, 2018.

Frederick BARTH, Ethnic Groups and Boundaries: The Social Organization of Culture Difference, Little, Brown and Company, Boston, 1969.

Michiel BAUD, Willem van SCHENDEL, Toward a Comparative History of Borderlands, Journal of World History, vol. 8, br. 2, 1997., 211-242.

Jean BERENGER, Die Geschichte des Habsburgerreiches 1273-1918, Böhlau Verlag WienKöln-Weimar, 1996.

Zrinka BLAŽEVIĆ, Triplex Confinium - Liminal Spaces of Transculturation and Hybridisation in the Early Moder Period, u: Die Erschließung des Raumes, ur. Karin Friedrich, Wiesbaden: Harrassowitz Verlag, 2014., 741-756.

Zrinka BLAŽEVIĆ, Istraživanje vojnokrajiške povijesti iz perspektive »studija granica«: mogućnosti i ograničenja, u: Franz Vaniček $i$ vojnokrajiška historiografija. Zbornik radova sa znanstvenog skupa s međunarodnim sudjelovanjem, ur. Robert Skenderović i Stanko Andrić, Hrvatski institut za povijest - Podružnica za povijest Slavonije, Srijema in Baranje, Slavonski Brod, 2017., 59-73. 
Zrinka BLAŽEVIĆ, At the Crossroads: Methodologies for Liminal Spaces, u: Liminal Spaces of Art between Europe and Middle East, ur. Ivana Prijatelj Pavičić, Marina Matijašić Vicelja, Martin Germ, Gašpar Cerkovnik, Ines Babnik i Nina Diaz Fernandez, Cambridge Scholars Publishig, Cambridge, 2018., 1-11.

Branko J. BOKAN, Srednjovjekovni grad Bihać izgrađen je na brežuljku pored Une, a ne na Uni, Istorijski zbornik, god. VII, br. 7, Univerzitet »Đuro Pucar Stari« Banja Luka, Institut za istoriju u Banjaluci, 1986., 233-236.

Ivan BOTICA, Krbavski knezovi u srednjem vijeku, doktorska disertacija, Filozofski fakultet Sveučilišta u Zagrebu, Zagreb, 2011.

BOROSY Andras, The Militia portalis in Hungary before 1526, u: From Hunyadi to Rakoczi War and Society in late Medieval and Early Modern Hungary, ur. Janos M. Bak, Bela K. Kiraly, War and Society in Eastern Central Europe, vol. III, Brooklyn College Press, Brooklyn, 1982.

Catherine Wendy BRACEWELL, Senjski Uskoci, Barbat, Zagreb, 1997.

Catherine Wendy BRACEWELL, Frontier Blood-brotherhood and the Triplex Confinium, u: Constructing Border Societies on the Triplex Confinium, ur. Drago Roksandić, Nataša Štefanec, Central European University, Budimpešta, 2000., 29-45.

Catherine Wendy BRACEWELL, The Historiography of the Triplex Confinium. Conflict and Community on a Triple Frontier $16^{\text {th }}-18^{\text {th }}$ centuries, u: Frontiers and the Writing of History, 1500-1850, ur. Steven G. Ellis i Raingard Eßer, Hannover-Laatzen: Wehrhahn Verlag, 2006., 211-227.

Silvio BRAICA, Kratki pojmovnik o moru, ribarstvu i pomorstvu, Ethnologica Dalmatica, vol. 22, br. 1, 2015., 343-406.

Franjo BUĆAR, Odnošaji Primoža Turbara prama hrvatskoj tiskari u Würtemberškoj, u: Trubarjev zbornik, ur. Fran Ilešič, Matica Slovenska, Ljubljana, 1908., 21-44.

Neven BUDAK, Uloga bihaćke komune u obrani granice, Historijski zbornik, god. XLII, 1989., 163-170.

Neven BUDAK, Pogranična gradska naselja sjeverne Hrvatske u 17. stoljeću, Radovi Zavoda za hrvatsku povijest Filozofskog fakulteta u Zagrebu, vol. 15, 1992., 27-38.

Neven BUDAK, Budući da smo htjeli u Zagrebu na brdu Gradecu sagraditi slobodni grad..., Rađanje Gradeca - okolnosti, poticaji, slijed, u: Zlatna bula 1242-1992, ur. Zlatko Stublić, Zagreb 1992., 21-32.

Neven BUDAK, Gradovi Varaždinske županije u srednjem vijeku, Nakladna kuća „Dr. Feletar“'Koprivnica, Zagreb-Koprivnica, 1994. 
Neven BUDAK, Der Einfluss der Migrationen auf die Veränderung der ethnischen Selbstidentifikation im Raum des Mittelalterlichen Slawoniens, u: Verfestigungen und Änderungen der ethnischen Strukturen im pannonischen Raum von 1526-1790, ur. Neven Budak and Božena Vranješ-Šoljan, Internationales kulturhistorisches Symposion Mogersdorf 1997, vol. 28, Zagreb: Zavod za hrvatsku povijest 2000., 5-21.

Neven BUDAK, Hrvatska i Slavonija u ranome novom vijeku, Leykam international:Barbat, Zagreb, 2007.

Peter BURKE, Concept of Continuity and Change in History, u: The New Cambridge Modern History, ur. Peter Burke, Cambridge University Press, svez. XIII, 1979., 1-15.

Constructing Border Societies on the Triplex Confinium, ur. Drago ROKSANDIĆ, Nataša ŠTEFANEC, Central European University, Budimpešta, 2000.

Linda DARLING, The Mediterranean as a Borderland, Review of Middle East Studies, vol. 46, No. 1, 2012., 54-63.

Christopher DUFFY, Siege Warfare. The Fortress in the Early Modern World 1494-1660, Routledge \& Kegan Paul, London, 1979.

Kathryn A. EDWARDS, Families and Frontiers: Re-Creating Communities and Boundaries in the Early Modern Burgundy, Studies in Central European Histories, Brill; Boston, 2002.

Steven G. ELLIS, Lud'á KLUSÁKOVÁ, Introduction: Frontiers and Identities in Context, u: Imagining Frontiers, Contesting Identities, ur. Steven G. Ellis, Lud'a Klusáková, Pisa University Press, 2007.

Pal ENGEL, The Realm of St. Stephen. A History of Medieval Hungary, I.B. Tauris, LondonNew York, 2001.

Ivan ERCEG, Šišićeve biljeske za povijest hrvatskih saboru u XVI. stoljeću, Zbornik Odsjeka za povijesne znanosti Zavoda za povijesne i društvene znanosti JAZU, vol. 1, 1954., 407-479. Fedor Moačanin. Radovi iz povijesti Vojne krajine, ur. Nataša ŠTEFANEC, Čedomir VIŠNJIĆ, SKD "Prosvjeta", Zagreb, 2016.

Thomas FELLNER, Heinrich KRETSCHMAYR, Die österreichische Zentralverwaltung. Geschichtliche Übersicht. Abt. I, Bd. 1, Veröff. d. Komission f. neuere Geschichte Österreichs 5, Beč, 1907.

Pal FODOR, Introduction, u: Ottomans, Hungarian, and Habsburgs in Central Europe. The Military Confines in the Era of Ottoman Conquest, ur. Géza David i Pal Fodor, Brill, Leiden;Boston; Köln, 2000. 
Franz Vaniček $i$ vojnokrajiška historiografija, Zbornik radova s znanstvenog skupa sa međunarodnim sudjelovanjem, Hrvatski institut za povijest - podružnica za povijest Slavonije Srijema in Baranje, ur. Robert SKENDEROVIĆ, Stanko ANDRIĆ, Slavonski Brod, 2017.

Leonhart FRONSPERGER, Das Kriegsbuch, II. dio, Frankfurt, 1596.

Ferdo GESTRIN, Gospodarstvo na slovenskem in Vojna krajina, Zgodovinski časopis, XXXX, br. 4, 1986., 413-421.

Stipe GRGAS, O zaokretu ka prostoru, Filozofska istraživanja, 125, god. 32, sv. 1, 2002., 169-177.

Borislav GRGIN, Počeci raspada. Kralj Matijaš Korvin i srednjovjekovna Hrvatska, Ibis grafika, Zagreb, 2001.

Isaiah GRUBER, The Muscovite Embassy of 1599 to Emperor Rudolf II of Habsburg, masters thesis, McGill University Montreal, 1999.

Anna Maria GRÜNFELDER, Vojna Krajina i reformski procesi u ranom novom vijeku, s posebnim osvrtom na Primorsku krajinu i grad Senj, Senjski zbornik, vol. 36, br.1, 2009., 91122.

Zlatko HERKOV, Prinosi za poznavanje naših starih mjera za dužinu i površinu, Zbornik Odsjeka za povijesne znanosti Zavoda za povijesne $i$ društvene znanosti Jugoslavenske akademije znanosti i umjetnosti, vol. 8, 1977., 143-215.

Carl Bernhard Edlen von HIETZINGER, Statistik der Militärgränze des österreichischen Kaiserthums, vol. 1, Beč, 1817.

Željko HOLJEVAC, Nenad MOAČANIN, Hrvatsko-slavonska Vojna krajina i Hrvati pod vlašću Osmanskoga Carstva u ranome novom vijeku, Leykam international:Barbat, Zagreb, 2007.

Karlo HORVAT, Kobenzelovi izvještaji (1592.-1594.) kardinalu Cintiju Aldobrandiniju, državnom tajniku pape Klementa VIII, Starine, Jugoslavenska akademija znanosti i umjetnosti, knj. 32, 1907., 131-316.

Karlo HORVAT, Prilozi za hrvatsku povijest iz arhiva rimskih, Starine, Jugoslavenska akademija znanosti i umjetnosti, knj. 34, 1913., 64-172.

Richard HORVATH, The Castle of Jajce in the Organization of the Hungarian Border Defence System under Matthias Corvinus, u: Stjepan Tomašević (1461-1463) - slom srednjovjekovnog Bosanskog Kraljevstva, ur. Ante Birin, Hrvatski Institut za povijest, Katoličko bogoslovni fakultet u Sarajevu, Zagreb, 2013., 89-98. 
Franjo Emanuel HOŠKO, Franjevci u Krbavskoj biskupiji, u: Krbavska biskupija u srednjem vijeku, ur. Mile Bogović, Visoka bogoslovska škola u Rijeci, Kršćanska sadašnjost, RijekaZagreb, 1988., 83-94.

Andrej HOZJAN, Die ersten steirischen Kundschafter vnd Postbeförderer. Spionage, Kontraspionage und Feldpost der Grazer Behörden zwischen 1538 und 1606, Mitteilungen des Steiermärkischen Landesarchivs, 48, 1998., 237-279.

Andrej HOZJAN, Prve pošte $i$ poštari kontinentalne Hrvatske. Postanak $i$ djelatnost vojnokrajiškog poštanskog sustava na području između Kupe i Mure do 1606. godine, Hrvatska akademija znanosti i umjetnosti, Zavod za znanstveni rad; Filozofski fakultet, Centar za komparativnohistorijske i interkulturne studije; Univerza v Mariboru, Filozofska fakulteta Zagreb, Varaždin:Zagreb:Maribor, 2017.

Aleksa IVIĆ, O prvoj srpskoj seobi u Žumberak (1530-1535), Vjesnik Kr. hrvatskoslavonsko-dalmatinskoga zemaljskog arkiva, god. XX, sv. 1-2, 1918., 245-279.

Danijel JELAS̆, Gradovi Požeške, Vukovske i Srijemske županije u srednjem vijeku, magistarski rad, Filozofski fakultet Sveučilišta u Zagrebu, 2011.

Danijel JELAŠ, Tipologija srednjovjekovnih gradskih naselja u donjem međurječju Drave i Save, Povijesni zbornik: godišnjak za kulturu i povijesno naslijeđe, vol. 4, br. 5, 2012., 33-50. Stanko JUG, Turški napadi na Kranjsko in Primorsko od prve tretjine 16. stoletja do bitke pri Sisku (1593), Zgodovinski časopis, IX, br. 1-4, 1955., 26-62.

Kornelija JURIN-STARČEVIĆ, Demografska kretanja u selima srednjodalmatinskog zaleđa u 16. stoljeću i početkom 17. stoljeća, Prilozi za orijentalnu filologiju, 54, 2005., 139-167.

Kornelija JURIN-STARČEVIĆ, Osmanski krajiški prostor: rat i društvo u jadranskodinarskom zaleđu u 16. i 17. stoljeću, doktorska disertacija, Filozofski fakultet Sveučilišta u Zagrebu, Zagreb, 2012.

Kornelija JURIN-STARČEVIĆ, Urbanization on the Ottoman Borders: Small Towns in the South-West Serhad of the Bosnian Eyalet from the Sixteenth to the Eighteenth Centuries, u. Bordering Early Modern Europe, ur. Maria Baramova, Grigor Boykov, Harrassowitz Verlag, 2015., 257-273.

Ivan JURKOVIĆ, Turska opasnost i hrvatski velikaši - knez Bernardin Frankopan i njegovo doba, Zbornik Odsjeka za povijesne znanosti Zavoda za povijesne $i$ društvene znanosti Hrvatske akademije znanosti i umjetnosti, vol. 17, 2000., 61-83.

Ivan JURKOVIĆ, Klasifikacija hrvatskih raseljenika za trajanja osmanske ugroze, Migracije $i$ etničke teme, vol. 19, No. 2-3, 2003., 147-174. 
Ivan JURKOVIĆ, The Fate of the Croatian Noble Families in the Face of the Ottoman Advance, doktorska disertacija, Central European University, Budimpešta, 2004.

Ivan JURKOVIĆ, Prozopografska analiza „Teštamenta“ gospe Jeleni, sestri pokojnoga kneza Petra Kružića, u: Raukarov zbornik, ur. Neven Budak, FF Press, Zagreb, 2005., 381-419.

Ivan JURKOVIĆ, Ugrinovići od Roga - raseljena obitelj plemenitog roda Šubića Bribirskih za trajanja osmanske ugroze, Zbornik Odsjeka za povijesne znanosti Zavoda za povijesne $i$ društvene znanosti Hrvatske akademije znanosti i umjetnosti, vol. 26, 2008., 71-85.

Karl KASER, Slobodan seljak $i$ vojnik. Rana krajiška društva (1545-1754.), knjiga I, Naprijed, Zagreb, 1997.

Hrvoje KEKEZ, Plemići rod Babonića do kraja 14. stoljeća, doktorska disertacija, Filozofski fakultet Sveučilišta u Zagrebu, Zageb, 2012.

Bela K. KIRALY, Society and war from mounted knights to the standing armies of absolute kings: Hungary and the West, u: From Hunyadi to Rakoczi War and Society in late Medieval and Early Modern Hungary, ur. Janos M. Bak, Bela K. Kiraly, Brooklyn College Press, Brooklyn, 1982., 23-59.

Frannz Christoph KHEVENHILLER, Annales Ferdinandei oder Wahrhaffte Beschreibung Kaysers Ferdinandi des Andern, prvi svezak, Leipzig, 1721.

Nada KLAIĆ, Prilog pitanju postanka slavonskih varoši, Zbornik radova. Filozofski fakultet Sveučilišta u Zagrebu, knjiga III, 1955., 41-59.

Nada KLAIĆ, »Ostaci ostataka« Hrvatske i Slavonije u XVI. stoljeću (od Mohačke bitke do Seljačke bune 1573. g.), Arhivski vjesnik, vol 16, br. 1, 1973., 253-322.

Nada KLAIĆ, Nastajanje Krajine u XVI stoljeću s posebnim obzirom na postanak Karlovca, u: Karlovac 1579-1979, ur. Đuro Zatezalo, Historijski arhiv u Karlovcu, Karlovac, 1979., 5357.

Vjekoslav KLAIĆ, Povijest Hrvata, knjiga 4, Nakladni zavod Matice Hrvatske, Zagreb, 1975. Vjekoslav KLAIĆ, Povijest Hrvata, knjiga 5, Nakladni zavod Matice Hrvatske, Zagreb, 1975. Vedran KLAUŽER, Petar Tarnok od Mačkaša (de Machkas), kapetan Senjske kapetanije (1486.-1492.), u: Ascendere historiam. Zbornik u čast Milanu Kruheku, ur. Marija Karbić, Hrvoje Kekez, Ana Novak i Zorislav Horvat, Hrvatski institut za povijest, Zagreb, 2014., 8194.

Vedran KLAUŽER, Ustrojstvo $i$ djelovanje Senjske kapetanije od njezina osnutka da organizacije Vojne krajine po vrhovnim zapovjedniku Ivanu Lenkoviću (1469.-1563.), doktorska disertacija, Hrvatski studiji Sveučilišta u Zagrebu, 2015. 
Lud'á KLUSÁKOVÁ, “A European on the Road”: in pursuit of "Connecting Themes" for Frontiers, Borders and Cultural Identities, u: Imagining Frontiers, Contesting Identities, ur. Steven G. Ellis, Lud'a Klusáková, Pisa University Press, 2007., 1-19.

Duška KNEŽEVIĆ-HOČEVAR, Studying International Borders in Geography and Anthropology: Paradigmatic and Conceptual Relations, Geografski zbornik, XXXX, 2000., 82-97.

Elma KORIĆ, Kapetani rijeke Save u 16. stoljeću, u: Rijeka Sava u povijesti, ur. Branko Ostajmer, Hrvatski institut za povijest - podružnica za povijest Slavonije, Srijema in Baranje, Slavonski Brod, 2013.

Midhat KOZLIČIĆ, Unsko-sansko područje na starim geografski kartama (Izbor karata, planova i veduta u kontekstu historije Unsko-sanskog područja od kraja 15. do početka 18. stoljeća), Nacionalna i univerzitetska biblioteka BIH, Arhiv Unsko-sanskog kantona, Sarajevo-Bihać, 2003.

Milan KRUHEK, Stvaranje i utvrđivanje granice na Kupi u XVI i XVII stoljeću, u: Vojna krajina. Povijesni pregled-historiografija-rasprave, ur. Dragutin Pavličević, Zagreb, 1984., 215-258.

Milan KRUHEK, Utvrde Senjske kapetanije u XVI. stoljeću, Senjski zbornik, vol. 17, No. 1, 1990., 93-112.

Milan KRUHEK, Krajiške utvrde Hrvatskog kraljevstva tijekom 16. stoljeća, Institut za suvremenu povijest, Zagreb, 1995.

Milan KRUHEK, Kostajnica u protuturskoj obrani Hrvatskoga Kraljevstva, Povijesni prilozi, vol. 21, br. 21, 2001., 71-94.

Ivan KUKULJEVIĆ SAKCINSKI, Beatrice Frankapan $i$ njezin rod, pretisak iz Vijenca, Zagreb, 1885., 25.

Vjeran KURSAR, Being an Ottoman Vlach: On Vlach Identity(ies), Role and Status in Western Parts od the Ottoman Balkans ( $15^{\text {th }}-18^{\text {th }}$ Centuries $)$ OTAM, 34, 2013., 115-161.

Owen LATTIMORE, The Frontier in History, u: Anthropological Theory, ur. Robert A. Manners, David Kaplan, New Jersey, 2009., reprint izdanja iz 1968., 374-386.

Sanja LAZANIN, Nataša ŠTEFANEC, Habsburg Military Conscription and Changing Realities of the Triplex Confinium (16th-18th Centuries), u: Constructing Border Societies on the Triplex Confinium, ur. Drago Roksandić, Nataša Štefanec, Central European University, Budimpešta, 2000., 91-116.

Patricia Nelson LIMERICK, The Legacy of Conquest: The unbroken Past of the American West, W.W. Norton \& Company, 1987. 
Radoslav LOPAŠIĆ, Bihać i Bihaćka krajina, Matica Hrvatska, Zagreb, 1890.

Radoslav LOPAŠIĆ, Oko Kupe i Korane, Matica Hrvatska, Zagreb, 1895.

Martine LÖW, Raumsociologie, Suhrkamp, Frankfurt am Main, 2001.

Michael MANN, The Sources of Social Power. Volume I: A History of Power from the Beginning to A.D. 1760., Cambridge, 1986.

Lujo MARGETIĆ, Zagreb i Slavonija. Izbor studija, HAZU-Vitograf-Adamić, ZagrebRijeka, 2000.

Oscar J. MARTINEZ, Border People. Life and Society in the U.S.-Mexico Borderlands, University of Arizona Press, Tucson, 1994.

Oscar J. MARTINEZ, Troublesome Border, drugo izdanje, University of Arizona Press, Tucson, 2006.

Ive MAŽURAN, Hrvati i Osmansko carstvo, Golden Marketing, Zagreb, 1998.

Matija MESIĆ, Banovanje Petra Berislavića, RAD, Jugoslavenska akademija znanosti i umjetnosti, knj. 3, Zagreb, 1868.

Fedor MOAČANIN, Osnovni problemi obrane Hrvatske u 16. stoljeću, u: Karlovac 15791979, ur. Đuro Zatezalo, Historijski arhiv u Karlovcu, Karlovac, 1979., 49-51.

Fedor MOAČANIN, Vojna krajina do kantonskog uređenja 1787., u: Vojna krajina. Povijesni pregled-historiografija-rasprave, ur. Dragutin Pavličević, Zagreb, 1984., 23-56.

Fedor Moačanin, Organizacijske strukture Vojne krajine do sredine 18. st., Arhivski vjesnik br. 34-35, 1991.-1992., 157-163.

Nenad MOAČANIN, Turska Hrvatska. Hrvati pod vlašću Osmanskog Carstva do 1791: preispitivanja, Matica Hrvatska, Zagreb, 1999.

Nenad MOAČANIN, Slavonija i Srijem u razdoblju osmanske vladavine, Hrvatski institut za povijest. Podružnica za povijest Slavonije, Srijema i Baranje, Slavonski Brod, 2001.

Nenad MOAČANIN, Town and country on the middle Danube: 1526-1690, Leiden, Boston:Brill, 2006.

Jelena MRGIĆ, Wine or Raki - The Interplay of Climate and Society in Early Modern Ottoman Bosnia, Environment and History, 17, 2011., 613-637.

Ivan Tonko MRNAVIĆ, Životopis Petra Berislavića, Hrvatski institut za povijest, Muzej grada Trogira, Zagreb-Trogir, 2008.

Nils MÜLLER, Social Frontiers Modernizig an old paradigm for modern border research, izlaganje s konferencije „The Multifaced Economic and Political Geographies of Internal and External EU Borders, održane 23-26. rujna 2011. u gradu Veria u Grčkoj. 
Zrinka NIKOLIĆ, Obitelj Čupor Moslavački, Radovi Zavoda za znanstvenoistraživački i umjetnički rad u Bjelovaru, br. 4, Zagreb-Bjelovar, 2011., 269-300.

Arpad NOGRADY, A List of Ransom for Ottoman Captives Imprisoned in Croatian Castles (1492), u: Ransom Slavery along the Ottoman Borders, (Early Fifteenth - Early Eighteenth Centuries), ur. Géza David i Pal Fodor, Brill, Leiden-Boston, 2007., 19-26

Claire NORTON, Nationalism and the Re-Invention of Early-Modern Identities in the Ottoman-Habsburg Borderlands. Region, Regional Identity and Regionalism in Southeastern Europe, Ethnologia Balkanica, vol. 11, Journal for Southeast European Anthropology, Berlin, 2007. 79-101.

Ana NOVAK, Gorski arhiđakonat Zagrebačke biskupije od 1334. do 1501. godine, doktorska disertacija, Hrvatski studiji Sveučilišta u Zagrebu, Zagreb, 2011.

Domagoj NOVOSEL, Stanovništvo upravne općine Gračani - Remete između dva svjetska rata, doktorska disertacija, Hrvatski studiji Sveučilišta u Zagrebu, Zagreb, 2015.

Géza PÁLFFY, A Magyarországi és délvidéki végvárrendszer 1576. és 1582. évi jegyzékei, Hadtörténelmy Közlemények, No. 1, Budimpešta, 1995., 114-185.

Géza PÁLFFY, The Origines and Development of the Border Defence System Against the Ottoman Empire in Hungary (up to the Early Eighteenth Century), u: Ottomans, Hungarians, and Habsburgs in Central Europe. The Military Confines in the Era of Ottoman Conquest, ur. Géza David i Pal Fodor, Brill, Leiden;Boston; Köln, 2000., 3-69.

Géza PÁLFFY, Die Türkenabwehr in Ungarn im 16. und 17. Jahrhundert - ein Forschungsdesiderat, u: Anzeiger der philosophischen-historischen Klasse der Österreichischen Akademie der Wissenschaftten, 137, (2002.), 99-131.

Géza PÁLFFY, The Border System in Hungary in the Sixteenth and Seventeenth Centuries, u: A Millennium of Hungarian History, ur. László Veszprémy-Bélá K. Király, Columbia University Press, New York, 2002., 111-135.

Geza PÁLFFY, Ransom Slavery along the Ottoman-Hungarian Frontier in the Sixteenth and Seventeenth Centuries, u: Ransom Slavery along the Ottoman Borders (Early Fifteenth Early Eighteenth Centuries), ur: Geza Dávid-Pál Fodor, Brill, Leiden-Boston-Köln, 2007. 35-83.

Géza PÁLFFY, Schorched-Earth Tactics in Ottoman Hungary: On Controversy in Military Theory and Practice on the Habsburg-Ottoman Frontier, Acta Orientalia Academiae Scientiarum Hungaricae, vol. 61, No. 1-2, 2008., 181-200.

Géza PÁLFFY, Povijest Madžarske - Ugarska na granici dvaju imperija (1526.-1711.), Meridijani, Zagreb, 2010. 
Géza PÁLFFY, The Habsburg Defense System in Hungary Against the Ottomans in the Sixteenth Century: A Catalyst of Military Development in Central Europe, u: Warfare in Eastern Europe, 1500-1800., ur. Biran J. Davies, Leiden-Boston, Brill, 2012., 35-61.

Bradley J. PARKER, Lars RODSETH, Introduction. Theoretical Considerations in the Study of Frontiers, u: Untaming the Frontier in Anthropology, Archeology and History, ur. Bradley J. Parker, Lars Rodseth, The University of Arizona Press, Tuscon, 2005., 3-21.

Andrew Charles Spencer PEACOCK, Introduction: The Ottoman Empire and its Frontiers, u: The Frontiers of the Ottoman World, ur. A.C.S. Peacock, Proceedings of the British Academy, Oxford University Press, Oxford, 2009., 1-30.

István PETROVICS, The role of towns in the defence system of medieval Hungary, $\mathrm{u}: \mathrm{La}$ guerre, la violence et les gens au Moyen Âge, ur. Philippe Contamine i Olivier Guyotjeannin, Éditions du CHTS, 1996., 263-271.

István PETROVICS, King Matthias and the Towns of the Realm, Analele Banatului, serie nouă. Arheologien. Istorie, vol. XXI, 2013., 283-294.

Maria Pia PEDANI, The Ottoman-Venetian Border (15th-18th Centuries), Hilal Studi tuchi e ottomani 5, Edizioni Ca' Foscari, Venezia, 2017.

Hrvoje PETRIĆ, O ukupnom broju stanovnika slobodnih kraljevskih gradova Hrvatskoslavonskog Kraljevstva od sredine 16. do početka 18. stoljeća, u: Raukarov zbornik, ur. Neven Budak, FF Press, Zagreb, 2005., 262-274.

Victor PRESCOTT, Gillian D. TRIGGS, International Frontiers and Boundaries. Law, Politics and Geography, Martinus Nijhoff Publishers, Leiden - Boston, 2008.

Tomislav RAUKAR, Društveni odnosi u Hrvatskoj u XV. stoljeću, Historijski zbornik, god. 38, 1985., 75-94.

Raukarov zbornik, ur. Neven Budak, FF Press, Zagreb, 2005.

Branka RAUNIG, Neki podaci o sojeničkim naseljima u Bihaćkom polju, Opuscula archeologica, 27, 2003., 269-276.

Juraj RATTKAY, Spomen na kraljeve i banove Kraljevstva Dalmacije, Hrvatske i Slavonije, Hrvatski institut za povijest, Zagreb, 2001.

Gyula RAZSO, The mercenary army of king Matthias Corvinus, u: From Hunyadi to Rakoczi War and Society in late Medieval and Early Modern Hungary, ur. Janos M. Bak, Bela K. Kiraly, Brooklyn College Press, Brooklyn, 1982., 125-140.

Branko REISP, Tiskarna Janzea Mandelca in leta 1578 tiskana pesem o zmagi Ivana Ferenbergerja nad Turki, Kronika, god. 23, br. 2, 1975., 81-87. 
Alfred J. RIEBER, Triplex Confinium in Comparative Context, u: Constructing Border Societies on the Triplex Confinium, ur. Drago Roksandić, Nataša Štefanec, Central European University, Budimpešta, 2000., 13-28.

Clifford J. ROGERS, Tactics and the face of battle, u: European Warfare, 1350-1750, ur. Frank Tallett i D. J. B. Trim, Cambridge University Press, Cambridge, 2010., 203-235.

Drago ROKSANDIĆ, Stojan Janković in the Morean War, or of Uskoks, Slaves and Subjects, u: Constructing Border Societies on the Triplex Confinium, ur. Drago Roksandić, Nataša Štefanec, CEU History Department Working Paper Series 4, Budimpešta, 2000., 239-288.

Drago ROKSANDIĆ, Triplex Confinium. Ili o granicama i regijama hrvatske povijesti, Barbat, Zagreb, 2003.

Drago ROKSANDIĆ, Dalmatinska zagora u ranome novom vijeku: pitanja za raspravu, u: Dalmatinska zagora nepoznata zemlja, katalog izložbe, ur. Vesna Kusin, Galerija Klovićevi dvori, Zagreb, 2007., 185-194.

Franz Otto ROTH, Wihitsch und Weitschwar, Zeitschrift des Historischen Vereines für Steiermark, god. LX, Graz, 1969., 199-275.

Gunther Erich ROTHENBERG, The Military Border in Croatia, 1522-1747, Urbana, 1960. Vladimir von SCHNURBEIN, Die Bemühungen des Hauses Habsburg zur Ansiedlung von Ritterorden beim Aufbau der Militägrenze, Arbeitskreis Militär und Gesellschaft in der Frühen Neuzeit e. V. Militär und Gesellschaft in der Frühen Neuzeit, 12, Heft 1, Sveučilište u Potsdamu, 2008., 36-52.

Winfried SCHULZE, Landesdefension und Staatsbildung. Studien zum Kriegswesen des innerösterreichischen Teritorialstaates (1564-1619), Wien-Graz-Köln, 1973.

Vasko SIMONITI, Prispevek k poznavanju turških vpadov v letih od 1570 do 1575 , Zgodovinski Časopis, XXXI, br. 4, 1977., 491-503.

Vasko SIMONITI, Prispevek k poznavanju turških vpadov od leta 1576 do začetka gradnje Karlovca leta 1579., Zgodovinski časopis, XXXIV, 1980., 87-99.

Vasko SIMONITI Turki su v deželi že, Mohorjeva družba, Celje, 1990.

Vasko SIMONITI, Vojaška organizacija na Slovenskem v 16. stoletju, Slovenska Matica Ljubljana, 1991.

Paul SRODECKI, Antemurale Christianitatis, u: Religiöse Erinnerungsorte in Ostmitteleuropa. Konstitution und Konkurrenz im nationen-und epochen übergreifenden Zugriff, ur. Joachim Bahlcke, Stefan Rohdewald, Thomas Wünsch, Berlin, 2013., 804-822.

Damir STANIĆ, Ambivalentna lojalnost na Hrvatskoj krajini u 16. stoljeću, u: Franz Vaniček $i$ vojnokrajiška historiografija. Zbornik radova sa znanstvenog skupa s međunarodnim 
sudjelovanjem, ur. Robert Skenderović, Stanko Andrić, Hrvatski institut za povijest Podružnica za povijest Slavonije, Srijema in Baranje, Slavonski Brod, 2017., 121-142.

Mark L. STEIN, Guarding the Frontier. Ottoman Border Forts and Garrisons in Europe Taurus Academic Studies, London-New York, 2007.

Ivan STEKLASA, Kako so Turki osvojili Bihać, Ljubljanski zvon, god. XI, br. VII, 1891., 404-410; 486-492.

Ivan STEKLASA, Padec Krupe leta 1565, Ljubljanski zvon, god. XII, br. III, 1892., 169-174; 286-292.

Ivan STEKLASA, Khevenhülerjeva vojska na Turke leta 1578, Ljubljanski zvon, god. XIV, br. XI, 1894., 662-669; 738-745.

Ivan STEKLASA, Protestantizem v Istri, v metliški in hrvatski Krajini, u: Trubarjev zbornik, ur. Fran Ilešič, Matica Slovenska, Ljubljana, 1908.

Ferenc SZAKALY, The Hungarian-Croatian Border Defense System and its Collapse, u: From Hunyadi to Rakoczi War and Society in late medieval and early modern Hungary, ur. Janos M. Bak i Bela K. Kiraly, Brooklyn College Press, Brooklyn, 1982., 141-158.

Blanka SZEGHYOVÁ, Coexistence of Diversities: Social, Ethnic and Religious Frontiers and Identities in Early Modern Hungarian Towns. u: Frontiers and Identities. III. Thematic work group 5. Cities in Regions and Nations., ur: Klusáková, Lud’a - Teulières, Laure, Edizioni Plus Pisa University Press, Pisa, 2008., 121-135.

Balázs A. SZELÉNYI, The Dynamics of Urban Development: Towns in Sixteenth and Seventeenth-Century Hungary, American Historical Review, 109, 2, 2004., 360-386.

Katalin SZENDE, Towns along the way. Changing patterns of long-distance trade and the urban network of medieval Hungary, u: Towns and communication. Volume 2; Communication between Towns, ur. Hubert Houben, Kristjan Toomaspoeg, Proceedings of the Meetings of the International Commision for the History of Towns (ICHT), ur. Mario Congedo, Lecce, 2011., 161-225.

Katalin SZENDE, The Urban Economy in Medieval Hungary, u: The Economy of Medieval Hungary, ur. József Laszlovszky, Balázs Nagy, Péter Szabó, András Vadas, Brill, LeidenBoston, 2018., 335-358.

Marko ŠARIĆ, Vlasi na tromeđi: suživot u sukobima u graničnim društvima $i$ kulturama Morlakije (16.-17. stoljeće), doktorska disertacija, Filozofski fakultet, Zagreb, 2010.

Marko ŠARIĆ, Etnokulturna kretanja u srednjem Pounju u ranom novom vijeku s posebnim osvrtom na bivšu općinu Zavalje, u: Podplješevički graničari. Zbornik radova: Povijesni 
prikaz podplješevičkih sela, Udruga bivše općine Zavalje, ur. Želimir Prša, Ivan Brlić, Željko Holjevac, br. I, Zagreb, 2017., 13-56.

Bruno ŠKREBLIN, Etničke i političke skupine u srednjovjekovnom gradu. Primjer gradečkih lingui, Povijesni Prilozi, 25, 2008., 91-148.

Nataša ŠTEFANEC, Heretik njegova veličanstva. Povijest o Jurju IV. Zrinskom i njegovom rodu, Barbat, Zagreb, 2001.

Nataša ŠTEFANEC, Diet in Bruck an der Mur (1578) and the Estates on the Croatian, Slavonian and Kanisian Military Border, doktorska disertacija, Central European University, Budimpešta, 2004.

Nataša ŠTEFANEC, Demographic Changes on the Habsburg-Ottoman Border in Slavonia (c. 1570-1640), u: Das Osmanische Reich und die Habsburger Monarchie in der Neuzeit: Akten des internationalen Kongresses zum 150-jährigen Bestehen des Instituts für Österreichische Geschichtsforschung, ur. Marlene Kurz, Martin Scheutz, Karl Vocelka, Thomas Winkelbauer, R. Oldenbourg Verlag, Beč-München, 2005., 551-578.

Nataša ŠTEFANEC, Država ili ne. Ustroj Vojne krajine 1578. godine i hrvatsko-slavonski staleži u regionalnoj obrani i politici, Srednja Europa, Zagreb, 2011.

Nataša ŠTEFANEC, Grad na prvoj crti obrane: 16. stoljeće, u: Povijest grada Zagreba. Knjiga 1. Od prethistorije do 1918., ur. Ivo Goldstein, Slavko Goldstein, Novi liber, Zagreb, 2012., 108-153.

Nataša ŠTEFANEC, Institutional Control of Violence: Imperial Peace and Local Wars on the Slavonian Border in the 16th Century, u: Frieden und Konfliktmanagemenet in interkulturellen Räumen. Das Osmanische Reich und die Habsburgermonarchie in der Frühen Neuzeit, ur. Arno Strohmeyer, Norbert Spannenberger, Robert Pech, Franz Steiner Verlag, Leipzig, 2013., 63-83.

Nataša ŠTEFANEC, Negotiating with the „Archenemy“: The Ethics of the Croatian and Slavonian Nobility at the Christian-Ottoman Border, u: Türkenkriege und Adelskultur in Ostmitteleuropa vom 16.-18. Jahrhundert, ur. Robert Born, Sabine Jagodzinski, Jan Thorbecke Verlag, Ostfildern, 2014., 89-104.

Nataša ŠTEFANEC, Osmanski zapovjednici i struktura osmanske i habsburške vojske na hrvatskom dijelu krajišta (prema špijunskim izvještajima iz 1570-ih), u: Ascendere historiam. Zbornik u čast Milana Kruheka, Hrvatski institut za povijest, Zagreb, 2014., 209-227.

Nataša ŠTEFANEC, Uskoks between War and Trade. Pirates on the Venetian-OttomanHabsburg Borderland in the Adriatic and Its Hinterland, u: Marine Merchants and Pirates 
During the 16th and 17th Centuries. Uskok of the Adriatic Sea and Wako of the East China Sea, ur. Isao Koshimura, Sairyusha Co., Tokyo, 2016., 11-32.

Nataša ŠTEFANEC, Vjerska politika u habsburškim zemljama u srednjoj Europi (od 20-ih godina 16. st. do 30- ih godina 17. st.), ur. Zrinka Blažević - Lahorka Plejić Poje, Tridentska baština: katolička obnova i konfesionalizacija u hrvatskim zemljama. Zbornik radova. Matica Hrvatska, Zagreb, 2016., 43-63.

Nataša ŠTEFANEC, O istraživanju nasilja u vojnokrajiškom kontekstu, u: Franz Vaniček $i$ vojnokrajiška historiografija. Zbornik radova sa znanstvenog skupa s međunarodnim sudjelovanjem, ur. Robert Skenderović, Stanko Andrić, Hrvatski institut za povijest Podružnica za povijest Slavonije, Srijema in Baranje, Slavonski Brod, 2017., 75-94.

James D. TRACY, Balkan Wars. Habsburg Croatia, Ottoman Bosnia, and Venetian Dalmatia, 1499.-1617., Rowman\&Littlefield, Lahman-Boulder-New York-London, 2016.

Triplex Confinium (1500.-1800.): ekohistorija: zbornik radova s 3. međunarodnog znanstvenog skupa, ur. Drago ROKSANDIĆ, Nataša ŠTEFANEC, Vinka GLUNČIĆBUŽANČIĆ, Ivan MIMICA Književni krug Split - Zavod za hrvatsku povijest Filozofskog fakulteta Sveučilišta, Zagreb-Split, 2003.

Mirko VALENTIĆ, Turski ratovi i hrvatska dijaspora, Senjski zbornik, 1990., vol. 17, br. 1, 45-60.

Johann Weichhard von VALVASOR, Die Ehre des Herzogthums Krain, IV svezak, knjiga XII-XV, Rudolfswerth, 1877.-1879.

Milan VASIĆ, Etnička kretanja u Bosanskoj krajini u XVI vijeku, Godišnjak društva istoričara Bosne i Hercegovine, god. XIII, Sarajevo 1963., 233-250.

Milan VASIĆ, Martolozi u jugoslovenskim zemljama pod turskom vladavinom, ANU BIH, Odjeljenje istorijsko filoloških nauka, knjiga 17, Sarajevo 1967.

Pavao RITTER VITEZOVIĆ, Oživljena Hrvatska, prevela i priredila Zrinka Blažević, Biblioteka Latina\&Greca, Hrvatski institut za povijest, Zavod za hrvatsku povijest Filozofskog fakulteta u Zagrebu, Zagreb, 1997.

Vojna krajina. Povijesni pregled-historiografija-rasprave, zbornik, ur. Dragutin Pavličević, Sveučilišna naklada Liber, Centar za povijesne znanosti Sveučilišta u Zagrebu, Zagreb, 1984.

Marko VEGO, Srednjevjekovni bihaćki latinski spomenici 16. vijeka, Glasnik Zemaljskog muzеja u Sarajevu, nova serija, sv. 9, arheologija, 1954., 255-272

Laszlo VESZPREMY, The state and military affairs in east-central Europe, 1380-c. 1520s, u: European Warfare, 1350-1750, ur. Frank Tallett i D. J. B. Trim, Cambridge University Press, Cambrigde, 2010., 96-109. 
Josip VRANDEČIĆ, Miroslav BERTOŠA, Dalmacija, Dubrovnik i Istra u ranome novom vijeku, Leykam international:Barbat, Zagreb, 2007.

Barney WARF, Santa ARIAS, Introduction: the reinsertion of space into the social sciences and humanities, u: The Spatial Turn. Interdisciplinary perspectives, ur. Barney Warf i Santa Arias, Routledge Studies in Human Geography, London-New York, 2009., 1-10.

Janez WEISS, In conterminiss. Razvoj mejne pokrajine Metliške in odnosi s hrvaškoslavonskim prostorom s poudarkom na prisotnosti in posesti rodbin Erdődy in Frankopan, u: Med cesarstvom in kraljevstvom. Študija čezmejnih kulturnozgodovinskih povezav, ur. Petra Svojšak, Miha Seručnik, Vanja Kočevar, Znanstvenoraziskovalni centar Slovenske akademije znanosti in umetnosti, Ljubljana, 2013., 13-82.

Richard WHITE, The Middle Ground. Indians, Empires, and Republics in the Great Lakes Region, 1650-1815, Cambridge University Press, 1991.

Thomas M. WILSON, Hastings DONNAN, Borders and Border Studies, u: A Companion to Border Studies, ur. Thomas M. Wilson, Hastings Donnan, Wiley-Blackwell, 2012., 1-25.

Eric R. WOLF, Europe and the People Without History, Berkley, 1982.

Nedim ZAHIROVIĆ, Two Habsburg Sources of Information at the Sublime Porte in the Second Half of the Sixteenth Century, u: Power and Influence in South-Eastern Europe, 16th19th Century, ur: Maria Baramova i dr., Zürrich-Münster, 2013., 417-423.

Nedim ZAHIROVIĆ, Crtica iz ratovanja na Krajini: napad zapovjednika Bihaća Franza Hornera na Ostrožac 31. svibnja 1585. godine, Historijski zbornik, god. LXVII, 2014., 83-92. Nedim ZAHIROVIĆ, Tragom jedne karijere: Halil-beg (Halil-paša) Memibegović od Like preko Jegra do Banja Luke, Historijski zbornik, god. LXX, br. 2, 2017., 353-364.

I. William ZARTMAN, Introduction. Identity, Movement and Response, u: Understanding Life in the Borderlands: Boundaries in Depth and in Motion, ur. I. William Zartman, University of Georgia Press, 2010., 1-18.

Josip ŽONTAR, Obveščevalna služba in diplomacija austrijskih Habsburžanov v boju proti Turkom v 16. stoletju, Slovenska akademija znanosti in umetnosti Ljubljana, 1973. 


\section{PRILOZI}

\section{Prilog 1.}

Popis plaćenih vojnika u utvrdama Bihać, Ripač, Sokol, Izačić i Toplički Turanj. Popis načinjen prije svibnja 1540.

SI AS 2. Deželni stanovi za Kranjsko, kutija 244, fascikl 143, 1540., 1r-4r, rbr. 252-258.

Muster Register der Dienstleuth so zu Wihitsch Repitsch vnnd Inn den anndern anhanngenten Ortfleckhen verhanndten sein.

Bärtlme von Raunach haubtman ver die Ringhen phard

Hanns Gall fendrich

Sein Jung

Michal von Rab waibl

Jörg Khleibnickh puchsenmaister

Gregor wachtmaister

Michäl Khautzelitsch

Hanns Rösch

Cristof Heritsch

Laure Khoschiz

Petter Rädonickh

Wartol Lauretsch

Hans Khoch

Lucä Raditscheuitsch

Gregor Petschenitsch

Simon Pollackh

Bartho Wartolitsch

Schkhallor

Petter Mitschiz

Stipan Plascheuitsch

Anndre Khellner

Petter Steymez

Paul Saletitsch 
Michal Vitatschiz

Laure Tremtschiz

Caspar Valetschiz

Jurckho Stemeckh

Micula Glabinouitsch

Iban Tschurili

Jurej Lontscharitsch

Jacab von Radtmänsstarf

Panj Petter

Simun Khuschatouitsch

Martin Martintschiz

Steffan Zenntman

Juray Peden

Anndre Striz

Micula Schossenitsch

Micula Jeglentschiz

Iban Khaitschiz

Iban Parbwier

Paul Wentschiz

Laure Derckhoschiz

Steffan Sideritsch

Wuckhasch Vugnitsch

Iban Khapiar

Martin Spän

Micula Khustriz

Iban Prebitscheuitsch

Micula Khrabatinouitsch

Wartol Goimertschiz

Luca Vunitsch

Janne Pollackh 
Hienach uolgen die Phert zum Wihitsch

Bartl von Raunach HaubtmanVber die Ringen Phert

Ibän Wudatzkhi

Hanns Gall

Marco Khrintschiz

Mäthiatsch Khrintschiz

Iban Rebruitsch

Petter Schismanick

Michal Khreliz

Sigmundt Hueber

Matheus Gallenwerger

Iban Wuckhoschin

Petter Sortschiz

Iban Chrellj

Caspar Wudischiz

Caspar Wutschebisch

Petter Khernetschiz

Dellj Raditsch

Jacab Radonisch

Mihal Preiclzouitsch

Iban Dorouitsch

Petter Reitschiz

Mitter Iffkhouitsch

Petter Muzkhouitsch

Hienach die dienstleuth zu fuess zu Repitsch

Michäl Wladitsch

Petter Wumeritsch

Mathiasch Tischeritsch

Gregor Khulonickh

Wartol Juranouitsch

Thamasch von Gollobisch

Jacob von Gollobisch 
Ibän Iurckhouitsch

Pop Luca

Phert zu Repitsch

Jurej Grabus

Petter Wuckhitscheuitsch

Iban Grabus

Issailh Woinukh

Micula Wlatitsch

Juniss

Jurkhuncholöitsch (?)

Schkhartleuth am Wasser bey der nods(?) zu Repitsch

Mathia Philipouitsch

Juray Phillipouitsch

Martin Khrall

Dienstleuth zu Socol

Petter Wegatsch

Hanns von Rakhelspurg

Jurej Schwirtschiz

Iban Selenökhouitsch

Schloss Issatschiz

Iban Issatschiz

Grubischa Tscherneritsch

Thomasch Sterckholitsch

Schlos Dopliz

Marco Nichischiz

Paull Wertschiz 


\section{Prilog 2.}

Popis plaćenih vojnika u utvrdama Bihać, Ripač, Sokol, Izačić i Toplički Turanj. Popis načinjen u Bihaću 3. srpnja 1540.

Radoslav LOPAŠIĆ, Spomenici Hrvatske krajine, knjiga III, Monumenta spectantia historiam Slavorum meridionalium, sv. 20, Zagreb, 1889., dok. V, 359-398.

Musterung der geringer phardt vnd fuesknecht, so in Wihitsch vnd den andern zuegehörenden fleckhen gehalten werden, durch den edlen Martin Gall von Ruedolfsegkh, diser zeit haubtman daselbst, unter des dritten tags julij anno in XL-sten (1540.)

Hernach uolgen dj phärdt, so zu Wihitsch sein, denen ir monat am 12. tag jun ausgangen vnd des 13. tags bemelts monat hinwiderumb angangen mit ani jedes per 30 gl. Rheinisch.

Gl. Rh.

Merth Gall von Rudolfsekh, haubtman hat sechs geringe phardt, tut

Marco Charintschitsch samb seinen bruedern hat vier geringe

phardt vnd pesserong

Iwan Rebrouitsch dreu ger. phard vnd besserung $\quad 10$

Peter Sismanikh sambt bruedern vier pfardt $\quad 15$

$\begin{array}{ll}\text { Iwan Wukaschin zbay phardt } & 7\end{array}$

$\begin{array}{ll}\text { Pauco Milosthnakh zbay phardt } & 7\end{array}$

$\begin{array}{ll}\text { Ysak Warakh, zbay phardt } & 7\end{array}$

Ywan Chlaptschich ain phardt 3

Mikula Krisanitsch ain phardt vnd besserung 4

Wutzkowytsch ain phardt 3

Mikula Wladitsch ain phardt 3

Iwan Chrella ain phardt vnd pesserung $\quad 4$

$\begin{array}{ll}\text { Iwan Politschanin dreu phardt } & 9\end{array}$

$\begin{array}{ll}\text { Iwan Michalowitsch phardt vnd pesserung } & 13\end{array}$

Martin Raskouitsch ain phardt 3

Caspar Wudasitsch zbay phardt $\quad 6$

Tomas Tnynanin ain phardt 3

$\begin{array}{ll}\text { Caspar Chlaptschitsch zbay phardt vnd besserung } & 7\end{array}$ 
Volgen noch die phardt, so Martin Gall, haubman zu Wihitsch, angenomen, vnd der Kobasitsch mit seinen dreien phardten.

Gl.Rh.

Kobaschitsch drey geringe phardt 9

Caspar Chlaptschitsch zbey phardt vnd pesserung $\quad 7$

Volgen noch die phardt, so haubtman vm des dritten tags jul angenomen:

Gl.Rh.

Juray Grabuss, haubtman vber di phardt, hat auf nein phardt auf

jedes per 3 gl. Rh., auf sein leib vnd ross acht gulden Rh.thuet 35

Hanss Gall vier phardt vnd pesserung $\quad 15$

Marko Juranitsch vier phardt 14

Wogdan dreu phardt $\quad 9$

$\begin{array}{ll}\text { Vukh Popovitsch zbay phardt } & 6\end{array}$

lat. 95 gul. Rh.

Ich Mert Gall, dieser zeit haubtman zu Wihitsch, bekhen, das die hieuorgeschriben phärdt laut des gefertigten muster-register, denen ir dienst ausgagange, durch Röm. k. M. kriegszalmeister der Krabatischen orthflekhen Hansen Peugerschamer in meinen beysein auf ain ganz monat bezalt sein worden, so da bracht hat zbay hubdert achtvnddreissig gulden, dreissig kr. Actum den 3.tag july a. XL.

Hernach uolgen die fuessknecht zu Wihitsch, Repitsch und den andern:

Volgen nach die dienstleut, so Mert Gall, haubtman, des 26. tags may angenomen:

Gl.Rh.

Merth Gall hat monatlich $\quad 7$

Gregor von Nynderthaimb $\quad 8$

Cristof Lex, buchsenmaister $\quad 6$

Jorg Vierzig 6

Mikula Skolas 3

Stipan Blasevitch 3 
Lovre Tromsitsch 3

Jurco Sternekher 3

Mikula Glauanouitsch 3

Juray Lontscharitsch 3

Caspar Waletitsch 3

Peter Pane 3

Simon Khustatouitsch 3

Andre Stutz 3

Mikula Schossteritsch 3

Paul Wentschitsch 3

Lovre Derkonitsch

Stipan Sidoritsch

Iwan Kopiari 3

Martin Span 3

Peter Kreatsch $\quad 3$

Janus von Rakerspurg, buchsenmaister $\quad 4$

Janus Rebrak 3

Jumas 3

Zivko, wachter 3

Stipan, Wachter 3

Janos, watcher 3

Jakob von Radtmansdorf 3

Hanns, koch $\quad 3$

Michal Witusich $\quad 3$

Paval Saletitsch 3

Bartol Lavratsch $\quad 3$

Sebastian Schlesinger 3

Marko Wutzkovitsch 3

Wugssan Wukitschevitsch 3

Thomas Gallowitsch 3

Jacob Arapin 3

Mikula Kustritsch 3

Brayanin 3

Iwan Allia 3 
Cristof Lisst 3

Matheus Waykh 3

Mathia Gallitsch 3

Martin Wlassitsch 3

Sarko Mikula $\quad 3$

Stipa Garetschitsch 3

Mikula Strasanya, vayvoda 3

Paul Kasunitch 3

Dobrussa Strasanin 3

Wukossav Kossouitsch 3

Juray Vsoratz 3

Jakob Martintschitsch 3

Thomas Ferand 3

Bartitsch Stanitsch 3

Volgen noch dj schartleut, so des 2.tags juni zu Reptisch aufs wasser gestellt:

Gl.Rh.

$\begin{array}{ll}\text { Luca Tschenitsch } & 3\end{array}$

Martin Mathulin 3

Juray Schadkouitsch 3

Volgen noch dj dinstleut des 3.tags jul angenomen:

Gl. Rh.

Mihal Starj 3

Fabian Brosonitch 3

Wugsan 3

Pavko Jugouitsch 3

Istvan Palbur 3

Paul Raitscheuitsch 3

Anthon Schechulitz 3

Andre Murath 3

Paul Domatscheuitsch 3 
Janco Radosl

Radossa Herakouitsch 3

Milly 3

Raussa Karanouitsch $\quad 3$

Franco Waritsch

Paval Lemetscheuitsch 3

Volgen die dienstleut in den schlössern:

Im schloss Toplitz

Gl.Rh.

Marco Michsitsch 3

Iwan Michitsch 3

Marco Frantschitsch 3

Im schloss Sogkholl

Gl.Rh.

Mik. Jegentschitsch, burgraf 4

Iwan Kositch 3

Iwan Bartholitsch 3

Juray Marin 3

Iwan Thursso 3

Mathia Wranitsch 3

Juray Moratitsch 3

Im schloss Ysathytch

Gl.Rh.

Iwan Ysatschitsch 3

Grubischa Tschemeritsch 3

Mathia Kreatschitsch 3

Peter Stchupina 3

Ich Merth Gall etc. haubtman vnd Wihitsch bekenne, das die hervorgeschriben dienstleut vnd fuessuolkh laut dits gefertigten muster-register denen ir dinst durch Röm k. Mt. 
kriegszalmaister der Krabatischn ortflekhen, Hansen Peugerschamer, in meinen beisein bezalt sein, der da bracht zway hundert ain und achtzig gulden Reinisch, 30 kreutzer. Zu vrkund hab ich mein angeborn petschaft vnd handschrift sambt Gregorn von Nynderhaimb wachtmeister hierunder gestelt. Actum den 3.tag july a. 1540.

\section{Prilog. 3.}

Popis plaćenih vojnika u utvrdama Bihać, Ripač, Sokol, Izačić, Toplički Turanj i Brekovica 1551.

Radoslav LOPAŠIĆ, Bihać i Bihaćka krajina, Matica Hrvatska, Zagreb, 1890., dok. IX, 242244.

Popis vojske Bihaćke kapetanije 1551.

Ivan Lenković, zapovjednik Hrvatske Krajine, ujedno kapetan senjski.

Juraj Sauer, kapetan bihaćki, s mjesečnom plaćom od 41 for. i za 8 konjanika mjesečno 32 for.

Andrijan Gal, namjesnik, s mjesečnom plaćom od 16 for.

\section{Konjanici u Bišću}

Stipan Jurjević, na konja 5 mjesečno

18 for.

Ivan Izačić na 3 konja mjesečno

13 for.

Ivan Rebrović na 2 konja mjesečno

9 for.

Bogdan Knežić na 3 konja mjesečno

10 for.

Petar i Marko Vučkovići, braća na 3 konja mjesečno

10 for. $30 \mathrm{kr}$.

Marko Hrinčić na 3 konja

12 for.

Vid Hrelja (Petričević) na 2 konja mjesečno

8 for.

Toma Kninjanin na 2 konja mjesečno

7 for. $30 . \mathrm{kr}$.

Luka Roginić na 2 konja mjesečno

7 for.

Stipan Keserić na 1 konja mjesečno

4 for.

Ferenc Stančić na 1 konja mjesečno

7 for.

Ivan Hlapčić na 1 konja mjesečno

4 for.

Bartol Hlapčić na 1 konja mjesečno

3 for. $30 \mathrm{kr}$.

Matija Hrenčić na 1 konja mjesečno

4 for

Novak Popović na 1 konja mjesečno

4 for. 
Martin Rošković na 1 konja mjesečno

4 for.

Juraj Rebrović na 1 konja mjesečno

4 for.

Matija Pastuh na 1 konja mjesečno

3 for.

\section{Pješaci u Bišću}

Juraj Neiderthaimb, stražmeštar, mjesečno

10 for.

Jerolim Podlipnik

8 for.

Pankrac Lustaler

8 for.

Erhard Folz, puškar

8 for.

Fridrik Kačić

8 for.

Wilim Wiser, puškar

3 for.

Ivan Kolarić, mj.

4 for. $30 \mathrm{kr}$.

Januš, puškar mj.

4 for $30 \mathrm{kr}$.

Gašpar Weihnacht, bubnjar mj.

4 for $30 \mathrm{kr}$.

Paval Feuchtner mjesečno

5 for.

Jurko Turk

4 for.

Marko Kaptolović

4 for.

Ivan Alić

4 for

Andre, zidar

4 for.

Mihael Starac

4 for.

Radić, uhoda

4 for.

Ivan Heraković

4 for.

Grgur Kohmanović

4 for.

Petar Spanić mj.

3 for. $30 \mathrm{kr}$.

Pop Jakov mj.

3 for. $30 \mathrm{kr}$.

Stipan Rošković mjesečno

3 for.

Matija Cvetan

3 for.

Jurko Urošić

3 for.

Juraj Moić

3 for.

Stipan Smokvić

3 for.

Stipan, krznar

3 for.

Petar Mihšić

3 for.

Šimun Bartolić, mjesečno

3 for. 
Januš Rebrak

3 for.

Juraj Uskok

4 for.

Luka Fumičić

3 for.

Bartol Lovrić

3 for.

Ivan Pauličević

3 for.

Lovre Frinčić

3 for.

Petar Pane

3 for

Ivan, kuhar

3 for.

Juraj Bribiranin

3 for.

Jurko Strlekar

3 for.

Simon Kušatović

3 for.

Mihovil Draganić

3 for.

Martin Stapešić

3 for.

Jakov Arapin

3 for.

Petar Barbierić

3 for.

Franko Barić

3 for.

Cvetko, stražar u gradu

3 for.

Stipan, stražar

3 for.

Cvetan Filipčić, vratar

3 for.

Gurgur Vornjavnić,

3 for.

Tomaš Kočevar

3 for.

Šimun, kovač

3 for.

Andraš Perinić

3 for.

Luka, zlatar

3 for.

Mihovil Kaptolović

3 for.

Paval Mladošević

3 for.

Mihal Herak

3 for.

Ivan Draganović

3 for.

Matija Prodić

3 for.

Marko Žribičić

3 for.

Gašpar Voletić

3 for.

Petar Pauličević

3 for.

Loveranac Kružić

3 for.

Grgur Paladin

3 for. 


\section{Konjanici u Ripču}

Erazmo Sauer, porkulab, plaća za njega i za četriri konja mjesečno 25 for.

Ivan Mihaljević za četiri konja 13 for.

\section{Pješaci u Ripču}

Juraj Zlatarić, mjesečno

4 for.

Jurica od Metlike

4 for.

Luka Mladošević

3 for.

Mihal Štifković, mjesečno

3 for. $30 \mathrm{kr}$.

Grgur Kamjenanin, mjesečno

3 for. $30 \mathrm{kr}$.

Stipan Mokrović, mjesečno

3 for.

Blaž, šicar

3 for.

Lovrenac Barac

3 for.

Štefan Krznarić

3 for.

Bogdan Kosić

3 for.

Bartol Juranović

3 for.

Andre Mršljenović

3 for.

Sebastian Deithman

3 for.

Toma Kozić

3 for.

Martin Milenčić

3 for.

Andre Murat, stražar

3 for.

Luka Difković

3 for.

Petar od Golubića

3 for.

Mikula Kustrić

3 for.

\section{Stražari na Uni kod Ripča}

Mihovil Dudić mj.

1. for $30 \mathrm{kr}$.

Matija Petrašić mj.

1. for $30 \mathrm{kr}$.

Martin Matolinić mj.

1. for $30 \mathrm{kr}$.

\section{Grad Sokol}


Juras Maras, porkulab, mjes

4.for.

Matija Skaričić mjes

3 for. $30 \mathrm{kr}$.

Antun Mršljenović mjes

3 for.

Šimun Čurilović

3 for.

Ivan Bartolić mjes.

1 for. $30 \mathrm{kr}$.

Šimon Mrsalenović mj.

1 for. $30 \mathrm{kr}$.

Matija Fromić mj.

1 for. $30 \mathrm{kr}$.

Petar Milišić mj.

1 for. $30 \mathrm{kr}$.

\section{Grad Izačić}

Frane Izačić, porkulab mjesečno

4 for.

Ivan iz polja, njegov sluga

4 for.

Matija Orlić, mjesečno

3 for.

Ivan Mihšić

3 for.

\section{Turanj Toplički i Brekovica}

Matija Sprinčić mjes.

3 for.

Lovre Kranjac

3 for.

Gašpar Šerperić

3 for.

Pavao Vederić

3 for.

Petar od Ostrožca

3 for.

Ukupna mjesečna potreba 760 forinti (rajnskih) i $40 \mathrm{kr}$.

\section{Prilog 4.}

Registar prihoda vlastelinstva Sokol te desetine topuskog opata koju je u zakupu držao bihaćki kapetan.

Napomena: iako se u njemačkim spisima slova - ̌c ili -ć najčešće navode kao -tsch, a -š kao $s c h$, pisar je u ovom izvoru umjesto slova $-c$ očito koristio slovo $-t$, pa se -č ili -ć navode kao - 


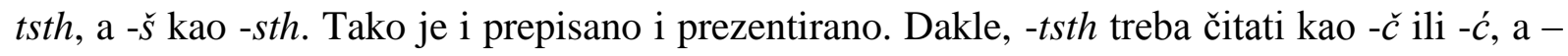
sth kao $-\check{s}$.

Također, treba naglasiti da između upisanih i na kraju registra sumarno iskazanih vrijednosti prikupljene desetine postoje određena diskrepancija.

ÖeStA, Finanz und Hofkammerarchiv, Hoffinanz Ungarn, kutija 5, Rote nr 2 fol. 126-135.

31. ${ }^{\text {Xber }} 1548$.

Das Schloss Sogkholl oberhalb Wichitsch gelegen, Einkhomben verschinen 48n Jars. Lenkovitsch bericht

Beschreibung der Einkünfte des Scloßes Sokhol nächst Wihits gelegen, sammt den Sassiner zehend so vormals zur Abtey Thopuszka gehorig war, später aber zur Hauptmannschaft Wihits eingezogen wurde. (regesta na izdvojenom komadu papira, naknadno umetnuta)

De $\beta$ Gschloss Sogkholl oberhalb Wyhitsch gelegenn Sambtt den Zasiner Zehenndt, zw der Abtey geen Topulßkh gehorig (welher Zehenndt, Nach waillendt herrn Erasm, Frayherrn vom Thurn, In Ainnembung gedachtes geschloss, darzue einzogen vnnd seidtherr albey durch die Haubtleüt daselbst gefexnt, vnd aingenomen worden) Sambt ainem Sondern, khlainen ainkhomben, zw der Haubtmanschafft Wyhitsch gehorig, hie zum besten aingefuert, was yedes, In verschinen achtundvierzigisten Jar, ertragen haben soll.

Dyße hernnach beschribne Paurn Vnder Sokholl sein schuldig Im Jar Drey Eerung Erstlich zum Weichnachten

Yeder Pogatsthen 1

Sthwainen Rippratten 1,5

Zum Osstern yeder pogatsthen 1

Ayr 6

Zw Sanndt Michelstag Jeder Pogatsthn 1

Vnnd Huen 1,5

Robatt etlich Ackhr Anzupauen vnd Was zum Garten Notturfftig, auch Hay zumaen vnd fieren. 
A wer der Traidt vnd Waiz Zehendt vom solhen Paueren gehert geen Zasin, wierdt auch hernach wass ain jeder dits gegenwurtig Achtvnndvierzig Jarr geben, anzaigt.

Vgrin Martin Waiz Quartn 3.5

Hiersth quartn 2.5

Pauckho Kharwautsthiz Waiz quartn 5.5

Habern Quartn 1

Hiersth Quartn 4

Iffan Miltsthiz Wayz Quartn 2

Petter Milisthiz Waiz Quartn 2

Hiersth quartn 2

Iffann Nouackh Waiz Quartn 1

Hiersth quartn 1.5

Styphan Juritsth Wayz Quartn 5

Habern quartn 1

Hiersth quartn 4

Pauall Khouatsthiz Waiz Quartn 2

Hiersth quartn 2

Petter Radtkhouitsth Waiz Quartn 3

Habern quartn 1.5

Hiersth quartn 3.5

Fabians Witib Waiz Quartn 1

Gregor Bressan Waiz Quartn 3.5

Habern quartn 1.5

Grgatsth Wittib Waiz Quartn 3.5

Hiersth quartn 2

Peinsteckh 2

Anndre Pelizeritsth Waiz quartn 3

Habern quartn 1.5

Hiersth quartn 3.5

Jury Skharitsthiz Waiz Quartn 3

Habern quartn 1.5

Hiersth quartn 2

Simon Marsthanouitsth Wayz Quartn 2.5 
Hiersth quartn 1

Sez Wittib waiz quartn 2.5

Hiersth quartn 1

Jurey Pauitsth waiz quartn 3

Habern quartn 1.5

Hiersth quartn 2

Mathia Khorenouitsth waiz quartn 1

Hiersth quartn 1

Iffan Wartholitsth Waiz quartn 1

Habern quartn 1.5

Hiersth quartn 1

Irey V $\beta$ khokh waiz Quartn 1.5

Hiersth quartn 1

Jurey Russelitsth des Khobasthiz Rychter

Waiz Zehenndt quartn 4.5

Marco Sthebrauitsth Waiz dem pharer geben

Hiersth quartn 4

Painstockh 1

Mathia Khosta Hiersth quartn 1

Simon Rudan Hiersth quartn 1

Daselbst Zu Sokholl gehördt das Perkhrechtt der Naünt Emp. Zu dem gschloss, vnnd der Zehenndt geen Zaßin

Pauall Khouatsthiz perkhrecht vnd Zehendt Emp 1

Iuan Grdasthiz Emp. 2

Vyd Grdasctiz Emp. 1

Pauckho Khorwautsthiz Emp. 2.5

Fabiann Wittib Emp. 4

Martin Ifelitsth Emp. 3

Iffan Nouackh Emp. 2.5

Andre Pelizeritsth Emp. 5.5

Marco Sthewrouitsth Emp. 6

Stipann Juritsth Emp. 12 
Petter Milisthiz Emp. 3.5

Juan Millisthiz Emp. 2.5

Mathia Khorenau Emp. 2

Petter Radtkhouitsth Emp. 6.5

Gregor Bressan Emp. 4

Fraynne Khorenou Emp. 2

Nicola Khokholitsth Emp. 4.5

Iffan Wartholitsch Emp. 2

Mathia Khesta Emp. 1

Gregor Pauiuitschiz Emp. 1.5

Mane Tsthurilouitsth Emp. 10

Pettr Grdasthiz Emp. 3

Martin Vgrin Emp. 2

Grgatsth Wittib Emp. 6.5

Jury Pauitsth Emp. 8

Michouil Voganitsch 6

Luca Rudar 2.5

Khate Wittib Emp. 1

Juri Skharetschiz Emp. 8

Simon Marsthanouitsth Emp. 7.5

Sez Wittib Emp. 6

Gollowyttsch

In demselben Dorff sein die Paurn nichtz Schuldig dan yeder zw S. Michels tag dem Purggraffn gen Repitsth Sex Krayzer, vnnd das sy denn Haubtman, Purggraffn, vnd Ander Khriegsvolkh von Wyhitsth gen Repitsth am Wasser fieren, vnd der Zehendt Wie hernach anzaigt wierdt, geherdt gen Zasin.

Duralia Waiz Quartn 1.5

Hiersth quartn 1

Lorenz Radouitsth Waiz Quartn 1.5

Thomas Jelentsthiz Waiz Quartn 1.5

Martin Seritsth Waiz Quartn 2.5 
Hiersth quartn 4.5

Gregor Radouitsth Waiz Quartn 1.5

Hiersth quartn 1

Simon Radouitsth Waiz Quartn 1.5

Hiersth quartn 2

Zehenndt most Emp. 1

Petter Webritsch Waiz Quartn 1

Margaretha Wittib Waiz Quartn 1.5

Clara Maitsthina Waiz Quartn 1.5

Khatarina Stipitschina Waiz Quartn 1.5

Hiersth quartn 2.5

Zehentmost Emp. 1.5

Iffan Mally Waiz Quartn 1

Hiersth quartn 2

Zehendt most Emp. 1

Iray Khazian Waiz quartn 1

Khatarina Sodina Waiz quartn 1.5

Hiersth quartn 1

Zehendt most Emp. 1.5

Stipan Jurin Waiz quartn 1

Petter Khorisma Waiz quartn 1.5

Hiersth quartn 1

Simon Grubanouitsth Hiersth quartn 2

Zehendt most Emp. 1

Solemene Hiersth quartn 1.5

Mathiasth Seritsth Hiersth quartn 1

Verannda Visther Hiersth quartn 1.5

Petter Marganouitsth Hiersth quartn 2.5

Gregor Fachschiz Hiersth quartn 1

Zehenndt most Emp. 1.5

Iffan Tsthurila Hiersth quartn 1.5

Zehenndt most Emp 1.5

Agina Millisthina Hiersth quartn 1.5 
Rywitsch

Dasselb Dorff ist glaichermassen sthuldig, Wie dan die von Gollewitsth, aber den Zehenndt gen Zasin, Wie hernach vollgtt

Michouill Wonitschiz Waiz quartn 1.5

Hiersth quartn 1.5

Pauall Vesthitsch Waiz quartn 1.5

Iray Wudkhouitsth Waiz quartn 1

Hiersth quartn 2

Zehenndt most Emp. 1.5

Stipan Zapitsth Waiz quartn 1.5

Hiersth quartn 1

Zehendt most Emp. 1

Lubenn Waiz quartn 1 (i)

Mathia Vessanouitsth Waiz quartn 1.5

Stipann Vessanouitsth Waiz quartn 1.5

Martin Iilitsth Waiz quartn 1.5

Hiersth quartn 1

Juriza Illitsch Waiz quartn 1.5

Hiersth quartn 1

Kharin Hiersth quartn 1

Zehendt most zu Rwyitsch gen Zäßin Gehorig

Vallennta Radinitsth Emp 1

Mathe Wesanouitsth Emp. 1

Clapnitsth Emp 1.5

Jurj Pristaulitsth Emp. 1.5

Luca Radonigkh Emp. 1

Marco Schenelitsth Emp. 1.5

Sthimon Grubanouitsth Emp. 1

Juriackh Emp. 2.5

Paul Vestosthiz Emp 1 
Thomas Rigathatschiz Emp. 1

Simon Pauinitsth Emp. 2.5

Pauall Stopeschiz Emp. 1.5

Anthon Woinitschiz Emp. 1.5

Martin Illitsth Emp. 1.5

Jurey Illitsth Emp. 1.5

Petter Sumbkohouitsth Emp. 1.5

Michouill Woinitsthiz Emp. 1

Volkh Rigatosthiz Emp. 1.5

Phillip Jackhitsth Emp. 1.5

Petter Draganouitsth Emp. 1

Dernnach Volgtt ein sunder Einkhomen zu der Haubtmanschafft Wihitsch aber der Neue

Traidt vnnd ander Zehendt, Wie die andern geenn Zäßin gehörig.

Omersl vnnd Schutsche Zwey Dörffll gehernn Zu der Haubtmanschafft vnd sein nichtt mer sthuldig dann zw S. Merttenns tag dem Haubt. R.f. 10

Vnnd der herrnach gesthriben Zehenndt gehort gen Zaßin.

Omersll

Pauall Iftsthiz Weiz quartn 1

Hiersth quartn 1

Marco Nasletkhouitsth Waiz quartn 1.5

Andre Nasletkhouitsth Waiz quartn 1.5.

Hiersth quartn 1.5

Petter Vladitsthiz Waiz quartn 1.5

Bro $\beta$ Vehnitsth waiz quartn 2.5

Hiersth quartn 2.5

Martin Fertschiz waiz quartn 1.5

Hiersth quartn 1

Anndre Vehnitsth waiz quartn 1

Jurco Radinitsth Hiersth quartn 1.5

Marco Khrailiza waiz quartn 1 
Hiersth quartn 1.5

Simbkho Nasetitsth waiz quartn 1

Smayokha Hiersth quartn 1.5

Gregor Khrailitsth Waiz quartn 2.5

Martin Nasetitsch waiz quart 1

Hiersth quartn 2.5

Iffan Nasetitsth Waiz quartn 1.5

Hiersth quartn 1

Mathia Soititsth Waiz quartn 1.5

Gregor Misthinouitsth Hiersth quartn 4.5

Ifan Waziz waiz quartn 1

Anthon Dumbouitsth Hiersth quartn 2.5

Jurj Supan Hiersth quartn 1

Simon Vachnitsth Hiersth quartn 1

Grgatschiz Hiersth quartn 1.5

Petter Michtitschiz Hiersth quartn 1.5

Schutsche

Sumitsth Waiz quartn 1.5

Hiersth quartn 2

Anthon Raduatsth waiz quartn 1.5

Hiersth quartn 2.5

Khate Craiatschiza waiz quartn 1.5

Hiersth quartn 1

Thomas Fursthiz waiz quartn 1.5

Painstokh 1

Jaga Miloianiza waiz quartn 1.5

Hiersth quartn 1

Painstockh 1

Mathia Jurtsthiz Waiz quartn 1

Painstockh 1

Marco Waziz Wain quartn 1.5

Hiersth quartn 1.5 
Iffiza Pappau waiz quartn 1

Andre Mladtkouitsth waiz quartn 1

Hiersth quartn 3

Pauall Mihitsth Waiz quartn 2.5

Hiersth quartn 3.5

Dewrenkha Wittib waiz quartn 1.5

Hiersth quartn 2

Pauall Khorwautschiz waiz quartn 1.5

Hiersth quartn 1.5

Luca Kherwautschiz Waiz quartn 1.5

Blaß Luziz Hiersth quartn 1.5

Luca Latschiz Hiersth quartn 1.5

Juray Maritschouiz Hiersth quartn 1.5

Vid Maritschouiz Hiersth quartn 2

Wanitsth Hiersth quartn 1.5

Serinsskhi Hiersth quartn 1.5

Gewöndlicher Zehent wein Zw Sutsche vnnd Ormesl gen Zaßin gehorig

Martin Theritsth Emp. 3

Martin Nasetitsth Emp. 3

Iffan Nasetitsth Emp. 3

Simbkho Nasetitsth Emp. 3

Dorkha Nasetitstha Emp. 3

Musthinouitsth Emp. 3

Smayoukha Emp. 3

Martin Srtschiz Emp. 3

Jurco Radinitsch Emp.3

Kralitscha Wittib Emp. 3

Wroß Vehnitsth Emp. 3

Martin Wrtschiz Emp. 3

Grgatschiza Emp. 3

Simon Vehnitsth Emp. 3

Kharin Nasletkhouitsth Emp. 3 
Thomas Nasletkhouitsth Emp. 3

Marco Nosletkouitsth Emp. 3

Michaill Nasletkhouitsth Emp. 3

Tuditsch Emp. 3

Volkh von Osstroßaz Emp. 3

Luca Khnessitsth Emp. 3

Khug Zaua Wittib Emp. 3

Turie

Dise Nachgeschriben Leütt gehorn Zw der Haubtmanschafft vnnd geben zu S. Mertten tag R.f. 3 kr. 30

Der Zehenndt gehort geen Zaßin Wie hernacht Vollgtt

Jurj Raditsth Waiz quartn 1.5

Luca Sodmilouitsth Waiz quartn 1.5

Frannkho Walabanouitsth Waiz quartn 3.5

Hiersth quartn 2

Zehent most Emp. 1

Luca Walobanouitsth Waiz quartn 1.5

Hiersth quartn 1.5

Zehenndt most Emp. 1.5

Nicola Wautschiz waiz quartn 1

Zehennt most Emp. 1.5

Michouill Raditsth Waiz quartn 1

Iffan Tstherne Waiz quartn 1

Hiersth quartn 1.5

Bro $\beta$ Khletschiz waiz quartn 2.5

Hiersth quartn 2

Zehenndt most Emp. 1.5

Bernarda Waiz quartn 1

Hiersth quartn 1.5

Zehent most Emp. 1.5 
Gregor Matenitsth Hiersth quartn 2

Zehennt most Emp. 1

Anndre Dragitsthouitsth hiersth quartn 1

Wogoraditsch Hiersth quartn 1.5

Zehenndt most Emp. 1.5

Michouil Raditsth Zehenndt most Emp. 1.5

Summa des Einkhomben $\beta \mathrm{Zu}$ dem Geschloss

Sokholl Im versthinen Achtundvierzigisten Jar

Sambt den Zehenndt, so vor Jarnn geen Zaßin, zu der

Abbtey geen Topulskh gehört, vnd Jezt Neben andern

Einkhomen, diser Haubtmanschafft vnd des gschloss

Gefexnnt vnd Eingenomen Wierdt.

Wein Wychitsther Emp. CCxi 1/2

Waiz Wichitsther quartn Cxxxviiii

Habern quartn $v$

Hiersth quartn Ci 1/2

Sthweinen Rippratten xii 1/2

Pogatsthen Lcviiii

Huener xii

Ayr Cxliiii

Painstockh Vi

Ain Wichitsther Emp. gar ain khleine vnndersthaid aines Wienner Emp.

Wyhitsther quartn drey machen vngeuerliche Laybacher Star zween

Der Wain In dem Versthinen Jar, ist daselbst Vbl geraten, aber etlich Annder Jar, soll vill mer Weins, vnd traidts, gefalen sein, vnnd Etlich Jar, noch Weniger als heuer, In welhem khein gewisshait, anzaigt werden mag, Weill derselben Einkhomben der merer thaill, als zehent sein.

Zu gemainen oder mittern Jarrn, soll daselbst zw Wyhitsch vnnd Sogckholl, ain Emp.Weins, In der Neu gelten vngeuerlich khraüzer Zwainzig, heuer aber, so derselb wein, mis $\beta$ ratten gildt der Ennp mer dan Kraizer drayssig. 
Wayz ainWyhitsher Quartn, zu gemainen oder mittern Jarrn, p. khraizer zwainzig, heuer aber ein quartn $p$. viervndzwainzig vnd bis In die draissig khrüzer.

Hiersth ist im versthinen Jar wolgeraten, vnd Pißheer, ein Wyhitscher quartn, p. Sechzehen, vnd bis In die Zwainzig Khraüzer verkhaufft werden.

Painstockh, ainer vngeuerlich p. khrayzer draissig.

Schwainen Ripprattn, Pogatsthen, Huener, vnd Ayr, haben khein khauff, derhalben Solches ainzufieren vnderlassen.

Suma des Einkhombens zu der Haubtmanschafft Wyhitsch vnnd Repitsch Gehörig.

Par Gellt Gld R. 17

Wein Ennp ${ }^{\text {o }}$

Wayz quartn ${ }^{\circ}$

Hiersth quartn ${ }^{\circ}$ 


\section{5. ŽIVOTOPIS}

Damir Stanić rođen je 4. siječnja 1983. u Zagrebu gdje je 1997. završio osnovnu školu te 2001. X. gimnaziju (danas X. gimnazija Ivana Supeka). Akademske godine 2003/2004. upisao je studij jednopredmetne povijest na Filozofskom fakultetu Sveučilišta u Zagrebu, na kojem je diplomirao u prosincu 2008., obranivši diplomski rad naslovljen „Frankopanski grad Slunj i Slunjska kapetanija u 16. stoljeću“, pod mentorstvom dr.sc. Nataše Štefanec. Od lipnja 2011. zaposlen je u Hrvatskom državnom arhivu, gdje je trenutno viši arhivist u Odsjeku za starije i vojno arhivsko gradivo.

Znanstveni interes usmjerio je na društvenu i vojnu povijest hrvatskog ranonovovjekovnog perioda, primarno na prostor Hrvatske krajine. Istraživački fokus usmjerio je na arhivsko gradivo pohranjeno u Hrvatskom državnom arhivu u Zagrebu, Arhivu Hrvatske akademije znanosti i umjetnosti u Zagrebu, Arhivu Republike Slovenije u Ljubljani, Štajerskom zemaljskom arhivu u Grazu te Austrijskom državnom arhivu u Beču.

Bibliografija (izbor):

a) Katalog izložbe:

Damir STANIĆ, Katalog izložbe "Tko su bili ti "strašni Hrvati" ?/ Exhibition catalogue "Who were those "terrible Croats"?, Hrvatski državni arhiv, Državni arhiv za Međimurje, Štrigova, 2018. Katalog autorske izložbe održane u sklopu međunarodne konferencije u povodu 400. godišnjice početka Tridesetogodišnjeg rata "Kronike plaćenika, legende i stereotipi". Zagreb, 2018.

b) Uredničke knjige:

Prvi svjetski rat. Vodič kroz fondove i zbirke Hrvatskog državnog arhiva, gl. ur. Hrvoje Baričević; Damir Stanić et alii, Hrvatski državni arhiv, Zagreb, 2016.

c) znanstveni radovi

Prilog poznavanju kolonizacije pograničja Karlovačkog generalata 1790-ih, Historijski zbornik, vol. 64, No. 1, 2014., 93-117. 
Ambivalentna lojalnost na Hrvatskoj krajini u 16. stoljeću, u: Franz Vaniček $i$ vojnokrajiška historiografija. Zbornik radova sa znanstvenog skupa s međunarodnim sudjelovanjem, ur. Robert Skenderović, Stanko Andrić, Hrvatski institut za povijest - Podružnica za povijest Slavonije, Srijema i Baranje, Slavonski Brod, 2017., 121-142.

d) sudjelovanje na znanstvenim skupovima i izlaganja:

„To je moja sloboda ili o slobodnom izboru žene u društvu prožetom represijom“, IV. kongres hrvatskih povjesničara, Zagreb 2012.

„Neke karakteristike društvenog razvitka Bihaća u krajiškom kontekstu (1527.-1592.)“, studijsko putovanje „Grad na Tromeđi“ u organizaciji Odsjeka za povijest Filozofskog fakulteta u Zagrebu, znanstvenog projekta „Triplex Confinium, Odsjeka za povijest jugoistočne Europe Instituta za povijesna istraživanja Humboldt-Universität Berlin te Centre/Zentrum March Bloch Berlin, 2013.

„Kolonizacija novog kordona Slunjske pukovnije 1788.-1803.“, 2. znanstveni skup u Cetingradu: Povijest i današnjica Cetina cetinskog kraja, Cetingrad, 2014.

„Primjena Frontier studies - međusobne interakcije i upitna lojalnost na Hrvatskoj krajini u 16. stoljeću“, „Franz Vaniček $i$ vojnokrajiška historiografija. Zbornik radova sa znanstvenog skupa s međunarodnim sudjelovanjem.", Hrvatski institut za povijest - Podružnica za povijest Slavonije, Srijema i Baranje, Slavonski Brod, 2014.

„Svištovski mir 1791.“, Znanstveno-stručni skup „Zavalje u prošlosti i sadašnjosti“, Zagreb, 2014.

„Zbrinjavanje bosanskih prebjega na području Slunjske krajiške pukovnije 1852. godine“, $V$. kongres hrvatskih povjesničara, Zadar, 2016.

„Gvozdansko - kaštel, rat i rudokopi“, Serija predavanja: Utvrde Siska i Banovine, u organizaciji Državnog arhiva u Sisku, Sisak, 2016. (koautorica: prof.dr.sc. Nataša Štefanec)

„Who were those "terrible Croats“? On the Origins of Croatian Soldiers in the Thirty Years' War", Chronicles of Mercenaries, Legends and Stereotypes. International Conference on the Occasion of the $400^{\text {th }}$ Anniversary of the Beginning of the Thirty Years ' War, Zagreb, 2018. 